UNIVERSIDADE DE SÃO PAULO

INSTITUTO DE GEOCIÊNCIAS

\title{
MAPEAMENTO E INVESTIGAÇÃO PETROLÓGICA E GEOCRONOLÓGICA DOS LITOTIPOS DA REGIÃO DO ALTO RIO NEGRO (PR-SC): UM EXEMPLO DE SUCESSIVAS E DISTINTAS ATIVIDADES MAGMÁTICAS DURANTE O NEOPROTEROZÓICO
}

OSSAMA MOHAMED MILAD HARARA

Orientador: Prof. Dr. Miguel Angelo Stipp Basei

TESE DE DOUTORAMENTO

COMISSÃO JULGADORA

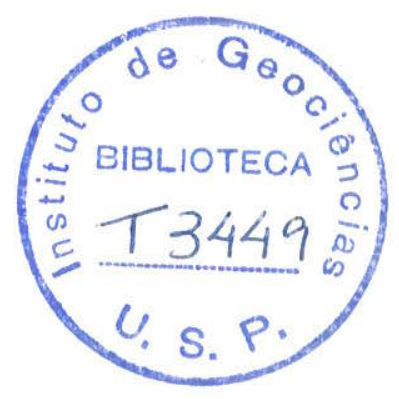

Nome

Presidente: Prof. Dr. Miguel Angelo Stipp Basei

Examinadores: Prof. Dr. Ian McReath .

Prof. Dr. Léo Afraneo Hartmann

Prof. Dr. Márcio Martins Pimentel

Prof. Dr. Valdecir de Assis Janasi

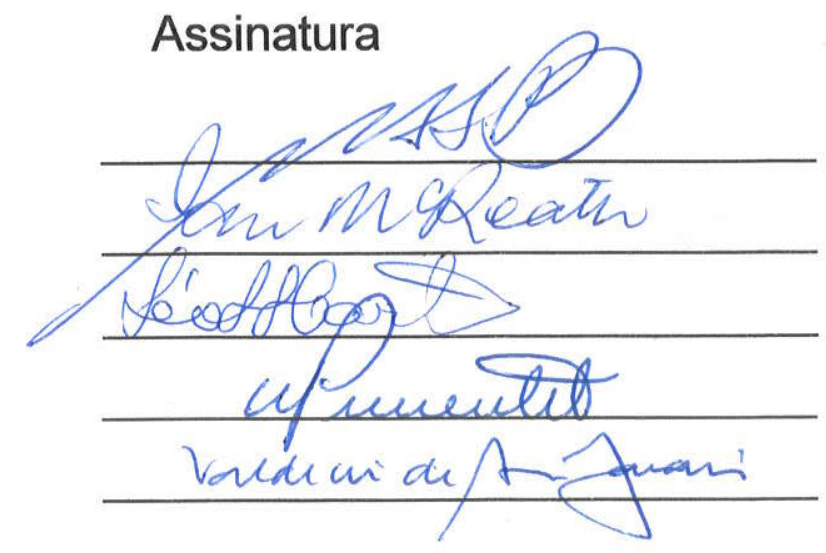




\section{Universidade de São Paulo \\ Instituto de Geociências}

Mapeamento e investigação petrológica e geocronológica dos litotipos da região do alto Rio Negro (PR-SC): Um exemplo de sucessivas e distintas atividades magmáticas durante 0 Neoproterozóico III

Ossama Mohamed Milad Harara

Orientador: Prof. Dr. Miguel Ângelo Stipp Basei

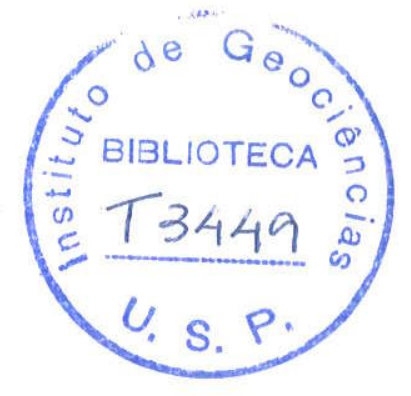

TESE DE DOUTORAMENTO

Programa de Pós- Graduação em Geoquímica e Geotectônica

São Paulo 2001

DEDALUS - Acervo - IGC

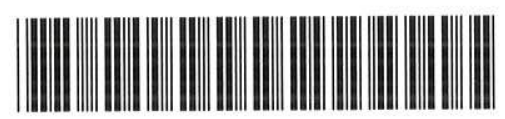

30900008186 
Aos Professores da Escola Pré-Universitária de Zawait Al Dahmani, Tripoli-Libia. Aos Professores do Departamento de Geologia da Universidade Federal do Paraná. Aos Professores do Instituto de Geociências da Universidade de São Paulo.

Muito Obrigado.

Aos meus pais (avós maternos), Salem Abushkewa e Mariuma Abushkewa.

À minha mãe Haluma Abushkewa e o meu padrasto Mohamed Al Aref (In Memorian). Aos meus tios-irmäos, Abel Hadi, Muktar, Nur Al deen, Fátima, Najmia e Haida. Aos meus Irmãos, Salah Al deen, Yassin, Adel, Nader e Muhamed. Às minhas Irmãs, Wafá, Intissar, Assma, Hanna, Nissrin, Iman, Samá, Hanan, Ibtisam, Karima, Dunia e Hajer.

Tanto tempo e tanta saudade de todos. 


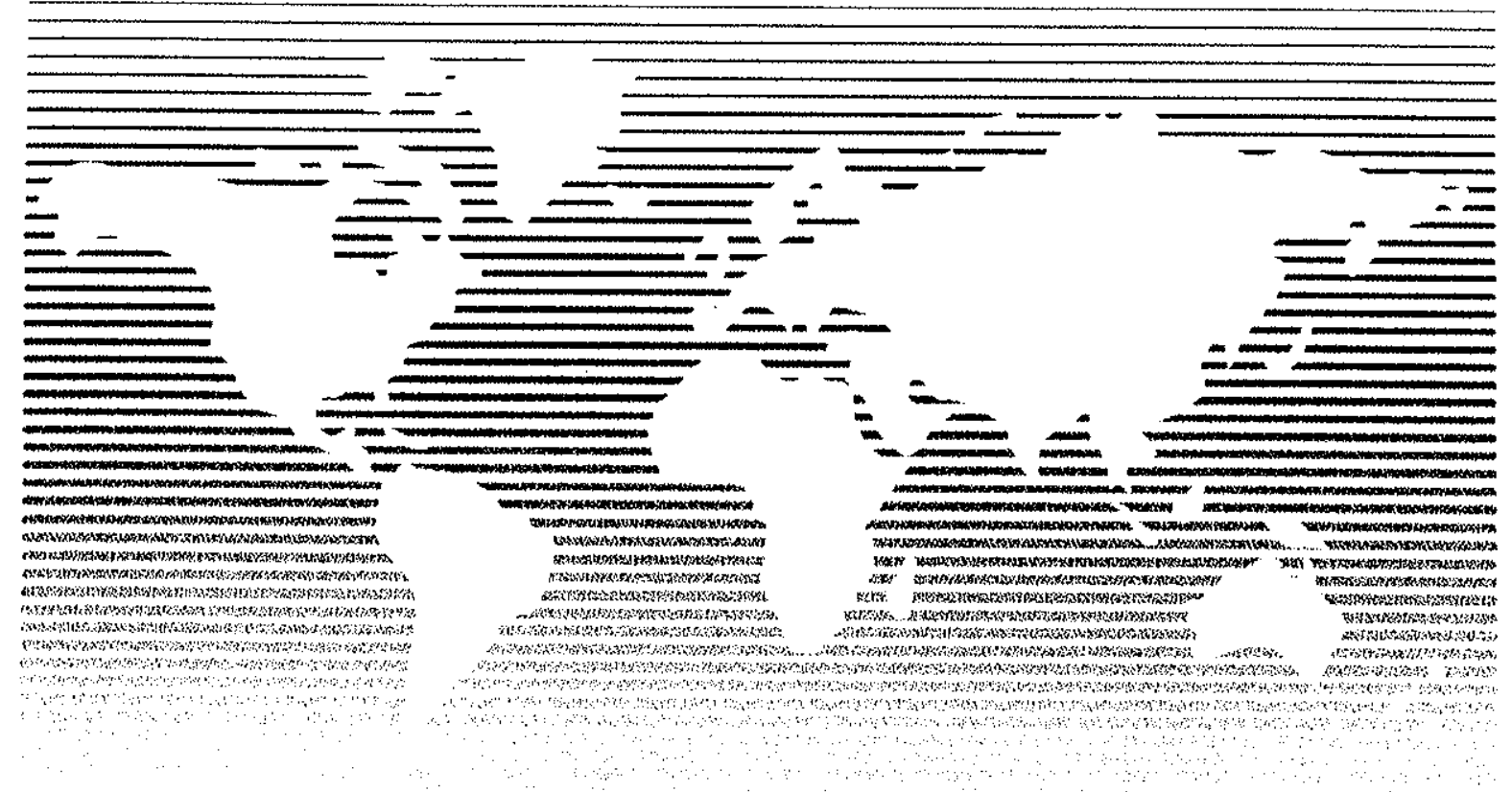

"The earth, we have spread It out, how excellently we did that?" "The mountains, how they have been pitched?

"The earth, how it was made even"?

"Have we not made the earth an expanse, and the mountains stakes .... and the mountains has fixed them firmly".

Versículos do Alcorão sobre processos geodinâmicos da terra. (acreçáo lateral e construçáo de arcos magmáticos, formaçáo de orogénos, acreção vertical, margens continentals ativas e passivas ...etc.) 
Índice

Agradecimentos

Abstract

1.0 - Introdução.

2.0 - Metodologias da Investigaçăo Geológica.................................................................. 01

3.0 - Contexto Geológico Regional.......................................................................... 07

3.1 - Introdução................................................................................................... 07

3.2 - O Terreno Gnáissico Anfibolito-Granulítico do Paraná e Santa Catarina........... 07

3.3 - O Cinturăo Gnáissico-Migmatítico Atuba.......................................................... 14

3.4 - Cinturão Granítico Costeiro.............................................................................. 17

3.5 - Síntese geológica da zona de transição.......................................................... 19

3.6 - O Magmatismo Granítico Alcalino-Peralcalino e o Vulcanismo-Sedimentação das Bacias de Guaratubinha, Campo Alegre e Corupá............................................. 21

3.7 - Propostas de compartimentação tectônica e evolução geodinâmica da região. 27

4.0 - Contexto Geológico Local ................................................................................ 30

5.0 - Granitos Palermo, Rio Negro, Agudos do Sul e Tarumä...........................................35

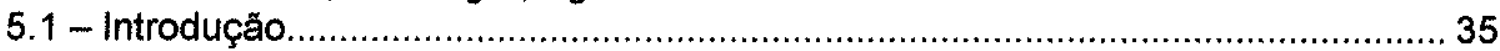

5.2 - Petrografia dos Granitos Palermo, Rio Negro, Agudos do Sul e Tarumä............ 36

5.2.1 - Monzo-Sienogranitos dos Granitos Palermo e Rio Negro.............................. 36

5.2.2 - Granito Agudos do Sul........................................................................... 39

5.2.3 - Rochas Gabróicas dos Granitos Palermo e Rio Negro......................................4 41

5.2.4 - Rochas Graníticas Híbridas Máficas e Félsicas.............................................. 44

5.2.5 - Rochas "peralcalinas" do Granito Palermo................................................... 48

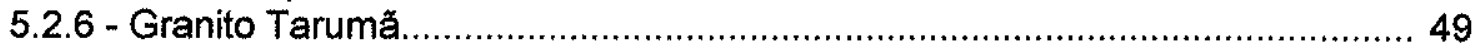

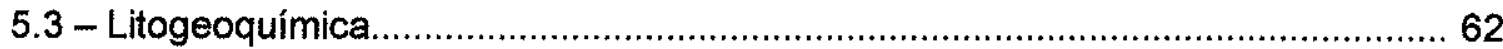

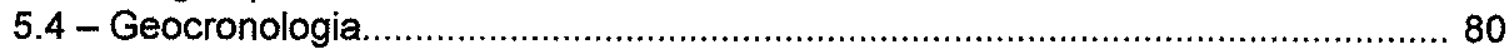

6.0 - Suite Granítica Piên - Mandirituba (SGPM)......................................................... 89

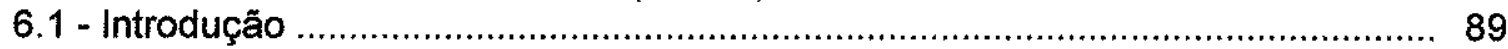

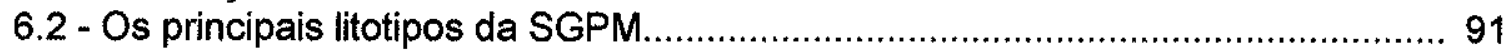

6.2.1 - Anfibolito Espigão das Antas (Dioritos-Quartzo-Dioritos)................................91

6.2.2 - Quartzo-Monzodioritos, Granodioritos sem epídoto magmático.....................92

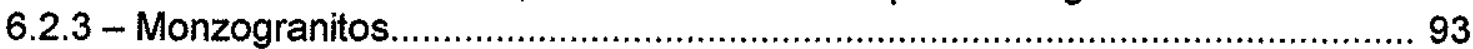

6.2.4 - Quartzo-Monzodioritos com epídoto magmático......................................... 93

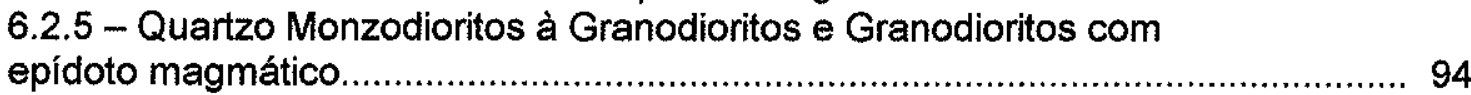

6.2.6 - Leucogranodioritos com epídoto magmático............................................ 94

6.3 - Características petrográficas microscópicas dos litotipos da SGPM................... 95

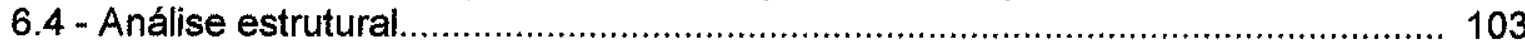

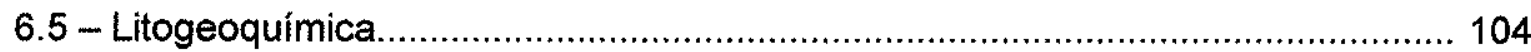

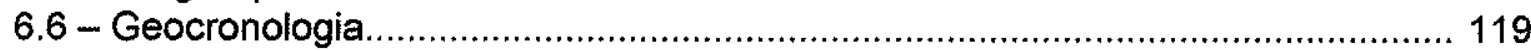

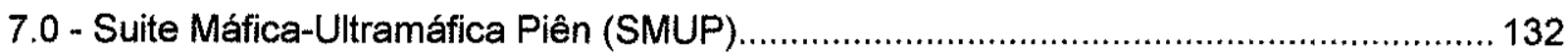

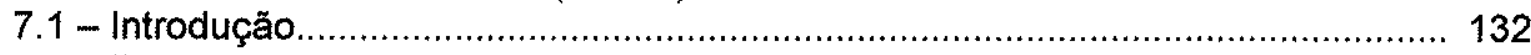

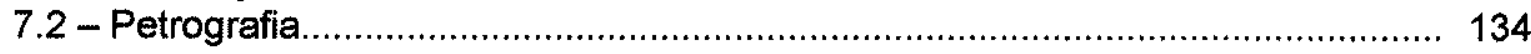

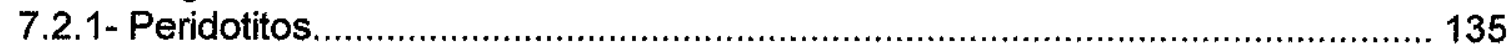


7.2.2 - Piroxenitos

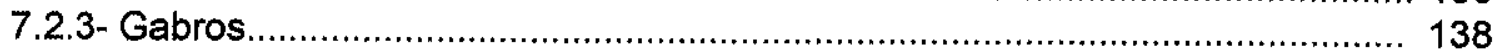

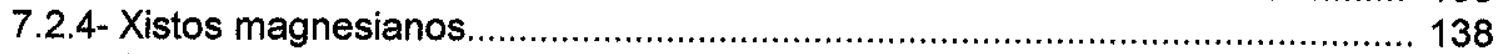

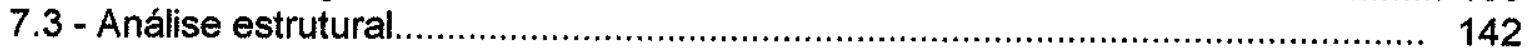

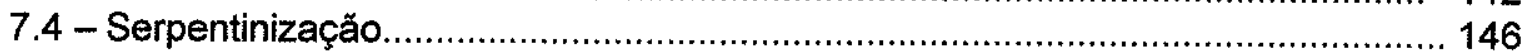

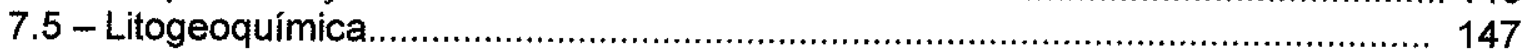

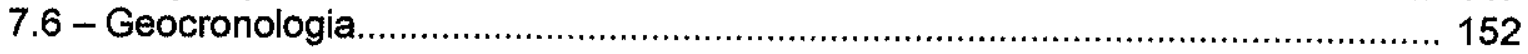

8.0 - Terreno Gnáissico Anfibolito Granulítico do Paraná e Santa Catarina...................... 155

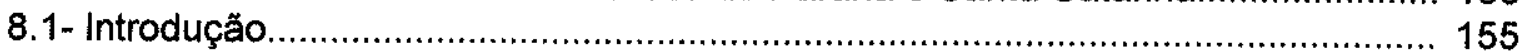

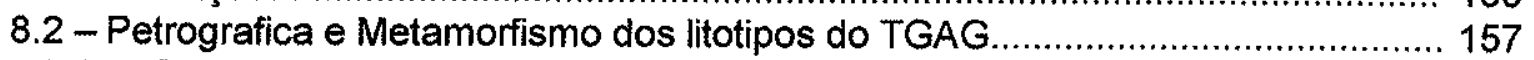

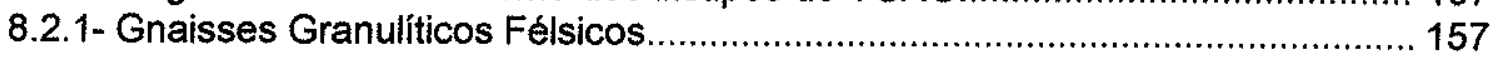

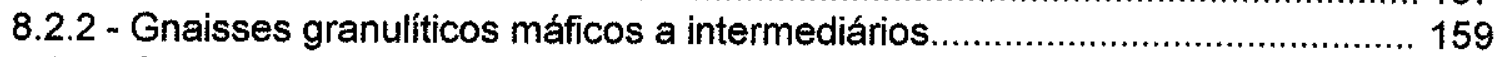

8.2.3 - Gnaisses granulíticos máficos ricos em megacristais de granada.................. 160

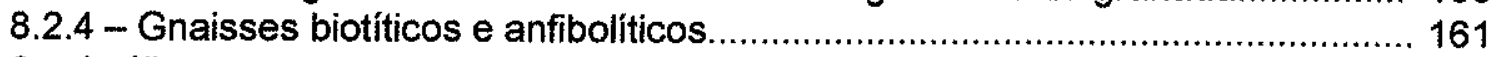

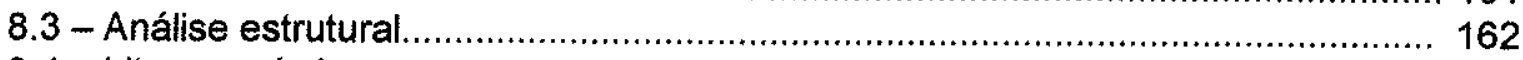

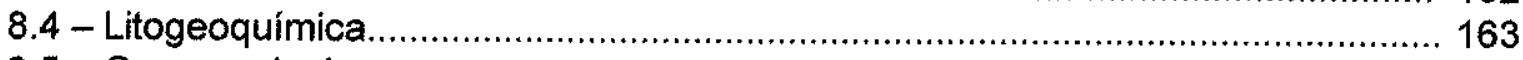

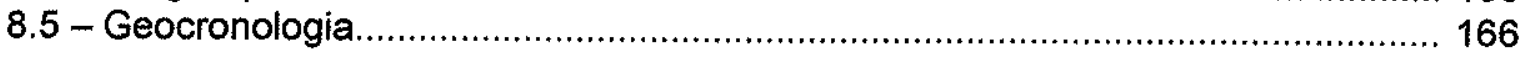

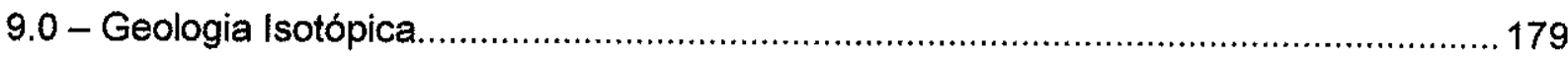

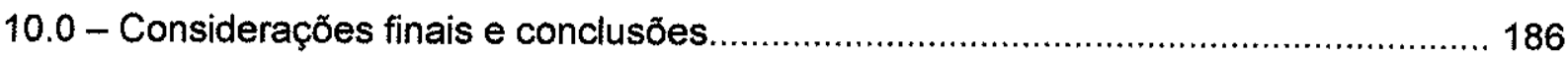

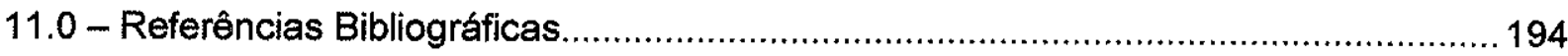

\section{Anexos:}

1.0 - Mapa geológico

2.0 - Mapa de controle e localização dos afloramentos.

3.0 - Tabelas de análises químicas 


\section{Índice das Figuras}

Figura 1.1 - Mapa de localização da área de pesquisa e vias de acesso....................................... 02

Figura 3.1 - Mapa Geológico do Sul do Paraná e Nordeste de Santa Catarina............................ 09

Figura 5.1 - Diagrama P.Q contendo os principais litotipos graníticos do GP e GRN....................37

Figura 5.2 - Diagrama P-Q contendo os principais litotipos graníticos do GAS.......................... 40

Figura 5.3 - Diagrama P-Q cocontendo as principais rochas máficas do GP $\Theta$ do GRN.............. 42

Figura 5.4 - Diagrama P-Q contendo os litotipos Graníticos híbridos máficos e félsicos do

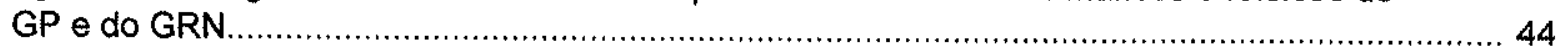

Figura 5.5 - Diagrama P-Q contendo os litotipos graníticos fracamente peralcalinos do GP.......... 48

Figura 5.6 - Diagrama Q-P com os principais litotipos graníticos do GT ....................................50

Figura 5.7 - Diagramas de variaçăo $\mathrm{SiO}_{2} \mathrm{X}$ óxidos GP, GAS, GRN, GT e a SGPM.....................70

Figura 5.8 - Diagramas de variação $\mathrm{SiO}_{2} \mathrm{X}$ elementos traços dos Granitos GP, GAS,

GRN, GT e a SGPM.

Figura 5.9 - Diagramas $\left(\mathrm{K}_{2} \mathrm{O}+\mathrm{Na}_{2} \mathrm{O}-\mathrm{Fe}_{2} \mathrm{O}_{3}-\mathrm{MgO}, \mathrm{K}_{2} \mathrm{O}+\mathrm{Na}_{2} \mathrm{O}-\mathrm{Fe}_{2} \mathrm{O}_{3}-\mathrm{CaO},\left(\mathrm{Al}_{2} \mathrm{O}_{3} / \mathrm{CaO}+\right.\right.$

$\mathrm{Na}_{2} \mathrm{O}+\mathrm{K} 2 \mathrm{O} \times \mathrm{Al}_{2} \mathrm{O}_{3} / \mathrm{Na}_{2} \mathrm{O}+\mathrm{K}_{2} \mathrm{O}, \mathrm{SiO}_{2} \times \mathrm{Rb} / \mathrm{Sr}, \mathrm{Rb} \times \mathrm{Sr}, \mathrm{Sr} \times \mathrm{Ba}, \mathrm{Sr}-\mathrm{Rb}-\mathrm{Ba}, \mathrm{CaO} \times \mathrm{Sr}$,

$\mathrm{SiO}_{2} \times \mathrm{Sr} / \mathrm{Y}$ e $\mathrm{Zr} \times \mathrm{Zr} / \mathrm{Y}$ para as rochas dos Granitos GP, GAS, GRN, GT e a SGPM.......

Figura 5.10 - Diagramas de variação $\mathrm{SiO}_{2} \mathrm{X}$ elementos terras raras leves (ETRL) e elementos

terras raras pesados (ETRP) para as rochas dos Granitos GP, GAS, GRN, GT e a SGPM........ 77

Figura 5.11 - Diagramas de elementos terras raras para as rochas dos Granitos GP, GRN,

GAS e GT.....

Figura 5.12 - Diagramas $\mathrm{Rb} X \mathrm{Y}+\mathrm{Nb}$ e $\mathrm{Nb} X \mathrm{Y}$ discriminando dos principais ambientes

geotectônicos das rochas graniticas dos Granitos GP, GAS, GRN, GT e a SGPM...

Figura 5.13- Diagrama Concórdia U-Pb para os zircőes dos anfibólio-biotita monzo-

sienogranito do GP

Figura 5.14- Diagrama Concórdia U-Pb para os zircóes dos biotita monzo-

sienogranitos do GRN..

Figura 5.15 - Diagrama Concórdia U-Pb para os zircőes dos monzogabros do GRN ................. 86

Figura 5.16- Diagrama isocrônico $\mathrm{Rb}^{87} / \mathrm{Sr}^{86} \times \mathrm{Sr}^{87} / \mathrm{Sr}^{86}$ ) para as rochas graníticas do GAS.......... 88

Figura 5.17 - Diagrama $\mathrm{Rb}^{87} / \mathrm{Sr}^{86} \times \mathrm{Sr}^{87} / \mathrm{Sr}^{86}$ para as rochas graníticas GP, GAS e GRN........... 88

Figura 6.1 . Diagrama P-Q contendo os principais componentes graníticos da SGPM................ 91

Figura 6.2 - Diagrama de freqüência dos pólos da foliação tectônica Sn na SGPM...................... 103

Figura 6.3 - Diagramas de variação $\mathrm{SiO}_{2} \mathrm{X}$ óxidos $\left(\mathrm{TiO}_{2}, \mathrm{MnO}, \mathrm{P}_{2} \mathrm{O}_{3}, \mathrm{CaO}, \mathrm{Fe}_{2} \mathrm{O}_{3}, \mathrm{MgO}\right.$,

$\mathrm{Na}_{2} \mathrm{O}$ e $\mathrm{K}_{2} \mathrm{O}, \mathrm{Na}_{2} \mathrm{O} / \mathrm{K}_{2} \mathrm{O}, \mathrm{K}_{2} \mathrm{O} \times \mathrm{Na}_{2} \mathrm{O}$ e $\mathrm{SiO}_{2} \times \mathrm{K}_{2} \mathrm{O}+\mathrm{Na}_{2} \mathrm{O}$, para as rochas da SGPM

e dos Granitos GT.GP, GAS e GRN..

Figura 6.4 - Diagramas de variação $\mathrm{SiO}_{2} \mathrm{X}$ elementos para as rochas da SGPM e dos

Granitos GT GP, GAS e GRN.

Figura 6.5 - Diagramas $\left(\mathrm{K}_{2} \mathrm{O}+\mathrm{Na}_{2} \mathrm{O}-\mathrm{Fe}_{2} \mathrm{O}_{3}-\mathrm{MgO}, \mathrm{Al}_{2} \mathrm{O}_{3} / \mathrm{CaO}+\mathrm{Na}_{2} \mathrm{O}+\mathrm{K}_{2} \mathrm{O} / \mathrm{Al}_{2} \mathrm{O}_{3} / \mathrm{Na}_{2} \mathrm{O}\right.$

$+\mathrm{K}_{2} \mathrm{O}, \mathrm{SiO}_{2} \times \mathrm{Rb} / \mathrm{Sr}, \mathrm{Rb} \times \mathrm{Sr}, \mathrm{Sr} \times \mathrm{Ba}, \mathrm{Sr}-\mathrm{Ba}-\mathrm{Rb}, \mathrm{CaO} \times \mathrm{Sr}$ e $\mathrm{SiO}_{2} \times \mathrm{Sr} / \mathrm{Y}$ para as rochas

da SGPM e dos Granitos GT, GP, GAS e GRN.

Figura 6.6 - Diagramas de variação $\mathrm{SiO}_{2} \mathrm{X}$ elementos de terras raras leves e elementos

terras raras pesadas para as rochas da SGPM e dos Granitos GT, GP, GAS e GRN................ 116

Figura 6.7 - Diagramas elementos terras raras para os principais litotipos graníticos da SGPM... 117

Figura 6.8 - Diagramas $\mathrm{Rb} X \mathrm{Y}+\mathrm{Nb}$ e $\mathrm{Nb} X Y$ discriminantes dos ambientes geotectônicos

das rochas graníticas da SGPM e dos Granitos GT, GP, GRN \& GAS ...................................... 118

Figura 6.9 - Diagrama concórdia U-Pb para os zircões e titanita dos quartzo

monzodioritos sem epidoto magmático da porção norte da SGPM.

Figura 6.10 - Diagrama concordia U-Pb para os zircōes e titanita dos quartzo

monzodioritos/granodioritos sem epídoto magmático da SGPM.

Figura 6.11 - Diagrama concórdia U.Pb para os zircões e titanita dos quartzo monzodioritos

e quartzo monzodioritos/granodioritos sem epídoto magmático da porção norte e

sul da SGPM.

Figura 6.12 - Diagrama concórdia U-Pb para os zircões dos quartzo monzodioritos com

epídoto magmático da SGPM.....

Figura 6.13 - Diagrama concórdia U-Pb para titanita dos quartzo monzodioritos/

granodioritos protomiloníticos com epídoto magmático da SGPM. 
Figura 6.14 - Diagrama concórdia U-Pb para titanita e zircões dos quartzo monzodioritos/granodioritos e zircões dos leucogranodioritos com epídoto magmático da SGPM.

Figura 6.15 - Diagrama concórdia U-Pb para os zircões dos leucogranodioritos e titanita dos quartzo monzodioritos/granodioritos com epídoto magmático da SGPM.

Figura 6.16 - Diagrama concórdia U.Pb para os zircőes e titanita dos quartzo monzodioritos, quartzo monzodioritos/granodioritos e leucogranodioritos com epídoto magmático da SGPM.

Figura 6.17 - Diagrama concórdia U-Pb para os zircões e titanitas de todos os componentes graníticos, com e sem epídoto magmático, da SGPM.

Figura 6.18 - Diagrama Isocrônico $\mathrm{Rb}^{87} / \mathrm{Sr}^{86} \times \mathrm{Sr}^{87} / \mathrm{Sr}^{86}$ (rocha total) para os quartzo monzodioritos, granodioritos e leucogranodioritos com epídoto magmático da SGPM.

Figura 7.1 - Diagrama triangular Olivina-Ortopiroxênio-Clinopiroxênio para as rochas ultramáficas da SMUP.

Figura 7.2 - De

Figura 7.2 - Diagrama de freqüência dos pólos da principal foliação Sn no corpo CC................... 142

Figura 7.3 - Diagrama das principais lineaçżes minerais no corpo CC. ..................................... 143

Figura 7.4 - Diagrama de freqüência dos pólos da principal foliação Sn no corpo CM................ 143

Figura 7.5 - Diagrama das principais lineações minerais no corpo CM........................................ 144

Figura 7.6 - Diagrama $\mathrm{Cr}(\mathrm{ppm}) \times \mathrm{TiO}_{2}(\%)$ para os peridotitos da SMUP................................... 149

Figura 7.7 - Diagrama $U^{238} / \mathrm{Pb}^{206} \times \mathrm{Pb}^{207} / \mathrm{Pb}^{206}$ para os zircóes do gabro da SMUP........................ 153

Figura 7.8 - Diagrama Isocrônico $\mathrm{Sm}^{147} / \mathrm{Nd}^{144} \times \mathrm{Nd}^{143} / \mathrm{Nd}^{144}$ do corpo $\mathrm{CC}$ da SMUP...................... 154

Figura 8.1 - Diagrama P-Q contendo os principais litotipos do TGAG........................................ 156

Figura 8.2 - Diagrama de freqüência dos pólos das foliações Sn da porção sul do trecho

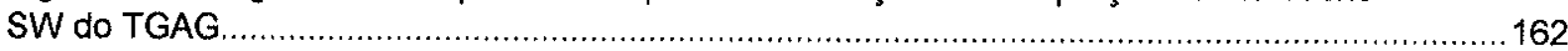

Figura 8.3 - Diagrama dos pólos das foliações Sn da porção norte do trecho SW do TGAG........ 163

Figura 8.4 - Diagrama concórdia U-Pb para os zircóes elipsoidais de charnoquito máfico............. 168

Figura 8.5 - Diagrama concórdia U-Pb para os zircões aciculares com terminaçōes

arredondadas do charnoquito máfico....

Figura 8.6 - Diagrama concórdia U-Pb para os zircões elipsoidais e aciculares com

terminaçóes arredondadas do charnoquito máfico rico em biotita e anfibólio.

Figura 8.7 - Diagrama concórdia U-Pb para os zircões elipsoidais dos gnaisses

granulíticos máficos

Figura 8.8 - Diagrama concórdia U-Pb para os zircões esféricos dos gnaisses granulíticos máficos do TGAG.

Figura 8.9 - Diagrama concórdia U-Pb para os zircões esféricos e elipsoidais dos

gnaisses granulíticos máficos.

Figura 8.10-Diagrama concórdia U-Pb para os zircões elipsoidais dos gnaisses

granulíticos félsicos.

Figura 8.11 - Diagrama concórdia U-Pb para os zircões esféricos dos gnaisses

granuliticos félsicos.

Figura 8.12 - Diagrama concórdia U-Pb para os zircões esféricos e elipsoidais dos

gnaisses granulíticos félsicos.

Figura 8.13 - Diagrama concórdia U-Pb para os zircões de todas as rochas granulíticas da

região investigada

Figura 8.14 - Perfil térmico-geocronológico K-Ar (biotita e anfibólio) entre o TGAG e a SGPM.... 177

Figura 8.15 - Diagrama isocrônico $\mathrm{Sm}^{147} / \mathrm{Nd}^{144}-\mathrm{Nd}^{143} / \mathrm{Nd}^{144}$ (rocha total, plagioclásio

e granada) para os gnaisses granulíticos máficos com megacristais de granada.

Figura 8.16 - Diagrama isocrônico $\mathrm{Sm}^{147} / \mathrm{Nd}^{144}-\mathrm{Nd}^{143} / \mathrm{Nd}^{144}$ (rocha total, plagioclásio e

granada) para os gnaisses granulíticos máficos com megacristais de granada........................ 178

Figura 9.1 - Diagrama $\mathrm{SiO}_{2} \times \delta^{18} \mathrm{O}$ das rochas graníticas SGPM, GP, GRN e rochas do TGAG.. 180

Figura $9.2-\in \mathrm{Nd}^{(\mathrm{Tc})} \times \mathrm{Sr}^{87} / \mathrm{Sr}^{86(\mathrm{Tc})}$ para as rochas do TGAG SGPM, GP, GAS, GRN e GT.......... 180

Figura $9.3-\in \mathrm{Nd}$ XT (Ga) para as rochas dos TGAG, SGPM, GP, GAS, GRN e GT................. 183

\section{Índice Tabelas}

Tabela 3.1 - Relaçăo dos principais dados geocronológicos e isotópicos do TGAG....... 
Tabela 3.3 - Relação dos principais dados geocronológicos e isotópicos do CGC 18

Tabela 3.4 - Relação dos principais componentes graníticos da Suite Serra do Mar e vulcánicos

das Bacias Guaratubinha, Campo Alegre e Corupá. 25

Tabela 3.5 - Relação dos principais dados geocronológicos e isotópicos da Suite Granítica

(A-PA) Serra do Mar e das vulcânicas das Bacias Guaratubinha e Campo Alegre. 26

Tabela 5.1 - Análises isotópicas U-Pb em zircões de anfibólio-biotita monzo-sienogranito do GP.81

Tabela 5.2 - Análises isotópicas U-Pb em zircões de biotita-monzo-sienogranito do GRN........... 81

Tabela 5.3 - Análises isotópicas e idades K-Ar (biotita) do litotipos do GP, GRN e GT .................. 84

Tabela 5.4 - Análises isotópicas U-Pb em zircőes de biotita-monzogabro do GRN........................ 85

Tabela 6.1 - Análises isotópicas U-Pb em zircões e titanitas dos litotipos graníticos da SGPM.... 120

Tabela 6.2 - Análises isotópicas e idades K-Ar (biotita e anfibólio) dos principais litotipos

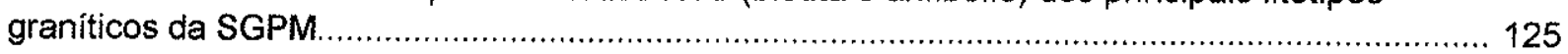

Tabela 7.1 - Características geológicas dos complexos máficos-ultramáficos Fanerozóicos.......... 151

Tabela 7.2 - Análises U-Pb (SHRIMP) em zircões do Gabro da SMUP ....................................... 153

Tabela 7.3 - Análises isotópicas e idades K-Ar da SMUP........................................................... 154

Tabela 8.1 - Análise isotópica U-Pb em zircões do TGAG (ortogranulítos) .................................. 167

Tabela 8.2 - Análises isotópicas e idades K-Ar da porção norte do TGAG .................................... 176

Tabela 8.3 - Análises Sm-Nd dos gnaisses granulíticos e anfibolíticos do TGAG.......................... 178

\section{Índice Fotos (macro e microscópicas)}

Foto 5.1: Aspecto macroscópico dos Monzo-sienogranitos. GP, ............................................ 52

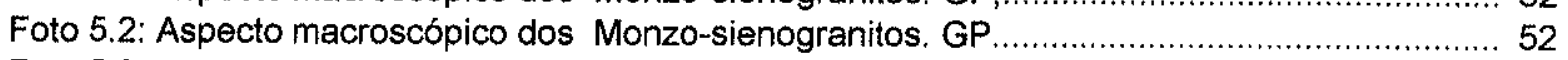

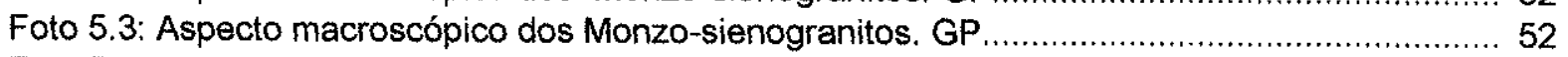

Foto 5.4: Aspecto macroscópico dos Monzo-sienogranitos. GRN ........................................... 52

Foto 5.5: Aspecto macroscópico dos Monzo-sienogranitos. GP................................................. 52

Foto 5.6: Aspecto macroscópico dos LeucoMonzo-sienogranitos. GP...................................... 52

Foto 5.7: Aspecto geral da textura xenomórfica em Monzo-sienogranitos. GP, .......................... 52

Foto 5.8: Aspecto geral da textura xenomórfica em Monzo-sienogranitos. GRN, ....................... 52

Foto 5.9: Fenocristais de quartzo corroído por pertita. Monzo-sienogranitos. GRN ..........................5 53

Foto 5.10:Cristal euhédrico de mesopertita com borda granofírica Monzo-sienogranito. GRN, ...... 53

Foto 5.11:Intercrescimento granofírico entre quartzo e pertita. Monzo-sienogranitos. GP, .......... 53

Foto 5.12: Intercrescimento granofírico entre quartzo e pertita. Monzo-sienogranitos. GP,............5 53

Foto 5.13: Cristais euhédricos de plagioclásio com pertita intersticial. Monzo-sienogranitos. GP .53

Foto 5.14: Cristal de plagioclásio manteado por pertita. Monzo-sienogranitos. GP....................... 53

Foto 5.15: Bitotita intersticial ao quartzo e feldspatos. LeucoMonzo-sienogranitos. GP................ 54

Foto 5.16: Aglomerados de biotita, allanita, anfibólio e fluorita intersticiais aos cristais de quartzo e feldspato em Monzo-sienogranitos. GP,

Foto 5.17: Biotita intersticial ao quartzo e feldspato com inclusão de zircäo em Monzo-

sienogranitos. GRN.

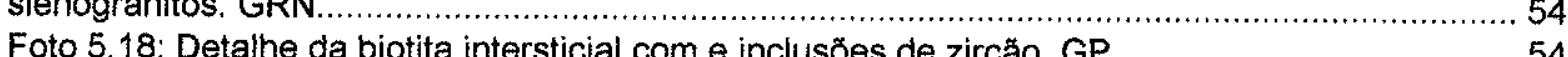

Foto 5.19: Aglomerados de biotita, anfibólio e titanita em Monzo-sienogranitos....................... 54

Foto 5.20: Simplectito de biotita e anfibólio com titanita, intersticiais ao quartzo e feldspato.

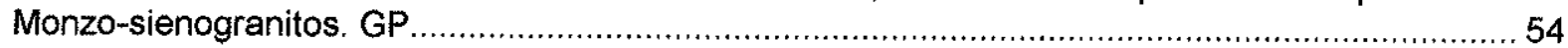

Foto 5.21: Biotita, anfibólio, titanita e allanita aglomerados máficos. Monzo-sienogranitos. GP... 55

Foto 5.22: Aspecto macroscópico dos Leucogranodioritos. GAS.............................................. 55

Foto 5.23 : Aspepcto macroscópico dos Leucogranodioritos. GAS ........................................... 55

Foto 5.24: Aspecto geral da textura em Leucogranodioritos. GAS ................................................ 55

Foto 5.25: Aspecto macroscópico dos Monzogabros. GRN....................................................... 55

Foto 5.26: Aspecto macroscópico dos Gabros/Monzogabros. GP............................................... 55

Foto 5.27: Aspecto geral da textura intersticial em Monzogabro. GRN....................................... 55

Foto 5.28: Aspecto geral da textura intersticial em Monzogabro. GRN, ....................................5 55

Foto 5.29: Simplectito de clinopiroxênio, biotita e anfibólio em Monzogabro. GRN, ........................ 56

Foto 5.30: Simplectito de clinopiroxênio e biotitat anfibólio em Monzogabros. GRN, ..................... 56

Foto 5.31: Cristais de zircão anédricos de cristalização tardia em Monzogabros. GRN................556

Foto 5.32: Aspecto dos Monzogabros/Monzodioritos a Quartzo Monzodioritos híbridos, GP........ 56 
Foto 5.33: Aspecto macroscópico dos Quartzo Dioritos a Quartzo Monzonitos híbridos. GRN..... 56

Foto 5.34 : Aspecto Macroscópico dos Monzodioritos a Quartzo Monzodioritos híbridos. GP, ...... 56

Foto 5.35: Aspecto Macroscópico dos Quartzo Monzodioritos hibridos. GRN, ........................... 56

Foto 5.36: Aspecto Macroscópico dos Quartzo Monzodioritos híbridos. GRN, ................................ 56

Foto 5.37 : Aspecto dos Quartzo Monzodioritos híbridos. GRN................................................... 57

Foto 5.38 :Aspecto dos Quartzo Monzodioritos a Quartzo Monzonitos híbridos. GRN.....................57

Foto 5.39: Aspecto Macroscópico dos Quartzo Monzonitos híbridos. GP................................... 57

Foto 5.40: Aspecto Macroscópico dos Quartzo Monzonitos híbridos. GP.................................. 57

Foto 5.41 : Aspecto Macroscópico dos Quartzo Monzodioritos a Monzogranitos híbridos. GRN....57

Foto 5.42: Aspecto Macroscópico dos Quartzo Monzonitos a Monzogranitos híbridos. GRN....... 57

Foto 5.43: Aspecto Macroscópico dos Monzo-Sienogranitos com Quartzo Monzonitos híbridos,

exibindo textura rapakivi. GP

Foto 5.44: Quartzo ocelar manteado por anfibólio tbiotita em Quartzo Monzodioritos

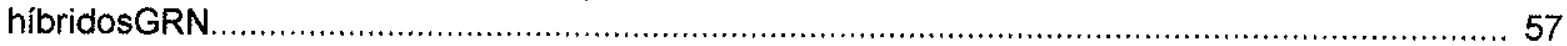

Foto 5.45: Quartzo ocelar anfibólio e biotita em Quartzo Monzodioritos híbridos . GRN, ............... 58

Foto 5.46: Quartzo ocelar manteado anfibólio \pm biotita em Quartzo Monzonitos híbridos. GP........ 58

Foto 5.47: Concentrações máficas de biotita e anfibólio em Quartzo Monzodioritos a Monzo-

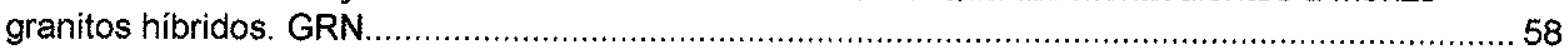

Foto 5.48: Textura Anti-Rapakivi produzida por mistura em Quartzo Monzonitos híbridos. GP..... 58

Foto 5.49: Detalhe da textura rapakivi produzida por mistura Monzo-sienogranitos híbridos. GP.. 58

Foto 5.50: Apatita acicular em Quartzo Monzodioritos híbridos. GRN , ................................ 58

Foto 5.51: Quartzo ocelar com pertita intersticial manteado por clinopiroxênio e anfibólio. GRN,.. 59

Foto 5.52: Concentrações máficas de biotita, anfibólio e clinopiroxênio em Monzogabros-

Monzodioritos a Quartzo Monzonitos híbridos. GP.

Foto 5.53 Concentração de anfibólio, biotita e clinopiroxênio em Monzogabros/Monzo-

dioritos hibridos. GP

Foto 5.54: Aspecto macroscópico geral dos Quartzo Monzonitos/Quartzo Sienitos. GP................. 59

Foto 5.55: Aspecto macroscópico geral dos Quartzo Monzonitos/Quartzo Sienitos . GP.............. 59

Foto 5.56 : Cristais de aegerina-augita, anfibólio e biotita intersticiais às pertitas e quartzo. GP, .. 59

Foto 5.57: Cristais de aegirina-augita intersticiais ao quartzo e pertita em

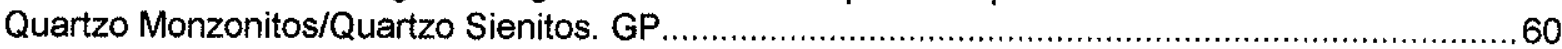

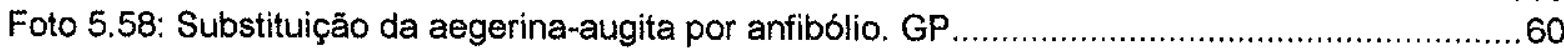

Foto 5.59: Simplectitos de aegerina-augita, anfibólio, riebeckita e biotita.....................................60 60

Foto 5.60: Substituição de anfibólio verde por anfibólio azul, em simplectitos com a biotita. GP... 60

Foto 5.61: Detalhe de simplectito da aegerina-augita, anfibólio verde substituido por anfibólio

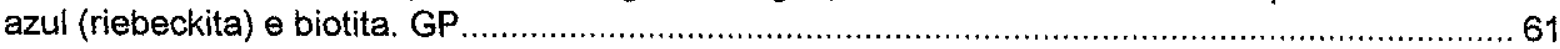

Foto 5.62: Aspecto macroscópico geral dos Monzogranitos. GT ..................................................61

Foto 5.63: Detalhe dos enclaves que ocorrem nos Monzogranitos. GT ......................................61

Foto 5.64: Biotita não intersticial aos cristais de quartzo e feldspatos em Monzogranitos. GT.......61 61

Foto 5.65: Enclave máfico com concentrações de biotitatanfibólio e plagioclásio em Monzo-

granitos. GT.

Foto 6.1: Aspecto macroscópico do anfibolito Espigão das Antas. SGPM............................... 99

Foto 6.2: Aspecto macroscópico dos Quartzo Monzodioritos sem epidoto magmático. SGPM,... 99

Foto 6.3: Aspecto dos Quartzo Monzodioritos/Granodioritos sem epidoto magmático. SGPM..... 99

Foto 6.4: Aspeco dos Granodioritos sem epidoto magmático. SGPM........................................ 99

Foto 6.5: Aspecto macroscópico geral dos Monzogranitos. SGPM .......................................... 99

Foto 6.6: Aspecto macroscópico geral dos Monzogranitos. SGPM............................................ 99

Foto 6.7: Aspecto macroscópico geral dos Monzogranitos. SGPM............................................... 99

Foto 6.8: Aspecto geral dos Quartzo Monzodioritos com epidoto magmático. SGPM................... 99

Foto 6.9: Aspecto dos Quartzo Monzodioritos/Granodioritos com epidoto magmático. SGPM,.... 100

Foto 6.10: Aspecto macroscópico geral dos Quartzo Monzodioritos/Granodioritos deformados com epidoto magmático. SGPM.

Foto 6.11: Quartzo Monzodioritos/Granodioritos com epidoto magmático. SGPM........................... 100

Foto 6.12: Aspecto macroscópico geral dos Granodioritos com epidoto magmático. SGPM........ 100

Foto 6.13: Aspecto geral dos Leucogranodioritos com epidoto magmático. SGPM.................... 100

Foto 6.14: Plagioclásio zonado, rotacionado, arredondados e sombras de pressão preenchidas 
por quartzo e biotita. Granodioritos sem epidoto magmático. SGPM......................................... 100

Foto 6.15: Aspecto geral textura milonítica dos Granodioritos sem epidoto magmático. SGPM... 100

Foto 6.16: Aspecto da textura protomilonítica nos Granodioritos sem epidoto magmático. SGPM 100

Foto 6.17: Estiramento e orientação dos cristais de quartzo e anfibólio. Granodioritos. SGPM $\ldots 101$

Foto 6.18: Sigmóides de biotita e anfibólio e simplectitos de biotita e anfibólio. Granodioritos

sem epidoto magmático. SGPM

Foto 6.19 :Relação textural do epidoto com biotita orientados. Quartzo Morizodioritos

com epidoto magmático. SGPM.

Foto 6.20: Sigmóide de simplectito (anfibólio, biotita e epidoto). Quartzo Monzodioritos/

Granodioritos com epidoto magmático deformados. SGPM.

Foto 6.21:Deformação e orientação da biotita, epidoto e anfibólio. Quartzo Monzodioritos

/Granodioritos. SGPM.

Foto 6.22: Forte deformação e orientação de biotita, anfibólio, epídoto e allanita.

Quartzo Monzodioritos/Granodioritos. SGPM

Foto 6.23: Allanita manteada por epidoto e biotita. Quartzo monzodioritos/Granodionitos. SGP 102

Foto 6.24: Relação textural do epidoto com biotita, anfibólio e titanita em

Quartzo Monzodiorito/Granodioritos. SGPM.

Foto 6.25: Relação textural do epidoto com biotita e anfibólio. Quartzo Monzodioritos. SGPM...... 102

Foto 6.26: Epidoto euhédrico manteado por biotita e anfibólio com restos de anfibólio no

epidoto. Quartzo Monzodioritos. SGPM.

Foto 7.1: Serpentinização parcial de Harzburgitos.

Foto 7.2: Textura porfiroclástica à granular serpentinizada. SMUP.

Foto 7.3: Detalhe do processo de serpentinização em Harzburgitos.

Foto 7.4: Cristais de olivina serpentinizados e ortopiroxênio não serpentinizados. SMUP .............. 139

Foto 7.5: Detalhe de cristal de olivina parcialmente serpentinizado. SMUP .............................. 139

Foto 7.6: Detalhe de ortopiroxênio parcialmente serpentinizado (Bastita) SMUP,.......................... 139

Foto 7.7: Foliação em Serpentinitos (orientação da serpentina e magnetita). SMUP...................... 140

Foto 7.8: Detalhe da orientaçäo da magnetita em serpentinitos. SMUP ...................................... 140

Foto 7.9: Orientação de cristais de serpentina conforme a foliação ................................................ 140

Foto 7.10: Textura pseudomórfica (mesh) em Serpentinitos. SMUP.............................................. 140

Foto 7.11: Aspecto geral da textura porfiroclástica em olivina-piroxenitos. SMUP............................ 140

Foto 7.12: Textura granular (em mosáico) em Ortopiroxenitos. SMUP, ....................................... 141

Foto 7.13: Textura granular (tabular) em Gabros...................................................................... 141

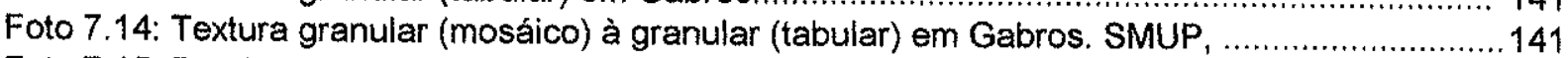

Foto 7.15: Detalhe de formação do anfibólio ao redor de clinopiroxénio em Gabros. SMUP........... 141

Foto 7.16: Foliação Sn anastomosada desenvolvida em peridotitos serpentinizados SMUP.......... 145

Foto 7.17: Detalhe da foliação Sn em peridotitos serpentinizados SMUP ................................... 145

Foto 7.18: Detalhe da foliação Sn em peridotitos serpentinizados SMUP................................... 145

Foto 7.19: Detalhe de dobras intrafoliais em serpentinitos SMUP............................................ 145 


\section{Agradecimentos}

Inicialmente, o meu obrigado aos amigos e professores Dr. Miguel Ângelo Stipp Basei e Dr. Oswaldo Siga Júnior pelas sugestões e críticas durante todo o curso desta pesquisa. (năo me façam pegar nojo outra vez).

Aos professores do IG-USP, Prof. Dr. Mário da Costa Campos Neto e Prof. Dr. Valdecir de Assis Janasi, os meus agradecimentos pelas sugestões, críticas, valiosas discussões e contribuições sobre os resultados dos estudos geológicos nesta região, desde o inicio do mestrado até o presente momento.

Aos meus amigos Cláudia Regina Passarelli, Hélcio dos Prazeres Filho, Maria da Glória Motta Garcia e Gilberto Alexander Kaulfuss pela importante ajuda nos trabalhos de laboratório, correção dos textos e confecção geral da tese, além das importantes sugestões. À Maria da Glória Motta Garcia em especial pelas sugestóes e correção ortográfica da maior parte da tese.

Ao amigo Prof. Dr. Gilson Guimarães, pelas importantes discussões, troca de idéias e informações sobre rochas graníticas em geral e, principalmente, pelo empréstimo do seu veiculo particular de campo, para a realização do mapeamento geológico nesta região.

Aos professores do IGC-USP, Prof. Dr. Benjamin (o mais querido ou o mais jovem dos filhos) Bley de Brito Neves pelo incentivo e pela sugestão "Alto Rio Negro" e Prof. Dr. Cláudio Riccomini pela disposição em ajudar.

Durante os trabalhos das análises geocronológicas realizados no Centro de Pesquisas Geocronológicas do Instituto de Geociências da USP (CPGeo-USP), gostaria de agradecer especialmente Walter M. Sproesser, Liliane Petronilho e Kay Sato e ainda Artur T. Ono, Ivone .K. Sonoki, Helen .M. Sonoki e Solange.

A fundação de Amparo a à pesquisa do Estado de São Paulo (FAPESP) pelo auxilio financeiro, durante dois anos e meio, na forma de bolsa de Doutorado (Processo 97/109642) e Reserva Técnica (98/2310- 5), sem os quais esta investigação não teria tido bons resultados.

Ao CNPq, pelo auxílio financeiro, na forma de bolsa de Doutorado, no periodo entre Março 1996 e Fevereiro 1998.

A todos os funcionários do Instituto de Geocienncias da USP pela atenção e serviços prestados, especialmente as secretárias da Seção de Pós-Graduação (Ana Paula e Magalí), 
secretárias do Departamento de Mineralogia e Geotectônica (Nícia, Sônia e Váleria), secretária do centro de Pesquisas Geocronológicas (Vera), Setor de Laminação (Cláudio, Paulo, Luiz e Roberto), Gráfica (Elmir, Claudionor e Enrique) e da Biblioteca.

Finalizando estes agradecimentos, desejo externar um agradecimento muito especial ao meu amigo/irmão Nelson Luis Chodur, sua esposa Mariléia Pereira Chodur e as filhas Andressa e Vanessa, pela hospedagem, onde tive mais do que a tranqüilidade necessária para a conclusão desta tese.

A todas as pessoas que contribuíram, de uma forma ou de outra, para a conclusão desta Tese do Doutoramento. 


\section{ABSTRACT}

New and recent geological investigations around Piên-Tijucas (suture) shear zone led to the identification of successive and different Neoproterozoic magmatic activities between 630 and $585 \mathrm{Ma}$. These magmatic activities are continuous responses to geotectonic scenery, which changes from subduction to collision and to late and post-collision extensional settings. The main geological units that were mapped and investigated by geochronological and petrological studies are: Gneiss-granulite Terrain, the Piên Maficultramafic Suite, the Piên-Mandirituba Granite Belt, and the Palermo, Agudos do Sul, Rio Negro and Tarumã Granites.

The Piên-Mandirituba calc-alkaline 1-type Granite Belt is a magmatic arc-related toward NW subduction zone. The suture zone results from oblique collision between the Piên-Mandirituba Granite Belt, to the north, and the reworked Neo-Archean-? Paleoproterozoic Gneiss-granulite Terrain, to the south. As a consequence, the neoproterozoic supra subduction zone (SSZ) Piên Mafic-ultramafic Suite is tectonically emplaced between these units. The Palermo, Agudos do Sul and Rio Negro Granites are late to post-collision A-PA type granites with mafic rocks and magma mixing processes.

The Piên-Mandirituba Granite Belt is formed by three main granite suites. The older (620-610 Ma, U-Pb zircon and titanite ages), pre-collisional granite suite is constituted by magmatic epidote-free deformed quartz monzodiorites to granodiorites and the younger (605-595 Ma, U-Pb zircon and titanite ages), sin-collisional granite suite is constituted by epidote-bearing deformed quartz monzodiorites, granodiorites and leuco-granodiorites. The third $\sin$ to late collisional granite suite is constituted by deformed biotite \pm amphibole monzogranites. Trace element contents such as $\mathrm{Rb}, \mathrm{Y}$, and $\mathrm{Nb}$, are compatible with continental arc-related granites both for the epidote-free and epidote-bearing granite suites. $\mathrm{Nd}, \mathrm{Sr}$ and $\delta^{18} \mathrm{O}(\mathrm{Zrc})$ isotopic data show clear differences between both suites and suggest mantle-derived mafic sources (amphibolitic, basaltic), more (epidote-free) or less contaminated (epidote-bearing) by infracrustal paleoproterozoic component (Gneiss-granulite Terrain). The K-Ar biotite ages between 607-595 and represent the principal collision age.

The Piên Mafic-Ultramafic Suite is an incomplete ophiolite sequence, composed by two ultramafic bodies tectonically emplaced along the Piên-Tijucas (Suture) shear zone and constituted by serpentinized peridotites, pyroxenites and rare tholeitic gabbros. The supra subduction zone (SSZ-type) residual mantle characteristics are indicated by the lithochemical signature such as $\mathrm{TiO}_{2}, \mathrm{Cr}, \mathrm{Co}, \mathrm{Y}$, and $\mathrm{Yb}$ contents of the peridotites. New U-Pb geochronological data (SHRIMP) on zircons of the tholeitic gabbros yielded crystallization ages of $631-632 \pm 17 / 18 \mathrm{Ma}$.

The Palermo, Agudos do Sul, and Rio Negro Granites are components of the expressive Neoproterozoic volcanic and plutonic alkaline-peralkaline Serra do Mar Suite (Kaul 1997), which was emplaced along the central and northern border of the Paleoproterozoic Gneiss-granulite Terrain, in extensional, late to post-collisional and anorogenic settings. The Palermo Granite is constituted mainly by non-deformed A-type amphibole-biotite and biotitetamphibole monzo-syenogranites. Slightly peralkaline (PA-type), sodic amphibole- and pyroxene-bearing quartz monzonites/quartz syenites and small intrusions of monzogabbros associated with mafic and felsic hybrid granites occur secondarily. The Rio Negro Granite exhibits a concentric zonation characterised by the presence, in the internal portion, of a high quantity small intrusions of monzogabbros and associated mafic and felsic hybrid granite rocks. In the external portion occur non-deformed, A-type biotitetamphibole monzo-syenogranites. The mafic and felsic hybrid granite rocks and associated monzogabbros occur more extensively in this granite than in the Palermo Granite. 
The Agudos do Sul Granite is essentially constituted by A-type leucogranodiorites with low contents of biotite and muscovite and miarolitic cavities with fluorite. The main accessories minerals are zircon, titanite, and apatite.

The A-type monzo-syenogranites of Palermo and Rio Negro are high silica $\left(\mathrm{SiO}_{2} 70\right.$ $80 \%$ ), aluminous with low $\mathrm{Al}_{2} \mathrm{O}_{3}, \mathrm{CaO}, \mathrm{MgO}, \mathrm{Sr}$, and $\mathrm{Ba}$ contents and high $\mathrm{K} 2 \mathrm{O}, \mathrm{Rb}, \mathrm{Ga}, \mathrm{Ta}$, $\mathrm{Nb}, \mathrm{Zr}, \mathrm{Hf}, \mathrm{U}, \mathrm{Th}, \mathrm{LREE}$, and HREE contents, with high Eu negative anomalies. These whole lithochemical characteristics, clearly indicate intraplate signature that are similar to all Serra do Mar volcanic and plutonic suite and to many world-wide A-PA type granites.

The Tarumä Granite represents the continuous magmatic activity between these contrasting I and A granite typology.

The monzogabbros intraplated in the Palermo and Rio Negro granites are alkaline and the main trace elements such as $\mathrm{Nb}, \mathrm{Ta}, \mathrm{Th}$, and $\mathrm{Yb}$ clearly indicate within plate signatures.

$\mathrm{U}-\mathrm{Pb}$ zircon dating yielded an age of $593 \pm 12 \mathrm{Ma}$ for the monzo-syenogranites of

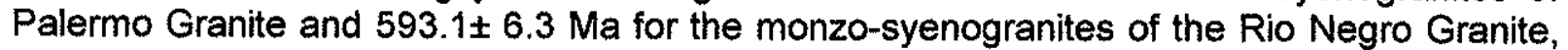
interpreted as the crystallization age of these rocks. For the monzogabbros of the Rio Negro Granite, U-Pb zircons isotopic data yielded an upper intercept age of $584 \pm 7 \mathrm{Ma}$, interpreted as the crystallization and cooling of the these rocks.

The $\in \mathrm{Nd}^{(\mathrm{T})}$ and $\mathrm{Sr}^{87} / \mathrm{Sr}^{8 \mathrm{G}(\mathrm{T})}$ of Palermo and Rio Negro monzogabbros are compatible with the contaminated intraplate and rift zone basalts. The same $\in \mathrm{Nd}^{(T)}$ for the monzosyenogranites, hybrid rocks and monzogabbros of the Rio Negro and Palermo granites suggest mixing, homogenisation and infracrustal contamination and probably generation of A-type monzo-syenogranites by melting of the contaminated monzogabbros. The average $\delta^{18} \mathrm{O}(\mathrm{Zrc})$ of $5.5 \%$ for monzogabbros are similar to the mantle values and do not indicate crustal contamination or contribution.

The Gneiss-granulite Terrain is constituted mainly by LILEE depleted mafic and felsic orthogranulites and biotitic and amphibolitic gneiss. Biotite and amphibole-rich mafic orthogranulite also occur. Garnet-rich mafic orthogranulites occur mainly along the PiênTijucas shear zone.

New U-Pb geochronological data on rounded and elliptical (Potato-type) zircon of mafic and felsic orthogranulites yielded ages between 2.1 and $2.0 \mathrm{Ga}$, interpreted as representative of high grade metamorphism period in the Gneiss-granulite Terrain. In the mafic granulite, elliptical and rounded zircons yielded an upper intercept age of $2062 \pm 65 \mathrm{Ma}$ with a zircon concordant age of $2059 \pm 6.6 \mathrm{Ma}$, when in the felsic granulites, rounded zircons yielded upper intercept age of $2.060 \pm 19 \mathrm{Ma}$ and the elliptical zircons yielded an upper intercept age of $2115 \pm 31 \mathrm{Ma}$. The age around $2060 \mathrm{Ma}$ of rounded metamorphic zircons in both mafic and felsic orthogranulites (or concordant rounded zircon age of $2059 \pm 6.6 \mathrm{Ma}$ ) is interpreted as the age of high grade metamorphism peak. Elliptical and acicular zircons extracted from biotite and amphibole- rich charnockites yielded similar an upper intercept age of $2200 \pm 7.3 / 9.9$. This age probably represents and indicates a previous high grade metamorphism. The time gap between $\mathrm{K}-\mathrm{Ar}$ and the $\mathrm{U}-\mathrm{Pb}$ rounded metamorphic zircon ages suggests a slow cooling path after the high grade metamorphism peak, in the Gneissgranulite Terrain.

This terrain remained tectonically stable until Neoproterozoic period, between 630 and $585 \mathrm{Ma}$, when its northern portion was heated ( $\mathrm{K}-\mathrm{Ar}$ ages) and involved by Neoproterozoic subduction, collision and post-collision tectonic-magmatic activities.

$\mathrm{Sm}-\mathrm{Nd}$ isotopic data indicate Neoarchean-paleoproterozoic depleted mantle Ages between 2.7 and $2.5 \mathrm{Ga}$ and suggesting the principal period of the mantle differentiation of the gneiss and granulite protholites. 


\section{0 - Introdução}

Os objetivos da presente pesquisa são o mapeamento geológico e o estudo petrológico e geocronológico dos litotipos da região do alto Rio Negro (PR-SC). Foram mapeadas e investigadas seis principais unidades geológicas: o Terreno Gnáissico Anfibolítico Granulítico do Paraná e Santa Catarina (TGAG), parte da porção norte da Microplaca Luis Alves, a Suite Máfica-Ultramáfica Piên (SMUP), a Suite Granítica PiênMandirituba (SGPM), o Granito Palermo (GP), o Granito Agudos do Sul (GAS), o Granito Rio Negro (GRN) e, alojado neste último, o Granito Tarumã (GT). Parte das bacias vulcanossedimentares Neoproterozóicas de Campo Alegre e Guaratubinha, do Granito Morro Redondo e a bacia quaternária de Tijucas do Sul afloram nesta região, mas não são alvos deste estudo.

Estas unidades geológicas mapeadas constituem parte da zona de transição neoproterozóica entre os terrenos paleoproterozóicos/neo-arqueanos? do TGAG, ao sul, e do Cinturão Gnáissico-Migmatítico de Atuba (CGMA) ao norte.

A área investigada situa-se na região do alto Rio Negro, divisa leste dos estados do Paraná e Santa Catarina, entre os municípios de São Bento do Sul-SC, Mandirituba-PR e Tijucas do Sul-PR e arredores (Figura 1.1). Esta região está inserida nas folhas planialtimétricas de Curitiba e Joinville (IBGE 1983, Escala 1:250.000) ou nas folhas Mandirituba, Tijucas do Sul, Campo Alegre (IBGE 1992, escala 1:50000) e São Miguel (serviço cartográfico do exército, escala 1:50.000). Os limites geográficos da área estão entre os paralelos $49^{\circ} 00^{\prime}$ e $49^{\circ} 30^{\prime}$ oeste e $25^{\circ} 45^{\prime}$ e $26^{\circ} 15^{\prime}$ sul.

A conclusão desta investigação geológica adiciona uma pequena mas importante contribuição para o melhor conhecimento geológico de parte da porção Sul-Brasileira.

\section{0 - Metodologias da Investigação Geológica}

Os dados geológicos foram obtidos por meio de mapeamento geológico, análise estrutural, análises petrográficas, análises litogeoquímicas e análises geocronológicas e isotópicas (métodos U-Pb em zircão e titanita, K-Ar em biotita e anfibólio, Sm-Nd em rocha total e minerais e, $\mathrm{Sr}^{87} / \mathrm{Sr}^{86(0)} \mathrm{em}$ rocha total). 


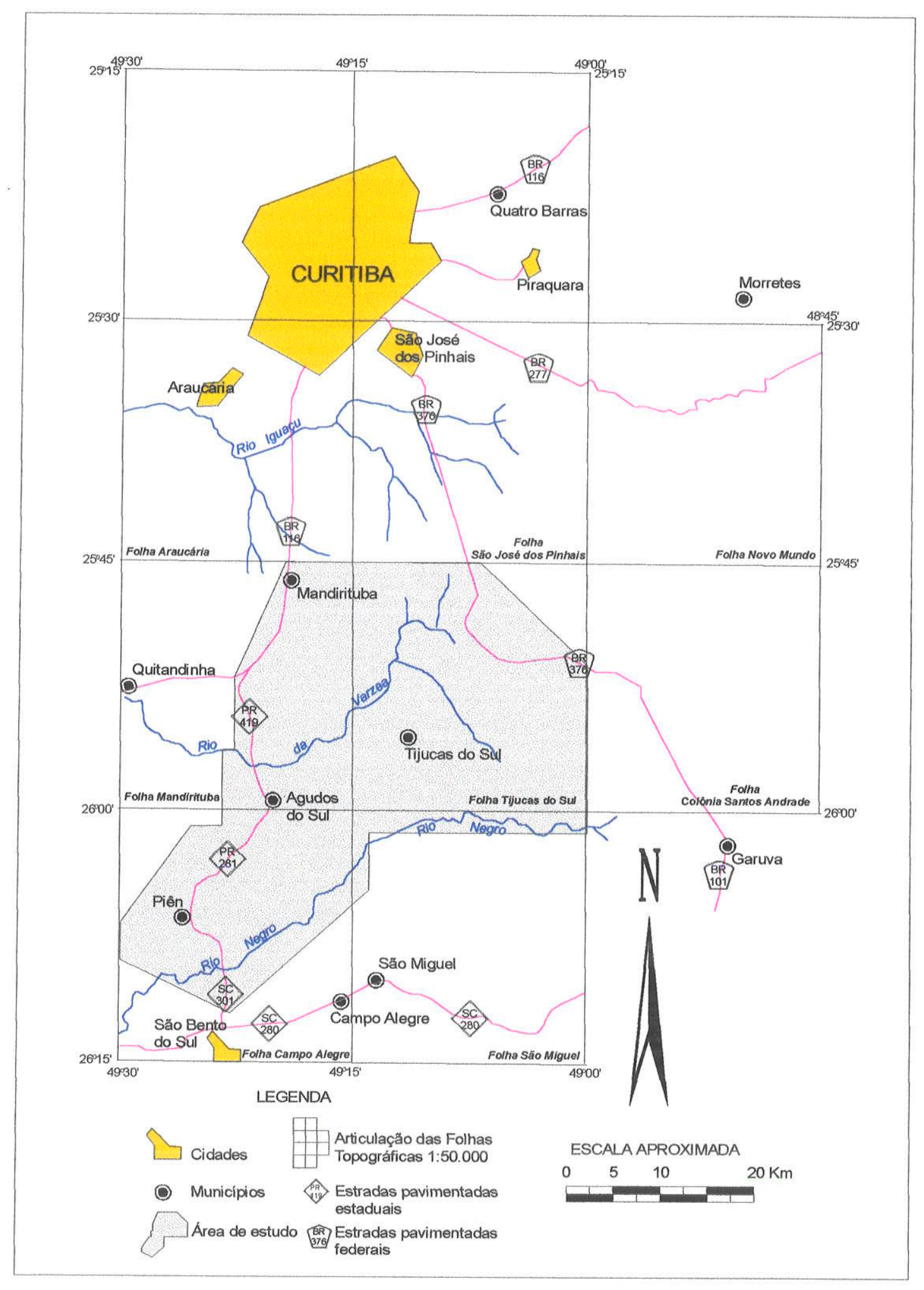

Figura 1.1 - Mapa de localização da área de pesquisa e vias de acesso 


\section{1- Mapeamento geológico}

O mapeamento geológico desta região foi feito utilizando como base, as folhas topográficas na escala de 1.50 .000 já citadas, teve com objetivo a confeç̧ão de perfis e mapa geológicos.

Devido a grande diversidade litológica da região, um total de 1141 afloramentos foram investigados. O mapa de controle e localização destes afloramentos encontra-se no anexo 2.

O mapa geológico final foi confeccionado com base tanto nas informações coletadas em campo como nos estudos petrográficos macro e microscópicos (Anexo 1). A partir deste mapa, foram elaborados perfis geológicos representativos da disposição e das relações entre as unidades mapeadas.

Para a melhor separação dos litotipos graníticos presentes no trecho oeste da porção sul da SGPM e para o melhor mapeamento do Granito Tarumã foram consultadas as descrições petrográficas microscópicas de amostras de rochas disponiveis nos trabalhos de mapeamento de graduação dos alunos da UFPR dos anos de 1987 e 1988.

\section{2- Petrografia}

Este estudo visa a descrição petrográfica macro e microscópica de amostras representativas das diferentes unidades geológicas mapeadas. Seus objetivos são a identificação e a separação dos principais litotipos de cada unidade, a identificação das principais assembléias mineralógicas presentes nas rochas, caracterização das relações macro e micro estruturais e texturais entre os minerais, estabelecimento da seqüência de início de cristalização e identificação das assembléias minerais metamórficas e do grau metamórfico, principalmente nas rochas do TGAG.

As descrições petrográficas foram também importantes bases para a escolha das rochas para as análises litoquímicas, geocronológicas e isotópicas.

As principais e mais importantes macro e micro estruturas e texturas observadas nas rochas são ilustradas neste estudo por meio de fotos e fotomicrografias.

\section{3- Litoquímica}

Um dos objetivo deste estudo é utilizar os dados litoquímicos obtidos em rochas representativas de cada unidade mapeada para a extração de importantes informações 
geológicas. Este investimento em litoquímica ou "microscopia litoquímica" em diversas rochas da região, tem fornecido importante suporte científico às interpretações geológicas.

As análises litoquimicas foram realizadas no laboratório Actlabs-Canadá. Neste laboratório, as análises dos óxidos $\left(\mathrm{SiO}_{2}, \mathrm{TiO}_{2}, \mathrm{Al}_{2} \mathrm{O}_{3}, \mathrm{Fe}_{2} \mathrm{O}_{3} \mathrm{~T}, \mathrm{MnO}, \mathrm{MgO}, \mathrm{CaO}, \mathrm{Na}_{2} \mathrm{O}, \mathrm{K}_{2} \mathrm{O}\right.$, $\mathrm{P}_{2} \mathrm{O}_{5}$ ) são feitos pelo método ICP, enquanto os elementos traços ( $\mathrm{Ba}, \mathrm{Rb}, \mathrm{Sr}, \mathrm{Cs}, \mathrm{Ga}, \mathrm{Ta}$, $\mathrm{Nb}, \mathrm{Hf}, \mathrm{Zr}, \mathrm{Y}, \mathrm{Th}, \mathrm{U}, \mathrm{Cr}, \mathrm{Ni}, \mathrm{Co}, \mathrm{Sc}, \mathrm{V}, \mathrm{Cu}, \mathrm{Pb}, \mathrm{Zn}$ ) e terras raras (La, Ce, Pr, Nd, Sm, Eu, Gd, Tb, Dy, Ho, Er, Tm, Yb e Lu) são feitos pelo método ICP-MS.

Foram efetuadas análises químicas em 21 amostras de rochas do Granito Palermo (GP), 17 do Granito Rio Negro (GRN), 6 do Granito Agudos do Sul (GAS), 4 do Granito Tarumã (GT), 33 da SGPM, 19 da SMUP e 26 do TGAG. Os resultados analíticos obtidos nestas rochas são apresentados no Anexo 3 . Incluem-se nesta relação análises químicas referente ao trabalho de mestrado de Harara (1996).

Somente os resultados das análises químicas das rochas do TGAG e da SMUP são apresentados de forma resumida, nos capítulos 7.0 e 8.0. As demais análises químicas das rochas dos granitos GP, GRN, GAS, GT e da SGPM, serão apresentadas e discutidas nos capítulos 5.0 e 6.0 .

\section{4- Geocronologia e Geologia Isotópica}

Os critérios utilizados na escolha das rochas para análises geocronológicas e isotópicas foram, a necessidade, a carência e o tipo da informação geológica desejada. Além disso foram levados em conta as limitações e resolução de cada método geocronológico e isotópico empregado e seu significado geológico.

Em razão da variedade das unidades geológicas e dos litotipos constituintes foi necessário o levantamento de uma grande quantidade de dados geocronológicos e isotópicos. Estes métodos foram aplicados em amostras representativas dos principais litotipos mapeados e são: U-Pb em zircão e titanita, K-Ar em biotita e anfibólio, $\mathrm{Sm}-\mathrm{Nd}$ em rocha total e minerais e $\mathrm{Rb}-\mathrm{Sr}$ em rocha total, bem como, análises das razöes $\mathrm{Sr}^{87} / \mathrm{Sr}^{86(0)}$ atuais em rocha total. A relação das amostras investigadas via geocronologia e geologia isotópica serão apresentadas nas seções correspondentes a cada unidade.

A separação de zircão e titanita para a metodologia U-Pb e a seqüência dos procedimentos nas análises químicas e espectrométricas foram realizados conforme as recomendações e os procedimentos do CPGeo-USP (Centro de Pesquisas Geocronológicas da Universidade de São Paulo), que encontram-se detalhados em Basei et al. (1995). As idades U-Pb em zircões são indicativas da idade da formação/cristalização 
das rochas magmáticas em geral ou da recristalização metamórfica e idade do metamorfismo de alto grau, no caso das rochas do TGAG.

Para o cálculo dos resultados analíticos, das idades U-Pb em zircões e das idades isocrônicas $\mathrm{Rb}-\mathrm{Sr}$ e Sm-Nd utilizou-se o programa de Ludwig (1994).

Os dados Rb-Sr em rocha total referentes à SGPM foram extraidos de Harara (1996) e aqueles referentes aos Granitos GAS e GP foram retirados de Siga Jr. (1995) e Kaul (1997). As análises da razão $S r^{87} / S r^{86(0)}$ em rocha foram feitas nas mesmas rochas analisadas via Sm-Nd. A comparação entre razão $\mathrm{Sr}^{87} / \mathrm{Sr}^{86(0)}$ da rocha e do reservatório condrítico (CHUR) para a idade da formação/cristalização da rocha (exceto rochas monzosienograníticas do GP e GRN com baixos a muito baixos valores de $\mathrm{Sr}$ ) fornece a estimativa da razão $\mathrm{Sr}^{87} / \mathrm{Sr}^{86(\mathrm{~T})}$ no tempo da cristalização das rochas. Os valores de $\mathrm{Sr}^{(\mathrm{T})}$ para a idade da formação da rocha foram calculados com base nos seguintes valores: $\mathrm{Sr}^{87} / \mathrm{Sr}^{86}=0.7045$ $\mathrm{Rb}^{87} / \mathrm{Sr}^{86}=0.0827$.

A metodologia K-Ar foi aplicada em biotita e anfibólio de litotipos representativos das unidades geológicas mapeadas. As temperaturas criticas (Tc) de difusão/retenção do gás argônio dentro do retículo cristalino do mineral são da ordem de $250 \pm 50^{\circ} \mathrm{C}$ para a biotita (Harrison et al. 1985) e de $500 \pm 50{ }^{\circ} \mathrm{C}$ para 0 anfibólio (Harrison, 1981). Estas temperaturas, da retenção do argônio para cada mineral, têm um intervalo restrito na qual se passa de um estado de perda completa do argónio (temperatura acima da Tc) para um estado de retenção completa do argônio (temperatura abaixo da Tc), podendo ainda haver situações de perdas parciais de Ar.

A datação de biotita e anfibólio pela metodologia $\mathrm{K}$-Ar fornece importantes informações geológicas como idades de resfriamento das rochas (que podem ser um pouco ou bem mais jovens do que as idades da cristalização magmática ou recristalização metamórfica fornecidas pelo método U.Pb em zircões) e o último evento térmico sofrido pela rocha, independente da idade da cristalização magmática ou recristalização metamórfica. Devido às diferentes temperaturas de difusão, a utilização conjunta das idades $\mathrm{K}$-Ar em biotita e anfibólio e a sua comparação com as idades em zircões ou titanita, entre rochas cogenéticas ou não, fornecem importantes informações geológicas.

A metodologia $\mathrm{K}-\mathrm{Ar}$ requer a obtenção de concentrados minerais puros (biotita, anfibólio, plagioclásio) que serão utilizados no ataque químico (análise de $\% \mathrm{~K}$ do mineral, duplicata de 0,09 a 0,1 grama do mineral) e na extração e dosagem do argônio da amostra. Para minimizar a interferência e o efeito de inclusőes minerais em biotita e anfibólio e aumentar a pureza dos concentrados utilizamos preferencialmente frações de biotita e 
anfibólio entre $100(0,150 \mathrm{~mm})$ e 150 Mesh $(0,106 \mathrm{~mm})$ e, mais raramente, concentrados entre $60(0.250 \mathrm{~mm})$ e $100 \mathrm{Mesh}$.

A metodologia Sm-Nd foi aplicada em minerais (somente TGAG) e rocha total dos principais litotipos das unidades geológicas mapeadas.

A comparação entre a razão $\mathrm{Nd}^{143} / \mathrm{Nd}^{144}$ da rocha e do reservatório condrítico (CHUR) para a idade da formação da rocha $\left(\in \mathrm{Nd}^{(T)}\right)$ possibilita a utilização dos isótopos de $\mathrm{Nd}$ como indicadores petrogenéticos. Valores de $\in \mathrm{Nd}^{(T)}$ positivos ou iguais a zero indicam fontes mantélicas enquanto valores pouco negativos representam fontes mantélicas com contribuição infra ou supra crustal dependendo ainda dos valores do $\left(\in \mathrm{Sr}^{(T)}\right)$. Valores intermediários pouco a muito negativos de $\in \mathrm{Nd}^{(\top)}$ são interpretados geralmente como resultado de interação manto/crosta com mistura de componentes mantélicos e infra e/ou supracrustais e até manto enriquecido, dependendo dos valores de $\in \mathrm{Sr}^{(\mathrm{T})}$. Podem ainda indicar retrabalhamento de rochas fontes supra ou infracrustais, dependendo também dos resultados dos outros indicadores petrogenéticos como $\mathrm{Sr}, \mathrm{Pb}, \mathrm{Os}, \mathrm{Hf}$ e até de isótopos de oxigênio em rocha total ou minerais (quartzo e zircão). Variações destas interpretações convencionais sobre os isótopos de Nd nas rochas em geral permanecem em dúvida e discussão.

A seqüência dos procedimentos quimicos e espectrométricos utilizados no CPGeoUSP para a metodologia Sm-Nd encontram-se em Kawashita et al. (1991) e Sato et al. (1995). As constantes utilizadas no cálculo das idades modelo $\mathrm{Sm}-\mathrm{Nd}\left(\mathrm{T}_{\mathrm{DM}}\right)$ e dos valores do $\in$ Nd são as seguintes (Jacobsen \& Wasserburg 1980, Jacobsen \& Wasserburg 1984): $\left(\mathrm{Nd}^{143} / \mathrm{Nd}^{144}\right)_{0} \mathrm{CHUR}$ (Chondritic Uniform Reservoir) $=0,5112638,\left(\mathrm{Nd}^{143} / \mathrm{Nd}^{144}\right)_{0} \mathrm{DM}$ (Depleted Mantle Reservoir $)=0,513114,\left(\mathrm{Sm}^{147} / \mathrm{Nd}^{144}\right)_{0} \mathrm{CHUR}=0,1967,\left(\mathrm{Sm}^{147} / \mathrm{Nd}^{144}\right)_{0} \mathrm{DM}=0,222$. As idades modelo $T_{D M}$ foram calculadas com base nos valores do Depleted Mantle Reservoir e os valores do $\in \mathrm{Nd}$ foram calculados com base nos valores do CHUR.

A escala do tempo geológico utilizada, para referenciar as eras e os períodos geológicos registrados nesta região com base em datações isotópicas, foi baseada em Fuck (1991). Nesta referência, as subdivisões do Pré-Cambriano são as seguintes: ArqueanoNeo-Arqueano (entre 2800 e $2500 \mathrm{Ma}$ ), limite Neo-Arqueano-Paleoproterozóico ( 2500 Ma), Paleoproterozóico (2500-1600 Ma), Mesoproterozóico (1600-1000 Ma) e Neoproterozóico (1000 a 540(?) Ma). Dentro da era Neoproterozóica, o período do Neoproterozóico Ill está entre 650 e 540 (?) Ma. 


\section{3 - Contexto Geológico Regional}

\section{1 - Introdução}

A região investigada (Figura 3.1) está situada na zona de transição entre a margem norte do Terreno Gnáissico Anfibolítico-Granulítico do Paraná e Santa Catarina (TGAG) e o Cinturão Gnáissico-Migmatítico Atuba (CGMA), componentes do embasamento paleoproterozóico-neoarqueano exposto entre os cinturões neoproterozóicos Apiaí (Ribeira), ao norte, e Dom Feliciano, ao sul. Nesta região, entre o limite norte do TGAG com o CGMA, afloram a Suite Máfica-Ultramáfica Piên (SMUP), a Suite Granítica Piên-Mandirituba (SGPM) e o Maciço Granítico Agudos do Sul (MGAS), dividido neste trabalho em, Granito Palermo, Granito Rio Negro, Granito Agudos do Sul e Granito Tarumã.

O TGAG tem recebido várias denominações, como: Complexo Granulítico de Santa Catarina (Hartmann et al. 1979), Cráton Luis Alves (Kaul 1980), Complexo Luis Alves (Kaul \& Teixeira 1982), Microplaca Luis Alves (Basei et al. 1992) ou Dominio Luis Alves (Siga Jr. 1995). O CGMA tem sido incluído na porção norte da Microplaca Curitiba (Basei et al. 1992) ou na porção norte do Dominio Curitiba (Siga Jr. 1995), sendo mais recentemente denominado Complexo Atuba (Siga Jr. et al. 1995).

O avanço no conhecimento geológico da porção sudeste do Paraná e nordeste de Santa Catarina tornou-se significativo a partir dos levantamentos geológicos realizados por Basei \& Siga Jr. e colaboradores a partir do fim dos anos 80 e o início dos anos 90 . A constante adição de novas informações geológicas tornou possível, assim, uma melhor compreensão do quadro evolutivo da região.

A seguir são relatados os principais dados geológicos existentes, até o momento, nas unidades geológicas regionais nas quais se insere a área pesquisada.

\section{2 - O Terreno Gnáissico Anfibolito-Granulitico do Paraná e Santa Catarina (TGAG)}

O Terreno Gnáissico Anfibolítico-Granulítico do Paraná e Santa Catarina aflora desde a borda norte do Cinturão Dom Feliciano (Basei 1985), ao sul, até a região de ltatinsSP, a norte, passando por Piên-PR, Tijucas do Sul-PR e Serra Negra-PR (Figura 3.1) e atingindo uma largura máxima de aproximadamente $100 \mathrm{Km}$ (Wernick 1979, Hartmann et al. 1979, Kaul 1980, Kaul \& Teixeira 1982, Cordani \& Brito Neves 1982, Wernick \& Oliveira 1982, Silva 1984 e 1987, Basei \& Teixeira 1987, lyer et al 19987, Brito Neves \& Cordani 1991, Basei et al. 1992, Siga Jr. et al. 1990, Figueiredo et al. 1991, Siga Jr. 1995, Basei et al.1997, Fornari 1998 e Basei et al. 1998). O limite norte se faz tectonicamente com a 
SGPM, por meio da qual é separada do CGMA. A leste, o contato com o Cinturão Granítico Costeiro ou Cinturão Granítico São Francisco do Sul - Paranaguá, é feito pelas zonas de cisalhamento Garuva, Alexandra e Serra Negra. A oeste encontra-se coberto pelos sedimentos paleo-mesozóicos da Bacia do Paraná.

O conhecimento geológico sobre o TGAG como um todo é ainda muito preliminar e sua evolução geológica pouco conhecida, principalmente em razão da falta de estudos sistemáticos. Mapeamento de detalhe ou semi detalhe discriminando os principais litotipos do TGAG e, adicionalmente, estudos petrológicos e geocronológicos mais aprofundados, permitiriam maiores esclarecimentos e o resgate da sua história geológica durante o Arqueano-Paleoproterozóico.

O TGAG, segundo os referidos autores, é constituido principalmente por ortognaisses granuliticos félsicos, intermediários e máficos, bandados a maciços. Associamse e intercalam-se com biotita-gnaisses, biotita-anfibólio gnaisses e anfibólio-biotita gnaisses (suites graníticas tipo Tijucas do Sul-PR, Pomerode-SC, Indaial-SC e Ibirama-SC) de composições thronjemítica-tonalítica-granodioritica/enderbítica-charnoenderbítica, com freqüentes variações para composições, quartzo-dioriticas/quartzo-noríticas e dioríticasnoríticas. Os novos mapeamentos revelam cada vez mais a presença de expressivas áreas constituidas por gnaisses, migmatitos e granitos deformados com biotita e anfibólio que não mostram quaisquer assembléias tipicas de metamorfismo de alto grau. Adicionalmente, ocorrem freqüentemente lentes de rochas máficas-ultramáficas, tais como anfibolitos, piroxenitos, noritos, gabronoritos e gabros (suites tipo Barra Velha-SC, Blumenau-SC e Massaranduba-SC) e rochas ultramáficas (dunitos e harzburgitos parcial a totalmente serpentinizados). Ocorrem ainda rochas gnáissicas alcalinas como dioritos, monzodioritos, monzonitos e sienitos da suite tipo Braço do Gavião, aflorante na porção meridional leste da unidade (Fornari 1998 e Hartmann et al. 1998), granulitos piroxeníticos, leucogranitos deformados (suite granítica tipo Ibirama-SC), quartzitos e granada-quartzitos, gnaisses kinzigiticos e formações ferriferas bandadas.

O TGAG mostra um padrão estrutural bastante complexo (Basei et al. 1992, Siga Jr. 1995 e Siga Jr. et al. 1995) caracterizado por um bandamento regional $\mathrm{Sn}$ com orientação que varia de $\mathrm{N} 30 \mathrm{E}$ a N4OW com mergulhos entre $60^{\circ}$ a $70^{\circ}$ predominantemente para NE e SW. $O$ bandamento é uma superfície $S_{2}$ paleoproterozóica gerada em condições de fácies anfibolito a granulito e que apresenta-se dobrada, com plano axial na direção NW/SE e eixos com orientações variando entre $\mathrm{S} 30-50 \mathrm{E} / 40^{\circ}-60^{\circ}$ e N20-60W/40 $\mathrm{N}-80^{\circ}$. Uma superfície de transposição $S n+1$ ocorre geralmente paralela a este bandamento. 


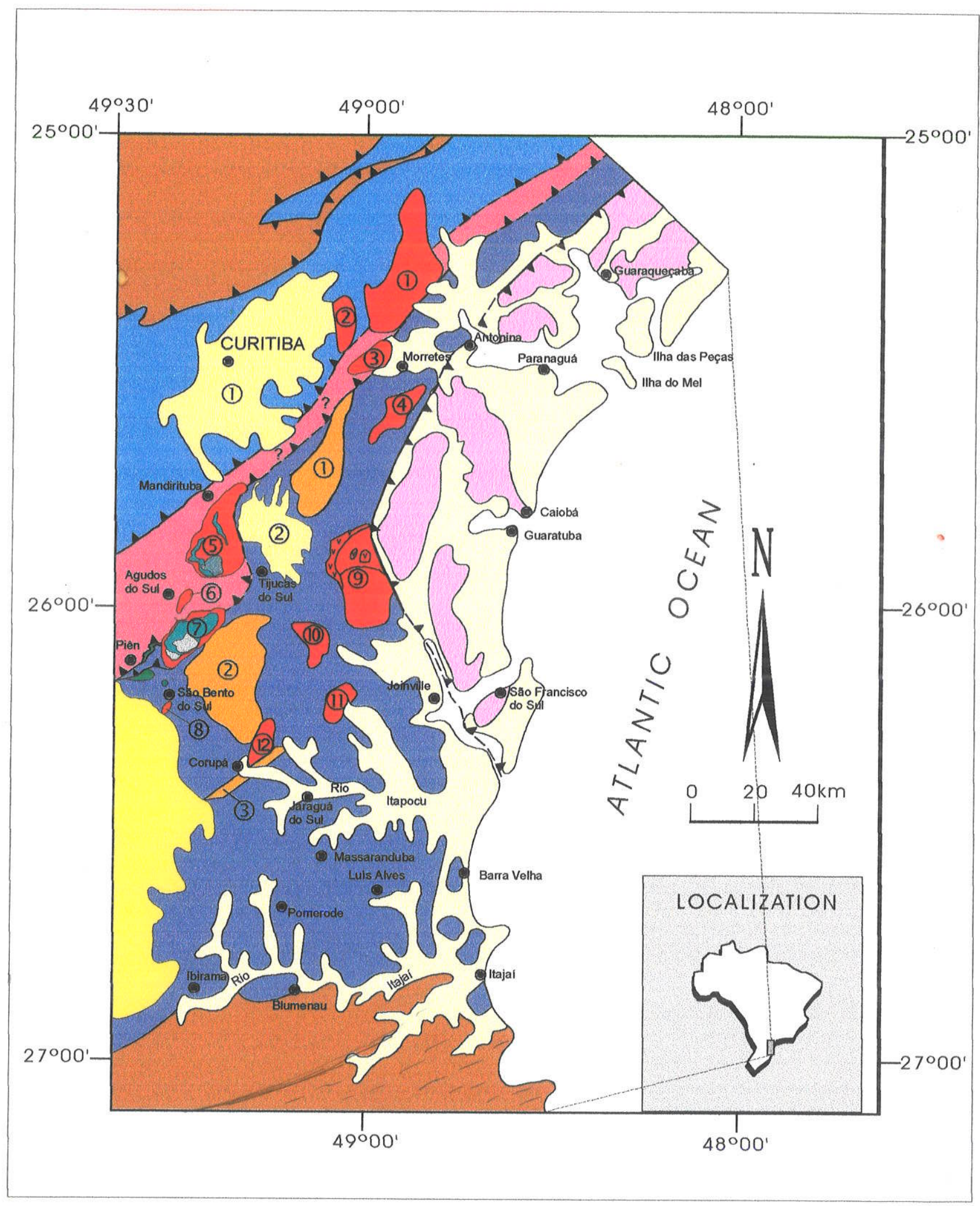

Figura 3.1 - Mapa Geológico do Sul do Estado do Paraná e Nordeste do Estado de Santa Catarina (Modificado de Siga Jr. 1995, Kaul 1997 and Basei et al 1999) 
Recent Alluvium

Cenozoic Sedimentary Basins : (1) Curitiba and (2) Tijucas do Sul.

Paleozoic Sediments of Paraná Basin.

Neoproterozoic III (600- 585 Ma) Alkaline-Peralkaline (A-PA) Plutonic and Vulcanic Serra do Mar Suite and the Underplated (?) and Intraplated Alcaline Monzogabbros and the associated mafic and Felsic hybrid granite rocks

Vulcano-sedimentary Basins: (1) Guaratubinha, (2) Campo Alegre and (3) Corupa. The felsic A-type vulcanic rocks emplaced within theses basins are mainly Riolites and Traquites are subordinate. The Alkaline mafic rocks (Gabbros to Monzogabbros and Basalts to andesitic Basalts) are rare and mainly present in the Campo Alegre Basin.

A-PA Serra do Mar Granite Suite: (1) Graciosa Granite, (2) Anhangava, (3) Marumbi, (4) Serra da Igreja, (5) Palermo, (6) Agudos do Sul, (7) Rio Negro, (8) Serra Alta, (9) Morro Redondo, (10) Dona Francisca, (11) Piraí and (12) Corupá.

Non-deformed and isotrope Monzo to Syenogranites, Syenogranites, Quartz-Syenites-Quartz-

Monzonites to Syenites-Monzonites and. Alcali-Feldspar Granites. The predominant mafic mineral phase in the alkaline granites are biotite and Biotite \pm Amphibole and in the peralkaline granites are biotite and calcic (Hornblende) and sodic (Arfvdsonite and Riebeckite) amphibole and pyroxene (Aegerine and Aegerine-Augite) and scarce olivine (fayalite). The hybrid mafic and felsic rocks are present only in the Palermo and Rio Negro Granites.

Neoproterozoic III ( \pm 600 Ma) Low to Medium Grade Metamorphic Complexes.

Vulcano-sedimentary Metamorphic Complexes, components of the Apiai (Ribeira) Belt to norte and, Itajai vulcanosedimentary Basin and Brusque vulcanosedimentary Metamorphic Complex, components of the Dom Feliciano Belt, to south.

\section{Neoproterozoic III (620 - 600 Ma) Deformed Cálc-Alkaline Granite Belts}

Piên-Mandirituba Granite Belt. Arc-Related, deformed to highly deformed medium to mainly high $\mathrm{K}$ Calc-Alkaline I-Type Granites. Biotite and amphibole-Bearing, Quartz-Monzodiorites, High mafic low silica Granodiorites to low mafic and high silica Leuco-Granodiorites and Monzogranites.with or without magmatic epidote. The K-Ar biotite ages are mainly between 605 and $595 \mathrm{Ma}$.

São Francisco do Sul - Paranaguá, Coastal Granite Belt. Arc-Related (?) deformed and isotrope high $\mathrm{K}$ Calc-Alkaline, I-Type granites. Biotite and amphibole-Bearing, Porphyritic Granodiorites and Monzogranites. The K-Ar Biotite ages ( $560-480 \mathrm{Ma}$ ) in this granite belt are younger than PiênMandirituba Granite Belt.

\section{Neoproterozoic III ( \pm 650-630 Ma) Piên Mafic-Ultramafic Suite}

Supra-Subduction Zone "SSZ-Type" mantle rocks. Highly deformed and serpentinized dunites and harzburgites, associated and correlated Olivine-Pyroxenites, Pyroxenites and rare Neoproterozoic $( \pm$ $650-630 \mathrm{Ma})$ tholeitic gabbros.

\section{Archean (?) - Paleoproterozoic (Deformed Granites-Gneisses-Migmatites-Orthogranulites) Terrains}

Atuba (Mainly Deformed Granites-Gneisses-Migmatites) Belt. Biotite and Amphibole bearing Gneisses and Migmatites with scarce orthogranulite-gneiss expositions (Ex. Curitiba and Itatins Granulites) and, I and A-Type deformed granites. The whole Terrain is highly deformed during the Neoproterooic III Period (620-600 Ma) with only total reseting of the K-Ar biotite and amphibole ages and, production of foliated and non-foliated leucogranites correlated to Piên-Mandirituba Granite Belt emplacement.

Paraná and Santa Catarina (Deformed Granites-Gneisses-Migmatites-Granulites Terrain). Mainly granulitic orthogneisses and, biotite and amphibole-bearing Gneisses (Monzodiorites, Diorites QuartzDiorites and Tonalites, Ex. Pomerode-type, Ibirama-type and Tijucas do Sul-type suites). Subordinatelly occur, Deformed Leucogranites (Ex. Ibirama-type suite), Serpentinized ultramafic (dunites and harzburgites, pyroxenites) lenses, mafic-ultramafic (amphibolites and pyroxenites, Barra Velha typesuite), quartzites, banded iron formations and rare S-Type migmatites-Granulites Gneisses (Ex. GarnetQuartzite, SW pomerode-SC) 
Estudos geotermobarométricos em rochas granuliticas da porção meridional do TGAG (Fornari, 1998) apontaram valores de pressão entre 5 e 6 kbar e temperaturas em torno de $800^{\circ} \mathrm{C}$. Estimativas acerca das condições de pressão e temperatura do metamorfismo granulitico (Girardi 1974, Girardi e Ulbrich 1980) feitas em rochas da porção norte do TGAG (exatamente na região ora investigada) indicaram pressões entre 5 e $7 \mathrm{kbar}$ e temperaturas ao redor de $800^{\circ} \mathrm{C}$. Hartmann (1988) obteve temperaturas em torno de $800^{\circ} \mathrm{C}$ para rochas granulíticas da porção meridional da unidade.

Os dados geocronológicos U-Pb, Rb-Sr, Pb-Pb, Sm-Nd e K-Ar (Cordani 1974, Girardi et al. 1974, Kaul \& Teixeira 1982, Basei 1985, Basei \& Teixeira 1987, Siga Jr. et al. 1990, Machiavelli 1991, Basei et al. 1992, Hartmann et al. 1998, Siga Jr. 1995, Harara et al. 1995, Harara 1996, Basei et al.1997 a e b, Basei et al. 1998 e Hartmann et al. 1998) indicam uma história geológica arqueana(?)-paleoproterozóica envolvendo estabilização tectônica no final do Paleoproterozóico (Tabela 3.1). Idades U-Pb ao redor de $2.4 \mathrm{Ga}$ obtidas em zircões das rochas granuliticas e idades isocrônicas $\mathrm{Rb}-\mathrm{Sr}$ (rocha total) entre 2.8 a $2.6 \mathrm{Ga}$ com razões $\mathrm{Sr}^{87} / \mathrm{Sr}^{86(l)}$ entre 0.702 e 0.704 , são encontradas principalmente na porção sul. Segundo os referidos autores, estas seriam representativas da época de formação e incorporação à crosta dos protólitos ígneos das rochas granulíticas. No restante do TGAG, principalmente na porção norte, a maioria das idades U-Pb e $\mathrm{Rb}-\mathrm{Sr}$ em rochas granulíticas estão entre 2.2 e $2.0 \mathrm{Ga}$ e representariam a época do metamorfismo granulítico. A variação nas idades U$\mathrm{Pb}$ em zircões e $\mathrm{Rb}-\mathrm{Sr}$ (rocha total) sugere a existência de rochas antigas diferenciadas e submetidas à granulitização em épocas distintas (Arqueano?-Paleoproterozóico).

Para os gnaisses granulíticos das porções central e meridional da unidade, o retrabalhamento de análises $U-\mathrm{Pb}$ em zircões prévias, somadas aos novos dados (Basei et al. 1999 e Basei 2000), permitiram o estabelecimento da idade do metamorfismo granulítico ao redor de $2350 \pm 20$. Esta interpretação, segundo os autores, baseia-se no fato de que em inúmeras localidades do complexo são obtidas idades neste intervalo em cristais de zircões com morfologia típica de rochas granulíticas (formas esféricas e elipsoidais). Uma segunda população de zircões (euhédricos e prismáticos) foi identificada em alguns granulitos, indicando idades próximas a $2.2 \mathrm{Ga}$ e sendo associados à descompressão que ocorre logo após o clímax do metamorfismo de alto grau (Basei et al. 1999 e Basei 2000). Em uma amostra de charno-enderbito coletada nas proximidades de Massaranduba-SC, ambas as populações foram reconhecidas e alinharam-se em uma mesma discórdia, com idade do intercepto superior ao redor de $2,35 \mathrm{Ga}$ (Basei et al 1998). Idades U-Pb ao redor de $2.28 \mathrm{Ga}$ (Basei 2000) foram obtidas em monazitas extraidas dos raros granulitos de origem sedimentar (granada-quartzitos com ortopiroxênio). Os leucogranitos deformados 
aflorantes na região de Ibirama-SC forneceram idades U-Pb em zircões ao redor de $2112 \pm$ 21 (Basei et al 1999), interpretadas como representativas da época de formação dos mesmos e sincrônicas aos eventos metamórficos paleoproterozóicos de alto grau. Segundo (Basei 2000), o alto grau de discordância observado em grande parte dos zircões é uma caracteristica marcante do TGAG, devendo tal fato representar sua evolução policíclica, bem como a forte herança crustal anterior aos eventos metamórficos. Isto sugere que, ao contrário do que foi observado no CGMA, os eventos ígneos geradores dos protólitos dos granulitos e o metamorfismo de alto grau foram separados por um considerável periodo de tempo. De acordo com o mesmo autor, o TGAG é uma unidade policíclica de idade paleoproterozóica cujos principais eventos metamórficos e deformacionais ocorreram no intervalo entre 3.35 e $2.1 \mathrm{Ga}$.

Os principais dados isotópicos $\mathrm{Sm}-\mathrm{Nd}$ revelaram idades modelo ( $\mathrm{T}_{\mathrm{DM}}$ ) predominantemente entre 2.7 e $2.5 \mathrm{Ga}$, com raras idades ao redor de $3.0 \mathrm{Ga}$, o que sugere que a diferenciação dos protólitos dos litotipos granulíticos tenha ocorrido durante a transição Paleoproterozóico-Arqueano e Arqueano.

Os perfis térmicos e geocronológicos $\mathrm{K}-\mathrm{Ar}$ em minerais (principalmente biotitas e anfibólios) ao longo e entre as bordas sul e norte do TGAG (Siga Jr. et al. 1990, Siga Jr. 1995 e Harara et al. 1997 a e b) apontam para um intervalo de idades entre 1.9 e $1.7 \mathrm{Ga}$ com um agrupamento modal ao redor de $1.8 \mathrm{Ga}$, indicando resfriamento e estabilidade tectônica desde o final do Paleoproterozóico. Ao contrário, nas proximidades da porção norte da unidade (região de Piên-PR e adjacências), as idades são híbridas (meso a neoproterozóicas) e resultam da reativação termo-tectônica desta margem do TGAG. Estes perfis sugerem, respectivamente, para as bordas sul e norte, um contato geológico frontal e frio do TGAG com o Cinturão Dom Feliciano e contato frontal e quente do TGAG com a SGPM e o CGMA. 
Tabela 3.1 - Relação dos principais dados geocronológicos @ isotópicos do TGAG

\begin{tabular}{|c|c|c|c|c|c|c|}
\hline $\begin{array}{l}\text { Mëtodo } \\
\text { Geocronológico }\end{array}$ & Mineral/Rocha Total & Lifotipo & Idade (Ma) \pm Erro & $\mathrm{Sr}^{87} / \mathrm{Sr}^{86}(\mathrm{i})$ & $\begin{array}{l}\text { Lucalizarião da } \\
\text { Amostra }\end{array}$ & Fontes Bibliog ráficas \\
\hline $\begin{array}{l}\text { U-Pb } \\
\text { U-Pp } \\
\text { U-Pb } \\
\text { U-Pb } \\
\text { U-Pb } \\
\text { U-Pb } \\
\text { U-Pb } \\
\text { U-Pb } \\
\text { U-Pb }\end{array}$ & $\begin{array}{l}\text { Zircão } \\
\text { Zircão } \\
\text { Zircão } \\
\text { Zircão (rosado) } \\
\text { Zircão (marron) } \\
\text { Zircão (esférico e elipsoidal) } \\
\text { Zircão (prismético) } \\
\text { Zircão } \\
\text { Monazita }\end{array}$ & $\begin{array}{l}\text { Gnaisses Granuliticios } \\
\text { Migmatitos } \\
\text { Gnaisses Granulfitios } \\
\text { Gnaisses Granulíticos } \\
\text { Gnaisses Granulificios } \\
\text { Chamo-Enclerbito } \\
\text { Chamo-Enderbito } \\
\text { Leucogranilo } \\
\text { Granada-Quartzito }\end{array}$ & $\begin{array}{l}2400 \\
2890 \\
2200 \pm 2 \\
2247 \pm 18 \\
2360 \pm 100 \\
2338 \pm 37 \\
2204 \pm 33 / 30 \\
2112 \pm 21 \\
22834 \pm 4.213 .3\end{array}$ & & $\begin{array}{l}\text { Luís Alves-SC } \\
\text { Luís Alves-SC } \\
\text { Dona Francista-SC } \\
\text { Dona Francista-SC } \\
\text { Dona Francisc:a-SC } \\
\text { Luis Alves-SC } \\
\text { Luis Alves-SC } \\
\text { Ibiram:a-SC } \\
\text { SW-Pomerode-SC }\end{array}$ & $\begin{array}{l}\text { Easei } 1985 \\
\text { Easei } 1985 \\
\text { Siga Jr. } 1995 \\
\text { Siga Jr. } 1995 \\
\text { Siga Jr. } 1995 \\
\text { Easei et al. } 199: 3 \text { e Basei } 2000 \\
\text { Easei et al. } 199: 3 \text { e Basei } 2000 \\
\text { Easei et al } 199 \text { S. e Basei } 2000 . \\
\text { Easei } 2000\end{array}$ \\
\hline $\begin{array}{l}\mathrm{Rb}-\mathrm{Sr} \\
\mathrm{Rb}-\mathrm{Sr} \\
\mathrm{Rb}-\mathrm{Sr} \\
\mathrm{Rb}-\mathrm{Sr} \\
\mathrm{Rb}-\mathrm{Sr} \\
\mathrm{Rb}-\mathrm{Sr} \\
\mathrm{Rb}-\mathrm{Sr} \\
\mathrm{Rb}-\mathrm{Sr} \\
\mathrm{Rb}-\mathrm{Sr} \\
\mathrm{Rb}-\mathrm{Sr} \\
\mathrm{Rb}-\mathrm{Sr} \\
\mathrm{Rb}-\mathrm{Sr}\end{array}$ & $\begin{array}{l}\text { Rocha total } \\
\text { Rocha total } \\
\text { Rocha total } \\
\text { Rocha total } \\
\text { Rocha total } \\
\text { Rocha total } \\
\text { Rocha total } \\
\text { Rocha total } \\
\text { Rocha total } \\
\text { Rocha total } \\
\text { Rocha total } \\
\text { Rocha total }\end{array}$ & $\begin{array}{l}\text { Gnaisses Granuliticios } \\
\text { Gnaisses Granuliticos } \\
\text { Mesossoma-Migmiatito } \\
\text { Leuicossoma-Migmatito } \\
\text { Gnaisses Granulfiticos } \\
\text { Gnaisses Granuliticios } \\
\text { Gnaisses Granullitios } \\
\text { Gnaisses Granuliticos } \\
\text { Gnaisses Granuliticos } \\
\text { Gnaisses Granuliticos } \\
\text { Gnaisses Granuliticos } \\
\text { Gnaisses Granulfticos }\end{array}$ & $\begin{array}{l}\quad: \\
2663 \pm 72 \\
2478 \pm 37 \\
2581 \pm 277 \\
1900 \pm 200 \\
2700 \pm 90 \\
1900 \pm 70 \\
2169 \pm 177 \\
1970 \pm 36 \\
2184 \pm 48 \\
2067 \pm 199 \\
2107 \pm 69 \\
2200 \pm 100\end{array}$ & $\begin{array}{l}\bullet \\
0.703 \$ 7 \\
0.7012: 9 \\
0.70418 \\
0.7048 ; 0 \\
0.704(19 \\
0.704514 \\
0.70150 \\
0.7024 .5 \\
0.70257 \\
0.7024 .4 \\
0.702844 \\
0.7085 ; 0\end{array}$ & $\begin{array}{l}\text { Luis Alves-SC } \\
\text { Pomerode-SC; } \\
\text { Luís Alves-SC } \\
\text { Luis Alves-SC } \\
\text { Dona Francisc:a-SC } \\
\text { Dona Francisca-SC } \\
\text { Blume } a u-S C \\
\text { Luís Alves-SC } \\
\text { Jaraguá do Sul-SC } \\
\text { Piên-PR } \\
\text { S. Berto do Sul-SC } \\
\text { Serra Negra-FR }\end{array}$ & $\begin{array}{l}\text { Hartmman et al. } 1979 \\
\text { Siga Jr. } 1995 \\
\text { Easei } 1985 \\
\text { Easei } 1985 \\
\text { Siga Jr. } 1995 \\
\text { Siga Jr. } 1995 \\
\text { Easei } 1985 \\
\text { Siga Jr. } 1995 \\
\text { Siga Jr. 1995 } \\
\text { Girardi et al. 1974 } \\
\text { Machiavelli 199.। } \\
\text { Siga Jr. } 1995\end{array}$ \\
\hline $\mathrm{Pb}-\mathrm{Pb}$ & Rocha total & Granulitos fels.e máficos & $2100 \pm 500$ & $M 1=8,9$ & Luis Alves-SC & Easei 1985 \\
\hline $\begin{array}{l}\text { Sm-Nd (Rocha Total) } \\
\text { Sm-Nd }\end{array}$ & $\begin{array}{l}\text { Rocha Total } \\
\text { Minerais } \\
\text { Allanita,titaniteı, anfibolio a } \\
\text { piroxério. }\end{array}$ & $\begin{array}{l}\text { Granulitos } \\
\text { Gnaisses alcalinos }\end{array}$ & $\begin{array}{l}2.5-2.8 \mathrm{Ga} \\
2258 \pm 67\end{array}$ & & Barra Velha-SC & $\begin{array}{l}\text { Siga Jr. } 1995 \\
\text { Hartmann et al. } 1998\end{array}$ \\
\hline K-Ar & $\begin{array}{l}\text { anfibolio, biotita, plagiociásic, } \\
\text { Piroxênio e rosha total }\end{array}$ & Gnaisses granulfticos & $2000-1700$ & - & Dados do todn o TGAG & $\begin{array}{l}\text { Hartmann et al. 1979, Minioli 1972, 1969, Ka Jl et al. } \\
\text { 1984, Eiasei et al. 1985, Girardi et al. 1974, } \\
\text { Machiavelli 199\%. Siga Jr. 1994; e Harara 1993. }\end{array}$ \\
\hline
\end{tabular}




\section{3 - O Cinturão Gnáissico-Migmatítico Atuba (CGMA)}

O CGMA ( Basei et al. 1992, Siga Jr. et al.1995 e Basei et al. 1999) aflora numa faixa orientada NE com largura máxima de aproximadamente $40.50 \mathrm{Km}$ (Figura 3.1) entre os metassedimentos da Faixa Apiaí ou Ribeira, a norte, e a SGPM, a sul. Outras exposições do CGMA ocorrem ainda em meio aos metassedimentos da Faixa Apiaí ou Ribeira (núcleos Betara, Tigre e Setuva). A unidade é recoberta por uma seqüência metassedimentar (Formações Setuva e Capiru) que apresenta afinidades paleogeográficas com esta, o mesmo que não ocorrendo com as seqüências metasedimentares da Faixa Apiaí ou Ribeira (Formações Votuverava, Água Clara, Itaiacoca e afins) aflorantes a norte da Zona de Cisalhamento da Lancinha. O limite norte e noroeste do CGMA é marcado pela Zona de Cisalhamento Lancinha-Itariri que, segundo Basei et al. (1999) representa, em superficie, importante zona de sutura que separa o CGMA dos terrenos ao norte. A sul, separados do CGMA pelas zonas de cisalhamento Mandirituba-Piraquara e Piên-Tijucas, afloram, respectivamente, a SGPM (Machiavelli et al. 1993, Siga Jr. 1995, Harara 1996 e Harara et al.1997 a e b), a SMUP (Girardi 1974, Girardi 1976, Girardi \& Ulbrich 1980 e Harara 1996) e a margem norte do TGAG.

O CGMA, segundo Basei et al. (1992), Siga Jr. et al.(1995) e Basei et al. (1999) é constituido por biotita-anfibólio gnaisses, anfibólio-biotita gnaisses e migmatitos cinzentos a róseos (mesossomas de biotita-anfibólio-gnaisses e leucossomas de composição tonalíticagranodiorítica-granítica), intensamente deformados e regionalmente metamorfisados na fácies anfibolito durante o Neoproterozóico. Dentro dos gnaisses e migmatitos e, preferencialmente, ao longo da porção norte, ocorrem núcleos de gnaisses granulíticos de composição enderbítica-charnoenderbítica (Pedreira Paulo Leminski-Curitiba e Maciço de Itatins). Ocorrem ainda gnaisses graníticos e granitos tipo 1 e A deformados, sendo comum a existência de mobilizados quartzo-feldspáticos foliados e isótropos alojados perpendicular ou paralelamente ao bandamento principal.

O padrão estrutural do CGMA é caracterizado por uma foliação de transposição regional na direção N40-60E, paralela ao bandamento (Basei et al. 1992, Siga Jr. 1995, Siga Jr. et al. 1995). Os indicadores cinemáticos sugerem um sentido de transporte de N-NW para S-SE, com as lineações de estiramento dispostas no sentido $550-70 \mathrm{E} / 20^{\circ}-40^{\circ}$. Os dobramentos cilindricos, desenhados pelas foliações $\mathrm{Sn}$, admitem uma direção axial NESW em escala regional, com os eixos construidos orientados na direção N30-60E $/ 05^{\circ}-40^{\circ}$.

Os principais dados geocronológicos obtidos para as rochas do CGMA são apresentados por Basei et al. (1992), Siga Jr. (1995), Siga Jr. et al. (1995), Basei et al. 
(1997), Picanço et al. (1998) e Basei et al. (1999) - Tabela 3.2. As idades U-Pb do intercepto superior em zircões concentram-se ao redor de 2.2-2.1 Ga, enquanto as isócronas (e/ou errócronas) $\mathrm{Rb}-\mathrm{Sr}$ (rocha total) forneceram idades entre 2.2 e $1.8 \mathrm{Ga}$, com razões $\mathrm{Sr}^{87} / \mathrm{Sr}^{86}(\mathrm{i})$ entre 0.703 e 0.706 . Segundo os referidos autores, estes valores representam o metamorfismo regional de fácies anfibolito a granulito com migmatização associada, impostos ao CGMA durante o Paleoproterozóico.

Idades $\mathrm{Rb}-\mathrm{Sr}$ (rocha total e minerais) entre 620 e $580 \mathrm{Ma}$, com razões $\mathrm{Sr}^{87} / \mathrm{Sr}^{86}$ (i) > 0.710 em leuco-mesossomas de migmatitos e mobilizados quartzo-feldspáticos, além de idades Sm-Nd (rocha total e minerais) ao redor de $585 \mathrm{Ma}$ e K-Ar (biotita e anfibólio) entre 640 e $560 \mathrm{Ma}$ (concentraçăo ao redor de $600 \pm 20 \mathrm{Ma}$ ), também foram obtidas. Estes dados geocronológicos indicam, segundo Basei et al. (1992), Siga Jr. (1995), Siga Jr. et al. (1995) e Basei et al. (1997), um forte retrabalhamento termo-tectônico da unidade, em condições metamórficas de fácies anfibolito, além de transporte e exposição durante o Neoproterozóico $(640 \pm 20)$ para niveis crustais superiores às isotermas de $500^{\circ} \mathrm{C}$. $\mathrm{O}$ resfriamento e a estabilização tectônica teria ocorrido a cerca de $600 \pm 20 \mathrm{Ma}$.

As idades modelo $\mathrm{Sm}-\mathrm{Nd}\left(\mathrm{T}_{\mathrm{DM}}\right)$, com exceção dos mobilizados graníticos, situam-se em torno de $2.8-2.7 \mathrm{Ga}$, com raras idades $\geq 3.0 \mathrm{Ga}$. Estas idades representam a época em que os protólitos do CGMA foram diferenciados do manto, sendo os valores de $\in \mathrm{Nd}$ ao redor de -21 sugestivos de um longo período de residência crustal. 
Tabela 3.2 - Relação dos principais dados Geocronológicos e isotópicas do CGMA

\begin{tabular}{|c|c|c|c|c|c|c|}
\hline \begin{tabular}{c} 
Método \\
Geocronologic \\
\hdashline
\end{tabular} & Mineral/Rocha Total & Litotipo & Idade (Ma) \pm Erro & $\mathrm{Sr}^{87} / \mathrm{Sr}^{36}(\mathrm{i})$ & $\begin{array}{l}\text { Localizaçäo da } \\
\text { Amostra }\end{array}$ & Fontes Bibliográficas \\
\hline $\begin{array}{l}\mathrm{U}-\mathrm{Pb} \\
\mathrm{U}-\mathrm{Pb}\end{array}$ & $\begin{array}{l}\text { Zircảo } \\
\text { Zircão }\end{array}$ & $\begin{array}{l}\text { Gnaisses Granulfticos } \\
\text { Chamo-Enderbito }\end{array}$ & $\begin{array}{c}2095 \pm 5 \\
2105.4 \pm 3.1\end{array}$ & $\begin{array}{c}T_{D M}=2.84 \mathrm{Ga} \\
\text { Pedreira Paulo Leminski }\end{array}$ & $\begin{array}{l}\text { Ped.CESB, N.Curitiba } \\
\text { Curitiba }\end{array}$ & $\begin{array}{l}\text { Siga Jr } 1995 \text { e Siga Jr et al. } 1995 \\
\text { Basei et al. } 1999 \text { e Basei } 2000\end{array}$ \\
\hline $\begin{array}{l}\text { U-Pb } \\
\dot{\mathrm{Rb}} \mathrm{PSr} \\
\mathrm{Rb}-\mathrm{Sr}\end{array}$ & $\begin{array}{l}\text { Zircão } \\
\text { Rocha Total } \\
\text { Rocha Total }\end{array}$ & $\begin{array}{l}\text { Biotita-antibolio-Gnaisses } \\
\qquad \begin{array}{l}\text { Gnaisses Granulfiticos } \\
\text { Gnaisses Granulíticos }\end{array}\end{array}$ & $\begin{array}{l}2138 \pm 6 \\
\bullet \\
1826 \pm 96 \\
2116 \pm 95\end{array}$ & $\begin{array}{c}T_{D M}=2.45 \mathrm{Ga} \\
0.71051 \\
0.70160\end{array}$ & $\begin{array}{c}\text { Mandirituba-PR } \\
\text { P. } \\
\text { Norte de Curitiba-PR } \\
\text { NE-Curitiba Graciosa- } \\
\text { PR }\end{array}$ & $\begin{array}{l}\text { Siga Jr } 1995 \text { e Siga Jr et al. } 1995 \\
\text { Siga Jr } 1995 \text { e Siga Jr et al. } 1995 \\
\text { Siga Jr } 1995 \text { e Siga Jr et al. } 1995\end{array}$ \\
\hline $\begin{array}{l}\mathrm{Rb}-\mathrm{Sr} \\
\mathrm{Rb}-\mathrm{Sr} \\
\mathrm{Rb}-\mathrm{Sr}\end{array}$ & $\begin{array}{c}\text { Rocha Total } \\
\text { Rocha Total } \\
\text { Rocha Total e Minerais } \\
\text { (Plagioclásio, granada e } \\
\text { anfibófio). }\end{array}$ & $\begin{array}{l}\text { Biotita-Anfibolio Gnaisses } \\
\text { mesossoma-Migmatitos } \\
\text { mesossoma-Migmatitos }\end{array}$ & $\begin{array}{l}2220 \pm 26 \\
598 \pm 48 \\
617 \pm 14\end{array}$ & $\begin{array}{c}0.70660 \\
0.71670, \mathrm{~T}_{D M}=2.77 \mathrm{Ga} \\
0.71594\end{array}$ & $\begin{array}{c}\text { PR } \\
\text { NE de Curitiba-PR } \\
\text { Ped.Atuba. Curitiba-PR } \\
\text { Ped.Atuba. Curitiba-PR }\end{array}$ & $\begin{array}{l}\text { Siga Jr } 1995 \text { e Siga Jr et al. } 1995 \\
\text { Siga Jr } 1995 \text { e Siga Jr et al. } 1995 \\
\text { Siga Jr } 1995 \text { e Siga Jr et al. } 1995\end{array}$ \\
\hline $\begin{array}{l}\mathrm{Rb}-\mathrm{Sr} \\
\mathrm{Rb}-\mathrm{Sr} \\
\mathrm{Rb}-\mathrm{Sr} \\
\mathrm{Rb}-\mathrm{Sr} \\
\end{array}$ & $\begin{array}{l}\text { Rocha Total } \\
\text { Rocha Total } \\
\text { Rocha Total } \\
\text { Minerais } \\
.\end{array}$ & $\begin{array}{l}\text { Anfibótio-Gnaisses } \\
\text { leucossoma-Migmatito } \\
\text { mesossoma-Migmatito } \\
\text { mobilizados Graniticos } \\
\text { - }\end{array}$ & $\begin{array}{c}2010 \pm 60 \\
595 \pm 41 \\
1868 \pm 89 \\
577 \pm 17 \\
\end{array}$ & $\begin{array}{c}0.70327 \\
0.71308 \\
0.70584, T_{D M}=2.84 \mathrm{Ga} \\
0.71791 \\
\bullet\end{array}$ & $\begin{array}{l}\text { Mandirituba-PR } \\
\text { Quitandinha-PR } \\
\text { Quitandinha-PR } \\
\text { Quitandinha-PR } \\
\qquad\end{array}$ & $\begin{array}{c}\text { Siga Jr } 1995 \text { e Siga Jr et al. } 1995 \\
\text { Siga Jr } 1995 \text { e Siga Jr et al. } 1995 \\
\text { Siga Jr } 1995 \text { e Siga Jr et al. } 1995 \\
\text { Siga Jr } 1995 \text { e Siga Jr et al. } 1995 \\
\text { Siga Jr } 1995 \text { e Siga Jr et al. } \\
1995\end{array}$ \\
\hline $\begin{array}{l}\mathrm{Sm}-\mathrm{Nd} \\
\mathrm{Sm}-\mathrm{Nd}\end{array}$ & $\begin{array}{c}\text { Rocha Total e Minerais } \\
\text { Rocha Total }\end{array}$ & $\begin{array}{l}\text { Gnaisses Migmatíticos } \\
\text { Gnaisses Migmatitcos }\end{array}$ & $\begin{array}{l}\quad 585 \pm 30 \\
\text { TDM do CGMA entre } 2.4 \text { e } \\
2.8 \mathrm{Ga}\end{array}$ & $\bullet$ & $\begin{array}{r}\text { Manditituba-PR } \\
\text { Ao longo do cinturăo }\end{array}$ & $\begin{array}{l}\text { Siga Jr } 1995 \text { e Siga Jr et al. } 1995 \\
\text { Siga Jr } 1995 \text { e Siga Jr et al. } 1995 \\
\text { - }\end{array}$ \\
\hline
\end{tabular}




\section{4 - Cinturão Granítico Costeiro (CGC)}

O Cinturão Granítico Costeiro ou Batólito Paranaguá ou Cinturão Granítico São Francisco do Sul-Paranaguá (Lopes 1987 a e b, Basei et al. 1990 e Siga Jr. 1995) aflora na porção oriental da região, possuindo aproximadamente $100 \mathrm{Km}$ de comprimento e $30 \mathrm{Km}$ de largura (Figura 3.1). Seu contato com o TGAG, a oeste, é marcado por importantes zonas de cisalhamento, denominadas lineamentos Garuva, Alexandra e Serra Negra.

O CGC é constituído por uma grande variedade de rochas graníticas deformados e isótropas, entre as quais predominam anfibólio-biotita granitóides e biotita-anfibólio granitóides porfiríticos do tipo I cálcio-alcalina, predominantemente. Ocorrem ainda restos de rochas encaixantes, tais como xistos, biotita gnaisses, quartzitos e anfibolitos.

A foliação principal observada na maioria das rochas graníticas desta unidade é uma superfície $\mathrm{Sn}$ com direção predominante $\mathrm{N} 40^{\circ}-60^{\circ} \mathrm{E}$, contendo uma lineação de estiramento com mergulhos entre $5^{\circ}$ e $30^{\circ}$ para SE.

Os dados geocronológicos e isotópicos apresentados foram extraidos de Kaul \& Teixeira (1982), Teixeira (1982), Kaul (1984), Basei et al. (1990), Siga Jr. (1995) e Basei et al. (1997) - Tabela 3.3. Idades U.Pb em zircões entre 615 e 590 Ma e Rb-Sr em rocha total entre 590 e $560 \mathrm{Ma}$, com razão $\mathrm{Sr}^{87} / \mathrm{Sr}^{86(i)}$ ao redor de $0.707-0.708$ representariam a formação e o alojamento das rochas graníticas num largo intervalo de tempo (entre 615 e $560 \mathrm{Ma}$ ). As idades K-Ar em biotitas entre 560 e $480 \mathrm{Ma}$ indicam que a deformação, o resfriamento e a estabilização tectônica das rochas granitóides, de parte ou de todo o CGC, ocorreu até o Eopaleozóico. As idades Modelo Sm-Nd ( $\left.T_{D M}\right)$ concentradas entre 2.2 e 1.9 Ga e, subordinadamente, entre 2.6 e $2.4 \mathrm{Ga}$, indicam que as rochas graníticas do CGC foram geradas por retrabalhamento de rochas fontes (protólitos) paleoproterozóicas e até mesmo arqueanas.

Campos Neto \& Figueiredo (1995) reconheceram episódios orogênicos Cambrianos relacionados à evolução do Cinturão Costeiro do sudeste brasileiro e os denominaram "Orogênese Rio Doce". Esta orogênese teria se desenvolvido entre 590-480 Ma, causando deformação e reativação tectôno-térmica nas rochas graniticas do CGC, fato sugerido pelas idades térmicas e geocronológicas K-Ar em biotita e anfibólio. 
Tabela 3.3 - Relação dos principais dados geocronológicos e isotópicos do CGC

\begin{tabular}{|c|c|c|c|c|c|c|}
\hline $\begin{array}{l}\text { Método } \\
\text { Geocronológico }\end{array}$ & $\begin{array}{l}\text { Mineral/Rocha } \\
\text { Total }\end{array}$ & Liotipo & Ifdade (Ma) \pm Erro & $\mathrm{Sr}^{87} / \mathrm{Sr}^{86}(\mathrm{i})$ & Local da Amostra & Fontes Bibliográficas \\
\hline $\begin{array}{l}\text { U-Pb } \\
\text { U-Pb } \\
\text { U-Pb }\end{array}$ & $\begin{array}{l}\text { Zircão } \\
\text { Zircão } \\
\text { Zircão }\end{array}$ & $\begin{array}{l}\text { Anfibólio-Biotita-Granitóides } \\
\text { Anfibólio-Biotita-Granitóides } \\
\text { Anfíbolio-Biotita-Granitóides }\end{array}$ & $\begin{array}{c}614 \pm 9 \text { (Granito Morro Inglês) } \\
609 \pm 28 \text { (Granito Rio do Poço) } \\
\\
\sim 590 \text { (Granito Estrela) }\end{array}$ & & $\begin{array}{l}\text { Próx. C.Paranaguá } \\
\text { Oeste do CGC } \\
\text { Norte de Garuva-SC }\end{array}$ & $\begin{array}{l}\text { Basei et al } 1990 \\
\text { Basei et al } 1990 \\
\text { Basei et al } 1990\end{array}$ \\
\hline $\begin{array}{l}\mathrm{Rb}-\mathrm{Sr} \\
\mathrm{Rb}-\mathrm{Sr} \\
\mathrm{Rb}-\mathrm{Sr} \\
\mathrm{Rb}-\mathrm{Sr} \\
\mathrm{Rb}-\mathrm{Sr}\end{array}$ & $\begin{array}{l}\text { Rocha Total } \\
\text { Rocha Total } \\
\text { Rocha Total } \\
\text { Rocha Total } \\
\text { Rocha Total }\end{array}$ & $\begin{array}{l}\text { Anfibólio-Biotita-Granitoides } \\
\text { Anfibólio-Biotita-Granitóides } \\
\text { Anfibólio-Biotita-Granitóides } \\
\text { Anfibólio-Biotita-Granitóides } \\
\text { Anfibófio-Biotita-Granitóides }\end{array}$ & $\begin{array}{c}537 \pm 35 \text { ? (Granito Morro Inglês) } \\
589 \pm 28 \text { (Granito Morro Inglês) } \\
562 \pm 33 \text { (Granito Morro Inglès) } \\
574 \pm 14 \text { (Granito Morro inglês) } \\
621 \pm 13 \\
607 \pm 2\end{array}$ & $\begin{array}{l}0.70820 \\
0.70757 \\
0.70816 \\
0.70785 \\
0.7101 \\
0.7101\end{array}$ & $\begin{array}{c}\text { Paranaguá-PR } \\
\text { Matinhos-PR } \\
\text { Quaratuba-PR } \\
\text { Paranaguá, Matinhos e Guaratuba-PR } \\
\text { Guaraqueçaba-PR e llha de São } \\
\text { Francisco do Sul-SC }\end{array}$ & $\begin{array}{l}\text { Siga Jr. } 1995 \\
\text { Siga Jr. } 1995 \\
\text { Siga Jr. } 1995 \\
\text { Siga Jr. } 1995 \\
\text { Teixeira } 1982\end{array}$ \\
\hline $\begin{array}{l}\mathrm{Rb}-\mathrm{Sr} \\
\dot{\mathrm{Sm}}-\mathrm{Nd}\end{array}$ & $\begin{array}{l}\text { Rocha Total } \\
\text { Rocha Total }\end{array}$ & $\begin{array}{l}\text { Anfibólio-Biotita-Granitóides } \\
\text { Anfibólio-Biotita-Granitóides }\end{array}$ & 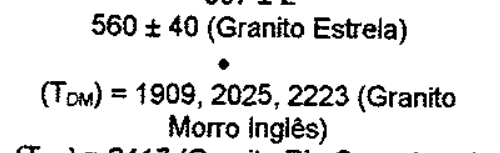 & $0.707-0.708$ & $\begin{array}{c}\text { Rio.S.João e Rio Cubatão } \\
\text { Leste do CGC. }\end{array}$ & $\begin{array}{l}\text { Siga Jr. } 1995 \\
\text { Siga Jr. } 1995\end{array}$ \\
\hline $\begin{array}{l}\text { Sm-Nd } \\
\text { Sm-Nd }\end{array}$ & $\begin{array}{l}\text { Rocha Total } \\
\text { Rocha Total }\end{array}$ & $\begin{array}{l}\text { Anfibolio-Biotita-Granitoides } \\
\text { Anfibólio-Biotita-Granitoides }\end{array}$ & $\begin{array}{l}\left(T_{D M}\right)=2417 \text { (Granito Rio Canavieras) } \\
\left(T_{D M}\right)=2572 \text { e } 2614 \text { (Granito Estrela) }\end{array}$ & & $\begin{array}{l}\text { Oeste do CGC } \\
\text { Oeste do CGC }\end{array}$ & $\begin{array}{l}\text { Siga Jr. } 1995 \\
\text { Siga Jr. } 1995\end{array}$ \\
\hline K-Ar & Biotita e Anfibólio & Anfibófio-Biotita-Granitóides & Entre 560 e 480 & & Dados de todo o CGC & $\begin{array}{c}\text { Kaul 1984, Basei et al. } 1990, \\
\text { Siga Jr. } 1995 \text { e Basei et al. } \\
1997\end{array}$ \\
\hline
\end{tabular}




\section{5 - Síntese geológica da zona de transição entre o TGAG e o CGMA}

A região investigada está inserida na zona de transição entre o TGAG e CGMA. Os primeiros trabalhos sistemáticos de mapeamento datam da década de 60 , quando a Comissão da Carta Geológica do Paraná elaborou, na escala 1:70.000, as folhas geológicas de São José dos Pinhais (Fuck 1967), Piên (Trein et al. 1969a), Tijucas do Sul (Trein et al. 1969b) e Mandirituba (Marini et al. 1970). Embora sem maiores detalhes, foram reconhecidos, entre outros, a SGPM, O MGAS, o Granito Morro Redondo e o Complexo Básico-Ultrabásico de Piên-PR.

Posteriormente, Girardi (1974), Girardi et al. (1974), Girardi (1976) e Girardi \& Ulbrich (1980) apresentaram novos dados sobre a geologia, geocronologia e petrologia do Complexo Básico-Ultrabásico de Piên-PR e rochas graniticas e granuliticas adjacentes. Segundo estes autores, as rochas máficas-ultramáficas deste complexo são comagmáticas e, juntamente com os granulitos adjacentes do TGAG, foram submetidas, no Paleoproterozóico, a um metamorfismo de alto grau (fácies granulito) e, posteriormente, no Neoproterozóico III, a um retrometamorfismo de mais baixo grau (fácies xisto verde a anfibolito). As rochas graníticas expostas nesta região foram geradas neste último evento.

Biondi et al. (1989) compilaram um mapa geológico integrado do Estado do Paraná na escala 1:650.000 e inseriram a região ora investigada no Bloco Costeiro. Posteriormente, Ribas (1993), realizando estudos geológicos para fins metalogenéticos na região de Vossoroca-Tijucas do Sul-PR, mapeou corpos máficos-ultramáficos e sugeriu uma correlação genética com os corpos máficos-ultramáficos aflorantes na região de Piên-PR.

Machiavelli (1991) e Machiavelli et al. (1993) apresentaram os primeiros estudos geológicos sobre os granitóides deformados da região de Piên-PR, parte dos granitos da SGPM. Os autores enfatizaram preliminarmente seus aspectos geoquímicos e geocronológicos e publicaram os primeiros dados geocronológicos (U-Pb, Rb-Sr e K-Ar) sobre parte da SGPM e do TGAG desta região. A formação e o alojamento destes granitóides foram associados a um arco magmático construido durante o Neoproterozóico III (750-650 Ma) entre o TGAG e o CGMA.

Harara et al. (1995), Harara (1996) e Harara et al. (1997 a e b) apresentaram novos dados petrológicos e geocronológicos sobre a SGPM, a porção meridional do MGAS (atuais granitos Rio Negro e Tarumã), a SMUP e o TGAG na região de Piên-PR e adjacências. Os levantamentos geológicos indicaram que os granitóides da SGPM compõem um terreno granítico de aproximadamente $20 \mathrm{~km}$ de largura, constituído por quartzo-monzodioritos a granodioritos e, subordinadamente, monzogranitos com biotita e anfibólio, meta-aluminosos 
e cálcio-alcalinos de médio a alto K. A principal feição observada nestas rochas foi uma foliação milonítica orientada preferencialmente N66E/64NW, gerada em regime dúctil e condições metamórficas de fácies xisto-verde (zona da biotita até o limite inferior da fácies anfibolito). Esta foliação teria sido, inicialmente, gerada pelo cavalgamento de NNW para SSE dos granitóides da SGPM e da suite máfica-ultramáfica sobre o TGAG, que posteriormente evoluiu para uma transcorrência dextral na direção NE. Na porção meridional do MGAS foram reconhecidas quatro fácies de rochas graníticas isótropas (Harara 1996). As principais são a fácies sienogranitica (Granito Rio Negro), de cor rosa a avermelhada e granulação grossa e a fácies granodioritica-monzogranítica, de granulação fina, cálcio-alcalina de alto $\mathrm{K}$ e meta-aluminosa a fracamente aluminosa (Granito Tarumã). Corpos gabro-dioriticos ocorrem dispersos em meio às rochas graníticas. Texturas típicas de mistura de rochas graníticas com rochas gabro-dioriticas foram descritas por Machiavelli (1991) e Harara (1996). A presença maciça de rochas graníticas híbridas máficas e félsicas na porção sul do MGAS (Granito Rio Negro) não foi observada pelos autores.

Os dados geocronológicos disponiveis (U-Pb em zircões, $\mathrm{Rb}-\mathrm{Sr}$ em rocha total e KAr em biotita e anfibólio) indicaram que os granitóides da SGPM tiveram sua formação, colocação, deformação e resfriamento entre 650 e $595 \mathrm{Ma}$ (Machiavelli 1991, Machiavelli et al. 1993, Harara et al.1995, Harara 1996 e Harara et al.1997 a e b). Determinações U-Pb em zircões e Rb-Sr em rocha total apresentadas por Siga Jr. (1995) indicam que os granitóides do MGAS são tardios em relação a estes e teriam se formado entre 590 e 570 Ma.

A SMUP é representada por dois corpos principais que ocorrem ao longo da Zona da Cisalhamento Piên-Tijucas (ZCPT). Os litotipos predominantes são serpentinitos, dunitos e harzburgitos parcialmente a totalmente serpentinizados, ocorrendo subordinadamente olivina-ortopiroxenitos, ortopiroxenitos, xistos magnesianos e raros gabros. Estes corpos encontram-se fortemente deformados e apresentam um caráter brechóide-milonítico, com foliação orientada predominantemente N40-60E. Seus contatos com as encaixantes são essencialmente tectônicos. O comportamento estrutural do corpo ultramáfico ao sul da ZCPT sugere que este constitua uma klippe sobre o TGAG.

Na região de Piên-PR predominam, no TGAG, duas unidades principais de gnaisses granulíticos félsicos e máficos, com lentes de gnaisses anfibolíticos e biotiticos, gnaisses granulíticos ricos em porfiroblastos de granada, gnaisses granuliticos com granada, gnaisses granulíticos ricos em biotita e anfibolitos e piroxenitos (Harara 1996 e Harara et al. 1997 a e b). Em geral, o padrão geocronológico Rb-Sr, K-Ar e Sm-Nd mostra idades entre 2.1 a $1.8 \mathrm{Ga}$, registrando a época do metamorfismo granulítico, resfriamento e a 
estabilidade tectônica (Machiavelli 1991, Siga Jr. 1995, Harara 1996 e Harara et al. 1997 a e b).

Ao longo da ZCPT e no interior do TGAG observa-se uma faixa orientada NE com 4 a $6 \mathrm{Km}$ de largura, caracterizada pela substituição parcial a total das paragêneses minerais da fácies granulito e por assembléias retrometamórficas típicas de baixo a médio grau. Esta faixa é caracterizada pela superposição de estruturas com orientação E-W e NE-SW neoproterozóicas e por rejuvenescimento isotópico no sistema K-Ar em minerais, que difere da estruturação geral NW paleoproterozóica. O padrão estrutural e térmico-geocronológico $\mathrm{K}-\mathrm{Ar}$ das rochas da margem norte do TGAG indicam sua reativação tectono-metamórfica parcial durante o Neoproterozóico III.

\section{6 - O Magmatismo Granítico Alcalino-Peralcalino (Suite Granitica Serra do Mar) e o Vulcanismo-Sedimentação das Bacias Guaratubinha, Campo Alegre e Corupá}

$\mathrm{Na}$ porção sul do CGMA e nas porções central e norte do TGAG ocorrem expressivas e importantes intrusões graníticas alcalinas-peralcalinas (A-PA) (Figura 3.1). Esta granitogênese alcalina-peralcalina é contemporânea ao vulcanismo ácido-intermediário tipo A neoproterozóico das bacias vulcanossedimentares de Guaratubinha, Campo Alegre e Corupá (Tabela 3.4).

As rochas graníticas da Suite Granítica Serra do Mar, tardi a pós-colisionais e/ou anorogênicas são representadas por inúmeros "stocks" e "batólitos" graníticos com formatos circulares a elipsoidais, constituidos por monzo a sienogranitos, alcali-feldspato granitos, sienitos, monzonitos, quartzo-sienitos e quartzo-monzonitos (Wernick \& Penalva 1978, Wernick 1982, Kaul 1984 e 1987, Kaul \& Cordani 1994, Siga Jr. et al. 1994, Siga Jr. 1995, Gois 1995, Siga Jr. et al.1997 e Kaul 1997). Os principais minerais máficos nas rochas graníticas alcalinas são biotita e anfibólio, enquanto nas rochas graníticas peralcalinas ocorrem biotita, anfibólio e piroxênio sódico. Os granitos Corupá, Piraí, Dona Francisca, Morro Redondo e Serra da Igreja estão alojados totalmente dentro do TGAG e os granitos Palermo, Rio Negro, Marumbi, Anhangava e Graciosa encontram-se ao longo da zona de transição e no contato entre o TGAG, a SGPM e o CGMA (ver Figura 3.1). Apenas o Granito Agudos do Sul está alojado inteiramente na SGPM, entre os granitos Palermo e Rio Negro.

As rochas vulcânicas (predominantemente riolitos $e$, raramente, basaltos) e plutônicas (granitos peralcalinos) da porção norte do Granito Morro Redondo apresentam, segundo Gois (1995), características litoquímicas de magmatismo tipo A. Petrograficamente, os riolitos e os granitos peralcalinos são bastante semelhantes, 
apresentando características geoquímicas que apontam para um possivel vínculo genético. Segundo estes autores, o parentesco entre os riolitos e os basaltos não pôde ser testada em termos conclusivos.

Os dados petrológicos e geocronológicos disponiveis sobre a Suite Granítica Serra do Mar revelaram a tipologia granitica A-PA e o caráter metaluminoso a fracamente peraluminoso (aluminoso) e fracamente peralcalino a peralcalino destes granitos (Kaul \& Cordani 1994, Siga Jr. et al. 1994, Siga Jr. 1995, Siga Jr. et al.1997, Kaul 1997, Siga Jr et al. 1999 e Cordani et al. 2000). As idades U-Pb em zircões, Rb-Sr em rocha total e K-Ar em biotita e anfibólio estão entre 600 e $550 \mathrm{Ma}$, e as idades modelo Sm-Nd ( $\left.T_{D M}\right)$ entre 2.1 e $1.85 \mathrm{Ga}$ (Tabela 3.5). Estes dados sugerem, segundo os referidos autores, que a formação, - alojamento e o resfriamento destes corpos graníticos ocorreram durante o Neoproterozóico III, entre 600 e $550 \mathrm{Ma}$, e que sua geração se deu por retrabalhamento de protólitos paleoproterozóicos. As Idades U-Pb em zircões (Tabela 3.5) indicam que o principal período da formação e alojamento destas rochas ocorreu entre 595 e $580 \mathrm{Ma}$.

O Maciço Granitico Agudos do Sul (MGAS), inserido na área ora estudada, foi inicialmente reconhecido e cartografado pela Comissão da Carta Geológica do Paraná (Trein et al. 1969 a e b e Marini et al. 1970), sendo posteriormente alvo de análises geocronológicas por Siga Jr. et al. (1994) e Siga Jr. (1995). Na presente pesquisa, o MGAS é dividido quatro unidades graníticas: Granito Palermo, Granito Agudos do Sul, Granito Rio Negro e Granito Tarumã (Figura 3.1). Os granitos Palermo e Rio Negro situam-se exatamente na zona de contato entre o TGAG e a SGPM, enquanto o Granito Agudos do Sul encontra-se alojado entre eles, totalmente inserido na SGPM. Associadas aos granitos Palermo e, principalmente, Rio Negro, foram identificadas e mapeadas rochas gabróicas e rochas graniticas hibridas máficas e félsicas. Estas últimas foram geradas a partir de mistura das primeiras com rochas graníticas convencionais provenientes destes mesmos corpos.

As três bacias vulcanossedimentares de Guaratubinha, Campo Alegre e Corupá (Figura 3.1), juntamente com a contemporânea granitogênese alcalina da Suite Granítica Serra do Mar, representam expressivas e importantes respostas magmáticas a eventos ocorridos na região no final do Neoproterozóico. Estes eventos de acreção vertical tiveram lugar após um periodo da acreção lateral com formação e deformação da SGPM e reativação térmica e tectônica parcial da porção norte do TGAG e do CGMA.

A Bacia de Campo Alegre situa-se na porção norte do TGAG (Basei et al. 1992, Siga Jr. 1995, Citroni 1998, Basei et al. 1998 e Citroni et al. 1999) - Figura 3.1. Esta bacia 
encontra-se preenchida por rochas sedimentares (conglomerados, arenitos, siltitos, argilitos) e piroclásticas, além de rochas vulcânicas predominantemente félsicas (riolitos e, subordinadamente, traquitos) e, mais raramente, máficas (basaltos e basaltos andesíticos). Os riolitos e traquitos são constituídos por K-feldspato (sanidina), quartzo e plagioclásio, além de biotita e olivina com texturas traquíticas, microlíticas e esferolíticas. Os raros basaltos e basaltos andesíticos (Citroni 1998 e Citroni et al. 1999) do tipo WPB (basaltos intraplaca) possuem granulação fina a muito fina e são constituídas por plagioclásio (andesina a labradorita), clinopiroxênio (pigeonita e augita) e, menos freqüentemente, olivina, arranjados em texturas subofiticas e intersticiais.

Os dados U-Pb em zircões disponiveis indicaram, para a formação das rochas vulcânicas (riolitos), idades do intercepto superior ao redor de $598 \pm 29 \mathrm{Ma}$ (Siga Jr. 1995 , Basei et al. 1998. Citroni 1999 et al., Siga Jr. et al. 1999 e Cordani et al. 2000). A idade da isócrona $\mathrm{Rb}-\mathrm{Sr}$ (rocha total) é de cerca de $570 \pm 39$, com razões $\mathrm{Sr}^{87} / \mathrm{Sr}^{86}$ (i) 0.707 . Dados U$\mathrm{Pb}$ mais precisos, via SHRIMP, para a mesma a amostra indicaram um valor ao redor de $595 \pm 16 \mathrm{Ma}$, interpretado como a idade de cristalização e, consequentemente, a idade do vulcanismo riolitico da Bacia de Campo Alegre (Cordani et al. 2000).

A Bacia de Guaratubinha, cuja abertura e instalação ocorreu inteiramente no TGAG durante o Neoproterozóico (Fuck et al. 1967, Basei et al. 1992 e Siga Jr. 1995 ) situa-se na porção norte da unidade, próximo a zona de transição para a SGPM e o CGMA (Figura 3.1). Esta bacia está preenchida por uma associação de rochas sedimentares, piroclásticas e vulcânicas ácidas a intermediárias. Dados geocronológicos (U-Pb em zircões) de Siga Jr. (1995) e Basei et al. (1997) indicaram, para a formação dos riolitos, idades ao redor de 602 $\pm 11 \mathrm{Ma}$. As idades isocrônicas Rb-Sr (rocha total) concentram-se ao redor de $570 \pm 10 \mathrm{Ma}$, com razão $\mathrm{Sr}^{87} / \mathrm{Sr}^{86}$ (i) em torno de 0.709 .

Os diques félsicos associados com a Suite Granitica Serra do Mar possuem ampla distribuição geográfica, sendo concentrados principalmente nas proximidades da Bacia de Campo Alegre, orientados preferencialmente na direção N25-30E, e junto ao flanco NW da Bacia de Guaratubinha, segundo uma direção N30-40E que é paralela ao "treno" da bacia (Kaul 1997). Na região ora investigada foram mapeados diques félsicos orientados na direção N20-30W, discordantes da estruturação geral da SGPM na qual estão inteiramente alojados. Estes diques félsicos são constituídos por microgranitos, riolitos, traquitos, felsitos, granófiros e quartzo pórfiros, equi ou inequigranulares, de granulação fina a afanítica e com texturas dos tipos porfiritica, microgranular, granofírica e esferulítica. Nos diques félsicos 
com textura porfirítica os megacristais são formados por ortoclásio róseo (1 a $10 \mathrm{~mm})$ e quartzo bipiramidal (1 a $5 \mathrm{~mm}$ ).

Segundo Kaul (1997), duas fases de distensão litosférica ocorridas durante o Neoproterozóico ( $580 \pm 20 \mathrm{Ma}$ ) e concentradas nas porções central e norte do TGAG são as responsáveis pelo alojamento, na crosta, dos corpos graníticos da Suite Granítica Serra do Mar e das rochas vulcânicas das bacias de Campo Alegre, Guaratubinha e Corupá. A primeira fase de distensão, com vetores na direção NE-SW, teria sido responsável pela formação das falhas/fraturas N20-30W, segundo as quais se alojaram a porção norte do Granito Graciosa, o Granito Anhangava, a maior parte dos Granitos Agudos do Sul e Morro Redondo, a metade sul da Bacia de Campo Alegre e o Granito Dona Francisca. A segunda fase de distensão, mais importante segundo o autor, com esforços na direção NW-SE, seria responsável pela formação das falhas/fraturas tensionais N50-60E por onde se alojaram a porção sul do Granito Graciosa, os diques félsicos, a Bacia de Guaratubinha, a metade norte da Bacia de Campo Alegre e a porção sul do Granito Agudos do Sul, o Granito Dona Francisca, o Granito Piraí, a Bacia de Corupá e o Granito Corupá. 


\title{
Tabela 3.4 - Relação dos principais componentes graníticos da Suite Serra do Mar e vulcânicos das Bacias Guaratubinha, Campo Alegre e Corupá.
}

\author{
Unidade Geológica Componentes Granf́ticos e / ou Vulcânicos \\ Granito Graciosa Biotita \pm hornblenda e biotita sienogranitos são as Granitos A e Vulcânica \\ rochas predominantes. Ocorrem ainda, hornblenda- \\ biotita alcali-feldspato granitos, hornblendat \\ clinopiroxęnio-biotita monzonitos, e arfvedsonita- \\ atcali-feldspatos granitos (PA) \\ Granito Anhangava Biotita \pm hornblenda e biotita sienogranitos e biotita- \\ alcali-feldspato granitos såo as rochas graniticas \\ predominantes. Ocorrem ainda, alcali-feldspato \\ granitos com biotita e Riebeckita (PA), homblenda- \\ alcali-feldspato sienitos $\theta$ hornblenda-clinopiroxénio- \\ quartzo-alcali feldspato sienito com faialita. \\ Granito Marumbi Biotita-alcali-feldspato granitos. \\ Serra da Igreja Riebeckita alcali-feldspato granitos (PA) \\ $\begin{array}{ll}\text { Granitos A e PA } & \text { Siga Jr. } 1995 \text { e Kaul } \\ \text { Granitos A e PA } & 1997 \\ & \text { Siga Jr. } 1995 \text { e Kaul } \\ & 1997\end{array}$ \\ Granito Palermo Anfibólio-biotita, biotita \pm anfibólio e biotita monzo- \\ sienogranitos, sienogranitos e leuco monzo- \\ sienogranitos e sienogranitos săo as rochas \\ graniticas predominantes. Ocorrem ainda quartzo-
sienitos-quartzo-monzonitos (PA), rochas granticas \\ hibridas máficas e félsicas e gabros-monzagabros \\ alcalinos. \\ Granito Agudos do Leucogranodioritos. \\ Sul \\ Predominantemente monzo-sienogranitos, grande \\ volume de rochas graniticas hibridas máficas e \\ félsicas e gabros-monzogabros alcalinos. Granito \\ Tarumă $=$ Monzogranitos calcio-alcalinos de alto $\mathrm{K}$ gabros/monzogabros \\ alojados nesta unidade granitica. \\ Granito Serra Alta Riebeckita alcali-feldspato granitos. \\ Granito Morro Porção Norte: Riebeckita \pm aegirina biotita alcali- Granitos A e PA
Redondo feldspato granitos (PA) e rochas vuicânicas Vulcánicas félsicas \\ associadas (predominam riolitos \\ associadas (predominam riolitos com riebeckita $e$ \\ e basaltos andesiticos. Riolitos: com e sem \\ megacristais de FK Basaltos: plagiociásio \\ (oligoclásio a andesina e até labradorita) \\ Clinopiroxênio (augita), Biotita (10 a $20 \%$ ), opacos \\ (magnetita-ilmenita), titanita, rutilo e raramente \\ quartzo e FK. Textura offica a subofitica e \\ intergranular. \\ Porcăo sul: predominam Biotita \pm homblenda e

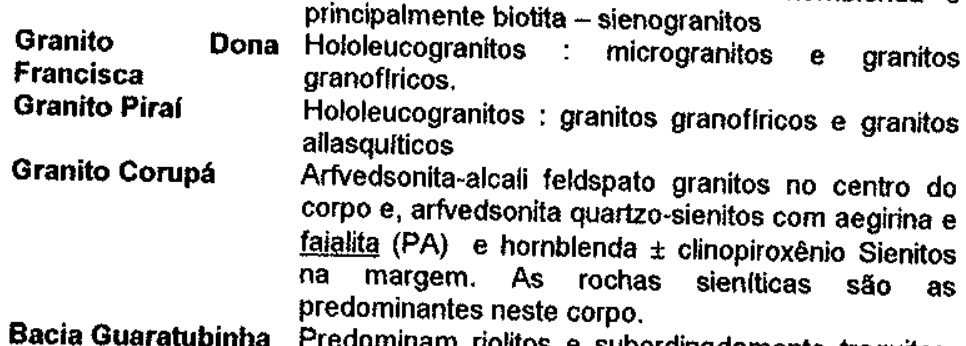 \\ Bacia Guaratubinha Predominam riolitos e subordinadamente traquitos, Vulcánicas félsicas e Siga Jr. 1995 e castro \\ traqui-andesitos e andesitos. Basaltos e basaltos máficas intraplaca et al. 1994 \\ Bacia \\ andesiticos ? \\ Vulcánicas felsicas e \\ Siga Jr. 1995, Góes \\ máficas intraplaca \\ Inédito (este trabalho) $\mathrm{e}$ \\ Siga Jr. 1995 \\ Granitos (A), hibridas Harara 1996, Inédito \\ e Siga Jr 1995 \\ gabrosimonzogabros \\ Granitos A \\ e (este trabalho) \\ 1995 e Kaul 1997 \\ Siga Jr. 1995 e Kaul \\ 1997 \\ Siga Jr. 1995 e Kaul \\ 1997 \\ Granitos A e PA \\ Siga Jr. 1995 e Kaul \\ 1997 \\ (WP)

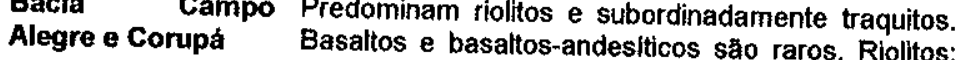 \\ Basaltos e basaltos-andesiticos são raros. Riolitos:
K-feldspato (sanidina), quartzo, plagioclásio e \\ raramente biotita e olivina. Texturas traquiticas, \\ Vulcânicas félsicas e Siga Jr. 1995 e Citroni \\ máficas intraplaca 1998 \\ (WP) \\ microlliticas e esferolíticas. Basaltos e basaltos- \\ andesíticos: plagioclásio (andesina-labradorita), \\ clinopiroxênio (pigeonita e augita) e raramente \\ olivina. Textura predominante subofitica

\footnotetext{
"A identificação da tipologia granitica é baseada no tipo da mineralogia principal e acessória, as relaçöes texturais entre os minerais constituintes em geral $\mathrm{e}$ as assinaturas quimicas destas rochas principalmente o conteúdo nos principais oxxis entre os $\mathrm{Sr}, \mathrm{Ga}, \mathrm{Zr}, \mathrm{Th}, \mathrm{Nb}, \mathrm{Y}$ e ETRL e ETRP. A = alcalina e aluminosa rochas principalmente o conteúdo nos principais óxidos e, Rb, peraicalina a peralcalina.
} 

Tabela 3.5 - Relação dos principais dados geocronológicos e isotópicos da Suite Granítica (A-PA) Serra do Mar
e das vulcánicas das Bacias Guaratubinha e Campo Alegre.

\begin{tabular}{|c|c|c|c|c|c|}
\hline $\begin{array}{l}\text { Método Geocronologico } \\
\text { Unidade Geológica }\end{array}$ & $\begin{array}{l}\text { U.Pb (Zircäo) } \\
\text { (Ma) }\end{array}$ & $\begin{array}{l}\text { Rb-Sr (Rocha Total) } \\
\text { (Ma) e } \mathrm{Sr}^{87} / \mathrm{Sr}^{86}(i)\end{array}$ & $\begin{array}{l}\text { K-Ar (Biotita e Anfibólio) } \\
\text { (Ma) }\end{array}$ & $\begin{array}{l}\text { Sm-Nd }\left(T_{D M}\right) \\
(\text { Ma }) \in N d d^{(n)}\end{array}$ & Fontes Bibliográficas \\
\hline Granito Graciosa & $\begin{array}{l}594 \pm 64^{*} \\
597 \pm 61^{*} \\
574 \pm 33^{* *}\end{array}$ & $\begin{array}{c}584 \pm 12, \mathrm{Sr}^{87} / \mathrm{Sr}^{86}(\mathrm{i})=0.70796 \\
585 \pm 11, \mathrm{Sr}^{87} / \mathrm{Sr}^{86}(\mathrm{i})=0.7076(\mathrm{~K})\end{array}$ & Biotita $=587 \pm 11$ e $569 \pm 11$ & & $\begin{array}{c}\text { Siga Jr. } 1995 \\
\text { Siga Jr et al } 1999 \\
\text { Cordani et al } 2000\end{array}$ \\
\hline Granito Anhangava & & $\begin{array}{c}600 \pm 20, \mathrm{Sr}^{87} / \mathrm{Sr}^{86}(\mathrm{i})=0.7193 \\
610 \pm 26, \mathrm{Sr}^{87} / \mathrm{Sr}^{88}(\mathrm{i})=0.7177(\mathrm{~K}) \\
520 \pm 30, \mathrm{Sr}^{87} / \mathrm{Sr}^{86}(\mathrm{i})=0.7085(\mathrm{~K})\end{array}$ & Biotita $=549 \pm 17(?)$ & 1874. $\in N d^{(1)}=-7.36$ & $\begin{array}{c}\text { Siga Jr. } 1995 \text { e Siga Jr. et } \\
\text { al } 1999 \\
\text { Kaul } 1997\end{array}$ \\
\hline $\begin{array}{c}\text { Granito Marumbi e Serra } \\
\text { da Igreja }\end{array}$ & & & $\begin{array}{c}\text { Marumbi: } 564 \pm 29 \text { (Biotita) e } 496 \\
\pm 35 \text { (Biotita). Serra da lgreja: } 589 \\
\pm 27 \text { (Anfibólio) e } 594 \pm 26 \\
\text { (Biotita) }\end{array}$ & & $\begin{array}{c}\text { Siga Jr. } 1995 \text { e Siga Jr , et } \\
\text { al } 1999 .\end{array}$ \\
\hline Granito Palermo & $\begin{array}{c}593 \pm 12 / 13^{*} \\
594 \pm 26^{*} \\
601^{*} \pm 21^{*}\end{array}$ & $\begin{array}{c}561 \pm 10 / 13, \mathrm{Sr}^{87} / \mathrm{Sr}^{86}(\mathrm{i})=0.707 \\
544 \pm 8, \mathrm{Sr}^{87} / \mathrm{Sr}^{88}(\mathrm{i})=0.709 \\
596 \pm 22, \mathrm{Sr}^{87} / \mathrm{Sr}^{88}(\mathrm{i})=0.705 \\
598 \pm 26, \mathrm{Sr}^{87} / \mathrm{Sr}^{88}(\mathrm{i})=0.70557 \\
557 \pm 12, \mathrm{Sr}^{87} / \mathrm{Sr}^{88}(\mathrm{i})=0.7091 \\
\left.570+22 \mathrm{sr}^{87} / \mathrm{s} r^{86} \mathrm{i}\right)=070725\end{array}$ & Biotita $=581 \pm 12$ & $2350-2100 . \in N d^{(n)}=-12.53 a-14.43$ & $\begin{array}{l}\text { Inédito (Este Trabalho) } \\
\text { Siga Jr. 1995, Kaul \& } \\
\text { Cordani 1994, Kaul } 1997 \\
\text { Siga Jr. et af. } 1999\end{array}$ \\
\hline Granito Agudos do Sul & & $\begin{array}{c}570 \pm 22, \mathrm{Sr}^{87} / \mathrm{Sr}^{86}(\mathrm{i})=0.70735 \\
570 \pm 42, \mathrm{Sr}^{87} / \mathrm{Sr}^{86}(\mathrm{i})=0.707 \\
579 \pm 5, \mathrm{Sr}^{87} / \mathrm{Sr}^{88}(\mathrm{i})=0.7054(\mathrm{~K}) \\
558 \pm 9, \mathrm{Sr}^{87} / \mathrm{Sr}^{88}(\mathrm{i})=0.7089(\mathrm{~K})\end{array}$ & & 2524. $\in N d^{(n)}=-18.05$ & $\begin{array}{l}\text { Inédito (Este Trabalho), } \\
\text { Siga Jr. 1995, Siga Jr. et } \\
\text { al. } 1999 .\end{array}$ \\
\hline Granito Rio Negro & $\begin{array}{r}593 \pm 6^{\star} \\
\underline{593^{*} \pm 16-} \\
585^{*} \pm 7 / 8(\mathrm{MG} \\
\end{array}$ & $\begin{array}{l}561 \pm 10 / 13, \mathrm{Sr}^{87} / \mathrm{Sr}^{88}(\mathrm{i})=0.707 \\
601 \pm 23, \mathrm{Sr}^{87} / \mathrm{Sr}^{86}(\mathrm{i})=0.70401\end{array}$ & $\begin{array}{l}\text { Biotita }=574 \pm 17-572 \pm 13 \\
\text { Biotita }=589 \pm 16(M G)\end{array}$ & $\begin{array}{l}\text { Granitos }=2400-2300 . \in N d^{(3)}=-11.72 \\
\text { Gabros }=2.300 . \in N d^{(1)}=11.57\end{array}$ & $\begin{array}{l}\text { Inédito (Este Trabalho). } \\
\text { Girardi et al. } 1974\end{array}$ \\
\hline Granito Morro Redondo & $\begin{array}{l}589 \pm 37^{*} \\
592 \pm 25^{*} \\
570 \pm 12^{* *}\end{array}$ & $\begin{array}{c}\sim 580, \mathrm{Sr}^{87} / \mathrm{Sr}^{86}(\mathrm{i})-0.710 \\
604 \pm 9, \mathrm{Sr}^{87} / \mathrm{Sr}^{88}(\mathrm{i}) \sim 0.7134 \mathrm{PA} \\
(\mathrm{K}) \\
632 \pm 30, \mathrm{Sr}^{87} / \mathrm{Sr}^{86}(\mathrm{i})=0.70720(\mathrm{~K}) \\
(\mathrm{BG})\end{array}$ & Anfibólio $=565 \pm 20(?)$ & 2.029. $\in \mathrm{Nd}^{(n)}=-7.76$ & $\begin{array}{l}\text { Siga Jr. 1995, Siga Jr. et } \\
\text { al } 1999 \text { e Cordani et al. } \\
2000\end{array}$ \\
\hline Granito Corupá & $\begin{array}{l}580 \pm 6^{*} \\
598 \pm 16^{\star} \\
P A\end{array}$ & $\begin{aligned} 550 \pm 26, \mathrm{Sr}^{87} / \mathrm{Sr}^{88}(\mathrm{i}) & =0.70703 \\
520 \pm 30, \mathrm{Sr}^{87} / \mathrm{Sr}^{86}(\mathrm{i}) & =0.7085 \\
500 \pm 10, \mathrm{Sr}^{87} / \mathrm{Sr}^{86}(\mathrm{i}) & =0.7099(\mathrm{~K})\end{aligned}$ & Anfibolio $=533 \pm 21$ (?) & 1950. $\in N d^{(1)}=-12.03$ & Siga Jr. 1995 \\
\hline Bacia Guaratubinha & $605 \pm 9 *$ & $570 \pm 10, \mathrm{Sr}^{87} / \mathrm{Sr}^{80}(\mathrm{i})=0.70947$ & & & Siga Jr. 1995 e Siga Jr. et \\
\hline Bacia Campo Alegre & $\begin{array}{l}598 \pm 29^{*} \\
595 \pm 16^{* *}\end{array}$ & $570 \pm 39\left(\mathrm{Sr}^{87} / \mathrm{Sr}^{88}(\mathrm{i})=0.70690\right.$ & & $\begin{array}{c}\text { 2300.1900. } \in \mathrm{Nd}^{(\mathrm{T})} \text { Basaltos }=-15.44 \mathrm{e} \\
\text { Traquitos }=-13.19\end{array}$ & $\begin{array}{l}\text { Siga Jr. } 1995, \text { Siga Jr. et } \\
\text { al. } 1999, \text { Cordani et al. } \\
2000 \text { e Citroni et al. } 1999 .\end{array}$ \\
\hline
\end{tabular}




\section{7 - Propostas de compartimentação tectônica e evolução geodinâmica da região}

A região que engloba o sudeste do Paraná e nordeste de Santa Catarina recebeu inúmeras propostas de denominações e divisões geotectônicas, tais como: Maciço Mediano de Joinville (Hasui et al. 1975), Província Mantiqueira (Jost \& Hartmann 1984), Complexo Granulítico de Santa Catarina (Hartmann et al 1979), Cráton Luis Alves (Kaul 1980), Complexo Luis Alves (Kaul \& Teixeira 1982), Cinturão Granulítico Atlântico (Wernick 1979 e Wernick \& Oliveira 1982), Cinturăo Móvel de Joinville (Silva 1984), Cráton Rio de La Plata (Fragoso César 1980, Basei 1985 e Basei \& Teixeira 1987), Cráton Garuva-São Francisco do Sul (Silva, 1987), entre outros.

A história geológica dos terrenos situados entre os cinturōes metasedimentares Apiaí (PR) e Dom Feliciano (SC) resulta de uma evolução policíclica no Arqueano, Paleoproterozóico e/ou Neoproterozóico, com eventos de reestruturação, migmatização e retrabalhamento tectono-metamórfico e termal com rejuvenescimento isotópico, além de adição lateral e vertical de litotipos graníticos e gabróicos neoproterozóicos por fusão de crosta continental antiga e do manto.

Com base nas características litoquimicas dos litotipos granuliticos máficos e félsicos e no tamanho reduzido do TGAG, Figueiredo et al. (1991) sugeriram um ambiente de arco insular arqueano-paleoproterozóico para a formação das rochas deste complexo.

Basei (1985) e Basei \& Teixeira (1987) compartimentaram os terrenos do sudeste do Paraná e nordeste de Santa Catarina em duas unidades tectônicas maiores, denominadas de: Maciço Marginal de Curitiba (terrenos entre o TGAG e a faixa Apiaí) e Cráton Rio de La Plata (incluindo o TGAG).

Com base em dados gravimétricos obtidos entre o Cinturão Dom Feliciano e o CGMA, a norte, Mantovani et al. (1989) observaram uma forte anomalia positiva entre as regiões de Jaraguá do Sul-SC e Agudos do Sul-PR. Esta feição foi atribuída ao soerguimento de segmentos de crosta inferior na região durante a justaposição do Maciço Marginal de Curitiba e o TGAG.

O Maciço Mediano de Joinville (Hasui et al.1975) foi compartimentado em três unidades geológicas por Siga Jr. et al. (1990) e Basei et al. (1990). Estas unidades são: Meridional (ortogranulitos) correspondente ao Cráton Luís Alves (Kaul 1980) ou Complexo Granulitico de Santa Catarina (Hartmann et al. 1979); Setentrional ou Nappe Rio Iguaçu (gnaisses e migmatitos representando o CGMA, a norte e a SGPM, a sul) e Cinturão Granitoide Costeiro ou Batolito Paranaguá. 
Basei et al. (1992) sugeriram que a atual configuração do Maciço do Joinville, alcançada no final do Neoproterozóico, seria resultante da aglutinação e amalgamento de diferentes fragmentos crustais. Os novos dados geocronológicos, geofísicos (Mantovani et al. 1989) e geológico-estruturais levaram os autores a propor um modelo geotectônico no qual foi individualizada a Microplaca Curitiba (constituida pelo CGMA, ao norte, e a SGPM, ao sul), a Microplaca Luis Alves (TGAG) e o Cinturão Granitoide Costeiro, a leste. Neste ensaio foi sugerida uma evolução geotectônica neoproterozóica baseada em processos de subducção de crosta oceânica e colisão continental entre pequenos fragmentos continentais ou microcontinentes, cujo sentido predominante de acreção lateral seria E-SE para W-NW. Estes fragmentos constituiriam as referidas microplacas. No mesmo trabalho os autores propõem ainda que a região de Piên-PR represente parte da sutura resultante da colisão e amalgamento das duas microplacas, Curitiba, a norte, e Luís Alves, ao sul - Zona de Cisalhamento Piên-Tijucas (ZCPT de Harara 1996 e Harara et al. 1997 a e b). A expressiva granitogênese de natureza alcalina a peralcalina da Suite Granitica Serra do Mar e o vulcanismo ácido- intermediário presente nas bacias de Guaratubinha, Campo Alegre e Corupá seriam, segundo a pesquisa, resultantes de processos magmáticos tardi a póscolisionais entre as duas microplacas e o Cinturão Granitóide Costeiro. $O$ alojamento destes vários corpos graníticos e as manifestações vulcânicas presentes nas referidas bacias teriam ocorrido em ambiente tectônico distensivo produzido por um adelgaçamento infra a supracrustal pós colisional e/ou anorogênico.

Uma colisão continental entre o TGAG e o Cráton do Paraná foi proposta por Siga Jr. (1995), segundo o qual o CGMA representaria a margem do microcontinente TGAG, intensamente deformada e migmatizada. Sistemas transcorrentes intracontinentais teriam sido responsáveis pelo alojamento e deformação dos granitóides da SGPM e pela reestruturação dos litotipos gnáissicos do CGMA. A justaposição do CGC, a leste, sobre o TGAG, teria ocorrido tardiamente à colagem e à colisão do TGAG contra o Cráton do Paraná, enquanto nos terrenos adjacentes, já relativamente estabilizados, ocorreu a expressiva granitogênese de natureza alcalina e peralcalina da Suite Serra do Mar e o vulcanismo ácido a intermediário Guaratubinha-Campo Alegre-Corupá.

Por meio de análise estrutural, petrológica e geocronológica dos litotipos da região de Piên-PR e adjacências, Harara (1996) sugere que esta região represente um dos principais sítios de manifestações geodinâmicas neoproterozóicas ocorridas entre 650 e 570 Ma. Estas manifestações envolveriam processos de subducção (?) e a construção de um arco magmático (SGPM) entre o TGAG e o CGMA, seguidas de colisão, deformação e amalgamento entre a SGPM, a margem norte do TGAG e o CGMA. A Suite Máfica- 
Ultramáfica Piên (SMUP) representaria restos de uma crosta oceânica (?) incompleta (afloram principalmente componentes da seção mantélica) obductada durante este processo colisional. O antigo MGAS (atuais granitos Palermo, Rio Negro e Agudos do Sul) registram, nesta região, evidências da ampla atividade granitica tardi a pós colisional e/ou anorogênica que afetou grande parte da porção central e norte do TGAG e a região entre a SGPM e o CGMA.

Basei et al. (1999) e Basei (2000), baseando-se principalmente em dados geológicos e geocronológicos dos núcleos granulíticos aflorantes no CGMA, sugerem que o TGAG (ou Microplaca Luis Alves) continue somente até a região de Serrra Negra-Guaraqueçaba-PR e excluem o Maciço de Itatins-SP, sugerindo que este seja componente da Microplaca Curitiba. Os limites entre o TGAG e o CGMA seriam representados pelas zonas de sutura Lancinha-Itariri, que separaria o CGMA dos terrenos a norte, e Piên-Tijucas, que separa a Microplaca Curitiba da Microplaca Luis Alves. Os metasedimentos das formações Capiru e Setuva, posicionados ao sul da Zona de Cisalhamento Lancinha-Itariri, teriam afinidades paleogeográficas com o CGMA (Microplaca Curitiba) e não estariam relacionados à Faixa Apiaí ou Ribeira. Estas seriam constituídas pelas formações Votuverava, Água Clara, Itaiacoca e afins, que afloram somente ao norte da Zona de Cisalhamento Lancinha-ltariri.

A trajetória final da evolução geológica dos terrenos pré-cambrianos do sudeste do Paraná e nordeste de Santa Catarina reflete a junção e o amalgamento de unidades geológicas distintas por meio de processos de subducção, colagem e/ou colisão, com sentido de acreção lateral predominantemente de leste para oeste. Este pequeno cenário geotectônico resulta de maiores e mais eventos geodinâmicos como subducções com consumo de placas oceânicas e colisões entre macro e micro continentes, que ocorreram durante o Neoproterozóico e que culminaram, entre outros, com a construção do Gondwana ocidental. 


\section{0 - Contexto Geologico Local}

O mapeamento geológico da região do alto Rio Negro (PR-SC) permitiu a individualização e a investigação de seis principais unidades geológicas: o Terreno Gnáissico Anfibolitico Granulítico do Paraná e Santa Catarina (TGAG), parte da porção norte da Microplaca Luis Alves, a Suite Máfica-Ultramáfica Piên (SMUP), a Suite Granítica Piên-Mandirituba (SGPM), o Granito Palermo (GP), o Granito Agudos do Sul (GAS), o Granito Rio Negro (GRN) e, alojado neste último, o Granito Tarumã (GT). Parte das bacias vulcano-sedimentares Neoproterozóicas de Campo Alegre e Guaratubinha, do Granito Morro Redondo e a bacia quaternária de Tijucas do Sul afloram nesta região, mas não são alvos deste estudo.

Estas unidades geológicas mapeadas constituem parte da zona de transição neoproterozóica entre os terrenos paleoproterozóicos/neo-arqueanos? do TGAG, ao sul, e do Cinturão Gnáissico-Migmatítico de Atuba (CGMA) ao norte.

Os dados geológicos, petrográficos, químicos e de campo levantados na região permitem a separação do antigo contexto geológico do Maciço Granítico Agudos do Sul (MGAS) em três corpos graniticos principais com diferentes tamanhos com fortemente correlacionados entre si (mapa em anexo 1). Esses corpos denominam-se, de norte para sul, Granito Palermo (GP), Granito Agudos do Sul (GAS), Granito Rio Negro (GRN) e, ocorrendo dentro deste último, Granito Tarumã (GT). As rochas quartzo monzodioríticas a granodioríticas e leucogranodioritcas com epídoto magmático deformadas, que afloram tanto entre o GP e o GRN como ao redor do GAS, anteriormente incluidas no MGAS (Siga Jr. 1995 e Kaul 1997), são como componentes graniticos da SGPM.

O Granito Agudos do Sul (GAS) aflora a leste do município de Agudos do Sul-PR entre os Granitos Palermo e Rio Negro, como um corpo de formato ovalado constituído essencialmente por leucogranodioritos. A denominação Granito Agudos do Sul, foi reutilizada unicamente para esta unidade granítica, que é totalmente intrusiva nos quartzo monzodioritos/granodioritos e leucogranodioritos da SGPM.

O Granito Palermo (GP) que corresponde à porção norte do antigo contexto geológico do MGAS, aflora entre os municipios de Tijucas do Sul-PR e Mandirituba-PR, apresentando uma forma do tipo "Árvore de Natal", orientada grosso modo na direção N-S. O GP encontra-se alojado ao longo do contato norte do TGAG com a SGPM, sendo constituído principalmente por monzo-sienogranitos $e$, subordinadamente quartzo 
monzonitos/quartzo sienitos "fracamente peralcalinos", monzogabros e rochas graníticas híbridas máficas e félsicas associadas.

O Granito Rio Negro (GRN) que corresponde à porção sul do antigo contexto geológico do MGAS, ocorre ao sul do municipio de Agudos do Sul-PR e a leste do municipio de Piên-PR. O GRN apresenta um formato elipsoidal irregular orientado aproximadamente na direção N40-60E, e intrusivo no contato tectônico (zona de cisalhamento Piên-Mandirituba, ZCPT) da SGPM com o TGAG. O GRN apresenta uma "zonação concêntrica" onde afloram, do núcleo para as bordas, monzogabros, rochas graniticas hibridas máficas e félsicas e, externamente, monzo-sienogranitos.

O Granito Tarumã (GT) aflora dentro da porção central e sul do GRN, sendo circundado, respectivamente, pelos monzogabros e rochas graníticas híbridas máficas e félsicas associadas e pelos monzo-sienogranitos do GRN.

A SGPM é um terreno granítico deformado constituído por três grupos de rochas graníticas não cogenéticas entre si e dentro de cada grupo as rochas são cogenéticas. Estes três grupos são: rochas graníticas sem epídoto magmático (quartzo monzodioritos, quartzo monzodioritos/granodioritos e granodioritos, protomiloníticos a miloníticos), rochas graníticas com epídoto magmático (quartzo monzodioritos, quartzo monzodioritos/granodioritos, granodioritos e leucogranodioritos protomiloníticos a miloníticos) e, monzogranitos (protomiloníticos a miloníticos e sem epídoto magmático). Ocorrem ainda anfibolitos, denominados de anfibolito Espigão das Antas, associados com as rochas graníticas sem epídoto magmático. As rochas graníticas com epídoto magmático ocorrem na porção sudeste e central da SGPM e as rochas graníticas sem epídoto magmático e os monzogranitos ocorrem preferencialmente na porção noroeste da SGPM.

Este terreno granítico aflora desde a região de Piên-PR até os arredores da região de Mandirituba-PR, numa faixa N40-60E com largura máxima de $30 \mathrm{Km}$. Os contatos tectônicos da SGPM com o CGMA, ao norte, e com ○ TGAG, ao sul, são definidos respectivamente pelas zonas de cisalhamento Mandirituba-Piraquara e Piên-Tijucas (ZCPT). Ao longo da ZCPT, que representa o contato tectônico da SGPM com o TGAG, ocorre a SMUP.

Por motivos estruturais (distintas rochas graniticas deformadas na mesma direção) e para facilitar apresentação e a compreensão dos resultados, estas rochas, mesmo sendo bem descriminados no mapa, foram agrupados segundo a mesma denominação (SGPM), devendo no futuro ser, obrigatoriamente, separadas nos três grupos mencionados. 
A foliação nas rochas graníticas em geral da SGPM é em geral bem desenvolvida, com direção modal predominante N50E/69NW, caracterizada pelo estiramento e orientação de K-feldspatos, plagioclásio e quartzo, além de estiramento e orientação de biotita, anfibólio e epídoto magmático. Esta foliação é bem mais desenvolvida nas rochas graníticas sem epídoto magmático e nos monzogranitos. Independentemente do litotipo componente da SGPM, as rochas graniticas com e sem epídoto magmático, monzogranitos e os anfibolitos apresentam geralmente foliações paralelas.

Não foram encontradas, em nenhum local dos afloramentos da SGPM, quaisquer tipos de rochas graníticas hibridas com texturas indicativas de misturas de magmas, tais como identificadas no GRN e o GP.

A SMUP é a mais expressiva e importante suite de rochas ultramáficas expostas nesta região, sendo constituida por dois corpos principais descontínuos, sinuosos e lentiformes com aproximadamente $11 \mathrm{~km}$ de extensão e alojados ao longo da ZCPT, entre a SGPM, a norte e o TGAG, a sul. O corpo setentrional é denominado Campina dos Crispins (CC) e o corpo meridional, Campina dos Maias (CM). O corpo CC está orientado na direção N45-50E e suas encaixantes são as rochas da SGPM, ao norte, e do TGAG, ao sul, apresentando comprimento de $6,5 \mathrm{~km}$ e largura máxima de $1 \mathrm{~km}$. O corpo $\mathrm{CM}$, com direção E-W, comprimento aproximado de $4,5 \mathrm{~km}$ e largura máxima de $2,5 \mathrm{~km}$ ocorre como uma "Klippe" sobre o TGAG.

Os contatos com a SGPM e o TGAG são essencialmente tectônicos, envolvendo falhas de cavalgamento e transcorrentes. As rochas, nas bordas e principalmente nas porções internas, encontram-se fortemente deformadas, dobradas e rompidas, com um aspecto fortemente cataclástico-milonítico e foliações paralelas às da SGPM e do trecho SW do TGAG.

As rochas predominantes na SMUP são peridotitos (dunitos e harzburgitos serpentinizados e serpentinitos) com intercalações de camadas e níveis centimétricos a milimétricos de piroxenitos (olivina-piroxenitos, ortopiroxenitos $e$, raramente, olivinawebsteritos, websteritos e plagioclásio-ortopiroxenitos) e intrusões de piroxenitos e raros gabros (bandados e isótropos). Raros enclaves de mica-serpentina xistos foram encontrados no corpo setentrional CC. Xistos magnesianos com serpentina, talco, magnetita, tremolita, carbonato e clorita ocorrem nas bordas (principalmente ao longo da borda sul do corpo meridional $\mathrm{CM}$ ) e são produtos tectono-metamórficos dos dunitos, harzburgitos e olivina-piroxenitos. Os raros gabros estão expostos no corpo meridional $\mathrm{CM}$, onde os dados estruturais sugerem seu alojamento como diques nos peridotitos. 
O mapeamento geológico revelou que a SMUP não é correlata às lentes de rochas ultramáficas inclusas no TGAG (a sudeste e nordeste de Tijucas do Sul-PR e nos arredores de Voçoroca-PR). Por isso, a SMUP permanece com importância e significado geológico único.

De acordo com a definição original de ofiolito (Penrose, 1972), a SMUP representaria uma seqüência ofiolítica incompleta, na qual somente a seção mantélica ultramáfica basal é exposta, estando ausente a seção crustal (rochas vulcânicas e sedimentos associados).

O Terreno Gnáissico Anfibolítico Granulítico do Paraná e Santa Catarina (TGAG) é constituido, nesta região, principalmente por ortognaisses granuliticos máficos a intermediário e félsicos e gnaisses biotíticos e anfibolíticos. $\mathrm{Na}$ área investigada, esta unidade ocorre como dois segmentos descontínuos, separados pelas rochas vulcanosedimentares da Bacia de Campo Alegre. Estes segmentos serão denominados trechos NE e SW, respectivamente.

Os gnaisses granuliticos máficos a intermediários (ortopiroxênio \pm clinopiroxênio \pm anfibólio \pm biotita noritos e quartzo-noritos) predominam sobre os félsicos (ortopiroxênio \pm clinopiroxênio \pm anfibólio \pm biotita enderbitos). Ocorrem ainda charnoquitos máficos a intermediários e félsicos. Os gnaisses granuliticos apresentam bandamento fino a grosso, paralelo à foliação, ocorrendo, raramente, porções "charnoquíticas" isótropas. Este bandamento é caracterizado pela alternância de niveis heterogêneos milimétricos a centimétricos félsicos (plagioclásio + quartzo \pm K-feldspato) e máficos (ortopiroxênio \pm clinopiroxênio \pm anfibólio \pm biotita). Os principais minerais acessórios são apatita, rutilo, zircão e magnetita. O zircão apresenta-se como cristais esféricos e/ou elipsoidais.

Os gnaisses granulíticos máficos e félsicos apresentam assembléias mineralógicas com plagioclásio (oligoclásio a labradorita), ortopiroxênio, clinopiroxênio, anfibólio e biotita, características do metamorfismo de alto grau (fácies granulito). Este metamorfismo ocorreu durante o Paleoproterozóico, entre 2,1 e 2,0 Ga, conforme indicam as idades U-Pb obtidas, tanto nos zircőes esféricos, como nos elipsoidais. Exceções são os charnoquitos máficos ricos em biotita e anfibólio do trecho NE do TGAG, que apresentaram idades U-Pb da ordem de 2,2 Ga obtidas em zircões elipsoidais e aciculares. O resfriamento e a estabilização tectônica do TGAG ocorreram por volta de 1,8 Ga, conforme indicam as idades K-Ar em anfibólio e, principalmente, biotita.

Os gnaisses biotíticos e anfibolíticos (dioritos/monzodioritos/quartzo dioritos/tonalitos, raros granodioritos e monzogranitos), rochas sem evidências de granulitização ou passagem por metamorfismo de alto grau, afloram expressivamente no trecho $N E e$, 
subordinadamente, no SW intercalados nos gnaisses granulíticos máficos a intermediários e félsicos. Apresentam em geral assembléias mineralógicas contendo plagioclásio (oligoclásio a andesina), \pm K-feldspato (microclínio), quartzo, anfibólio, biotita e epídoto, com ausência total de ortopiroxênio e clinopiroxênio ou presença somente de pseudomorfos destes dois minerais. Os minerais acessórios mais freqüentes são zircão, apatita, titanita e allanita. $O$ zircão apresenta morfologia elipsoidal semelhante a encontrada nos gnaisses granulíticos máficos a intermediários e félsicos.

São freqüentes lentes de anfibolitos e rochas ultramáficas (piroxenitos e peridotitos serpentinizados) e, mais raramente, lentes de quartzitos.

Não foram encontrados no TGAG desta região, litotipos granulíticos de origem pelítica tais como, gnaisses e xistos com assembléias mineralógicas contendo, corderita, granada, cianita e sillimanita e com minerais acessórios como, a monazita.

Reativaçöes tectônicas neoproterozóicas estão registradas principalmente nos litotipos gnáissicos da porção norte do trecho SW. Evidências são sugeridas pela deformação e o paralelismo das estruturas tectônicas das rochas do TGAG e as da SGPM e da SMUP, o retrometamorfismo de baixo a médio grau imposto às paragêneses minerais de alto grau, a forte orientação e recristalização da biotita dos gnaisses anfibolíticos e biotíticos e as idades K-Ar obtidas em biotita e anfibólio.

São apresentados a seguir, em capítulos separados, a maioria das informações geológicas levantadas, sobre estas unidades geológicas investigadas. 


\section{5. - Granitos Palermo, Rio Negro, Agudos do Sul e Tarumã}

\section{1 - Introdução}

Os dados geológicos, petrográficos, químicos e de campo levantados na região permitem a separação do antigo contexto geológico do Maciço Granítico Agudos do Sul (MGAS) em três corpos graníticos principais com diferentes tamanhos e fortemente correlacionados entre si (mapa em anexo 1). Esses corpos denominam-se, de norte para sul, Granito Palermo (GP), Granito Agudos do Sul (GAS), Granito Rio Negro (GRN) e, ocorrendo dentro deste último, Granito Tarumã (GT). Os quartzo monzodioritos/ granodioritos a leucogranodioritos com epídoto magmático deformados, que afloram tanto entre o GP e o GRN como ao redor do GAS, anteriormente incluídas no MGAS (Siga Jr. 1995 e Kaul 1997), são componentes graníticos da SGPM.

O Granito Agudos do Sul (GAS) aflora a leste do município de Agudos do Sul-PR entre os Granitos Palermo e Rio Negro, como um corpo de formato ovalado constituído essencialmente por leucogranodioritos. A denominação Granito Agudos do Sul, foi reutilizada unicamente para esta unidade granítica, que é totalmente intrusiva nos quartzo monzodioritos/granodioritos e leucogranodioritos da SGPM.

O Granito Palermo (GP) que corresponde à porção norte do antigo contexto geológico do MGAS, aflora entre os municipios de Tijucas do Sul-PR e Mandirituba-PR, apresentando uma forma do tipo "Árvore de Natal", orientada grosso modo na direção N-S. O GP encontra-se alojado ao longo do contato norte do TGAG com a SGPM, sendo constituido principalmente por monzo-sienogranitos $e$, subordinadamente quartzo monzonitos/quartzo sienitos "fracamente peralcalinos", monzogabros e rochas graníticas hibridas máficas e félsicas associadas.

O Granito Rio Negro (GRN) que corresponde à porção sul do antigo contexto geológico do MGAS, ocorre ao sul do município de Agudos do Sul-PR e a leste do município de Piên-PR. O GRN apresenta um formato elipsoidal irregular orientado aproximadamente na direção N40-60E, e intrusivo no contato tectônico (zona de cisalhamento Piên-Mandirituba, ZCPT) da SGPM com o TGAG. O GRN apresenta uma "zonação concêntrica" onde afloram, do núcleo para as bordas, monzogabros, rochas graníticas hibridas máficas e félsicas e, externamente, monzo-sienogranitos.

O Granito Tarumã (GT) aflora dentro da porção central e sul do GRN, sendo circundado, respectivamente, pelos monzogabros e rochas graníticas híbridas máficas e félsicas associadas e pelos monzo-sienogranitos do GRN.

A seguir são apresentadas, em seções separadas, as informações petrográficas, litoquímicas, geocronológicas e isotópicas levantadas sobre estas unidades geológicas mapeadas. 


\section{2 - Petrografia dos Granitos Palermo (GP), Rio Negro (GRN), Agudos do Sul (GAS) e Taruma (GT)}

Nesta seção são apresentados as principais características macro e microscópicas das principais rochas componentes dos Granitos GP, GRN, GAS e GT. Estas descrições petrográficas são dos monzo-sienogranitos, quartzo monzonitos/quartzo sienitos rochas graníticas híbridas máficas e félsicas e gabros/monzogabros dos Granitos GP e GRN, leucogranodioritos do GAS e monzogranitos do GT.

\subsection{1 - Monzo-Sienogranitos dos Granitos Palermo (GP) e Rio Negro (GRN)}

Os monzo-sienogranitos que constituem GP e GRN afloram ao longo de toda a margem externa do GRN, contornando a zona de hibridez constituida pelas rochas graníticas híbridas máficas e félsicas e as rochas gabróicas, e predominam em larga escala no GP.

As principais rochas graniticas convencionais do GP e GRN são monzosienogranitos e leuco monzo-sienogranitos (Figura 5.1), isótropos, com predominância de biotita e biotita \pm anfibólio e, subordinadamente, anfibólio e biotita. Possuem coloração predominantemente rósea a, rósea acinzentada, textura xenomórfica equigranular e inequigranular e granulação normalmente média a grossa, embora tipos finos a médios (porção central do GP) e, eventualmente muito grossos, também ocorrem (Fotos 5.1-5.6).

Os leuco-monzo-sienogranitos com biotita ou biotita \pm anfibólio (Foto 5.6) afloram principalmente ao longo da margem oeste do GP, enquanto que os monzo-sienogranitos com biotita e anfibólio (Fotos 5.1 e 5.2) ocorrem na porção sudeste do GP e são praticamente ausente no GRN. Os monzo-sienogranitos com biotita \pm anfibólio (Fotos $5.3 \mathrm{e}$ 5.4) de granulação média a grossa afloram ao longo de toda a porção leste do GP e são as rochas graniticas predominantes no GRN. Os monzo-sienogranitos de granulação fina a média, cujo único máfico é a biotita (Foto 5.5) e com muscovita primária ?, afloram principalmente na porção central do GP. 


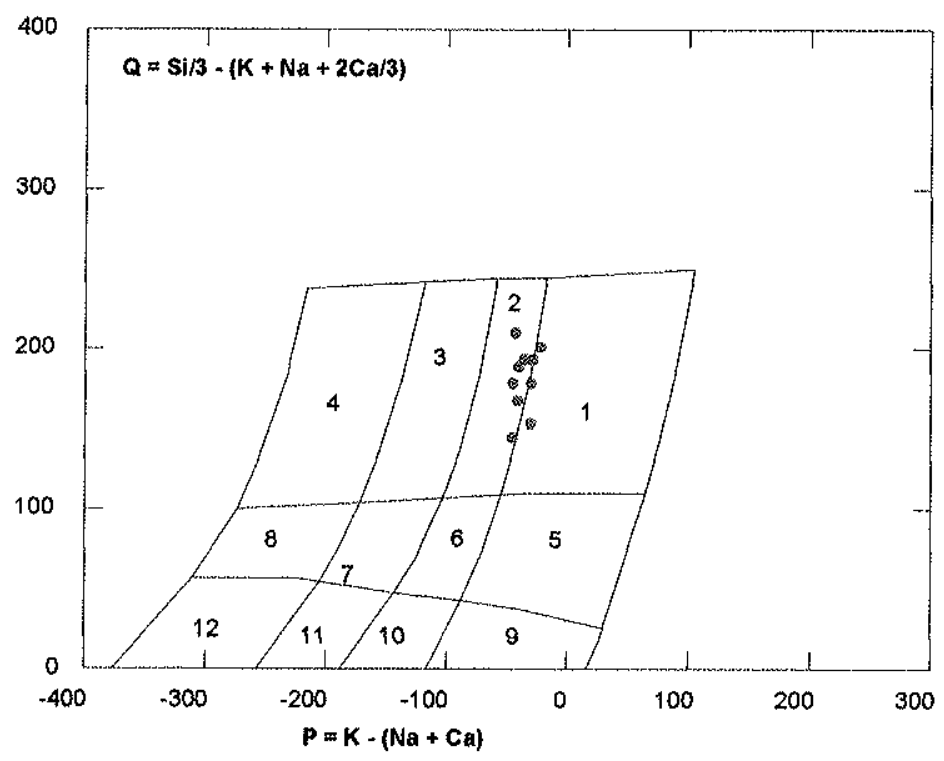

Figura 5.1 - Diagrama P-Q (Debon \& Lefort 1983) indicando a composição dos principais litotipos graníticos do GP e GRN

1- Granitos, 2- Monzogranitos, 3- Granodioritos, 4- Tonalitos, 5- Quartzo-Sienitos, 6-Quartzo-Monzonitos, 7Quartzo-Monzodioritos, 8- Quartzo-Dioritos, 9-Sienitos, 10- Monzonitos, 11- Monzodioritos/Monzogabros, $12-$ Dioritos/Gabros. As rochas com valor de $Q \leq 150$ são os monzo-sienogranitos com biotita e anfibólio do GP. As rochas com valor de $Q>150$ são aquelas com biotita \pm anfibólio ou somente biotita.

Os monzo-sienogranitos do GP e do GRN são constituídos, em geral, por Kfeldspato (mesopertitas a pertitas e, microclina pertítica), quartzo, plagioclásio (albita a oligoclásio sódico), biotita (cor verde e marrom-avermelhado), anfibólio (hornblenda ? ou hastingsita ?, de cor verde oliva a verde escuro) e, ocasionalmente, muscovita (primária ?). A biotita é o principal mineral máfico sempre presente nestes granitos, porém, rochas com biotita e anfibólio afloram principalmente na porção sul e sudeste do GP. Os minerais acessórios mais comuns em todas as rochas são zircão, apatita, fluorita, titanita, allanita e magnetita, que ocorrem geralmente associados com biotita ou biotita e anfibólio e inclusos nestes últimos, sendo intersticiais aos cristais de quartzo e feldspato. A textura xenomórfica (Fotos 5.7 e 5.8) é típica da maioria destes monzo-sienogranitos.

O quartzo ocorre como cristais essencialmente anédricos, distribuidos caoticamente na matriz quartzo-feldspática, inclusos e contornados ou envolvidos por K-feldspato pertítico ou constituindo intercrescimentos granofíricos com pertita. Ocorrem ainda como fenocristais arredondados $(0.5$ até $1 \mathrm{~cm})$, corroídos e circundados ou contornados por cristais de pertita, plagioclásio, biotita ou, biotita e anfibólio (Fotos $5.9-5.12$ )

O K-feldspato (microclina pertítica, mesopertita e pertita) ocorre em geral como megacristais (até $1.5 \mathrm{~cm}$ ) geralmente anédricos e, ocasionalmente, euhédricos a subédricos. São fortemente pertíticos e aparecem freqüentemente em intercrescimento granofírico com 
- quartzo, o que sugere uma simultânea cristalização destes minerais $e$, intersticialmente aos cristais de quartzo e plagioclásio (Fotos 5.8 - 5-12). Apresentam geralmente inclusões de cristais euhédricos a subédricos de plagioclásio e de quartzo e geralmente não possuem inclusões dos demais minerais como máficos (biotita e anfibólio) e acessórios (zircão, fluorita, allanita, titanita e apatita). O plagioclásio ocorre, como megacristais euhédricos a anédricos zonados ou não, e como pequenos cristais euhédricos a anédricos dispersos na massa quartzo-feldspática, isentos ou parcial a fortemente pertitizados, inclusos ou contornados por K-feldspato (Fotos 5.13 e 5.14).

Os minerais máficos anfibólio e biotita ocorrem em diferentes proporções tanto com predomínio da biotita em relação ao anfibólio (anfibólio-biotita monzo-sienogranitos do GP) como, principalmente, biotita \pm anfibólio ou somente biotita, nos demais monzosienogranitos do GP e GRN. O anfibólio ocorre como cristais predominantemente subédricos a anédricos e, ocasionalmente, euhédricos prismáticos, normalmente associados com biotita ou isolados. Aparecem normalmente em simplectitos (Fotos 5.19 - 5.21), de biotita e anfibólio com contatos irregulares e nítidos, sugestivos de substituição magmática parcial a total de anfibólio por biotita. Ambos os minerais ocorrem sempre nos interstícios entre os feldspatos e quartzo, contornando-os ou não. Este caráter intersticial dos minerais máficos, principalmente da biotita (Fotos 5.7, 5.8, 5.15, 5.16 e 5.17), é característico dos monzo-sienogranitos convencionais do GP e do GRN. Os cristais da biotita são subédricos (euhédricos são raros) a predominantemente anédricos e ocorrem isolados ou em aglomerados, com ou sem anfibólio. São sempre intersticiais, preenchendo espaços intergranulares entre feldspato e quartzo (Fotos 5.7, 5.8, 5.15, 5.16 e 5.17), o que indica a sua cristalização tardia em relação aos últimos. Nos monzo-sienogranitos de granulação fina a média com biotita como único máfico, aflorantes na porção central do GP, foi identificada muscovita (primária ?) associada à biotita, apresentando contatos irregulares e nítidos sugestivos de formação da muscovita por substituição parcial ou total da biotita. A muscovita, nestas rochas, ocorre também como cristais euhédricos inclusos nos feldspatos.

Em todos os monzo-sienogranitos do GP e do GRN, observa-se uma intima associação entre a biotita e o anfibólio e os minerais acessórios (allanita, titanita, zircão, apatita, fluorita e opacos) que ocorrem preferencialmente parcial a totalmente inclusos nos cristais de biotita e anfibólio ou, concentram-se junto a estes (Fotos 5.16 - 5.21). Isto sugere também, da mesma forma que para os máficos, a cristalização tardia dos minerais acessórios.

Cristais de zircão são presença marcante em todos os monzo-sienogranitos, principalmente associados ou inclusos nos cristais intersticiais de biotita e/ou anfibólio. Ocorrem ainda entre os cristais de feldspatos e quartzo, sugerindo cristalização anterior ou 
simultânea aos máficos, claramente tardios e intersticiais aos primeiros (Fotos 5.17 e 5.18). A tipologia ou a morfologia dos zircões, segundo a classificação de (Pupin 1980 e outros), observada tanto em lâmina delgada como em lupa é idêntica em todas essas rochas e típica de granitos A ou PA, sendo completamente distinta, tanto em tipo como em tamanho, da morfologia dos zircões das rochas graniticas da SGPM. A apatita ocorre como cristais prismáticos, geralmente associados ou inclusos em biotita e anfibólio ou biotita e anfibólio, sendo raros ou ausentes cristais aciculares (agulhas) dispersos na massa quartzo feldspática, típicos das rochas graníticas híbridas máficas e félsicas aflorantes no GP e GRN. A titanita, quando presente (principalmente em rochas com anfibólio), varia em formato desde euhédrico até anédrico, estando sempre associada ou, inclusa nos máficos (Fotos 5.19 - 5.21). A flúorita é presença constante em todas as rochas graníticas convencionais do GP e do GRN, incluindo as rochas graníticas hibridas máficas e félsicas, mas é ausente nas rochas graníticas da SGPM. Ocorre geralmente associada aos minerais máficos e acessórios (Foto 5.16), principalmente zircões, e preenchendo cavidades miaroliticas presentes principalmente nos biotita \pm anfibólio monzo-sienogranitos que ocorrem ao longo da margem leste do GP.

As relaçōes texturais entre os minerais observadas nos monzo-sienogranitos do GP e do GRN sugerem claramente, uma seqüência de inicio de cristalização do tipo: plagioclásio $\rightarrow$ quartzo $\rightarrow$ feldspato alcalino pertítico $\rightarrow$ zircão + apatita + allanita+ titanita + anfibólio $\rightarrow$ zircão + apatita + allanita + titanita + anfibólio + biotita $\rightarrow$ biotita $\rightarrow$ flúorita.

A presença de cavidades miaroliticas preenchidas por flúorita e o intercrescimento granofírico entre feldspatos e quartzo, são características texturais e mineralógicas que sugerem que a cristalização dos monzo-sienogranitos do GP, GRN e do GAS tenha ocorrido sob baixas pressões $(\leq 4 \mathrm{~Kb})$.

\subsection{2 - Granito Agudos do Sul (GAS)}

O Granito Agudos do Sul (GAS) é constituido essencialmente por leucogranodioritos (Figura 5.2) de granulação fina a média e grossa e coloração principalmente rosa (Fotos 5.22 e 5.23). São constituidos por quartzo, plagioclásio (albita a oligoclásio sódico), Kfeldspato (microclina, pertitica ou não), biotita e muscovita (2 a 4\%) e raros cristais de granada. Os raros e principias minerais acessórios presentes nas rochas do GAS são zircão, fluorita, titanita e apatita. 


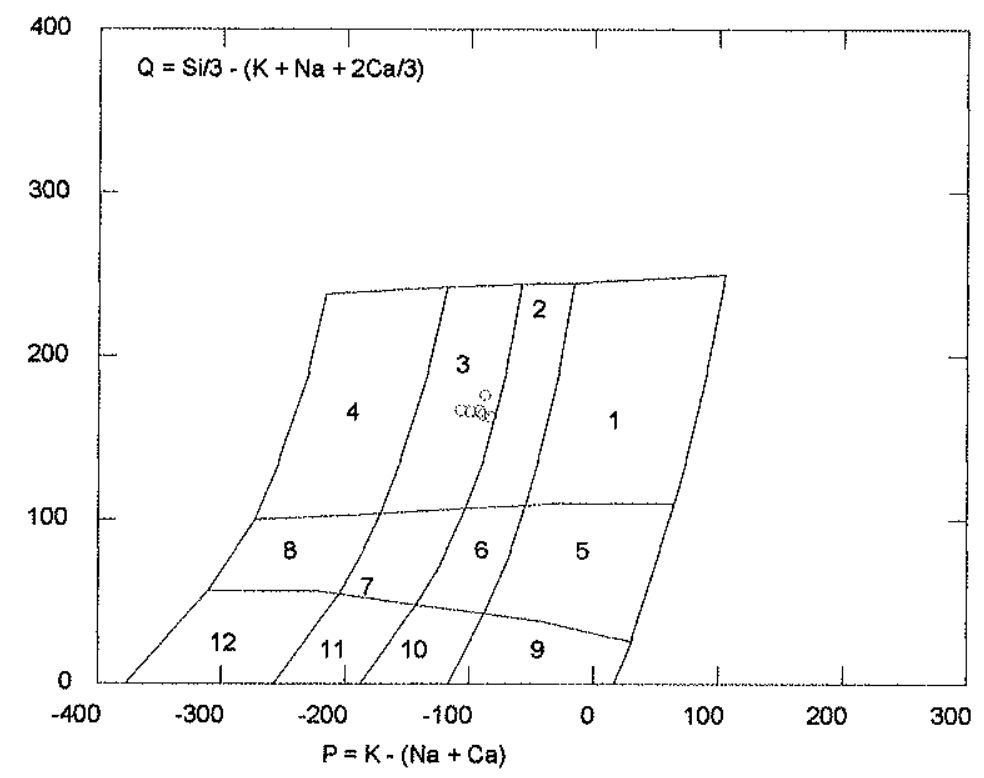

Figura 5.2 - Diagrama P-Q (Debon \& Lefort 1983) indicando a composição dos principais litotipos graníticos do GAS.

1- Granitos, 2- Monzogranitos, 3- Granodioritos, 4- Tonalitos, 5- Quartzo-Sienitos, 6-Quartzo-Monzonitos, 7Quartzo-Monzodioritos, 8- Quartzo-Dioritos, 9-Sienitos, 10- monzonitos, 11- Monzodioritos/Monzogabros, 12Dioritos/Gabros-

O plagioclásio (cor branca) ocorre como cristais menores e mais euhédricos do que o K-feldspato (cor rosa). Os interstícios entre os cristais destes feldspatos são preenchidos por cristais anédricos de quartzo que ocorre também como megacristais alcançando até $1 \mathrm{~cm}$. A forte pertitização, característica comum dos monzo-sienogranitos do GP e do GRN, ocorre em intensidade bem menor nestes leucogranodioritos.

Os poucos cristais de biotita (cor marrom) são principalmente anédricos a subédricos e encontram-se intersticiais aos feldspatos e quartzo. Mostram, freqüentemente, substituições parciais a totais por muscovita. A muscovita é presença constante e marcante nos leucogranodioritos do GAS, tendo sido observada também nas rochas monzosienograníticas de granulação fina a média com biotita que ocorrem na porção central do GP. Sâo cristais subédricos a anédricos, que apresentam geralmente contatos irregulares e nítidos com a biotita, sugestivos da substituição da biotita por muscovita e, são intersticiais aos feldspatos e quartzo (Foto 5.24). A muscovita ocorre ainda, freqüentemente, com cristais euhédricos a subédricos inclusos nos feldspatos. A granada ocorre raramente como cristais anédricos, isolados ou associados à biotita e à muscovita.

A titanita ocorre geralmente associada à biotita e à muscovita. A fluorita ocorre junto aos raros máficos ou preenchendo cavidades miarolíticas presentes em algumas rochas do GAS. O zircão ocorre associado a biotita e muscovita ou incluso nestes. A tipologia ou 
morfologia dos zircões das rochas do GAS é semelhante à dos zircões dos monzosienogranitos do GP e do GRN.

As relações texturais sugerem, da mesma forma que para os monzo-sienogranitos do GP e do GRN, a cristalização inicial dos feldspatos e quartzo e tardia da biotita, muscovita es minerais acessórios.

A ocorrência de leucogranodioritos, a identificação da muscovita (primária ?), a presença de raros cristais de granada associados, a ausência de exsoluções significativas entre os feldspatos $e$, a assinatura química destes leucogranodioritos, são características que podem mascarar a tipologia granítica do GAS em relação ao GP e o GRN. As principais semelhanças texturais, mineralógicas e químicas do GAS com monzo-sienogranitos do GP e do GRN são a presença constante de fluorita, em cavidades miarolíticas ou associados aos minerais máficos, o caráter intersticial e a cristalização tardia dos máficos, a tipologia e - modo de ocorrência dos zircões (sempre associados aos máficos tardios), além da assinatura química, principalmente em alguns elementos traços, tais como $\mathrm{Ga}, \mathrm{Nb}, \mathrm{Ta}, \mathrm{Rb}, \mathrm{e}$ Ba. Estas características são incompativeis também com os quartzo monzodioritos/granodioritos e leucogranodioritos com epidoto magmático da SGPM, dentro dos quais, os leucogranodioritos do GAS encontram-se alojados.

Não foram encontrados no GAS, enclaves ou xenólitos de qualquer natureza, mas ocorrem diques rioliticos com textura microporfiritica a afanitica.

\subsection{3 - Rochas Gabróicas dos Granitos Palermo (GP) e Rio Negro (GRN)}

As rochas gabróicas afloram expressivamente no GRN e, subordinadamente, no GP. Não foram encontradas no GAS nem na SGPM, mas estas rochas somadas às rochas graníticas hibridas máficas e félsicas, cortam os monzogranitos do GT sem que estes se envolvam na mistura, ocorrendo somente como blocos dentro das rochas híbridas.

As rochas gabróicas, predominantemente biotita-monzogabros (Figura 5.3) e, ocasionalmente biotita-gabros/monzogabros com olivina, afloram como pequenos corpos (diques descontínuos), intrusivos na direção NE e NW (GRN) e NW (GP). A sua colocação gera, expressivamente no GRN e, subordinadamente, no GP, grandes zonas de hibridez constituídas por rochas graniticas híbridas máficas e félsicas. Estas rochas gabróicas, juntamente com as rochas hibridas máficas e félsicas adjacentes, afloram em grande escala e ocupam maior parte do GRN. 


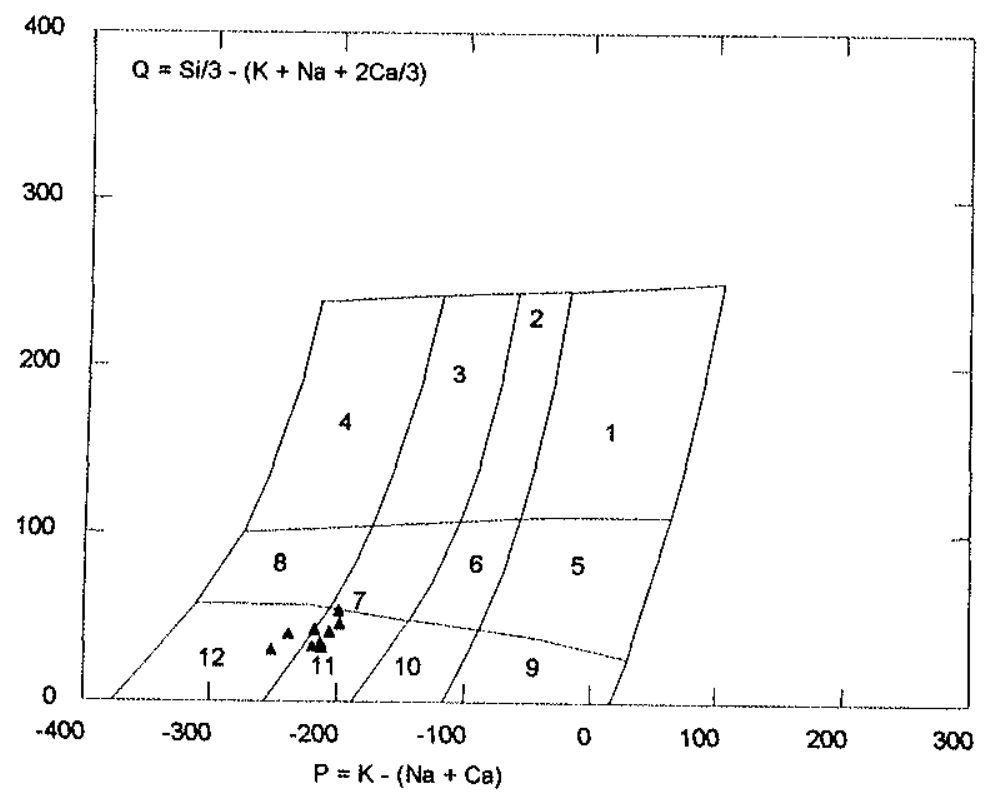

Figura 5.3 - Diagrama P-Q (Debon \& Lefort 1983) indicando a composição das principais rochas máficas do GP e do GRN.

1- Granitos, 2- Monzogranitos, 3- Granodioritos, 4- Tonalitos, 5- Quartzo-Sienitos, 6-Quartzo Monzonitos, $7-$ Quartzo Monzodioritos, 8- Quartzo Dioritos, 9-Sienitos, 10- monzonitos, 11- Monzodionitos/Monzogabros, 12 Dioritos/Gabros-

A mistura destas intrusões de monzogabros com os monzo-sienogranitos no GP e GRN, gerou ao seu redor, uma grande variedade de rochas graniticas híbridas máficas (monzogabros/monzodioritos, quartzo monzodioritos e quartzo-monzonitos híbridos) e félsicas (quartzo monzodioritos, quartzo monzonitos e monzogranitos híbridos), transicionais para os monzo-sienogranitos do GP e GRN.

Os monzogabros apresentam geralmente coloração cinza clara a cinza escura, granulação predominantemente fina e, subordinadamente, média, sendo sempre isótropos e raramente com textura de fluxo (Fotos 5.25 e 5.26). São constituídas por plagioclásio (andesina a labradorita), biotita (de cor marrom avermelhado), anfibólio (hornblenda ou hastingsita ?, de cor verde claro, verde oliva ou verde escuro), clinopiroxênio (augita, augitaaegirina) e ortopiroxênio (enstatita-bronzita), além de K-feldspato (pertita) e quartzo em proporções menores. Os principais minerais acessórios são zircão ( + badeleíta ?), apatita, titanita e opacos (magnetita). Apresentam em geral textura intersticial (Fotos 5.27 e 5.28) caracterizada pela cristalização desordenada e inicial de cristais euhédricos a subédricos de plagioclásio seguida de cristalização de cristais subédricos a anédricos de piroxênio, anfibólio e biotita, geralmente ocupando os espaços entre os cristais de plagioclásio ou invadindo-os. 
Os cristais de plagioclásio são geralmente euhédricos a subédricos, finos e alongados, distribuídos caoticamente na rocha e sempre invadidos por cristais de piroxênio, anfibólio e biotita ou simplectitos destes máficos.

Os minerais máficos, piroxênio (predominantemente clinopiroxênio e subordinadamente ortopiroxênio), biotita, anfibólio (biotita $\geq$ anfibólio) e, raramente, olivina, ocorrem constantemente nestes gabros. Aparecem geralmente como simplectitos com crescimento desordenado de anfibólio sobre clinopiroxênio e de biotita sobre anfibólio ou biotita sobre clinopiroxênio (Fotos 5.29 e 5.30) ou como aglomerados em forma de texturas coroniticas de ortopiroxênio-clinopiroxênio-anfibólio-biotita (do núcleo para a borda). Estes minerais máficos ocupam em geral 40 a $60 \%$ do volume destas rochas, definindo, dependendo da sua variação relativa, anfibólio-piroxênio monzogabros, biotita-anfibóliopiroxênio monzogabros ou piroxênio-biotita-anfibólio monzogabros.

A biotita é presença marcante e constante em todas as rochas gabróicas do GP e o GRN e ocorre como cristais subédricos a anédricos distribuidos caoticamente, isolados ou formando simplectitos com anfibólio e clinopiroxênio (Fotos 5.29 e 5.30) sugestivos da formação da biotita por substituição do anfibólio e do anfibólio por clinopiroxênio.

O clinopiroxênio ocorre geralmente como cristais subédricos a anédricos distribuídos, caoticamente, principalmente entre os cristais de plagioclásio, exibindo contatos irregulares e nítidos com estes ou invadindo-os, caracterizando a textura intersticial. Texturas coroníticas caracterizadas por clínopiroxênio e/ou ortopiroxênio no centro, passando gradativamente para anfibólio e biotita, nas bordas, ou simplectitos de biotita e anfibólio são freqüentes nestes gabros, e sugerem que o piroxênio tenha sofrido hidratação, formando simplectitos com anfibólio e biotita. Intercrescimentos entre ortopiroxênio (no centro) e clinopiroxênio (nas bordas) foram observados em algumas rochas, assim como, entre clinopiroxênio (augita, no centro) e augita-aegirina (nas bordas), ambos sugestivos de substituições mineralógicas tardias entre clinopiroxênios, por incorporação final de alcális.

O K-feldspato pertitico, quando presente, ocorre como cristais anédricos intersticiais ao plagioclásio, piroxênio, biotita e anfibólio. O quartzo ocorre como cristais anédricos distribuidos entre o plagioclásio e os minerais máficos em geral. A textura do quartzo ocelar manteado por máficos (piroxênio e/ou anfibólio e/ou biotita) é rara nestes monzogabros, sendo bem expressiva e típica das rochas graníticas hibridas máficas e félsicas.

A apatita ocorre principalmente como cristais euhédricos prismáticos inclusos em biotita e anfibólio e, subordinadamente, como cristais aciculares (agulhas) que cortam indiscriminadamente tanto os minerais máficos, como o plagioclásio. Este último modo de ocorrência, é raro nos monzogabros, sendo típico das rochas graníticas híbridas máficas e 
félsicas. O zircão (+ badeleíta ?), presença marcante nestas rochas, ocorre geralmente como cristais prismáticos incompletos e corroídos e como cristais totalmente anédricos, com formas exóticas e indefinidas e tamanhos bastante variados e podem ocorrer orientados (Foto 5.31). Cristais euhédricos prismáticos alongados foram observados mais raramente. Estas formas cristalinas indefinidas dos cristais de zircão, distribuídos caoticamente nestas rochas, além das relações texturais destes cristais com os demais principais constituintes, sugerem resfriamento rápido e cristalização tardia deste mineral. A titanita ocorre nestes gabros, associada principalmente com biotita e anfibólio.

Associados aos biotita-monzogabros foram encontrados, principalmente no GRN, raros monzogabros com olivina. A olivina, presente nestas rochas, ocorre como cristais anédricos granulares, exibindo contatos irregulares e nítidos com plagioclásio e piroxênio. Ocorre também preservada em núcleos de cristais de piroxênio envolvidos por anfibólio e/ou biotita e em texturas coroníticas caracterizadas, do centro para a borda por olivina, clinopiroxênio e/ou ortopiroxênio, anfibólio e biotita.

\subsection{4 - Rochas Graníticas Híbridas Félsicas (Quartzo Monzodioritos, Quartzo Monzonitos a} Monzogranitos hibridos) e Máficas (Monzogabro/Monzodioritos, Quartzo Monzodioritos a QuartzoMonzonitos hibridos)

As rochas graníticas híbridas máficas e félsicas (Fotos 5.32 - 5.43) afloram expressivamente no GRN e, subordinadamente, no GP, sendo ausentes no GAS e na SGPM. Ocorrem geralmente associadas aos monzogabros, transitando gradativamente para os monzo-sienogranitos do GP e do GRN.

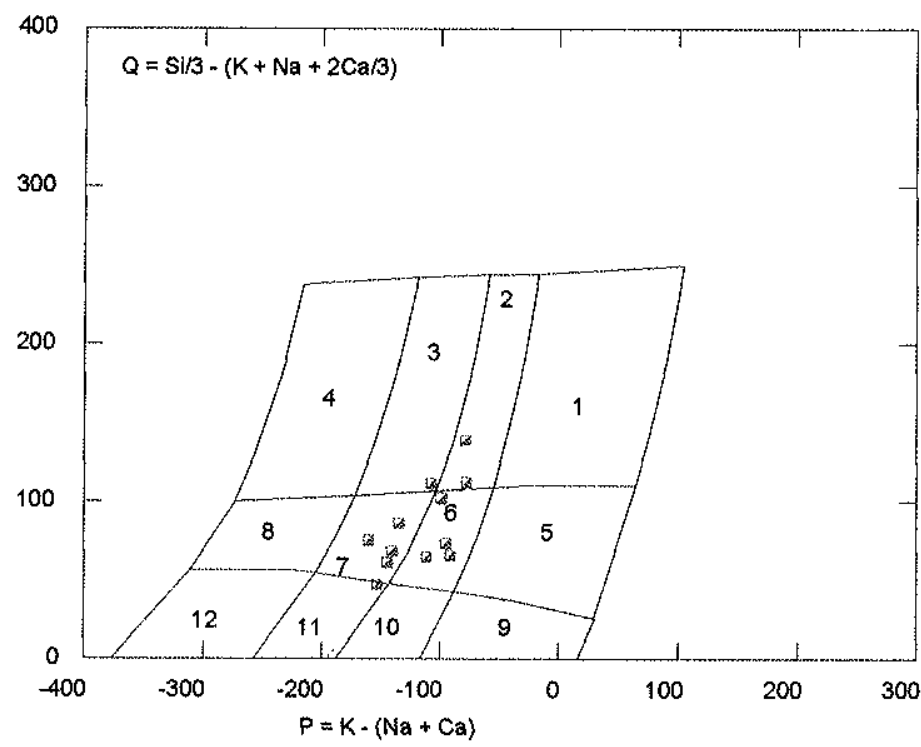

Figura 5.4 - Diagrama P-Q (Debon \& Lefort 1983) indicando a composição dos principais litotipos Graníticos híbridos máficos e félsicos do GP e do GRN.

1- Granitos, 2- Monzogranitos, 3- Granodioritos, 4- Tonalitos, 5- Quartzo Sienitos, 6-Quartzo Monzonitos, 7Quartzo Monzodioritos, 8- Quartzo Dioritos, 9-Sienitos, 10- Monzonitos, 11- Monzodioritos/Monzogabros, $12-$ Dioritos/Gabros* 
As rochas graníticas hibridas félsicas (Fotos 5.39 - 5.43) são quartzo monzodioritos, quartzo monzonitos a monzogranitos híbridos (Figura 5.4), composições graníticas produzidas por mistura. Possuem coloração rosa e/ou cinza claro e são inequigranulares, de granulação geralmente média a grossa e, mais raramente fina. São rochas constituídas por plagioclásio (megacristais e cristais menores), K-feldspato (mesopertitas e pertitas, megacristais e cristais menores), anfibólio, biotita e quartzo (cristais anédricos menores, fenocristais e em forma ocelar, esférico ou elipsoidal manteado por máficos). Os principais minerais acessórios são apatita acicular, titanita, zircão, allanita, fluorita e opacos. Texturas típicas de mistura de magmas são observadas com freqüência, tanto na escala macroscópica como microscópica. Exemplares destas texturas são:

- Cristais esféricos e/ou elipsoidais de quartzo (quartzo ocelar) de vários tamanhos (até $1,5 \mathrm{~cm}$ de diâmetro), com ou sem pertita intersticial, manteados parcial ou totalmente por cristais euhédricos, subédricos e anédricos de anfibólio ou anfibólio e biotita ou simplectitos de anfibólio e biotita (Fotos 5.39 - 5.41 e $5.44-5.46$ ). Esta textura do quartzo ocelar manteado por máficos é a principal textura caracteristica das rochas graníticas hibridas máficas e félsicas aflorantes do GP e do GRN, sendo praticamente ausente nos monzo-sienogranitos e monzogabros do GP e do GRN.

- Concentrados máficos com formatos predominantemente circulares (até $2 \mathrm{~cm}$ de diâmetro), distribuídos caoticamente e constituidos por cristais euhédricos a anédricos de anfibólio e biotita, e por cristais de plagioclásio finos e euhédricos (Fotos $5.39-5.42$ e Foto 5.47)

- Megacristais de K-feldspato pertítico manteados por plagioclásio ou plagioclásio manteado por K-feldspato pertítico (texturas rapakivi e anti-rapakivi produzidas por mistura, sugestão de Hibbard 1981 e 1991). (Fotos 5.42, 5.43, 5.48 e 5.49)

- Megacristais euhédricos a anédricos de plagioclásio (cor branca) e K-feldspatos (cor rosa), de até $1,5 \mathrm{~cm}$, com fortes exsoluções, distribuídos caoticamente nestas rochas (Fotos $5.38-5.42$ ).

- Cristais aciculares de apatita cortando indiscriminadamente todos os minerais máficos e os feldspatos (Foto 5.50). Ocorrem ainda cristais prismáticos de apatita inclusos ou associados a biotita e anfibólio.

As rochas graníticas hibridas máficas (Fotos 5.32 - 5.38) concentram-se principalmente ao redor dos corpos gabróicos e sua ocorrência denuncia a presença dos monzogabros nas adjacências. Distinguem-se de seus correspondentes félsicos, pela elevada quantidade de máficos e pela presença freqüente de piroxênios (clinopiroxênio \pm ortopiroxênio). 
São rochas de granulação fina a grossa, constituidas principalmente por plagioclásio, anfibólio, clinopiroxênio, ortopiroxênio, biotita e K-feldspato pertítico e quartzo em quantidades variáveis. O quartzo ocelar é geralmente manteado por anfibólio e biotita, além de clinopiroxênio e, subordinadamente, ortopiroxênio. Os principais minerais acessórios são, titanita, apatita, zircão (badeleíta), fluorita e opacos. O volume de máficos varia entre 20 e $45 \%$, dependendo principalmente da distância em relação aos gabros, em cujas proximidades verifica-se um aumento na quantidade de piroxênios na matriz e nos cristais de biotita e anfibólio que envolvem o quartzo ocelar.

O quartzo ocorre principalmente sob a forma de cristais esféricos e/ou elipsoidais, com ou sem pertita intersticial e manteados principalmente por anfibólio e, biotita e piroxênio e, são distribuídos caoticamente nestas rochas. A variação em volume desta textura é a principal responsável pela ampla gama composicional verificada nestas rochas.

A biotita é presença constante nestas rochas, sendo observada sob vários arranjos texturais. Pode ocorrer como cristais euhédricos a anédricas, formando simplectitos com piroxênio e anfibólio, ou somente anfibólio, ao redor de cristais de quartzo esférico/elipsoidal, ou como fenocristais euhédricos a anédricos distribuidos caoticamente e freqüentemente associados aos máficos. Ocorrem também, por vezes, com parte coroas de ortopiroxênio-clinopiroxênio-anfibólio-biotita ao redor de quartzo ocelar.

O K-feldspato, ocorre como cristais e/ou fenocristais (até $1 \mathrm{~cm}$ de diâmetro) anédricos a arredondados, pertíticos envolvidos ou não por minerais máficos ou plagioclásio, distribuídos caoticamente ou, orientados numa textura ou estrutura de fluxo. 0 plagioclásio (oligoclásio a andesina, zonados ou não e com freqüentes exsoluções) ocorre geralmente como pequenos cristais euhédricos a anédricos e como fenocristais, distribuidos caoticamente na rocha. Ocorre também por vezes, como cristais euhédricos aprisionados com quartzo ocelar, manteados por máficos.

As principais feições e texturas resultantes de mistura de magmas encontradas freqüentemente nas rochas graníticas híbridas máficas do GP e do GRN são:

- Cristais de quartzo ocelar (esféricos ou elipsoidais), corroídos ou não por pertitas anédricas e intersticiais, manteados parcial ou totalmente por clinopiroxêniotortopiroxênio-anfibólio-biotita ou clinopiroxênio-anfibólio com biotita (Foto 5.51). Ocorrem ainda, em algumas rochas, cristais de quartzo ocelar parcial a totalmente manteados por pertitas, sendo estas, por sua vez, manteadas por máficos. Estas texturas apresentam distribuição caótica e variam em forma (esférico ou elipsoidal) e tamanho (desde 0,2 até $1 \mathrm{~cm}$ ). Mais raramente, o quartzo ocelar apresenta-se sob a forma de elipsóides orientados, em uma matriz na qual alinham-se preferencialmente 
com cristais de anfibólio e biotita, em rochas graníticas híbridas com estrutura de fluxo (Fotos 5.32, 5.37 e 5.46).

- Presença ocasional de cristais de zircão, biotita e/ou anfibólio e/ou plagioclásio, aprisionados junto com o quartzo ocelar, com ou sem pertita intersticial (Foto 5.51).

- Freqüente presença, em todas as rochas híbridas, de cristais aciculares de apatita, cortando indiscriminadamente todos os principais minerais, principalmente os máficos. Esta forma de ocorrência da apatita é rara ou ausente nos monzogabros e nos monzosienogranitos do GP e do GRN.

- Ocorrência de megacristais de K-feldspato manteado por plagioclásio (textura rapakivi não convencional produzida por mistura) e vice-versa (anti-rapakivi), com fortes exsoluções entre ambos, conforme mencionado anteriormente.

- Cristais de zircão geralmente distribuídos caoticamente, apresentando diversas formas e tamanhos tais como: prismas alongados incompletos, cristais aciculares e, sobretudo, cristais anédricos corroídos com formas indefinidas e exóticas, tal como observado nas rochas gabróicas. As relações texturais do zircão com os demais minerais sugerem cristalização tardia deste mineral. Os poucos cristais de zircão aprisionados com o quartzo ocelar, são geralmente mais euhédricos e apresentam a mesma tipologia ou morfologia observada nos monzo-sienogranitos do GP e do GRN.

- Concentrações de minerais máficos (Fotos 5.52 e 5.53), constituídas por piroxênio, anfibólio e biotita, além do plagioclásio, são freqüentes e típicos destas rochas híbridas tanto máficas como félsicas. O volume e o tipo de máficos (biotita, anfibólio ou piroxênio) presentes nestes aglomerados, varia de acordo com a proximidade destas rochas aos monzogabros.

As texturas indicativas de mistura de magmas observadas nas rochas graníticas híbridas máficas e félsicas sugerem que rochas graniticas formadas por quartzo, K-feldspato (mesopertitas e pertitas), plagioclásio, biotita, \pm anfibólio e zircão (típicas dos monzosienogranitos) tenha sido invadidas, durante os estágios de cristalização, por magmas máficos cristalizando plagioclásio, piroxênio, anfibólio e biotita (mineralogia principal dos monzogabros). Como produto desta invasão e da mistura dos componentes magmáticos félsicos e máficos, formaram-se as rochas graníticas híbridas em geral. 


\subsection{5 - Quartzo Monzonitos/Quartzo Sienitos "fracamente peralcalinos" do Granito Palermo}

Estas rochas afloram somente no GP (região de Saltinho-PR) e são circundadas totalmente pelos monzo-sienogranitos do GP. Este tipo de rochas são ausentes no GRN. São quartzo monzonitos/quartzo sienitos (Figura 5.5) de coloração cinza a cinza-verde e granulação média a grossa (Fotos 5.54 e 5.55). Constituem-se de quartzo, K-feldspato (mesopertitas e pertitas), plagioclásio (albita-oligoclásio), biotita, anfibólio (arfvedsonita e riebeckita, cor verde e azul) e clinopiroxênio (aegirina-augita). Os minerais acessórios mais freqüentes são, zircão, fluorita, allanita, titanita e apatita.

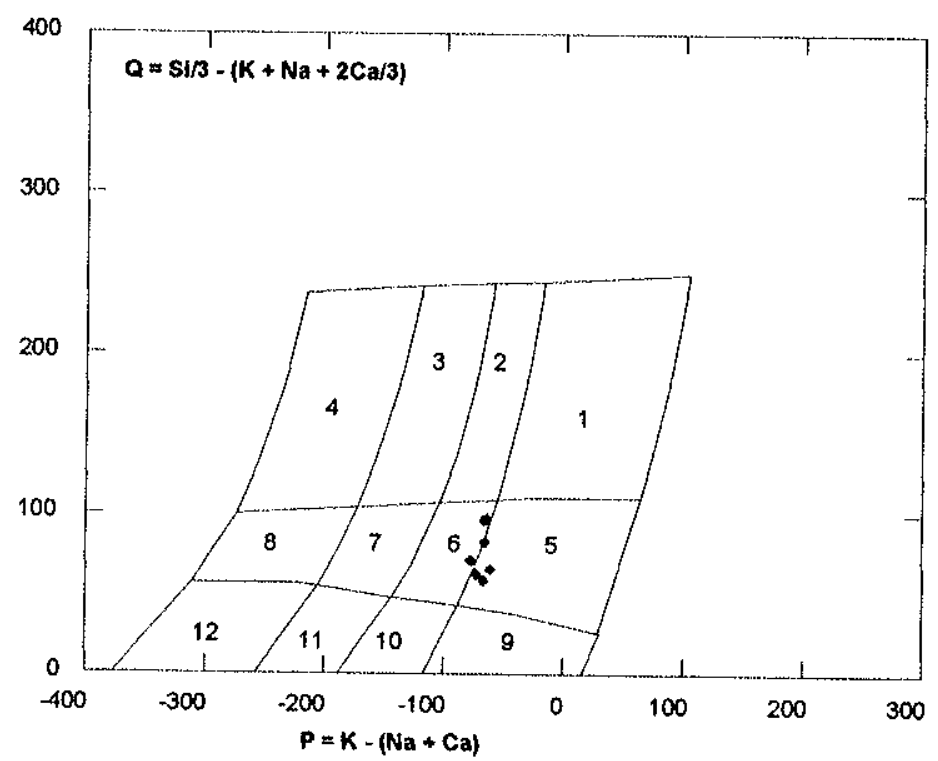

Figura 5.5 - Diagrama P.Q (Debon \& Lefort 1983) indicando a composição dos litotipos graníticos fracamente peralcalinos do GP.

1- Granitos, 2- Monzogranitos, 3- Granodioritos, 4- Tonalitos, 5- Quartzo-Sienitos, 6-Quartzo-Monzonitos, 7Quartzo-Monzodioritos, 8- Quartzo-Dioritos, 9-Sienitos, 10- Monzonitos, 11- Monzodioritos/Monzogabros, 12-
Dioritos/Gabros.

Nestas rochas, os minerais máficos anfibólio (cor verde escuro = arfvedsonita, hastingsita e cor azul = riebeckita), biotita (cor marrom escuro a marrom avermelhado) e piroxênios (aegirina-augita, aegirina) representam volumes entre 15 e $25 \%$, sendo os teores de anfibólios e biotita são maiores do que os de clinopiroxênio. Os máficos, geralmente em aglomerados, ocorrem como cristais euhédricos (anfibólios e piroxênios), e principalmente, subédricos e anédricos (anfibólios, piroxênios e biotitas), sempre intersticiais ao quartzo e feldspatos (Fotos 5.56 e 5.57), indicando uma cristalização tardia dos máficos em geral. Simplectitos com cristais de anfibólios, biotita e piroxênio são freqüentes nestas rochas, onde os cristais de aegirina-augita são substituidos por cristais desordenados de anfibólios e biotita (Foto 5.58). Ocorrem ainda nestas rochas, cristais aciculares, ou não, de anfibólio azul (riebeckita) substituindo anfibólio verde (arfvedsonita) e, estes últimos substituindo 
aegirina-augita (Fotos 5.60 - 5.61). A biotita ocorre geralmente associada com os anfibólios e piroxênio em simplectitos que sugerem a formação deste mineral por substituição de anfibólio.

Associados aos minerais máficos, principalmente biotita e anfibólio, ou inclusos nestes (e raramente em quartzo e feldspato), ocorrem zircão, fluorita, apatita, allanita, titanita e opacos. Os cristais de zircão são geralmente euhédricos a subédricos e, mais raramente, anédricos. Apresentam a mesma tipologia ou morfologia daqueles observados nos monzo-sienogranitos do GP e do GRN. Intercrescimentos granofíricos entre pertita e quartzo foram observados nestas rochas. O modo de ocorrência intersticial dos máficos associados com os acessórios tardios e o intercrescimento granofírico, observados nestes quartzo monzonitos quartzo sienitos, são características também dos adjacentes monzosienogranitos do GP.

Não foram observadas nestes quartzo monzonitos/quartzo sienitos do GP, texturas típicas de mistura de magmas, anteriormente mencionadas.

\subsection{6 - Granito Tarumã (GT)}

O Granito Tarumã (GT) aflora na porção central e sul do GRN, sendo circundado e invadido pelos monzogabros, as rochas graniticas máficas e félsicas híbridas e os monzosienogranitos do GRN.

O GT é constituído por biotita \pm anfibólio-monzogranitos (Figura 5.6), equigranulares finos, geralmente cinzentos e eventualmente róseos (Fotos 5.62 e 5.63). Apresentam freqüentemente enclaves máficos (Foto 5.63 ) $\mathrm{em}$ formas esféricas e/ou ovaladas (elipsoidais). Os principais minerais constituintes são K-feldspato (microclina pertítica a micropertítica), quartzo, plagioclásio (albita a oligoclásio sódico), biotita e, raramente, anfibólio. Os principais minerais acessórios são zircão, allanita, titanita, apatita, magnetita e opacos. A fluorita, como nos litotipos graníticos da SGPM, é ausente. 


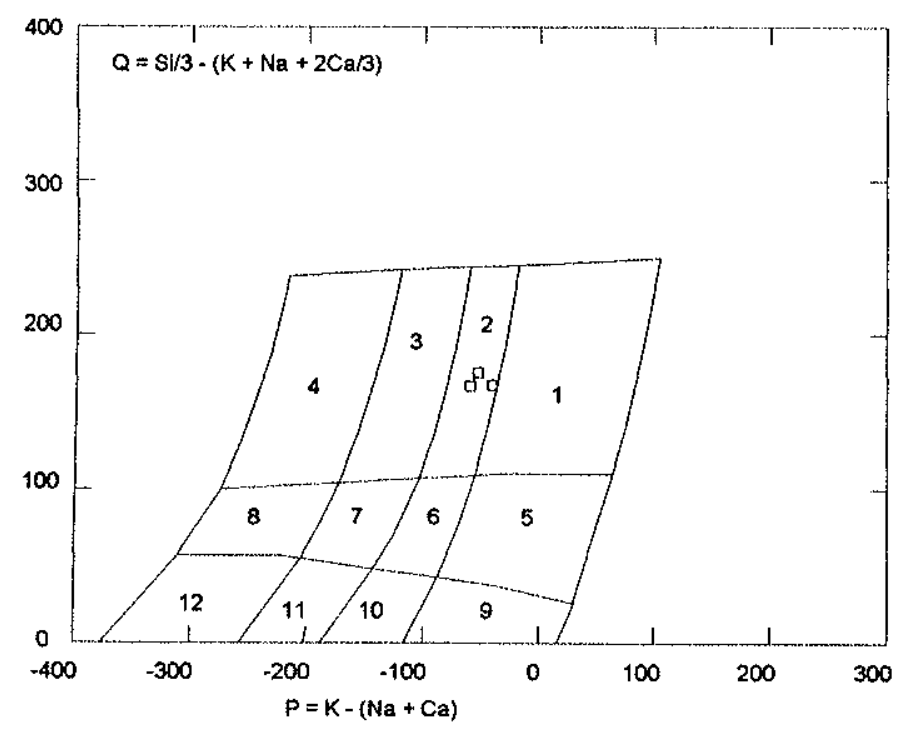

Figura 5.6 - Diagrama Q-P (Debon \& Lefort 1983) indicando a composição dos principais litotipos graníticos do GT.

1- Granitos, 2- Monzogranitos, 3- Granodioritos, 4- Tonalitos, 5- Quartzo Sienitos, 6- Quartzo Monzonitos, 7Quartzo Monzodioritos, 8- Quartzo Dioritos, 9-Sienitos, 10- Monzonitos, 11- Monzodioritos/Monzogabros, 12Dioritos/Gabros.

O quartzo ocorre como cristais anédricos finos, inequigranulares e com rara extinção ondulante, sendo intersticial a feldspatos, biotita e hornblenda (quando presente). Os cristais de plagioclásio são geralmente euhédricos (zonados ou não) a subédricos e, ocasionalmente, anédricos, com dimensões inferiores às do K-feldspato. Os cristais de Kfeldspato são geralmente subédricos a anédricos, intersticiais aos cristais de plagioclásio e biotita.

A biotita é o mineral máfico predominante no GT e ocorre geralmente como cristais lamelares euhédricos a subédricos, dispersos caoticamente na matriz destas rochas numa relação textural que não mostra intersticialidade em relação a feldspatos e quartzo (Foto 5.64). Quando presentes, os raros cristais de hornblenda estão associados à biotita formando simplectitos com formatos variados. Ocorrem núcleos de anfibólio contornados por cristais desordenados de biotita euhédricos a subédricos, sugestivos da formação da biotita por substituição de anfibólio. O caráter intersticial da biotita em relação ao quartzo e feldspatos não foi reconhecido.

As relações texturais entre os minerais constituintes das rochas do GT sugerem uma seqüência de início de cristalização do tipo plagioclásio $\rightarrow$ hornblenda $\rightarrow$ biotita $\rightarrow K$ feldspato $\rightarrow$ quartzo. Esta seqüência é totalmente distinta da observada nos monzosienogranitos do GP e do GRN. 
Ocorrem freqüentemente no GT, concentrados máficos ou enclaves microgranulares máficos (na classificação de Didier \& Barbarin 1991). Estes enclaves, característicos desta unidade, apresentam formas normalmente circulares e elipsoidais (Foto 5.63) e, ocasionalmente, amebóides, com dimensões entre 0,2 e $2 \mathrm{~cm}$, sendo constituídos por biotita e anfibólio com granulação semelhante ou inferior à da rocha hospedeira. Microscopicamente (Foto 5.65), estes enclaves são constituidos por concentrações, sob a forma de simplectitos, de biotita e anfibólio, e por cristais de plagioclásio zonados finos e alongados. Estes enclaves representam possivelmente restitos do magma parental incorporados pelos monzogranitos do GT, ou fases minerais cumuláticas do inicio da cristalização destas rochas graníticas.

Nos monzogranitos do GT não ocorrem intercrescimentos granofíricos entre feldspatos e quartzo nem quartzo contornado e/ou corroído por pertita, cavidades miaroliticas preenchidas por fluorita ou máficos intersticiais (sugestivos de cristalização tardia). Estas feições são características dos monzo-sienogranitos do GRN e do GP. Também não foram observadas texturas típicas de mistura de magmas, tais como apatitas aciculares e quartzo ocelar manteado por máficos, ambos amplamente presentes nas rochas graníticas híbridas máficas e félsicas adjacentes. Este fato aliado à presença dos monzogranitos do GT como pequenos blocos incorporados por estas rochas híbridas adjacentes na região de contato, constitui forte indicio do não envolvimento do GT no processo de mistura, sendo este unicamente circundado e invadido pelos monzogabros, rochas hibridas e monzo-sienogranitos do GRN. 


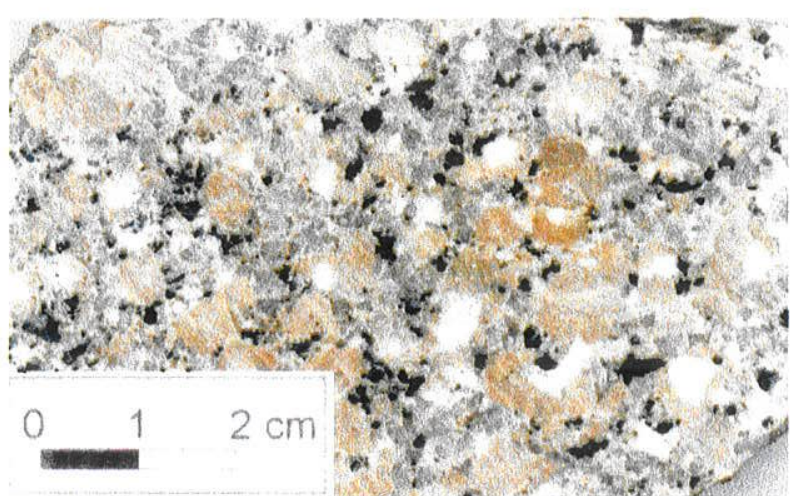

Foto 5.1: Aspecto macroscópico dos Anfibólio-Biotita Monzosienogranitos. GP, amostra OM 691.

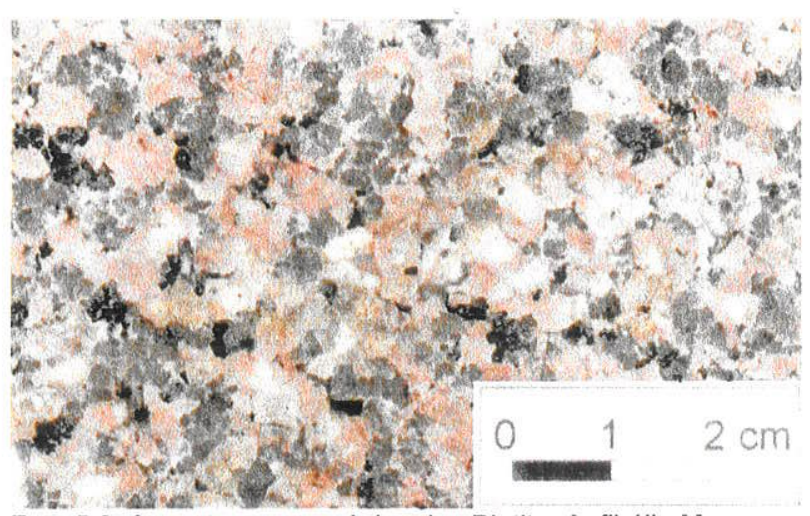

Foto 5.3: Aspecto macroscópico dos BiotitatAnfibólio Monzosienogranitos. GP, amostra OM 740 .

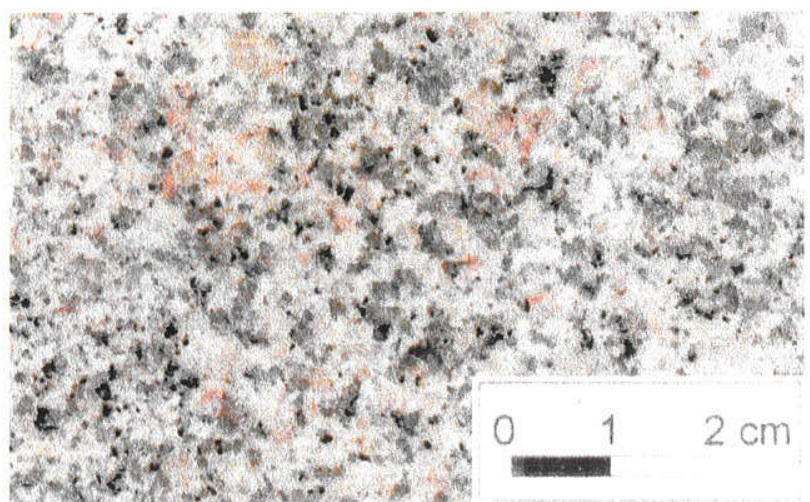

Foto 5.5: Aspecto macroscópico dos Biotita Monzosienogranitos. GP, amostra OM 649.

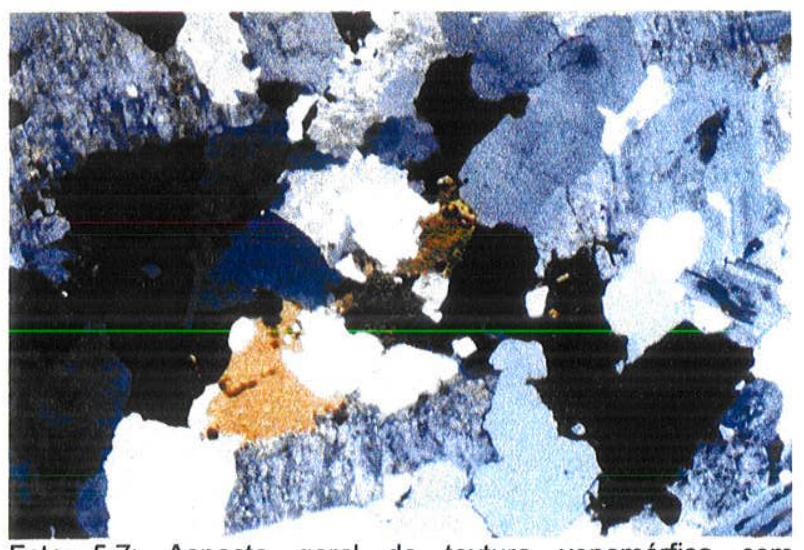

Foto 5.7: Aspecto geral da textura xenomórfica com plagioclásio, quartzo, pertita e biotita intersticial em Biotita Monzo-sienogranitos. GP, amostra 649 (Lado maior da Foto $5,5 \mathrm{~mm}$. Nicóis $X)$.

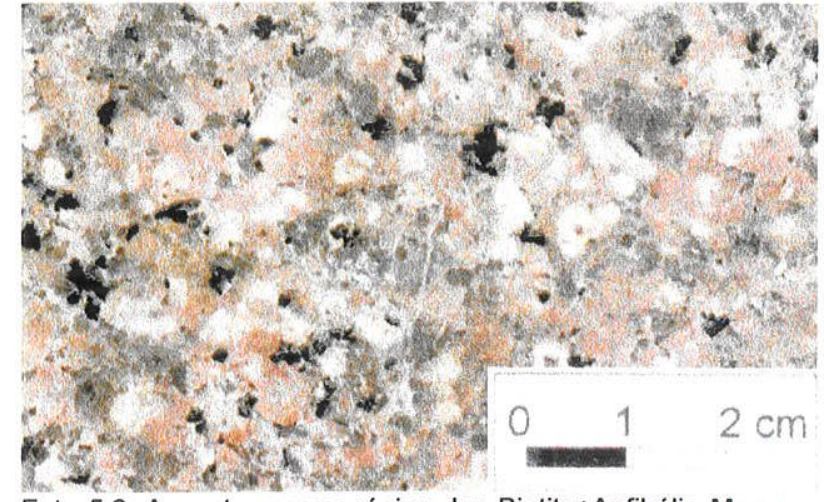

Foto 5.2: Aspecto macroscópico dos BiotitatAnfibólio Monzosienogranitos. GP, amostra OM 748 .

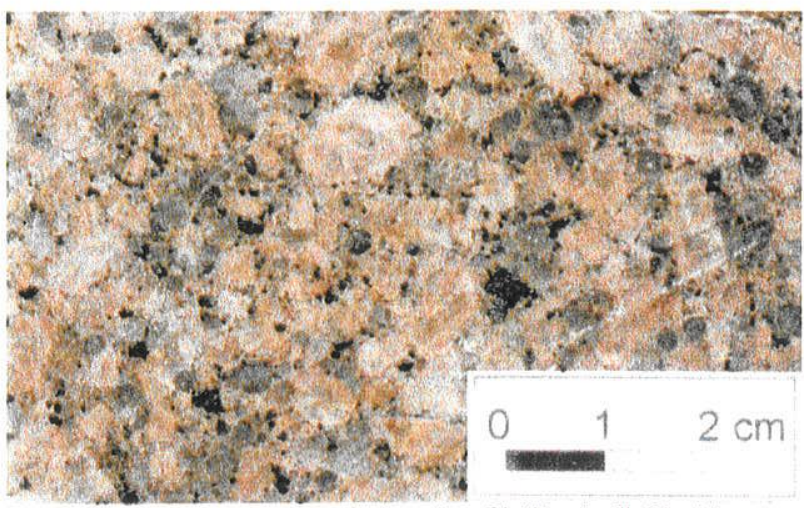

Foto 5.4: Aspecto macroscópico dos Biotita土Anfibólio Monzosienogranitos. GRN, amostra OM 589.

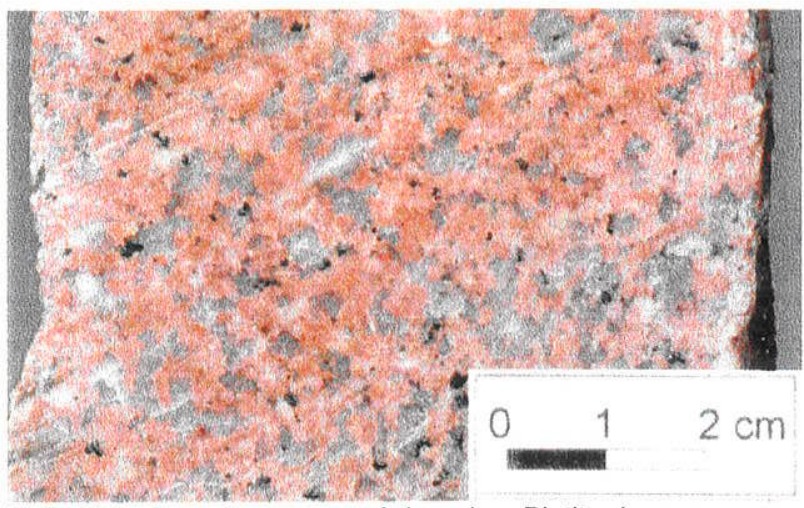

Foto 5.6: Aspecto macroscópico dos Biotita Leucomonzosienogranitos. GP, amostra OM 616 .

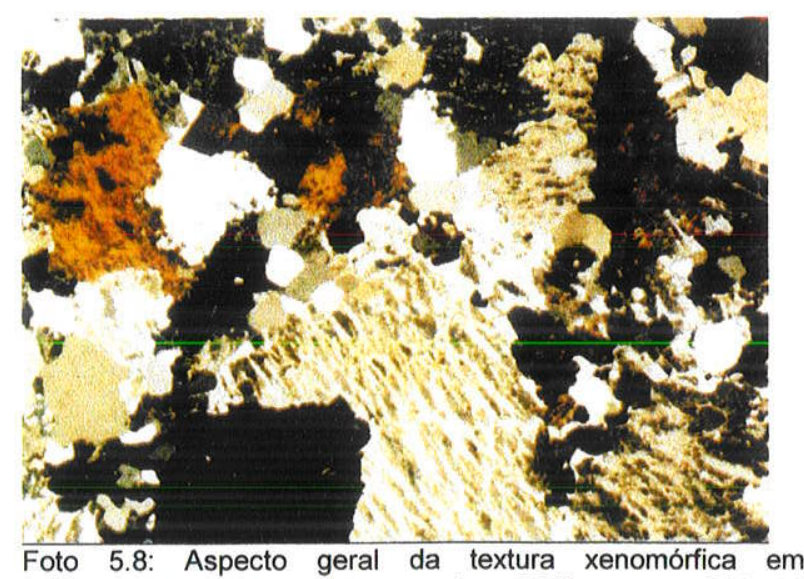

Biotita \pm Anfibólio Monzo-sienogranitos. GRN, amostra OM 589 (Lado maior da Foto 5,5 mm. Nicóis X). 


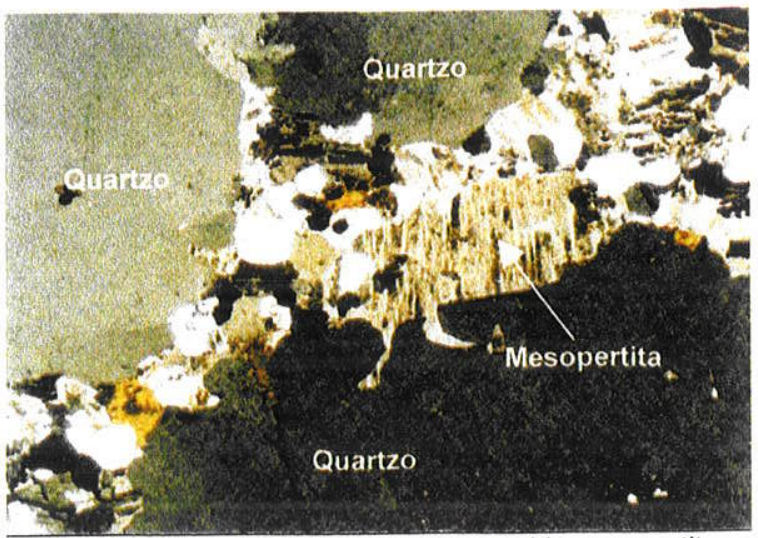

Foto 5.9: Fenocristais de quartzo corroído por pertita com pertita, quartzo e biotita intersticiais. Biotita \pm Anfibólio Monzosienogranitos. GRN, amostra OM 598 (Lado maoir da Foto 5,5 $\mathrm{mm}$. Nicóis $\mathrm{X}$ ).

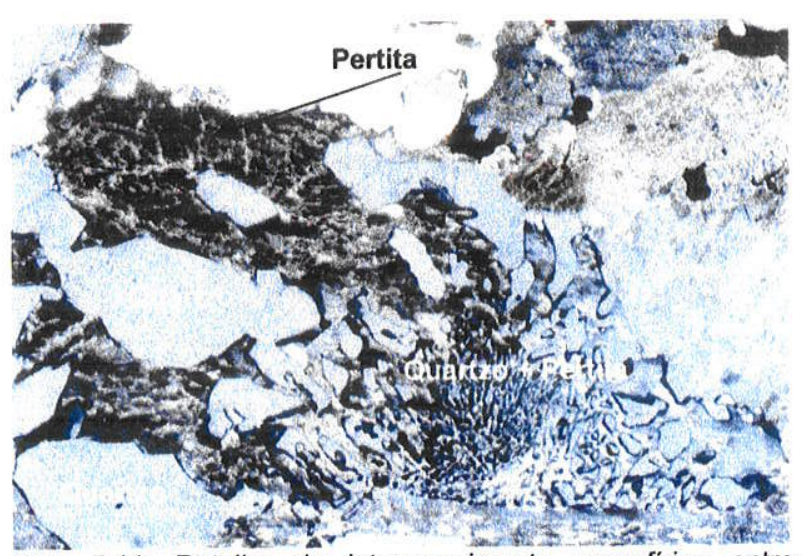
Foto 5.11: Detalhe do intercrescimento granofírico entre quartzo e pertita em BiotitatAnfibólio Monzo-sienogranitos. GP, amostra OM 740 (Lado maior da Foto $2,8 \mathrm{~mm}$ Nicóis $\mathrm{X}$ ).

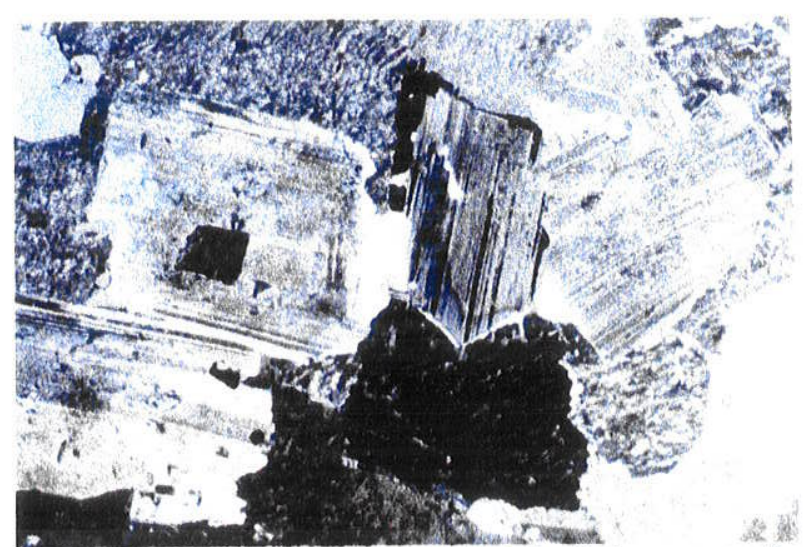

Foto 5.13: Cristais euhédricos de plagioclásio com pertita intersticial em Biotita \pm Anfibólio Monzo-sienogranitos. GP, amostra OM 748 (Lado maior da Foto $2,8 \mathrm{~mm}$. Nicóis X).

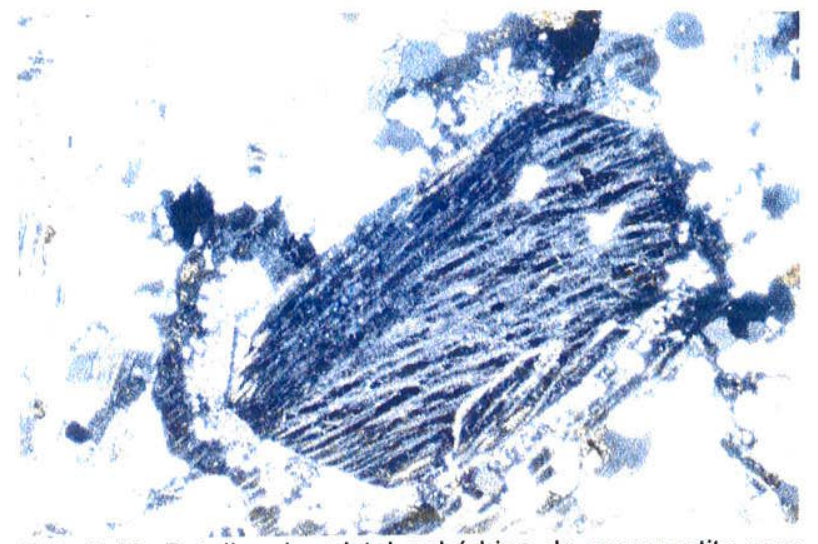

Foto 5.10: Detalhe de cristal euhédrico de mesopertita com borda granofírica (intercrescimento de pertita e quartzo) em Monzo-sienogranito. GRN, amostra OM 589 (Lado maior da Foto $5,5 \mathrm{~mm}$. Nicóis $\mathrm{X}$ ).

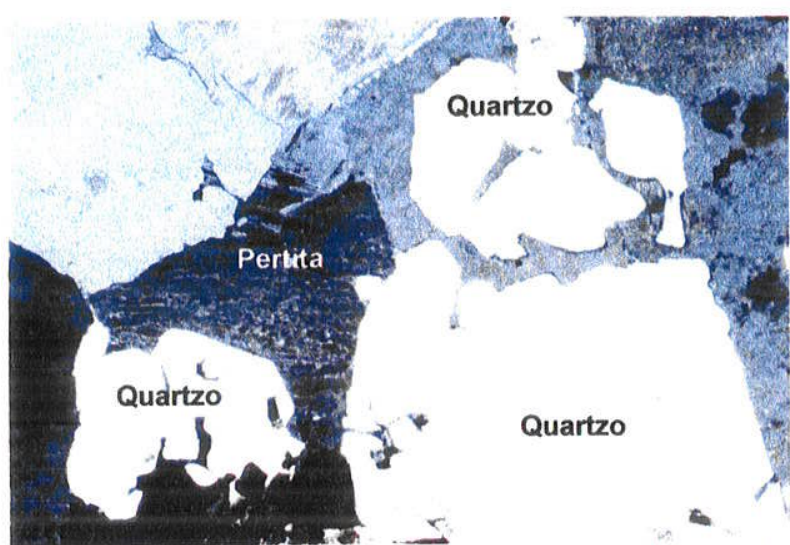

Foto 5.12: Detalhe do intercrescimento granofírico entre quartzo e pertita em Biotita \pm Anfibólio Monzo-sienogranitos. GP, amostra OM 748 (Lado maior da Foto 0,7 mm. Nicóis X).

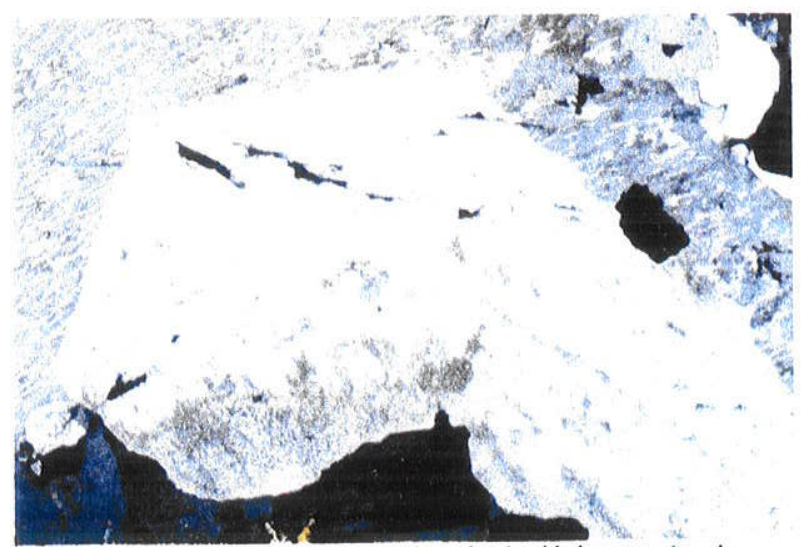

Foto 5.14: Cristal euhédrico de plagioclásio manteado por pertita em Biotita \pm Anfibólio Monzo-sienogranitos. GP, amostra OM 666 (Lado maior da Foto $5,5 \mathrm{~mm}$. Nicóis X) 


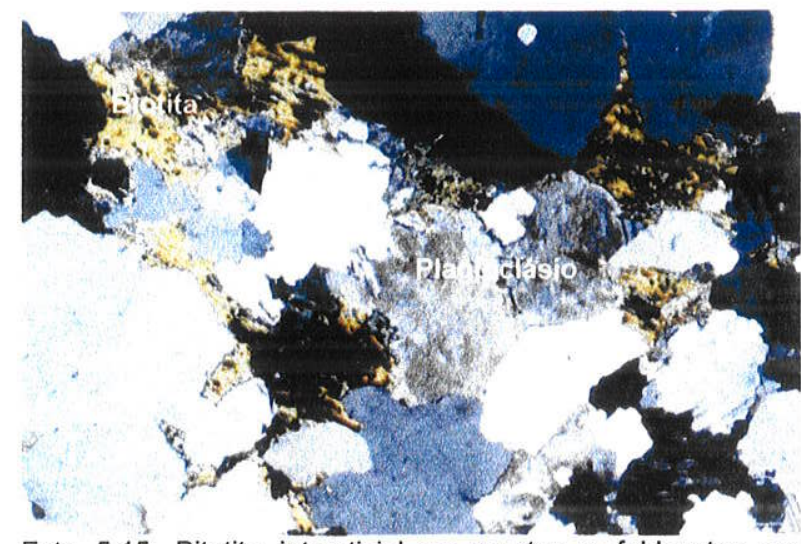

Foto 5.15: Bitotita intersticial ao quartzo e feldspatos em Leucomonzo-sienogranitos. GP, amostra 610 (Lado maior da Foto $5,5 \mathrm{~mm}$. Nicóis $\mathrm{X}$ ).

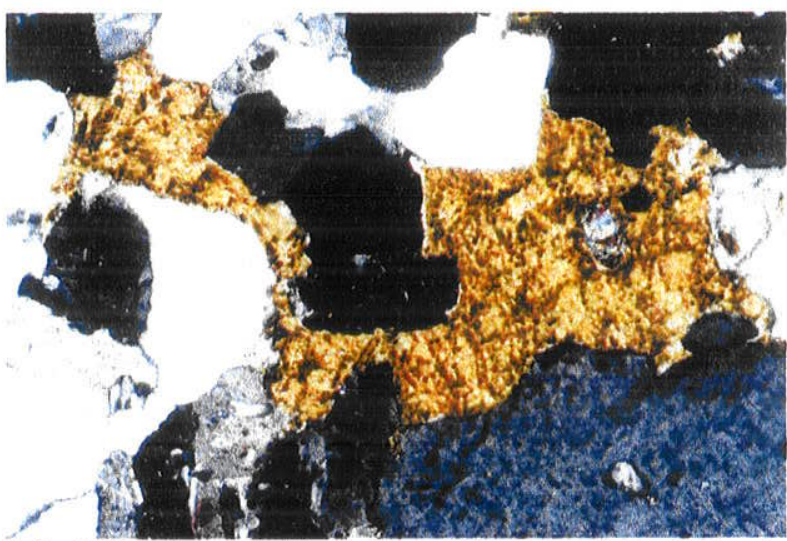

Foto 5.17: Detalhe da biotita intersticial ao quartzo e feldspato (canto direito inferior) com inclusão de zircão em Monzosienogranitos. GRN, amostra OM 589 (Lado maior da Foto $5,5 \mathrm{~mm}$. Nicóis $X)$

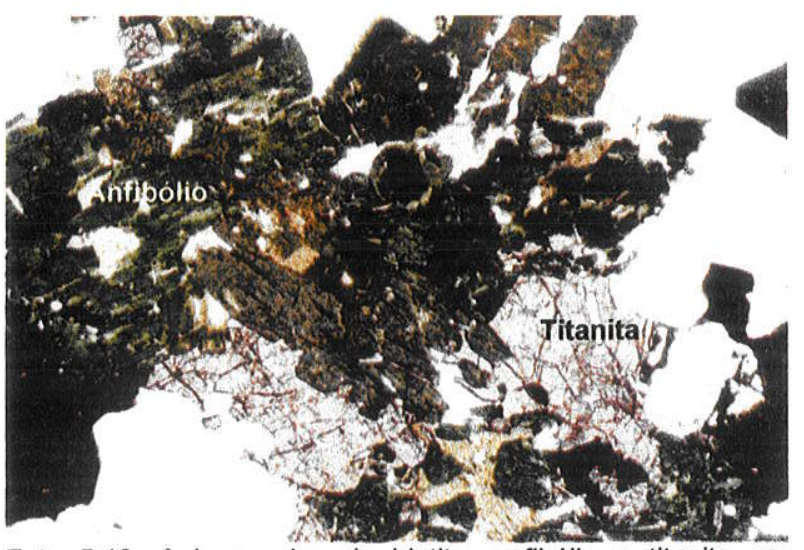

Foto 5.19: Aglomerados de biotita, anfibólio e titanita em Biotita tAnfibólio Monzo-sienogranitos. GP, amostra OM 691 (Lado maior da Foto $2,8 \mathrm{~mm}$. Nicóis //).

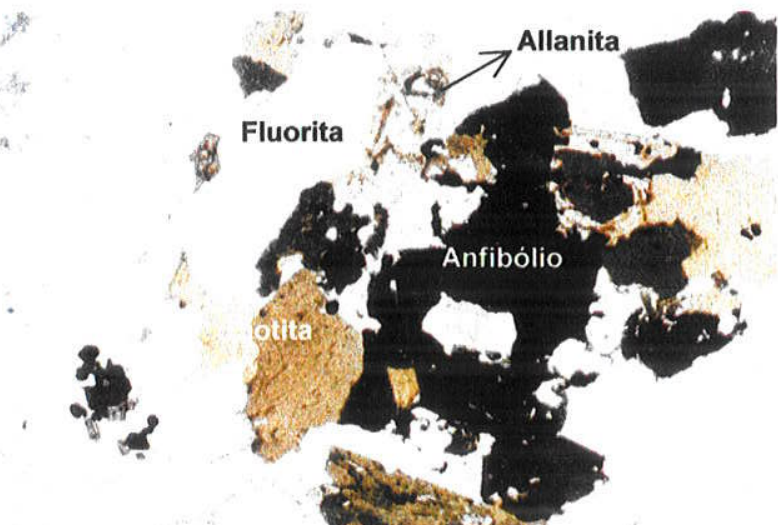

Foto 5.16: Aglomerados de biotita, allanita, anfibólio e fluorita intersticiais aos cristais de quartzo e feldspato em Biotita \pm Anfibólio Monzo-sienogranitos. GP, amostra OM 666 (Lado maior da Foto $2,8 \mathrm{~mm}$. Nicóis //).

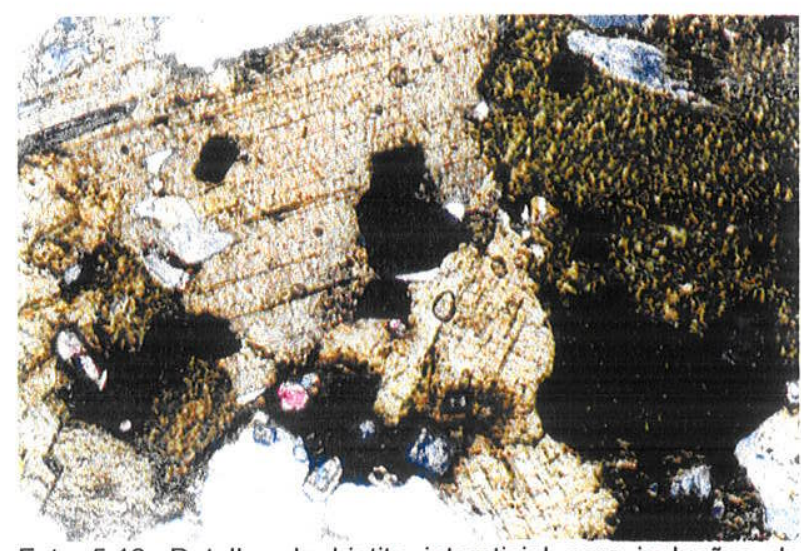

Foto 5.18: Detalhe da biotita intersticial com inclusões de zircão. Característica típica dos Monzo-sienogranitos do GP e GRN. GP, amostra OM 649 (Lado maior da Foto 0,7 mm. Nicóis X).

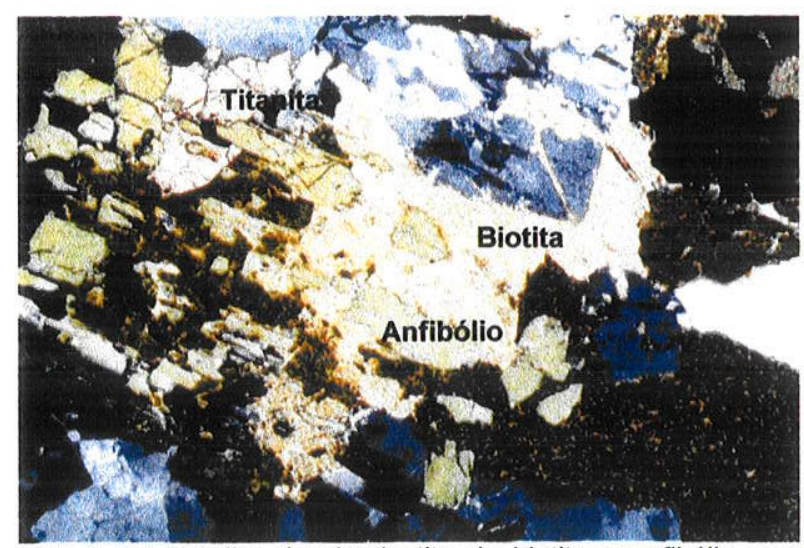

Foto 5.20: Detalhe de simplectito de biotita e anfibólio com titanita, intersticial ao quartzo e feldspato em Anfibólio \pm Biotita Monzo-sienogranitos. GP, amostra OM 691 (Lado maior da Foto $2,8 \mathrm{~mm}$. Nicóis $\mathrm{X}$ ). 


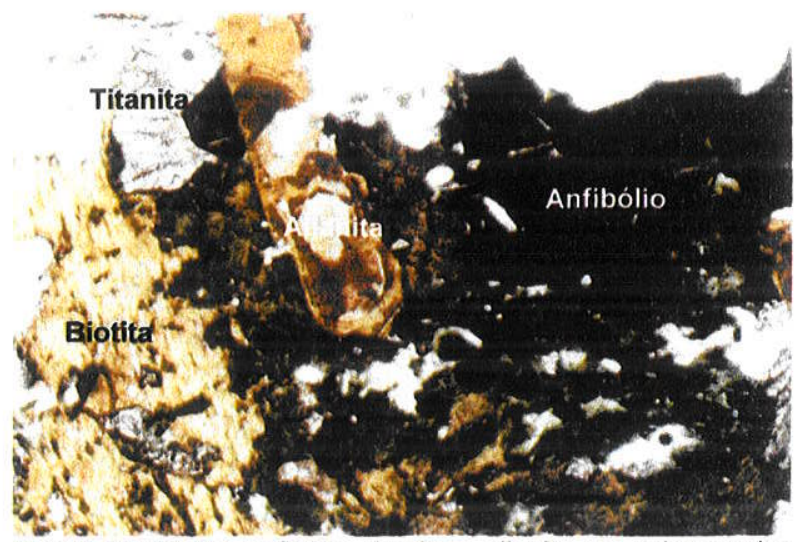

Foto 5.21: Biotita, anfibólio, titanita e allanita em aglomerados máficos intersticiais aos cristais de feldspato em AnfibóliołBiotita Monzo-sienogranitos. GP, amostra OM 691 (lado maior da Foto $0,7 \mathrm{~mm}$. Nicóis /I)

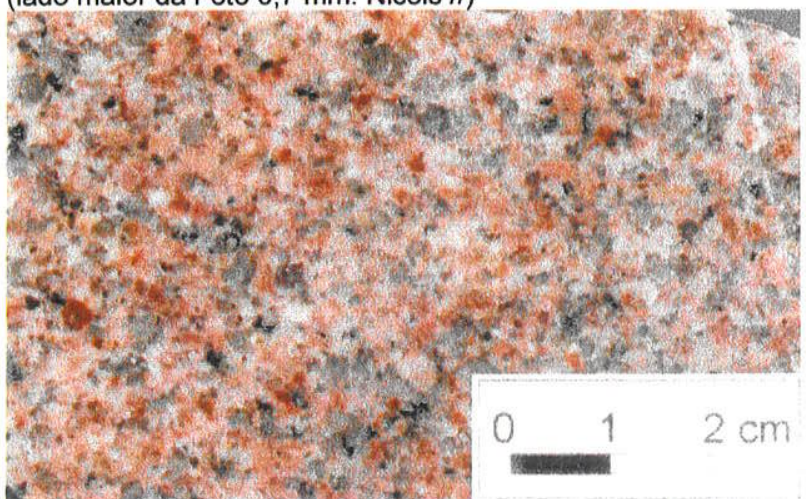

Foto 5.23 : Aspepcto macroscópico dos Leucogranodioritos. GAS, amostra OM 700.

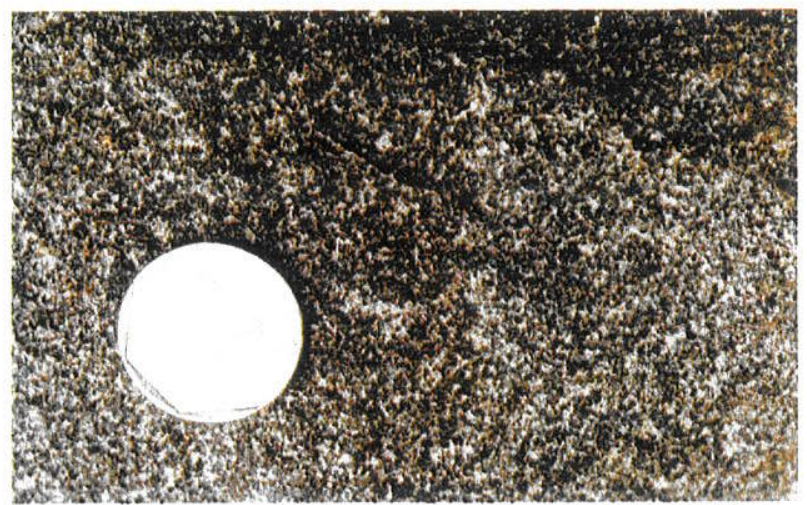

Foto 5.25: Aspecto macroscópico dos Monzogabros. GRN,

amostra OM 473.

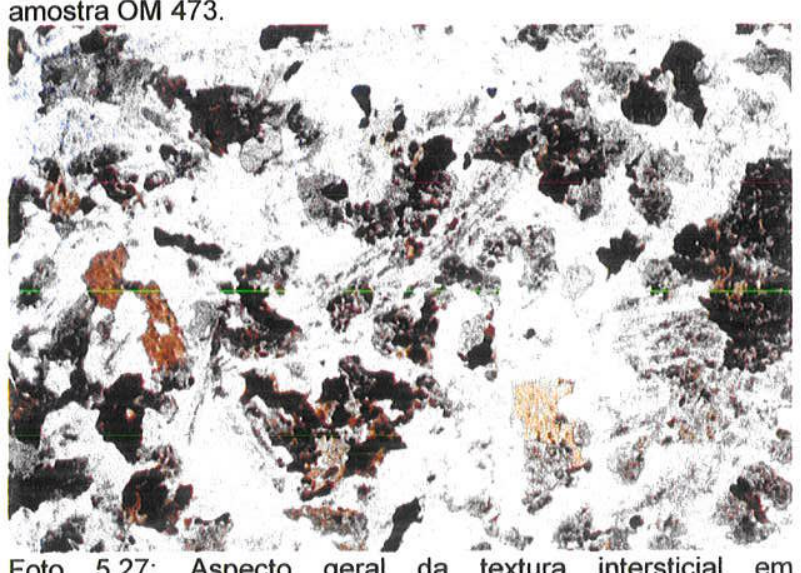

Foto 5.27: Aspecto geral da textura intersticial em Monzogabro. GRN, amostra 473 (Lado maior da foto $5,5 \mathrm{~mm}$. Nicóis /).

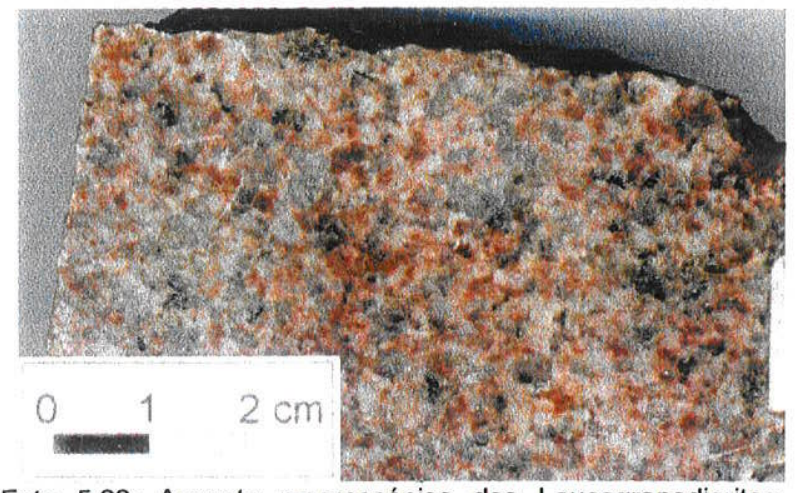

Foto 5.22: Aspecto macroscópico dos Leucogranodioritos. GAS, amostra OM 661.

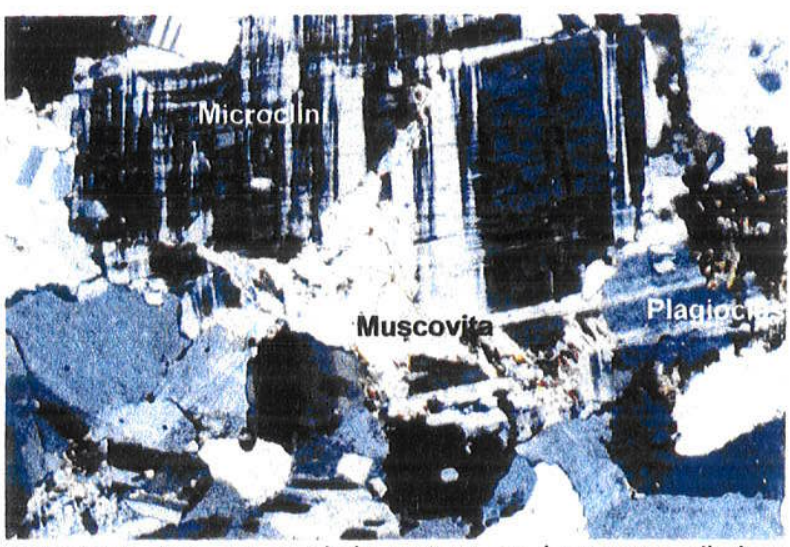

Foto 5.24: Aspecto geral da textura em Leucogranodioritos. Notar cristal de muscovita intersticial . GAS, amostra OM 700 (Lado maior da foto $5,5 \mathrm{~mm}$. Nicóis $X$ )

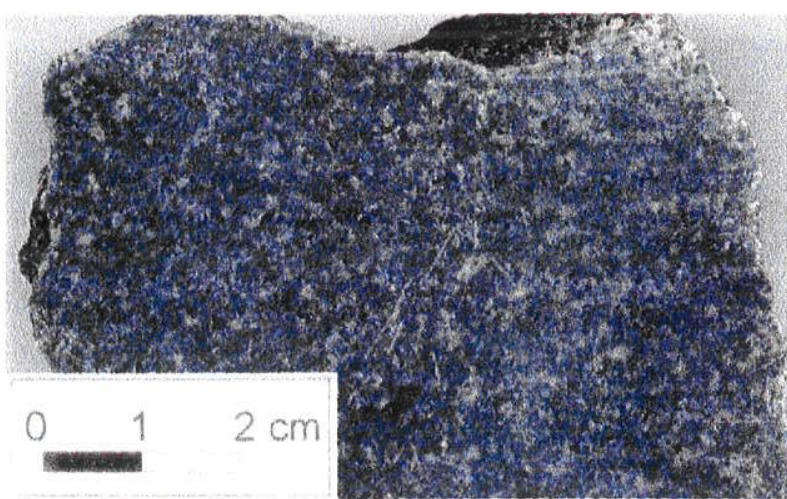

Foto 5.26: Aspecto macroscópico dos Gabros/Monzogabros GP, amostra OM 426.

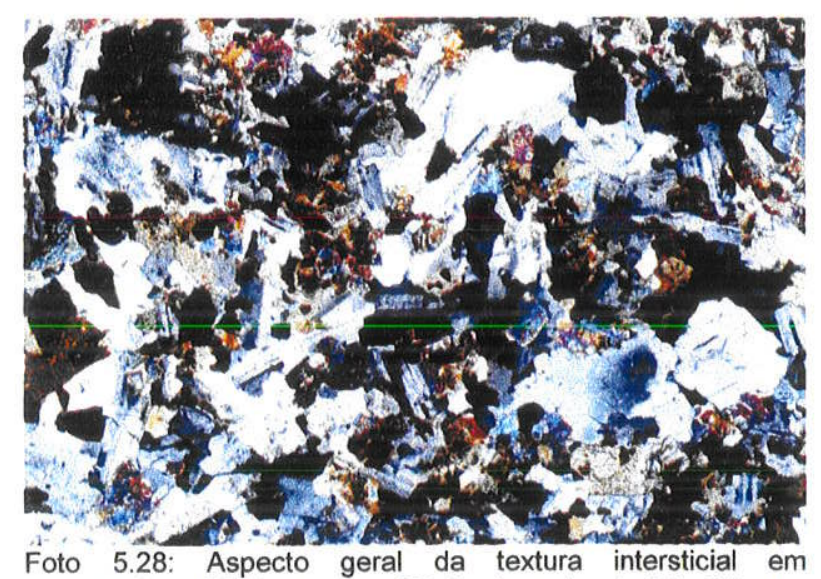

Monzogabro. GRN, amostra 473 (Lado maior da foto $5,5 \mathrm{~mm}$. Nicóis X). 


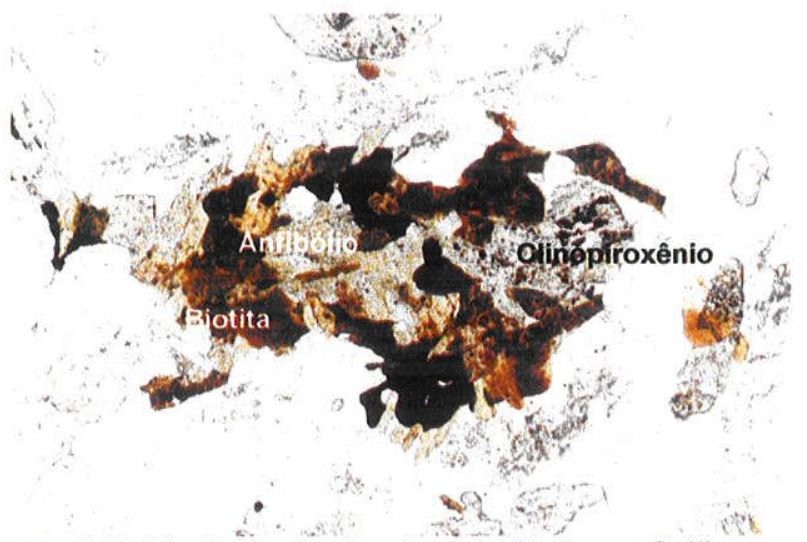

Foto 5.29: Simplectito de clinopiroxênio, biotita e anfibólio em Monzogabro. GRN, amostra 473 (Lado maior da foto $5,5 \mathrm{~mm}$. Nicóis /I).

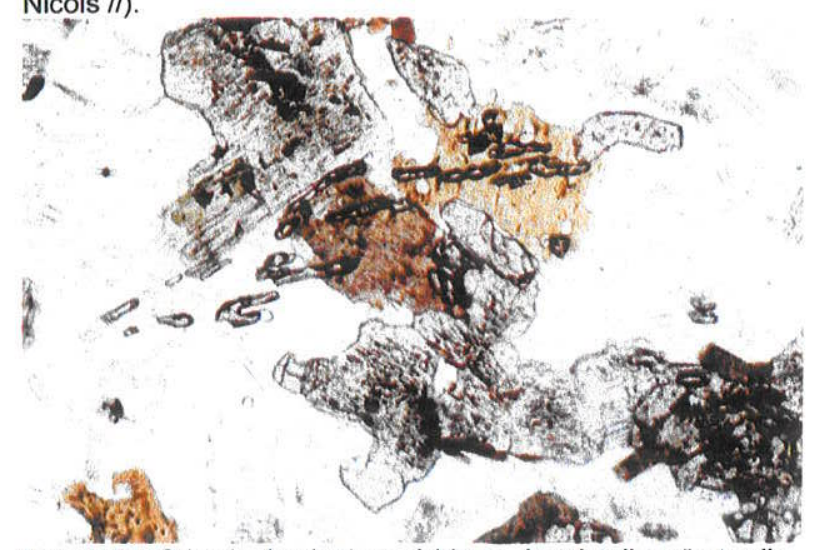

Foto 5.31: Cristais de zircão anédricos de cristalização tardia e orientados em Monzogabros. GRN, amostra 473 (Lado maior da foto $1,39 \mathrm{~mm}$. Nicóis //).

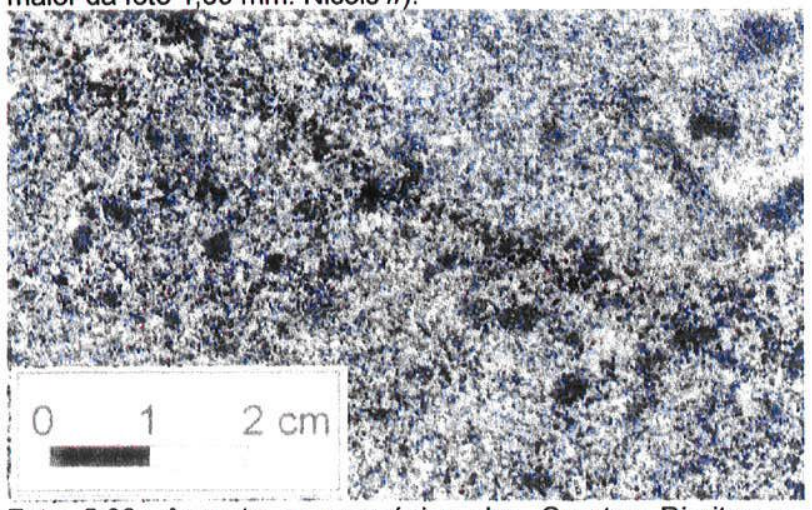

Foto 533: Aspecto macroscópico dos Quartzo Dioritos a Quartzo Monzonitos híbridos. GRN, amostra OM 642.

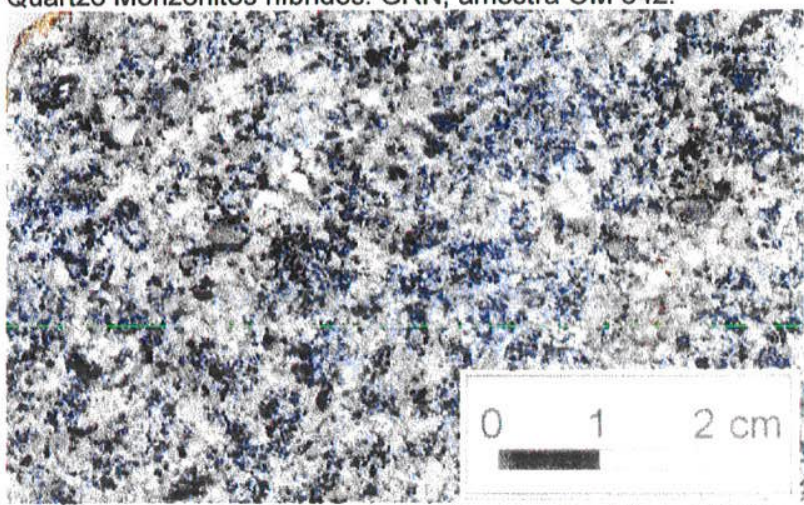

Foto 5.35: Aspecto Macroscópico dos Quartzo Monzodioritos híbridos. GRN, amostra OM 428.

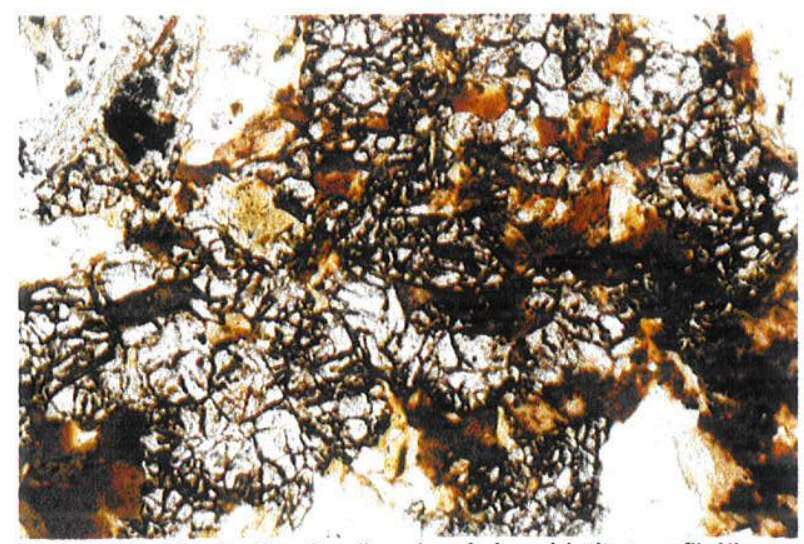

Foto 5.30: Simplectito de clinopiroxênio e biotitat anfibólio em Monzogabros. GRN, amostra 473 (Lado maior da foto $0,7 \mathrm{~mm}$. Nicóis //).

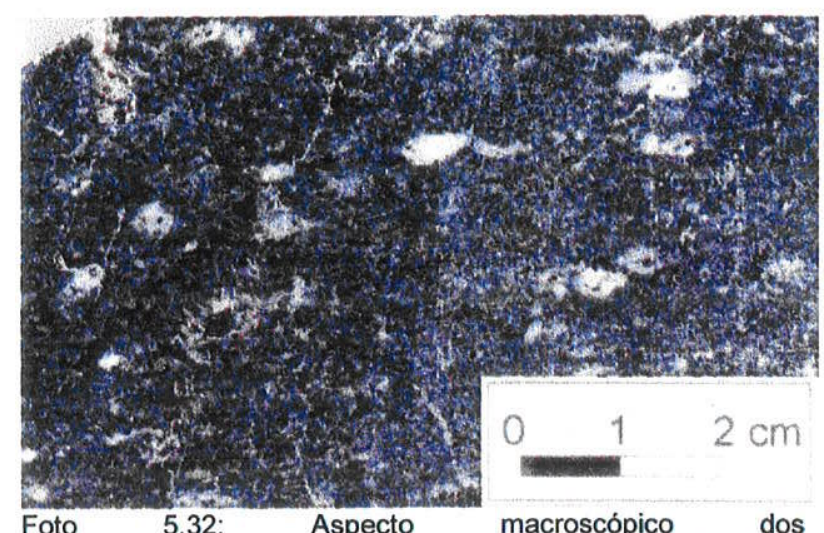

Monzogabros/Monzodioritos a Quartzo Monzodioritos híbridos, com textura de fluxo magmático. GP, amostra OM 94.

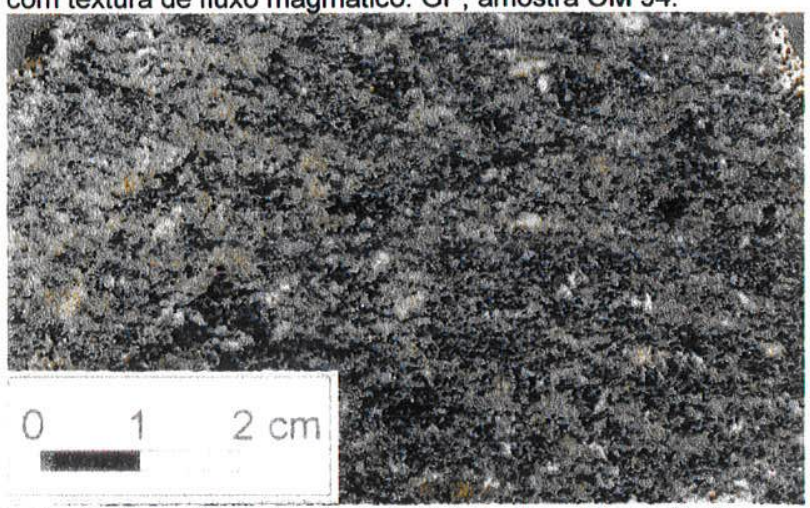

Foto 5.34 : Aspecto Macroscópico dos Monzodioritos a Quartzo Monzodioritos híbridos. GP, amostra OM 1052.

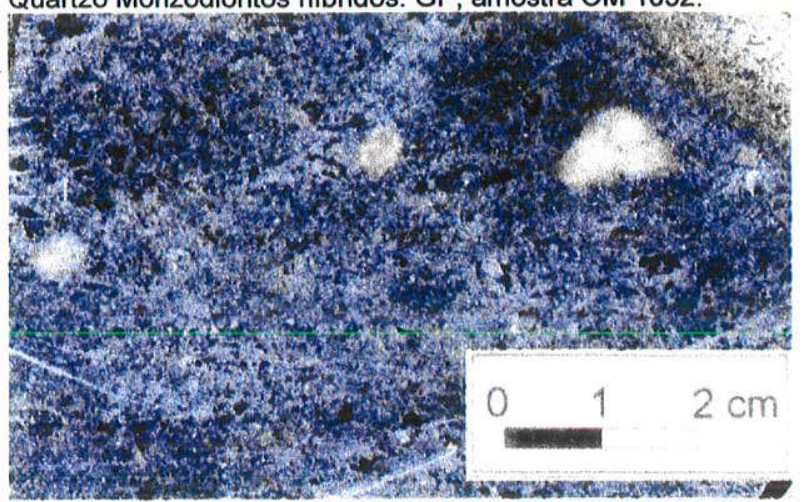

Foto 5.36: Aspecto Macroscópico dos Quartzo Monzodioritos híbridos. GRN, amostra OM 469. 


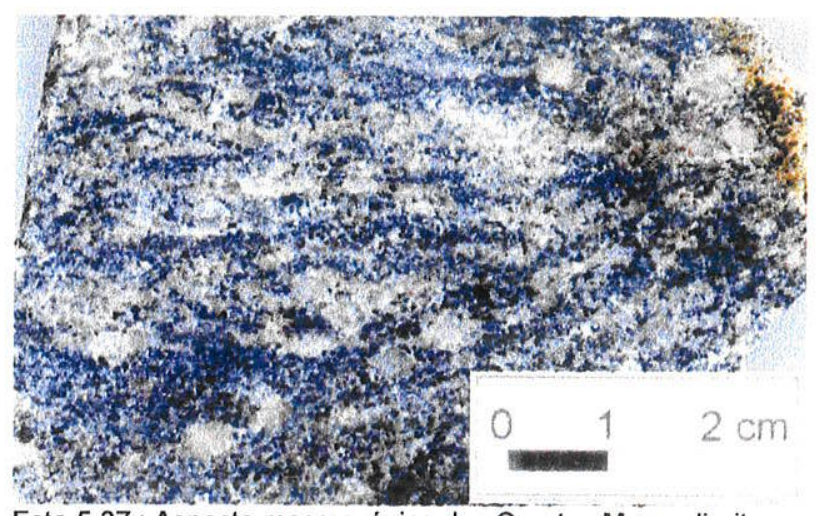

Foto 5.37 : Aspecto macroscópico dos Quartzo Monzodioritos hibridos com textura ou estrutura de fluxo magmático. GRN, amostra OM 427

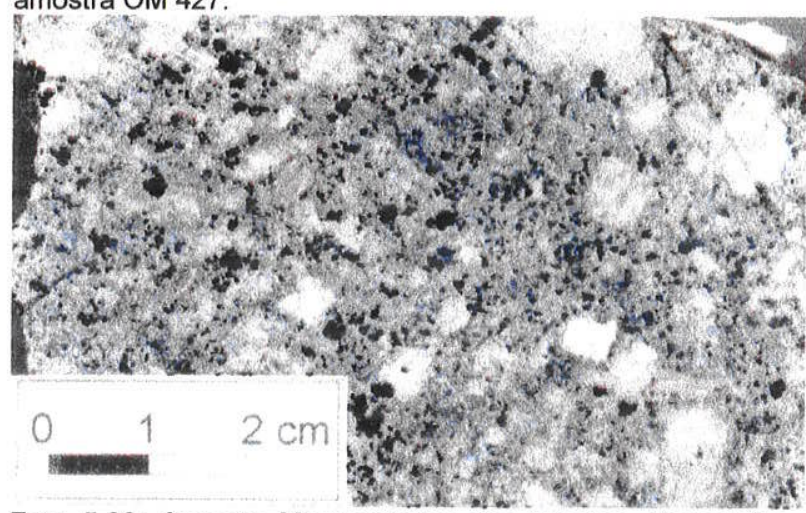

Foto 5.39: Aspecto Macroscópico dos Quartzo Monzonitos híbridos. GP, amostra OM 1057.

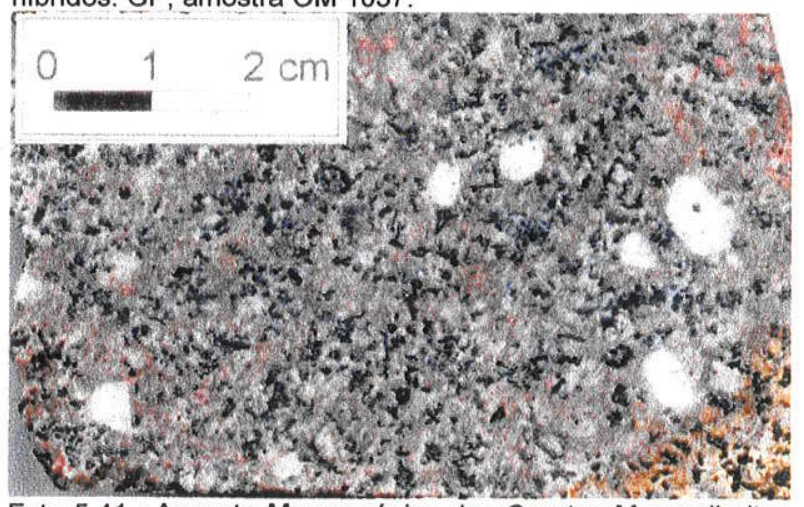

Foto 5.41 : Aspecto Macroscópico dos Quartzo Monzodioritos a Monzogranitos híbridos. GRN, amostra OM 499.

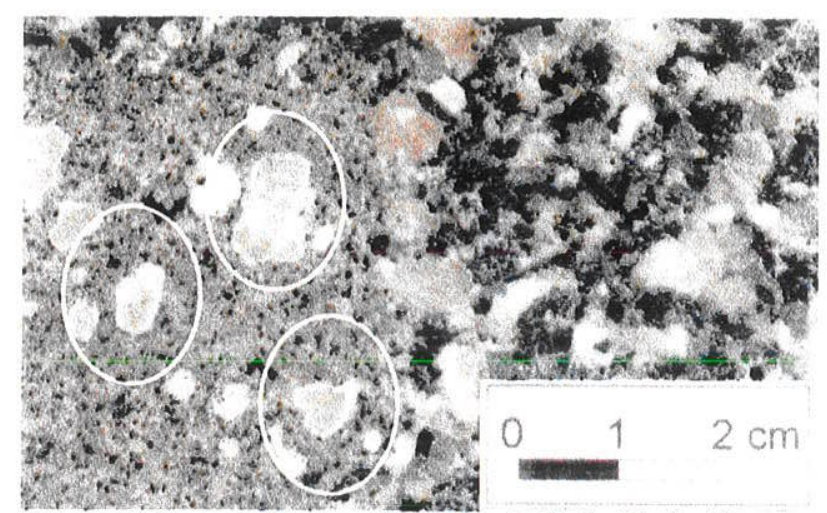

Foto 5.43: Aspecto Macroscópico dos Anfibólio-Biotita MonzoSienogranitos (direita) com Quartzo Monzonitos híbridos, exibindo textura rapakivi (à esquerda - circulos. GP, amostra OM 691.

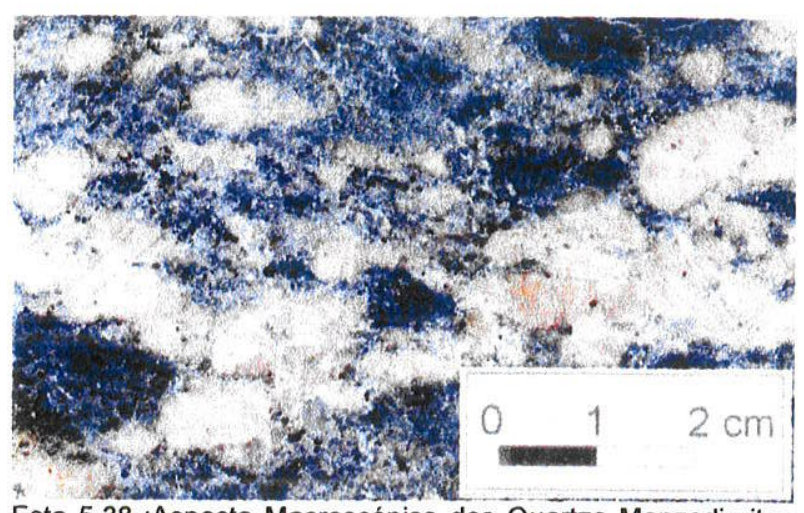

Foto 5.38 :Aspecto Macroscópico dos Quartzo Monzodioritos a Quartzo Monzonitos híbridos com textura ou estrutura de fluxo magmático. GRN, amostra OM 550 .

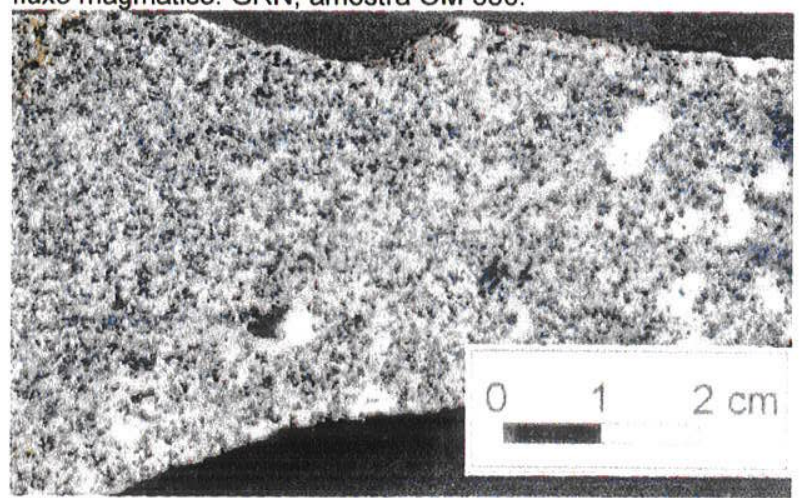

Foto 5.40: Aspecto Macroscópico dos Quartzo Monzonitos

híbridos. GP amostra OM 118 .

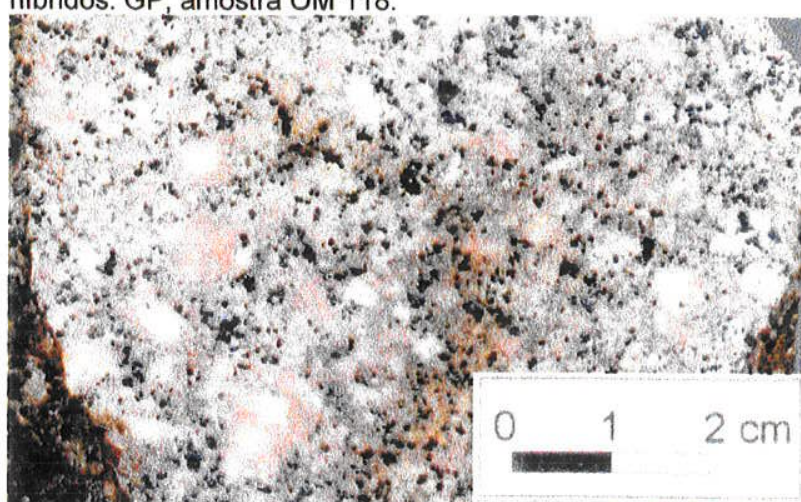

Foto 5.42: Aspecto Macroscópico dos Quartzo Monzonitos a Monzogranitos híbridos. GRN, amostra OM 425.

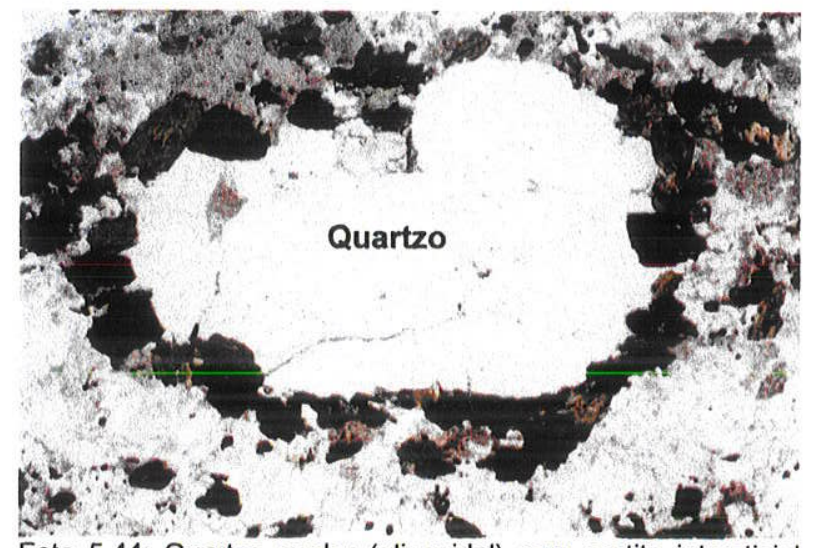

Foto 5.44: Quartzo ocelar (elipsoidal) com pertita intersticia manteado por anfibóliotbiotita em Quartzo Monzodioritos híbridos. GRN, amostra OM 428 (Lado maior da Foto $5,5 \mathrm{~mm}$, Nicóis //). 


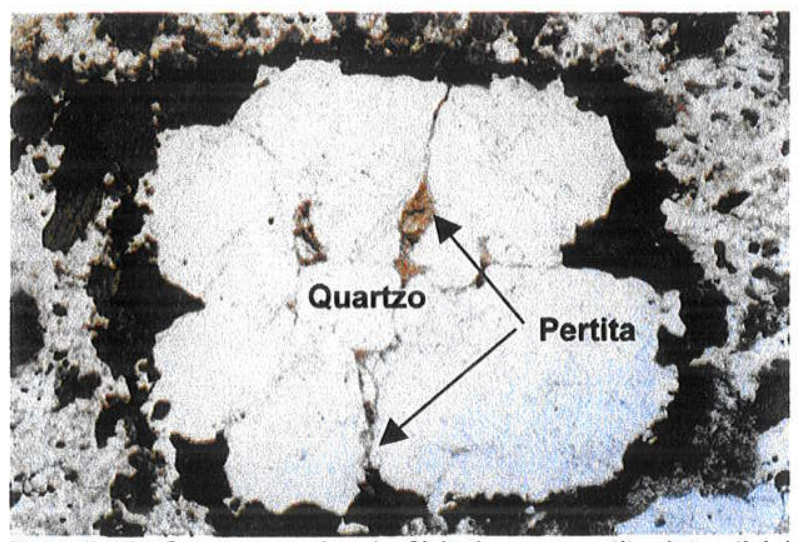

Foto 5.45: Quartzo ocelar (esférico) com pertita intersticial manteado por anfibólio e biotita em Quartzo Monzodioritos híbridos. GRN, amostra OM 428 (Lado maior da Foto 5,5 mm, Nicóis //).

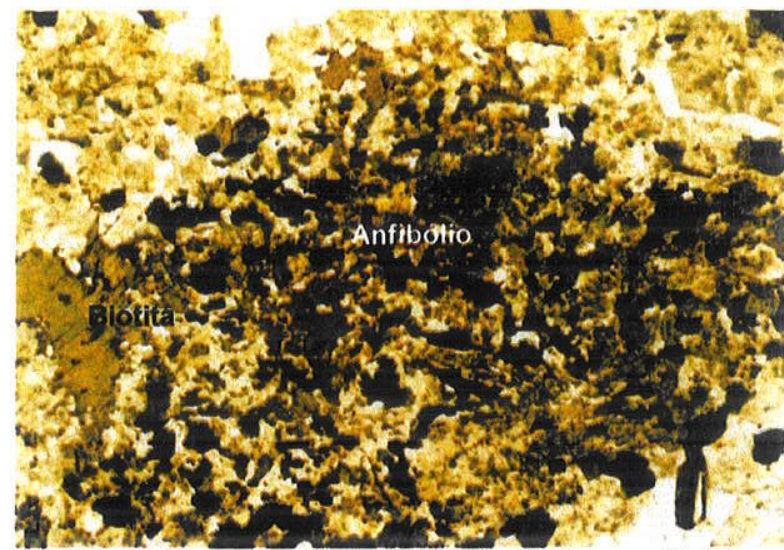

Foto 5.47: Concentraçöes máficas de biotita e anfibólio em Quartzo Monzodioritos a Monzogranitos híbridos. GRN, amostra OM 499 (Lado maior da Foto $5,5 \mathrm{~mm}$, Nicóis //).

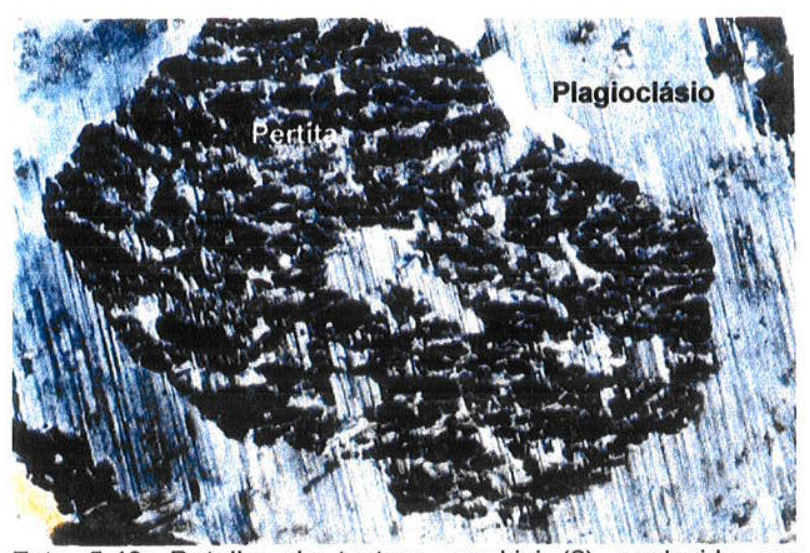

Foto 5.49: Detalhe da textura rapakivi (?) produzida por mistura (mesopertita manteada por plagioclásio em Monzosienogranitos híbridos. GP, amostra OM 691d (Lado maior da foto $5,5 \mathrm{~mm}$. Nicóis $X$ ).

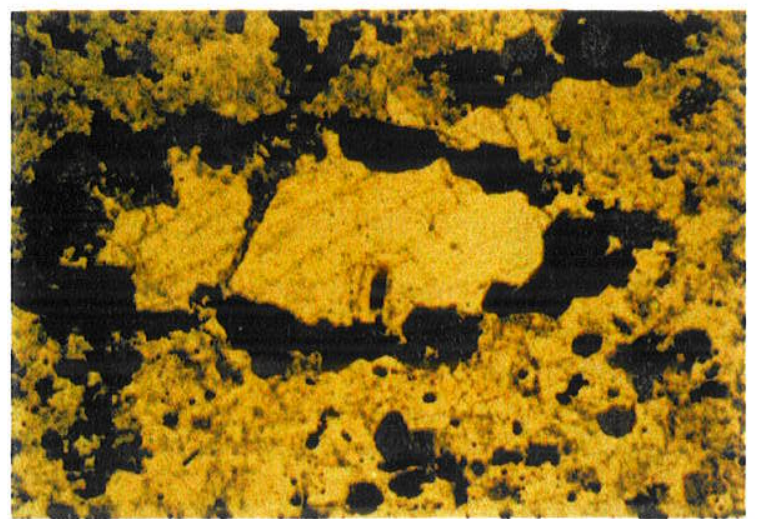

Foto 5.46: Quartzo ocelar (elipsoidal) manteado por cristais de anfibóliotbiotita em Quartzo Monzonitos híbridos com textura ou estrutura de fluxo magmático. GP, amostra OM 427 (Lado maoir da foto $5,5 \mathrm{~mm}$. Nicóis //).

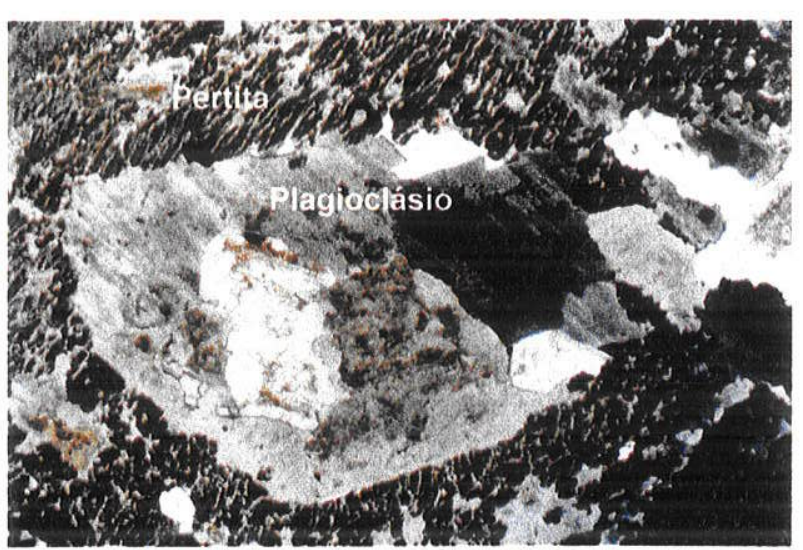

Foto 5.48: Textura Anti-Rapakivi (?) produzida por mistura em Quartzo Monzonitos hibridos. GP, amostra OM1057 (Lado maior da Foto $5,5 \mathrm{~mm}$, Nicóis $X$ )

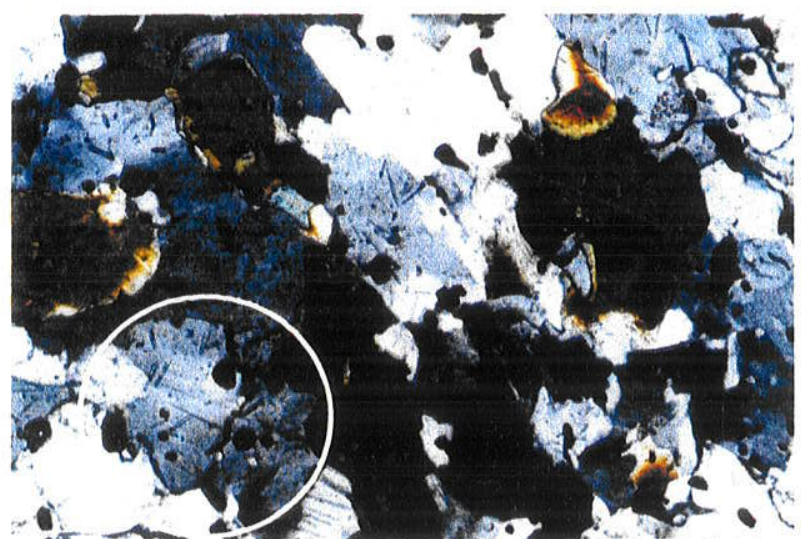

Foto 5.50: Apatita acicular em Quartzo Monzodioritos híbridos. GRN, amostra OM 427 (Lado maior da Foto $0,7 \mathrm{~mm}$, Nicóis $\mathrm{X})$. 


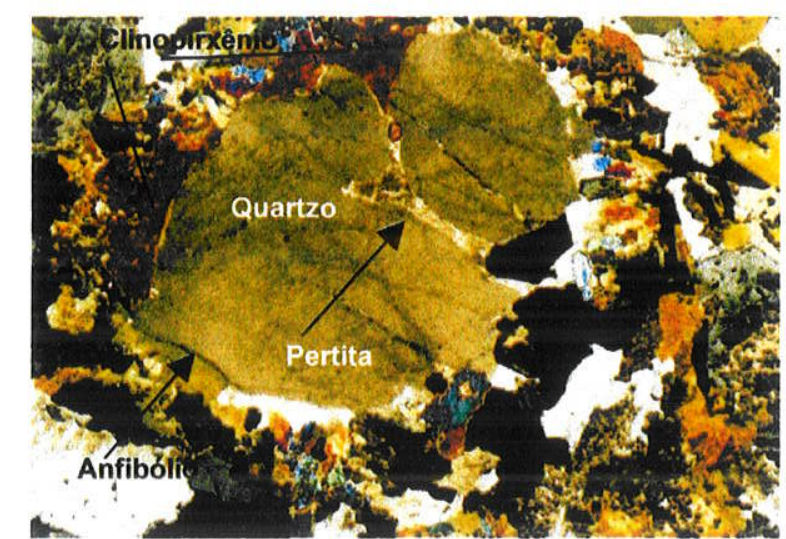

Foto 5.51: Quartzo ocelar com pertita intersticial manteado por clinopiroxênio e anfibólio. GRN, amostra OM 545 (Lado maior da foto $5,5 \mathrm{~mm}$. Nicóis $\mathrm{X}$ ).

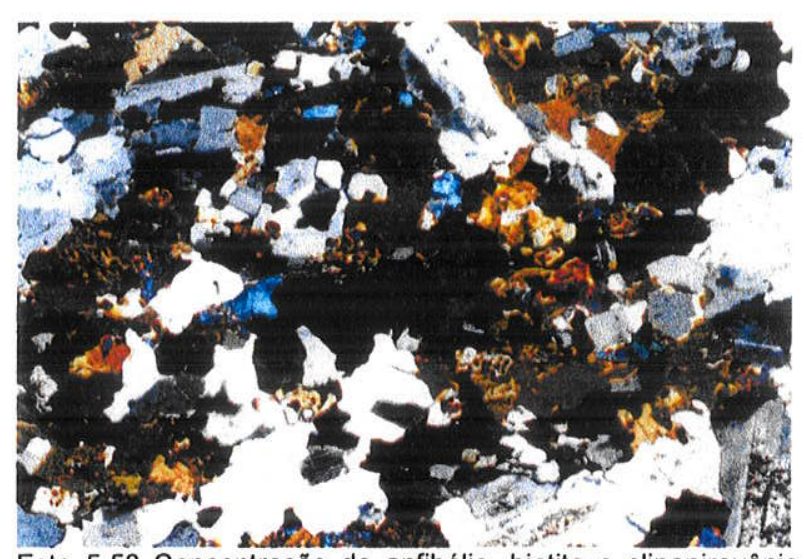

Foto 5.53 Concentração de anfibólio, biotita e clinopiroxênio em Monzogabros/Monzodioritos hibridos. GP, amostra OM 94 (Lado maior da foto $5,5 \mathrm{~mm}$, Nicóis $\mathrm{X}$ ).

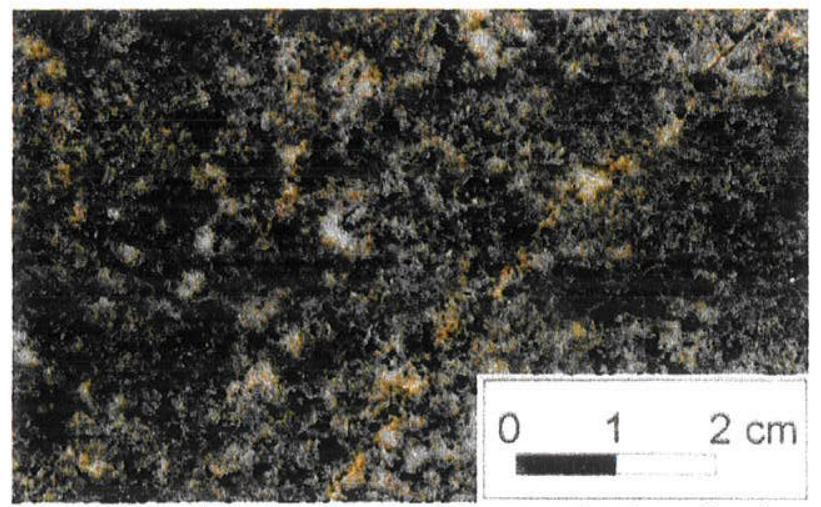

Foto 5.55: Aspecto macroscópico geral dos Quartzo Monzonitos/Quartzo Sienitos. GP, amostra OM 677.

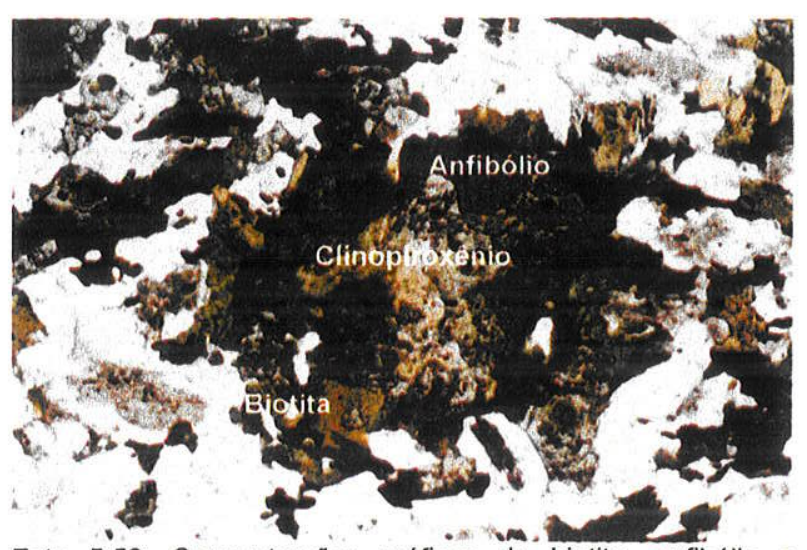

Foto 5.52: Concentraçöes máficas de biotita anfibólio e clinopiroxênio em Monzogabros-Monzodioritos a Quartzo Monzonitos híbridos. GP, amostra OM 94 (Lado maior da foto $5,5 \mathrm{~mm}$, Nicóis //)

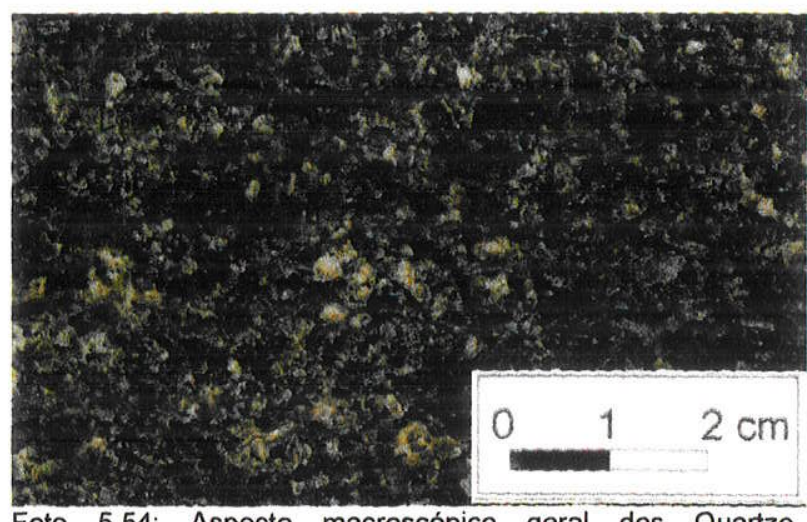

Foto 5.54: Aspecto macroscópico geral dos Quartzo Monzonitos/Quartzo Sienitos. GP, amostra OM 656.

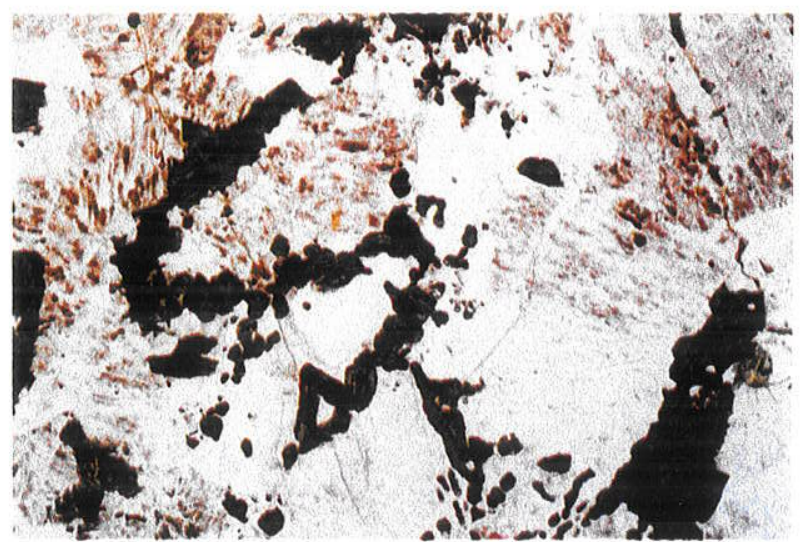

Foto 5.56 : Cristais de aegerina-augita, anfibólio e biotita intersticiais às pertitas e quartzo. GP, amostra OM 656 (Lado maior da foto $5,5 \mathrm{~mm}$. Nicóis //). 


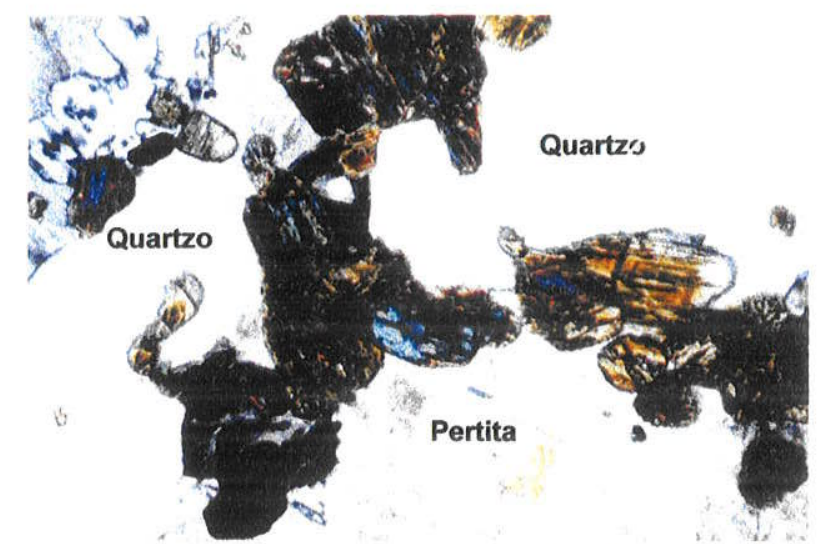

Foto 5.57: Detalhe dos cristais de aegerina-augita intersticiais ao quartzo e pertita em Quartzo Monzonitos/Quartzo Sienitos. GP, amostra OM 656 (Lado maior da foto $0,7 \mathrm{~mm}$. Nicóis X).

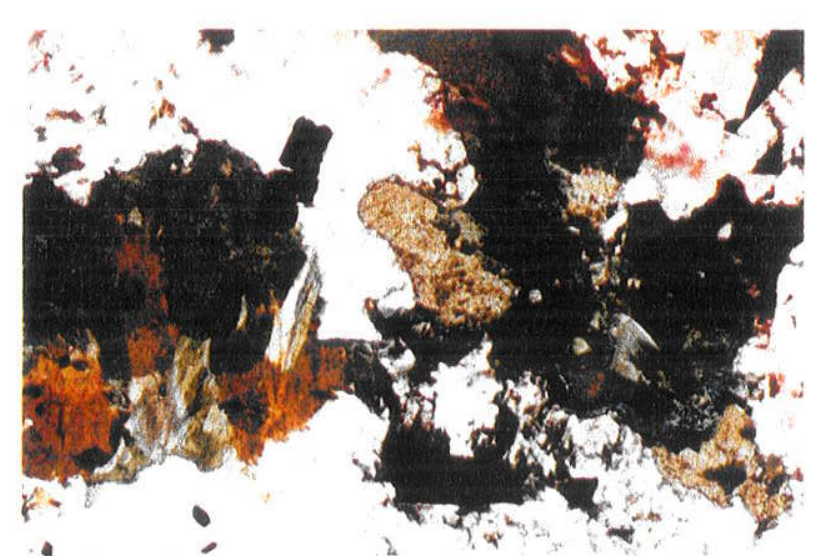

Foto 5.59: Simplectitos de aegerina-augita, anfibólio (verde), riebeckita (azul) e biotita. GP, amostra OM 656 (Lado maior da foto $2,8 \mathrm{~mm}$. Nicóis II).
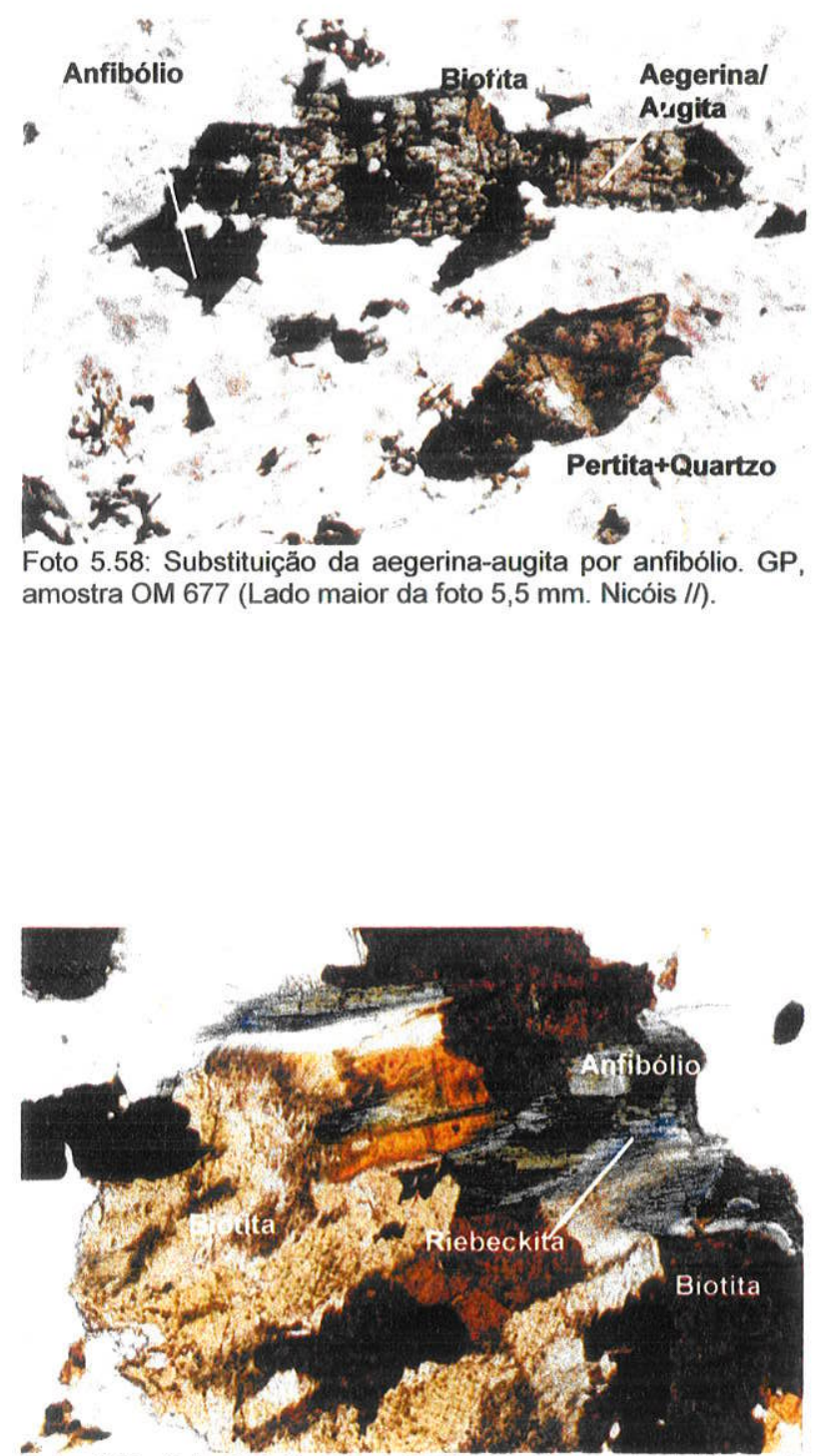

Foto 5.60: Substituição de anfibólio verde por anfibólio azul, em simplectitos com a biotita. GP, amostra OM 677 (Lado maior da foto $0,7 \mathrm{~mm}$. Nicóis //). 


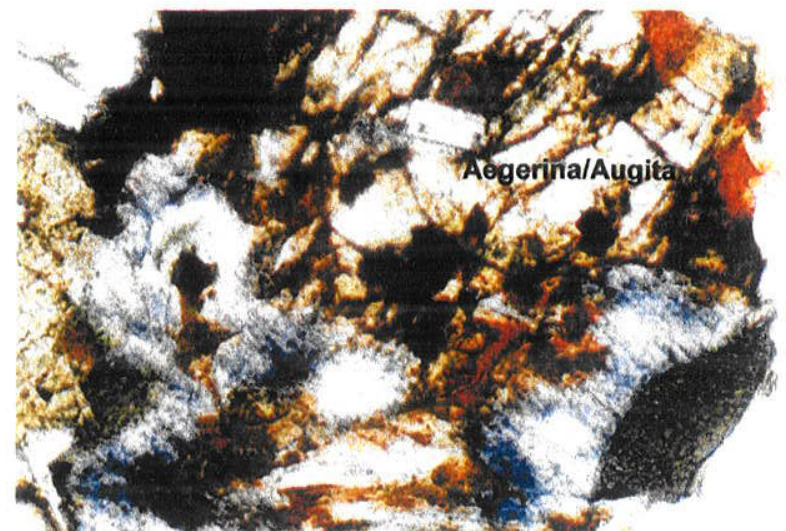

Foto 5.61: Detalhe de simplectito da aegerina-augita, anfibólio verde substituido por anfibólio azul (riebeckita) e biotita. GP, amostra OM 677 (Lado maior da foto 0,33 mm. Nicóis //).

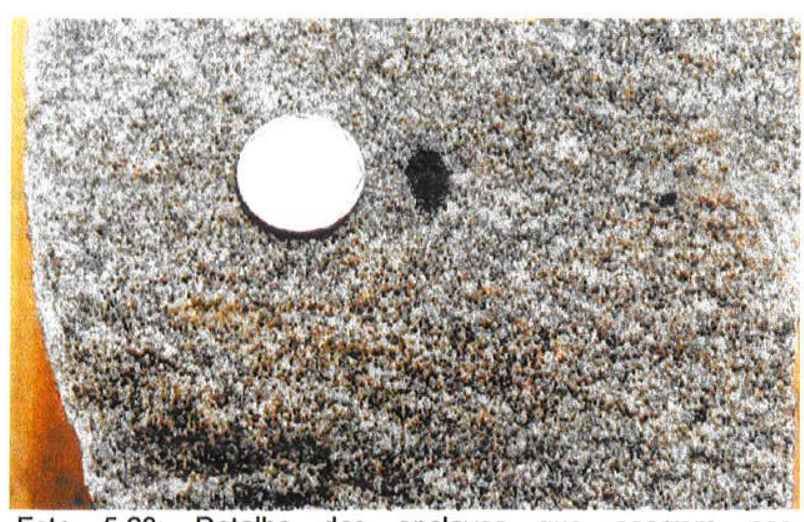

Foto 5.63: Detalhe dos enclaves que ocorrem nos Monzogranitos. GT, amostra OM 504.

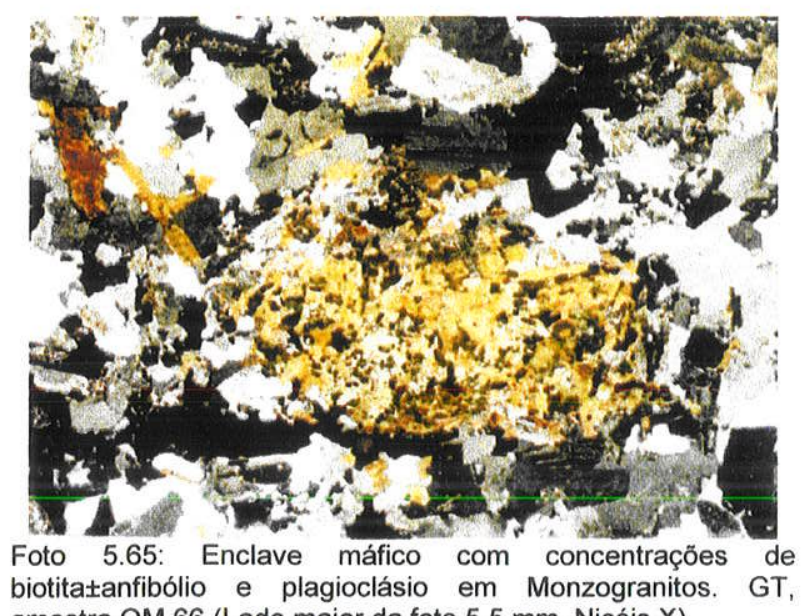

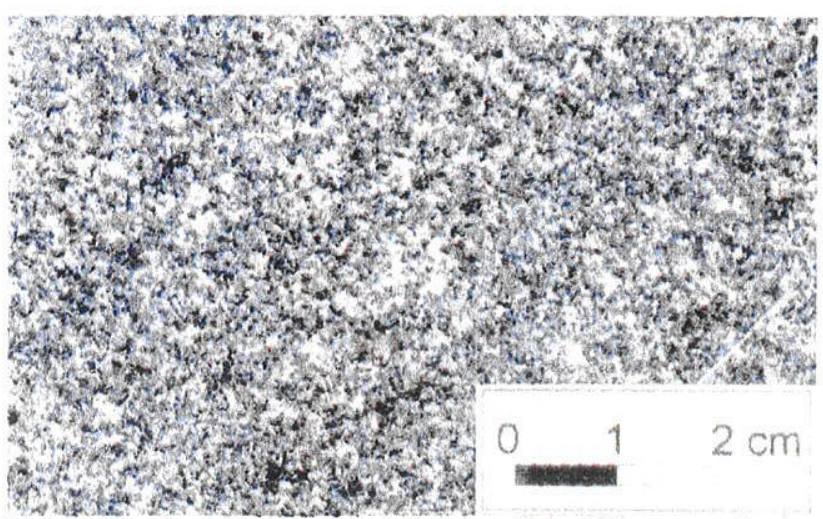

Foto 5.62: Aspecto macroscópico geral dos Monzogranitos. GT, amostra OM 66

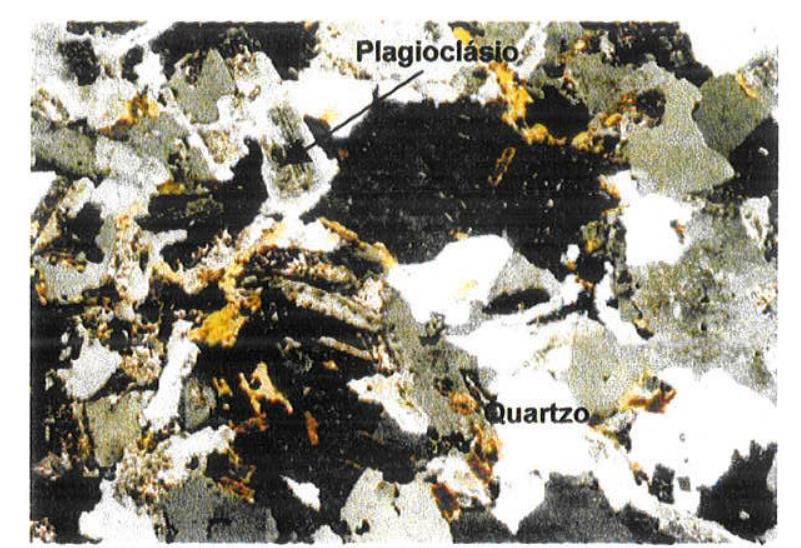

Foto 5.64: Biotita não intersticial aos cristais de quartzo e feldspatos em Monzogranitos. GT, amostra OM 504 (Lado maior da foto $5,5 \mathrm{~mm}$. Nicóis $\mathrm{X}$ ). 


\section{3 - Litogeoquímica}

Nesta seção apresentamos e discutimos os resultados das análises químicas efetuadas nas principais rochas do GP, GRN, GAS e do GT e, necessariamente, confrontalos com os resultados das análises químicas das rochas da SGPM, que serão apresentados também no próximo capítulo.

As rochas graniticas sem epidoto magmático (quartzo monzodioritos, quartzo monzodioritos/granodioritos e granodioritos) apresentam conteúdo em $\mathrm{SiO}_{2}$ entre 60 e $70 \%$, as rochas graníticas com epídoto magmático (quartzo monzodioritos, quartzo monzodioritos/granodioritos, granodioritos e leucogranodioritos) entre 60 e $75 \%$, os monzogranitos da SGPM entre 66 e $74 \%$, os monzogranitos do GT entre 72 e $75 \%$ os monzo-sienogranitos do GP e do GRN entre 70 e $80 \%$, os quartzo sienitos/quartzo monzonitos do GP entre 65 e $70 \%$, as rochas graníticas hibridas máficas e félsicas entre 55 e $70 \%$ e os monzogabros entre 48 e $55 \%$. Em função da ampla variação do $\mathrm{SiO}_{2}$ e da variação da tipologia e dos componentes destas unidades, a $\mathrm{SiO}_{2} \mathrm{X}$ óxidos, traços e ETR (Figuras $5.7,5.8$ e 5.10) são os melhores diagramas para a análise da conduta e do conteúdo destes elementos nas rochas do GP, GAS, GRN, GT e, da SGPM.

As análises litoquímicas indicam (Figura 5.9 C) o caráter predominantemente metaluminoso das rochas graníticas sem e com epidoto magmático da SGPM, metaluminoso a fracamente peraluminoso dos monzogranitos da SGPM e fracamente peraluminoso dos monzogranitos do GT. Os monzo-sienogranitos do GP e do GRN e os leucogranodioritos do GAS são metaluminosos a fracamente peraluminosos (aluminosos, aluminous A-type granites, sugestão de King et al. 1997). Os quartzo monzonitos/quartzo sienitos do GP apresentam razőes $A N K=1.0$ a 1.1 e ACNK entre 0.8 a 0.9 , distinguindo-os dos monzo-sienogranitos adjacentes do GP e são fracamente peralcalinas, conforme sugere a mineralogia destas rochas. Os monzogabros do GRN e do GP são fortemente metaluminosos $e$ as rochas graníticas hibridas máficas e félsicas são metaluminosas apresentando razões ANK e ACNK intermediárias entre os monzogabros e os monzosienogranitos do GP e do GRN.

$\mathrm{Na}$ observação geral dos diagramas de $\mathrm{SiO}_{2} \mathrm{X}$ óxidos, traços e ETR (Figuras 5.7, 5.8 e 5.10) de todas as rochas graniticas desta região, exceção dos monzogabros e das rochas graníticas híbridas, nota-se uma clara diferença, (para $\mathrm{SiO}_{2} 65$ a 80\%), na maioria dos óxidos, traços e ETR, entre as rochas graníticas sem e com epídoto da SGPM, monzogranitos da SGPM, monzogranitos do GT, leucogranodioritos do GAS, monzosienogranitos do GP e do GRN e, quartzo monzonitos/quartzo sienitos do GP. A diferença 
torna-se bem mais evidente principalmente no conteúdo e na conduta da maioria dos elementos traços como $\mathrm{Ba}, \mathrm{Rb}, \mathrm{Sr}, \mathrm{Ga}, \mathrm{Ta}, \mathrm{Nb}, \mathrm{Hf}, \mathrm{Zr}, \mathrm{Y}, \mathrm{Th}$ e U e ETRL e ETRP.

As rochas graníticas com epidoto magmático da SGPM compõem a suite granítica mais expandida da região. As rochas graníticas com e sem epídoto magmático da SGPM são as rochas mais ricas em Ba (2000-1000 ppm) e Sr (2000-1000 ppm) e as mais pobres em $\mathrm{Rb}(50-100 \mathrm{ppm})$ e apresentam características bem distintas em relação à todas as rochas graníticas desta região. (Figura 5.8 A, B e C e Figura 5.9 E, F e G). Entre estes elementos, somente $\circ \mathrm{Ba}$ com valores similares ou relativamente mais altos são apresentados pelos monzogranitos da SGPM e monzogranitos do GT. Estes últimos apresentam mais alto $\mathrm{Rb}$ e mais baixo $\mathrm{Sr}$ em relação as rochas com e sem epidoto magmático da SGPM.

Entre os monzogranitos do GT $\left(\mathrm{SiO}_{2}=71-75 \%\right)$, monzogranitos da SGPM (somente os com $\left.\mathrm{SiO}_{2}=71-74 \%\right)$ e os monzo-sienogranitos do GP e do GRN $\left(\mathrm{SiO}_{2}=70-80 \%\right)$, os dados litoquímicos mostram, claras diferenças na maioria dos óxidos (Figura 5.7), e principalmente traços (Figura 5.8) e ETR (Figura 5.10). Os monzo-sienogranitos do GP e GRN são claramente bem mais enriquecidos em $\mathrm{Rb}, \mathrm{Ga}, \mathrm{Nb}, \mathrm{Hf}, \mathrm{Zr}, \mathrm{Th}, \mathrm{U}, \mathrm{Y}$ e ETRP e bem mais empobrecidos em principalmente $\mathrm{Al}_{2} \mathrm{O}_{3}, \mathrm{CaO}, \mathrm{MgO}, \mathrm{Sr}, \mathrm{Ba}$ e Eu. Os monzogranitos do GT, mesmo circundados pelos monzogabros, as rochas graníticas híbridas e monzosienogranitos do GRN, apresentam características químicas (Figuras 5.7, 5.8 e 5.10) distintas das rochas graníticas sem e com epidoto magmático da SGPM e dos adjacentes monzo-sienogranitos do GRN e, são muito semelhantes aos monzogranitos (os com $\mathrm{SiO}_{2}$ =71-74) da SGPM. Os monzogranitos do GT apresentam perfil de ETR (Figura $5.11 \mathrm{~F}$ ) caracterizado pelo relativo enriquecimento em ETRP $\left(\mathrm{Yb}_{\mathrm{N}}=7-10\right)$ e forte fracionamento e enriquecimento em ETRL $\left(\operatorname{La}_{\mathrm{N}}=200-300\right)$, com aparecimento de fraca anomalia negativa de Eu. Este perfil é similar ao apresentado pelos monzogranitos $\left(\mathrm{SiO}_{2}>70 \%\right)$ da SGPM (Figura $5.11 \mathrm{G})$.

Entre os monzo-sienogranitos $\left(\mathrm{SiO}_{2}\right.$ entre 70 e $\left.80 \%\right)$, com anfibólio e biotita e biotita \pm anfibólio do GP e do GRN, observa-se tendências de correlaçōes negativas e positivas, com $\mathrm{SiO}_{2}$. As tendências de correlações negativas são definidas pela gradativa diminuição e empobrecimento em $\mathrm{TiO}_{2}, \mathrm{MnO}, \mathrm{Al}_{2} \mathrm{O}_{3}, \mathrm{CaO}, \mathrm{Fe}_{2} \mathrm{O}_{3}, \mathrm{MgO}, \mathrm{K}_{2} \mathrm{O}, \mathrm{K} \mathrm{O}+\mathrm{Na}_{2} \mathrm{O}$ (Figura 5.7) e, $\mathrm{Sr}, \mathrm{Ba}, \mathrm{Hf}, \mathrm{Zr}$, Sc (Figura 5.8), ETRL e Eu (Figura 5.10). As correlações positivas são observadas em $\mathrm{Rb}, \mathrm{Rb} / \mathrm{Sr}, \mathrm{Ga}, \mathrm{Ta}(?)$ e $\mathrm{Nb}$ e $\mathrm{Th}$. Comportamentos indefinidos com valores constantes ou não, em relação ao aumento da sílica, são observados em $\mathrm{Na}_{2} \mathrm{O}, \mathrm{K}_{2} \mathrm{O} / \mathrm{Na}_{2} \mathrm{O}$, $\mathrm{Na}_{2} \mathrm{O} / \mathrm{K}_{2} \mathrm{O}, \mathrm{Th}, \mathrm{U}, \mathrm{Y}$ e ETRP. Estas condutas e conteúdos destes elementos neste tipo de rochas sugerem atuação de fases minerais como feldspatos e acessórios (allanita, zircão e titanita) durante a cristalização fracionada destas rochas cogenéticas. O decréscimo de Zr e 
Hf e aumento de Th e $U$ indicam que o zircão é fase participativa no processo de fracionamento de minerais durante o processo de cristalização destas rochas. $O$ aumento de $\mathrm{Nb}$ sugere fracionamento de titanita e o aumento do $\mathrm{Ga}$ com o decréscimo de $\mathrm{Al}_{2} \mathrm{O}_{3}, \mathrm{Ca}, \mathrm{Ba}$, $\mathrm{Sr}$ e $\mathrm{Eu}$ indicam fracionamento de feldspatos alcalinos e retenção de plagioclásio mais cálcico. A retenção do ortopiroxênio e plagioclásio mais cálcico no resíduo, em baixas pressões ao redor de $4 \mathrm{Kbar}$, provoca o aumento da razão $\mathrm{Ga} / \mathrm{Al}$ neste tipo de rochas.

As características mineralógicas (presença de flúorita, máficos intersticiais e tardios, forte pertitização, tipologia e cristalização tardia dos zircões nestas rochas, sequência de cristalização mencionada) e químicas (enriquecimento em $\mathrm{Rb}, \mathrm{Ga}, \mathrm{Ta}, \mathrm{Nb}, \mathrm{Hf}, \mathrm{Zr}, \mathrm{Th}, \mathrm{U}, \mathrm{Ye}$ ETR (principalmente ETRP) e empobrecimento em $\mathrm{Al}_{2} \mathrm{O}_{3}, \mathrm{CaO}, \mathrm{MgO}, \mathrm{Sr}, \mathrm{Ba}$ e Eu indicam claramente que os monzo-sienogranitos do GP e do GRN são rochas graníticas tipicamente representativas da tipologia A (A de Alcalinos, Anorogênicos, Anidros e aluminosos termos sugeridos por Loisele \& Wones 1979, Collins et al. 1982 e King et al. 1995).

Os quartzo monzonitos/quartzo sienitos $\left(\mathrm{SiO}_{2} 65-70 \%\right)$ do GP fracamente peralcalinos distinguem-se dos monzo-sienogranitos $\left(\mathrm{SiO}_{2}=70-80 \%\right)$ do GP e GRN principalmente por serem mais enriquecidas em, $\mathrm{Na}_{2} \mathrm{O}, \mathrm{K}_{2} \mathrm{O}, \mathrm{Na}_{2} \mathrm{O}+\mathrm{K}_{2} \mathrm{O}, \mathrm{Zr}, \mathrm{Hf}, \mathrm{Y}$ e ETRL e ETRP e relativamente mais empobrecidas principalmente em $\mathrm{MgO}, \mathrm{Rb}, \mathrm{Sr}$ e $\mathrm{Ba}$. Os monzo-sienogranitos do GRN e do GP e os quartzo monzonitos/quartzo sienitos do GP, apresentam perfil de ETR (Figura $5.11 \mathrm{C}$ e D) caracterizado pelo enriquecimento em ETRP, forte enriquecimento e fracionamento em ETRL e forte empobrecimento Eu com aumento gradativo da forte anomalia negativa de $\mathrm{Eu}$ com o aumento da $\mathrm{SiO}_{2}$. Enquanto que nos monzo-sienogranitos do GP e do GRN ocorre, com aumento do $\mathrm{SiO}_{2}$, somente a progressiva diminuição de ETRL e progressivo aumento da anomalia negativa de Eu, nos quartzo monzonitos/quartzo sienitos ocorre o aumento de ETRL e ETRP. O aumento da anomalia negativa do $\mathrm{Eu}$ com aumento do $\mathrm{SiO}_{2}$, ou a correlação negativa do $\mathrm{Eu} \mathrm{com} \mathrm{SiO}_{2}$, são mais típicos dos monzo-sienogranitos do GP e do GRN do que os quartzo monzonitos/quartzo sienitos do GP. O progressivo empobrecimento em $\mathrm{Al}_{2} \mathrm{O}_{3}, \mathrm{CaO}, \mathrm{Sr}$, Ba e Eu com o aumento gradativo da anomalia negativa do $\mathrm{Eu}$, o progressivo decréscimo de $\mathrm{K}_{2} \mathrm{O}$ e $\mathrm{Na}_{2} \mathrm{O}$ (?) com aumento da sílica, nos quartzo monzonitos/quartzo sienitos do GP e nos monzosienogranitos do GP e do GRN (Figuras 5.7, 5.8 e $5.9 \mathrm{~F}$ e $\mathrm{H}$ ), são fortes indícios de fracionamento do plagioclásio (retenção do plagioclásio mais cálcico no residuo e remoção e cristalização do plagioclásio mais sódico) e feidspatos alcalinos durante o curso de cristalização destas rochas. 
Os leucogranodioritos do $\mathrm{GAS}\left(\mathrm{SiO}_{2}=75 \%\right)$ apresentam, em relação aos monzosienogranitos do GP e do GRN, claramente maior conteúdo em $\mathrm{Na}_{2} \mathrm{O}$ e menor em $\mathrm{K}_{2} \mathrm{O}$, $\mathrm{Fe}_{2} \mathrm{O}_{3}$ e $\mathrm{TiO}_{2}$ (Figuras $5.7 \mathrm{~A}, \mathrm{E}, \mathrm{G}$ e H). Os leucogranodioritos do GAS apresenta, ainda, conteúdos mais altos em $\mathrm{Sr}, \mathrm{Ga}$ e U, $\mathrm{Nb}$ (?) e bem mais baixos em $\mathrm{Rb}, \mathrm{Hf}, \mathrm{Zr}, \mathrm{Y}, \mathrm{ETRL}$ e ETRP (Figuras 5.8 e 5.10). O forte empobrecimento em ETRL $\left(\operatorname{La}_{N}=7-15\right)$ e ETRP $\left(Y b_{N}=1\right.$ 3), é o que mais chama atenção nestes leucogranodioritos em relação aos demais granitos da região, principalmente, os monzo-sienogranitos do GP e do GRN (Figura 5.11 E e C)

Os dados mineralógicos (presença de biotita, muscovita, fluorita, e traços de granada) e litoquímicos, sugerem tratar-se de rochas com características que podem ser confundidas com os granitos tipo S (Chappel \& White 1992, Chappel \& White 1974, Chappel \& White 1983, Harris et al. 1986, White \& Chappel 1988, Inger \& Harris 1993, Inger 1994, Le fort 1988, Sylvester 1999, e outros). O GAS é um granito tipo A com duas micas e com flúorita e traços de granada, a exemplo dos granitos tipo A mesoproterozóicos do sudoeste norte americano (Anderson 1982 e Anderson \& Bender 1989) e tipo A neoproterozóicos do Cinturão Damara (Jung et al. 1998). A presença de flúorita em cavidades miaroliticas ou não, o alto conteúdo em $\mathrm{Rb} \mathrm{Ga}, \mathrm{Ta}, \mathrm{Nb}$, Th e, o baixo conteúdo em $\mathrm{Sr}, \mathrm{Ba}, \mathrm{Al}_{2} \mathrm{O}_{3}$ e $\mathrm{CaO}$, são características similares aos monzo-sienogranitos do GP e o GRN.

A baixa concentração dos máficos e a raridade dos acessórios (allanita e zircão) nos leucogranodioritos do GAS, devem ser os responsáveis pela assinatura quimica modificada, principalmente, em vários elementos traços e todos os ETR, em relação aos monzosienogranitos do GP e do GRN. Os poucos cristais de zircão do GAS apresentam tipologia ou morfologia idêntica a dos monzo-sienogranitos do GP e do GRN. Desta forma, os dados geológicos em geral sugerem que os leucogranodioritos do GAS, são rochas graníticas do tipo A e seguramente correlacionáveis aos monzo-sienogranitos do GP e do GRN.

As diferenças em relação às assinaturas quimicas dos leucogranodioritos da SGPM que circundam os leucogranodioritos do GAS são marcantes principalmente em $\mathrm{Al}_{2} \mathrm{O}_{3}, \mathrm{TiO}_{2}$, $\mathrm{CaO}$ e $\mathrm{Na}_{2} \mathrm{O}$ (Figura 5.7), traços como Ba, $\mathrm{Rb}, \mathrm{Sr}, \mathrm{Ga}, \mathrm{Ta}, \mathrm{Nb}, \mathrm{Hf}, \mathrm{Zr}$, Th e U (Figura 5.8) e ETR (Figura 5.10). Estas caracteristicas químicas somadas às diferenças mineralógicas descartam qualquer possibilidade dos leucogranodioritos do GAS serem cogenéticos dos adjacentes leucogranodioritos da SGPM. Deve-se lembrar que foram encontrados cristais de muscovitas primárias ? nos monzo-sienogranitos de granulação fina a média da porção central do GP, porém estas rochas demonstram sem dúvida, não como o caso do GAS, claras características mineralógicas, texturais e químicas dos granitos da tipologia $A$ da região. Lembramos que é comum a presença de raros ou poucos cristais de muscovitas em rochas graníticas tipo $A$ metaluminosas à fracamente peraluminosas, principalmente, rochas 
que possuem a biotita como o principal máfico predominante (Barbarin 1999, Anderson e Bender 1989, Jung et al. 1998 e outros)

As características litoquímicas apresentadas pelos monzo-sienogranitos e quartzo monzonitos/quartzo sienitos do GP, monzo-sienogranitos do GRN e pelos leucogranodioritos do GAS são semelhantes e típicas das rochas graniticas da tipologia A-PA amplamente descritas e abordadas por (Loiselle \& Wones 1979, Creaser 1991, Clemens et al. 1986, Anderson 1981, Turner et al 1992, Sylvester 1989, Anderson \& Bender 1989, Whalen et al. 1987, Dall'Agnol et al 1990 e 1994, Hogan et al 1992, Ramo \& Haapla 1995, Haapla \& Ramo 1992 e 1999, Rogers \& Greenberg 1993, Lendenberger \& Collins 1996, Patino Douce 1997 , Whalen et al 1996, Pearce et al. 1984, Collins et al.1982, Eby 1990, Eby 1992, King et al.1995, Nédélic et al 1995, Windley 1993 e outros).

Os monzogabros em geral $\left(\mathrm{SiO}_{2}=48-55 \%\right)$ do GP e o GRN apresentam (Figuras 5.7, $5.8,5.10$ e 5.11) semelhantes caracteristicas litoquímicas definidas, principalmente, pelo alto conteúdo em $\mathrm{Na}_{2} \mathrm{O}$ (3 a $4 \%$ ), $\mathrm{K}_{2} \mathrm{O}(1-2 \%$ ), Ba, Rb, Sr, Ga, $\mathrm{Zr}$ e $\mathrm{Y}$ e, enriquecimento em ETRL $\left(L a_{N}=100\right.$ a 150) e ETRP $\left(Y_{\left.b_{N}=10-20\right)}\right.$. Os monzogabros do GP são, em relação aos monzogabros do GRN, mais enriquecidos em $\mathrm{Al}_{2} \mathrm{O}_{3}$ e mais empobrecidos em $\mathrm{Na}_{2} \mathrm{O}$, ETRL e ETRP.

Estas características químicas dos monzogabros são semelhantes e típicas dos basaltos CFB intracontinentais ou basaltos WPB intraplaca conforme indicações (Figura 5.9 J) de Sun \& McDonough (1989) e Pearce \& Norry (1979).

As rochas graníticas híbridas máficas e félsicas $\left(\mathrm{SiO}_{2}, 55-70 \%\right)$ do $\mathrm{GP}$ e principalmente do GRN apresentam caracteristicas químicas herdadas por mistura entre os dois componentes máficos (monzogabros) e félsicos (monzo-sienogranitos). Estas características litoquímicas são indicadas pelo alto conteúdo em $\mathrm{TiO}_{2}, \mathrm{Na}_{2} \mathrm{O}, \mathrm{CaO}, \mathrm{K}_{2} \mathrm{O}, \mathrm{Ba}$, $\mathrm{Ga}, \mathrm{Nb} \mathrm{Zr}, \mathrm{Hf}, \mathrm{Y}, \mathrm{SC}, \mathrm{V}$ ETRL, ETRP, baixo a médio $\mathrm{Rb}$, médio $\mathrm{Sr}$ e baixo $\mathrm{Al}_{2} \mathrm{O}_{3}$ (Figuras 5.7, 5.8 e 5.10). O perfil de ETR (Figura $5.11 \mathrm{~B}$ ) é caracterizado pelo enriquecimento em $\operatorname{ETRP}\left(\mathrm{Yb}_{\mathrm{N}}=20-40\right)$ e forte enriquecimento e fracionamento de ETRL $\left(\mathrm{La}_{N}=100-300\right) \mathrm{com}$ a presença de fracas anomalias negativas de Eu que aumentam fortemente em direção aos monzo-sienogranitos, componentes félsicos da mistura. Todas estas características químicas herdadas dos seus genitores máficos e félsicos, imprimem nestas rochas graníticas híbridas máficas e félsicas, assinaturas químicas típicas de rochas graniticas da tipologia $\mathrm{A}$, tais como, alto $\mathrm{Ga}, \mathrm{Nb}, \mathrm{Hf}, \mathrm{Zr}, \mathrm{Y}, \mathrm{ETRL}$ e ETRP e baixo $\mathrm{Al}_{2} \mathrm{O}_{3}$ e $\mathrm{Sr}$.

As correlações em óxidos, traços e ETR (Figuras 5.7, 5.8 e 5.10) entre os componentes máficos (monzogabros) e félsicos (monzo-sienogranitos) e as rochas graníticas híbridas máficas e félsicas, não sugerem um processo de cristalização fracionada, 
partindo dos monzogabros e produzindo os monzo-sienogranitos mas sim, a invasão dos monzo-sienogranitos em cristalização pelos monzogabros produzindo as rochas híbridas. Desta forma, sugere-se que os monzogabros não são magmas parentais que produziriam, via cristalização fracionada, os monzo-sienogranitos do GP e do GRN e os quartzo monzonitos/quartzo sienitos do GP. Caso contrário, as rochas graníticas produzidas no intervalo de $\mathrm{SiO}_{2}$ entre 55 e $70 \%$, seriam rochas graníticas convencionais e não híbridas.

O conteúdo em elementos traços tais como, $\mathrm{Rb}, \mathrm{Y}$ e Nb (Figura 5.12) indicam claramente que os monzo-sienogranitos do GP e o GRN, os quartzo monzonitos/quartzo sienitos do GP e as rochas graniticas híbridas máficas e félsicas do GP e do GRN são granitos intraplaca e da tipologia $A$ e as rochas graníticas sem e com epídoto magmático da SGPM são de arcos magmáticos e da tipologia I. Os monzogranitos do GT e os monzogranitos em geral da SGPM assumem, neste diagrama (Figura 5.12), uma posição intermediária, entre as rochas graníticas sem e com epídoto magmático da SGPM e as rochas graníticas em geral do GP e GRN. Sugere-se que estes monzogranitos são sin a tardi-tectônicos (sin a tardi-colisionais) calcio-alcalinos de alto $\mathrm{K}$, que registram a contínua resposta magmática da região entre a orogênia (SGPM) e a anorogênia (GP e GRN). Entre estes ambientes geotectônicos extremos, há a continuidade das respostas magmáticas formando e alojando os monzogranitos do GT em região preservada (?) da deformação (sul da ZCPT) neste período e, os monzogranitos da SGPM, alojados em região ainda sob esforços compressivos e deformação final (norte da ZCPT).

Os leucogranodioritos do GAS no diagrama da Figura 5.12 apresentam indefinição com falsas tendências de algumas amostras para os granitos tipo $S$, devido principalmente ao empobrecimento em $Y$, porém conforme as observações anteriores, trata-se de um granito tipo A, da mesma tipologia dos monzo-sienogranitos do GP e do GRN. 

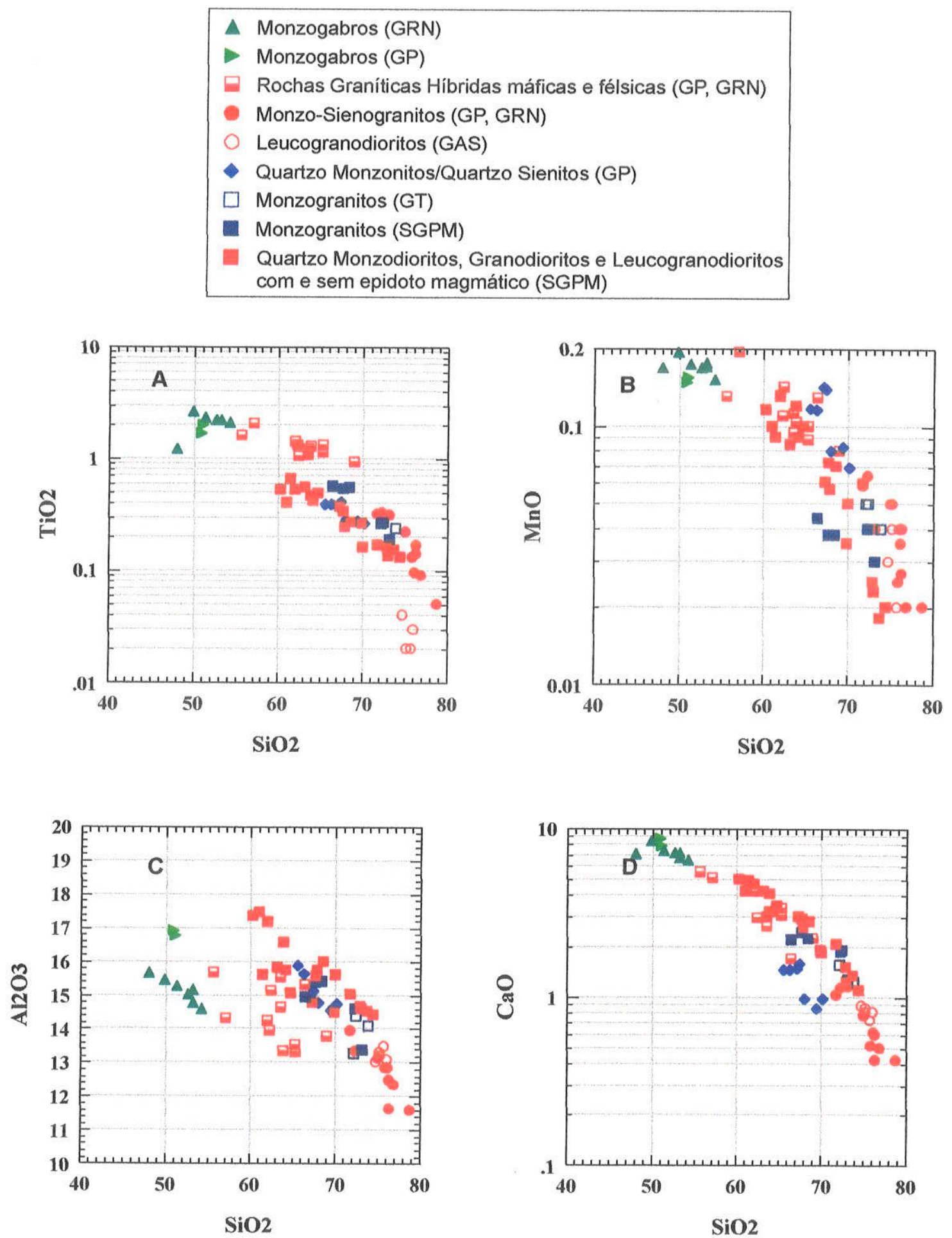

Figura 5.7 - Ver legenda página 70 

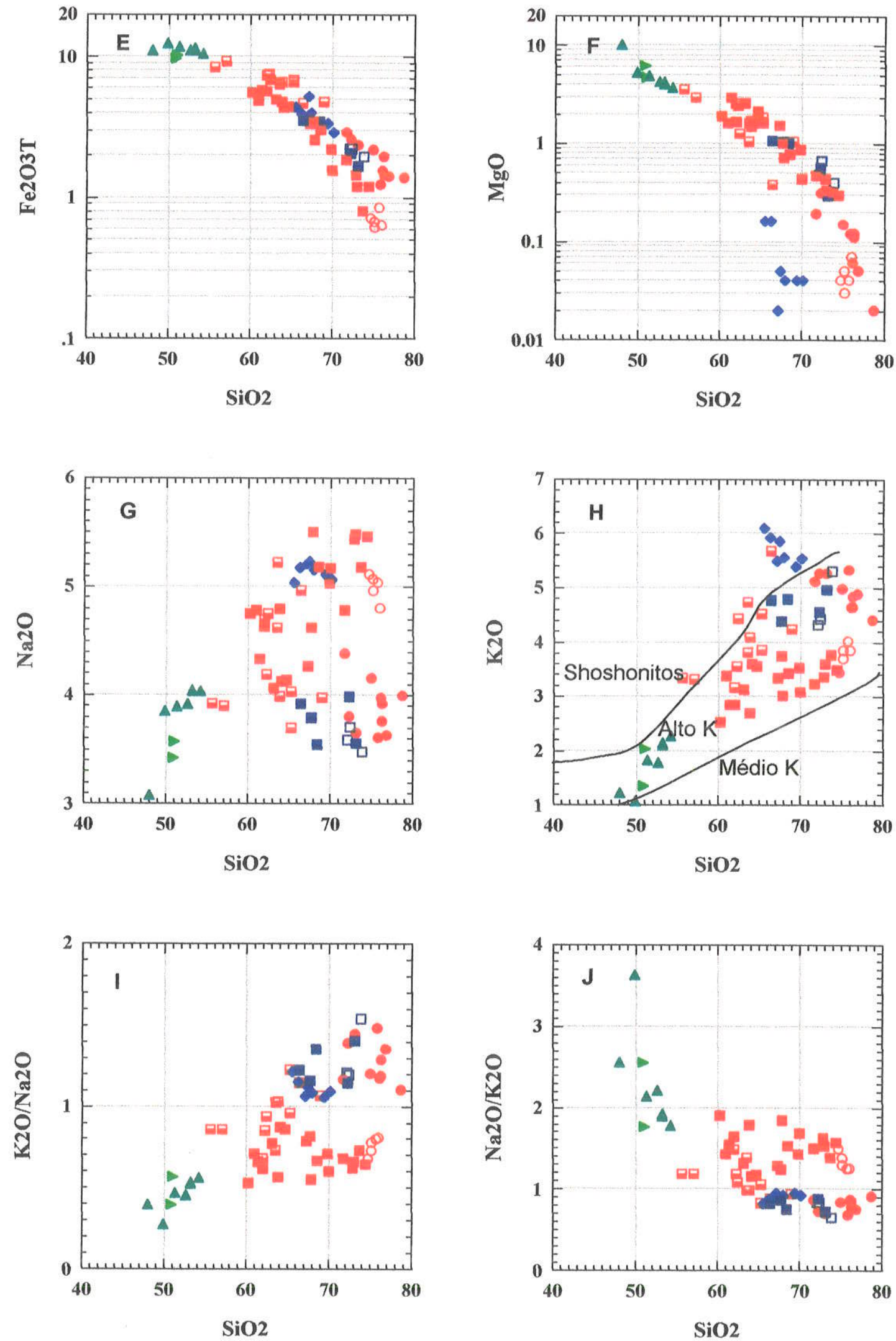

Figura 5.7 - Ver legenda página 70 


\begin{tabular}{|l} 
Monzogabros (GRN) \\
Monzogabros (GP) \\
Rochas Graníticas Híbridas máficas e félsicas (GP, GRN) \\
Monzo-Sienogranitos (GP, GRN) \\
Leucogranodioritos (GAS) \\
$\square$ Quartzo Monzonitos/Quartzo Sienitos (GP) \\
Monzogranitos (GT) \\
Monzogranitos (SGPM) \\
comartzo Monzodioritos, Granodioritos e Leucogranodioritos \\
\hline
\end{tabular}
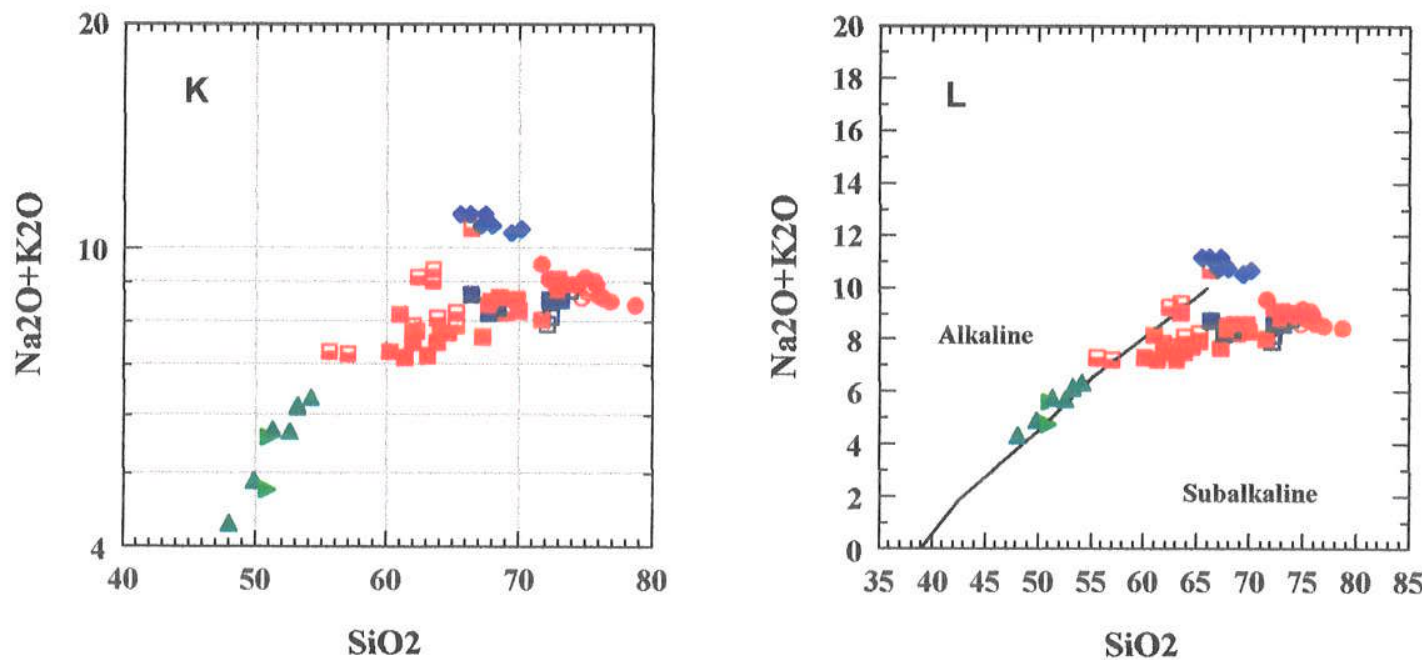

Figura 5.7 - Diagramas de variação $\mathrm{SiO}_{2} \mathrm{X}$ óxidos $\left(\mathrm{TiO}_{2}, \mathrm{MnO}, \mathrm{Al}_{2} \mathrm{O}_{3}, \mathrm{CaO}, \mathrm{Fe}_{2} \mathrm{O}_{3}, \mathrm{MgO} \mathrm{Na}_{2} \mathrm{O}\right.$ e $\mathrm{K}_{2} \mathrm{O}$ : Limites de Rickwood et.al. 1989, calcio-alcalinos de médio e alto $\mathrm{K}$ e shoshonítico ) e $\mathrm{K}_{2} \mathrm{O} / \mathrm{Na}_{2} \mathrm{O}, \mathrm{Na}_{2} \mathrm{O} / \mathrm{K}_{2} \mathrm{O}$ e $\mathrm{Na}_{2} \mathrm{O}+\mathrm{K}_{2} \mathrm{O}$ para as rochas dos Granitos GP, GAS, GRN, GT e a SGPM. Valores dos óxidos em porcentagens.
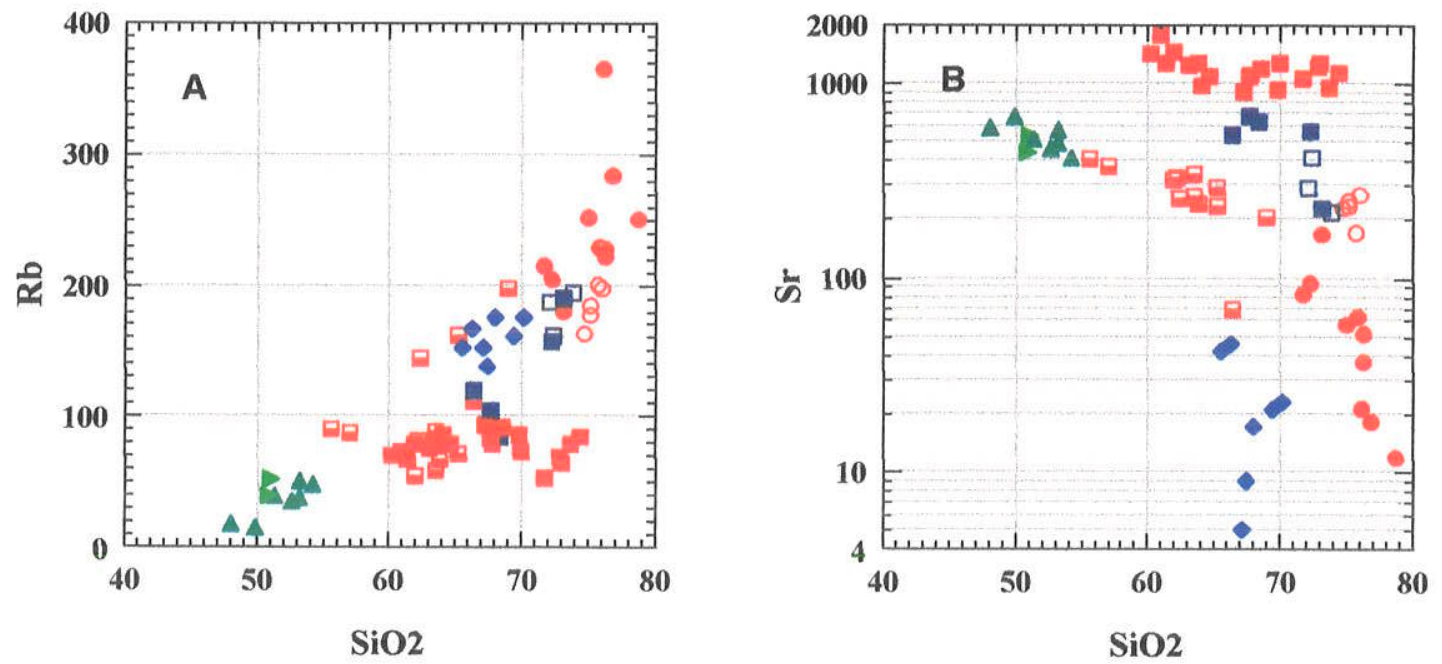

Figura 5.8 - Ver legenda página 73 

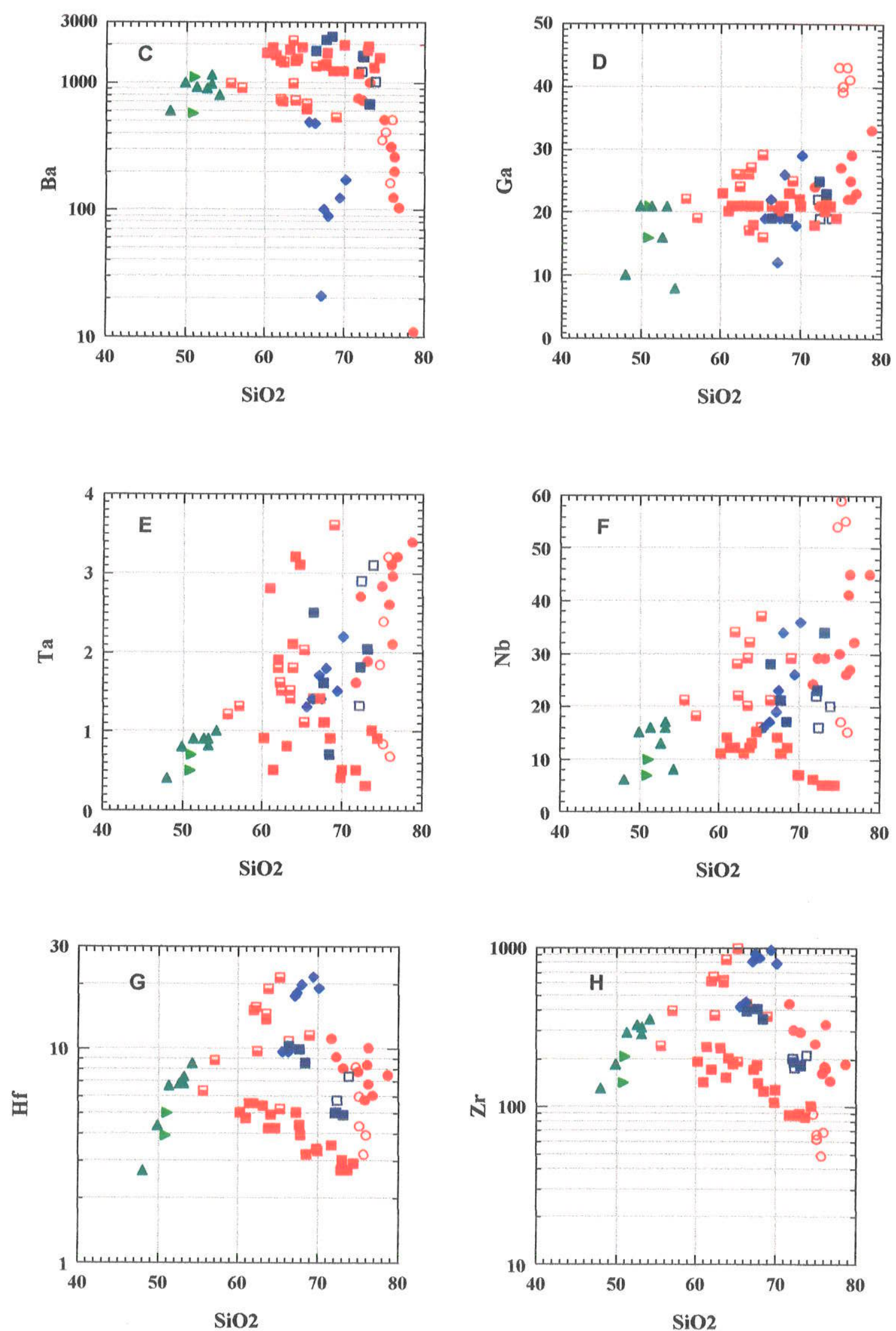

Figura 5.8 - Ver legenda página 73 

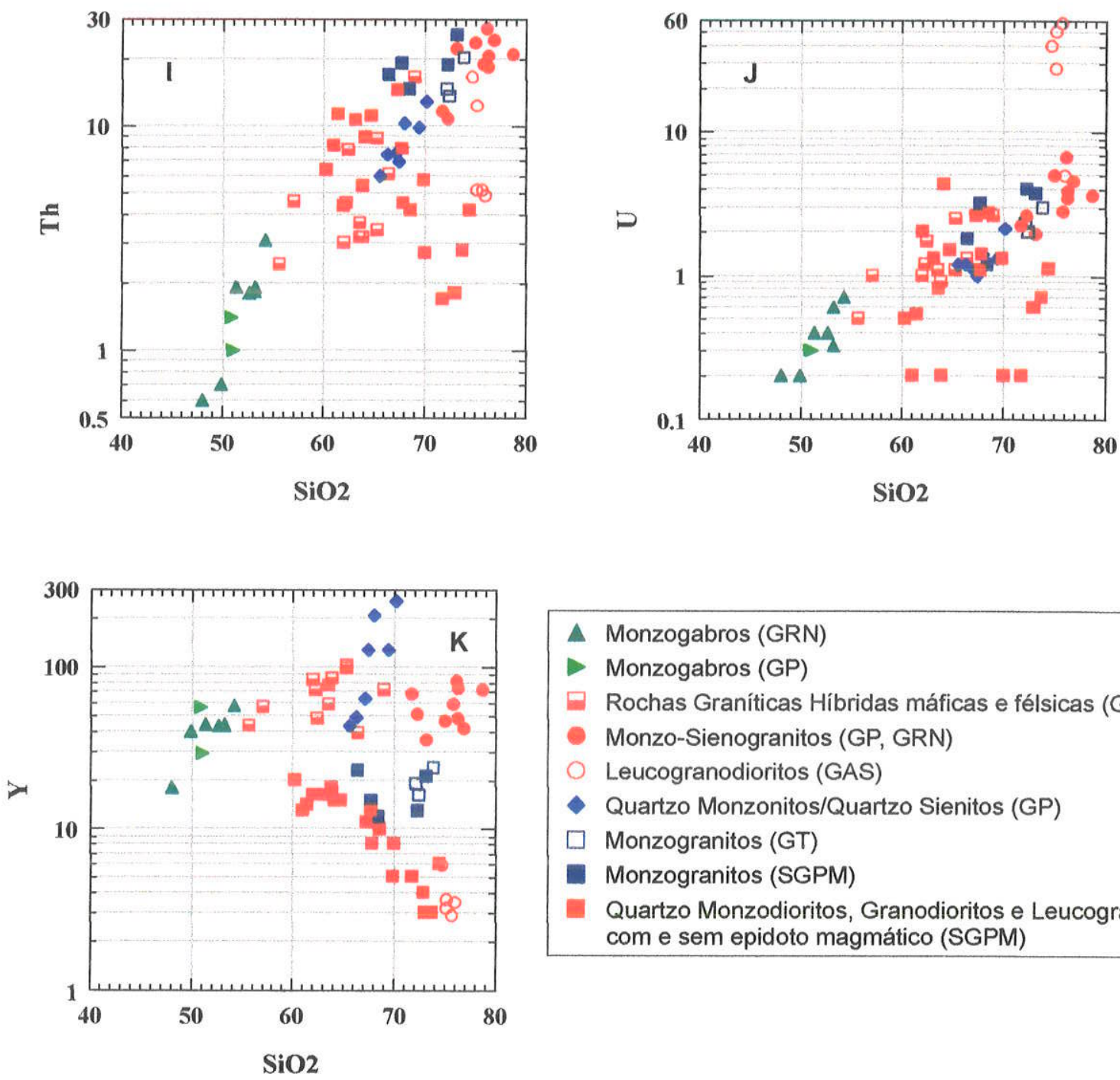

A Monzogabros (GRN)

- Monzogabros (GP)

$\square$ Rochas Graníticas Híbridas máficas e félsicas (GP, GRN)

- Monzo-Sienogranitos (GP, GRN)

- Leucogranodioritos (GAS)

- Quartzo Monzonitos/Quartzo Sienitos (GP)

$\square$ Monzogranitos (GT)

- Monzogranitos (SGPM)

- Quartzo Monzodioritos, Granodioritos e Leucogranodioritos com e sem epidoto magmático (SGPM)
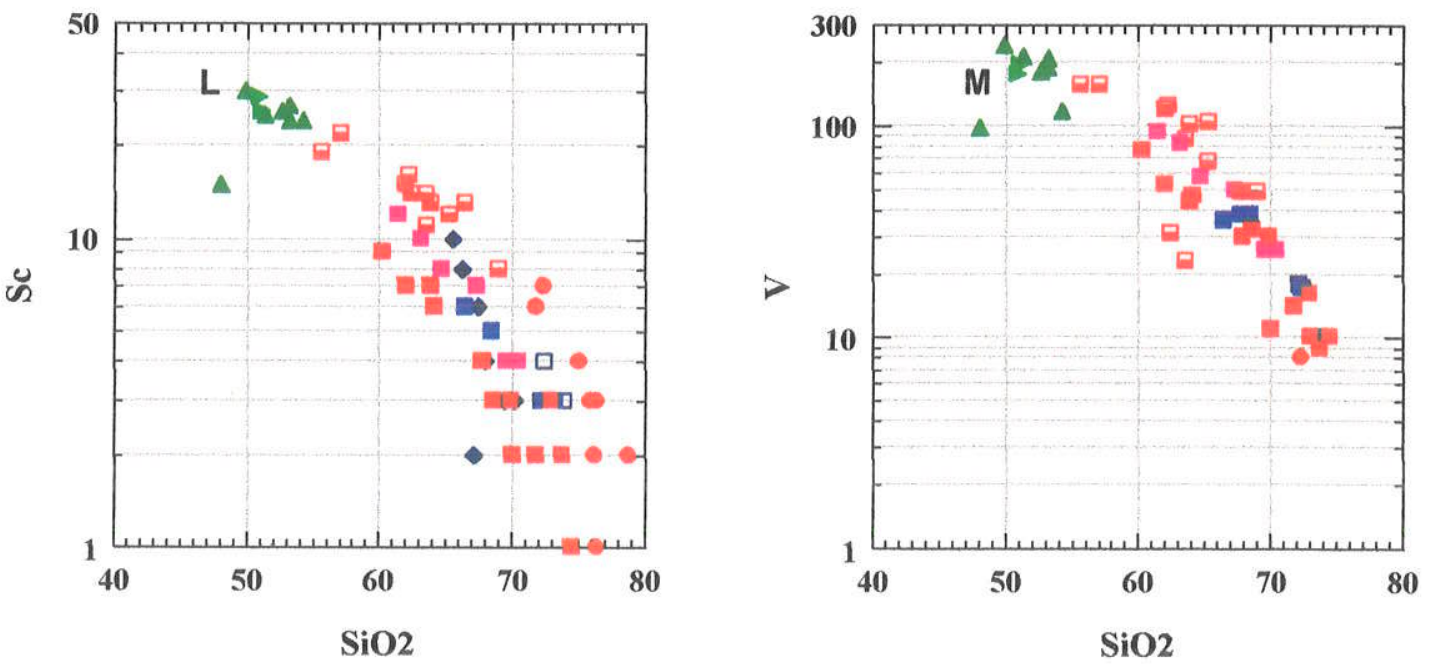

Figura 5.8 - Ver legenda página 73 

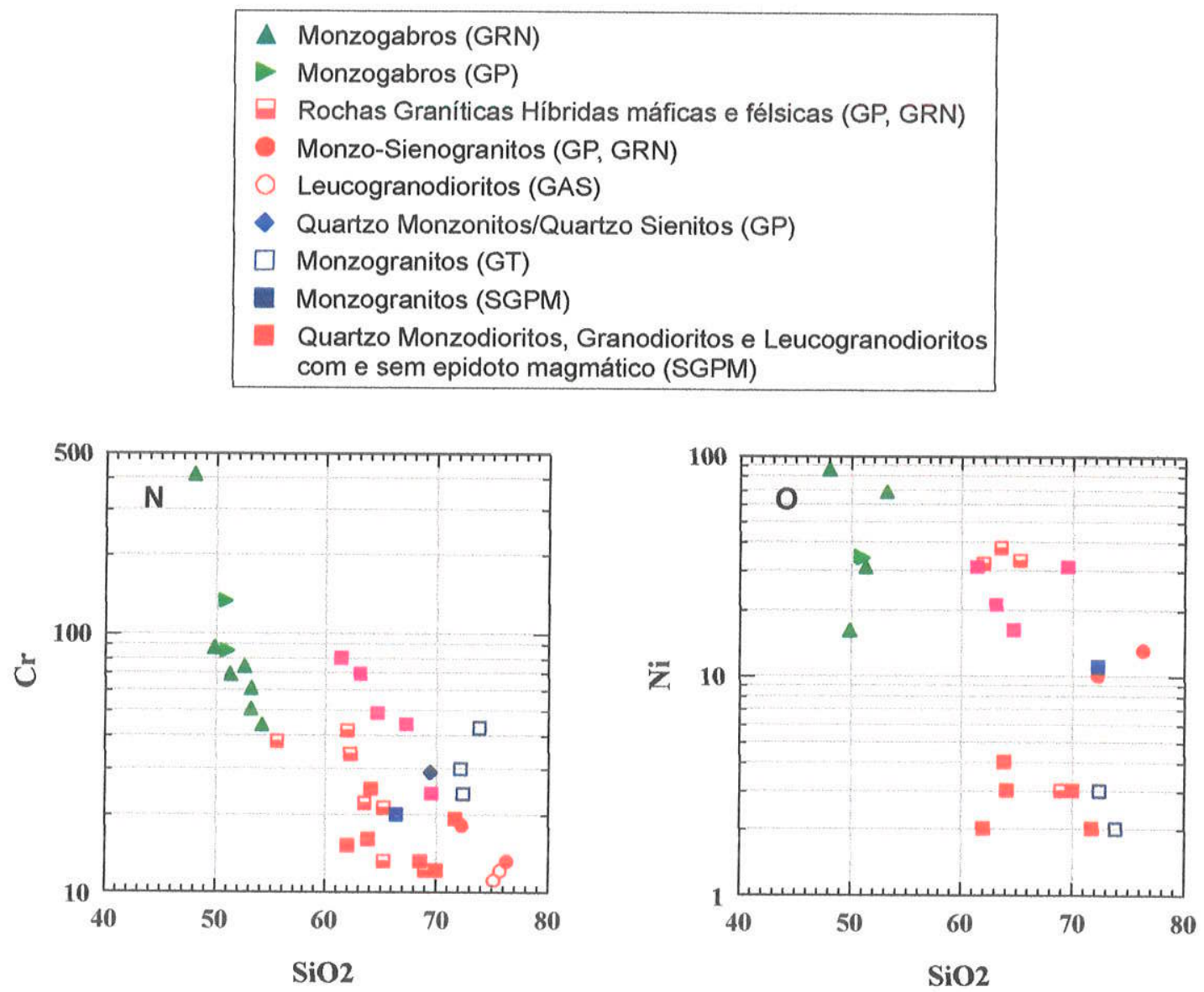

Figura 5.8 - Diagramas de variação $\mathrm{SiO}_{2} \mathrm{X}$ elementos traços (Rb, $\mathrm{Sr}, \mathrm{Ba}, \mathrm{Ga}, \mathrm{Ta}, \mathrm{Nb}, \mathrm{Hf}, \mathrm{Zr}, \mathrm{Th}, \mathrm{U}, \mathrm{Y}, \mathrm{Sc}, \mathrm{V}$, $\mathrm{Cr}$ e Ni) para as rochas dos Granitos GP, GAS, GRN, GT e a SGPM. Valores dos elementos traços em ppm.

Fe2O3T

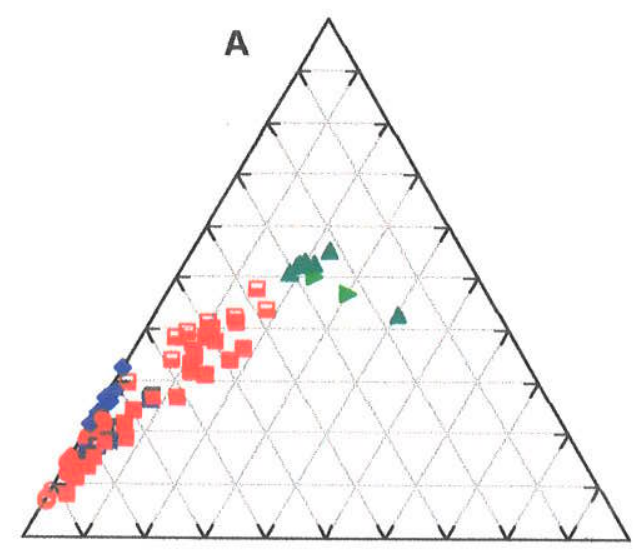

$\mathrm{K} 2 \mathrm{O}+\mathrm{Na2O}$

MgO
Fe2O3T

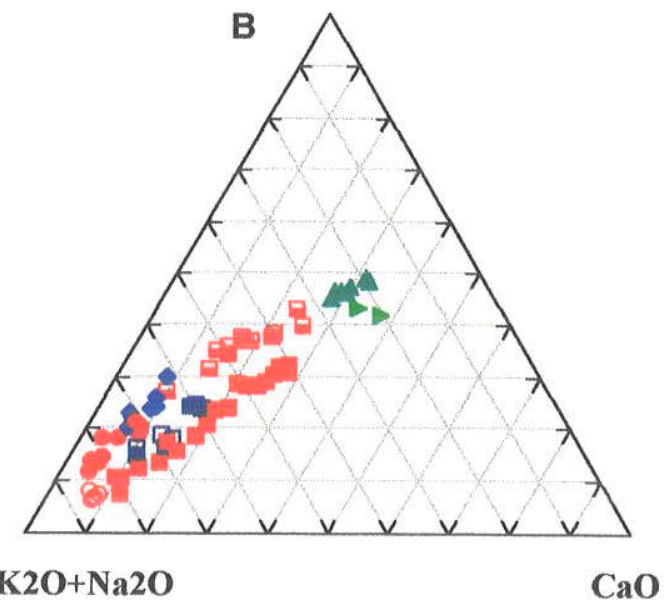

Figura 5.9 - Ver legenda página 75 


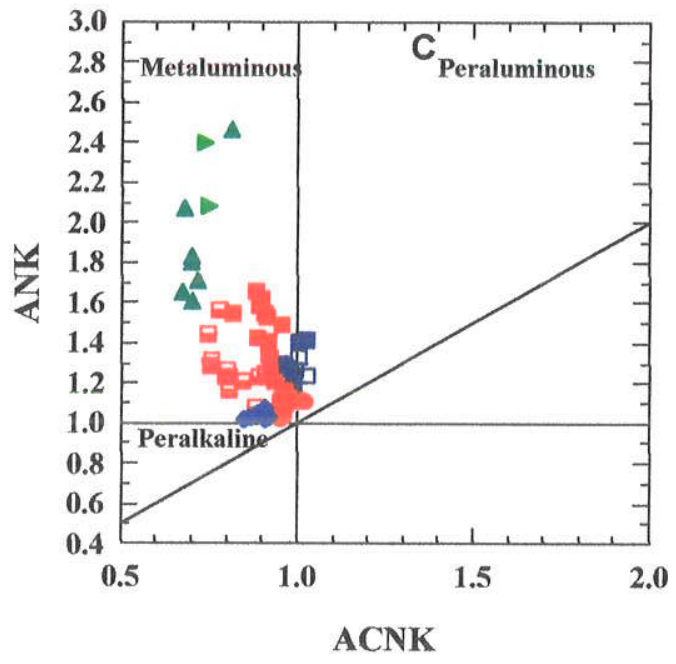

$\Delta$ Monzogabros (GRN)

- Monzogabros (GP)

$\square$ Rochas Graníticas Híbridas máficas e félsicas (GP, GRN)

- Monzo-Sienogranitos (GP, GRN)

- Leucogranodioritos (GAS)

- Quartzo Monzonitos/Quartzo Sienitos (GP)

$\square$ Monzogranitos (GT)

Monzogranitos (SGPM)

- Quartzo Monzodioritos, Granodioritos e Leucogranodioritos com e sem epidoto magmático (SGPM)
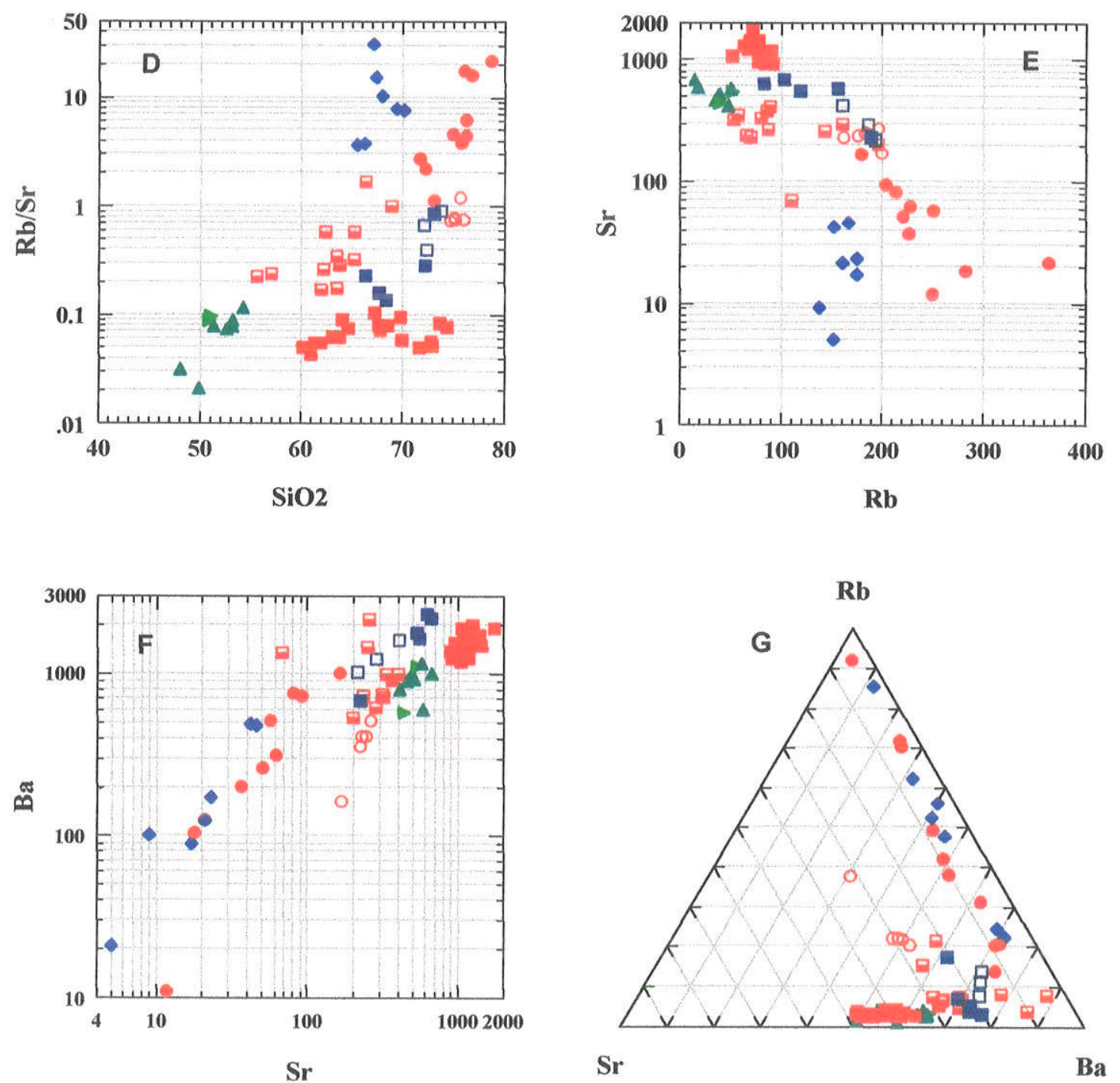

Figura 5.9 - Ver legenda página 75 

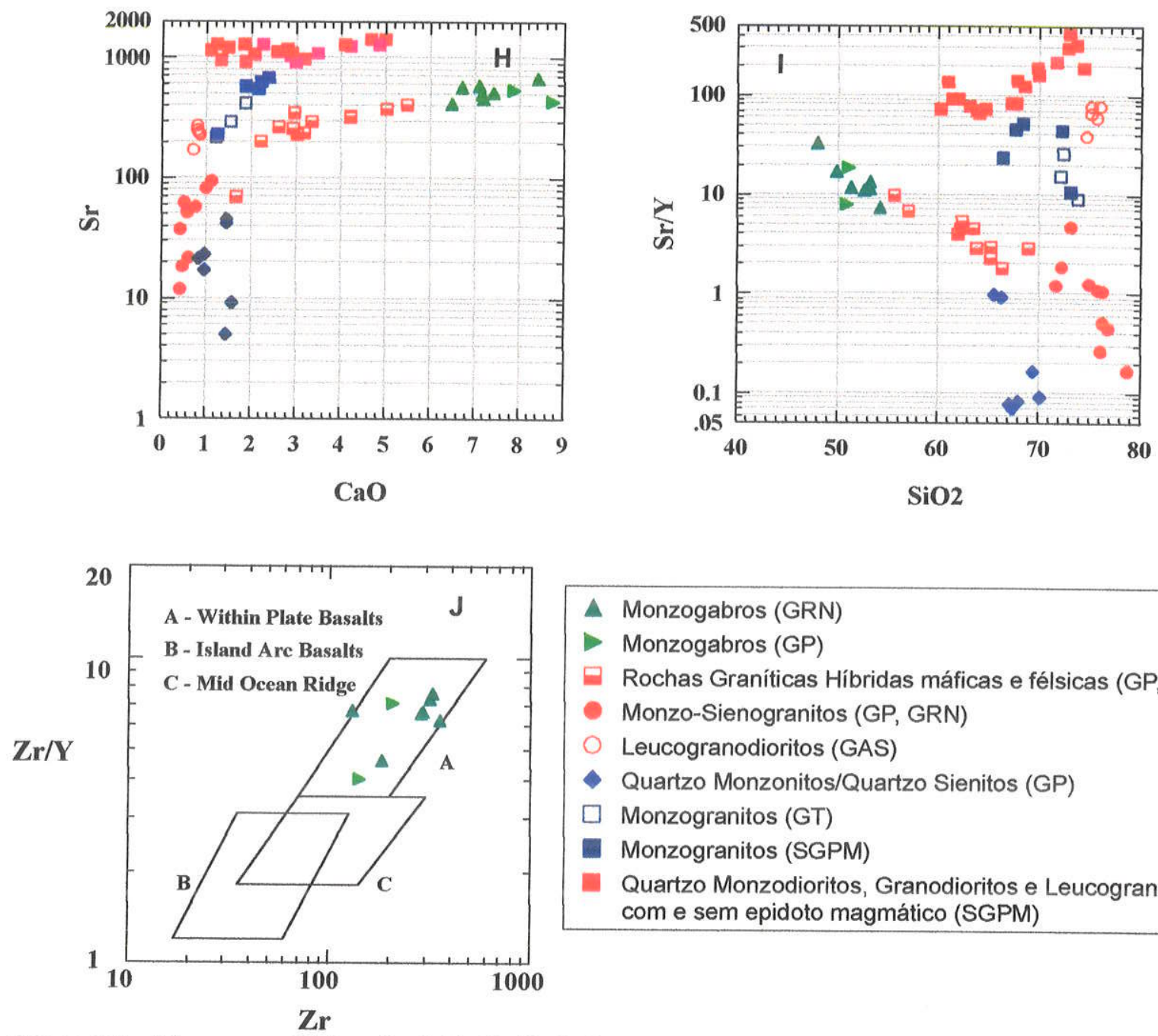

A Monzogabros (GRN)

Monzogabros (GP)

$\square$ Rochas Graníticas Híbridas máficas e félsicas (GP, GRN)

- Monzo-Sienogranitos (GP, GRN)

- Leucogranodioritos (GAS)

- Quartzo Monzonitos/Quartzo Sienitos (GP)

$\square$ Monzogranitos (GT)

Monzogranitos (SGPM)

Quartzo Monzodioritos, Granodioritos e Leucogranodioritos com e sem epidoto magmático (SGPM)

Figura 5.9 - Diagramas $\left(\mathrm{K}_{2} \mathrm{O}+\mathrm{Na}_{2} \mathrm{O}-\mathrm{Fe}_{2} \mathrm{O}_{3}-\mathrm{MgO}\right.$, fonte: Irvine \& Baragar 1971), $\mathrm{K}_{2} \mathrm{O}+\mathrm{Na}_{2} \mathrm{O}-\mathrm{Fe}_{2} \mathrm{O}_{3}-\mathrm{CaO}_{\text {, }}$ $\left(\mathrm{Al}_{2} \mathrm{O}_{3} / \mathrm{CaO}+\mathrm{Na}_{2} \mathrm{O}+\mathrm{K} 2 \mathrm{O} \times \mathrm{Al}_{2} \mathrm{O}_{3} / \mathrm{Na}_{2} \mathrm{O}+\mathrm{K}_{2} \mathrm{O}\right.$, fonte : Maniar \& Piccoli, 1989) e diagramas de variação $\mathrm{SiO}_{2} \times \mathrm{Rb} / \mathrm{Sr}, \mathrm{Rb} \times \mathrm{Sr}, \mathrm{Sr} \times \mathrm{Ba}, \mathrm{Sr}-\mathrm{Rb}-\mathrm{Ba}, \mathrm{CaO} \times \mathrm{Sr}, \mathrm{SiO}_{2} \times \mathrm{Sr} / \mathrm{Y}$ e $\mathrm{Zr} \times \mathrm{Zr} / \mathrm{Y}$ (Fonte Pearce \& Norry, 1979) para as rochas dos Granitos GP, GAS, GRN, GT e a SGPM.
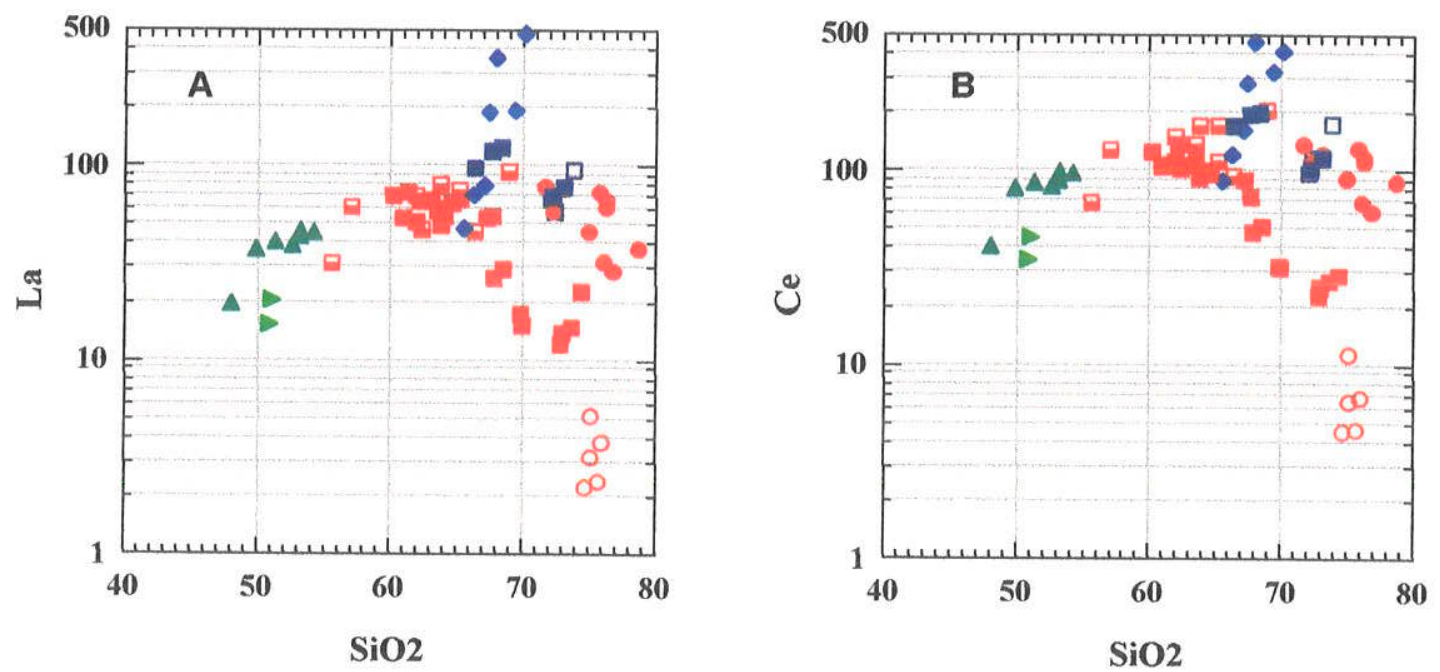

Figura 5.10 - Ver legenda página 77 

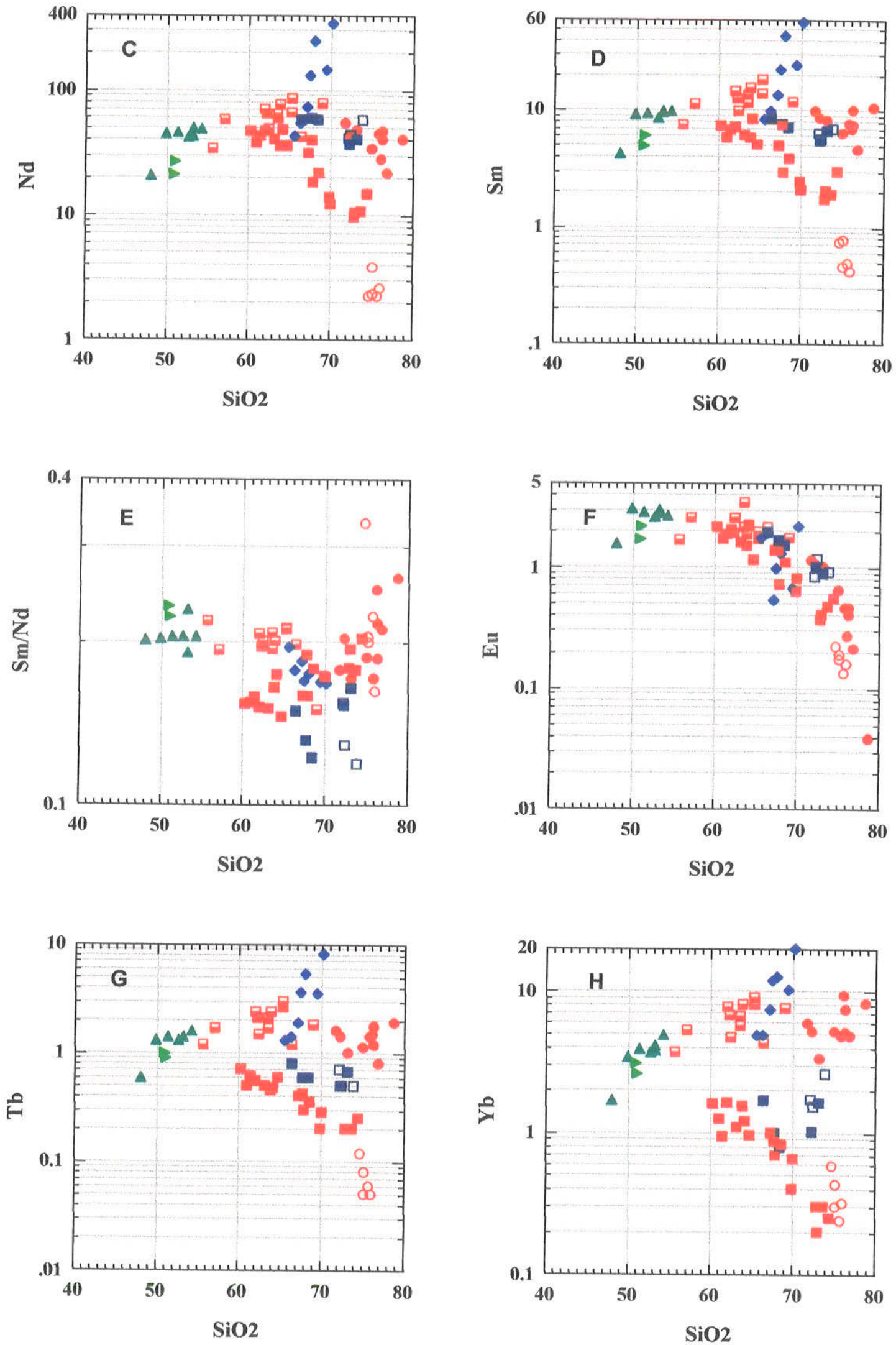

Figura 5.10 - Ver legenda página 77 


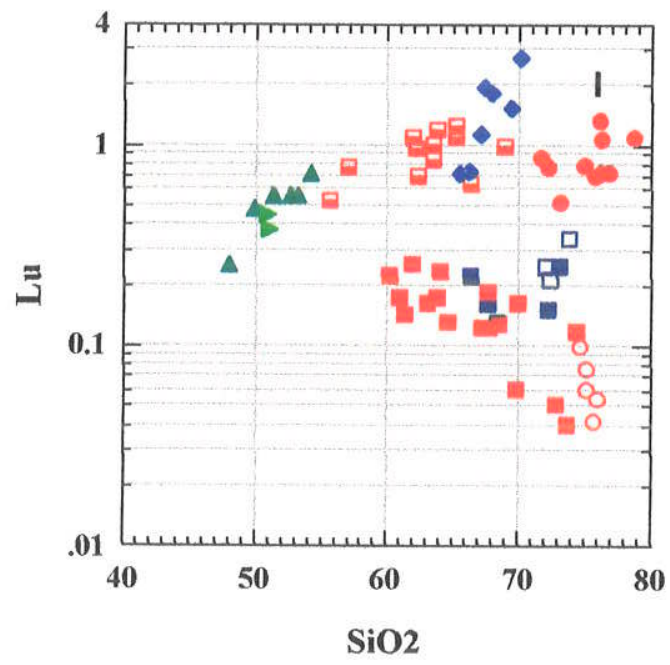

\begin{tabular}{|l}
\hline Monzogabros (GRN) \\
Monzogabros (GP) \\
Rochas Graníticas Híbridas máficas e félsicas (GP, GRN) \\
Monzo-Sienogranitos (GP, GRN) \\
Leucogranodioritos (GAS) \\
$\square$ Quartzo Monzonitos/Quartzo Sienitos (GP) \\
Monzogranitos (GT) \\
Quartzo Monzodioritos, Granodioritos e Leucogranodioritos \\
com e sem epidoto magmático (SGPM)
\end{tabular}

Figura 5.10 - Diagramas de variação $\mathrm{SiO}_{2} \mathrm{X}$ elementos terras raras leves (ETRL) e elementos terras raras pesados (ETRP) para as rochas dos Granitos GP, GAS, GRN, GT e a SGPM. Valores dos ETRL e ETRP em ppm.
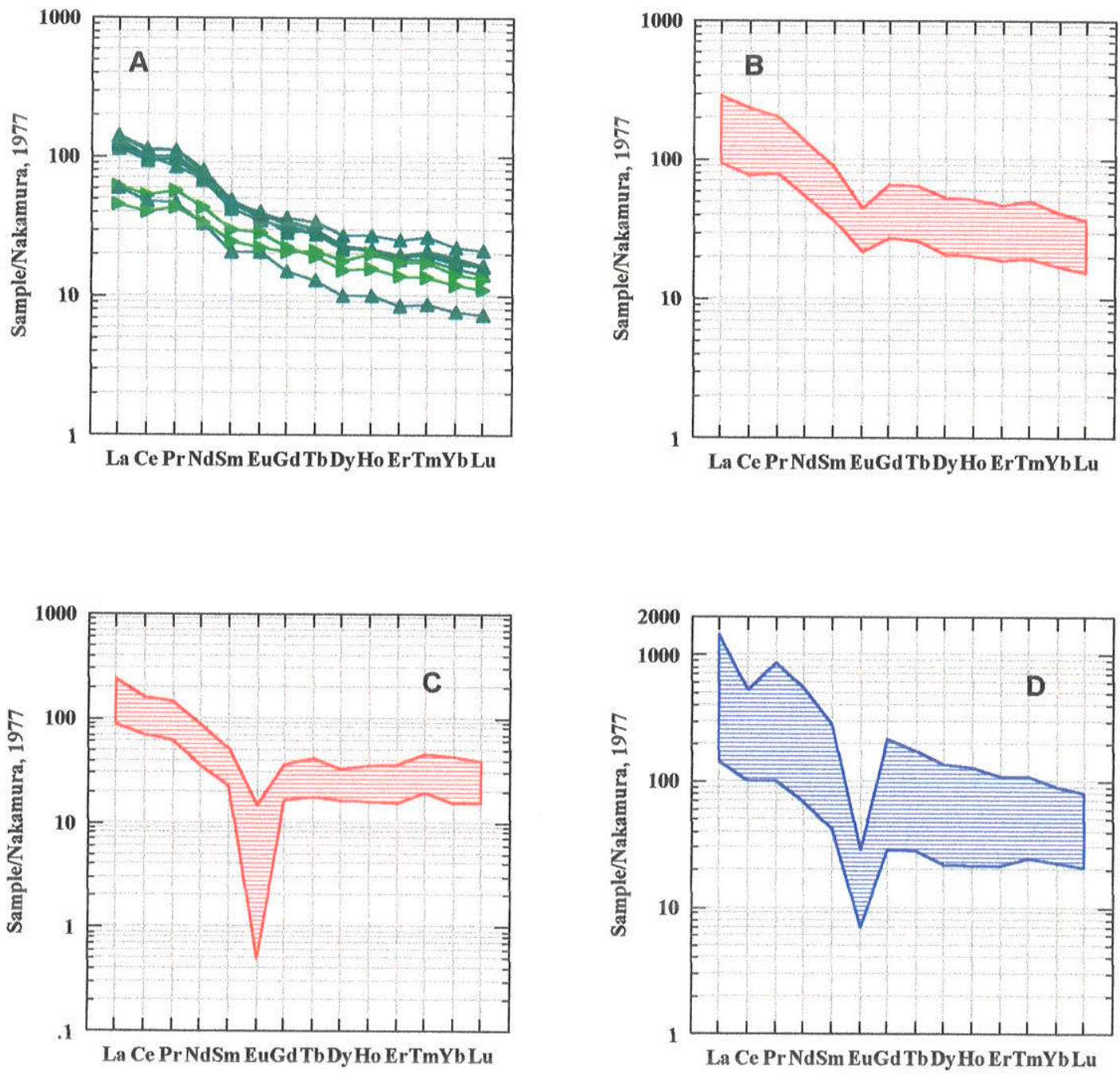

Figura 5.11 - Ver legenda página 78 

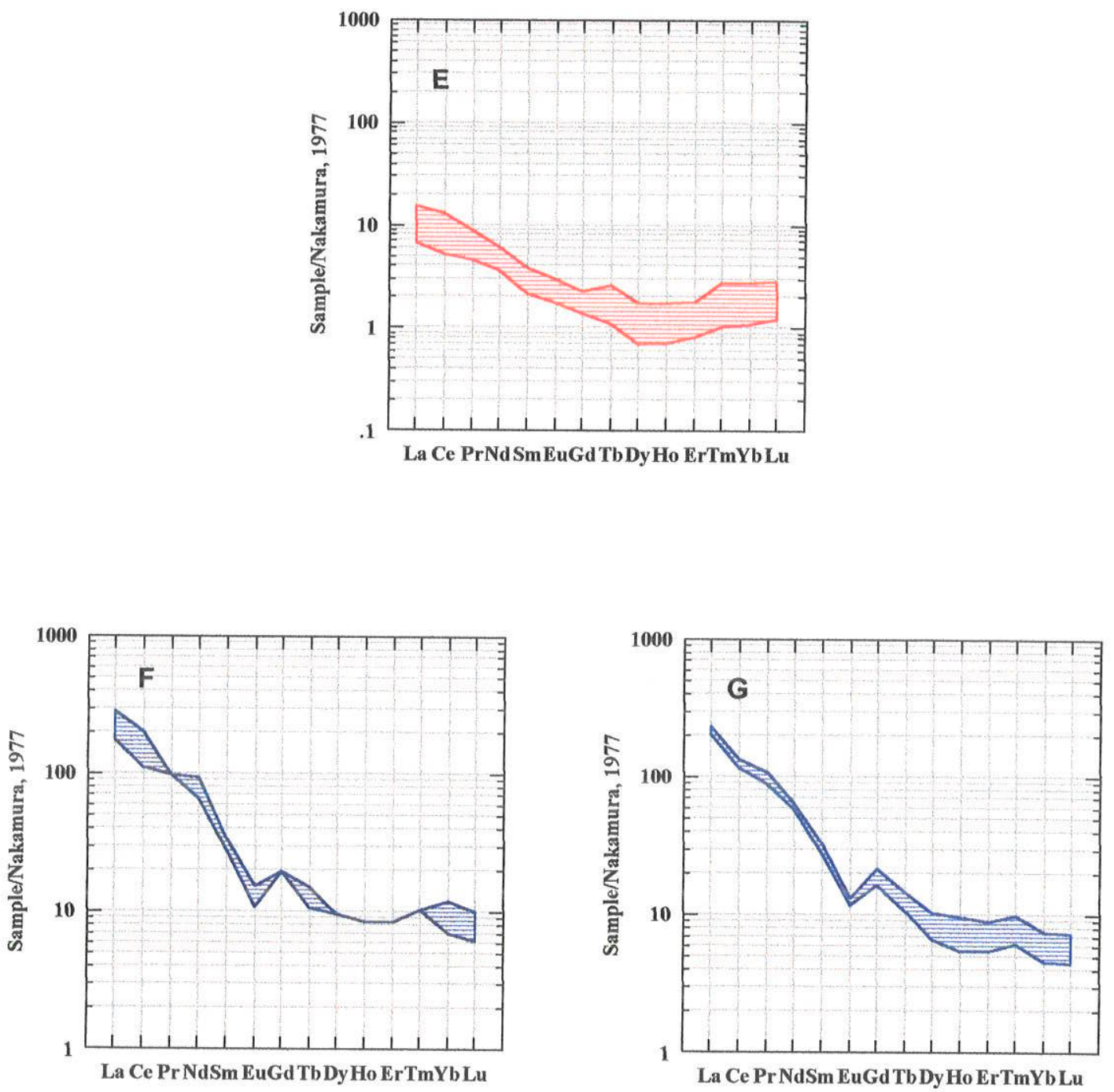

Figura 5.11 - Diagramas de elementos terras raras para as rochas dos Granitos GP, GRN, GAS e GT. Normalização ao condrito (Nakamura 1974). A) Monzogabros dos Granitos GP e GRN. B) Rochas Graníticas Híbridas Máficas e Félsicas (GP+GRN). C) Monzo-sienogranitos do GP e GRN. D) Quartzo Monzonitos - Quartzo Sienitos do GP. E) Leucogranodioritos do GAS. F) Monzogranitos do GT (SiO 72 $73 \%)$. G) Monzogranitos da SGPM $\left(\mathrm{SiO}_{2} \mathbf{7 2 - 7 3 \% )}\right.$. 


\begin{tabular}{|l}
\hline Monzogabros (GRN) \\
$\square$ Monzogabros (GP) \\
- Monzos Graníticas Híbridas máficas e félsicas (GP, GRN) \\
$\square$ Leucogranodioritos (GAS) \\
$\square$ Quartzo Monzonitos/Quartzo Sienitos (GP) \\
$\square$ Monzogranitos (GT) \\
Monzogranitos (SGPM) \\
Quartzo Monzodioritos, Granodioritos e Leucogranodioritos \\
com e sem epidoto magmático (SGPM)
\end{tabular}
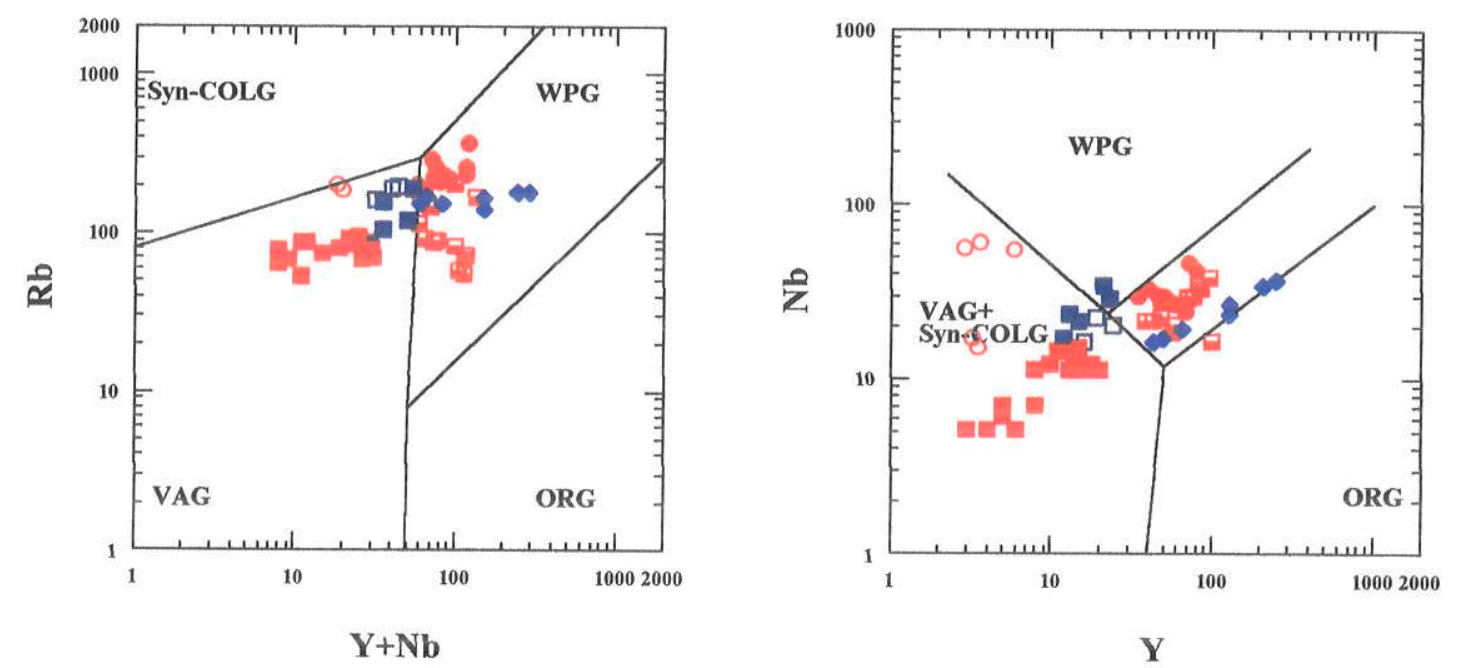

Figura 5.12 - Diagramas Rb X Y+Nb e Nb X Y (Fonte : Pearce et al. 1984 e Harris et al. 1988) discriminantes dos principais ambientes geotectônicos produtores de rochas graníticas, aplicado para as rochas graníticas dos Granitos GP, GAS, GRN, GT e a SGPM.

Granitos de fusóes supracrustais = granitos sin-colisionais, tipo S (Chappel e White 1974) incluindo os tardi e pós colisionais (tipo S) e os de ambientes extensionais formados por fusões supracrustais ou por alta assimilação e/ou contaminação crustal.

$W P G=$ Granitos Intraplaca, típicos granitos tipo A (Chappel e White 1974) ou PA (peralcalinos), póstectônicos/pôs-orogênicos e anorogênicos.

VAG = Granitos calcio alcalinos de baixo, médio e alto $\mathrm{K}$ de arcos magmáticos de margens continentais ativas, tipo I (Chappel e White 1974) incluindo os tardi a pós tectônicos/pós orogênicos associados e influenciados pela mesma fonte (componente mantélica e crustal) em zonas de subducção.

ORG = hipotéticos Granitos formados em cadeias Médio-Oceânicas, plagiogranitos, tipo M (Chappel e White 1974). 


\section{4 - Geocronologia}

Nesta seção, são apresentados os resultados das análises geocronológicas e isotópica de $\mathrm{U}-\mathrm{Pb}$ em zircões, K-Ar em biotita e anfibólio, nos principais litotipos do Granito Palermo (GP), Granito Rio Negro (GRN), Granito Agudos (GAS) e Granito Tarumã (GT).

A metodologia U-Pb em zircões foi aplicada em anfibólio-biotita monzo-sienogranito do GP, biotita \pm anfibólio monzo-sienogranito do GRN e biotita-monzogabro do GRN, sendo os resultados apresentados nas Tabelas 5.1, 5.2 e 5.3. Ainda não foram concluídas as análises isotópicas U-Pb em zircões de quartzo-monzonito-quartzo-sienito, fracamente, peralcalino do GP, monzogabro do GP e biotita-monzo-sienogranito de granulação fina a média da porção central do GP.

A metodologia K-Ar foi aplicada em biotita e anfibólio dos monzo-sienogranitos do GP e do GRN, em biotita dos monzogranitos do GT e em biotita dos monzogabros do GP e GRN. Somente os resultados K-Ar concluidos são apresentados na Tabela 5.4.

A metodologia $\mathrm{Sm}-\mathrm{Nd}$ em rocha total, a análise das razões $S r^{87} / \mathrm{Sr}^{86}$ e $\mathrm{O}^{19}$ (zircão) são aplicada nos principais litotipos do GP, GRN, GAS e GT, sendo os resultados apresentados e discutidos no Capítulo 9.0, referente à Geologia Isotópica.

Os resultados isotópicos U.Pb (Tabelas 5.1 e 5.2) em zircões dos monzosienogranitos do GP e GRN revelaram, em diagramas concórdia U-Pb (Figuras 5.13 e 5.14), idades do intercepto superior de $593 \pm 12( \pm 13) \mathrm{Ma}$ para os anfibólio-biotita monzosienogranitos do GP e 593,1 \pm 6,3 Ma para os biotita-monzo-sienogranitos do GRN. Estas idades U-Pb em zircões ao redor de $593 \mathrm{Ma}$ correspondem à formação/cristalização dos monzo-sienogranitos do GP e do GRN em geral. 
Tabela 5.1 - Análises isotópicas U-Pb em zircões de anfibólio-biotita monzo-sienogranito do GP

\begin{tabular}{|c|c|c|c|c|c|c|c|c|c|c|c|c|c|c|}
\hline Amostra e Fraçōes & $\mathrm{Pb}^{269} / \mathrm{U}^{253}$ & Erro & $\mathrm{Pb}^{206} \mathrm{~N}^{238^{2}}$ & Erro & Rho & $\mathrm{Pb}^{209} / \mathrm{Pb}^{206}$ & Erro & $\mathrm{Pb}^{206} / \mathrm{Pb}^{204^{2 *}}$ & $\begin{array}{l}U \\
\text { (ppm) }\end{array}$ & $\begin{array}{l}\mathrm{Pb} \\
\text { (ppm) }\end{array}$ & $\begin{array}{l}\text { Peso } \\
(\mu \mathrm{g})\end{array}$ & $\begin{array}{l}\text { Idade (Ma) } \\
\mathrm{Pb}^{207} \mathrm{U} t^{206}\end{array}$ & $\begin{array}{l}\text { Idade (Ma) } \\
\mathrm{Pb}^{207} / \mathrm{U}^{235}\end{array}$ & $\begin{array}{l}\text { Idade (Ma) } \\
\mathrm{Pb}^{206} / \mathrm{U}^{239}\end{array}$ \\
\hline SPU777 / OM 691(M-4) & 0.747651 & 1.06 & 0.0897471 & 0.805 & 0.76095 & 0.0604195 & 0.688 & 1022.053 & 87.537 & 9.2843 & 96 & 618 & 567 & 554 \\
\hline SPU $1046 / O M 691 M(-4) 2$ & 0.601221 & 1.25 & 0.0743954 & 1.05 & 0.84655 & 0.058612 & 0.664 & 267.3695 & 187.43 & 18.069 & 85 & 553 & 478 & 462 \\
\hline SPU775 / OM 691(M-3) & 0.561414 & 1.27 & 0.0687881 & 1.25 & 0.985851 & 0.0591928 & 0.213 & 842.0122 & 1567.8 & 127.16 & 109 & 574 & 452 & 429 \\
\hline SPU 1048 / OM $691 \mathrm{M}(-2)$ & 0.565258 & 0.678 & 0.069093 & 0.637 & 0.940356 & 0.0593349 & 0.231 & 643.8286 & 637.56 & 53.525 & 74 & 579 & 455 & 431 \\
\hline MJ 132*-OM 691 (M5) & 0.37365 & 0.909 & 0.04622 & 0.904 & 0.9956 & & & 618.0607 & 1503.4 & 84.876 & 140 & 553 & & \\
\hline MJ 132*-OM 691 (M3) & 0.41563 & 0.912 & 0.05133 & 0.905 & 0.9936 & & & 740.686 & 1142 & 69.281 & 265 & 557 & & \\
\hline MJ 132*-OM 691 (M2) & 0.4748 & 0.91 & 0.05825 & 0.904 & 0.9947 & & & 838.223 & 1094.6 & 74.397 & 225 & 572 & & \\
\hline MJ 132*-OM 691 (M1) & 0.52572 & 0.909 & 0.06441 & 0.904 & 0.9946 & & & 979.8553 & 629.63 & 50.403 & 165 & 574 & & \\
\hline MJ 132**-OM 691 (M3) 2 & 0.391763 & 0.764 & 0.0480651 & 0.717 & 0.939638 & 0.0591142 & 0.261 & 1109.455 & 901.55 & 48.954 & 132 & 571 & 336 & 303 \\
\hline MJ 132**-OM 691 (MS) 2 & 0.329851 & 0.895 & 0.040699 & 0.848 & 0.947802 & 0.0587805 & 0.286 & 875.2582 & 1201.6 & 56.419 & 102 & 559 & 290 & 257 \\
\hline
\end{tabular}

*Dados retirados de Siga Jr. 1995. * dados inéditos da mesma amostra.

Tabela 5.2 - Análises isotópicas U-Pb em zircões de biotita-monzo-sienogranito do GRN

\begin{tabular}{|c|c|c|c|c|c|c|c|c|c|c|c|c|c|c|}
\hline Amostra e Fraçöes & $\mathrm{Pb}^{208} / \mathrm{U}^{235}$ & Erro & $\mathrm{Pb}^{206} / \mathrm{U}^{238}$ & Erro & Rho & $\mathrm{Pb}^{20 /} / \mathrm{Pb}^{206}$ & Erro & $\mathrm{Pb}^{266} / \mathrm{Pb}^{264}$ & $\mathrm{U}(\mathrm{ppm})$ & $\begin{array}{l}\mathrm{Pb} \\
(\mathrm{ppm})\end{array}$ & $\begin{array}{l}\text { Peso } \\
(\mu g)\end{array}$ & $\begin{array}{l}\text { Idade (Ma) } \\
\mathrm{Pb}^{207} \mathrm{U}^{206}\end{array}$ & $\begin{array}{l}\text { Idade (Ma) } \\
\mathrm{Pb}^{207} / \mathrm{U}^{235}\end{array}$ & $\begin{array}{l}\text { Idade (Ma) } \\
\mathrm{Pb}^{206} / \mathrm{U}^{238}\end{array}$ \\
\hline SPU772/ OM 589 (M-5) & 0.712505 & 1.04 & 0.0867072 & 0.953 & 0.915212 & 0.0595979 & 0.421 & 592.605 & 193.06 & 19.115 & 71 & 589 & 546 & 536 \\
\hline SPU771 / OM $589(M-4)$ & 0.673747 & 1.74 & 0.0813531 & 1.63 & 0.941629 & 0.060065 & 0.584 & 608.6139 & 400.59 & 37.94 & 88 & 606 & 523 & 504 \\
\hline SPU770 / OM 589 (M-3) & 0.70414 & 1.55 & 0.0864663 & 1.17 & 0.76653 & 0.0590623 & 0.997 & 463.3657 & 261.32 & 26.729 & 81 & 569 & 541 & 534 \\
\hline SPU773/OM 589 (M 4) & 0.547132 & 1.23 & 0.0665943 & 1.09 & 0.88744 & 0.0595873 & 0.567 & 306.5765 & 214.54 & 18.308 & 177 & 589 & 443 & 416 \\
\hline
\end{tabular}



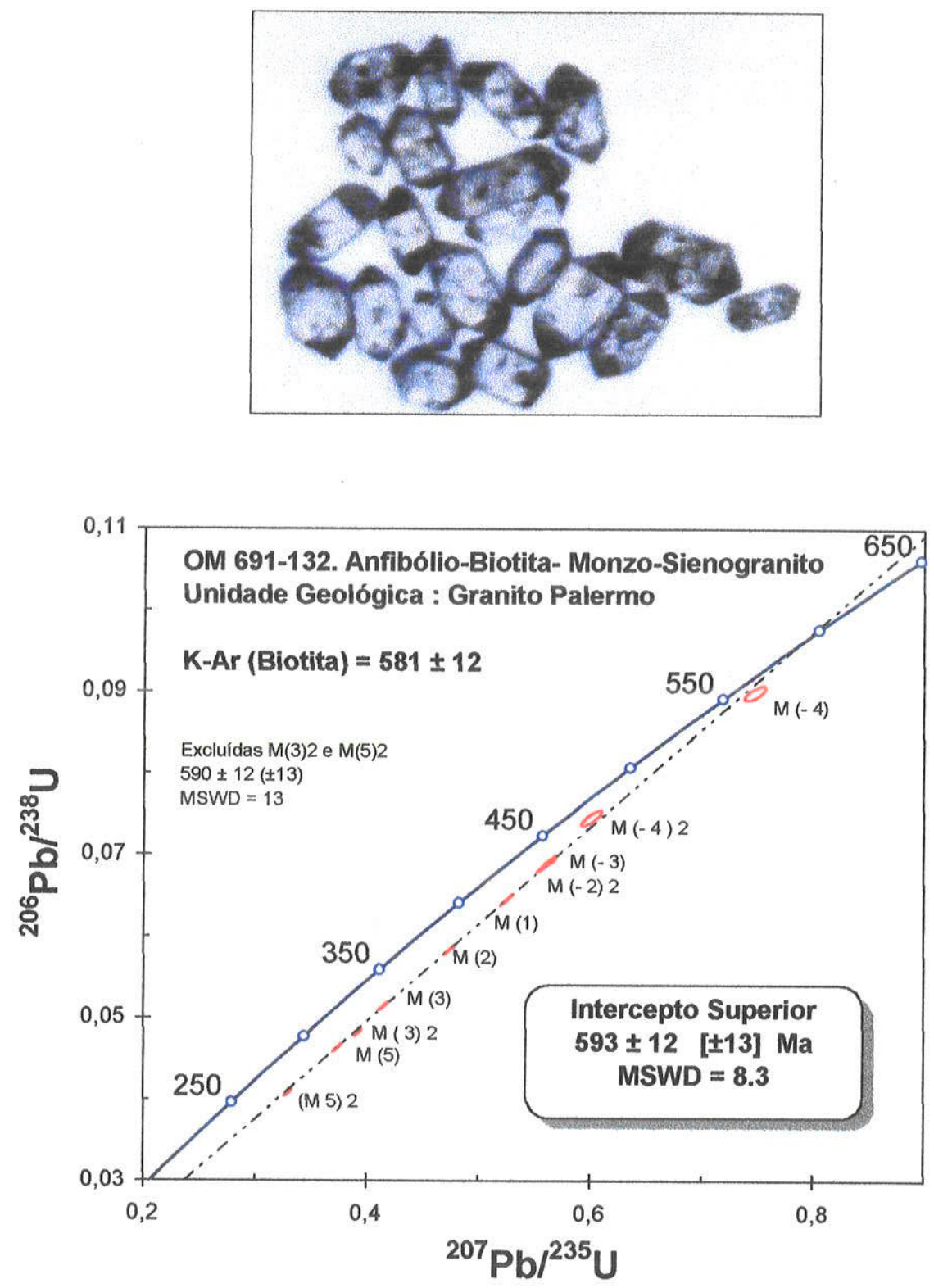

Figura 5.13- Diagrama Concórdia U-Pb para os zircões dos anfibólio-biotita monzo-sienogranito do GP. 

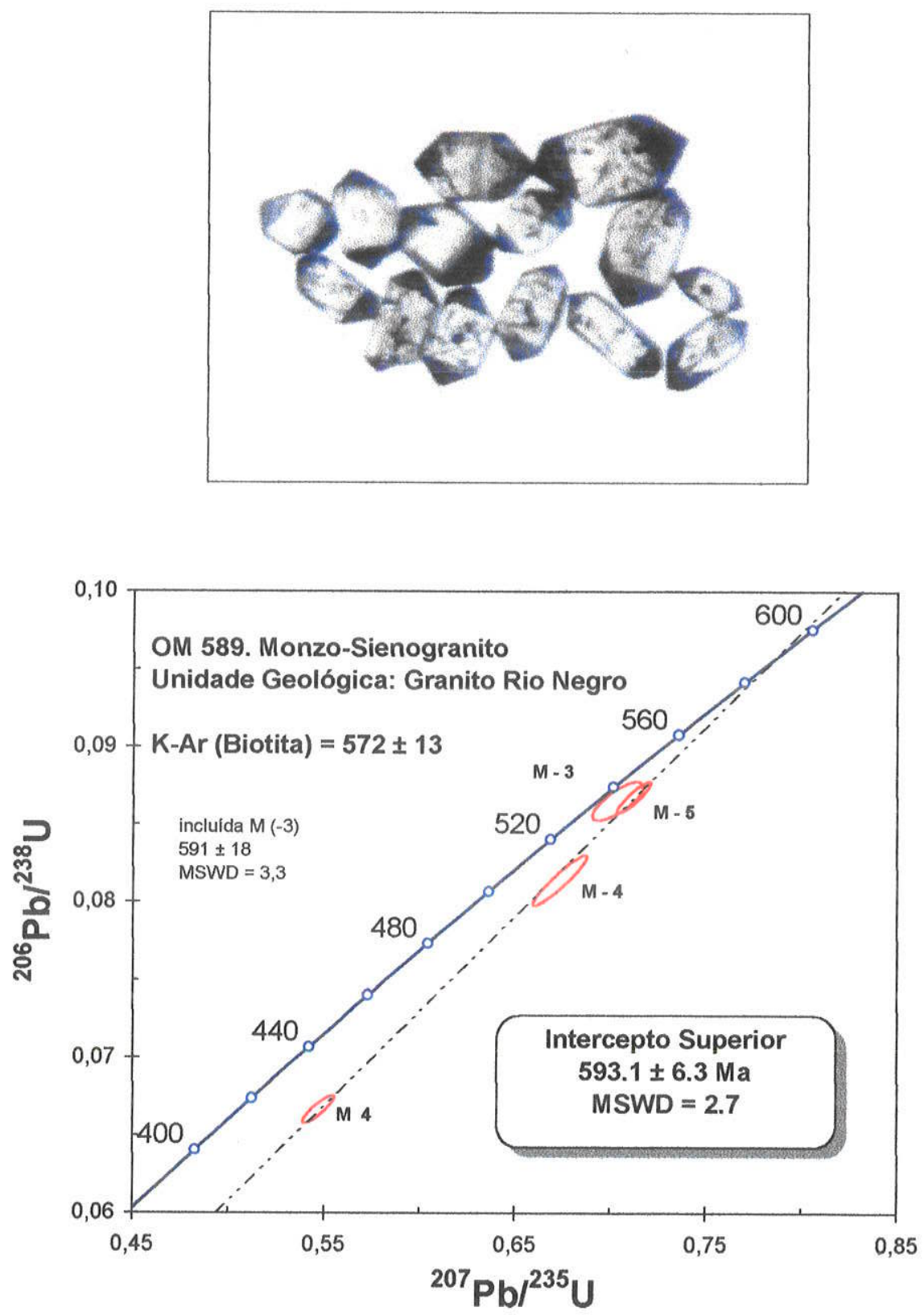

Figura 5.14- Diagrama Concórdia U-Pb para os zircões dos biotita monzo-sienogranitos do GRN.

As idades K-Ar em biotita (Tabela 5.3), das mesmas rochas datadas pela metodologia U-Pb, sugerem um resfriamento inicial em cerca de $581 \pm 12 \mathrm{Ma}$ para os anfibólio-biotita monzo-sienogranitos do GP ( $\pm 10 \mathrm{Ma}$ após a cristalização) e tardio, ao redor de $572 \pm 13 \mathrm{Ma}$, dos biotita-monzo-sienogranitos do GRN ( $\pm 20 \mathrm{Ma}$ após a cristalização). A idade $\mathrm{K}$-Ar de $574 \pm 17 \mathrm{Ma}$ em biotita dos monzogranitos do GT sugere que o resfriamento destas rochas ocorreu anterior (?) ou simultaneamente aos monzo-sienogranitos do GRN (572 \pm 13 Ma). A invasão e incorporação das rochas gabróicas, graníticas híbridas máficas e félsicas e monzo-sienogranitos do GRN resultou, provavelmente, em rejuvenescimento das idades K-Ar em biotita do GT à valores similares aos monzo-sienogranitos do GRN. 
Tabela 5.3 - Análises isotópicas e idades K-Ar (biotita) do litotipos do GP, GRN e GT.

\begin{tabular}{|c|c|c|c|c|c|c|}
\hline Amostra & Rocha/Unidade & Mineral & $K(\%)$ & $\mathrm{Ar}^{\circ} \operatorname{Rad} 10^{-6}$ & $\% A r^{40}$ atm & Idade (M.a) \\
\hline OM 691 & Monzo-Sienogranito/GP & Biotita & 6.4339 & 171.36 & 2.68 & $581 \pm 13$ \\
\hline OM 589 & Monzo-Sienogranito/GRN & Biotita & 6.8020 & 177.82 & 5.15 & $572 \pm 13$ \\
\hline OM 473 & Biotita-Monzogabro/GRN & Biotita & 6.9894 & 189.24 & 3.15 & $589 \pm 16$ \\
\hline OM 504 & Monzogranito/GT & Biotita & 5.6646 & 148.74 & 4.20 & $574 \pm 17$ \\
\hline
\end{tabular}

A comparação entre as idades U-Pb em zircões e titanitas ( 618 - $596 \mathrm{Ma}$ ) e K-Ar em biotitas (607-595 Ma) dos componentes graniticos da SGPM e as idades U-Pb em zircões ( $593 \mathrm{Ma}$ ) dos monzo-sienogranitos do GP e GRN indica a formação/cristalização destes últimos logo após a formação, deformação, resfriamento e estabilização tectônica da SGPM.

Ao contrário dos zircões dos monzo-sienogranitos do GP e do GRN, os cristais de zircão dos monzogabros do GP e GRN, observados em lâmina e lupa são, normalmente, prismáticos, incompletos e, principalmente, corroidos e anédricos, com diversas formas indefinidas, diversos tamanhos e ricos em inclusões minerais. Cristais anédricos, prismáticos, bipiramidais são raros. Estas formas cristalinas são típicas de cristalização tardia com resfriamento muito rápido. Quando da seleção destes cristais para a datação U. $\mathrm{Pb}$ escolhemos os cristais mais euhédricos possiveis com a menor quantidade de inclusões.

Os resultados isotópicos U-Pb (Tabela 5.4) obtidos em zircões de um biotitamonzogabro do GRN indicaram, em diagrama concórdia (Figura 5.15), idade do intercepto superior de $584+7,2 /-7,1 \mathrm{Ma}$. $A$ inclusão da fração $(M-4)$ neste cálculo resulta num valor de $580 \pm 17( \pm 18)$ Ma. Estas idades são inferiores à idade K-Ar em biotita de $589 \pm 16 \mathrm{Ma}$ (Tabela 5.3), obtida na mesma rocha, com diferenças da ordem de 5 a $10 \mathrm{Ma}$. Mesmo com a grande diferença existente entre a alta temperatura de difusão do $\mathrm{Pb}$ em zircão e a baixa temperatura de difusão do Ar em biotita, a superposição de idades U-Pb em zircão e K-Ar em biotita e até anfibólio é relativamente comum em rochas igneas, cujas histórias envolvem cristalização tardia e resfriamento rápido dos zircões. Considera-se, portanto, que a idade $\mathrm{U}-\mathrm{Pb}$ em zircão ao redor de $585 \mathrm{Ma}$ corresponda à formação/cristalização e resfriamento dos monzogabros do GP, após a mistura com os monzo-sienogranitos do GP e do GRN e a formação das rochas graniticas hibridas máficas e félsicas. 
Tabela 5.4 - Análises isotópicas U-Pb em zircões de biotita-monzogabro do GRN

\begin{tabular}{|c|c|c|c|c|c|c|c|c|c|c|c|c|c|c|}
\hline Amostra e Fraçöes & $\mathrm{Pb}^{201} / \mathrm{U}^{235}$ & Erro & $\mathrm{Pb}^{206} / \mathrm{U}^{238}$ & Erro & Rho & $\mathrm{Pb}^{201} / \mathrm{Pb}^{266}$ & Erro & $\mathrm{Pb}^{26} / \mathrm{Pb}^{204}$ & $\mathrm{U}(\mathrm{ppm})$ & $\begin{array}{l}\mathrm{Pb} \\
\text { (ppm) }\end{array}$ & $\begin{array}{l}\text { Peso } \\
(\mu \mathrm{g})\end{array}$ & $\begin{array}{l}\text { ldade (Ma) } \\
\mathrm{Pb}^{207} \mathrm{U}^{206}\end{array}$ & $\begin{array}{l}\text { Idade (Ma) } \\
\mathrm{Pb}^{207} / \mathrm{U}^{235}\end{array}$ & $\begin{array}{l}\text { Idade (Ma) } \\
\mathrm{Pb}^{206} / \mathrm{U}^{238}\end{array}$ \\
\hline SPU787/OM $473(M-2)$ & 0.75084 & 1.22 & 0.0914995 & 1.13 & 0.92346 & 0.0595151 & 0.468 & 699.6663 & 170.35 & 23.97 & 104 & 586 & 569 & 564 \\
\hline SPU 766/OM $473(M-5)$ & 0.756711 & 0.967 & 0.0923854 & 0.843 & 0.88621 & 0.0594053 & 0.448 & 815.6808 & 413.1 & 56.546 & 99 & 582 & 572 & 570 \\
\hline SPU 1052/OM $473(M-4)$ & 0.674326 & 1.2 & 0.083102 & 1.1 & 0.922315 & 0.0588514 & 0.465 & 465.359 & 171.98 & 21.443 & 104 & 562 & 523 & 515 \\
\hline SPU1051/OM $473(M-3)$ & 0.623492 & 1.16 & 0.0760977 & 1.07 & 0.926446 & 0.0594234 & 0.438 & 839.0743 & 188.03 & 20.806 & 81.46 & 583 & 492 & 473 \\
\hline
\end{tabular}



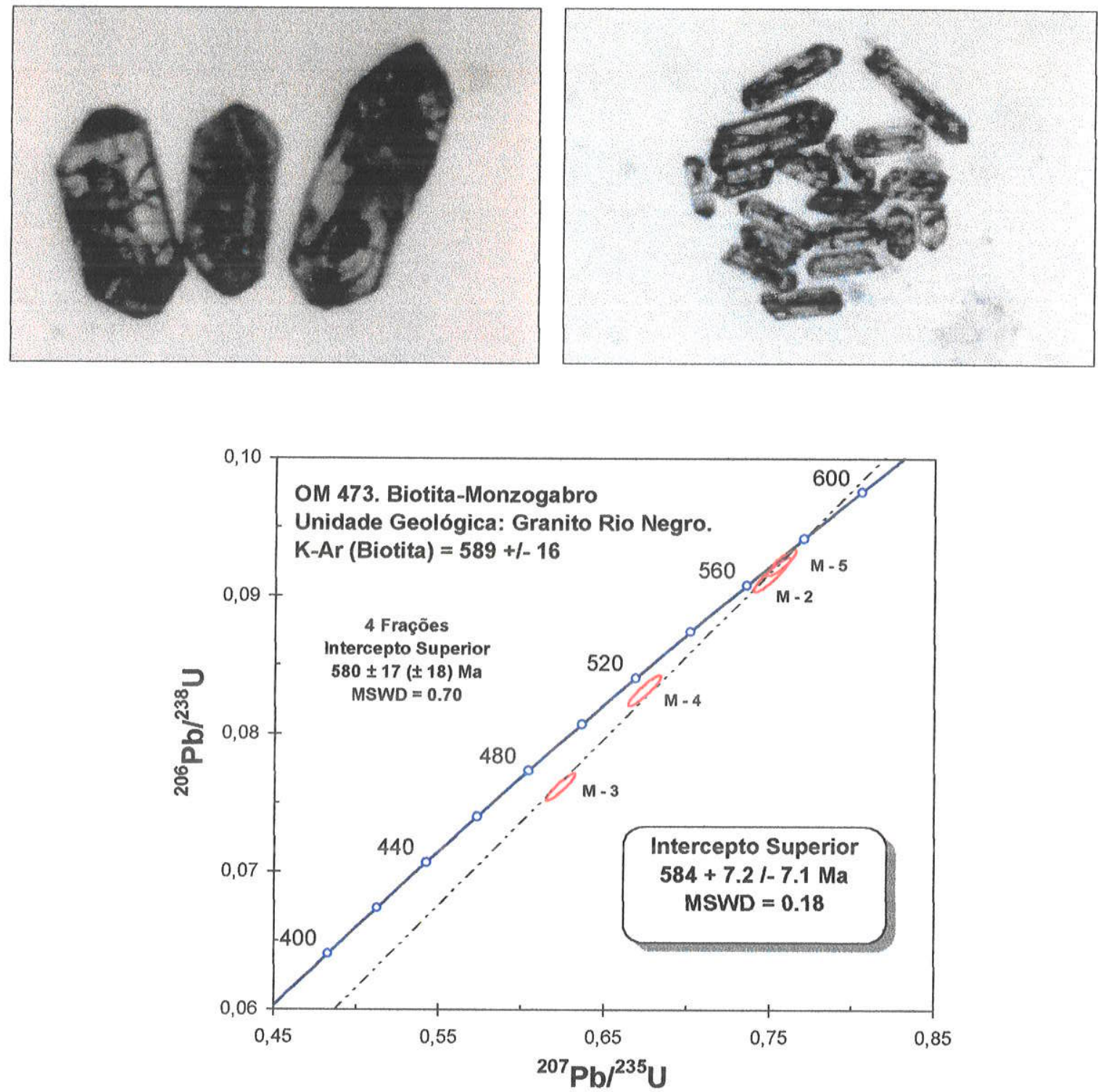

Figura 5.15 - Diagrama Concórdia U-Pb para os zircões dos monzogabros do GRN.

As idades U-Pb em zircão e K-Ar em biotita dos monzogabros do GRN, monzogranitos do GT e monzo-sienogranitos do GP e GRN indicam que a formação/cristalização e resfriamento dos primeiros ocorreu ao redor de $585 \mathrm{Ma}$, aproximadamente $10 \mathrm{Ma}$ após a formação/cristalização dos monzo-sienogranitos do GP e do GRN ( $593 \mathrm{Ma}$ ). A seqüência de resfriamento para estas rochas é: monzogabros do GRN ( $585 \mathrm{Ma})$, anfibólio-biotita monzo-sienogranitos do GP (581 $\pm 13 \mathrm{Ma})$, monzogranitos do GT (574 $\pm 17 \mathrm{Ma})$ e monzo-sienogranitos do GRN (572 $\pm 13 \mathrm{Ma})$. 
Nesta investigação geocronológica a metodologia $\mathrm{Rb}-\mathrm{Sr}$ (rocha total) não foi aplicada aos litotipos graníticos do GP, GRN, GAS e GT, sendo preterida a favor de U-Pb em zircões devido ao alto poder de resolução deste último. Além disto dados anteriores (ver Kaul 1997) demostraram incertezas na obtenção de valores $\mathrm{Rb}-\mathrm{Sr}$ confiáveis que indicassem, claramente, a idade de formação destas rochas. Estas incertezas devem-se principalmente à aplicação desta metodologia em rochas graníticas de alto $\mathrm{Rb}$ e baixo ou muito $\mathrm{Sr}$, como é o caso dos leucogranodioritos do GAS, dos monzo-sienogranitos do GP e GRN e da ampla maioria das rochas da Suite Granítica Serra do Mar. Com exceção dos leucogranodioritos do GAS ( $R b=160$ a 200 ppm e Sr 150 a 300 ppm) e os monzogranitos do $G T(R b=160$ a $200 \mathrm{ppm}$ e $\mathrm{Sr}=200$ a $400 \mathrm{ppm})$, a maioria dos monzo-sienogranitos do GP e o GRN $\left(\mathrm{SiO}_{2}\right.$ entre 70 e $80 \%$ ) apresentam conteúdo de $\mathrm{Rb}$ entre 200 e $300 \mathrm{ppm}$ (raramente > $300 \mathrm{ppm}$ ) e $\mathrm{Sr} \leq 100 \mathrm{ppm}$. Além disso, a aplicação da metodologia $\mathrm{Rb}-\mathrm{Sr}$ em rocha total, necessita de mapeamento detalhado dos principais componentes graníticos cogenéticos destas unidades.

A idade isocrônica $\mathrm{Rb}-\mathrm{Sr}$ (rocha total) de $570 \pm 22 \mathrm{Ma}\left(\mathrm{Sr}^{87} / \mathrm{Sr}^{86(i)}=0,7073\right)$ apresentada por Siga Jr. (1995) é interpretada como representativa do periodo de formação do Maciço Granítico Agudos do Sul. Esta isócrona é constituída por rochas da SGPM (baixo $\mathrm{Rb}$ e alto $\mathrm{Sr}$ ) e por rochas do GAS (com alto $\mathrm{Rb}$ e baixo $\mathrm{Sr}$ ). Considerando-se apenas as análises referentes ao GAS, obteve-se por recálculo, uma isócrona de afloramento com idade de $570 \pm 42 \mathrm{Ma}$ e razão inicial $\mathrm{Sr}^{87} / \mathrm{Sr}^{86(i)}$ de 0.7074 (Figura 5.16) similar à obtida pelo referido autor. O recálculo para os valores obtidos em rochas graníticas do GP e do GAS por Siga Jr. (1995) e Kaul (1997), com ou sem as rochas com altas razões $\mathrm{Rb}^{87} / \mathrm{Sr}^{86}(>40)$, forneceu duas isócronas (Figura 5.17) com idades de $561 \pm 10$ e razão inicial $\mathrm{Sr}^{87} / \mathrm{Sr}^{86(i)} \mathrm{de}$ 0,70766 e $561 \pm 13 \mathrm{Ma}$ e razão inicial $\mathrm{Sr}^{87} / \mathrm{Sr}^{86(i)}$ de 0,70767 , respectivamente. As rochas do GAS apresentam, entre todas as rochas graniticas consideradas as mais baixas razões $\mathrm{Rb}^{87} / \mathrm{Sr}^{86}$ (entre 2 e 5) e não forçam a definição da razão inicial $\mathrm{Sr}^{87} / \mathrm{Sr}^{86(i)}$ que, em todas as isócronas recalculadas, está sempre entre 0,70740 e 0,70767.

Estas idades Rb-Sr entre 570 e 560 Ma são próximas das idades K-Ar em biotita dos monzo-sienogranitos do GRN, devendo representar a idade do resfriamento dos componentes graníticos destas unidades. Qualquer distúrbio envolvendo rejuvenescimento isotópico no sistema $\mathrm{Rb}-\mathrm{Sr}$ deve ocorrer entre a cristalização e o resfriamento destas rochas. 


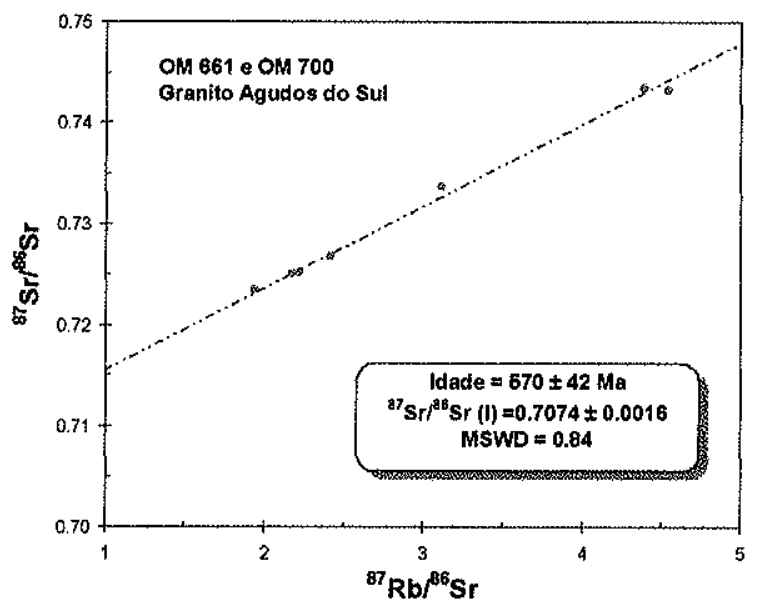

Figura 5.16- Diagrama isocrónico $\mathrm{Rb}^{87} / \mathrm{Sr}^{86} \times \mathrm{Sr}^{87} / \mathrm{Sr}^{86}$ (rocha total) para as rochas graníticas do GAS. Dados retirados de (Siga Jr. 1995) e recalculados.

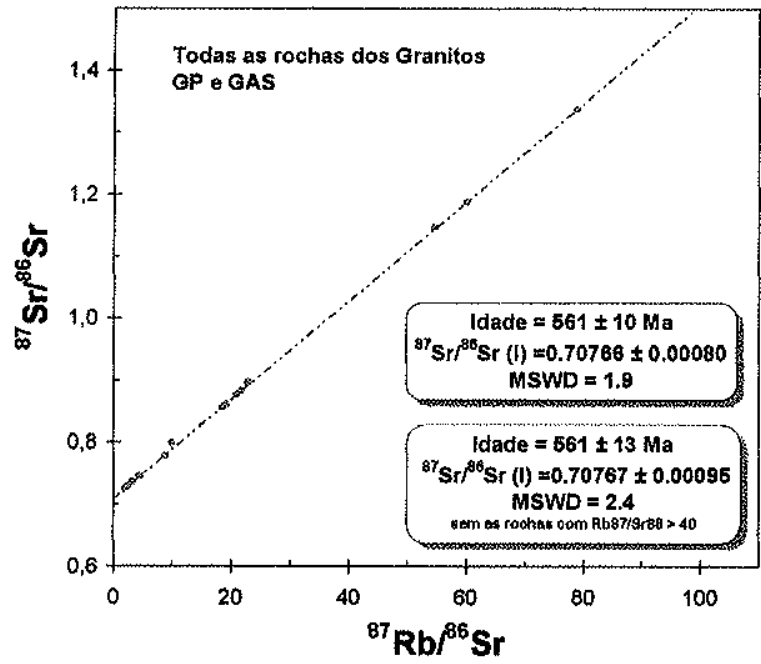

Figura 5.17 - Diagrama isocrónico $\mathrm{Rb}^{87} / \mathrm{Sr}^{86} \times \mathrm{Sr}^{87} / \mathrm{Sr}^{86}$ (rocha total) para as rochas graníticas do GP, GAS e GRN. Numero das análises Rb-Sr $=17$. Dados retirados de (Siga Jr. 1995 e Kaul 1997) e recalculados. 


\section{0 - Suite Granitica Piên - Mandirituba (SGPM)}

\section{1 - Introdução}

A SGPM é um terreno granítico deformado constituido por três grupos de rochas graníticas não cogenéticas entre si e dentro de cada grupo as rochas são cogenéticas. Estes três grupos são (Figura 6.1): rochas graniticas sem epídoto magmático (quartzo monzodioritos, quartzo monzodioritos/granodioritos e granodioritos, protomiloníticos a miloniticos), rochas graníticas com epídoto magmático (quartzo monzodioritos, quartzo monzodioritos/granodioritos, granodioritos e leucogranodioritos protomiloníticos a miloníticos) e, monzogranitos (protomiloníticos a miloníticos e sem epídoto magmático). Ocorrem ainda anfibolitos, denominados de anfibolito Espigão das Antas, associados com as rochas graniticas sem epidoto magmático. As rochas graníticas com epidoto magmático ocorrem na porção sudeste e central da SGPM e as rochas graníticas sem epídoto magmático e os monzogranitos ocorrem preferencialmente na porção noroeste da SGPM.

Este terreno granítico aflora desde a região de Piên-PR até os arredores da região de Mandirituba-PR, numa faixa N40-60E com largura máxima de $30 \mathrm{Km}$. Os contatos tectônicos da SGPM com o CGMA, ao norte, e com o TGAG, ao sul, são definidos respectivamente pelas zonas de cisalhamento Mandirituba-Piraquara e Piên-Tijucas (ZCPT). Ao longo da ZCPT, que representa o contato tectônico da SGPM com o TGAG, ocorre a SMUP.

Os dados petrográficos, químicos, geocronológicos e isotópicos indicam claramente a existência dentro da SGPM de três grupos principais de rochas graníticas sendo que as rochas com e sem epídoto magmático apresentam semelhantes composições graníticas (Figura 6.1). Por motivos estruturais (distintas rochas graniticas deformadas na mesma direção) e para facilitar apresentação e a compreensão dos resultados, estas rochas, mesmo sendo bem descriminados no mapa, foram agrupados segundo a mesma denominação (SGPM), devendo no futuro ser, obrigatoriamente, separadas nos três grupos mencionados.

Os componentes graníticos da SGPM em geral apresentam freqüentemente megacristais de K-feldspato, plagioclásio, além de proporções variadas de anfibólio e biotita, com ou não epídoto magmático, dependendo do grupo de rochas. As rochas graniticas sem epídoto magmático apresentam geralmente maior volume de máficos (biotita e anfibólio). Os principais minerais acessórios presentes nas rochas em geral são, titanita, apatita, allanita, zircão e opacos (magnetita). Estes minerais acessórios são mais freqüentes e evidentes nas 
rochas graníticas (quartzo monzodioritos a granodioritos) sem epídoto magmático e nos monzogranitos. As rochas da SGPM exibem coloração cinzenta e/ou rósea e granulação média a grossa, raramente muito grossa, variando de acordo com o local de ocorrência dentro desta unidade geológica, entre não a pouco deformadas (protomiloníticas) a miloníticas e até ultramiloníticas (nomenclatura de rochas miloníticas de Sibson 1977). A foliação é em geral bem desenvolvida, com direção modal predominante N50E/69NW, caracterizada pelo estiramento e orientação de K-feldspatos, plagioclásio e quartzo, além de estiramento e orientação de biotita, anfibólio e epídoto magmático. Esta foliação é bem mais desenvolvida nas rochas graníticas sem epídoto magmático e nos monzogranitos. Independentemente do litotipo componente da SGPM, as rochas graníticas com e sem epídoto magmático, monzogranitos e os anfibolitos apresentam geralmente foliações paralelas.

As rochas graniticas com epídoto magmático apresentam uma "zonalidade normal", destruída principalmente pela forte deformação imposta à SGPM. Esta zonalidade é definida pelo predomínio dos quartzo monzodioritos/granodioritos e granodioritos nas margens e leucogranodioritos na região central.

Não foram encontradas, em nenhum local dos afloramentos, quaisquer tipos de rochas graníticas híbridas com texturas indicativas de misturas de magmas, tais como identificadas no GRN e o GP.

Dentro dos quartzo monzodioritos com epidoto magmático ocorrem, raramente, rochas máficas com textura cumulática (autólitos, "cumulate mafic enclaves" ou "disrupted cumulate" na definição de Didier \& Barbarin 1991). Estas são constituídas por cristais euhédricos de anfibólio (prismas de $1 \mathrm{~cm}$ de comprimento por 0,5 de largura) \pm plagioclásio \pm biotita e \pm epidoto, com granulação semelhante ou pouco superior à da hornblenda e biotita dos hóspedes quartzo-monzodioríticos. Estas rochas representam fases cumuláticas de minerais do início da seqüência da cristalização dos quartzo monzodioritos com epídoto magmático, como a hornblenda e o plagioclásio.

Veios com concentração de megacristais de K-feldspato ocorrem associados aos quartzo monzodioritos/granodioritos com epídoto magmático.

Enclaves tipo "xenolith" (na definição de Didier \& Barbarin 1991) ocorrem por vezes, nas rochas graníticas com epidoto magmático, tais como lentes de serpentinitos, xistos magnesianos e gnaisses anfibolíticos. Ocorrem ainda diques riolíticos com textura microporfirítica a afanítica alojados na direção N30W dentro dos componentes graníticos da SGPM. Estes diques félsicos apresentam assinatura química similar à dos monzosienogranitos do GP e do GRN. 


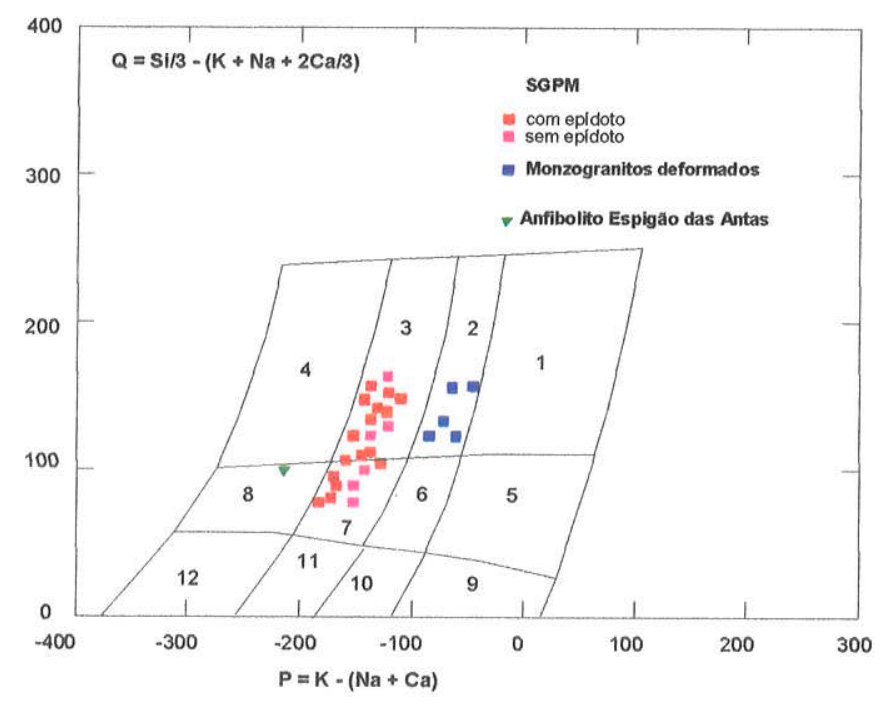

Figura 6.1 - Diagrama P-Q (Debon \&. Lefort 1983) indicando a composição dos principais componentes graníticos da SGPM.

1- Granitos, 2- Monzogranitos, 3- Granodioritos, 4- Tonalitos, 5- Quartzo-Sienitos, 6- Quartzo Monzonitos, 7 Quartzo Monzodioritos, 8- Quartzo Dioritos, 9- Sienitos, 10- Monzonitos, 11- Monzodioritos/Monzogabros, 12 Dioritos/Gabros. O diagrama sugere que as rochas graníticas sem epídoto magmático são mais potássicas do que as rochas graníticas com epídoto magmático.

\section{2 - Os Principais Componentes Graníticos}

A SGPM é constituida por três grupos graníticos principais: rochas graníticas sem epídoto magmático (quartzo monzodioritos, quartzo monzodioritos/granodioritos e granodioritos ricos em biotita e anfibólio e sem epídoto magmático) com anfibolitos (dioritos/quartzo-dioritos) associados, monzogranitos com anfibólio \pm biotita e, rochas graníticas com epídoto magmático (quartzo monzodioritos, quartzo monzodioritos/granodioritos e leucogranodioritos com biotita, anfibólio e epídoto magmático). As rochas da SGPM em geral são raramente não ou pouco deformadas e geralmente deformadas, protomiloníticas a miloníticas e até ultramiloníticas.

A seguir são descritas as principais características petrográficas dos componentes graníticos da SGPM.

\subsection{1 - Anfibolito Espigão das Antas (Dioritos/Quartzo-Dioritos):}

Estes anfibolitos ocorrem na porção norte da SGPM, entre as rochas graníticas sem epídoto magmático e os quartzo monzodioritos/granodioritos e granodioritos com epídoto magmático da porção mediana da SGPM, apresentando contato tectônico com estas rochas adjacentes.

São rochas de coloração verde a verde escuro, granulação fina média, constituídas essencialmente por anfibólio, com raros megacristais de K-feldspato róseo, fortemente 
deformados (forma sigmoidal) e orientados segundo a foliação (Foto 6.1). A foliação é caracterizada essencialmente pela forte deformação e orientação de anfibólio. Ocorrem ainda pequenas quantidades de biotita e quartzo. Os principais minerais acessórios são zircão, apatita e titanita.

Caracteristicas como a presença de raros e deformados megacristais de K-feldspato, ocorrência de biotita, zircão, apatita e titanita e maior concentração de anfibólio (minerais que fazem parte da constituição mineralógica dos quartzo monzodioritos sem epídoto magmático) sugerem que estes anfibolitos representem fases minerais cumuláticas fortemente deformadas, na mesma intensidade e direção dos quartzo monzodioritos.

\subsection{2 - Quartzo Monzodioritos, Quartzo Monzodioritos/Granodioritos e Granodioritos
sem epidoto magmático}

Estas rochas afloram principalmente na porção norte da SGPM, ao oeste do GP e, subordinadamente, na porção sul, sempre em contato tectônico com os demais componentes da SGPM. Na porção norte ocorrem Intercaladas tectonicamente com os monzogranitos miloníticos, a norte e noroeste, e com os anfibolitos (espigão das Antas), a sul. $\mathrm{Na}$ porção sul, ocorrem a oeste das rochas com epidoto magmático apresentando contato tectônico com estas e com os monzogranitos a oeste.

Os quartzo monzodioritos, quartzo monzodioritos/granodioritos e granodioritos sem epidoto magmático (Fotos $6.2,6.3$ e 6.4) são de granulação média a grossa e coloração cinza claro a cinza escuro. Apresentam sempre megacristais de K-feldspato (cor rosa), que atingem até $1-1.5 \mathrm{Cm}$. O plagioclásio é oligoclásio cálcico a andesina, possui cor branca e raramente ocorre como megacristais, alcançando normalmente $0.5-0.7 \mathrm{~cm}$. Uma caracteristica típica destas rochas é a freqüente presença de cristais de plagioclásio zonados. Ocorrem ainda quartzo e alta concentração de máficos, biotita e anfibólio sem epídoto magmático, num volume entre 20 e $30 \%$. Entre os máficos predomina ora o anfibólio ora a biotita, ocorrendo rochas com anfibólio \pm biotita e raramente biotitatanfibólio. A foliação, caracterizada pela forte orientação de feldspatos, biotita e anfibólio, é bem marcada na maioria das rochas da porção norte e em determinados domínios da porção sul, principalmente ao longo da ZCPT.

As principais diferenças entre estas rochas graníticas e aquelas com epidoto magmático são a pronunciada milonitização, a ausência de epídoto magmático, a maior presença de allanita, titanita e zircão e geralmente o maior conteúdo em biotita e anfibólio. 


\subsection{3 - Monzogranitos}

Os biotitatanfibólio e raramente anfibólio-biotita monzogranitos (Fotos 6.5, 6.6 e 6.7) ocorrem na porção norte e sul da SGPM em contato tectônico principalmente com as rochas sem epidoto magmático da porção norte e sul da SGPM. São rochas de granulação variada fina a grossa, coloração cinza a rosa, protomiloniticas a miloniticas e ultramiloníticas. Podem conter ou não megacristais de K-feldspato (de até $1 \mathrm{~cm}$ ) além de plagioclásio, quartzo, biotita e anfibólio. Não foi identificado epidoto magmático. Os principais minerais acessórios são allanita, zircão, titanita e apatita. Da mesma forma que as rochas graníticas sem epídoto magmático, observa-se nestes monzogranitos, a freqüente presença de allanita, zircão e titanita.

A concentração de minerais máficos, como biotita e ocasionalmente anfibólio, é alta (10 a $25 \%$ ) estando quase sempre orientados e, ocasionalmente, formando concentrados fortemente deformados e orientados e alinhados segundo a foliação. Esta foliação, caracterizada pela orientação e pelo estiramento de feldspatos, biotita e anfibólio, é paralela à foliação observada nas rochas graníticas sem epídoto adjacentes e também nos demais componentes graniticos da SGPM.

\subsection{4 - Quartzo Monzodioritos com epídoto magmático}

Os biotita-anfibólio e anfibólio-biotita quartzo monzodioritos protomiloníticos a miloníticos com epídoto magmático afloram somente na porção sul da SGPM, apresentando, a leste, contato tectônico com os quartzo monzodioritos/granodioritos e leucogranodioritos com epídoto magmático cogenéticos e com as rochas da SMUP. Na porção sul, apresentam, à oeste, contato tectônico com as rochas graníticas sem epídoto magmático e os monzogranitos da SGPM.

São rochas de granulação média a grossa, coloração cinza claro, protomiloníticas a miloníticas (Foto 6.8). Constituem-se por plagioclásio (cor branca, raramente como megacristais, geralmente até $0.5-0.7 \mathrm{~cm}$ ), quartzo, biotita, anfibólio e epidoto magmático. Podem ou não conter megacristais de K-feldspato (até $1-1.5 \mathrm{~cm}$, cor rosa). Entre os máficos, predomina geralmente o anfibólio sobre a biotita ocorrendo ainda rochas com biotita $\geq$ anfibólio. $O$ volume de epídoto magmático pode alcançar até $3 \%$. Os principais minerais acessórios são zircão, titanita, apatita, allanita e opacos (magnetita). A foliação é caracterizada em geral pela orientação e estiramento de feldspatos, quartzo, biotita, anfibólio e epídoto. 


\subsection{5 - Quartzo Monzodioritos/Granodioritos e Granodioritos com epídoto magmático}

Afloram na porção norte e sul da SGPM. Na porção sul, ocorrem ao longo da ZCPT, em contato tectônico com os quartzo monzodioritos e leucogranodioritos cogenéticos e as rochas do TGAG e da SMUP. Na porção norte, ocorrem ao norte dos cogenéticos leucogranodioritos, em contato tectônico com o anfibolito Espigão das Antas e rochas graniticas sem epídoto magmático. Apresentam relação intrusiva com o GRN e o GP.

São rochas de granulação média a grossa, coloração cinza claro a rosa, protomiloniticas a miloníticas. Contêm freqüentemente megacristais (até $1 \mathrm{~cm}$ ) de Kfeldspato (cor rosa), quartzo, plagioclásio (oligoclásio), anfibólio, biotita e epídoto magmático (Fotos 6.9 - 6.12). O volume dos máficos varia entre 10 e $20 \%$, predominando ora anfibólio, ora biotita ou ambos em proporções iguais. $O$ epídoto magmático é presença constante em, podendo alcançar até $3 \%$ do volume total, principalmente quando predomina a biotita na rocha. Em todas as rochas com epídoto magmático, quando maior a quantidade da biotita, maior é a quantidade e a presença do epídoto. Os principais minerais acessórios são zircão, allanita, apatita, titanita e opacos (magnetita).

A foliação, dependendo do local, é incipiente a forte, sendo caracterizada pela orientação de biotita, anfibólio, epídoto e pelo estiramento e orientação de quartzo e feldspatos.

\subsection{6 - Leucogranodioritos com epídoto magmático}

São os termos graniticos mais fracionados e finais das rochas graniticas com epidoto magmático. Afloram principalmente na porção central, entre o GRN e o GP e, na porção sul, onde intercalam-se tectonicamente, próximo a ZCPT, com os quartzo monzodioritos/granodioritos e granodioritos com epídoto magmático cogenéticos. Na porção central, são circundados ao norte e ao sul pelos quartzo monzodioritos/granodioritos e granodioritos cogenéticos, caracterizado, neste trecho, a "zonalidade normal" observada neste grupo de rochas graníticas.

Estes leucogranodioritos (Foto 6.13) apresentam granulaçăo média a grossa, coloração rosa a cinza claro, sendo geralmente protomiloníticos a milonítcos. São constituídos por K-feldspato (megacristais de até $1.5 \mathrm{~cm}$ e cristais menores dispersos na matriz), plagioclásio, quartzo (até $1.5 \mathrm{~cm}$, típico dos leucogranodioritos), biotita, anfibólio e epidoto magmático. Os principais minerais acessórios são zircão, apatita, allanita, titanita e magnetita. A flúorita é ausente nestas e nas demais rochas graníticas da SGPM. O volume dos máficos (anfibólio, biotita e epídoto) é baixo (entre 3 e $5 \%$ ) podendo alcançar por vezes $7 \%$. Predomina ora biotita \pm anfibólio (afloramentos a $W$ e $S W$ ) e ora anfibólio $\geq$ biotita 
(afloramentos a NE e porção central). O epídoto magmático, mesmo sendo mais corroído e anédrico e em menor volume, é presença constante nestas rochas.

A foliação, dependendo do local, é ausente ou incipiente a moderada sendo bem marcante na região típica de afloramento destas rochas (Serra Piador-Cabral) e em locais ao longo da ZCPT. Na Serra Piador-Cabral ocorrem leucogranodioritos com alta quantidade de megacristais de quartzo (até $1.5 \mathrm{~cm}$ ), K-feldspato e plagioclásio, praticamente sem máficos e forte foliação milonítica.

\section{3 - Características Petrográficas Microscópicas dos Componentes Graníticos}

Os principais minerais constituintes dos litotipos em geral da SGPM são, K-feldspato (geralmente microclinal pertítica a micropertítica), plagioclásio (oligoclásio sódico a oligoclásio cálcico), quartzo, biotita, hornblenda com ou sem epídoto magmático. Os principais minerais acessórios são, zircão, titanita, allanita, apatita e opacos (magnetita).

Mineralogicamente, os quartzo monzodioritos, quartzo monzodioritos/granodioritos e granodioritos sem epídoto magmático e os monzogranitos destacam-se, em relação aos quartzo monzodioritos, quartzo monzodioritos/granodioritos, granodioritos e leucogranodioritos com epídoto magmático, pelo maior conteúdo em biotita, anfibólio e minerais acessórios, tais como zircão, allanita e titanita.

O K-feldspato (cor rosa) ocorre principalmente como megacristais subédricos a anédricos (deformados) e euhédricos (quando pouco deformados, mesmo em matriz deformada). Os cristais de plagioclásio (cor branca) são geralmente euhédricos a subédricos com granulação geralmente inferior à do K-feldspato $(<1 \mathrm{~cm}$ de comprimento). Ocorrem raramente como megacristais e geralmente como cristais menores dispersos na matriz. Os cristais de plagioclásio das rochas graníticas sem epídoto magmático distinguem-se em relação as rochas graníticas com epídoto magmático por apresentarem freqüentes zoneamentos (normal ou oscilatório) em todas as rochas constituintes deste grupo. 0 plagioclásio nas rochas graníticas sem epídoto magmático, apresenta composição da componente anortita de $\mathrm{An}^{23-28}$ (oligoclásio cálcico) e, nas rochas graníticas com epídoto magmático apresenta componente $\mathrm{An}^{16-20}$ (oligoclásio sódico).

Os feldspatos (K-feldspato e plagioclásio) nas rochas em geral da SGPM, encontram-se geralmente alongados e orientados segundo a foliação presente na maioria das rochas, apresentando ou não formas sigmóidais ou arredondadas (Fotos 6.14 - 6.16). Esta deformação dos feldspatos em muitas rochas, é marcada pela rotação e estiramento dos cristais, intenso fraturamento intracristalino, formação de finos subgrãos anédricos nas margens dos cristais e desenvolvimento de sombras de pressão, que alojam cristais de 
quartzo, biotita e/ou anfibólio e/ou epídoto magmático. Ocorrem ainda, em várias rochas, megacristais euhédricos de K-feldspato, somente rotacionados, em matrizes extremamente deformadas, com texturas miloníticas. A formação de finos subgrãos ao longo das microfraturas intracristalinas ou contornando as bordas dos megacristais de feldspatos são produtos de recristalizações dinâmicas que causam até o arredondamento das bordas destes cristais. A deformação intracristalina nos feldspatos é materializada por meio de trituramento e ruptura dos cristais, encurvamento ou destruição das lamelas da geminação, formação de microfraturas intracristalinas com ou sem deslocamentos, bandas de deformação e forte extinção ondulante dos cristais. Ocorrem ainda, nestes feldspatos, inclusões de biotita, hornblenda, epídoto, quartzo e minerais acessórios como apatita e zircão.

Nas rochas graníticas protomiloníticas da SGPM, o quartzo é anédrico e geralmente intersticial aos feldspatos e máficos enquanto que nas rochas graniticas miloníticas, este mineral apresenta forte recristalização e estiramento, estando orientado segundo a foliação (feição mais típica do quartzo na maioria dos granitos da SGPM). Os cristais de quartzo nas rochas miloniticas ocorrem sob a forma de sigmoides ou intercalados heterogeneamente com biotita e anfibólio (com ou sem epídoto), como niveis finos descontínuos anastomosados e orientados segundo a direção da foliação (Fotos 6.14-6.17).

A biotita é presença constante em todas as rochas graníticas com e sem epídoto magmático e nos monzogranitos. Este mineral ocorre como cristais subédricos a anédricos ou como sigmóides orientados, isolados ou associados a anfibólio. Também ocorre com anfibólio em simplectitos magmáticos deformados (sigmóides) ou não, com ou sem epídoto magmáticos e em niveis finos descontínuos e anastomosados, que envolvem cristais de feldspatos e quartzo (Fotos 6.18 - 6.22). A biotita exibe, em várias rochas, forte deformação e recristalização de cristais euhédricos, preferencialmente nas bordas.

Nas rochas pouco deformadas e protomiloníticas com epidoto e mesmo nas rochas miloníticas, observa-se a cristalização desordenada de biotita (associada ou não a epídoto), ao longo das margens ou dentro de cristais de anfibólio, com os quais mostra contatos difusos com o anfibólio e irregulares e nítidos com o epídoto. Estas feições texturais são remanescentes do estágio magmático e resultam de reações peritéticas que cristalizam biotita (rochas graníticas sem epídoto magmático) e biotita e epidoto (rochas graníticas com epidoto magmático) por substituição do anfibólio. Admite-se desta forma que as feições texturais da passagem do anfibólio para biotita e anfibólio para biotita e epidoto são de origem magmática, sendo posteriormente deformadas. Apenas a biotita foi recristalizada e a biotita, anfibólio e epídoto deformados pelos processos tectônicos que afetaram a SGPM. A recristalização da biotita e forte recristalização e estiramento de feldspatos e quartzo em 
muitas rochas, são sugestivos do metamorfismo (?) de baixo grau das rochas graníticas da SGPM.

O anfibólio ocorre como cristais euhédricos prismáticos (até $0.5 \mathrm{~cm}$ de comprimento e $0.2 \mathrm{~cm}$ de largura) ou subédricos a anédricos e está geralmente associado à biotita (rochas graníticas sem epídoto) e biotita e epídoto (rochas graníticas com epídoto), em arranjos simplectíticos, sigmoides ou em níveis descontínuos e anastomosados. Nas rochas miloniticas, o anfibólio apresenta-se intensamente deformado, sendo freqüente o aparecimento de sigmóides (com biotita ou, biotita e epídoto) orientados conforme a foliação (Fotos 6.17-6.22).

Uma reavaliação da forma de ocorrência e das relações texturais do epídoto com os demais minerais constituintes (principalmente a biotita e o anfibólio revelaram, a origem magmática deste mineral e a existência realmente de dois grupos de rochas graníticas com e sem epidoto magmático. Os indícios petrográficos que indicam a origem magmática do epidoto nestas rochas são:

- Preservação de epidoto manteando allanita em rochas pouco e fortemente deformadas, formando com a allanita forte zonação (feição magmática) somente nos litotipos graníticos com epídoto magmático (Fotos 6.19 e 6.23). A ausência desta textura, entretanto não exclui a origem magmática deste mineral. Os quartzo monzodioritos a granodioritos sem epídoto magmático, mesmo apresentando maior conteúdo em allanita em relação aos litotipos com epídoto magmático, não exibem esta feição.

- Nas rochas graníticas com epídoto, a presença de epídoto como cristais geralmente euhédricos a subédricos nos quartzo monzodioritos, quartzo monzodioritos/granodioritos e granodioritos, formando simplectitos com contatos difusos com o anfibólio e nítidos e irregulares com biotita (Fotos 6.25 e 6.26), enquanto nos leucogranodioritos aparece como cristais anédricos e corroídos. A falta do hábito euhedral, nas rochas graníticas deformadas, não exclui também a origem magmática deste mineral. Manteamento do epídoto por biotita e destes dois minerais por anfibólio, apresentando contatos nitidos e irregulares com a biotita e difusos com o anfibólio são sugestivos da simultânea cristalização da biotita e do epídoto por reações magmáticas do tipo plagioclásio + anfibólio + liquido $=$ biotita + epidoto (Schmidt \& Thompson 1996). Nas rochas onde a biotita predomina sobre o anfibólio o volume de epídoto é maior, sugerindo, com base nas feições texturais, sincronicidade da cristalização da biotita e do epídoto por substituição do anfibólio durante o estágio magmático. As rochas graníticas miloníticas com epidoto apresentam preservação parcial da textura original do epídoto com a biotita e o anfibólio, ocorrendo sigmóides ou simplectitos deformados contendo biotita, epídoto e anfibólio (Fotos 6.19, 6.20 e 6.22 - 6.24). 
- Em rochas da SGPM onde não ocorre saussuritização do plagioclásio e cloritização da biotita, o epídoto ocorre como cristais euhédricos a subédricos e anédricos, exibindo as relações texturais já descritas. Por isso, descarta-se a formação deste mineral por possíveis reações metamórficas envolvendo plagioclásio e anfibólio.

- Ausência de epidoto magmático e presença marcante de allanita nos quartzo monzodioritos a granodioritos sem epídoto magmático da porção norte e sul e nos monzogranitos da SGPM. Se a formação do epidoto estivesse relacionada à deformação e metamorfismo, sua presença seria bem mais expressiva em volume e nunca estaria ausente nestas rochas.

Discussões sobre a gênese do epidoto magmático e sua ocorrência em rochas graníticas cálcio-alcalinas, além de descrições das relações texturais com os demais minerais constituintes, implicações petrogenéticas com indicação da temperatura e, principalmente, pressão da cristalização, encontram-se em Naney (1983), Zen \& Hammastrom (1984 e 1986), Moench (1986), Tulloch (1986), Zen (1988), Schmidt \& Thompson (1996), Brandon et al. (1996), Sial et al. (1999) e outros. Estes trabalhos sugerem que o epidoto de origem magmática forma-se em temperaturas mínimas da ordem de 600$700{ }^{\circ} \mathrm{C}$ e pressões variáveis, entre 5 e $8 \mathrm{Kbar}$. Os referidos autores não descartam a possibilidade de cristalização, como cristais corroídos e anédricos, de epídoto magmático em rochas graníticas formadas neste intervalo de pressão e alojadas rapidamente em níveis crustais superiores (caso dos leucogranodioritos com epidoto magmático ? da SGPM).

Os minerais acessórios zircão, apatita, titanita, allanita e magnetita ocorrem como cristais principalmente euhédricos, geralmente associados ou inclusos em anfibólio e biotita e, subordinadamente, feldspatos. Sigmóides de cristais de titanita são freqüentemente observados nos quartzo monzodioritos a granodioritos sem epidoto magmático. A presença dos minerais acessórios zircão, titanita e allanita é bem mais freqüente nos quartzo monzodioritos à granodioritos sem epídoto magmático do que em seus correspondentes com epídoto magmático.

A seqüência do início da cristalização dos minerais constituintes das rochas da SGPM em geral foi extraída das relações texturais entre os minerais constituintes, principalmente a partir das rochas pouco deformadas. Esta seqüência é : plagioclásio $\rightarrow$ hornblenda (titanita, allanita, zircão) $\rightarrow$ biotita + epidoto $\rightarrow$ K-feldspatos $\rightarrow$ quartzo. Os minerais máficos (biotita, hornblenda e epidoto) e os minerais acessórios (zircão, allanita e titanita) nas rochas da SGPM fazem parte da seqüência inicial da cristalização, ao contrário das rochas graníticas do GP, GAS e GRN, onde os máficos (biotita e/ou anfibólio) e os minerais acessórios (zircão, allanita e titanita) fazem parte da seqüência final de cristalização. 


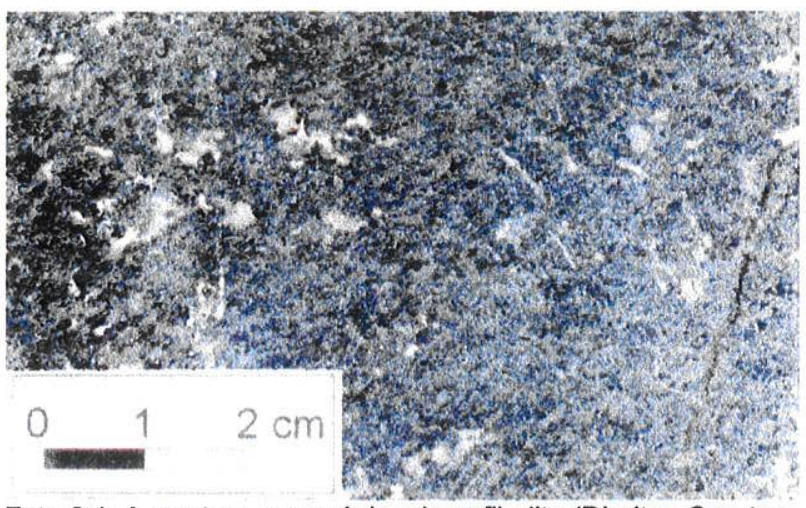

Foto 6.1: Aspecto macroscópico do anfibolito (Dioritos-Quartzo Dioritos) Espigäo das Antas. SGPM, amostra OM SA.

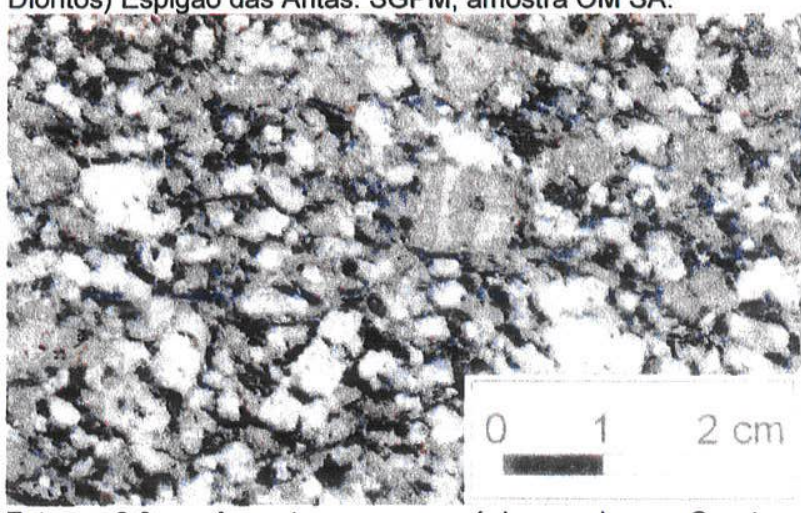

Foto 6.3: Aspecto macroscópico dos Quartzo Monzodioritos/Granodioritos sem epidoto magmático. SGPM, amostra OM 409

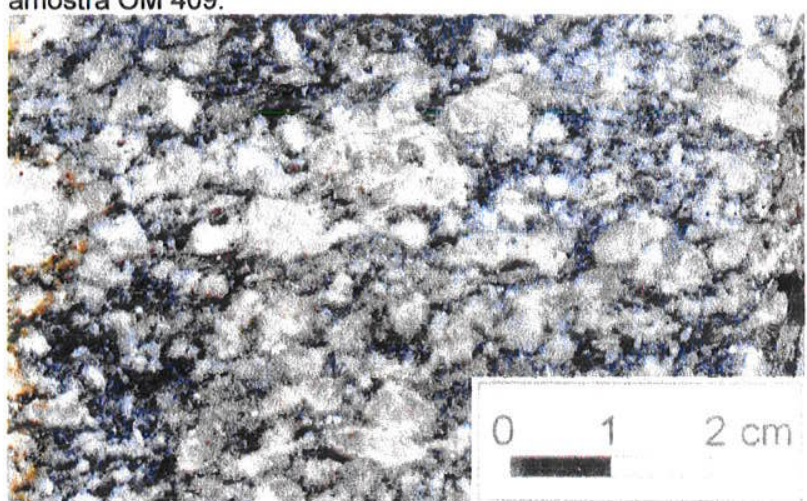

Foto 6.5: Aspecto macroscópico geral dos BiotitatAnfibólio Monzogranitos. SGPM, amostra OM1089.

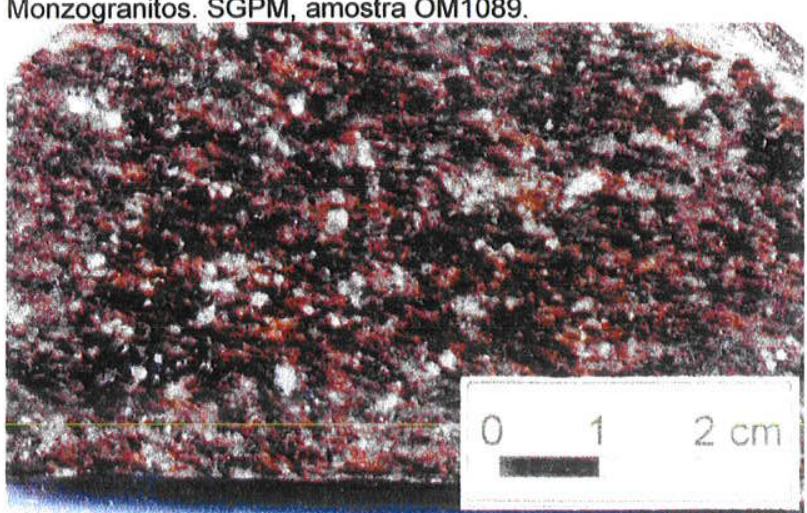

Foto 6.7: Aspecto macroscópico geral dos BiotitatAnfibólio Monzogranitos. SGPM, amostra OM 1033.

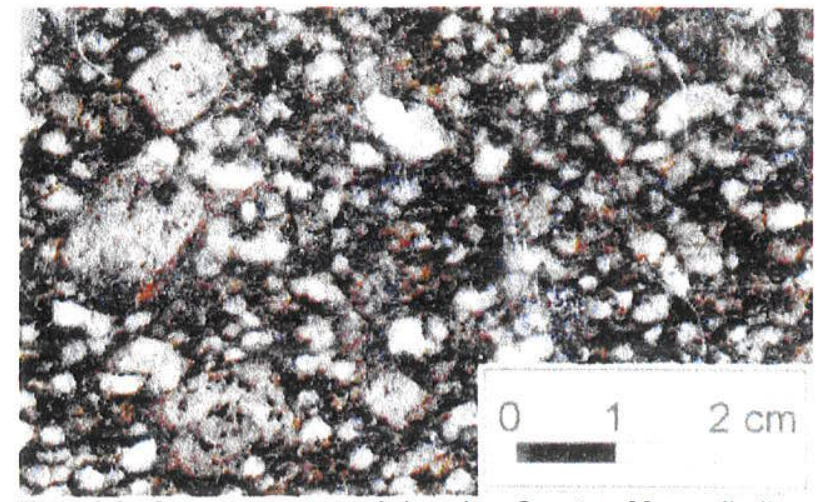

Foto 6.2: Aspecto macroscópico dos Quartzo Monzodioritos sem epidoto magmático. SGPM, amostra OM 1106.

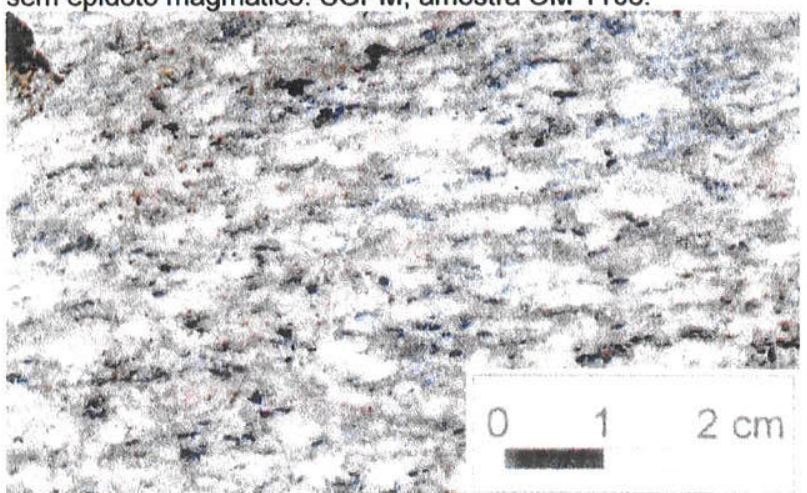

Foto 6.4: Aspecto macroscópico dos Granodioritos sem epidoto magmático. SGPM, amostra OM 1108.

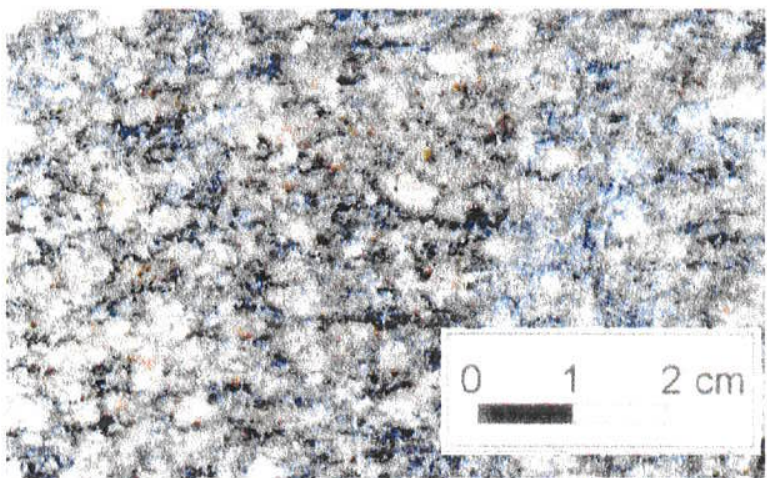

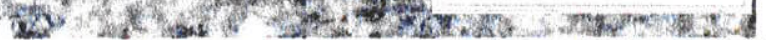
Foto 6.6: Aspecto macroscópico geral dos Biotita土Anfibólio Monzogranitos. SGPM, amostra OM 1094-19.

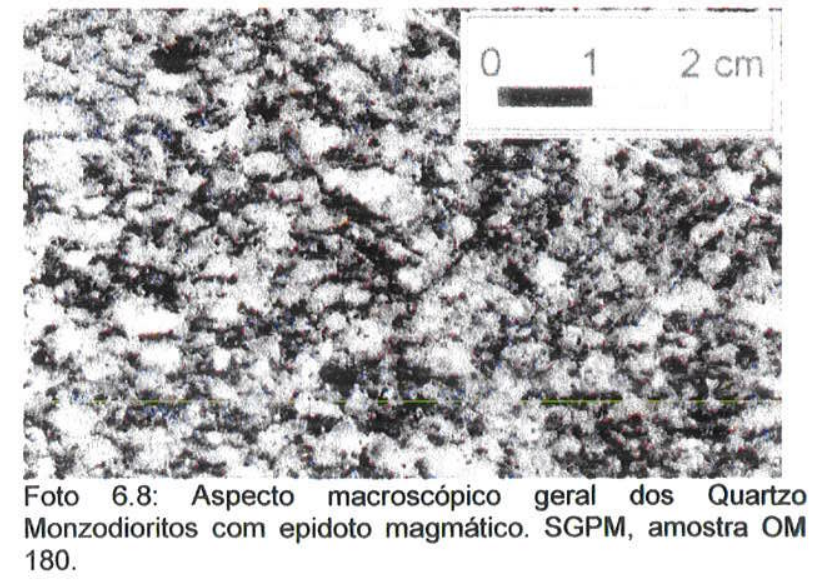




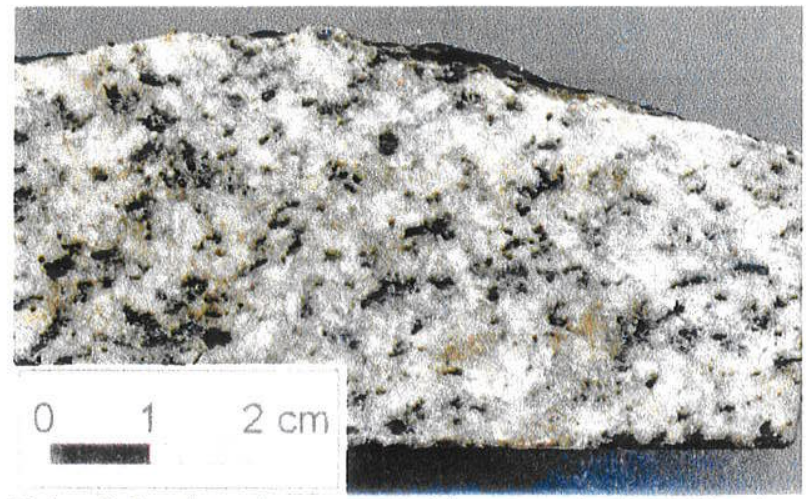

Foto 6.9: Aspecto macroscópico geral dos Quartzo Monzodioritos/Granodioritos com epidoto magmático. SGPM, amostra OM 629

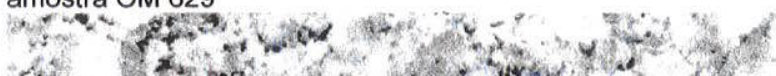

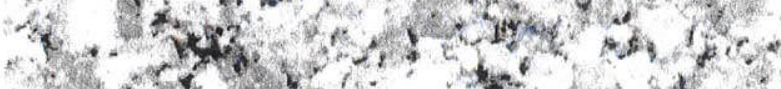

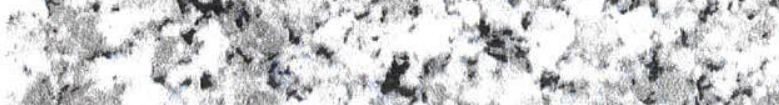

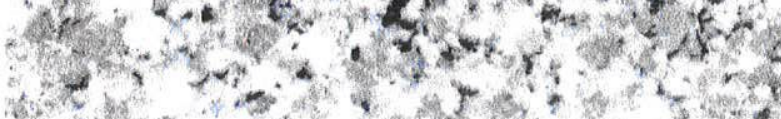

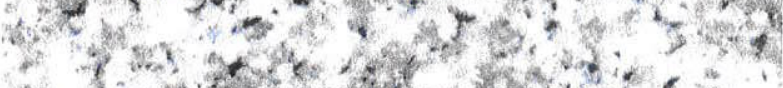

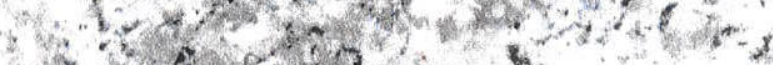
2.

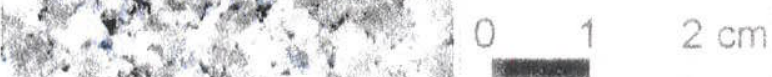

Foto 6.11: Aspecto macroscópico geral dos Quartzo Monzodioritos/Granodioritos com epidoto magmático. SGPM, amostra OM 820

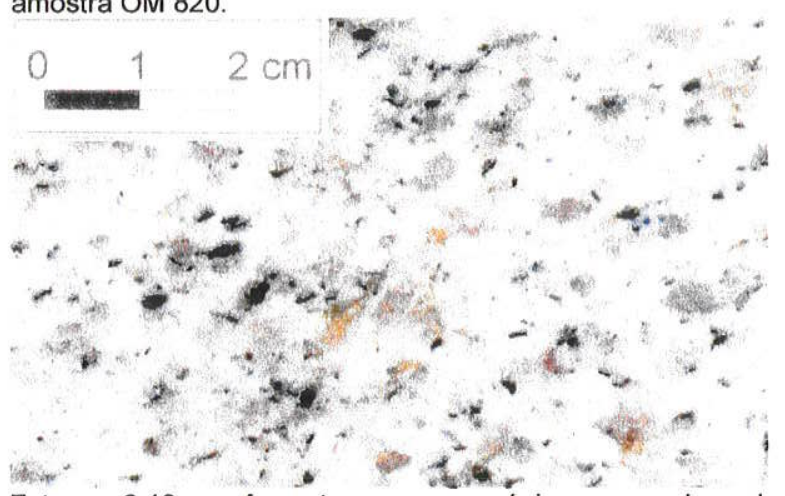

Foto 6.13: Aspecto macroscópico geral dos Leucogranodioritos com epidoto magmático. SGPM, amostra OM 942.

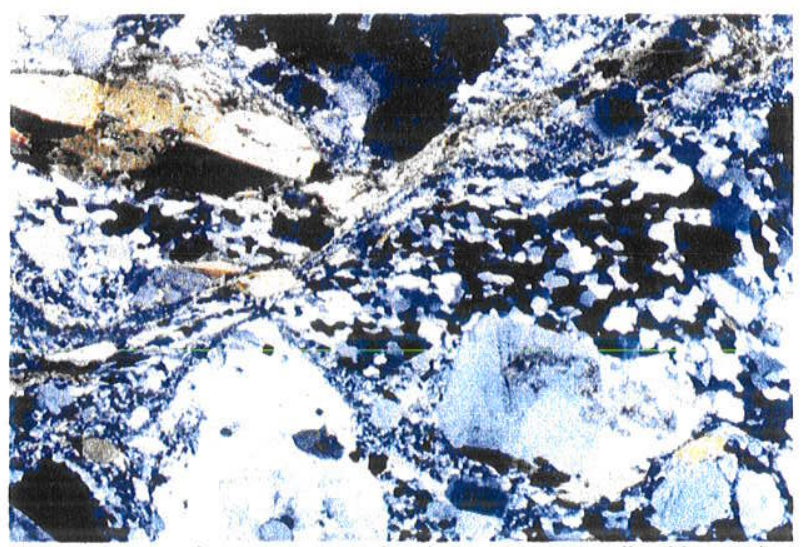

Foto 6.15: Aspecto geral da textura milonítica dos Granodioritos sem epidoto magmático caracterizada pelo forte estiramento e orientação dos cristais de quartzo e anfibólio e arrendondamento dos cristais de feldspato. SGPM, amostra OM 406 (Lado maior da foto $5,5 \mathrm{~mm}$. Nicóis X).

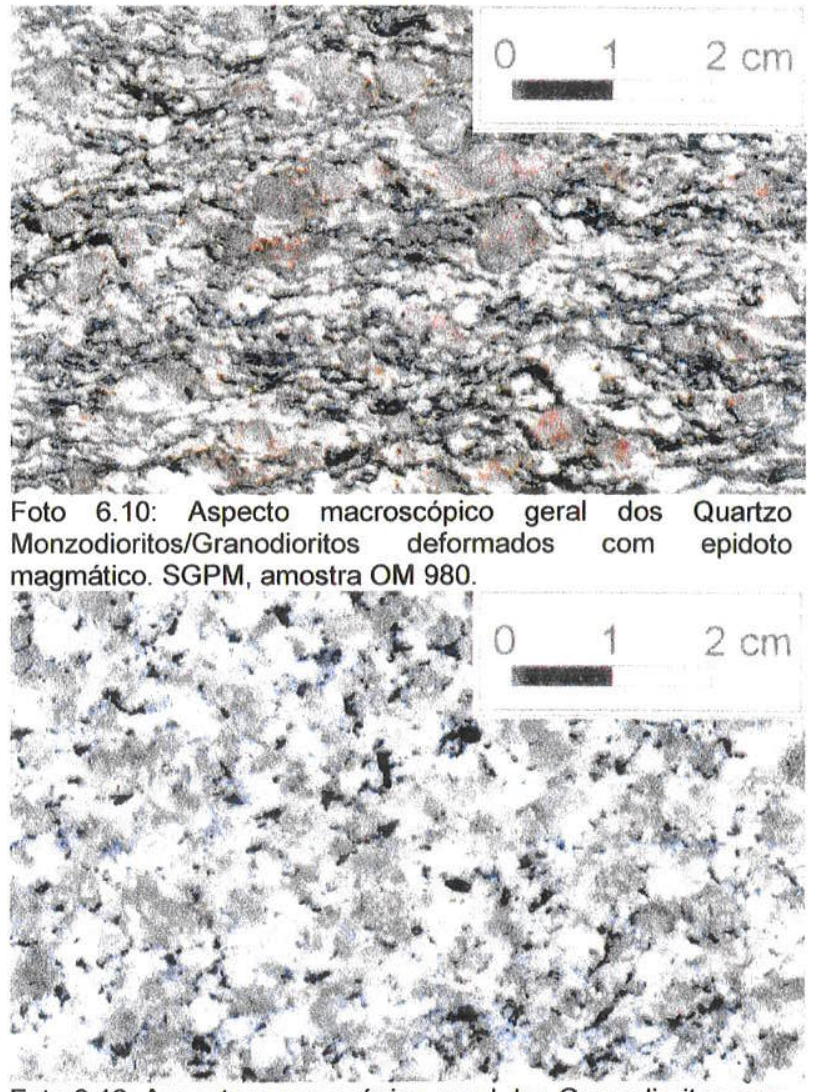

Foto 6.12: Aspecto macroscópico geral dos Granodioritos com epidoto magmático. SGPM amostra OM 705

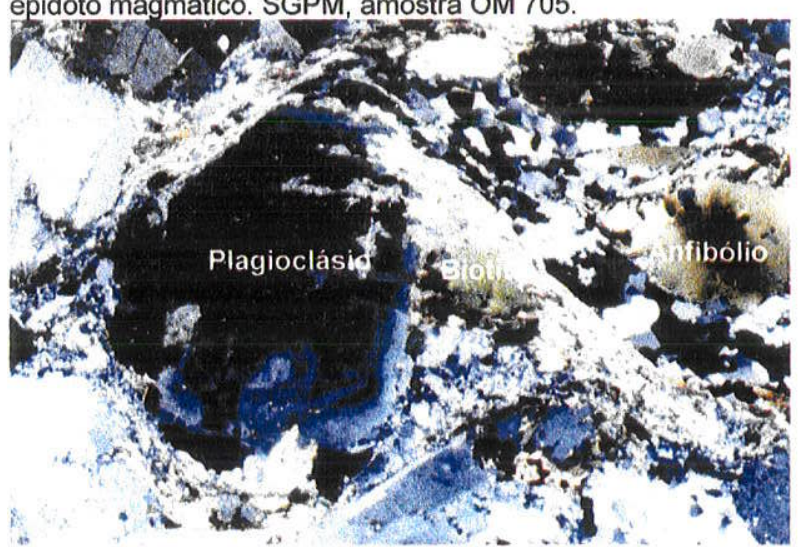

Foto 6.14: Plagioclásio zonado, rotacionado, arredondado com sombras de pressão preenchidas por quartzo e biotita. Granodioritos sem epidoto magmático. SGPM, amostra OM 406 (Lado maior da foto $5,5 \mathrm{~mm}$. Nicóis $X$ )

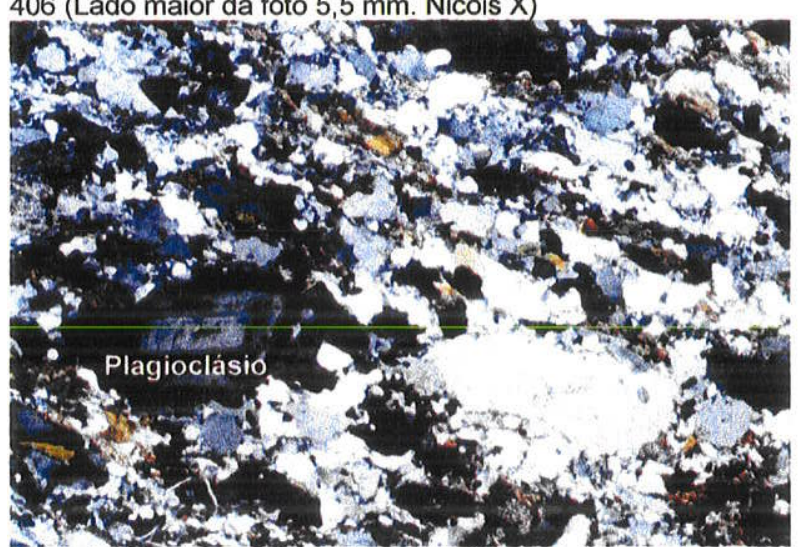

Foto 6.16: Aspecto geral da textura protomilonítica nos Granodioritos sem epidoto magmático. Notar plagioclásio zonado e deformado. SGPM, amostra OM 1108 (Lado maior da foto $5,5 \mathrm{~mm}$. Nicóis $X$ ). 


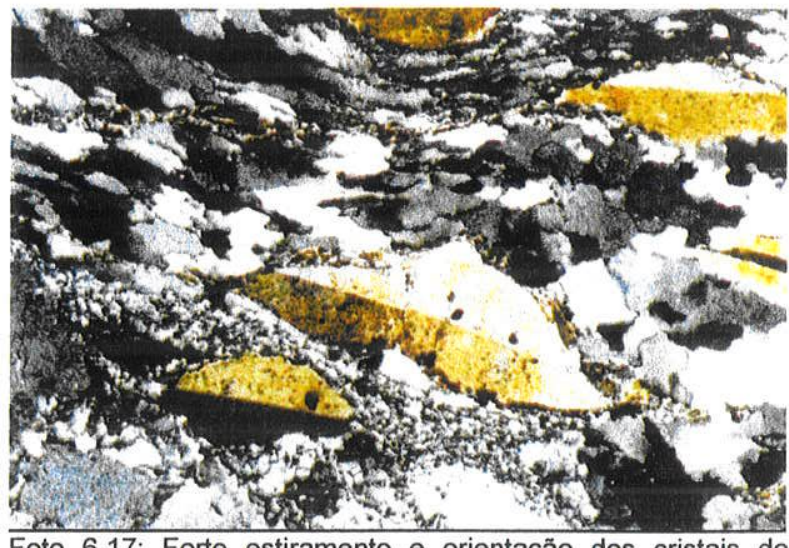

Foto 6.17: Forte estiramento e orientação dos cristais de quartzo e anfibólio (sigmóides) em Granodioritos. SGPM, amostra OM 406 (Lado maior da foto 2,8 mm. Nicóis X).

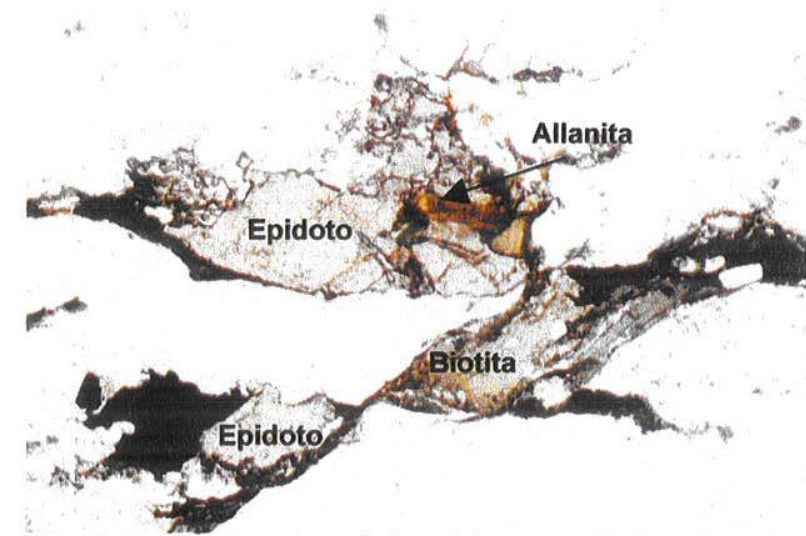

Foto 6.19 :Relação textural do epidoto com biotita orientados em Quartzo Monzodioritos com epidoto magmático. Observar allanita manteada por epidoto. SGPM, amostra OM 180 (Lado maior da foto $5,5 \mathrm{~mm}$. Nicóis //)

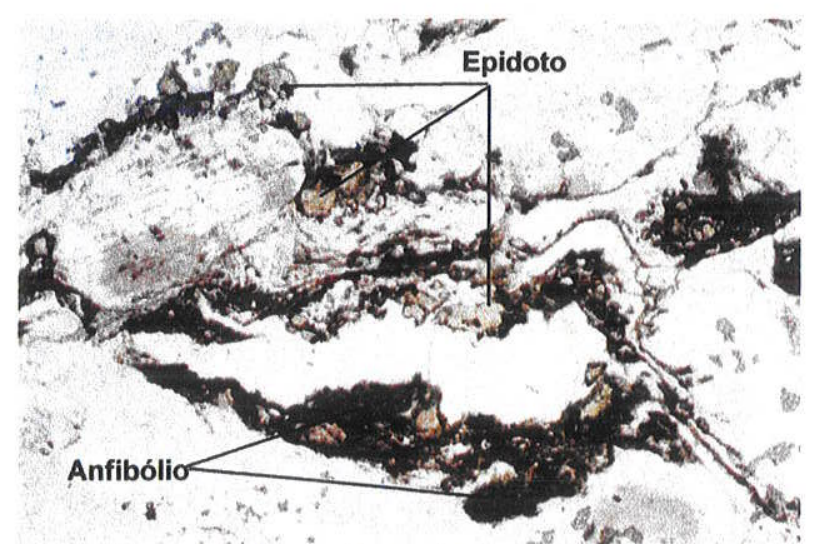

Foto 6.21: Forte deformação e orientação da biotita, epidoto e anfibólio em Quartzo Monzodioritos/Granodioritos. SGPM, amostra OM 980 (Lado maior da foto $5,5 \mathrm{~mm}$. Nicóis //)

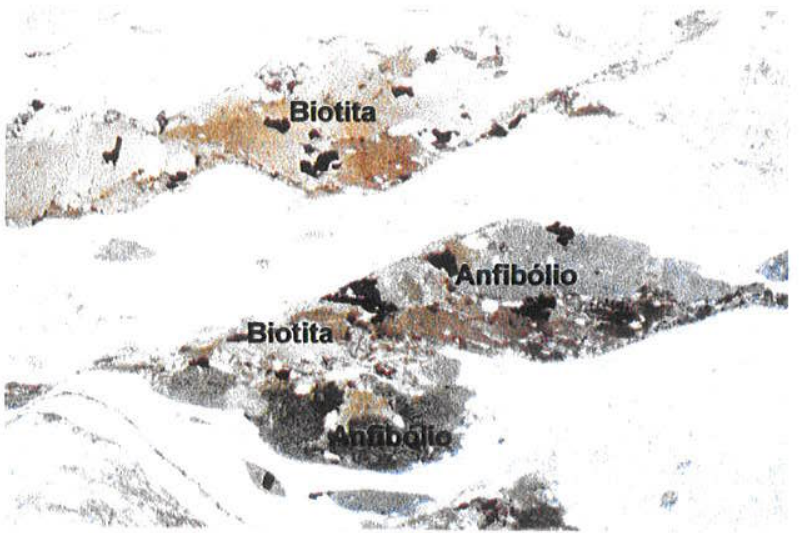

Foto 6.18: Sigmóides de biotita e anfibólio e simplectitos de biotita e anfibólio em Granodioritos sem epidoto magmático. SGPM, amostra OM 406 (Lado maior da foto 5,5 mm.Nicóis //)

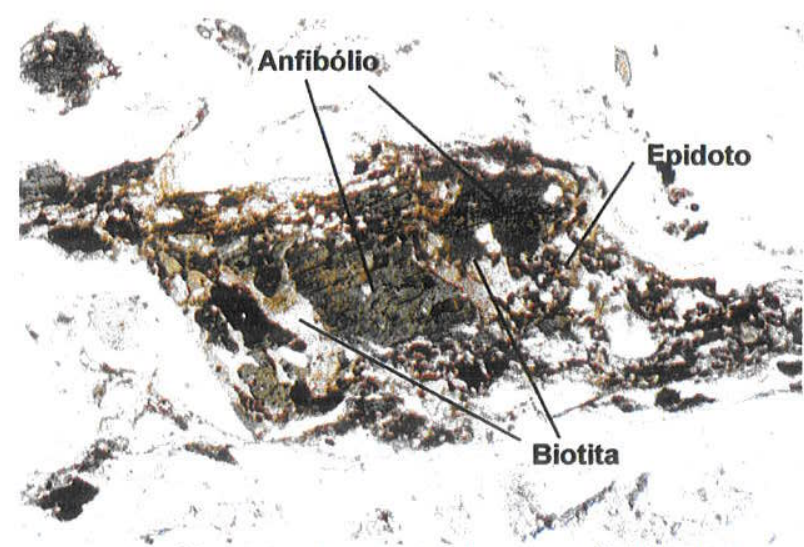

Foto 6.20: Sigmóide de simplectito de anfibólio, biotita e epidoto em Quartzo Monzodioritos/Granodioritos com epidoto magmático deformados. SGPM, amostra OM 980 (Lado maior da foto $2,8 \mathrm{~mm}$. Nicóis //).

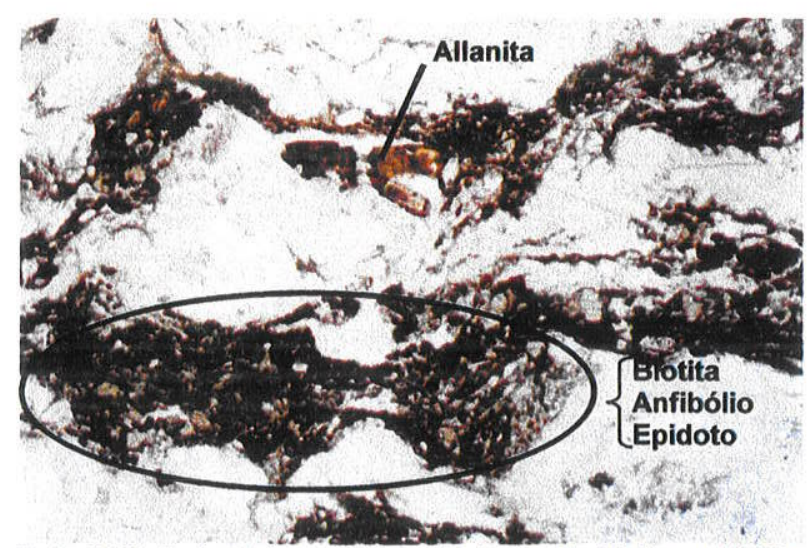

Foto 6.22: Forte deformação e orientação de biotita, anfibólio epídoto e allanita em Quartzo Monzodioritos/Granodioritos. SGPM, amostra OM 981 (Lado maior da foto $5,5 \mathrm{~mm}$. Nicóis II) 


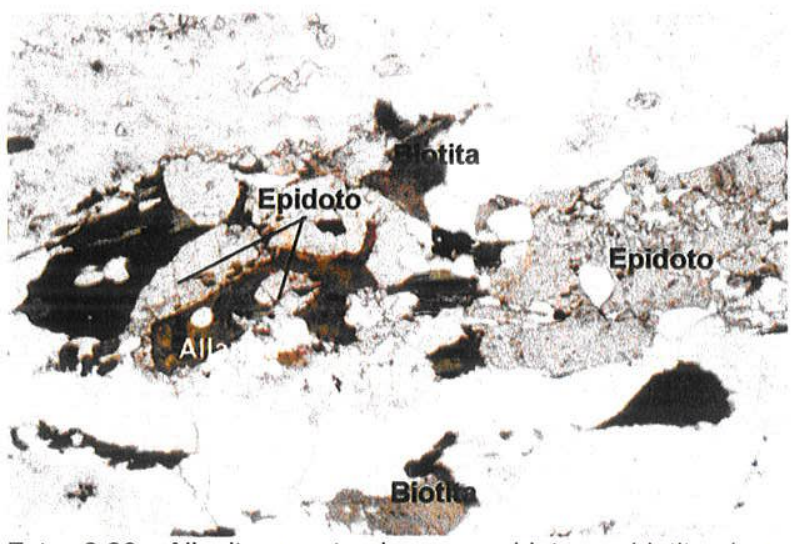

Foto 6.23: Allanita manteada por epidoto e biotita (com inclusão de epidoto), orientados em Quartzo Monzodioritos/Granodioritos. SGPM, amostra OM 335 (Lado maior da foto $5,5 \mathrm{~mm}$. Nicóis //)

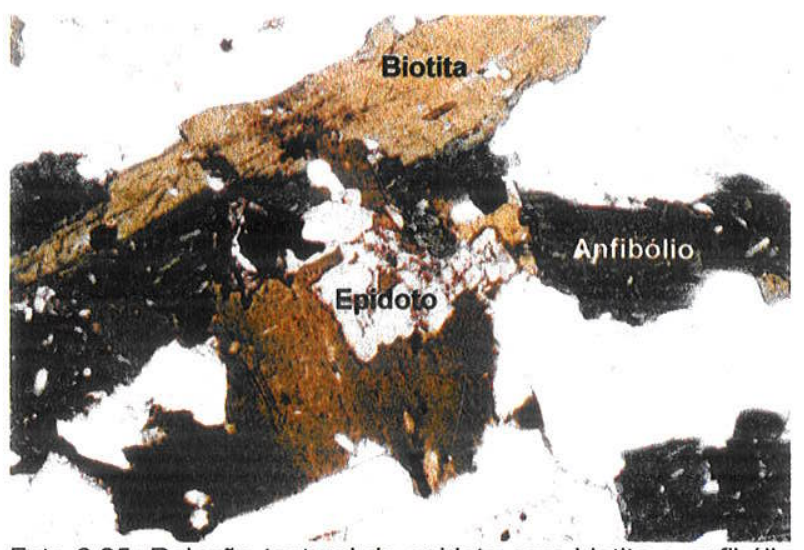

Foto 6.25: Relação textural do epidoto com biotita e anfibólio em Quartzo Monzodioritos. SGPM, amostra OM 183 (Lado maior da foto $2,8 \mathrm{~mm}$. Nicóis /I)

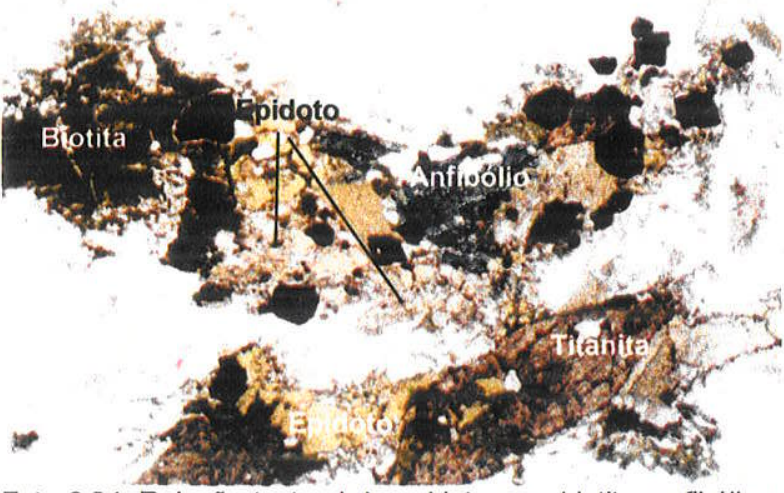

Foto 6.24: Relação textural do epidoto com biotita, anfibólio e titanita em Quartzo Monzodiorito/Granodioritos. SGPM, amostra OM 629 (Lado maior da foto 5,5 mm. Nicóis //).

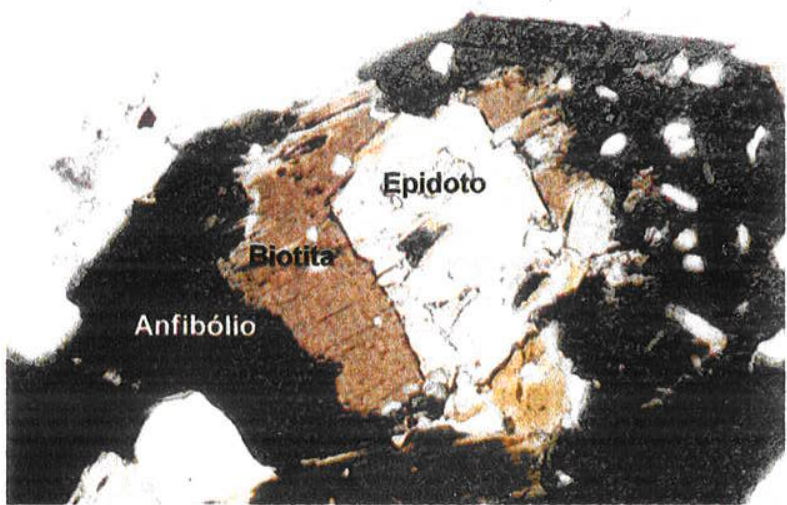

Foto 6.26 : Epidoto euhédrico manteado por biotita e anfibólio com restos de anfibólio no epidoto em Quartzo Monzodioritos. SGPM, amostra OM 183 (Lado maior da foto 0,7 mm. Nicóis 


\section{4 - Análise estrutural}

A principal estrutura observada na maioria dos componentes graníticos da SGPM é uma foliação $\mathrm{Sn}$ protomilonítica a milonítica, com aspecto freqüentemente anastomosado e definida pela orientação preferencial de feldspatos, quartzo, biotita, anfibólio, titanita e epídoto magmático (quando presente). As foliações miloníticas concentram-se preferencialmente na direção N50E/69NW (Figura 6.2), com variações no mergulho para SE mais freqüentes na porção norte. Mergulhos NW mais suaves do que os máximos também foram observados. As variações principalmente na direção destas foliações são conseqüência do padrão anastomosado e da componente compressiva NW-SE (cavalgamento) do regime transpressional principal que gerou estas foliações.
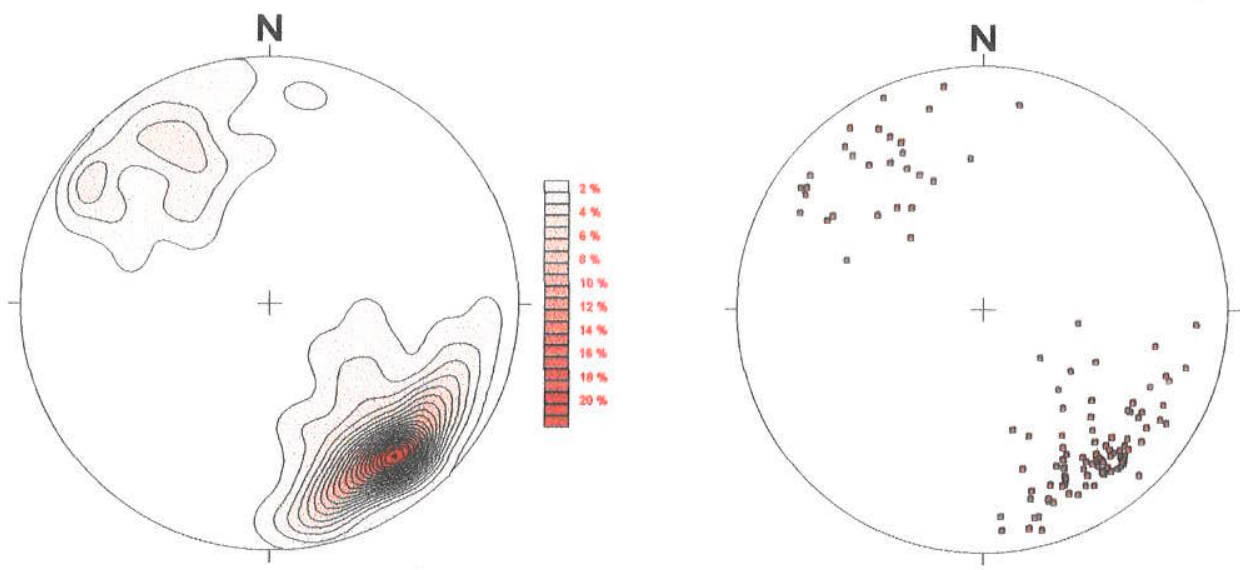

Figura 6.2 - Diagrama de freqüência dos pólos da foliação tectônica Sn na SGPM. No. das Foliações 122. Sn Max. $=$ N50E/69NW.

O paralelismo das foliações Sn da SMUP (corpos ultramáficos norte e sul) e da porção SW do TGAG com as foliações da SGPM sugerem a mesma tectônica deformadora. O desenvolvimento das foliações na SGPM estaria associado a um processo de cavalgamento/empurrão (componente compressiva de sistema transpressional regional) em regime dúctil a dúctil-rúptil de N-NW para S-SE, deformando e colocando as rochas da SGPM sobre as rochas da SMUP e estas sobre as do TGAG. As inflexões nas foliações da porção SW do TGAG, ao longo da ZCPT, transitando gradativamente para direções e mergulhos paralelos às foliações da SGPM sugerem a atuação da tectônica transpressional. Durante esta tectônica deformadora, o corpo meridional da SMUP (Campina dos Maias) foi colocado como uma "Klippe" sobre as rochas do TGAG, conforme indicam as foliações e lineações deste corpo ultramáfico, que serão apresentadas adiante. 


\section{5 - Litogeoquímica}

Nesta seção, são apresentados, analisados e discutidos os resultados das análises químicas das rochas da SGPM (Figuras 6.3 à 6.8). Para a visualização das diferenças em relação as rochas da SGPM, os resultados das análises químicas das rochas graníticas dos Granitos GP, GAS, GRN e GT (exceto os monzogabros e as rochas graníticas híbridas do GP e GRN) são apresentados juntamente nestes diagramas. Os quartzo monzodioritos a granodioritos sem epídoto magmático apresentam valores de $\mathrm{SiO}_{2}$ entre 60 e $70 \%$. Os quartzo monzodioritos, granodioritos e leucogranodioritos com epídoto magmático apresentam valores de $\mathrm{SiO}_{2}$ entre 60 e $75 \%$ e compõem uma suite granítica mais expandida do que a dos sem epidoto magmático. Os monzogranitos apresentam conteúdo em $\mathrm{SiO}_{2}$ entre 66 e $73 \%$.

Os diagramas de correlaçäo $\mathrm{SiO}_{2} \mathrm{X}$ óxidos, traços e ETR (Figuras, 6.3, 6.4 e 6.6) mostram notáveis diferenças, para $\mathrm{SiO}_{2}$ entre 60 e $70 \%$, entre as rochas graníticas com e sem epídoto magmático e destas em relação aos monzogranitos. As rochas sem epídoto magmático, neste mesmo intervalo de $\mathrm{SiO}_{2}$, são mais enriquecidas em $\mathrm{TiO}_{2}, \mathrm{P}_{2} \mathrm{O}_{5}, \mathrm{Fe}_{2} \mathrm{O}_{3}$, $\mathrm{MgO}, \mathrm{K}_{2} \mathrm{O}, \mathrm{Ba}$ (?), $\mathrm{Nb},(?), \mathrm{Hf}, \mathrm{Zr}, \mathrm{Th}, \mathrm{Y}, \mathrm{Sc}, \mathrm{V}, \mathrm{Cr}, \mathrm{Ni}$, ETRL e ETRP, em relação as rochas com epídoto magmático. Estas rochas, por sua vez, são mais enriquecidas, em relação as rochas graníticas sem epídoto magmático, principalmente em $\mathrm{Al}_{2} \mathrm{O}_{3}$ e $\mathrm{Na}_{2} \mathrm{O}$, em relação as com epidoto magmático. Similares valores, para as rochas graniticas com e sem epídoto magmático são principalmente apresentados em $\mathrm{CaO}, \mathrm{Fe}_{2} \mathrm{O}_{3}, \mathrm{Sr}, \mathrm{Rb}$ e $\mathrm{Ga}$.

Os monzogranitos da SGPM, para $\mathrm{SiO}_{2}$ entre 66 e $73 \%$ apresentam (intra suite) valores distintos em relação as rochas graníticas com e sem epídoto magmático sendo mais enriquecidos em $\mathrm{TiO}_{2}, \mathrm{P}_{2} \mathrm{O}_{3}, \mathrm{~K} 2 \mathrm{O}, \mathrm{Rb}, \mathrm{Ba}$ (?), $\mathrm{Ga}(?), \mathrm{Nb}, \mathrm{Hf}, \mathrm{Zr}, \mathrm{Th}, \mathrm{Y}, \mathrm{Rb} / \mathrm{Sr}, \mathrm{ETRL}$, Eu e ETRP e, mais empobrecidos em $\mathrm{MnO}, \mathrm{Na}_{2} \mathrm{O}$ e $\mathrm{Sr}$ (Figuras 6.3 e 6.5). Os monzogranitos $\left(\mathrm{SiO}_{2} 66\right.$ a $73 \%$ ) apresentam correlação positiva com a $\mathrm{SiO}_{2} \mathrm{em} \mathrm{K}_{2} \mathrm{O}, \mathrm{Rb}, \mathrm{Rb} / \mathrm{Sr}, \mathrm{Ga}, \mathrm{Nb}, \mathrm{Y}$, Th e ETRP e correlação negativa nos demais óxidos e traços a exemplo de $\mathrm{Ba}, \mathrm{Sr}, \mathrm{Hf}, \mathrm{Zr}$, Sc, V, ETRL (La e Sm) e Eu. Esta conduta e conteúdo destes elementos nos monzogranitos da SGPM são bem distintos das rochas graníticas com e sem epidoto magmático. Os monzogranitos com $\mathrm{SiO}_{2}>70 \%$ apresentam conteúdos, na grande maioria dos óxidos, traços e ETR, similares aos monzogranitos do GT, independentemente da deformação ou não destes monzogranitos e do local do alojamento.

As correlações negativas observadas na maioria dos diagramas de $\mathrm{SiO}_{2} \times$ óxidos (exceto $\mathrm{K}_{2} \mathrm{O}$ e $\mathrm{Na}_{2} \mathrm{O}$ ), traços e terras raras, para os quartzo monzodioritos a granodioritos sem epídoto magmático, quartzo monzodioritos, granodioritos e leucogranodioritos com epidoto magmático e os monzogranitos, são compativeis com processos de cristalização 
fracionada para a formação de cada um deste grupo de rochas que compõem a SGPM. Isto é, a medida que a diferenciação e a cristalização fracionada avança, ocorre a progressiva diminuição na maioria dos óxidos (exceto $\mathrm{K}_{2} \mathrm{O}$ e $\mathrm{Na}_{2} \mathrm{O}$, aumento), traços (exceto $\mathrm{Rb}, \mathrm{Sr}$ ? $\mathrm{Ba}$ ? $\mathrm{Ga}$ ?) e ETR nas rochas graniticas produzidas durante este processo.

$\mathrm{O}$ anfibolito Espigão das Antas $\left(\mathrm{SiO}_{2}=52 \%\right)$ apresenta assinaturas quimicas caracterizadas por altos valores de $\mathrm{CaO}, \mathrm{Fe}_{2} \mathrm{O}_{3}, \mathrm{MgO}, \mathrm{Ba}, \mathrm{Sc}, \mathrm{Cr}$ e $\mathrm{Ni}$ e baixos valores de $\mathrm{TiO}_{2}, \mathrm{P}_{2} \mathrm{O}_{3}, \mathrm{Al}_{2} \mathrm{O}_{3}, \mathrm{Na}_{2} \mathrm{O}(1 \%), \mathrm{K}_{2} \mathrm{O}(1 \%), \mathrm{Rb}(25 \mathrm{ppm}), \mathrm{Sr}(200 \mathrm{ppm}), \mathrm{Rb} / \mathrm{Sr}(0.1), \mathrm{Zr}(60$ ppm) e ETRL (Figuras 6.3, 6.4, 6.5 e 6.6). Estas características são compativeis com rochas anfibolíticas cumuláticas, possivelmente das rochas graníticas sem epidoto magmático.

As rochas graníticas com e sem epídoto magmático são cálcio-alcalinos de alto $\mathrm{K}_{2} \mathrm{O}$ (2.5 a 4\%) e os monzogranitos são cálcio alcalinos de mais alto $\mathrm{K}_{2} \mathrm{O}$ (4.5 a $5 \%$ ) e mais baixo $\mathrm{Na}_{2} \mathrm{O}(3.5$ a $4 \%$ ) conforme mostrado nas figuras $6.3 \mathrm{~J}$ e $6.5 \mathrm{~A}$. Os quartzo monzodioritos a granodioritos sem epídoto magmático apresentam maior conteúdo em $\mathrm{K}_{2} \mathrm{O}$ e menor em $\mathrm{Na}_{2} \mathrm{O}$ do que os quartzo monzodioritos e granodioritos com epídoto magmático e os monzogranitos maior conteúdo em $\mathrm{K}_{2} \mathrm{O}$ e menor em $\mathrm{Na}_{2} \mathrm{O}$, em relação as rochas graníticas com e sem epidoto magmático (Figuras 6.3 l, J, $\mathrm{K} \mathrm{e} \mathrm{L}$ ). Enquanto o $\mathrm{Na}_{2} \mathrm{O}$ permanece constante com aumento do $\mathrm{SiO}_{2}$ nos monzogranitos, nas rochas graníticas com e sem epídoto magmático ocorre progressivo aumento do $\mathrm{Na}_{2} \mathrm{O}$ com aumento do $\mathrm{SiO}_{2}$ (Figura 6.3 1).

As rochas graníticas sem epidoto magmático (quartzo monzodioritos a granodioritos) são predominantemente meta-aluminosos à fracamente peraluminosos com valor de ACNK entre 1.0 a 1.1 (Figura $6.5 \mathrm{~B}$ ). As rochas graníticas com epídoto magmático (quartzo monzodioritos, granodioritos e leucogranodioritos) são metaluminosas. Os quartzomonzodioritos são meta-aluminosos, com a progressiva diminuição da razão ANK e aumento da razão ACNK com aumento do $\mathrm{SiO}_{2}$. Os monzogranitos são meta-aluminosos a fracamente peraluminosos com valor de ACNK entre 1 e 1.1 (Figura 6.5 B).

As rochas graníticas com e sem epídoto magmático apresentam em comum baixo $\mathrm{Rb}$, alto $\mathrm{Sr}$, baixa razão $\mathrm{Rb} / \mathrm{Sr}$ e alto $\mathrm{Ba}$ enquanto que os monzogranitos apresentam mais alto $\mathrm{Rb}$, mais baixo $\mathrm{Sr}$, mais alta razão $\mathrm{Rb} / \mathrm{Sr}$ e alto $\mathrm{Ba}$ (Figura 6.4 A, B e C, Figura 6.5 C, D, $E, F \in G)$

Os perfis do comportamento e do conteúdo dos elementos terras raras (ETR) na SGPM (Figura 6.7 A-F), normalizados ao condrito (Nakamura 1977), mostram padrões distintos em ETRL e ETRP entre os três grupos de rochas graniticas que compõem a SGPM. As rochas graníticas sem epidoto magmático são, para similar conteúdo de $\mathrm{SiO}_{2}$, mais enriquecidas em ETRL e ETRP do que as rochas com epídoto magmático, 
principalmente comparando quartzo monzodioritos e granodioritos de cada grupo. Independentemente do conteúdo em ETRL e ETRP, a progressiva diminuição em ETRL e ETRP com aumento do $\mathrm{SiO}_{2}$ é característico tanto das rochas graníticas sem epídoto magmático quanto das rochas com epidoto magmático (Figura 6.7 B-E e Figura 6.6 A-I). Os monzogranitos, para $\mathrm{SiO}_{2}$ entre 66 e $73 \%$ apresentam, em relação as rochas graníticas com e sem epidoto magmático, maior enriquecimento e fracionamento em ETRL e ETRP com a progressiva diminuição dos ETRL e aumento de ETRP com aumento do $\mathrm{SiO}_{2} \mathrm{e}$, aparecimento de anomalias negativas de Eu (Figura $6.7 \mathrm{G}$ e $\mathrm{F}$ e Figura $6.6 \mathrm{~A}-1$ ). $O$ padrão em ETR apresentado pelos monzogranitos com $\mathrm{SiO}_{2}>70 \%$ da SGPM é semelhante ao apresentando pelos monzogranitos do GT.

Os leucogranodioritos $\left(\mathrm{SiO}_{2}>70 \%\right.$ ), termos graniticos mais fracionados e finais das rochas graniticas com epidoto magmático apresentam muito baixa quantidade de acessórios (allanita, zircão e titanita) que são, os responsáveis pelo forte empobrecimento em ETRL e ETRP (Figura 6.7 E) em relação as demais rochas cogenéticas deste grupo. Nas rochas da SGPM, principalmente as com e sem epídoto magmático, a concentração de ETRL e ETRP decresce com aumento da $\mathrm{SiO}_{2}$ (Figura $6.6 \mathrm{~A}-\mathrm{I}$ ), ou seja a medida que a diferenciação e cristalização fracionada prossegue com fracionamento de fases minerais acessórias que hospedam ETR. A fase mineral acessória que hospeda ETRL, observada freqüentemente nas rochas da SGPM é allanita ( e titanita ?) sendo bem mais freqüente nas rochas graníticas sem epídoto magmático e nos monzogranitos justificando os padrões mais enriquecidos apresentados por estas rochas.

Os monzogranitos do GT apresentam perfis de ETR com comportamentos e conteúdos semelhantes aos monzogranitos da SGPM com $\mathrm{SiO}_{2}>70 \%$. Da mesma forma que nos monzogranitos do GT, a correlação negativa do $\mathrm{Sr}$, Eu e $\mathrm{CaO} \mathrm{com} \mathrm{SiO}_{2}$ (Figura 6.4 B, Figura 6.6 F e Figura 6.3 F), a progressiva diminuição do $\mathrm{CaO}, \mathrm{Sr}, \mathrm{Ba}$ e $\mathrm{Na}_{2} \mathrm{O}$ (?) (Figura $6.3 \mathrm{I}, 6.5 \mathrm{E}$ e G) e o aparecimento de anomalias negativas de Eu (Figura $6.7 \mathrm{G}$ ) nos monzogranitos da SGPM sugerem, fracionamento de feldspatos e retenção progressiva de plagioclásio mais cálcico no restito, ao contrário do que ocorre nas rochas graníticas com e sem epidoto magmático da SGPM. Destra forma sugere-se, a passagem do plagioclásio da condição da remoção (rochas com e sem epídoto magmático) para a condição da retenção (monzogranitos da SGPM e do GT e tipicamente os monzo-sienogranitos do GP e GRN).

No diagrama de elementos traços $\mathrm{Rb}, \mathrm{Y}$ e Nb (Figuras $6.8 \mathrm{~A}$ e B) discriminante dos principais ambientes geotectônicos produtores e hospedes de rochas graniticas, as rochas graníticas com e sem epidoto magmático da SGPM apresentam francas afinidades com 
rochas graníticas produzidas em ambientes de arcos magmáticos, construídos em margens continentais ativas (Pearce et al . 1984, Harris et al . 1986, Harris et al . 1988, Debon et al. 1986 e outros). Os monzogranitos apresentam valores mais elevados em $\mathrm{Y}, \mathrm{Yb}$ e Rb em relação as rochas com e sem epídoto magmático sugerindo, da mesma forma que para os monzogranitos do GT, tratar-se de rochas graníticas cálcio-alcalinas de mais alto $K, R b, Y e$ $\mathrm{Nb}$, transicionais entre os típicos granitos I (rochas com e sem epídoto magmático) e granitos A (monzo-sienogranitos do GP e GRN). Os monzogranitos da SGPM e do GT não apresentam as caracteristicas mineralógicas e as assinaturas químicas típicas dos granitos A desta regiăo, tais como, os monzo-sienogranitos do GP e GRN e os leucogranodioritos do GAS. Os monzogranitos da SGPM e do GT são considerados com rochas graníticas sin a tardi tectônicas ou sin a tardi orogênicos e registram a continua resposta magmática granítica, durante a mudança do cenário geotectônico da regiảo, entre os típicos granitos I (rochas graniticas com e sem epídoto magmático) e típicos A (monzo-sienogranitos do GP e GRN e leucogranitos do GAS). 

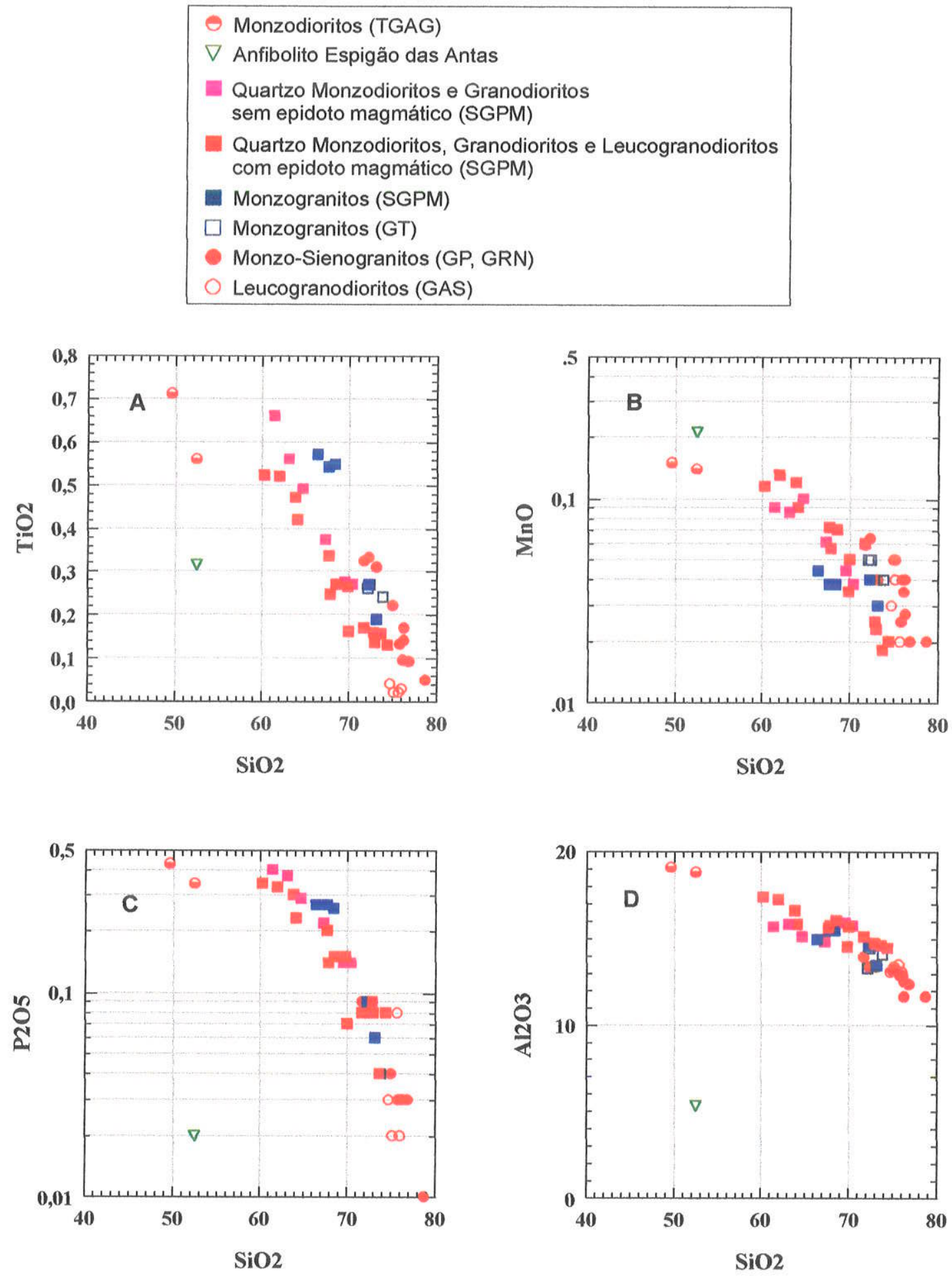

Figura 6.3 - Ver legenda página 110 

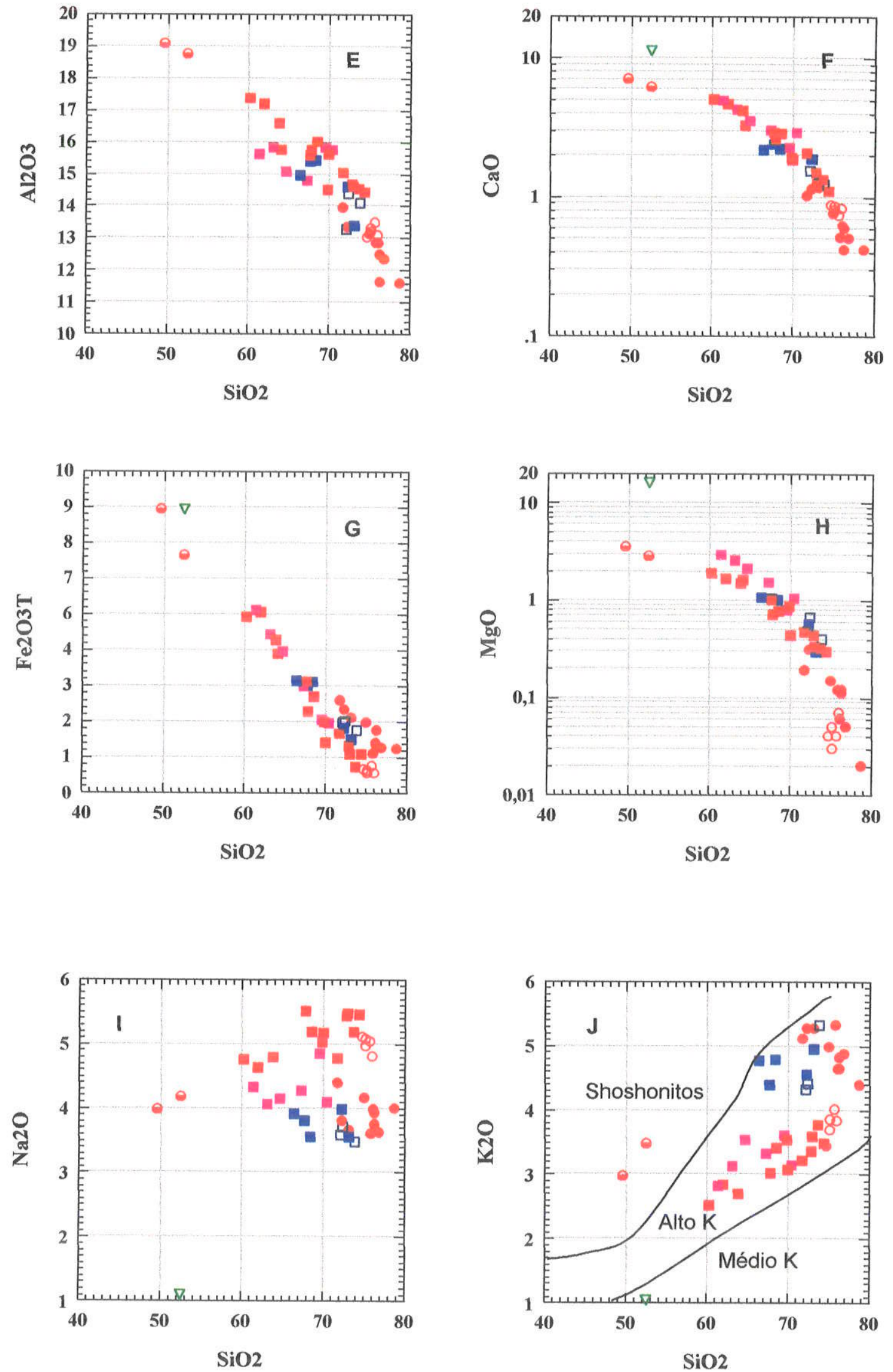

Figura 6.3 - Ver legenda página 110 

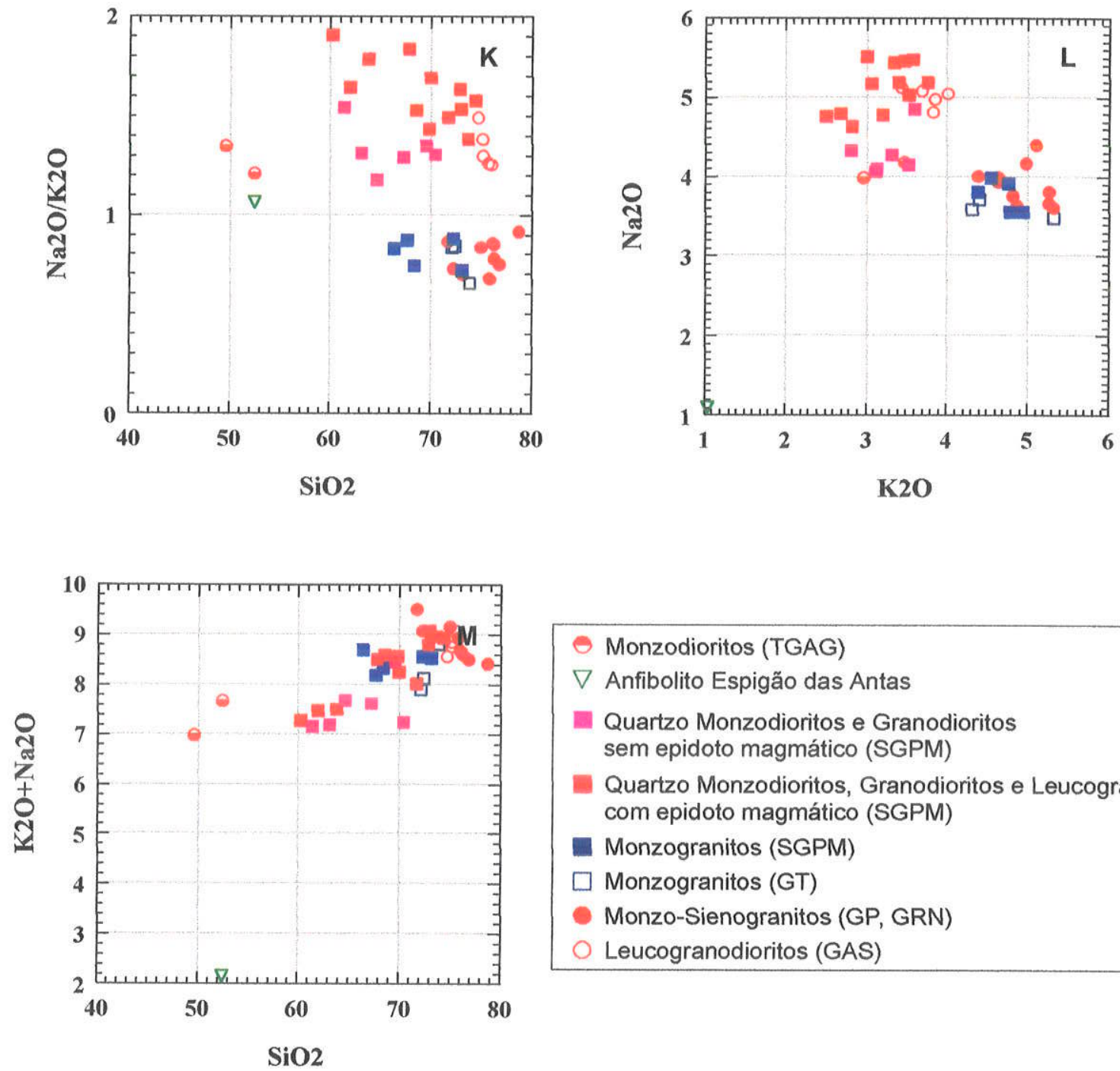

- Monzodioritos (TGAG)

$\nabla$ Anfibolito Espigão das Antas

Quartzo Monzodioritos e Granodioritos sem epidoto magmático (SGPM)

Quartzo Monzodioritos, Granodioritos e Leucogranodioritos com epidoto magmático (SGPM)

Monzogranitos (SGPM)

$\square$ Monzogranitos (GT)

Monzo-Sienogranitos (GP, GRN)

Leucogranodioritos (GAS)

Figura 6.3 - Diagramas de variação $\mathrm{SiO}_{2} \mathrm{X}$ óxidos $\left(\mathrm{TiO}_{2}, \mathrm{MnO}, \mathrm{P}_{2} \mathrm{O}_{3}, \mathrm{CaO}, \mathrm{Fe}_{2} \mathrm{O}_{3}, \mathrm{MgO}, \mathrm{Na}_{2} \mathrm{O}\right.$ e $\mathrm{K}_{2} \mathrm{O}$ :limites de Rickwood et al. 1989), $\mathrm{Na}_{2} \mathrm{O} / \mathrm{K}_{2} \mathrm{O}, \mathrm{K}_{2} \mathrm{O} \times \mathrm{Na}_{2} \mathrm{O}$ e $\mathrm{SiO}_{2} \times \mathrm{K}_{2} \mathrm{O}+\mathrm{Na}_{2} \mathrm{O}$, para as rochas da SGPM e dos Granitos GT.GP, GAS e GRN. Valores dos óxidos em (\% rocha total). 

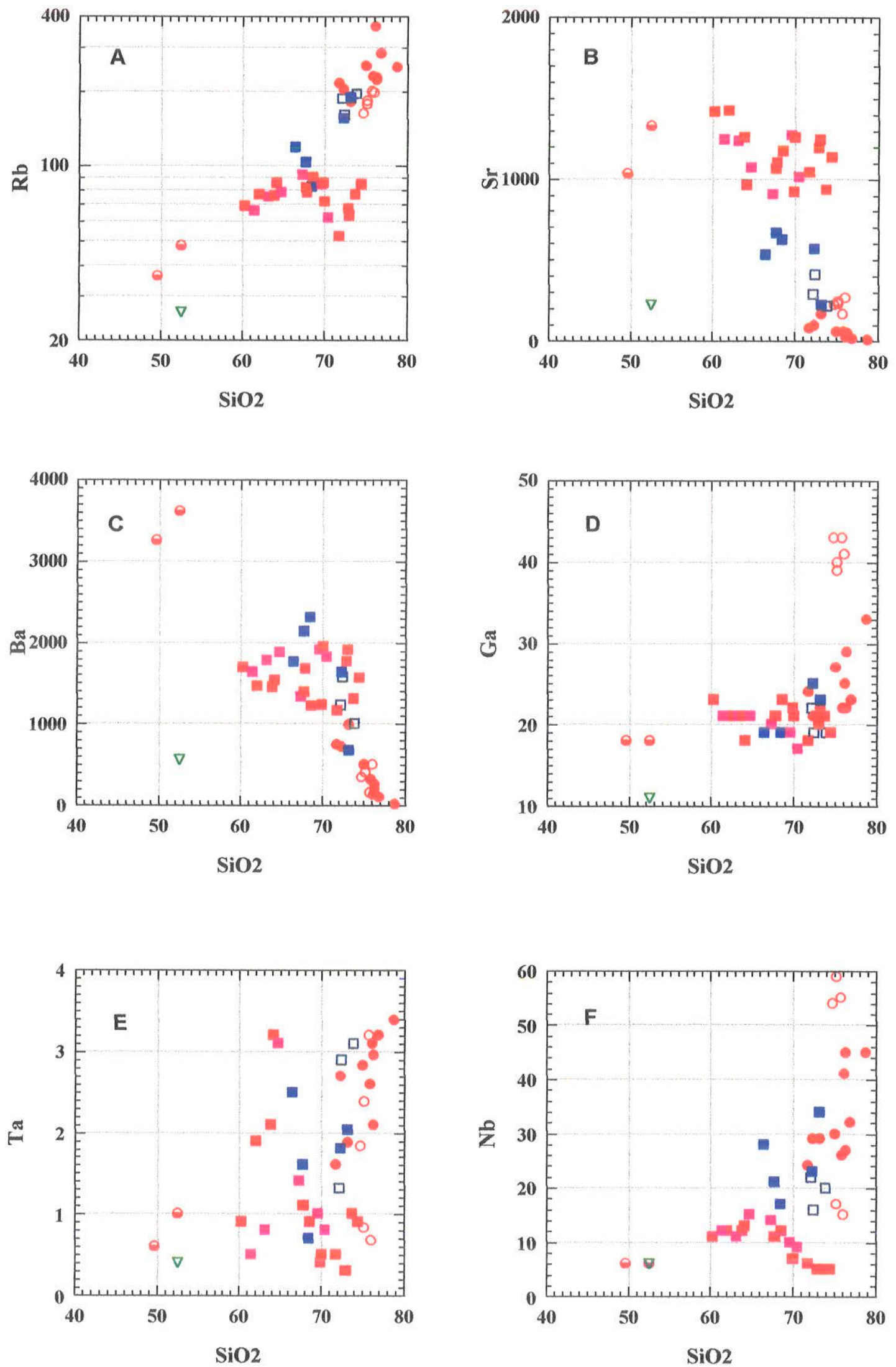

Figura 6.4 - Ver legenda página 113 

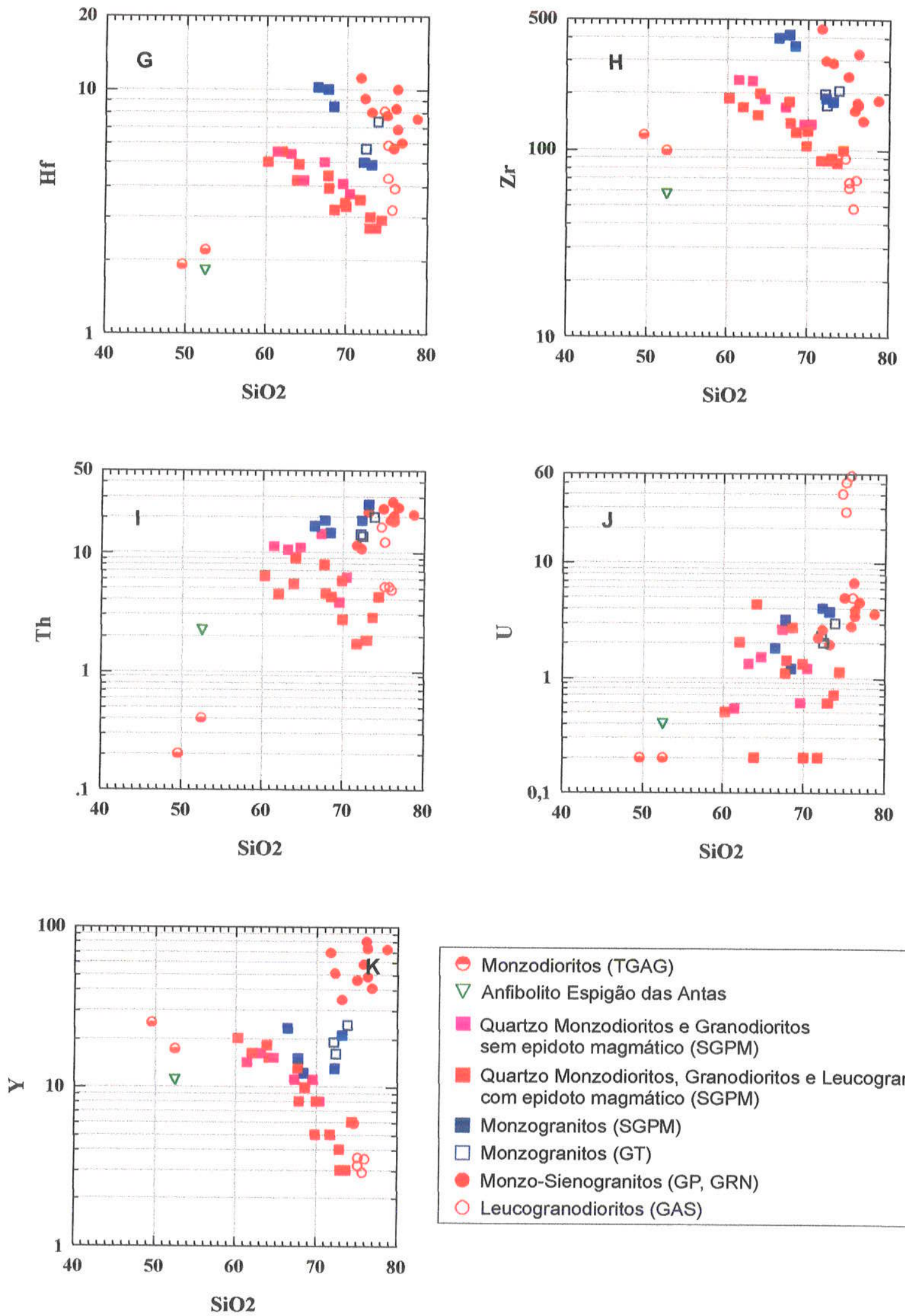

- Monzodioritos (TGAG)

$\nabla$ Anfibolito Espigão das Antas

Quartzo Monzodioritos e Granodioritos sem epidoto magmático (SGPM)

- Quartzo Monzodioritos, Granodioritos e Leucogranodioritos com epidoto magmático (SGPM)

Monzogranitos (SGPM)

$\square$ Monzogranitos (GT)

Monzo-Sienogranitos (GP, GRN)

Leucogranodioritos (GAS)

Figura 6.4 - Ver legenda página 113 

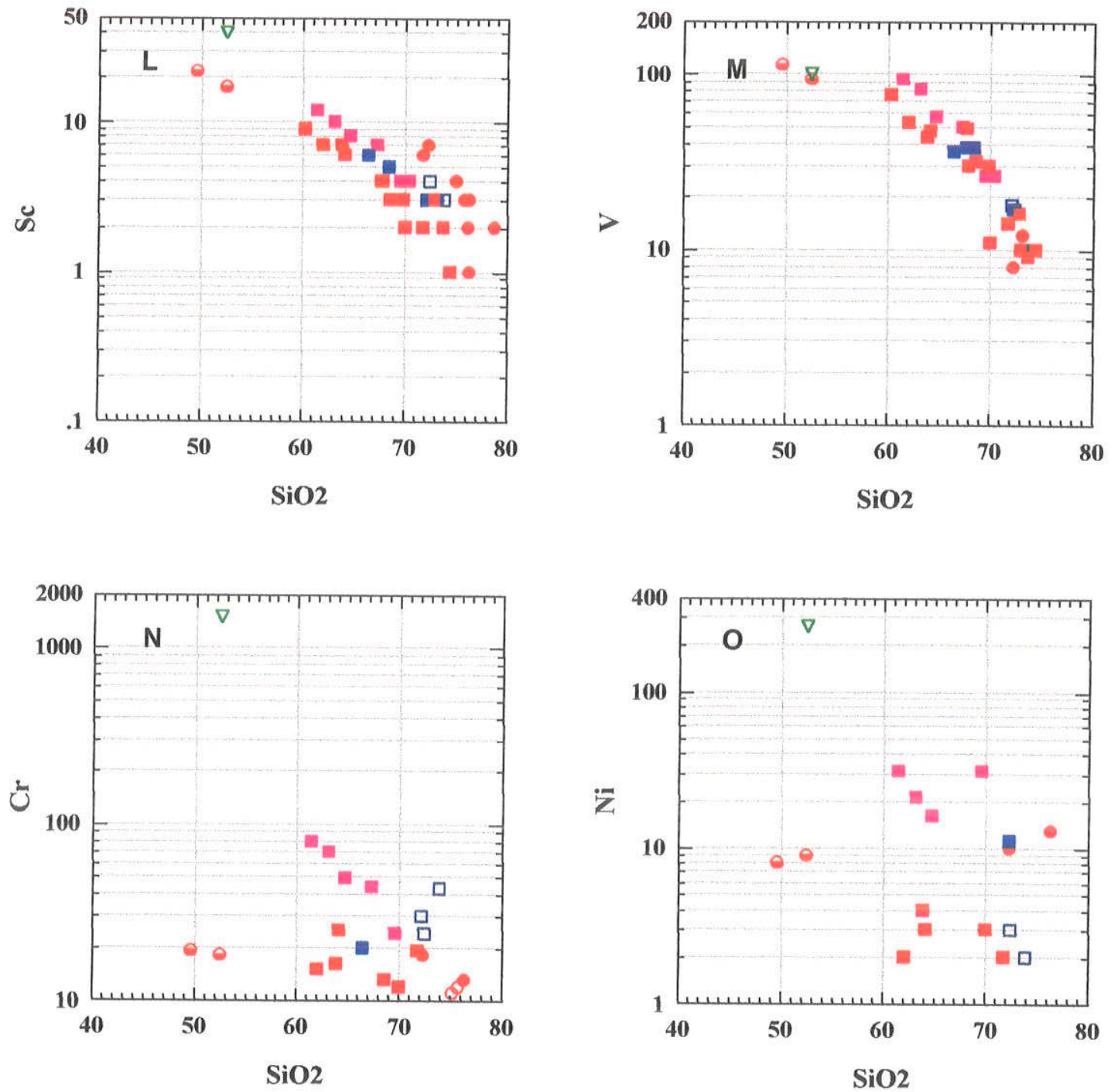

Figura 6.4 - Diagramas de variação $\mathrm{SiO}_{2} \mathrm{X}$ elementos traços (Rb, $\mathrm{Sr}, \mathrm{Ba}, \mathrm{Ga}, \mathrm{Ta}, \mathrm{Nb}, \mathrm{Hf}, \mathrm{Zr}, \mathrm{Th}, \mathrm{U}, \mathrm{Y}, \mathrm{Sc}, \mathrm{V}$, $\mathrm{Cr}$ e Ni) para as rochas da SGPM e dos Granitos GT GP, GAS e GRN. Valores dos elementos traços em ppm.
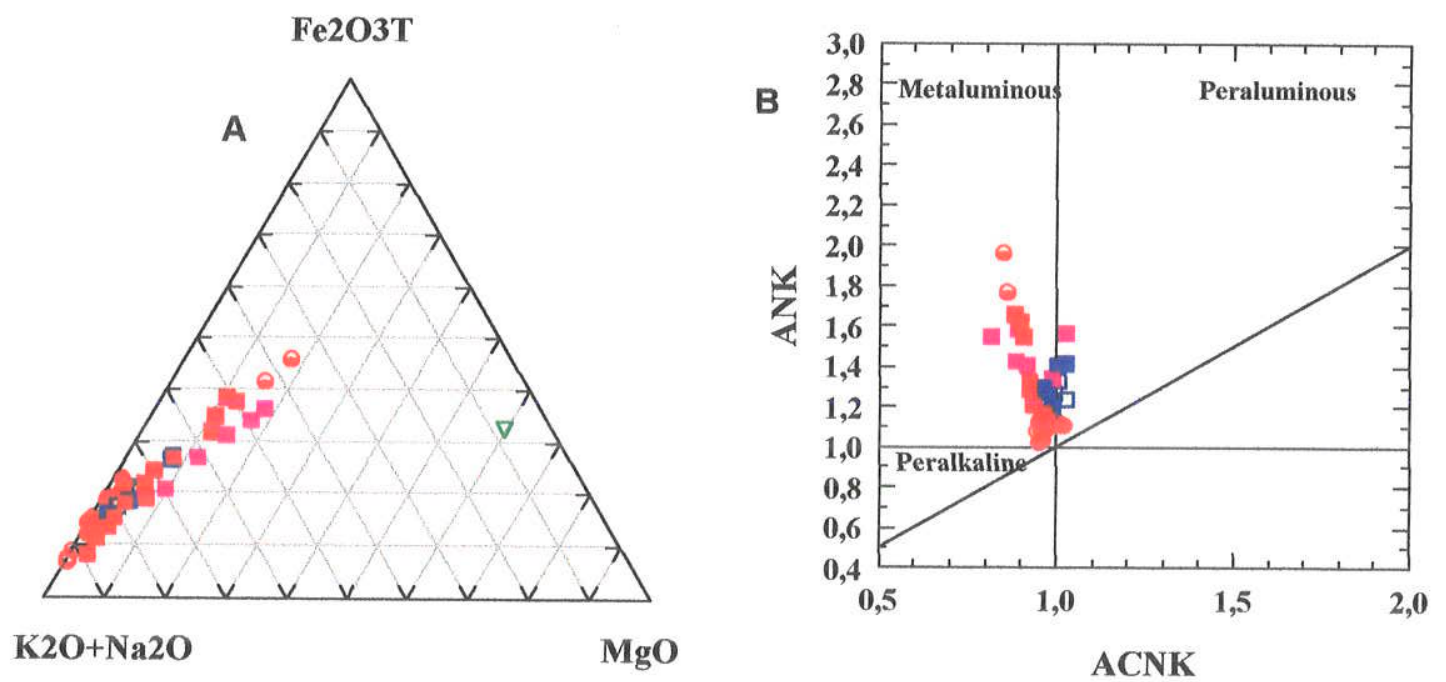

Figura 6.5 - Ver legenda página 114 

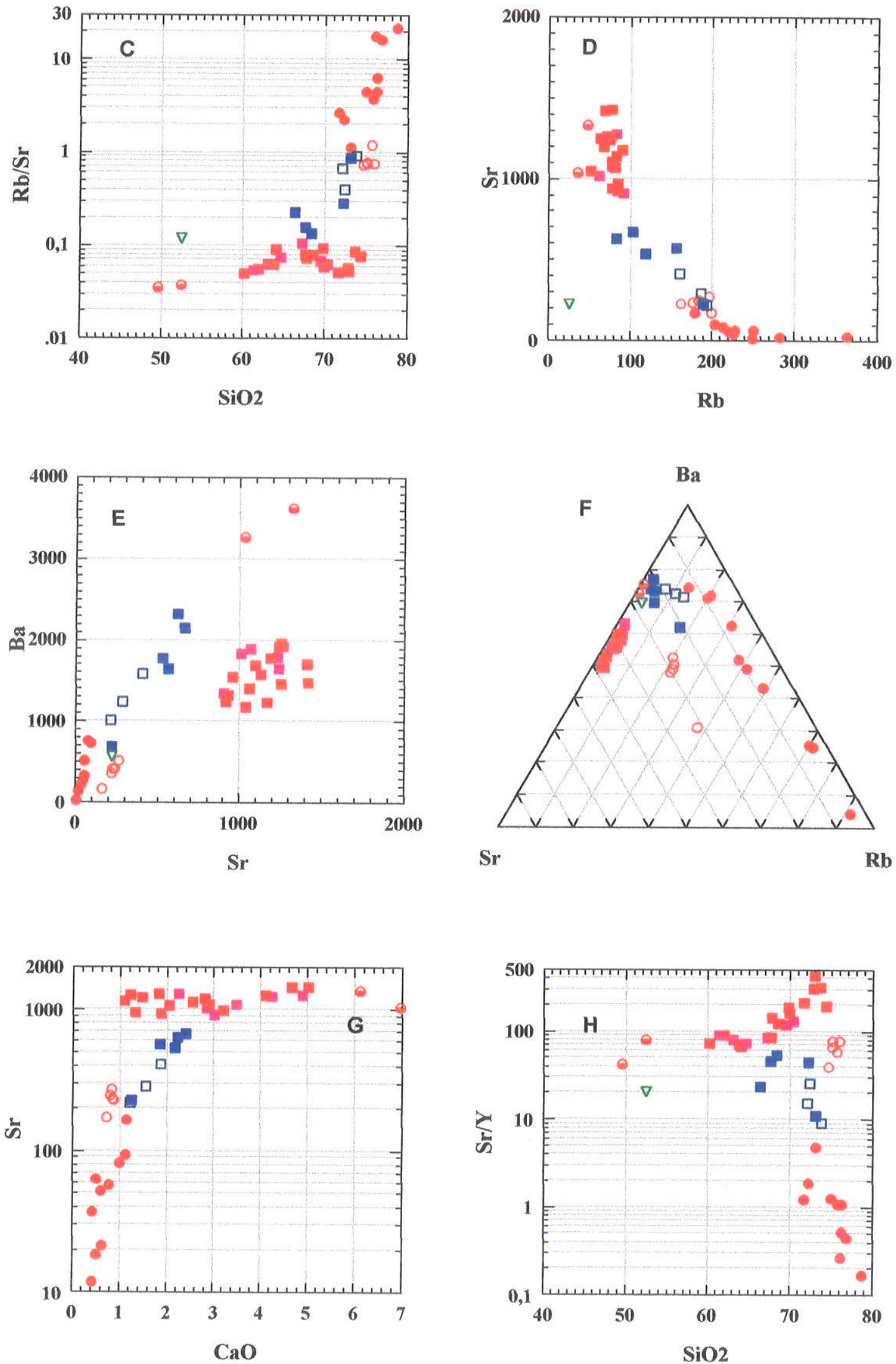

Figura 6.5 - Diagramas $\left(\mathrm{K}_{2} \mathrm{O}+\mathrm{Na}_{2} \mathrm{O}-\mathrm{Fe}_{2} \mathrm{O}_{3}-\mathrm{MgO}\right.$, fonte: Irvine \& Baragar 1971), $\mathrm{Al}_{2} \mathrm{O}_{3} / \mathrm{CaO}+\mathrm{Na}_{2} \mathrm{O}+\mathrm{K}_{2} \mathrm{O}$ I $\mathrm{Al}_{2} \mathrm{O}_{3} / \mathrm{Na}_{2} \mathrm{O}+\mathrm{K}_{2} \mathrm{O}$, fonte: Maniar \& Piccoli 1989), $\mathrm{SiO}_{2}$ X Rb/Sr, Rb X Sr, Sr X Ba, Sr-Ba-Rb, CaO X Sr e $\mathrm{SiO}_{2} \mathrm{X} \mathrm{Sr} / \mathrm{Y}$ para as rochas da SGPM e dos Granitos GT, GP, GAS e GRN. 

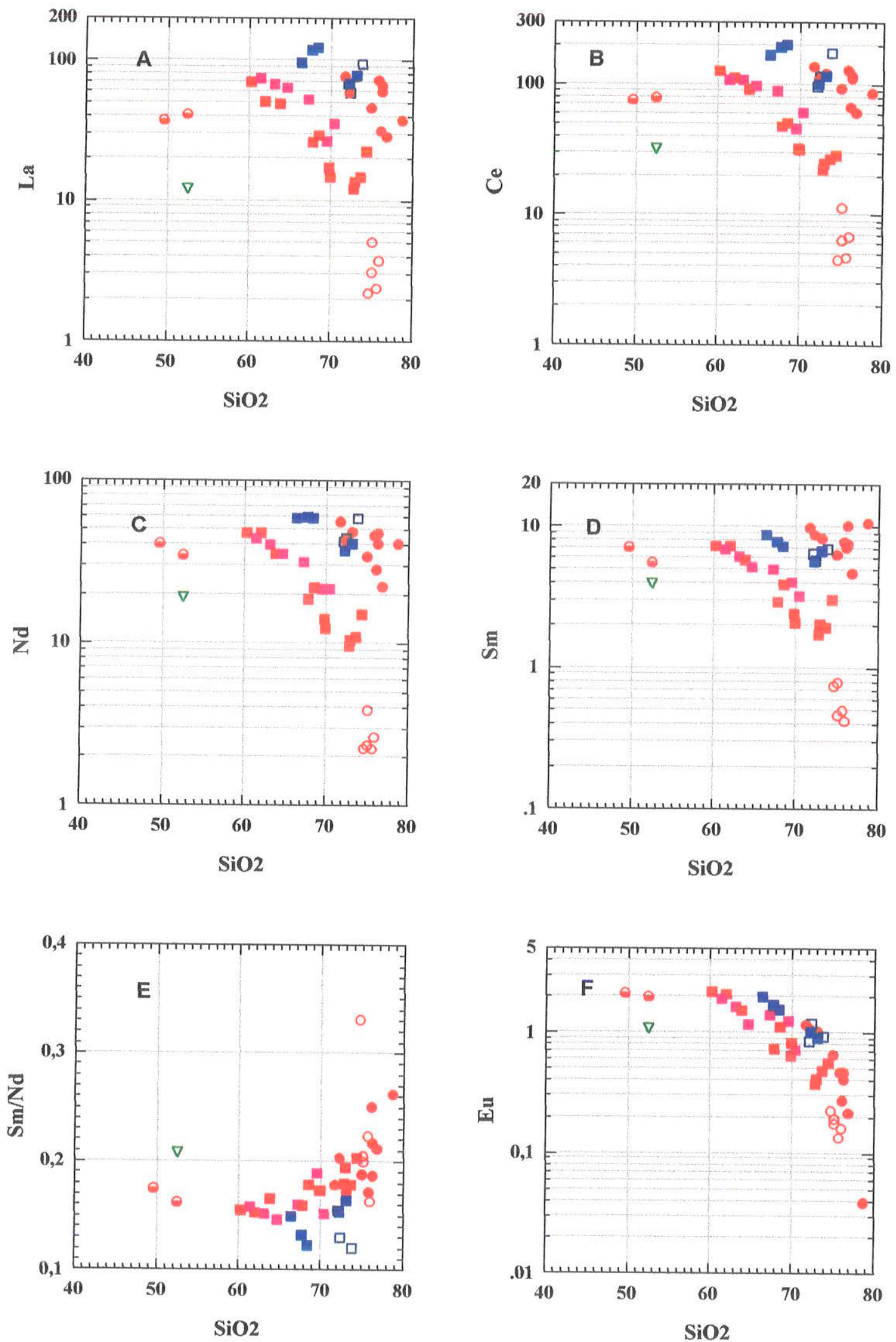

Figura 6.6 - Ver legenda página 116 

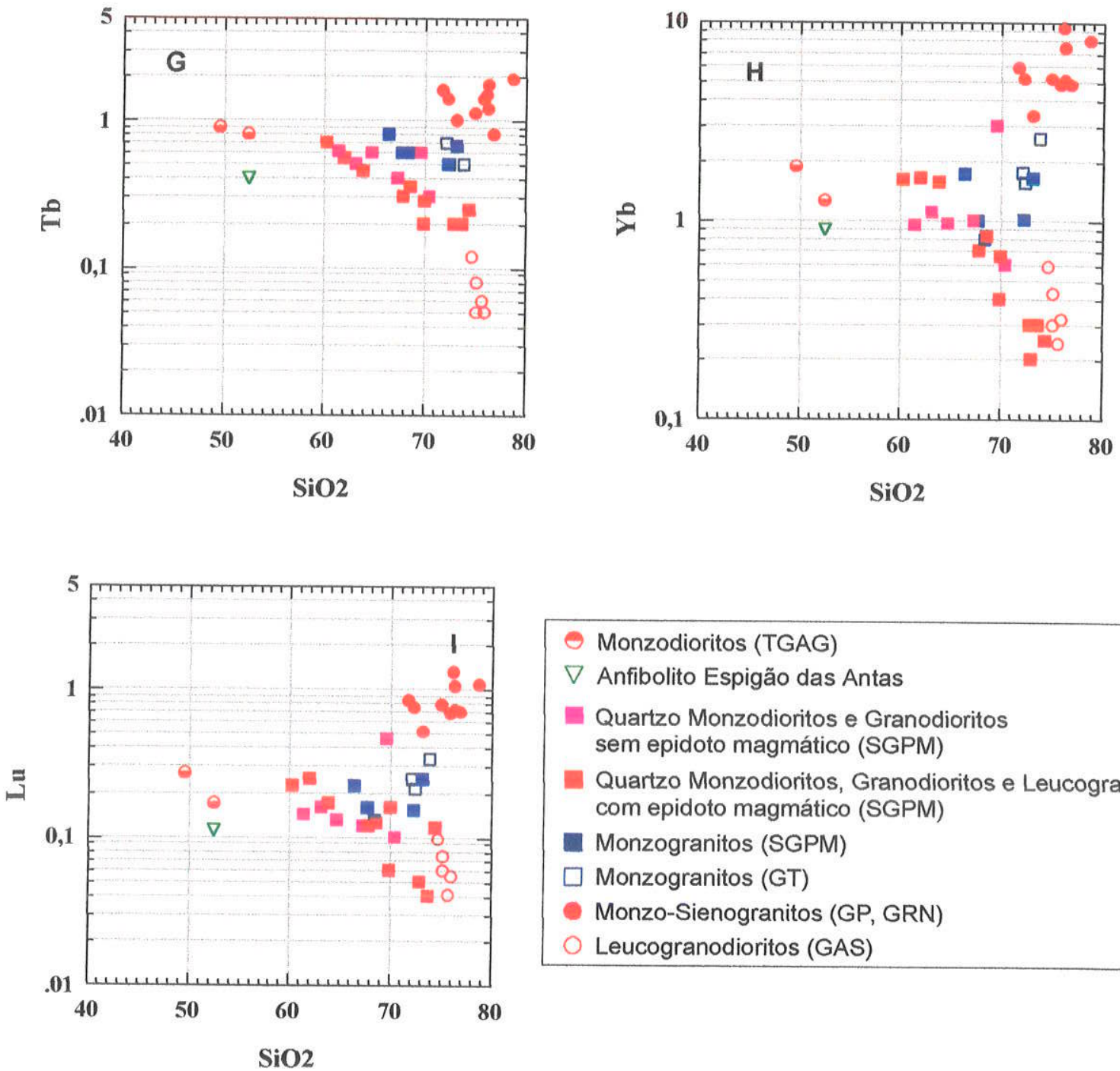

Monzodioritos (TGAG)

$\nabla$ Anfibolito Espigão das Antas

Quartzo Monzodioritos e Granodioritos sem epidoto magmático (SGPM)

Quartzo Monzodioritos, Granodioritos e Leucogranodioritos com epidoto magmático (SGPM)

Monzogranitos (SGPM)

$\square$ Monzogranitos (GT)

- Monzo-Sienogranitos (GP, GRN)

Leucogranodioritos (GAS)

Figura 6.6 - Diagramas de variação $\mathrm{SiO}_{2} \mathrm{X}$ elementos de terras raras leves (ETRL) e elementos terras raras pesadas (ETRP) para as rochas da SGPM e dos Granitos GT, GP, GAS e GRN. Valores de ETRL e ETRP em ppm.

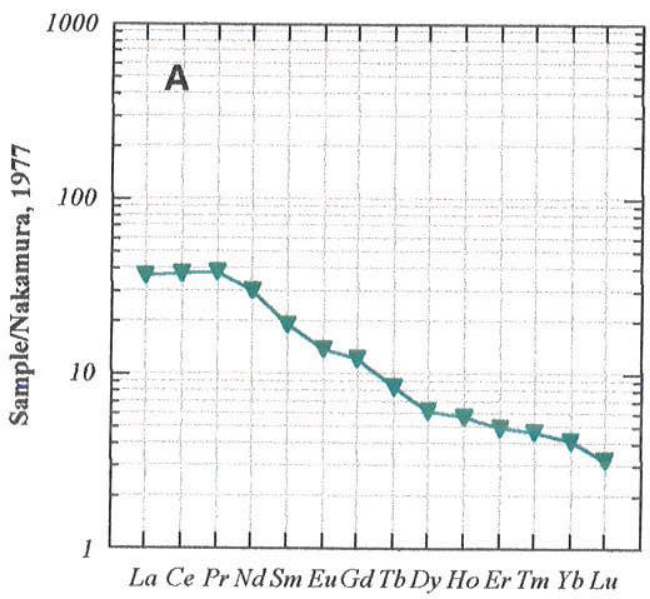

Figura 6.7 - Ver legenda página 117 

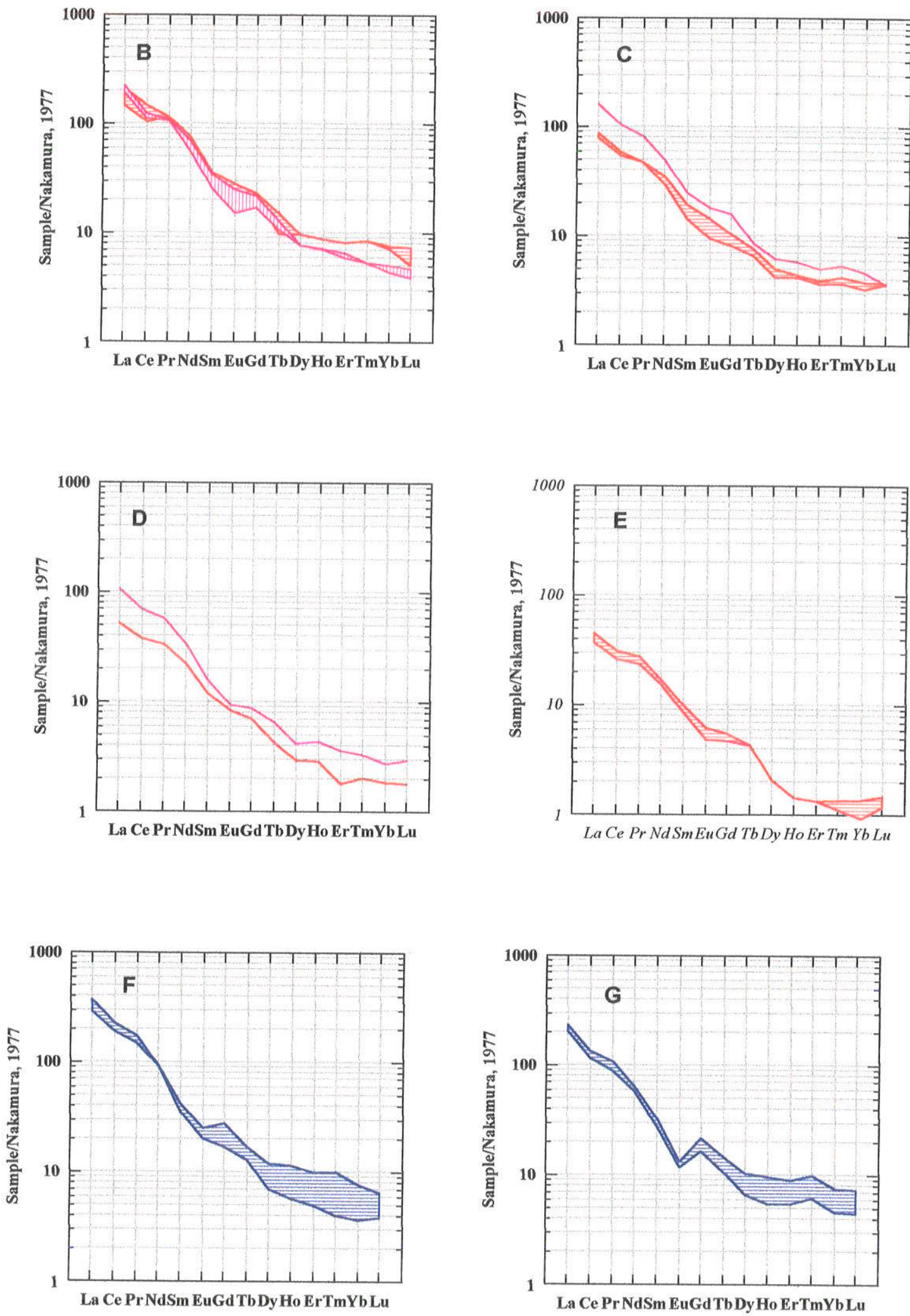

Figura 6.7 - Diagramas elementos terras raras para os principais litotipos graníticos da SGPM. Normalização ao condrito (Nakamura 1974). A: Anfibolito Espigão das Antas $\left(\mathrm{SiO}_{2}=51-52 \%\right)$. B: QuartzoMonzodioritos com e sem epidoto magmático $\left(\mathrm{SiO}_{2}=60-65 \%\right)$. Preenchimento com linhas horizontais de cor vermelha são as rochas com epídoto magmático e preenchimento com linhas verticais de cor rosa são as rochas sem epídoto magmático. C: Quartzo monzodioritos/granodioritos com e sem epídoto magmático $\left(\mathrm{SiO}_{2}=65-70 \%\right)$. D: Leucogranodioritos com epídoto magmático $\left(\mathrm{SiO}_{2}=70-75 \%\right)$. E: Monzogranitos $\left(\mathrm{SiO}_{2}=66-\right.$ $69 \%)$. F: Monzogranitos $\left(\mathrm{SiO}_{2}=72-73 \%\right)$. 

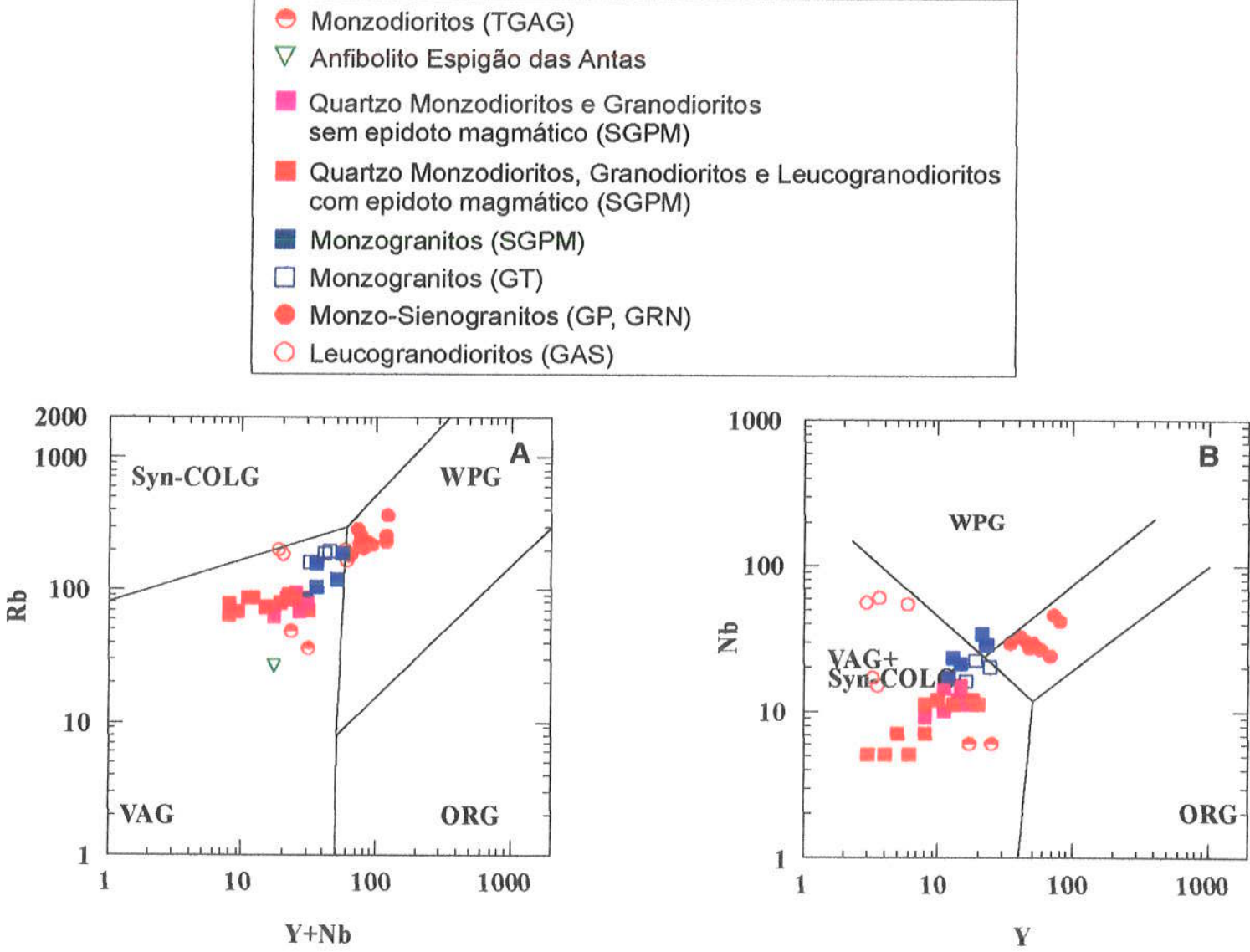

Figura 6.8 - Diagramas Rb X Y+Nb e Nb X Y (Fonte : Pearce et al. 1984 e Harris et al. 1988) discriminantes dos principais ambientes geotectônicos produtores de rochas graníticas, aplicado para as rochas graníticas da SGPM e dos Granitos GT, GP, GRN e GAS.

Granitos de fusões supracrustais = granitos sin-colisionais, tipo S (Chappel e White 1974) incluindo os tardi e pós colisionais (tipo S) e os de ambientes extensionais formados por fusões supracrustais ou por alta assimilação e/ou contaminação crustal.

WPG = Granitos Intraplaca, típicos granitos tipo A (Chappel e White 1974) ou PA (peralcalinos), póstectônicos/pôs-orogênicos e anorogênicos.

$V A G=$ Granitos calcio alcalinos de baixo, médio e alto $\mathrm{K}$ de arcos magmáticos de margens continentais ativas, tipo I (Chappel e White 1974) incluindo os tardi a pós tectônicos/pós orogênicos associados e influenciados pela mesma fonte (componente mantélica e crustal) em zonas de subducção.

ORG = hipotéticos Granitos formados em cadeias Médio-Oceânicas, plagiogranitos, tipo M (Chappel e White 1974). 


\section{6 - Geocronologia}

Nesta seção são apresentados, analisados e discutidos os principais resultados geocronológicos obtidos nos minerais e rochas dos principais componentes graníticos da SGPM. Os métodos geocronológicos aplicados da SGPM incluem, U-Pb em zircão e titanita, $\mathrm{Rb}-\mathrm{Sr}$ em rocha total e K-Ar em anfibólio e biotita.

As metodologias isotópicas $\mathrm{Sm}-\mathrm{Nd}$ em rocha total, a análise das razões $\mathrm{Sr}^{87} / \mathrm{Sr}$ atuais e $\mathrm{O}^{18}$ (zircão) são aplicados nos principais litotipos da SGPM, com os resultados apresentados e discutidos no Capítulo 9.0, referente à Geologia Isotópica.

A metodologia U-Pb em zircão e titanita foi aplicada aos principais componentes graníticos da SGPM, tais como, os quartzo monzodioritos com epídoto magmático (amostra OM 180), quartzo monzodioritos sem epídoto magmático (amostra OM 1106) quartzo monzodioritos/granodioritos sem epidoto magmático (amostra OM 409) e quartzo monzodioritos/granodioritos (OM 629) e, os leucogranodioritos (OM 933) com epídoto magmático. O objetivo da aplicação desta metodologia foi obter idades mais confiáveis e precisas nestas rochas, representativas da formação/cristalização dos principais componentes graníticos (com ou sem epídoto magmático) da SGPM. Estes resultados estão apresentados na Tabela 6.1 .

Os resultados U-Pb obtidos em zircões dos quartzo monzodioritos milonítcos sem epídoto magmático da porção norte da SGPM apresentaram, em diagrama concórdia U-Pb (Figura 6.9), idade do intercepto superior de $618 \pm 14 / 15 \mathrm{Ma}$. Os resultados U-Pb em titanita para os quartzo monzodioritos/granodioritos sem epídoto magmático indicaram idade próxima de $610 \mathrm{Ma}$. Quando considerados em conjunto, os resultados da titanita e das três frações de zircões fornecem idades de intercepto superior de $618 \pm 9.6 / 11 \mathrm{Ma}$ (Figura 6.9).

As temperaturas de difusão (Tc) do $\mathrm{Pb}$ em titanita situam-se entre $550 \mathrm{e} \geq 600^{\circ} \mathrm{C}$, atingindo até valores superiores do que $710^{\circ} \mathrm{C}$ (Mezger et al. 1990, Mezger 1991, Tucker et al. 1997, Cherniack 1993 e Zhang \& Scharer 1996), enquanto para o zircão estas temperaturas variam, de 650 a $>900{ }^{\circ} \mathrm{C}$ (Mezger 1991, Lee et al. 1997). Nas rochas estudadas, a similaridade ou mesmo superposição entre os valores obtidos para ambos os minerais indicam que estas representam a idade da formação/cristalização dos quartzo monzodioritos sem epídoto magmático da SGPM, que está ao redor de $618 \mathrm{Ma}$. O diagrama concórdia (Figura 6.9) destas rochas mostra que os resultados analíticos U-Pb em titanita são mais concordantes do que os resultados da fração $(M-3)$ de zircão, mais concordante. O sistema U-Pb em titanita nesta rocha é bem menos sensivel para a abertura do seu cronômetro do que o sistema U.Pb em zircão, que mostra sinais de perda de $\mathrm{Pb}$ radiogênico. 
Tabela 6.1 - Análises isotópicas U-Pb em zircões e titanitas dos litotipos graníticos da SGPM

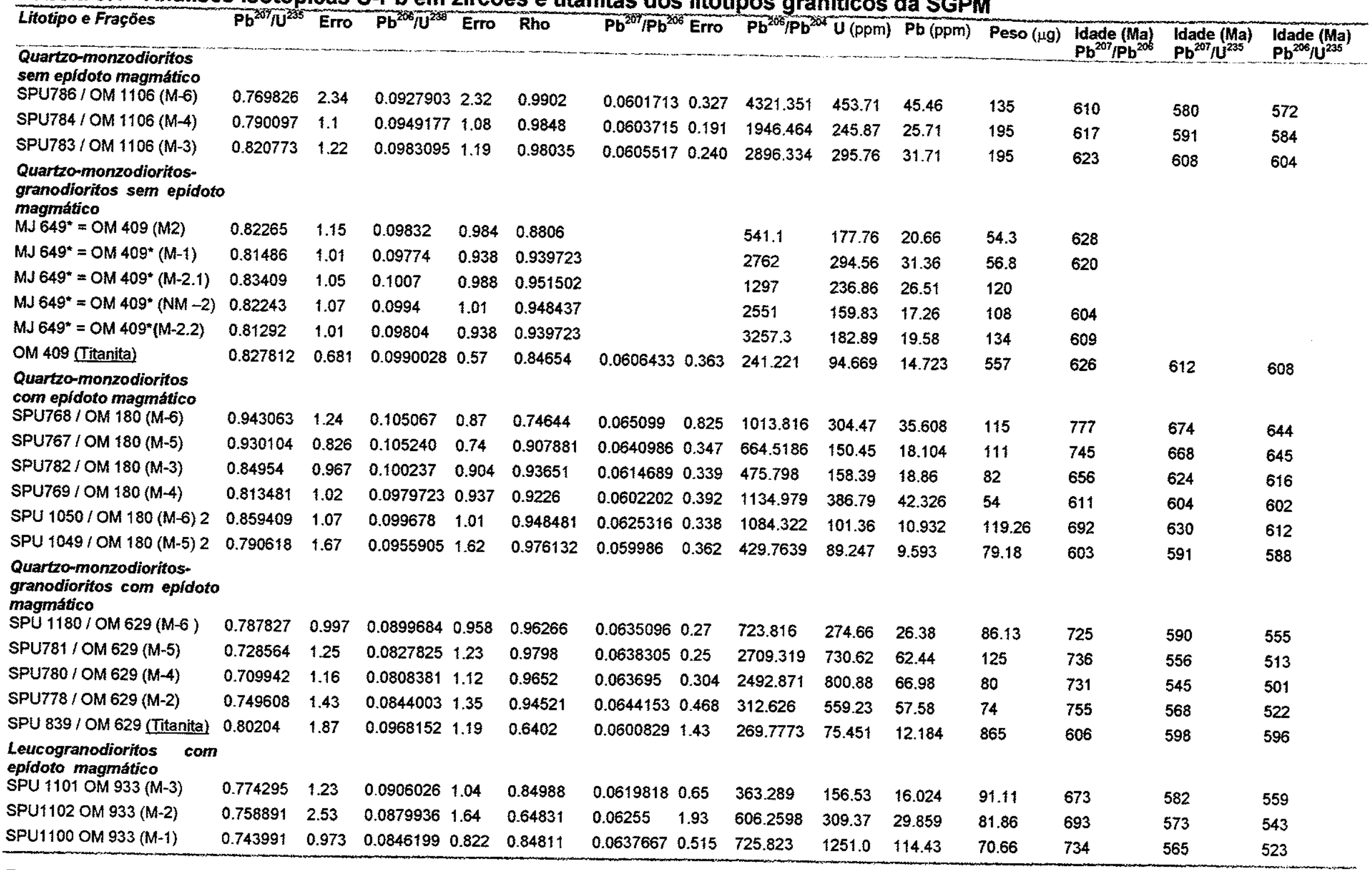

Dados retirados de Siga Jr. 1995 e Basei 2000 

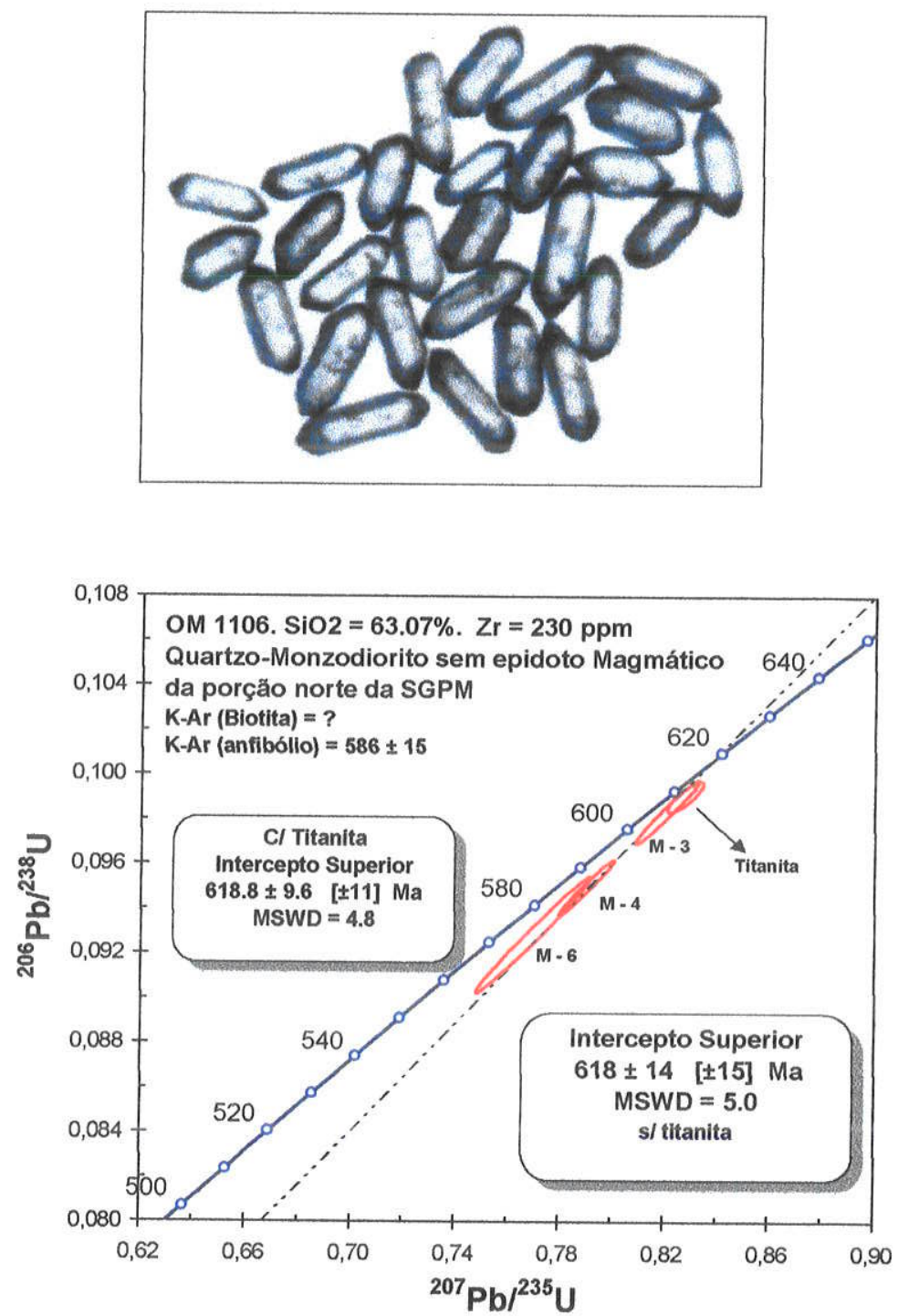

Figura 6.9 - Diagrama concórdia U-Pb para os zircões e titanita dos quartzo monzodioritos sem epídoto magmático da porção norte da SGPM.

Os resultados de zircão e titanita destes quartzo monzodioritos não apresentam, no diagrama concórdia, indicações de herança de componentes isotópicos U-Pb dos protólitos. Os zircões ou núcleos de zircões herdados (potenciais carregadores do $\mathrm{Pb}$ radiogênico herdado) da rocha fonte devem ter sido completamente destruídos durante os processos de formação e, provavelmente, deformação destas rochas.

Os resultados U-Pb em zircão dos quartzo monzodioritos/granodioritos miloníticos, sem epídoto magmático foram obtidos por Siga Jr. (1995) e recalculados por Basei (2000), com a adição de novos resultados em zircões desta rocha. Os resultados U-Pb em titanita são inéditos. Zircões abradados e não abradados da mesma fração de zircão não apresentaram diferenças nas razões U-Pb obtidas. Os resultados U-Pb em zircão e titanita são apresentados no diagrama concórdia (Figura 6.10) e indicaram idades do intercepto superior de $613 \pm 13 / 14 \mathrm{Ma}$ (sem titanita) e 616 (614) $\pm 11 / 12 \mathrm{Ma}$ (com titanita) interpretadas 
como a idade da formação/cristalização destas rochas. Frações de zircões concordantes (Figura 6.10) com idades de $\pm 615 \mathrm{Ma}, 608.6 \pm 4.8 \mathrm{Ma}$ e $604.5 \pm 4.6 \mathrm{Ma}$, também foram obtidas. Esta última idade ao redor de $605 \mathrm{Ma}$ é também encontrada nos quartzo monzodioritos com epídoto magmático. A análise conjunta dos resultados $\mathrm{U}-\mathrm{Pb}$ em zircão e titanita dos quartzo monzodioritos e quartzo monzodioritos/granodioritos sem epídoto magmático (cogenéticos) indicaram, em diagrama concórdia (Figura 6.11), idades do intercepto superior de $616 \pm 6 / 6.7 \mathrm{Ma}$ (sem titanita) e $615 \pm 6.3 \mathrm{Ma}$ (com titanita). Quando excluirmos os zircões concordantes dos quartzo monzodioritos/granodioritos obtemos idades de intercepto superior de $620(618) \pm 6 / 8$.
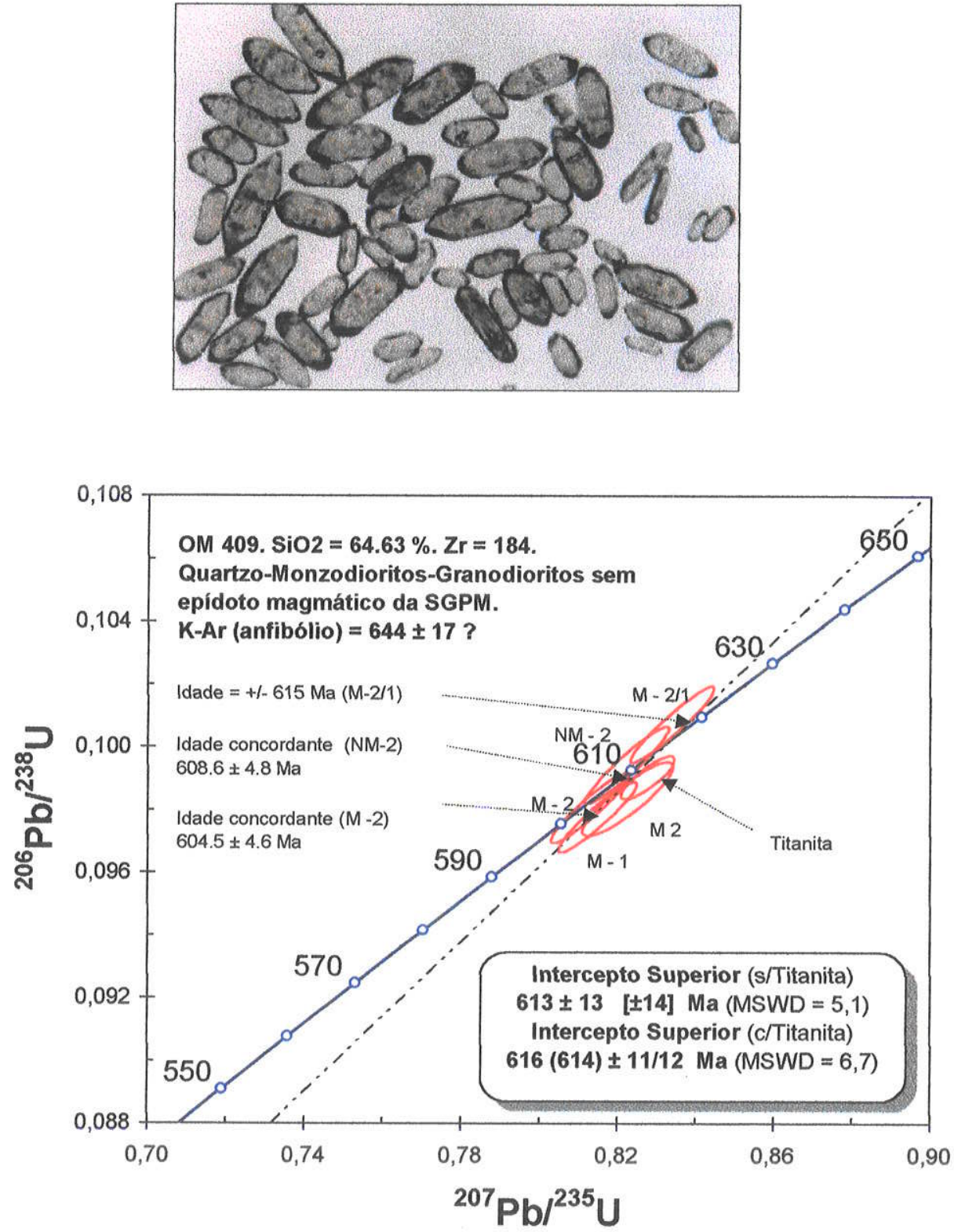

Figura 6.10 - Diagrama concórdia U-Pb para os zircões e titanita dos quartzo monzodioritos/granodioritos sem epídoto magmático da SGPM. As análises analíticos U-Pb em zircão desta rocha (Siga Jr. 1995) são recalculados com a adição de novas análises por (Basei 2000). Os resultados U-Pb em titanita são inéditos. 


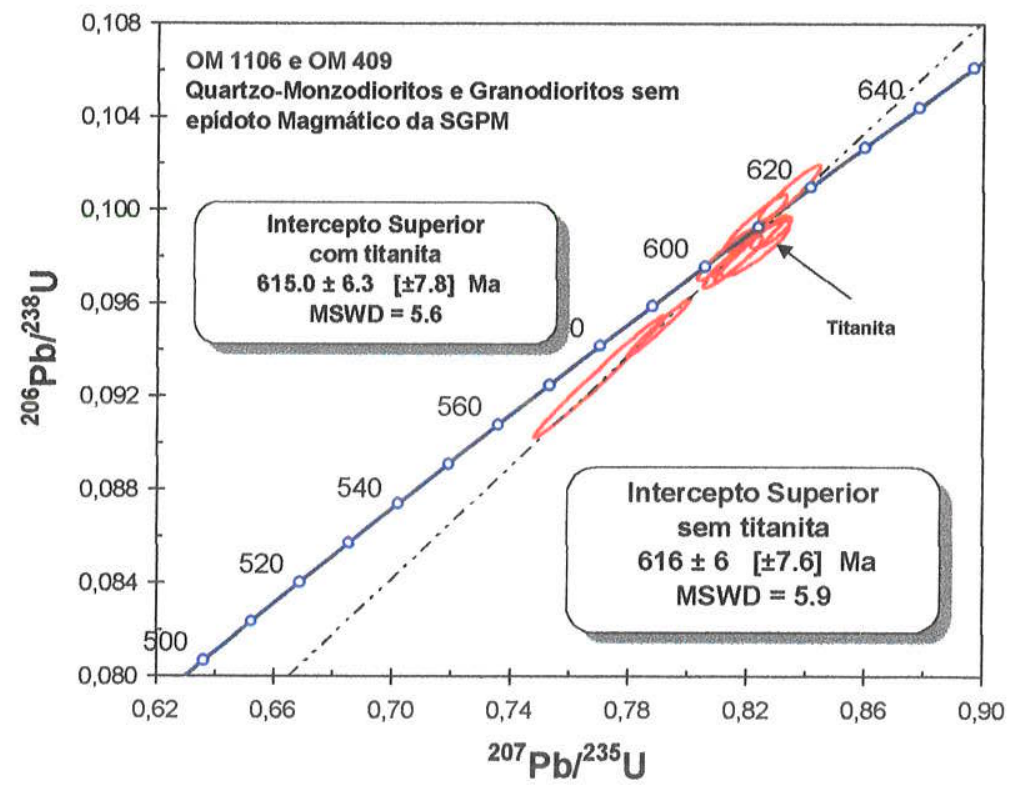

Figura 6.11 - Diagrama concórdia U-Pb para os zircões e titanita dos quartzo monzodioritos e quartzo monzodioritos/granodioritos sem epídoto magmático da porção norte e sul da SGPM.

As idades do intercepto superior, com ou sem titanita, para os quartzo monzodioritos/granodioritos sem epídoto magmático são relativamente mais jovens do que as obtidas para os quartzo monzodioritos sem epídoto magmático, levando-se em consideração de que os dois tipos apresentam valores próximos de erros nas idades da ordem de $10 \mathrm{Ma}$. Não há indicação de herança (Figuras 6.9 e 6.10) em nenhuma das rochas com epídoto magmático.

Os resultados obtidos para os quartzo monzodioritos e quartzo monzodioritos/granodioritos indicam o intervalo de 620-615 Ma para a formação/cristalização dos quartzo monzodioritos sem epidoto magmático e 615-610 Ma para a formação/cristalização dos seus cogenéticos quartzo monzodioritos-granodiortios.

Os resultados U-Pb obtidos em zircões nos quartzo monzodioritos protomiloníticos a miloníticos com epídoto magmático da SGPM (Figura 6.12) indicam sinais de herança em seus zircões, com idade do intercepto superior de $1650 \pm 650 \mathrm{Ma}$ ou $1650 \pm 650 \mathrm{Ma}$ e idade do intercepto inferior de $597 \pm 28 \mathrm{Ma}$ ou $594 \pm 21 \mathrm{Ma}$. As duas frações de zircões concordantes que definem o intercepto inferior apresentam idades de 604.7 $\pm 4.7 \mathrm{Ma}$ e 597 $596 \mathrm{Ma}$. A idade do intercepto inferior é próxima da idade K-Ar em biotita (595 $\pm 12 \mathrm{Ma}$, Tabela 6.2) da mesma rocha e da concordante idade U-Pb em titanita de 596.2 $\pm 6.7 \mathrm{Ma}$ (Figura 6.13). A fração de zircão concordante, que define o intercepto inferior nesta rocha, tem idade ao redor de $605 \pm 5 \mathrm{Ma}$, sendo representativa da idade da formação/cristalização 
destes quartzo monzodioritos com epídoto magmático. Esta idade concordante foi obtida somente em uma única fração dos quartzo monzodioritos/granodioritos sem epídoto.

Ao contrário dos quartzo monzodioritos sem epídoto magmático, os resultados U-Pb em zircão dos quartzo monzodioritos com epídoto magmático sugerem herança de componentes isotópicos de $\mathrm{Pb}$ radiogênico de seus protólitos. Os indícios desta herança estão presentes na maioria das frações de zircão desta última, sugerindo a incapacidade de eliminar a memória dos componentes isotópicos paleoproterozóicos (?). O $\mathrm{Pb}$ radiogênico herdado foi preservado em núcleos (?) de zircões, com a cristalização de novos grãos durante sua formação, ao redor de $605 \pm 5$ Ma. Estes quartzo monzodioritos, componentes graníticos inicias das rochas da SGPM com epídoto magmático, são rochas propícias a registrar herança e idade da formação/cristalização destas rochas.
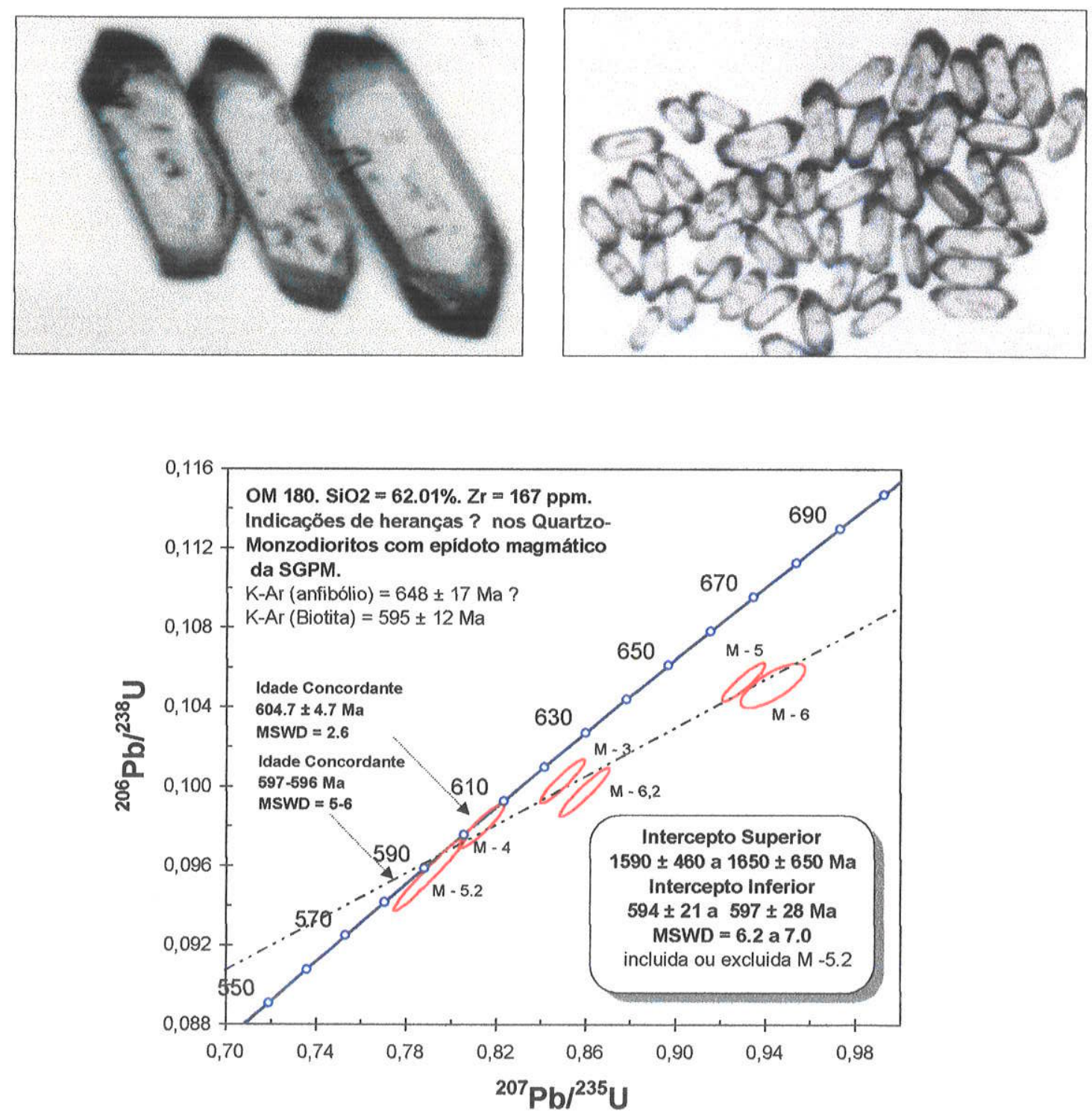

Figura 6.12 - Diagrama concórdia U-Pb para os zircões dos quartzo monzodioritos com epídoto magmático da SGPM. 
Tabela 6.2 - Análises isotópicas e idades K-Ar (biotita e anfibólio) dos principais litotipos graníticos da SGPM.

\begin{tabular}{|c|c|c|c|c|c|c|}
\hline No. Amostra & Litotipo & Mineral & $K(\%)$ & $\begin{array}{l}\mathrm{Ar}^{40} \text { Rad. } \\
10^{-6} \text { cCSTP/G }\end{array}$ & $\begin{array}{l}\% A r^{40} \\
\text { atm }\end{array}$ & $\begin{array}{c}\text { Idade } \\
\text { M.a }\end{array}$ \\
\hline $\begin{array}{l}\text { OM } 182-105 \\
\text { OM } 414 \\
\text { OM } 409-649 \\
\text { OM } 335\end{array}$ & $\begin{array}{l}\text { Quartzo -monzodiorito/epídoto } \\
\text { Quartzo-monzodiorito } \\
\text { Quartzo -monzodiorito } \\
\text { Quartzo -monzodiorito a } \\
\text { granodiorito/epidoto }\end{array}$ & $\begin{array}{l}\text { Anfibólio } \\
\text { Anfibólio } \\
\text { Anfibólio } \\
\text { Biotita }\end{array}$ & $\begin{array}{l}1.2362 \\
1.3824 \\
0.9206 \\
6.2630\end{array}$ & $\begin{array}{c}37.42 \\
41.64 \\
27.67 \\
175.58\end{array}$ & $\begin{array}{l}15.27 \\
6.65 \\
4.03 \\
1.93\end{array}$ & $\begin{array}{l}648 \pm 17 \\
645 \pm 13 \\
644 \pm 17 \\
607 \pm 13\end{array}$ \\
\hline OM 04 & $\begin{array}{l}\text { Quartzo - monzodiorito a } \\
\text { granodiorito/epídoto }\end{array}$ & Biotita & 6.8934 & 192.76 & 1.50 & $606 \pm 11$ \\
\hline $\begin{array}{l}\text { OM } 416 \\
\text { OM } 182 \\
\text { OM } 1106\end{array}$ & $\begin{array}{l}\text { Monzogranitos } \\
\text { Quartzo - monzodiorito/epídoto } \\
\text { Quartzo - monzodiorito/eípdoto }\end{array}$ & $\begin{array}{l}\text { Biotita } \\
\text { Biotita } \\
\text { Anfibólio }\end{array}$ & $\begin{array}{l}6.6655 \\
6.5191 \\
0.9263\end{array}$ & $\begin{array}{l}183.5 \\
178.52 \\
24.90\end{array}$ & $\begin{array}{l}3.12 \\
2.40 \\
16.46\end{array}$ & $\begin{array}{l}598 \pm 14 \\
595 \pm 12 \\
586 \pm 15\end{array}$ \\
\hline
\end{tabular}

São utilizados, nestas análises K-Ar, concentrados de minerais de biotita e anfibólio entre $100 \mathrm{mesh}(0.150 \mathrm{~mm})$ e 150 mesh $(0.106 \mathrm{~mm})$ e raramente concentrados entre 60 mesh $(0.250 \mathrm{~mm})$ e 100 mesh.
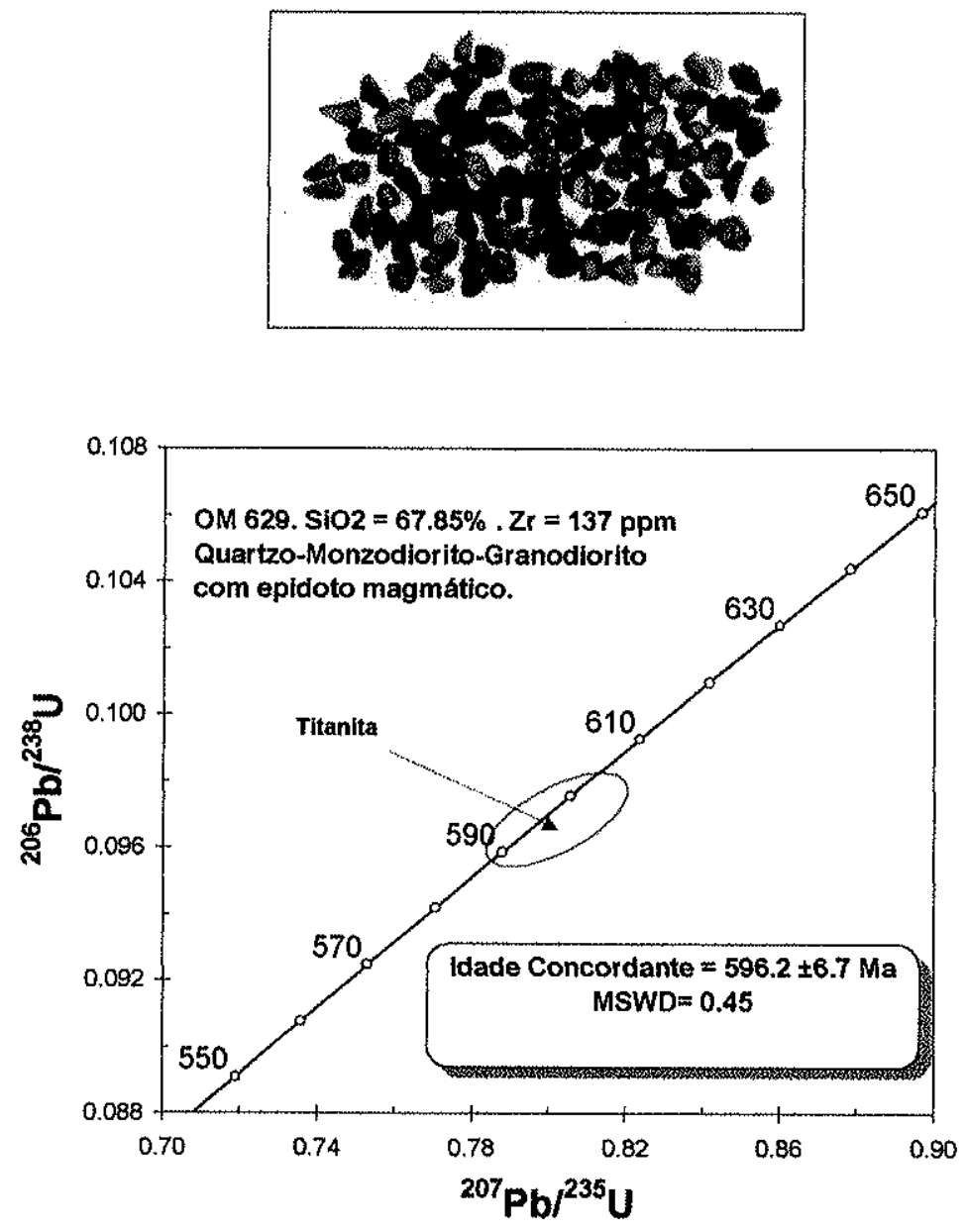

Figura 6.13 - Diagrama concórdia U-Pb para titanita dos quartzo monzodioritos/granodioritos protomiloniticos com epídoto magmático da SGPM.

O resultado em uma fração de titanita dos quartzo monzodioritos/granodioritos protomiloníticos com epídoto magmático (Figura 6.13) indicou, em diagrama concórdia U$\mathrm{Pb}$, idade concordante de 596.2 $\pm 6.7 \mathrm{Ma}$, interpretada como a idade da cristalização deste mineral. Este resultado está dentro do intervalo de resfriamento dos quartzo monzodioritos 
com epídoto magmático e dos litotipos da SGPM em geral, cogenéticos. Resultados U-Pb em 4 frações de zircões desta mesma rocha e em 3 frações de zircões dos leucogranodioritos com epídoto magmático foram testados em conjunto com os dados U-Pb em titanita e zircões concordantes dos quartzo monzodioritos cogenéticos. Os diagramas concórdia (Figuras 6.14 e 6.15) mostram, considerando-se ou não os últimos, idades do intercepto superior de $602 \pm 14 \mathrm{Ma}, 604 \pm 16 \mathrm{Ma}$ e $602 \pm 10 \mathrm{Ma}$, respectivamente, interpretadas como $\circ$ período da formação/cristalização dos quartzo monzodioritos/granodioritos e leucogranodioritos com epídoto magmático da SGPM.
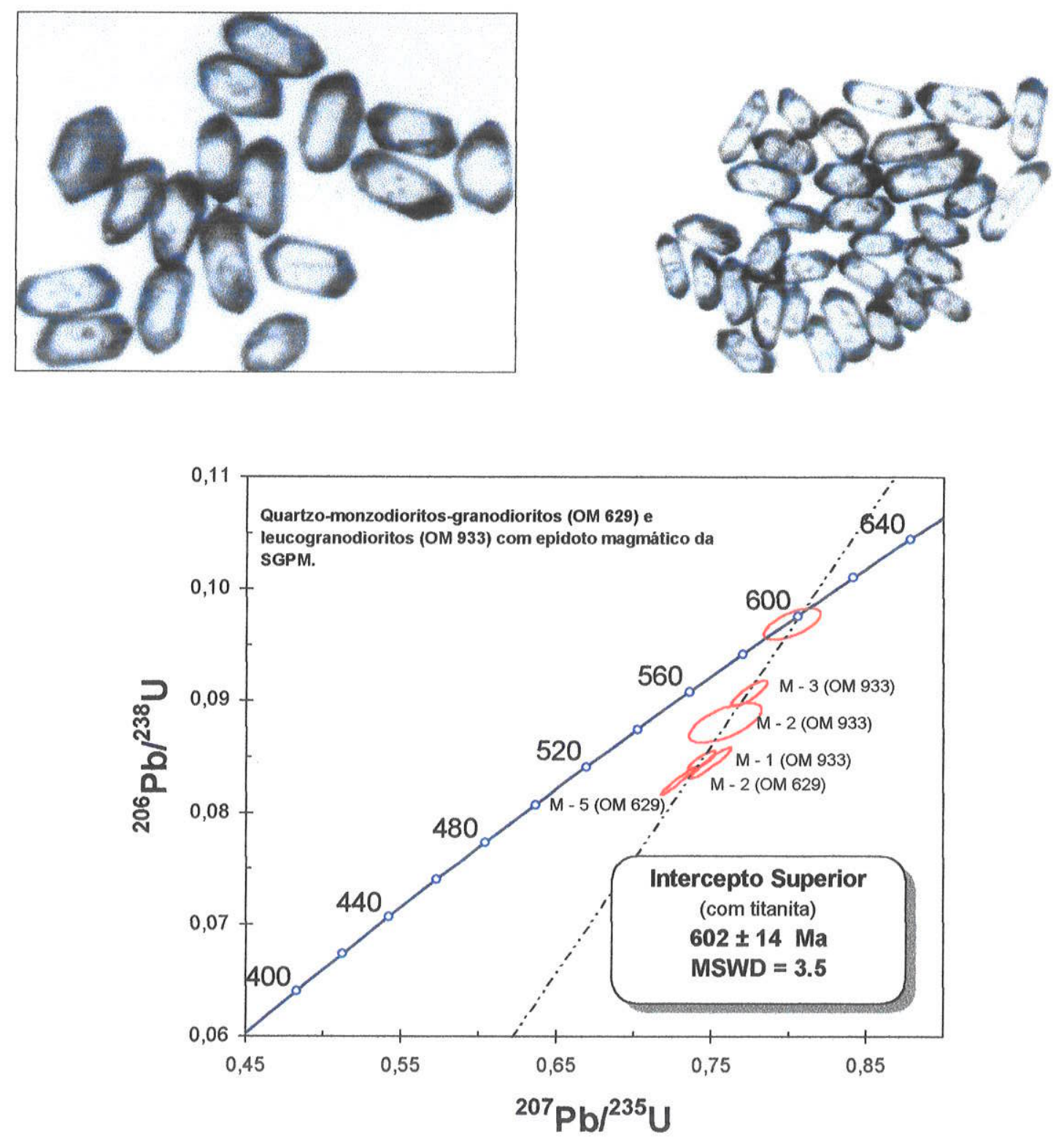

Figura 6.14 - Diagrama concórdia U-Pb para titanita e zircões dos quartzo monzodioritos/granodioritos e zircões dos leucogranodioritos com epídoto magmático da SGPM. 

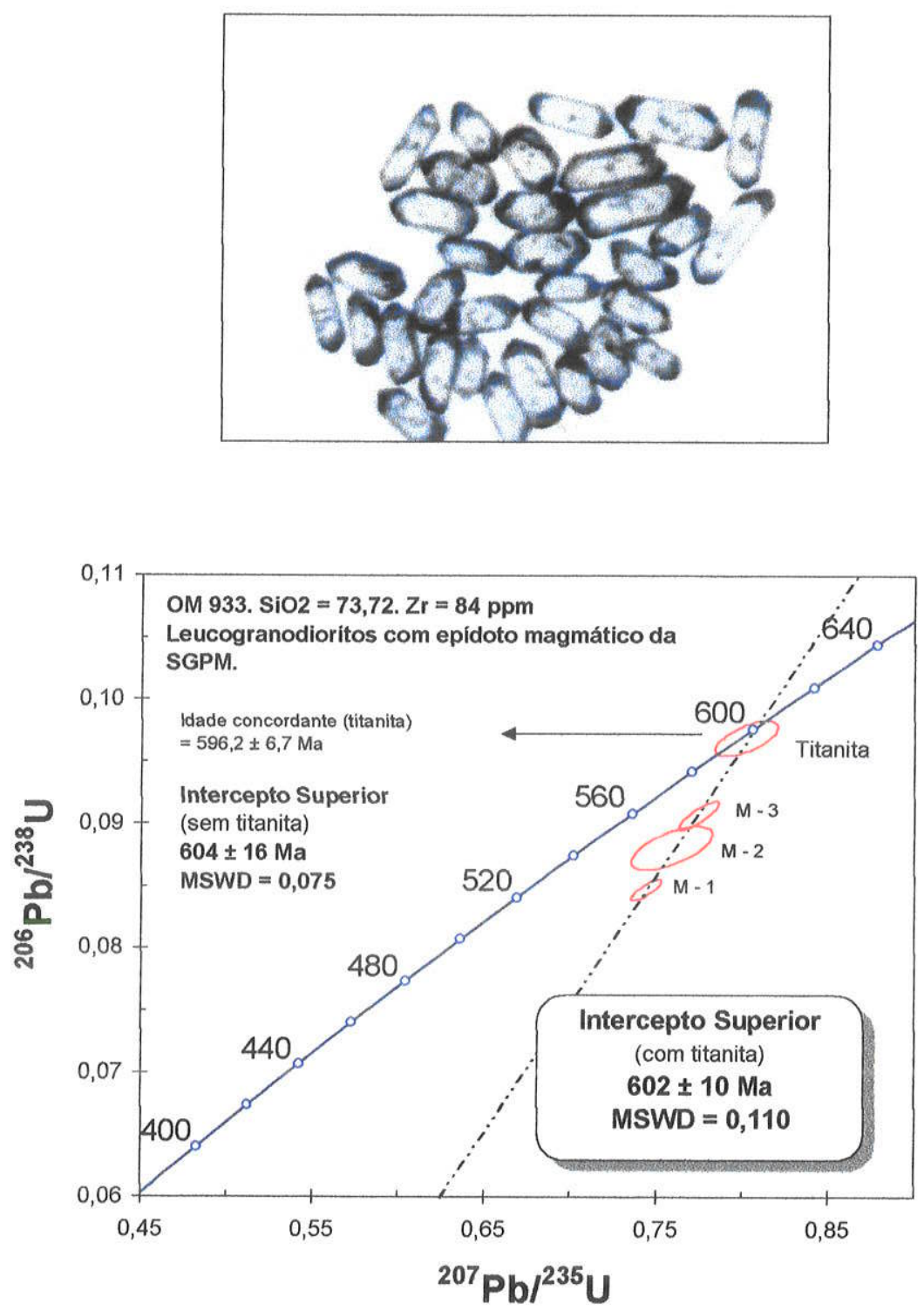

Figura 6.15 - Diagrama concórdia U-Pb para os zircões dos leucogranodioritos e titanita dos quartzo monzodioritos/granodioritos com epídoto magmático da SGPM.

Nota-se que a idade discordante U-Pb em titanita (620-610 Ma) dos quartzo monzodioritos/granodioritos sem epídoto magmático é inferior à idade concordante U-Pb em titanita ( $596.2 \pm 6.7 \mathrm{Ma}$ ) dos quartzo monzodioritos/granodioritos com epídoto magmático. Estas diferentes idades indicam a formação/cristalização inicial das rochas graníticas sem epídoto magmático e a formação tardia das rochas graníticas com epídoto magmático da SGPM.

Os resultados U-Pb (Figura 6.12) em zircões dos quartzo monzodioritos com epídoto magmático apresentam indicações de heranças, enquanto os resultados dos quartzo monzodioritos/granodioritos (Figuras 6.14 e 6.15) sugerem superposição de histórias de heranças e perda tardia de $\mathrm{Pb}$ radiogênico. Este fato torna, os últimos, imprecisos (idades $\mathrm{Pb}^{207} / \mathrm{Pb}^{206}$ entre 800 e $630 \mathrm{Ma}$ ) para o cálculo e para a definição exata da idade da 
formação/cristalização destas rochas. Uma alternativa para calcular a idades U-Pb em zircão foi acrescentar ou não os resultados U-Pb em titanita destas mesmas rochas, conforme apresentado nas (Figuras 6.14 e 6.15).

Os resultados U-Pb em zircões e titanita de todas as rochas graníticas com epídoto magmático da SGPM (Figura 6.16) sugerem que as idades entre 605 (idades dos zircões concordantes nos quartzo monzodioritos e do intercepto superior dos quartzo monzodioritos/granodioritos e leucogranodioritos) e $595 \mathrm{Ma}$ (idades U-Pb em titanita e K-Ar em biotitas) representem o período da formação/cristalização, deformação e o resfriamento destas rochas.

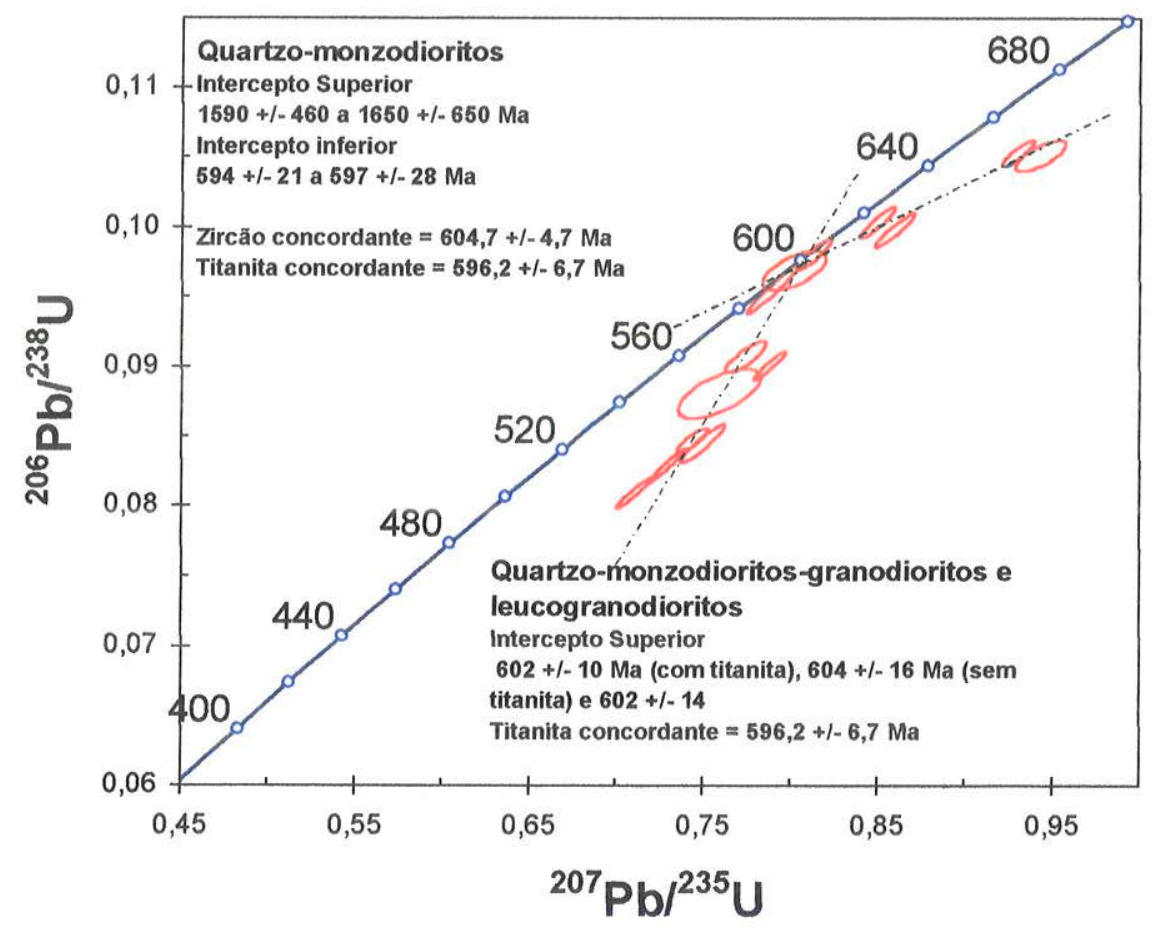

Figura 6.16 - Diagrama concórdia U-Pb para os zircões e titanita dos quartzo monzodioritos, quartzo monzodioritos/granodioritos e leucogranodioritos com epídoto magmático da SGPM.

Os resultados $\mathrm{U}-\mathrm{Pb}$ em zircões e titanita de todas as rochas graníticas com ou sem epídoto magmático da SGPM (Figura 6.17) indicam maior concordância e idades superiores nas rochas graníticas sem epídoto magmático em relação às rochas com epídoto magmático. As rochas graníticas com epídoto magmático apresentam indicações de heranças (quartzo monzodioritos) ou superposição de heranças com perda de $\mathrm{Pb}$ radiogênico (quartzo monzodioritos/granodioritos e leucogranodioritos), maior discordância e idades inferiores, registradas principalmente em zircões concordantes dos quartzo monzodioritos e em titanita dos quartzo monzodioritos/granodioritos. 


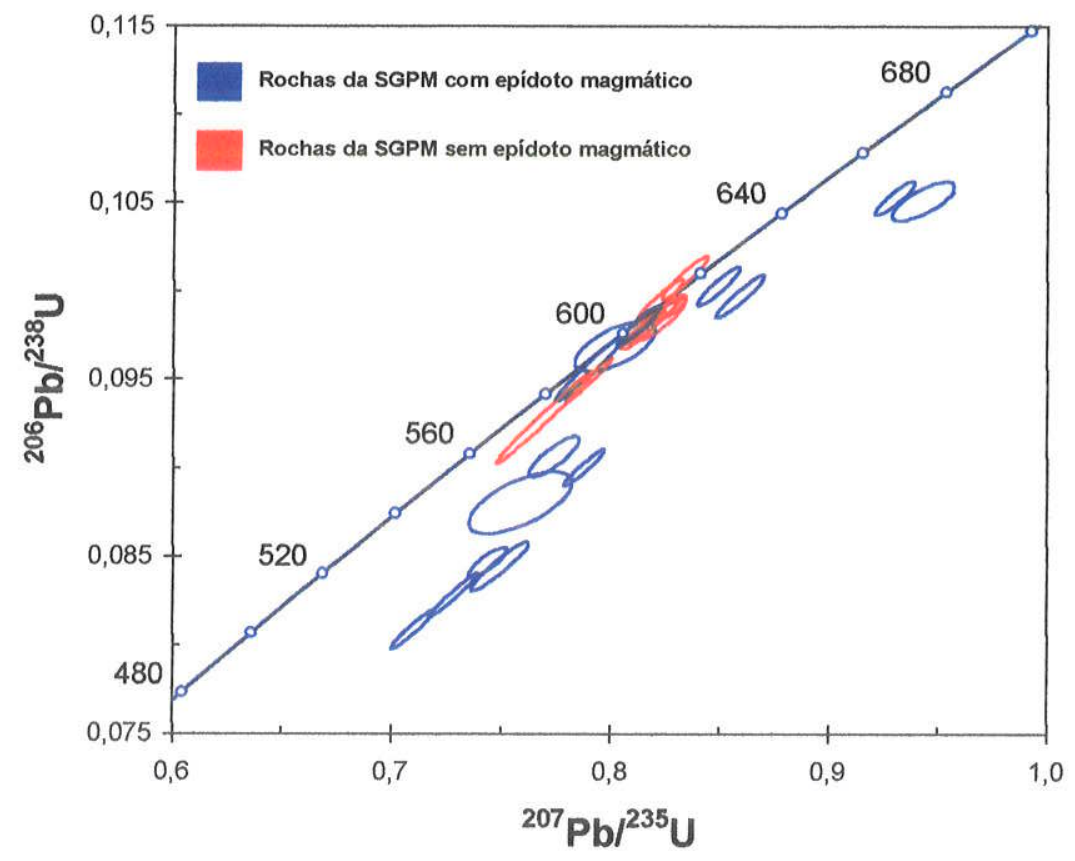

Figura 6.17 - Diagrama concórdia U-Pb para os zircões e titanitas de todos os componentes graníticos, com e sem epídoto magmático, da SGPM.

Os resultados isotópicos $\mathrm{Rb}-\mathrm{Sr}$ em rocha total (Harara 1996) dos quartzo monzodioritos granodioritos e leucogranodioritos com epídoto magmático da porção sul e central da SGPM revelaram uma idade isocrônica de $605 \pm 24$ Ma (Figura 6.18), com razão inicial $\mathrm{Sr}^{87} / \mathrm{Sr}^{86}$ de 0.70462 . Esta idade representa a formação destas rochas.

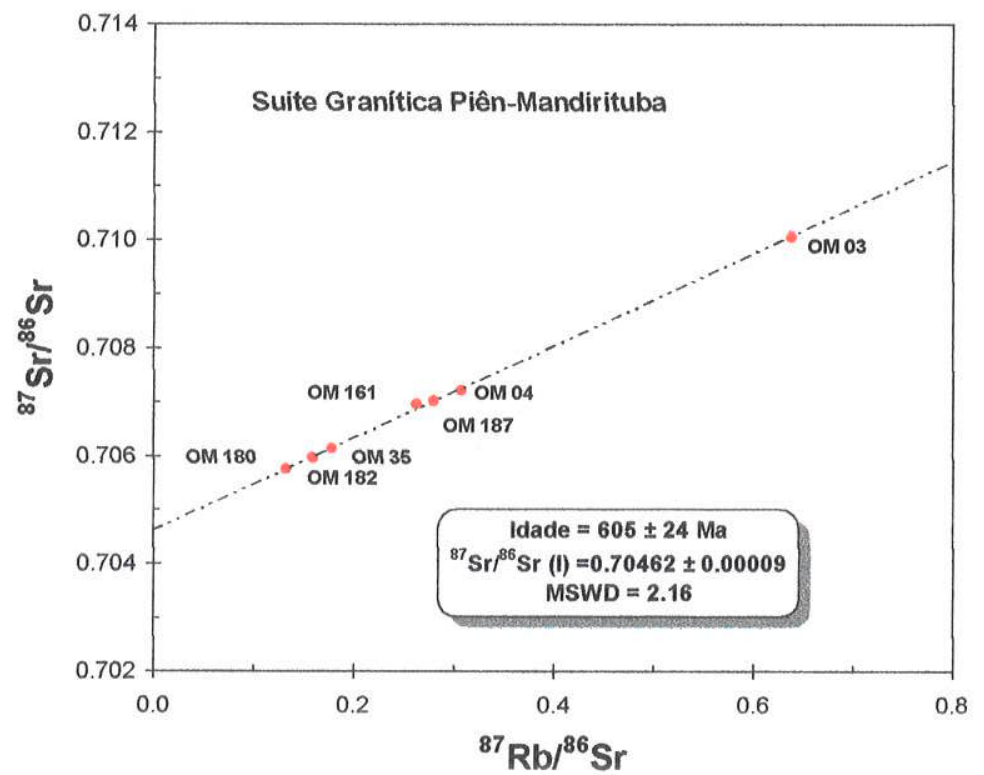

Figura 6.18 - Diagrama Isocrônico $\mathrm{Rb}^{87} / \mathrm{Sr}^{86} \times \mathrm{Sr}^{87} / \mathrm{Sr}^{86}$ (rocha total) para os quartzo monzodioritos, granodioritos e leucogranodioritos com epídoto magmático da SGPM. (Fonte: Harara 1996). 
Os resultados geocronológicos K-Ar em biotita e anfibólio concluídos até o momento para os quartzo monzodioritos e quartzo monzodioritos/granodioritos com ou sem epídoto magmático e para os monzogranitos milonítcos da SGPM são apresentados na Tabela 6.2. Os dados em biotitas para os quartzo monzodioritos e granodioritos miloníticos sem epídoto magmático próximos da ZCPT e em contato tectônico com os gnaisses do TGAG estão entre 607-606 Ma, enquanto os quartzo monzodioritos protomiloníticos e miloníticos com epidoto magmático e dos monzogranitos forneceram valores entre 598 e $595 \mathrm{Ma}$.

Desta forma, as idades K-Ar em biotita dos litotipos graniticos da SGPM apresentam um intervalo de idades entre 607 e $595 \mathrm{Ma}$, que representa o período de seu resfriamento e estabilidade tectônica. Observa-se uma tendência de decréscimo (?) das idades K-Ar de SSE para N-NW, independe do tipo e da idade da formação/cristalização (U-Pb em zircão e titanita) do componente considerado. Isto sugere que o cavalgamento de N-NW para S-SE (componente compressivo do sistema transpressional principal) ocorreu com os granitóides ainda aquecidos, sendo inicialmente resfriados os componentes graníticos da porção sul da SGPM. Coincidentemente ou não, as idades K-Ar mais antigas em biotita, ao redor de 607 $606 \mathrm{Ma}$, são obtidas nos quartzo monzodioritos/granodioritos com epídoto magmático e sobrepöem às idades U.Pb em zircão e titanita obtidas nas mesmas rochas, sugerindo um curto periodo de tempo entre sua formação, deformação e resfriamento. Isto significa que, durante a deformação das rochas graníticas sem epídoto, entre 607 e $595 \mathrm{Ma}$, as rochas graníticas com epídoto magmático, foram neste intervalo de tempo, formadas e deformadas em um processo de cristalização e resfriamento rápido. Isto pode explicar a preservação e a presença do epídoto magmático neste grupo de rochas graníticas da SGPM.

As idades $\mathrm{K}$-Ar em biotita indicam, claramente, que a deformação e a estabilidade tectônica de seus componentes graníticos ocorreu antes do inicio do magmatismo, máfico e félsico, Palermo e Rio Negro (idades U-Pb em zircões entre 593 e $585 \mathrm{Ma}$ ).

Os resultados K-Ar em anfibólio (Tabela 6.2) para os quartzo monzodioritos e quartzo monzodioritos/granodioritos com e sem epídoto magmático mais antigos (entre 648 e $644 \mathrm{Ma}$ ) ou mais jovens ( $585 \mathrm{Ma}$ ) do que os de U-Pb em zircões e titanitas. As idades $\mathrm{K}$ Ar em anfibólio são similares, independente do grau de deformação, local da ocorrência na SGPM, granulometria dos cristais datados e da presença ou não do epidoto magmático na rocha.

A temperatura de difusão/retenção ( $\mathrm{Tc}$ ) do $\mathrm{Pb}$ em titanita e em outros minerais, conforme o sistema isotópico, depende do tamanho, forma e composição do cristal, dos fluídos presentes e da deformação e taxa de resfriamento regional. Esta temperatura, no caso da titanita, é da ordem de $500-550^{\circ} \mathrm{C}$, podendo alcançar até $650^{\circ} \mathrm{C}$ (Mezger et al. 
1990, Mezger 1991 e Tucker et al. 1987), $600-630^{\circ} \mathrm{C}$ (Cherniack 1993) e até $710-800^{\circ} \mathrm{C}$ (Zhang and Scharer 1996). A temperatura de difusão do Ar em anfibólio é aproximadamente de $450 \pm 50^{\circ} \mathrm{C}$ (Harrisson 1981). Assumindo-se que as temperaturas de difusão da titanita e anfibólio sejam próximas é dificil explicar as persistentes idades $\mathrm{K}$-Ar em anfibólio mais antigas ou mais jovens do que as idades U-Pb em titanita, tanto nas rochas da SGPM, como dentro da mesma rocha. Por serem rochas igneas, mesmo deformadas, estas deveriam apresentar idades $\mathrm{K}-\mathrm{Ar}$ em anfibólio compativeis com a história geológica das rochas detentoras. A incorporação ou perda de pequena ou substancial quantidade de $\mathrm{Ar}^{40}$ pode resultar em idades K-Ar em anfibólio mais antigas (OM 182, OM 414 e OM 409) ou mais jovens (OM 1106) do que as idades U-Pb em zircão e titanita. $O$ anfibólio presente em rochas graníticas deformadas, como é o caso da SGPM, pode incorporar ou perder $\mathrm{Ar}^{40}$ radiogênico e fornecer idades $\mathrm{K}$-Ar mais antigas ou mais jovens do que as idades U-Pb em zircão e titanita nas mesmas rochas.

Se comparadas às idades $\mathrm{K}-\mathrm{Ar}$ em biotita e U-Pb em zircão e titanita, as idades $\mathrm{K}-\mathrm{Ar}$ em anfibólio obtidas na SGPM são questionáveis e não tem significado geológico dentro da história geocronológica da unidade. A melhor solução para este problema é o uso do método $\mathrm{Ar}^{40}-\mathrm{Ar}^{39}$, a fim de se obter um perfil térmico-isotópico mais preciso deste mineral, detectar possiveis ganhos ou perdas de $\mathrm{Ar}^{40}$ radiogênico e fazer as correções necessárias.

Com base em todos os resultados das análises geocronológicas U-Pb em zircões e titanitas e K-Ar em biotitas concluímos que, as rochas graníticas (quartzo monzodioritos e granodioritos) sem epídoto magmático se formaram entre 620 e 610 Ma enquanto que as rochas graníticas (quartzo monzodioritos à leucogranodiortios) com epídoto magmático foram formadas e ao mesmo tempo deformadas, entre 605 e $595 \mathrm{Ma}$. A deformação das rochas graníticas sem epídoto magmático e dos monzogranitos ocorreu conjuntamente com as rochas graníticas sem epídoto magmático neste mesmo período, entre 605 e $595 \mathrm{Ma}$. 


\section{0 - Suite Máfica-Ultramáfica Piên (SMUP)}

\section{1 - Introdução}

A SMUP é a mais expressiva e importante suite de rochas ultramáficas expostas nesta região, sendo constituida por dois corpos principais descontinuos, sinuosos e lentiformes com aproximadamente $11 \mathrm{Km}$ de extensão e alojados ao longo da ZCPT, entre a SGPM, a norte e o TGAG, a sul. O corpo setentrional é denominado Campina dos Crispins (CC) e o corpo meridional, Campina dos Maias (CM). O corpo CC está orientado na direção N45-50E e suas encaixantes sẫo as rochas da SGPM, ao norte, e do TGAG, ao sul, apresentando comprimento de $6,5 \mathrm{~km}$ e largura máxima de $1 \mathrm{~km}$. $O$ corpo $\mathrm{CM}$, com direção E-W, comprimento aproximado de $4,5 \mathrm{~km}$ e largura máxima de $2,5 \mathrm{~km}$ ocorre como uma "Klippe" sobre o TGAG.

Os contatos com a SGPM e o TGAG são essencialmente tectônicos, envolvendo falhas de cavalgamento e transcorrentes. As rochas, nas bordas e principalmente nas porções internas, encontram-se fortemente deformadas, dobradas e rompidas, com um aspecto fortemente cataclástico-milonítico e foliações paralelas às da SGPM e porção SW do TGAG.

As rochas predominantes na SMUP são peridotitos (dunitos e harzburgitos serpentinizados e serpentinitos) com intercalações de camadas e niveis centimétricos a milimétricos de piroxenitos (olivina-piroxenitos, ortopiroxenitos $e$, raramente, olivinawebsteritos, websteritos e plagioclásio-ortopiroxenitos) e intrusões de piroxenitos e raros gabros (bandados e isótropos). Raros enclaves de mica-serpentina xistos foram encontrados no corpo setentrional CC. Xistos magnesianos com serpentina, talco, magnetita, tremolita, carbonato e clorita ocorrem nas bordas (principalmente ao longo da borda sul do corpo meridional $\mathrm{CM}$ ) e são produtos tectono-metamórficos dos dunitos, harzburgitos e olivina-piroxenitos. Os raros gabros estão expostos no corpo meridional CM, onde os dados estruturais sugerem seu alojamento como diques nos peridotitos.

O mapeamento geológico revelou que a SMUP não é correlata às lentes de rochas ultramáficas inclusas no TGAG (a sudeste e nordeste de Tijucas do Sul-PR e nos arredores de Voçoroca-PR). Estas rochas, mapeadas por Ribas (1993), com extensão areal questionável e correlacionadas geneticamente, por este autor, à SMUP, nada mais são do que as freqüentes lentes de rochas ultramáficas presentes ao longo de toda a extensão do TGAG (Minioli 1972, Siga Jr. 1995, Harara 1996 e Fornari 1998). Por isso, o termo PiênTijucas, conforme sugerido por Ribas (1993), não é utilizado neste trabalho e a SMUP permanece com importância e significado geológico único. 
O alojamento dos ofiolitos em continentes envolve colisão de zonas de subducção com margens continentais ativas ou arcos de itha. Estas representam litosferas oceânicas formadas em grandes bacias oceânicas de margens continentais passivas ou pequenas bacias oceânicas formadas próximo a zonas de subducção, como bacias de retro-arco e de pré-arco. De acordo com a definição original de ofiolito (Penrose 1972), a SMUP representaria uma sequeência ofiolítica incompleta, na qual somente a seçăo mantélica ultramáfica basal é exposta, estando ausente a seção crustal (rochas vulcânicas e sedimentos associados).

A predominância ou ausência da seção mantélica e/ou crustal e a variação da espessura destas seções são características comuns a muitos ofiolitos paleoproterozóicos, neoproterozóicos e fanerozóicos (Pearce et al. 1984, Helmstaedt \& Scott 1992, Moores 1986 e outros) sendo atribuidas a fatores petrogenéticos ou tectônicos. A quantidade de ofiolitos com falta de um ou mais unidades (seção crustal e/ou mantélica) é bem maior do que os que apresentam a seqüência ofiolítica completa. A presença ou ausência da seção crustal ou mantélica, a natureza, o tipo, a espessura e o estilo tectônico são funções do cenário geotectônico onde a seqüência ofiolítica está alojada e não do próprio ofiolito. Enquanto a diversidade do ofiolito depende do tipo de ambiente oceânico onde se forma, o estilo do alojamento e a chance de sobrevivência do ofiolito parecem ser controlados amplamente pelo tamanho dos fragmentos continentais envolvidos na acreção que, por sua vez, determinam o tipo e a intensidade da sutura. Durante a obducção, uma espessa lasca da crosta oceânica (ou a seção crustal de um ofiolito) pode descolar-se da sua porção mantélica subductada, fazendo com que esta esteja ausente na seqüência ofiolítica (Helmstaedt \& Scott 1992, Moores 1986).

Pearce et al. (1984), Pearce (1991), Elthon (1991), Parkinson \& Pearce (1998) e outros sugerem dois principais ambientes geotectônicos para a formação e o alojamento de rochas ofioliticas (seqüências mantélicas e/ou crustais): ofiolitos SSZ- de ambientes compressionais formados em bacias oceânicas próximas e relacionadas a zonas de subducção, como pré e retro-arco e ofiolitos MORB- de ambientes extensionais formados em bacias oceânicas, como as cadeias médio-oceânicas. No geral, os peridotitos dos ofiolitos SSZ são harzburgitos e, mais raramente Iherzolitos, com forte empobrecimento em elementos moderadamente a altamente incompativeis. Os peridotitos dos ofiolitos MORB são geralmente Iherzolitos e, secundariamente harzburgitos, com moderado empobrecimento em elementos moderadamente a altamente incompativeis. Os peridotitos residuais MORB ou SSZ são geralmente residuos abandonados após a extração dos magmas basalticos MORB ou IAT que afloram ao longo de cadeias médio-oceânicas e de pequenas bacias oceânicas como pré e retro-arco. Os peridotitos residuais constituintes da 
seção mantélica de ofiolitos são considerados como remanescentes do embasamento ultramáfico de antigas bacias oceânicas.

Basei et al. (1992) sugeriram que a SMUP represente, nesta região, o registro de um assoalho oceânico obductado durante o Neoproterozóico, em razão do fechamento do oceano e da colisão entre o TGAG e a SGPM (incluindo o CGMA). Em um perfil gravimétrico na direção NW entre o CGMA e o TGAG passando pela SGPM e a SMUP, Mantovani et al. (1989) detectaram, na região entre Piên-PR e Agudos do Sul-PR, uma anomalia positiva com valor em torno de $10 \mathrm{mgal}$, interpretada como a resposta ao alojamento tectônico da SMUP. Os autores sugeriram, com base nos dados geológicos disponiveis, um contato inclinado e quente, representando uma descontinuidade crustal profunda entre a SGPM e o TGAG.

\section{2 - Petrografia}

São descritos aqui os aspectos petrográficos macro e microscópicos das rochas da SMUP. O estudo petrográfico baseou-se na descrição de inúmeras amostras e lâminas petrográficas, afim de verificar os principais minerais constituintes e as estruturas e texturas presentes. As rochas ultramáficas predominantes (Figura 7.1) são peridotitos (dunitos e harzburgitos serpentinizados e serpentinitos) com intercalações de camadas ou níveis de piroxenitos (olivina-ortopiroxenitos, ortopiroxenitos e raramente olivina-websteritos, websteritos e plagioclásio-piroxenitos) e intrusões de piroxenitos em forma de diques alojados nos dunitos e harzburgitos. As raras rochas máficas são gabros bandados e isótropos e xistos magnesianos. Raros enclaves de mica-serpentina xistos foram encontrados no corpo setentrional CC.

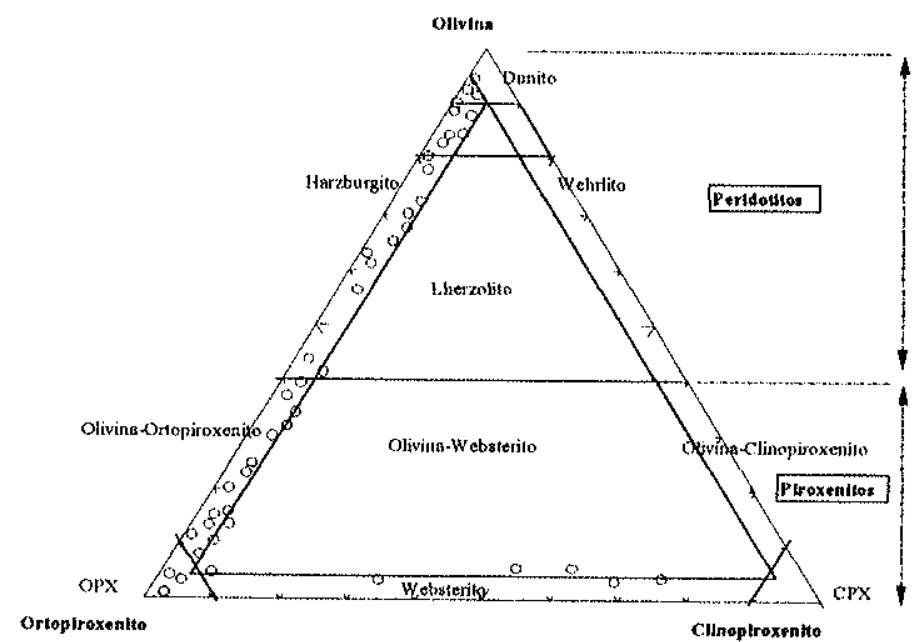

Figura 7.1 - Diagrama triangular Olivina-Ortopiroxênio-Clinopiroxênio (Streckeisen 1976, nomenclatura do IUGS) para as rochas uitramáficas da SMUP. Espinélio, plagioclásio e anfibólio em volume < $5 \%$.Peridotitos $>40 \%$ de olivina e piroxenitos $<40 \%$ de olivina. Os volumes dos minerais são determinados por estimativa visual. Ol=olivina + serpentina, $O p x=0 p x+$ bastita. 
Rochas basálticas em forma de diques ou derrames com rochas sedimentares associadas, que compõem a seção crustal dos ofiolitos, são ausentes. As lentes de cromititos, geralmente embutidas e associadas à seção mantélica, também inexistem.

\subsection{1- Peridotitos}

São as rochas predominantes nos dois corpos principais $\mathrm{CC}$ e $\mathrm{CM}$. Os dunitos e harzburgitos serpentinizados apresentam coloração verde a cinza escuro, granulação fina e são constituidos por olivina (forsterita), serpentina, ortopiroxênio (enstatita), espinélio (hercenita-paleonasto, Girardi 1974), magnetita, opacos (cromita ?) e, em menor proporção, clinopiroxênio (diopsídio). Carbonato, tremolita, talco e clorita são produtos da alteração secundária pós serpentinização. Granada e anfibólio são ausentes. 0 processo de serpentinização é mais intenso nas porções mais deformadas e ricas em olivina, propiciando - aparecimento de niveis de olivina-serpentina intercalados com niveis de olivinaserpentina-ortopiroxênio (Fotos 7.4, 7.5 e 7.6). Este processo é responsável pela transformação de olivina e, subordinadamente, ortopiroxênio, em serpentina e bastita (Fotos 7.4-7.6), respectivamente, pela formação de magnetita e pela mudança de cor do espinélio de verde para marrom (Fotos 7.7 e 7.8 ).

Os cristais de olivina (geralmente $<1 \mathrm{~mm}$ ), sempre com extinção ondulante, são subédricos a anédricos inequigranulares, alongados segundo a foliação em um arranjo granular com piroxênio, espinélio e opacos (Fotos 7.1, 7.2 e 7.3), caracterizando uma textura protogranular a profiroclástica (classificação de Mercier \& Nicolas 1975). Os cristais maiores ( 1 a $1.5 \mathrm{~mm}$ ) estão fortemente deformados e triturados, formando subgrãos com núcleos de olivina envolvidos por serpentina. A substituição da olivina por serpentina ocorre preferencialmente ao longo das fraturas internas paralelas à foliação e ao redor dos subgrãos, a partir das bordas em direção ao centro, sendo os núcleos de olivina orientados segundo a foliação (Fotos 7.4 e 7.5). Os cristais de magnetita definem a foliação e, em várias rochas, preenchem os interstícios entre os pseudomórfos de olivina e piroxênio (Fotos 7.7 e 7.8), ocorrendo ainda em fraturas e microfraturas preenchidas por serpentina.

Os cristais de piroxênio são euhédricos à anédricos, geralmente com granulação maior do que os da olivina. Apresentam contatos nítidos e irregulares com a olivina ou podem estar intensamente fraturados, deformados e/ou serpentinizados (Fotos 7.1-7.3). Feições como extinção ondulante, lamelas de deformação, alteração e fraturas internas múltiplas preenchidas por serpentina são comuns. Em algumas rochas, o ortopiroxênio encontra-se totalmente serpentinizado (bastita, segundo Dungan 1974), sendo este mineral menos susceptivel à serpentinização do que a olivina (Fotos 7.4 e 7.6). Por isso o processo de serpentinização é bem mais intenso ao redor da olivina do que do ortopiroxênio. 
O espinélio (cor verde e marrom) ocorre como cristais subédricos a anédricos e, raramente, euhédricos, geralmente preenchendo os interstícios entre olivina e/ou piroxênio.

O talco (com ou sem tremolita e/ou carbonato) quando presente, ocorre como cristais euhédricos a anédricos, substituindo parcialmente ortopiroxênio ou disseminado em serpentinitos, substituindo cristais de serpentina, ao longo ou não de microfraturas.

Os serpentinitos constituem a maioria das rochas peridotiticas da SMUP e apresentam granulação fina a muito fina e coloração verde a cinza escuro, sendo constituídos por serpentina, magnetita, espinélio (predomina cor marrom) e minerais opacos. Análises pelos métodos de difração de raios $X$, análise térmica diferencial e de dissolução seletiva (Girardi 1976) revelaram que os tipos mais comuns do grupo da serpentina são a lizardita e crisotilo, ocorrendo ainda a antigorita.

Os serpentinitos deformados apresentam textura milonítica caracterizada pela orientação de cristais aciculares e placóides de serpentina e magnetita orientados segundo a foliação (Fotos 7.7-7.9). Estas rochas apresentam ainda textura pseudomórfica "mesh" (Moody 1976 e Prichard 1979), formada por pseudomorfos de olivina totalmente serpentinizada (Foto 7.10) e típica de serpentinitos pouco ou não deformados. A formação desta textura ocorre pela substituição progressiva da olivina por serpentina e magnetita ao longo das fraturas internas e nas margens dos cristais de olivina.

São freqüentes nos peridotitos sistemas de fraturas em rede e fraturas paralelas à foliação, ambas preenchidas por serpentina.

Os peridotitos apresentam uma foliação $S n$ anastomosada, facilmente observada na maioria das rochas e caracterizada pela orientação de cristais de serpentina e magnetita e pelo alinhamento de cristais de olivina e piroxênio (Fotos 7.1, 7.2, 7.7, 7.8, 7.16-7.18). A alternância de niveis contendo ortopiroxênio \pm olivina com níveis contendo olivina/serpentina \pm ortopiroxênio, orientados e alinhados conforme a foliação, definem, nas rochas, um bandamento composicional ígneo (?) observado macro e microscopicamente, com textura porfiroclástica.

\subsection{2 - Piroxenitos}

$\mathrm{Na}$ SMUP ocorrem principalmente ortopiroxenitos e olivina-ortopiroxenitos serpentinizados e, mais raramente, olivina-websteritos, websteritos, espinélio-ortopiroxenito cumuláticos e plagioclásio-piroxenitos. Estas rochas ocorrem como camadas e niveis milimétricos a centimétricos, intercaladas com os peridotitos ou em forma de diques cumuláticos tardios deformados e dobrados, alojados nos peridotitos. 
Os piroxenitos apresentam granulação fina a muito fina e por vezes média grossa, coloração cinza a cinza escuro e são constituídos por ortopiroxênio (enstatita), olivina (forsterita), serpentina, espinélio, clinopiroxênio (diopsídio) e minerais opacos. Ocorrem ainda anfibólio (cor marrom) e plagioclásio. Talco, tremolita, carbonato e clorita são minerais de alteração pós serpentinização.

Os cristais de piroxênio são subédricos a anédricos, geralmente maiores (até 2.5 $\mathrm{mm}$ ) do que os da olivina e apresentam intensa deformação, com freqüente fraturamento intracristalino preenchido por serpentina ou bastita (Foto 7.11). Observa-se, em algumas rochas localizadas nas margens da SMUP, a substituição parcial do piroxênio por carbonato, tremolita, serpentina e talco ao redor e ao longo dos intersticios entre os cristais. A olivina ocorre como cristais anédricos granulares, intensamente fraturados e orientados, com formação de subgrãos e substituição parcial a total por serpentina. O espinélio ocorre como cristais euhédricos a anédricos, preenchendo os interstícios entre o piroxênio (Foto 7.12), podendo alcançar até $10 \%$ de volume nos piroxenitos cumuláticos.

Os piroxenitos, sem exceção, contêm espinélio em quantidades variáveis, fato que os diferenciam dos piroxenitos que ocorrem em forma de lentes no TGAG desta região.

Os piroxenitos não deformados exibem geralmente uma textura granular (em mosaico) caracterizada pela poligonização entre cristais euhédricos a subédricos de piroxênio. Quando deformados, apresentam textura granular (tabular) ou porfiroclástica (classificação de Mercier \& Nicolas 1975) caracterizada pelo intenso fraturamento e orientação de ortopiroxênio e olivina (Foto 7.11).

Estruturas em forma de "colunas" constituídas por piroxenitos cumuláticos são observados na porção sul do corpo CM. Estas colunas, de $7 \mathrm{~cm}$ de comprimento e $3-4 \mathrm{~cm}$ de largura são perpendiculares à foliação e contornadas por peridotitos serpentinizados e foliados. Apresentam textura granular ou equigranular (em mosaico) caracterizada pela poligonização entre cristais de piroxênio com os intersticios preenchidos por espinélio (Foto 7.12). Representam provavelmente estruturas magmáticas primárias modificadas por processos tectono-metamórficos neoproterozóicos e relacionados à serpentinização.

Os peridotitos e piroxenitos da SMUP apresentam diferentes tipos de texturas que variam entre porfiroclástica e granular (em mosaico ou tabular). A mais freqüente é a porfiroclástica, presente nos peridotitos, caracterizada por forte alongamento e deformação de olivina e piroxênio, que definem a foliação. A textura granular ou equigranular, em mosaico (granoblástica) ou tabular (granoblástica alongada) é mais típica dos piroxenitos e gabros. 


\subsection{3- Gabros}

Os gabros (olivina-gabros ou olivina-gabronoritos) são raros na SMUP e estão alojados principalmente nos peridotitos e piroxenitos do corpo meridional CM. São constituidos por ortopiroxênio (enstatita), clinopiroxênio (diopsídio), plagioclásio (labradorita), anfibólio (cor marrom) e, em menor volume, espinélio, olivina, serpentina e minerais opacos. Apresentam estrutura maciça ou bandada e textura granular em mosaico (granoblástica) ou tabular (granoblástica alongada), caracterizada pelo arranjo poligonal e/ou alongamento de cristais de plagioclásio, ortopiroxênio, clinopiroxênio, olivina e anfibólio (Fotos 7.13 e 7.14). A relação textural entre os minerais indica cristalização tardia do espinélio, que ocorre preenchendo os interstícios entre piroxênio e olivina.

Em gabros com anfibólio, este mineral é formado pela substituição parcial (hidratação) do clinopiroxênio, ao redor do qual está concentrado (Fotos 7.13 e 7.15).

\subsection{4- Xistos magnesianos:}

Ocorrem principalmente ao longo da borda meridional do corpo $\mathrm{CM}$, a sul, e nas bordas do corpo CC, a norte. São rochas de granulação fina a muito fina, constituídas por talco, serpentina, tremolita, clorita, carbonato e minerais opacos. Apresentam textura nemato-lepidoblástica caracterizada pela orientação de talco, serpentina, tremolita e clorita.

Os xistos magnesianos são produtos do metamorfismo e deformação dos peridotitos e piroxenitos, serpentinizados ou não, em zonas de contato tectônico da SMUP com as rochas encaixantes do TGAG e da SGPM. 


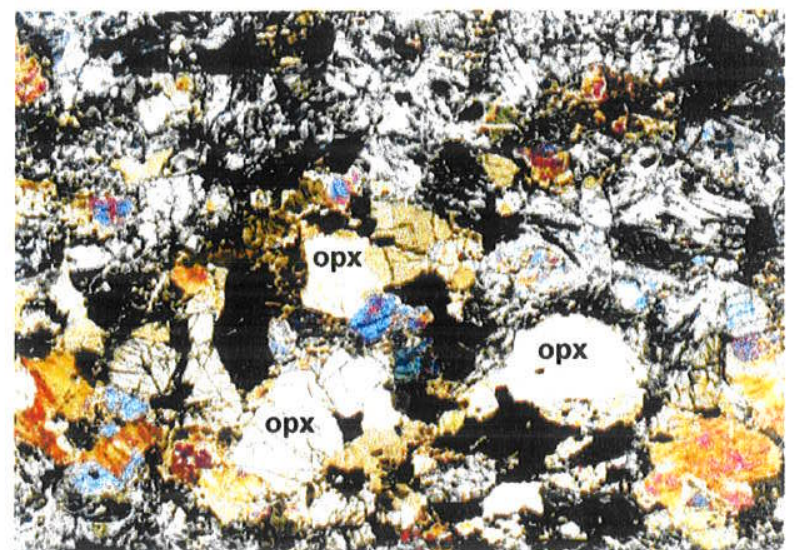

Foto 7.1: Serpentinização parcial de Harzburgitos. Maior serpentinização nos níveis ricos com olivina e menor nos niveis ricos com ortopiroxênio (opx). Textura porfiroclástica serpentinizada. SMUP, Corpo CC, amostra OM 191 (Lado maior da foto $5,5 \mathrm{~mm}$. Nicóis X).

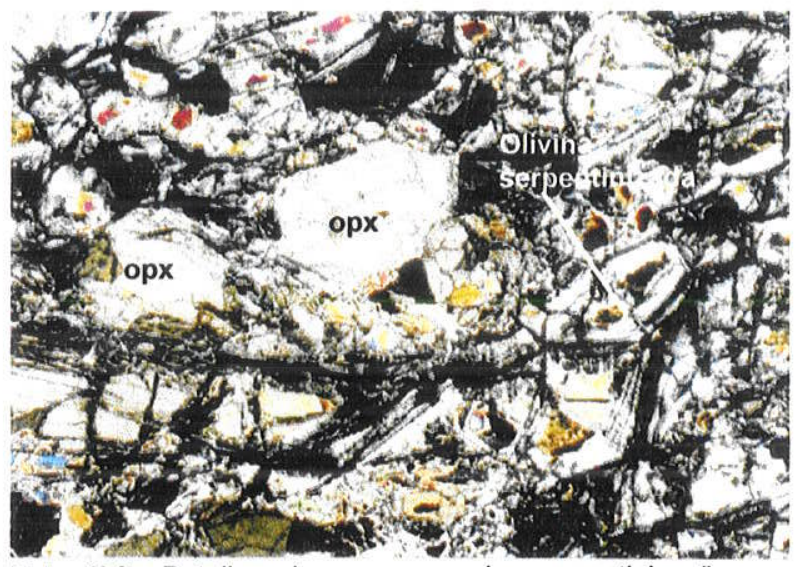

Foto 7.3: Detalhe do processo de serpentinização em Harzburgitos. Textura porfiroclástica serpentinizada. SMUP, Corpo CC, amostra OM 188 (Lado maior da foto 2,8 mm. Nicóis X).

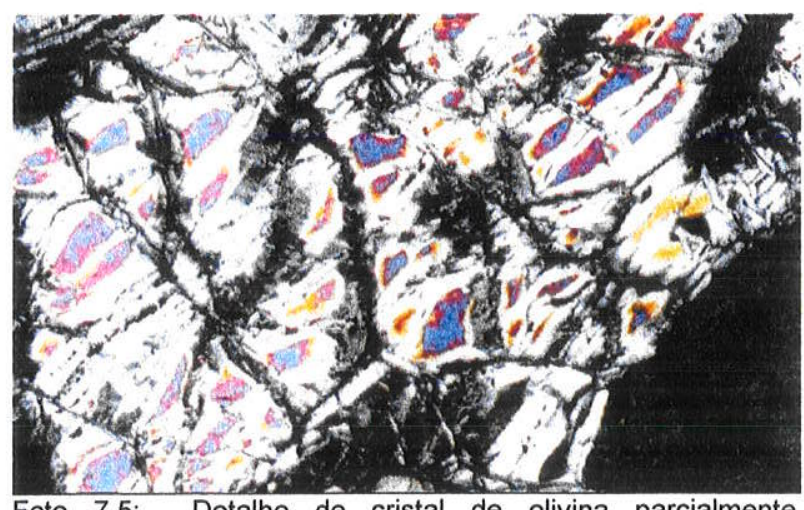

Foto 7.5: Detalhe de cristal de olivina parcialmente serpentinizado. Observar núcleos orientados de olivina $e$ bordas de serpentina. SMUP, Corpo CC, amostra OM 148 (Lado maior da foto $1,39 \mathrm{~mm}$. Nicóis X).

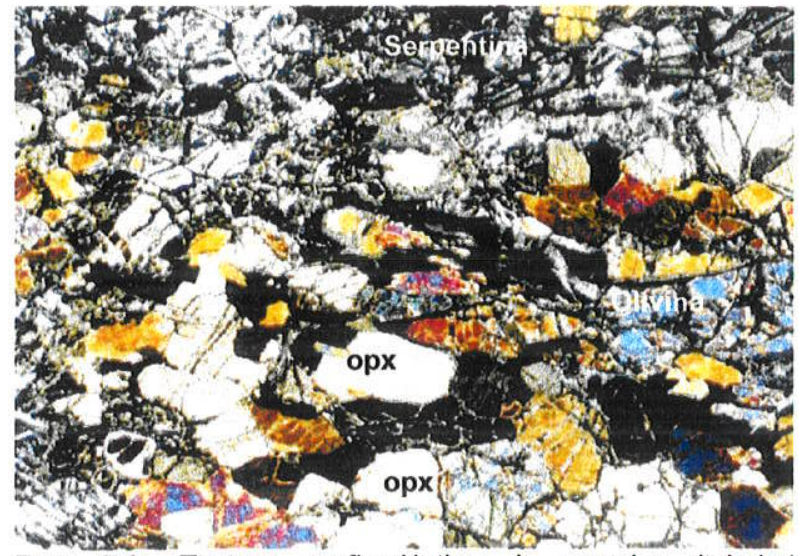

Foto 7.2: Textura porfiroclástica à granular (tabular) serpentinizada caracterizada pela orientação dos cristais de olivina e ortopiroxênio (opx). SMUP, Corpo CC, amostra OM 188 Lado maior da foto $5,5 \mathrm{~mm}$. Nicóis $\mathrm{X}$ ).

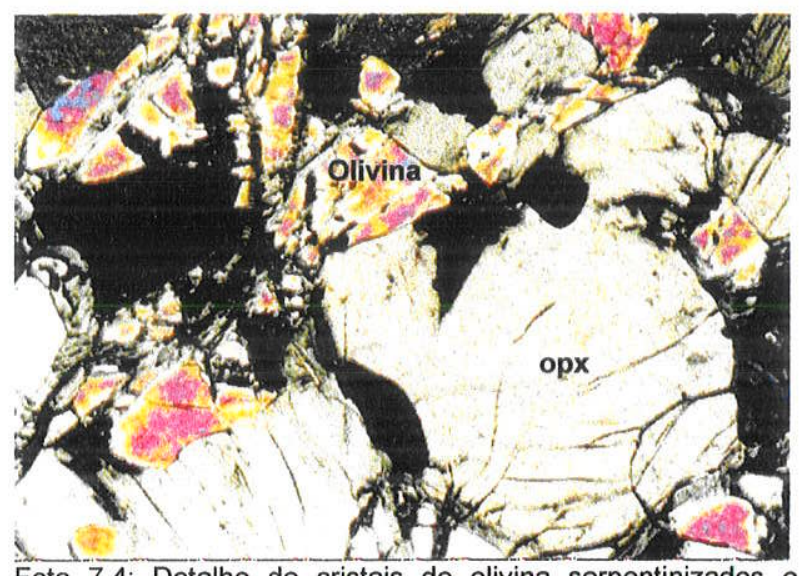

Foto 7.4: Detalhe de cristais de olivina serpentinizados e ortopiroxênio não serpentinizados. SMUP, Corpo CC, amostra OM 191 (Lado maior da foto $0,7 \mathrm{~mm}$. Nicóis X).

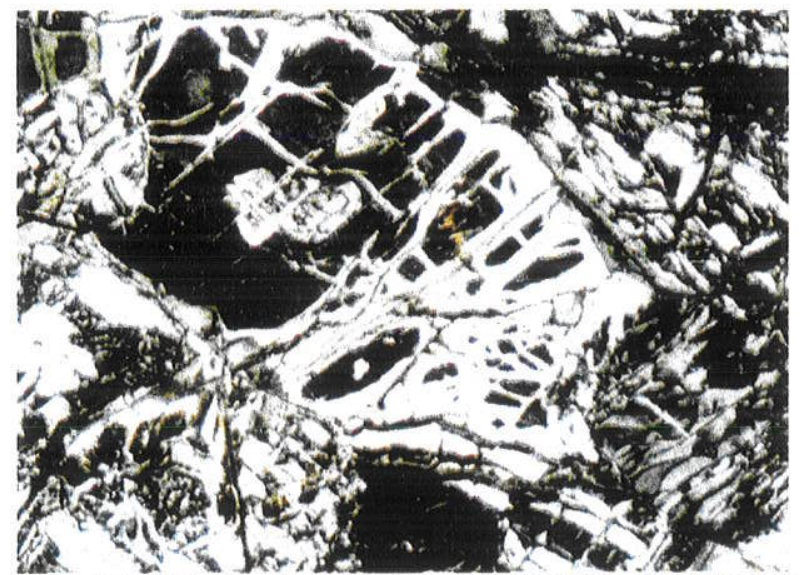

Foto 7.6: Detalhe de cristal de ortopiroxênio parcialmente serpentinizado (Bastita) em serpentinitos. SMUP, corpo CM, amostra OM 38 (Lado maior da foto $0,7 \mathrm{~mm}$. Nicóis $\mathrm{X}$ ). 


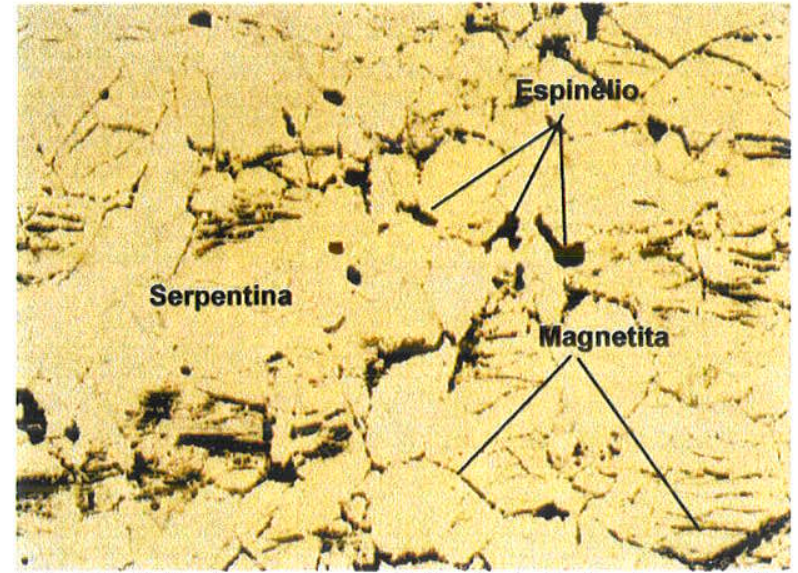

Foto 7.7: Foliaçăo em Serpentinitos (orientação da serpentina e magnetita). SMUP, Corpo CM, amostra OM 60 (Lado maior da foto $0,7 \mathrm{~mm}$. Nicóis $X$ )

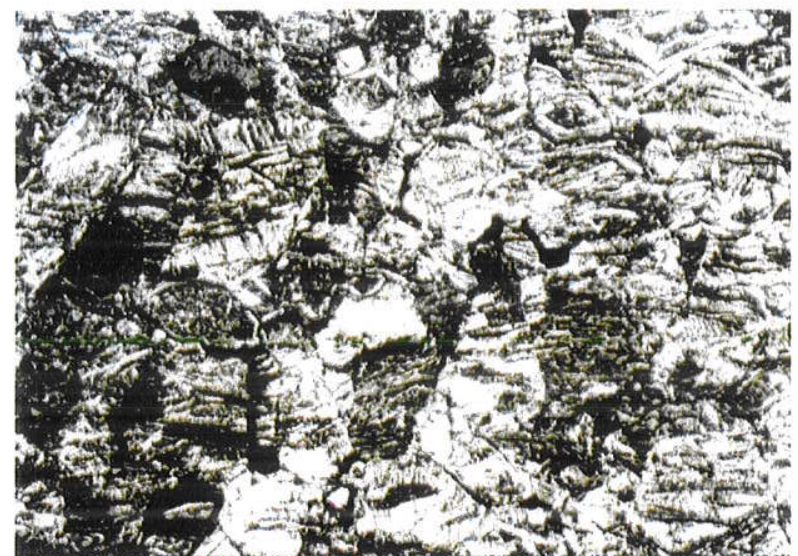

Foto 7.9: Foliação em Serpentinitos. Orientação de cristais de serpentina conforme a foliação. Observar a textura mesh parcialmente preservada em Serpentinitos. SMUP, Corpo CM, amostra OM 38 (Lado maior da foto $5,5 \mathrm{~mm}$. Nicóis $\mathrm{X}$ ).

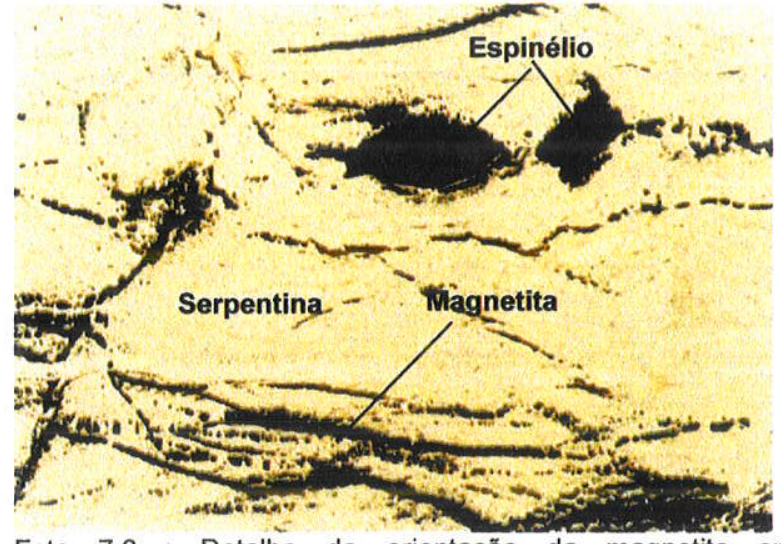

Foto 7.8 : Detalhe da orientaçäo da magnetita em serpentinitos. SMUP, Corpo CM, amostra OM 38 (Lado maior da foto $1,39 \mathrm{~mm}$. Nicóis //).

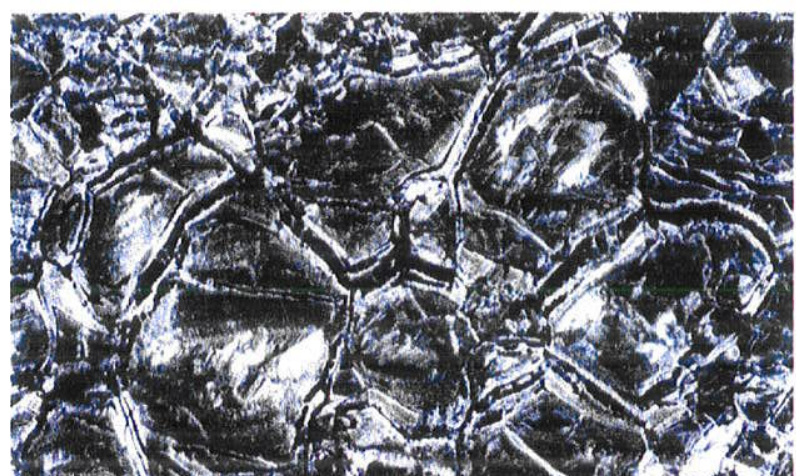

Foto 7.10: Textura pseudomórfica (mesh) em Serpentinitos. SMUP, Corpo CM, amostra OM 60 (Lado maior da foto 0,7 $\mathrm{mm}$. Nicóis $\mathrm{X}$ )

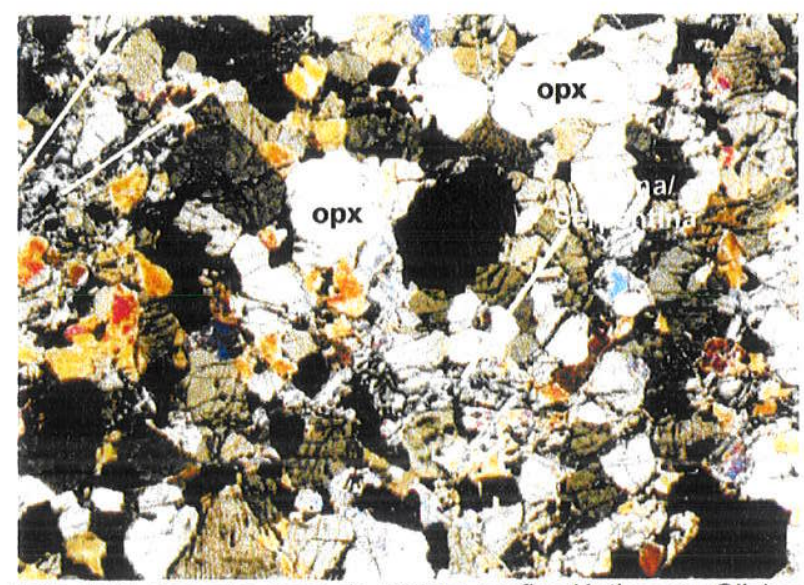

Foto 7.11: Aspecto geral da textura porfiroclástica em OlivinaPiroxenitos. SMUP, Corpo CC, amostra OM 148 (Lado maior da foto $5,5 \mathrm{~mm}$. Nicóis $X$ ). 


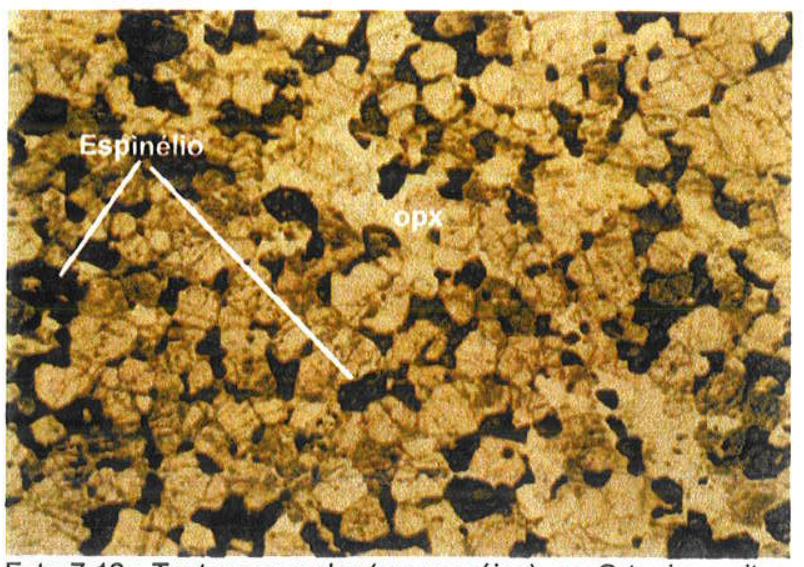

Foto 7.12 : Textura granular (em mosáico) em Ortopiroxenitos com espinélio intersticial. SMUP, Corpo CM, amostra OM 345 (Lado maior da foto $5,5 \mathrm{~mm}$. Nicóis //).

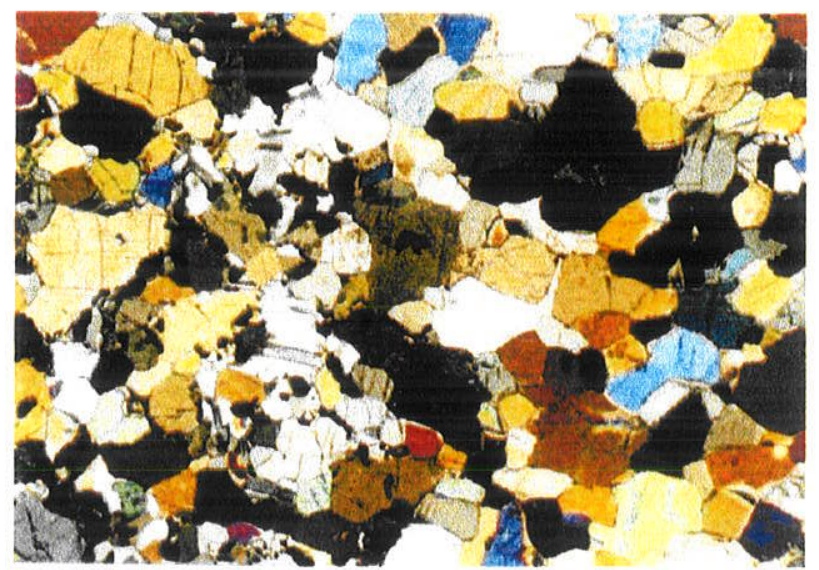

Foto 7.14: Textura granular (mosáico) à granular (tabular) em Gabros. SMUP, Corpo CM, amostra OM 39 (Lado maior da foto $5,5 \mathrm{~mm}$. Nicóis $\mathrm{X}$ ).

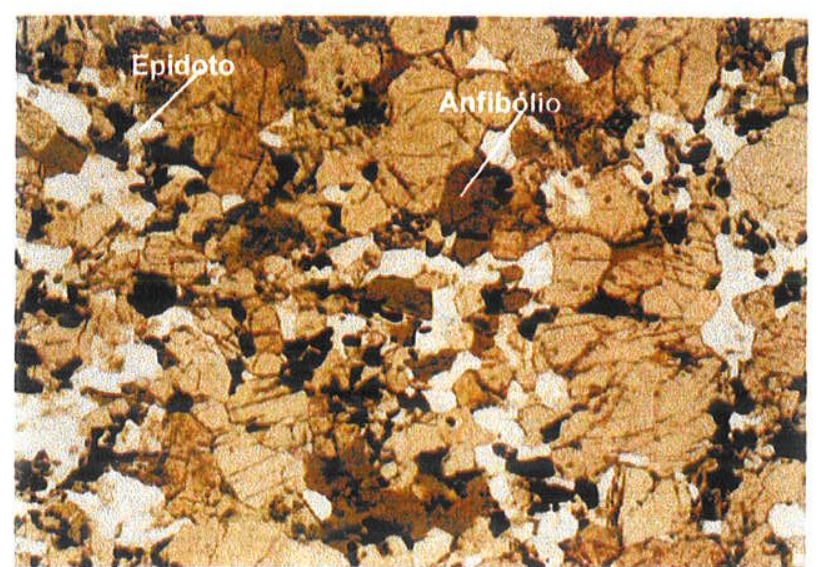

Foto 7.13: Textura granular (tabular) em Gabros com olivina, ortopiroxênio, clinopiroxênio, espinélio e anfibólio. SMUP, Corpo CM, amostra OM 40 (Lado maior da foto $5,5 \mathrm{~mm}$. Nicóis II).

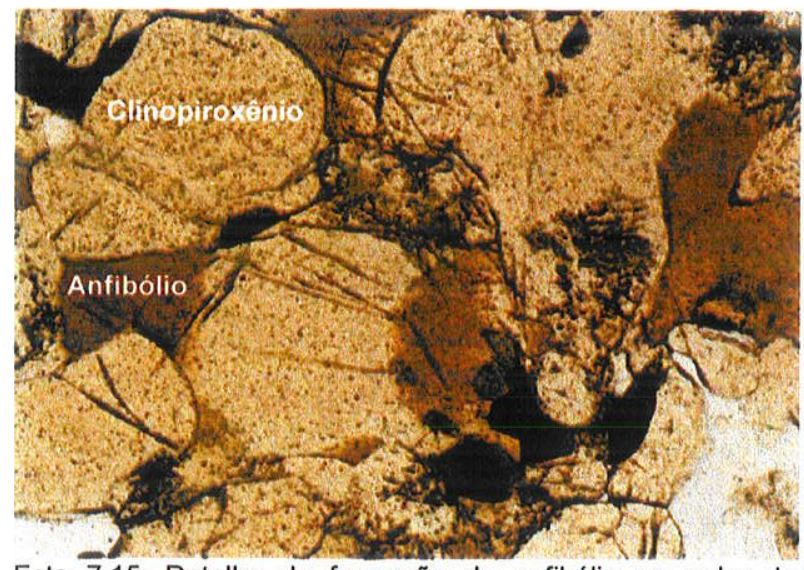

Foto 7.15: Detalhe de formação do anfibólio ao redor de clinopiroxênio em Gabros. SMUP, Corpo CM, amostra OM 40 (Lado maior da foto $0,7 \mathrm{~mm}$. Nicóis //). 


\section{3 - Análise estrutural}

A intensa deformação e serpentinização são feiçōes marcantes da SMUP. As rochas exibem em geral, uma foliação principal Sn anastomosada bem desenvolvida (Fotos 7.167.18 ), caracterizada pela orientação de olivina, serpentina, piroxênio e magnetita.

No corpo setentrional $\mathrm{CC}$, as foliações $\mathrm{Sn}$ concentram-se em torno de N64E/5070NW (Figura 7.2) com variações para direções NW e mergulhos para SW principalmente na extremidade nordeste deste corpo. Estas são conseqüência do anastomosamento das foliações neste corpo. O diagrama (Figura 7.2) sugere dobramento cilíndrico assimétrico, cujo eixo construído está inclinado para $\mathrm{W}$ a SW.

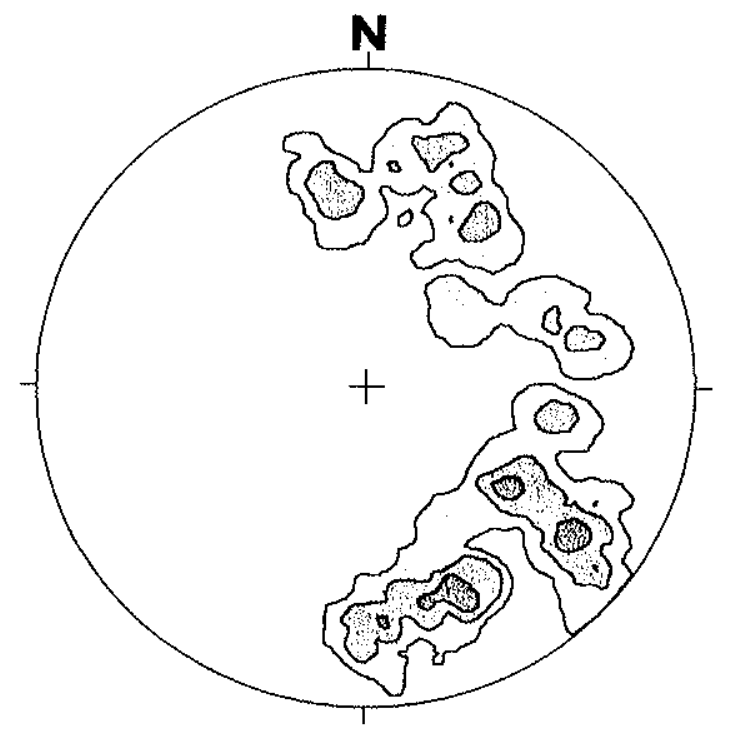

Figura 7.2 - Diagrama de freqüência dos pólos da principal foliação Sn no corpo CC. No. de foliaçóes : 125, Sn máximo.: N64E/50-70NW, Isocurvas: 2, 4, 6 e $8 \%$.

As lineações minerais (definidas pelo alinhamento de serpentina e magnetita) no corpo CC e medidas nos planos da foliação Sn concentram-se entre $20^{\circ}-50^{\circ} / \mathrm{S} 43-89 \mathrm{~W}$ e $10^{\circ}-50^{\circ} / \mathrm{N} 40 \mathrm{~W}-\mathrm{N} 70 \mathrm{~W}$ (Figura 7.3). As lineações NW, mais dispersas, são ortogonais às foliações NE e as lineações SW, menor dispersas, são ortogonais às foliações NW. Este arranjo sugere que as primeiras estejam relacionadas com o cavalgamento de NW para SE, que envolveu a SGPM e a porção SW do TGAG, enquanto as últimas seriam o resultado da rotação e modificação principalmente na extremidade nordeste deste corpo. 


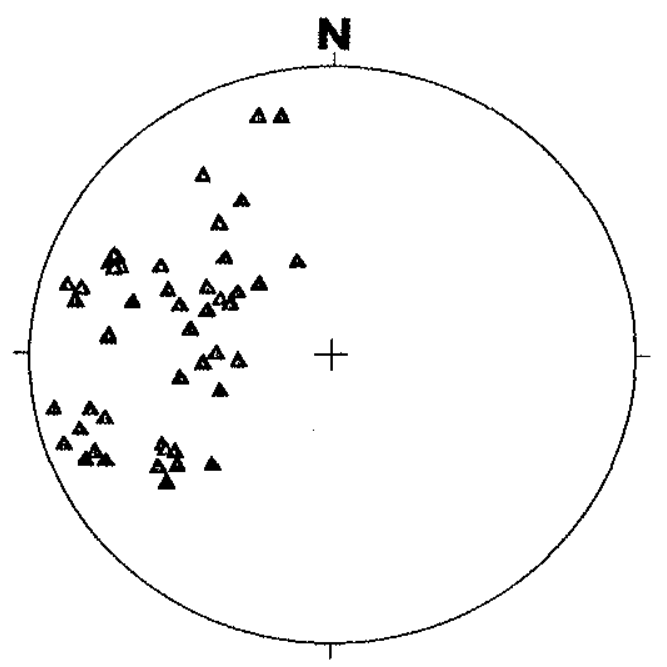

Figura 7.3 - Diagrama das principais lineaçס̃es minerais no corpo CC. No. de lineações: 51.

No corpo meridional $\mathrm{CM}$, as foliações $\mathrm{Sn}$ apresentam baixos mergulhos com concentrações em torno de N66E/ 20NW (Figura 7.4) e freqüentes ondulações e dispersões entre N40E/40NW e N54W/29NE. São observadas mesodobras intrafoliais (Foto 7.19) simétricas a assimétricas com eixos N80E subhorizontais. As lineações minerais variam entre $10^{\circ}-30 \%$ N20-60W (Figura 7.5) o que, aliado aos baixos mergulhos da foliação $\mathrm{Sn}$ e os dobramentos mencionados, sugere a colocação deste corpo como uma klippe sobre os gnaisses do TGAG.

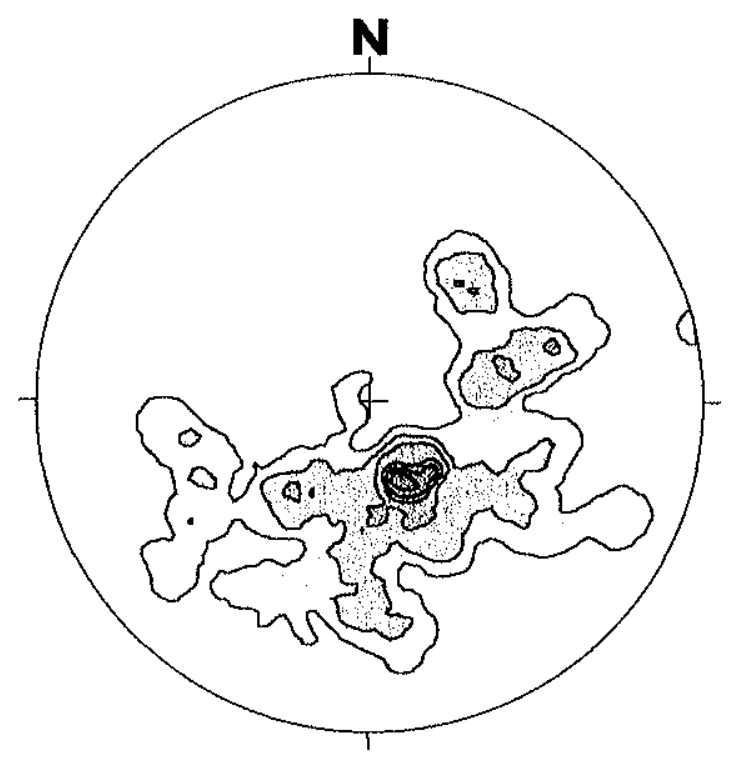

Figura 7.4 - Diagrama de freqüéncia dos pólos da principal foliação Sn no corpo CM. No. de foliações: 120, Sn Máximo: N66E/20NW, isocurvas: $2,4,6,8,9$ e $10 \%$. 


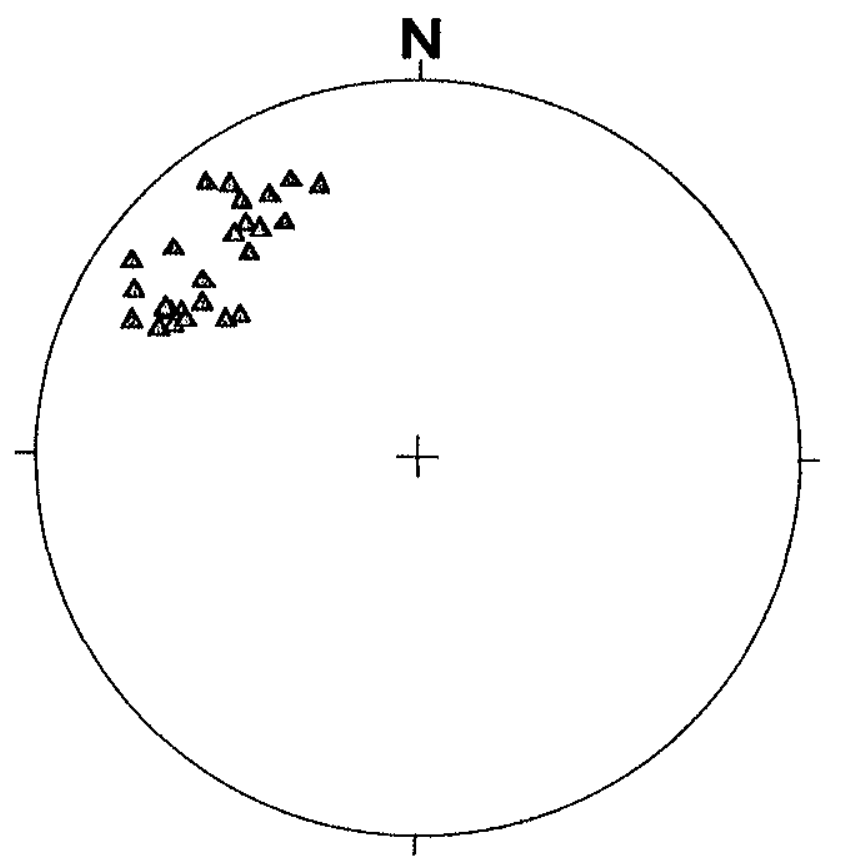

Figura 7.5 - Diagrama das principais lineações minerais no corpo CM. No. de foliações: 33.

Os contatos observados, em campo, entre o corpo meridional CM e os gnaisses subjacentes do TGAG, são marcados por superficies onduladas e de baixo ângulo, nas quais o corpo CM repousa sobre rochas do TGAG.

A observação conjunta das foliações e lineações dos dois corpos da SMUP, das rochas da SGPM e as da porção SW do TGAG sugerem o trapeamento do corpo setentrional CC da SMUP entre a SGPM e o TGAG e colocação do corpo CM como uma "klippe" sobre o TGAG. 


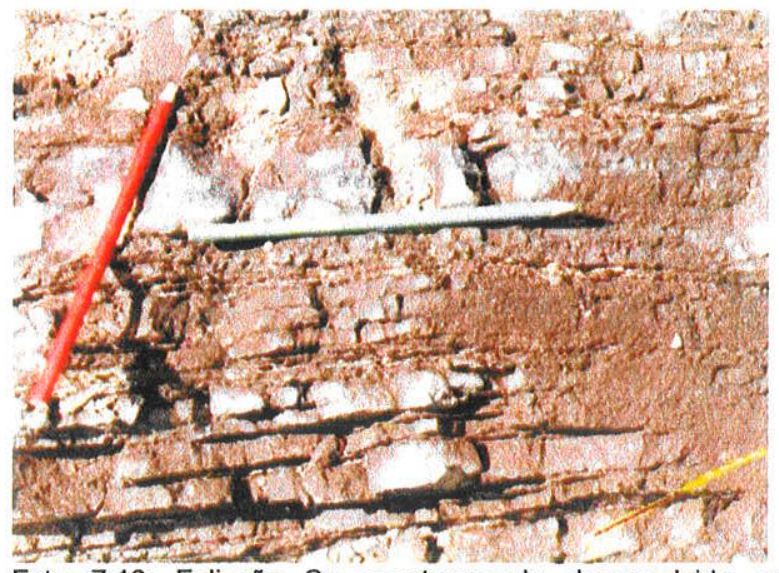

Foto 7.16: Foliação $\mathrm{Sn}$ anastomosada desenvolvida em peridotitos serpentinizados. Afloramento OM 191. Corpo setentrional CC.

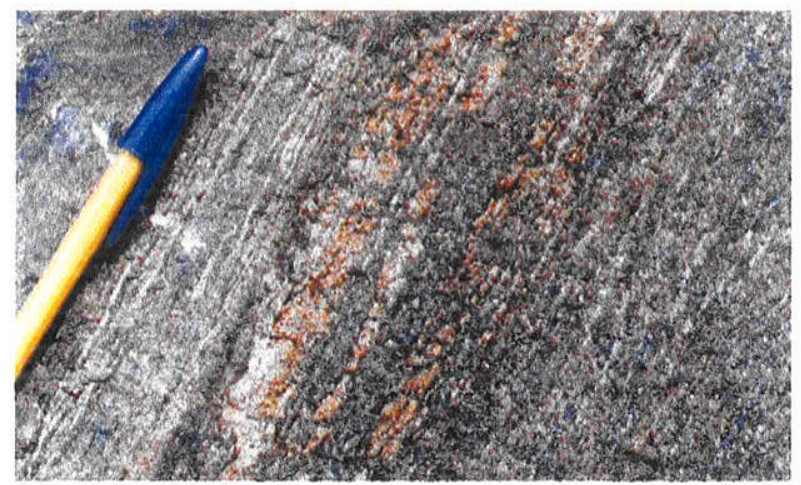

Foto 7.18: Detalhe do aspecto macroscópico da foliação $\mathrm{Sn}$ em peridotitos serpentinizados. Afloramento OM181. Corpo setentrional CC.

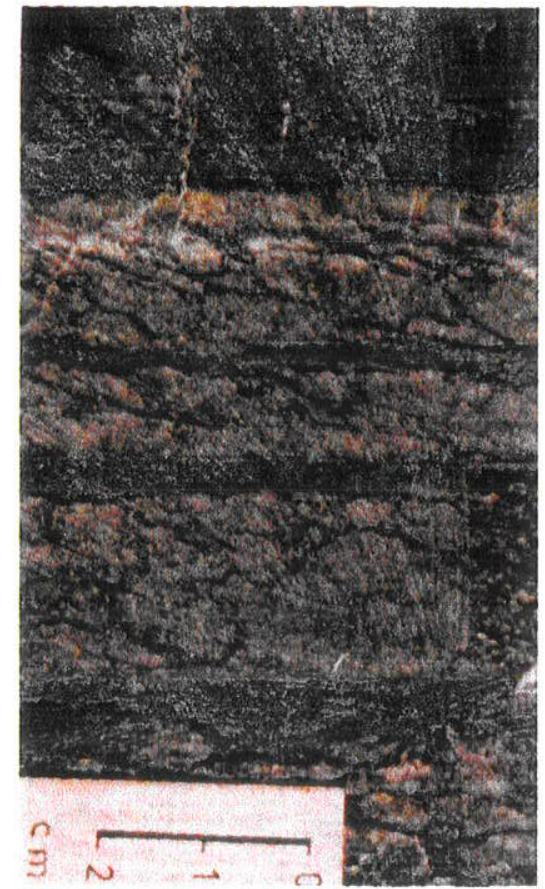

Foto 7.17: Detalhe do aspecto macroscópico da foliação $\mathrm{Sn}$ em peridotitos serpentinizados. Afloramento OM 149. Corpo setentrional CC.

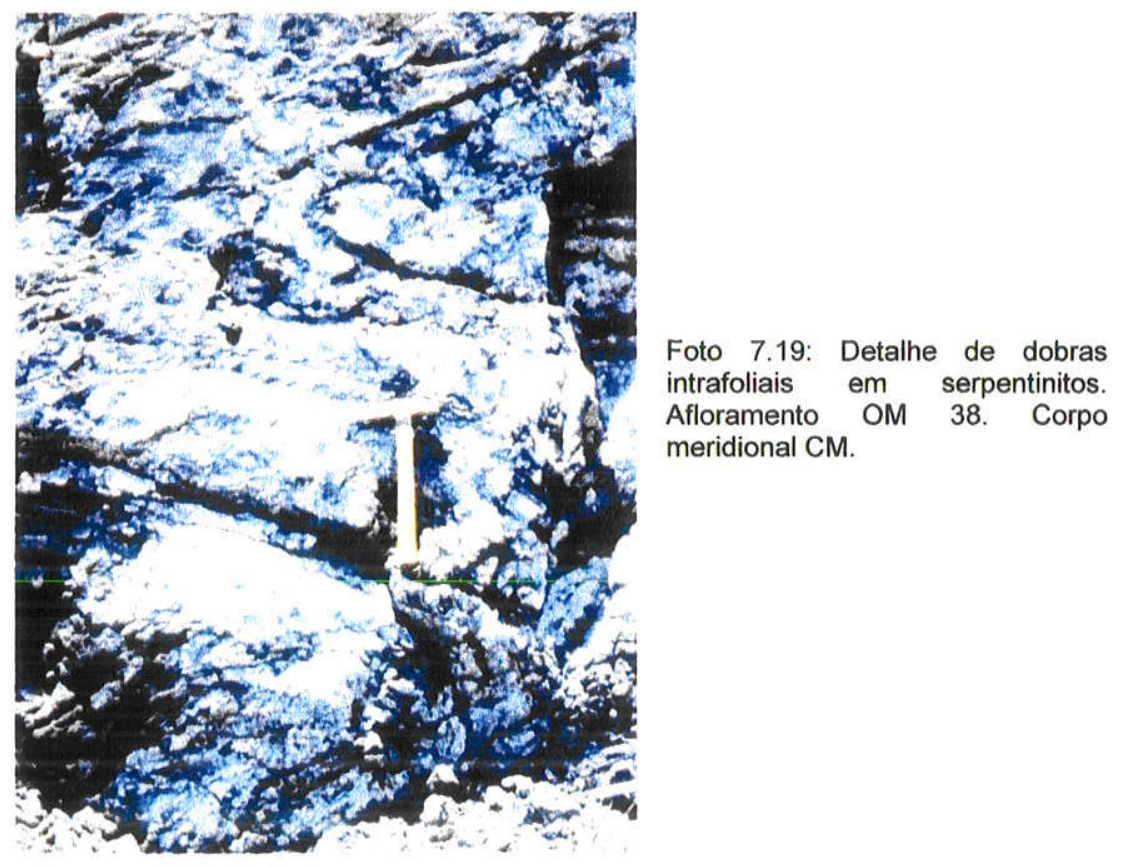




\section{4 -Serpentinização}

As observações petrográficas e as análises litoquímicas indicam claramente que a serpentinização se desenvolveu por infiltração de fluidos ricos em água em dunitos, harzburgitos e olivina-piroxenitos da SMUP e, subordinadamente, em piroxenitos. As reações de serpentinização envolveram a substituição da olivina e, secundariamente, piroxênio, por serpentina.

Estudos sobre a estabilidade dos minerais do grupo da serpentina (lizardita, crisotilo e antigorita) indicam amplos intervalos de pressão (2 a $10 \mathrm{kbar}$ ) e temperatura (400 a 650 ${ }^{\circ} \mathrm{C}$ ) para os processos de serpentinização de rochas peridotíticas (Moody 1976, Evans 1977). Em trabalhos experimentais recentes, pressões de até 50 kbar e temperaturas mais altas $\left(650^{\circ} \mathrm{C}\right)$ são atribuidas para a estabilidade principalmente da antigorita (Wunder \& Schreyer 1997 e Ulmer \& Trommsdorff 1995) Entre as possiveis reações de serpentinização nas rochas estudadas, destacam-se:

- olivina (forsterita) $+\mathrm{H}_{2} \mathrm{O}=$ serpentina + brucita.

- olivina + ortopiroxênio (enstatita) $+\mathrm{H}_{2} \mathrm{O}=$ serpentina. Reação em temperaturas ao redor de $650^{\circ} \mathrm{C}$ e pressões entre 15 e $40 \mathrm{kbar}$ ). Serpentinização em alta pressão.

- olivina + talco $+\mathrm{H}_{2} \mathrm{O}=$ serpentina + brucita. Temperaturas entre 500 e $650^{\circ} \mathrm{C}$ e pressões até 15 kbar. Serpentinização em baixa pressão.

- olivina $\rightarrow$ serpentina + magnetita $+\mathrm{H}_{2} \mathrm{O}$

- olivina + talco $+\mathrm{H}_{2} \mathrm{O}=$ serpentina (temperaturas entre $500-650{ }^{\circ} \mathrm{C}$ e pressões até $15 \mathrm{Kbar})$

- Serpentina $+\mathrm{H}_{2} \mathrm{O}+\mathrm{CO}_{2}=$ talco

- Serpentina + quartzo $=$ talco $+\mathrm{CO}_{2}$. Formação de talco por incorporação de silica a partir de rochas encaixantes.

As reações de formação do talco por adição de sílica ocorrem em condições de pressão e temperatura inferiores às da serpentinização. A concentração de rochas contendo talco, tremolita e carbonato, nas margens da SMUP, sugere a infiltração de fluidos com $\mathrm{SiO}_{2}$ e $\mathrm{CaO}$ em zonas de falhas/fraturas. A substituição de serpentina por talco nos xistos magnesianos sugere uma origem a partir dos serpentinitos, em zonas de falhas. Fluidos derivados das rochas do TGAG subjacente podem contribuir com $\mathrm{CO}_{2}$ e $\mathrm{CaO}$, já que o retrometamorfismo em fácies anfibolito que afetou a porção SW do TGAG é sincrônico à serpentinização. 
A deformação e a serpentinização das rochas da SMUP ocorreram em condições metamórficas de baixo a médio grau que variam desde a fácies xisto verde (zona da biotita) até o início da fácies anfibolito. Este metamorfismo, compativel com o retrometamorfismo das rochas do trecho SW do TGAG subjacente, ocorreu durante o alojamento tectônico da SMUP no Neoproterozóico.

As observações petrográficas das assembléias minerais sugerem a ocorrência de duas fases de metamorfismo na SMUP. A primeira fase foi a responsável pela serpentinização parcial a total dos dunitos, harzburgitos e olivina-piroxenitos e a segunda pela formação dos xistos magnesianos nas bordas desta unidade.

Os dados estruturais e geocronológicos sugerem que a serpentinização e a deformação das rochas SMUP são sincrônicos à deformação da SGPM e ao retrometamorfismo nas rochas da porção norte do trecho SW do TGAG, e ocorreriam durante o Neoproterozóico.

Estudos de geotermobarometria efetuados em piroxênios das rochas da SMUP, indicaram temperaturas da ordem de $750-800^{\circ} \mathrm{C}$ e pressões de 5 a 7 Kbar (Girardi 1974). Estas condições são indicativas, segundo este autor, do metamorfismo granulítico, sincrônico ao sofrido pelas rochas do TGAG e que ocorreu durante o Paleoproterozóico. Estes intervalos de pressão e temperatura estão fora do campo da estabilidade da serpentina (Peacock et al. 1994 e Wunder e Schreyer 1997) e dentro do campo de baixas pressões do facies granulito, podendo indicar ainda o ambiente da segregação dos protólitos ultramáficos mantélicos de alta temperatura. A presença de texturas granoblásticas alongadas, típica de paragêneses minerais sob deformação em alta temperatura e sem minerais hidratados, não significa obrigatoriamente a passagem destas rochas por um metamorfismo do facies granulito.

\section{5 - Litogeoquímica}

Nesta seção apresentamos somente um resumo dos principais dados litoquimicos da SMUP.

Os peridotitos (dunitos e harzburgitos serpentinizados e serpentinitos, $\mathrm{SiO}_{2} 37$ a $41 \%, \mathrm{Al}_{2} \mathrm{O}_{3} / \mathrm{MgO}$ até $0.05, \mathrm{MgO}=39-41 \%$ base não anidra) apresentam as seguintes características químicas: $\mathrm{TiO}_{2}(\leq 0.01 \%), \mathrm{Fe}_{2} \mathrm{O}_{3}(5.5$ a $7 \%), \mathrm{CaO}(0.01$ a $0.05 \%), \mathrm{Na}_{2} \mathrm{O}(<$ $0.05 \%), \mathrm{MnO}(0.06$ a $0.1 \%), \mathrm{Al}_{2} \mathrm{O}_{3}(0.05$ a $2 \%)$, Ni (1300-1900 ppm), LOI (10 a $\left.16 \%\right), \mathrm{Cr}$ (2000-2900 ppm), Sc(3-10 ppm), Co (80-110 ppm), V (20-40 ppm), Ta (<0.05 ppm), Ga (<1 $\mathrm{ppm}), \mathrm{Nb}(<0.5 \mathrm{ppm}), \mathrm{Y}(<1 \mathrm{ppm})$ e $\mathrm{Sr}(0-5 \mathrm{ppm})$. Os peridotitos apresentam-se empobrecidos em ETRP $\left(\mathrm{Yb}_{\mathrm{N}}=0.1\right.$ a 0.5$)$ com valores similares aos peridotitos residuais $\mathrm{e}$ são mais enriquecidos em ETRL ( $\operatorname{La}_{N}=0.6$ a 6$)$ em relação aos peridotitos residuais. As 
relações $\mathrm{MgO}$ ou $\mathrm{Al}_{2} \mathrm{O}_{3} / \mathrm{MgO} \times$ LOI $\times$ ETRL sugerem sensiveis mobilidades destes elementos durante a serpentinização. Em rochas peridotíticas, vários processos geológicos são atribuídos ao enriquecimento em ETRL (Prinzhofer \& Alegre 1985, Frey et al. 1984, Menzies et al. 1993, Sun \& Mcdonoguh 1989, Bodinier et al 1988). O conteúdo em ETRL nos peridotitos não são típicos dos peridotitos residuais (ETRL 0.5 a composição condrítica) porém não exclui o caráter residual destes peridotitos definido não só pelo padrão e conteúdo em ETRL mas também pela assinatura em outros elementos como, $\mathrm{TiO}_{2}, \mathrm{CaO}, \mathrm{Sc}$, $\mathrm{MnO}, \mathrm{V}$ e Co.

Os olivina-piroxenitos e piroxenitos $\left(\mathrm{SiO}_{2}=42\right.$ a $48 \%, \mathrm{Al}_{2} \mathrm{O}_{3} / \mathrm{MgO}=0.1-0.3 \mathrm{e}$ $\mathrm{MgO}=30-36 \%$, base não anidra) apresentam as seguintes características químicas: $\mathrm{TiO}_{2}$ (0.05 a $0.1 \%), \mathrm{Fe}_{2} \mathrm{O}_{3}(8$ a $9 \%), \mathrm{CaO}(1 \mathrm{a} 4 \%), \mathrm{Na}_{2} \mathrm{O}(0.05$ a $0.2 \%), \mathrm{MnO}(0.1$ a $0.4 \%), \mathrm{Al}_{2} \mathrm{O}_{3}$ (3 a $8 \%), \mathrm{Ni}(1000-1700 \mathrm{ppm})$, LOI (1 a $6 \%), \mathrm{Cr}(2500-3500 \mathrm{ppm}), \mathrm{Sc}(12-5), \mathrm{Co}(90-120$ ppm), V (50-100 ppm), Ta (<0.05 ppm), Ga (2 a 5 ppm), Nb (<0.5 ppm), Y (1 a $5 \mathrm{ppm})$ e Sr (0-10 ppm). Os piroxenitos apresentam-se mais enriquecidos em ETRP $\left(\mathrm{Yb}_{\mathrm{N}}=1-3\right) \mathrm{em}$ relação aos peridotitos, mas apresentam valores em ETRL $\left(L a_{N}=0.6-6\right)$ relativamente similares a estes. Enquanto há uma marcante diferença em ETRP entre os peridotitos e piroxenitos, os valores em ETRL, para diferentes valores de $\mathrm{MgO}$ ou $\mathrm{Al}_{2} \mathrm{O}_{3} / \mathrm{MgO}$, são similares.

Os gabros toleíticos $\left(\mathrm{SiO}_{2}=48-50 \%, \mathrm{Al}_{2} \mathrm{O}_{3} / \mathrm{MgO}=0.5-0.6\right.$ e $\left.\mathrm{MgO}=20 \%\right)$, apresentam as seguintes características químicas: $\mathrm{TiO}_{2}(0.3-0.4 \%), \mathrm{Fe}_{2} \mathrm{O}_{3}(10$ a $12 \%), \mathrm{CaO}$ (7.5 a $8.5 \%), \mathrm{Na}_{2} \mathrm{O}(0.6-0.8 \%), \mathrm{MnO}(0.8 \%), \mathrm{Al}_{2} \mathrm{O}_{3}(10$ a $11 \%), \mathrm{Ni}(700$ a 800 ppm), LOI (1 a $6 \%), \mathrm{Cr}(2100-2500 \mathrm{ppm}), \mathrm{Sc}(35 \mathrm{ppm}), \mathrm{Co}(90-100 \mathrm{ppm}), \mathrm{V}(55-70 \mathrm{ppm}), \mathrm{Ta}(0.07 \mathrm{ppm}), \mathrm{Ga}$ (9 ppm), $\mathrm{Nb}(<0.5 \mathrm{ppm}), \mathrm{Y}(8-12 \mathrm{ppm})$ e $\mathrm{Sr}(10-20 \mathrm{ppm})$.

Os valores de $\mathrm{Nb}$ são semelhantes para os peridotitos, piroxenitos e gabros. As relações $\mathrm{MgO} / \mathrm{Al}_{2} \mathrm{O}_{3}$ ou $\mathrm{MgO}$ X Rb (0.15-2), $\mathrm{Ba}(0-30)$ e $\mathrm{K}_{2} \mathrm{O}(0.01-0.04)$ sugerem, com exceção dos gabros $(\mathrm{Ba}=4$ e $\mathrm{Rb}=2-4)$, mobilidade e a entrada destes elementos nos peridotitos e piroxenitos da SMUP, a partir provavelmente das rochas encaixantes da SGPM e do TGAG.

Os peridotitos e, subordinadamente, os piroxenitos, são variavelmente serpentinizados, conforme indicado pelos valores de perda ao fogo (LOI) entre 10 e $16 \%$, nestas rochas.

Os peridotitos, quando normalizados aos valores dos principais óxidos do manto primitivo ou primordial (Hofmann 1988, Sun e McDonough 1989), apresentam-se empobrecidos em $\mathrm{CaO}, \mathrm{Al}_{2} \mathrm{O}_{3}$ e $\mathrm{TiO}_{2}$. Por outro lado, as concentrações de $\mathrm{MgO}$ (base não anidra) são similares aos peridotitos harzburgíticos mantélicos em geral. 
$\mathrm{O}$ baixo conteúdo em $\mathrm{TiO}_{2}, \mathrm{Y}$, e $\mathrm{Sr}$ e o padrão e o conteúdo em elementos como $\mathrm{Cr}$, $\mathrm{Ni}, \mathrm{Sc}, \mathrm{V}, \mathrm{Co}, \mathrm{Cu}, \mathrm{e} \mathrm{Zn}$ nos peridotitos, quando normalizados aos valores do manto (Hofmann 1988, Sun \& McDonough 1989), revelam fortes analogias e semelhanças com peridotitos residuais formados em ambientes ofiolíticos tipo SSZ tais como, Ronda (Frey et al. 1985), Liguria ( Rampone et al. 1996), Leka (Furnes et al. 1992), Horoman (Frey et al. 1991), Bay of Islands (Elthon 1991), Nan Uttaradit-Tailândia (Orberger et al. 1995) e outros (Pearce et al. 1984, Pearce 1991, Parkinson \& Pearce 1998).

Os peridotitos (dunitos, harzburgitos serpentinizados e serpentinitos) da SMUP mostram forte empobrecimento em $\mathrm{TiO}_{2}$ (geralmente $=0.01 \%$ ) característico das seções mantélicas peridotíticas de ambientes do tipo $S S Z$, relacionados a margens continentais ativas (Figura 7.6). Considerando a imobilidade do $\mathrm{Ti}$ durante os processos de serpentinização e outros eventos metamórficos (Pearce \& Norry 1979, Parkinson \& Pearce 1998), este elemento pode ser utilizado como indicador do possivel local da origem dos peridotitos.

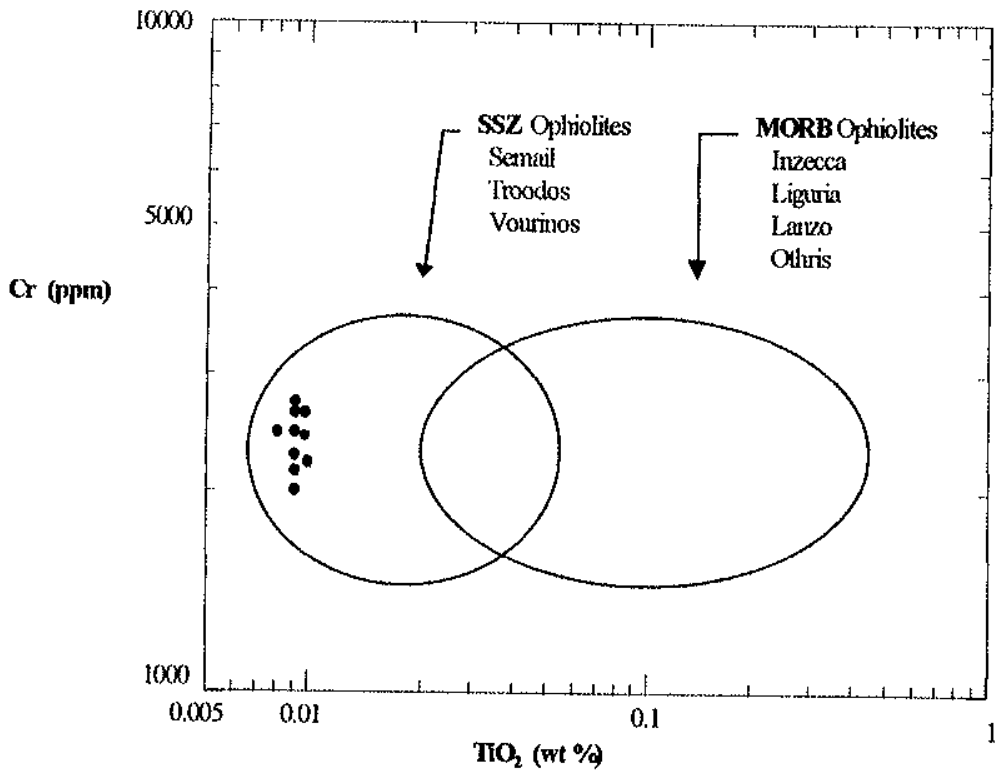

Figura 7.6 - Diagrama $\mathrm{Cr}(\mathrm{ppm}) \times \mathrm{TiO}_{2}(\%)$ para os peridotitos (dunitos a harzburgitos serpentinizados e serpentinitos) da SMUP. SSZ = peridotitos residuais de margens continentais ativas. MORB = peridotitos de margens continentais passivas em pequenas ou grandes bacias oceanicas tipo "Mid-Ocean spreading" (Fonte: Pearce ot al. 1984).

As evidências do caráter residual das rochas peridotíticas serpentinizadas são a composição harzburgítica e o empobrecimento em elementos como $\mathrm{TiO}_{2}, \mathrm{Y}, \mathrm{CaO}, \mathrm{Al}_{2} \mathrm{O}_{3}, \mathrm{Co}$, $V, S c$, ETRP e ETRL (?).

As principais características de ofiolitos SSZ e MORB Fanerozóicos que ocorrem em diversos locais do mundo são mostrados na Tabela 7.1 (Fonte: Pearce et al. 1984). Mesmo 
com a ausência da seção crustal, a SMUP mostra semelhanças com os do tipo SSZ. Nos ofiolitos onde não ocorrem rochas vulcânicas e sedimentos associados, a ausência dos componentes crustais é explicada pelo curto periodo de tempo entre a formação, alojamento e a deformação destas rochas, ou seja, entre a extensão crustal responsável pelo alojamento dos "Sheet diques", rochas basálticas e os sedimentos associados e a compressão deformadora. Em cenários geotectônicos onde as zonas de subducção tem longa duração e onde há desenvolvimento de pequenas bacias oceânicas associadas, as seqüências ofiolíticas geralmente apresentam-se completas, com seçōes mantélicas e crustais, a exemplo do ofiolito SSZ de Semail no Sultanato de Oman. 
Tabela 7.1 - Características geológicas dos complexos máficos-ultramáficos Fanerozóicos (Fonte: Pearce et al. 1984)

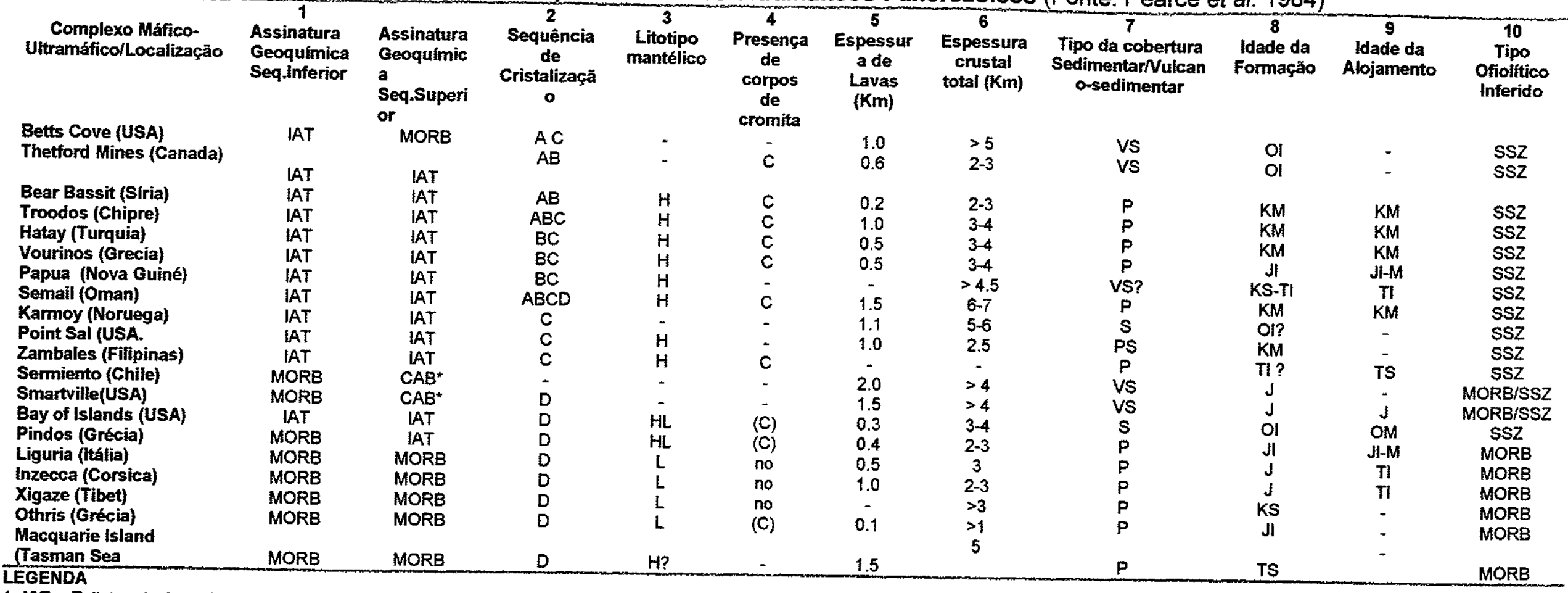

1. IAT = Tolietos de Arco de liha; MORB = Basaltos de ambientes meso oceânicos; CAB* = Basaltos Cálcio-Alcalinos " não é parte da sequência ofiolitica, M= leves afinidades com MORB, leves afinidades com IAT

2. $A=$ ol opx cpx plag; $B=$ ol $\operatorname{cpx}$ opx plag; $C=$ of $c p x$ plag; $D=$ ol plag $c p x$.

3. $H=$ predominantemente harzburgito; $H L=$ hazburgito + therzolito; $L=$ predominantemente therzolito

4. $C=$ Ocortência significante; $(C)$ ocorrência insignificante.

7. $\mathbf{P}=$ Sedimentos pelágicos; $\mathbf{S}=$ Sedimentos terrígenos; $\mathbf{V S}=$ Sedimentos vulcanoctásticos \pm lava.

8 e $9 . \mathbf{O}=$ Ordoviciano; $\mathbf{J}=$ Jurássico; $\mathbf{K}=$ Cretácio; $\mathrm{T}=$ Terciário; $\boldsymbol{I}=\operatorname{Inferior} ; \boldsymbol{M}=$ Médio e $\mathbf{S}=$ Superior

10. SSZ = ofiolitos relacionados com zonas de subducção; MORB = ofiolitos relacionados com margens continentais passivas. 


\section{6 - Geocronologia}

As análises Sm-Nd em rocha total dos principais litotipos da SMUP, não foram concluidas até o momento. Por este motivo, serão apresentados apenas resultados preliminares e dados extraidos de Siga Jr. (1995).

As análises $\mathrm{U}-\mathrm{Pb}$ em zircões dos gabros foram efetuadas pela metodologia U-Pb SHRIMP, que consiste-se em análises pontuais das razões isotópicas de $U$ e $\mathrm{Pb}$ dos zircões representativos desta rocha. $A$ opção pelo SHRIMP deve-se à pequena quantidade de zircões extraídos destes gabros $(\mathrm{Zr}=30$ a $60 \mathrm{ppm})$.

A metodologia $\mathrm{K}$-Ar foi aplicada em plagioclásio de plagioclásio-espinélioortopiroxenito.

Oito análises U-Pb (SHRIMP) foram efetuadas em 5 cristais de zircões extraídos de gabros toleíticos (Tabela 7.2, Figura 7.7) e os resultados são apresentados na Figura 7.7. As duas análises U-Pb em zircões esféricos, raramente encontrados neste gabro, indicaram em um mesmo cristal, idades paleoproterozóicas de $2191 \pm 44 \mathrm{Ma}$ (núcleo) e $2128 \pm 33 \mathrm{Ma}$ (borda). As demais 6 análises foram efetuadas em zircões prismáticos, mais freqüentes nesta rocha, com zoneamentos oscilatórios tipicamente ígneos e sem sobrecrescimentos.

Os dois cristais de zircões prismáticos e com zoneamento oscilatório ígneo desta rocha (pontos 3.1 e 5.1, Tabela 7.2, Figura 7.7) indicaram idades neoproterozóicas de $632 \pm$ $18 \mathrm{Ma}$ (borda) e $631 \pm 17 \mathrm{Ma}$ (parte mediana do cristal, entre borda e núcleo).

As demais análises (pontos 1.1, 3.2, 4.1 e 4.2, Figura 7.7, Tabela 7.2) demonstraram variável perda de $\mathrm{Pb}$ radiogênico e ganho de $\mathrm{Pb}$ comum (Tabela 7.2), devido principalmente à metamictização destes zircões, indicando idades sem significado geológico entre 577 e $531 \mathrm{Ma}$.

A idade concordante de $631 \pm 17 \mathrm{Ma}$ é interpretada como a melhor e mais confiável idade de formação destes gabros.

Os raros zircões esféricos paleoproterozóicos, típicos das rochas granulíticas máficas e félsicas do TGAG adjacente, foram incorporados durante o alojamento dos gabros da SMUP. Nestas rochas granuliticas, obtivemos, pela metodologia U-Pb convencional, conforme apresentado adiante, idades entre 2100 e $2050 \mathrm{Ma}$, em zircões esféricos e elipsoidais, compativeis com as idades encontradas nos zircões esféricos destes gabros. 
Tabela 7.2 - Análises U-Pb (SHRIMP) em zircões do Gabro da SMUP.

\begin{tabular}{|c|c|c|c|c|c|c|c|}
\hline Local da análise no zircão. & $u$ & Th & $T h / U$ & 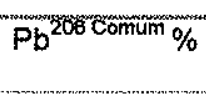 & $\mathrm{U}^{236} / \mathrm{Pb}^{206}$ & $\mathrm{~Pb}^{20 /} / \mathrm{Pb}^{20 \mathrm{~B}}$ & $\begin{array}{l}\text { Idade Ma } \\
\text { Erro }=1 \mathrm{~s}\end{array}$ \\
\hline 1.1 & 302 & 174 & 0.58 & $1.06 \pm 0.17$ & $10.650 \pm 0.307$ & $0.0678 \pm 0.0014$ & $573 \pm 16$ \\
\hline 2.1 & 192 & 270 & 1.41 & $0.65 \pm 0.07$ & $2.277 \pm 0.088$ & $0.1371 \pm 0.0034$ & $2191 \pm 44$ \\
\hline 2.2 & 199 & 121 & 0.61 & $0.21 \pm 0.05$ & $2.740 \pm 0.085$ & $0.1323 \pm 0.0025$ & $2128 \pm 33$ \\
\hline 3.1 & 163 & 80 & 0.49 & $0.50 \pm 0.08$ & $9.665 \pm 0.285$ & $0.0632 \pm 0.0006$ & $632 \pm 18$ \\
\hline 3.2 & 260 & 87 & 0.34 & $0.37 \pm 0.07$ & $10.644 \pm 0.324$ & $0.0622 \pm 0.0006$ & $577 \pm 17$ \\
\hline 4.1 & 172 & 94 & 0.55 & $0.79 \pm 0.08$ & $11.250 \pm 0.312$ & $0.0656 \pm 0.0006$ & $545 \pm 15$ \\
\hline 4.2 & 179 & 118 & 0.66 & $0.85 \pm 0.08$ & $11.555 \pm 0.378$ & $0.0660 \pm 0.0007$ & $531 \pm 17$ \\
\hline 5.1 & 219 & 145 & 0.66 & $0.25 \pm 0.10$ & $9.700 \pm 0.270$ & $0.0612 \pm 0.0008$ & $631 \pm 17$ \\
\hline
\end{tabular}

Observacão: Efetuamos uma cuidadosa coleta de amostras $(40-50 \mathrm{~kg})$ desta rocha, com a textura original e sem fraturas. Os processos de britagem, moagem, peneiramento e separação dos minerais pesados na mesa vibratória e no separador magnético (Frantz) foi feita com a completa limpeza dos equipamentos utilizados, evitando qualquer tipo de contaminação da amostra. Os líquidos densos foram também filtrados. Estes cuidados foram tomados em razäo destas rochas apresentarem baixo conteúdo de $\mathrm{Zr}=30$ a $60 \mathrm{ppm}$, sujeitando-a facilmente aos possíveis problemas de contaminação durante todo o procedimento de concentração dos zircőes. Os mesmos procedimentos foram adotados para as demais rochas, mas esta em especial mereceu maior cuidados.
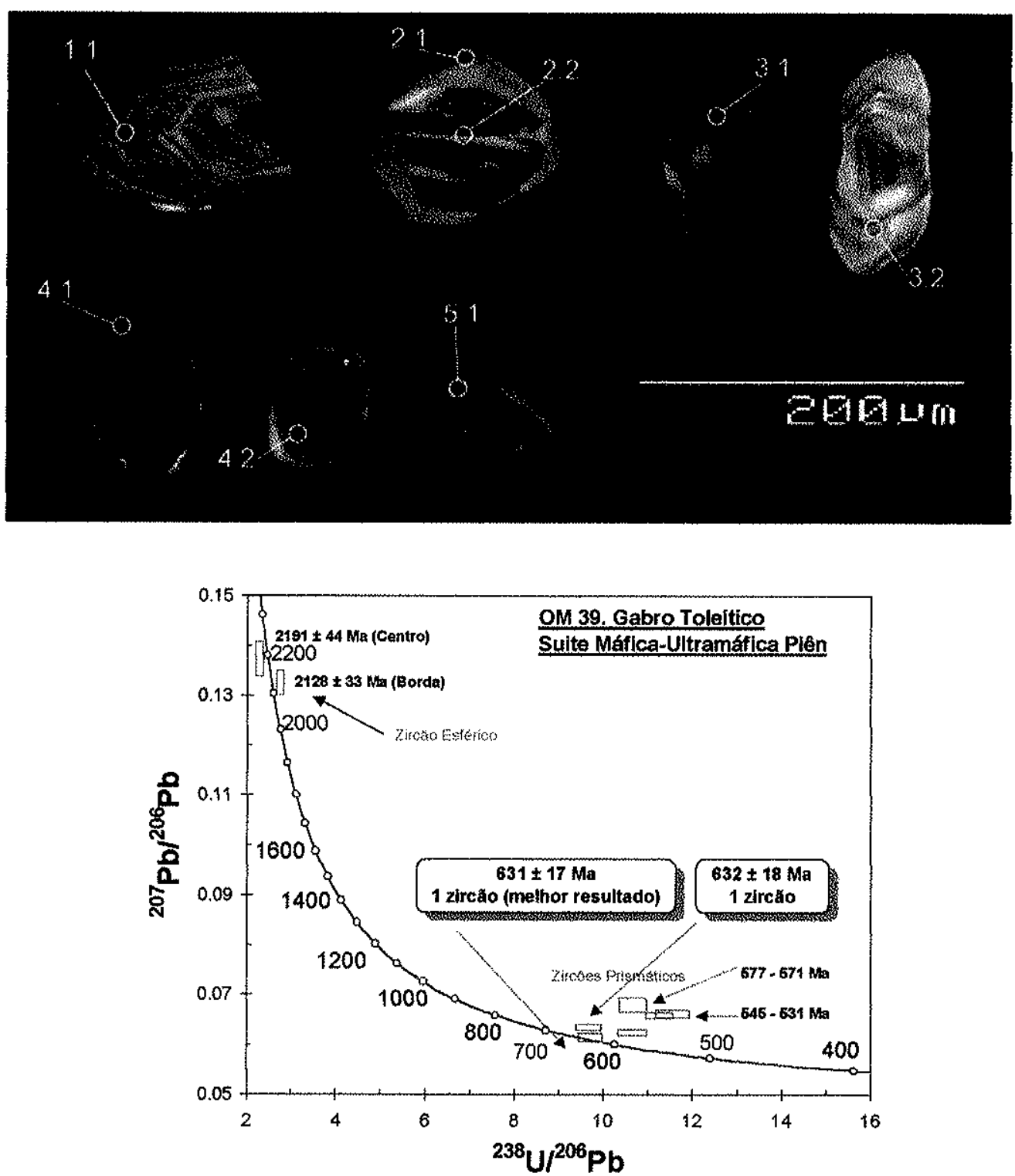

Figura 7.7 - Diagrama $\mathrm{U}^{238} / \mathrm{Pb}^{206} \times \mathrm{Pb}^{207} / \mathrm{Pb}^{206}$ para os zircठes do gabro da SMUP. 
$\mathrm{A}$ análise $\mathrm{K}-\mathrm{Ar}$ em plagioclásio de um espinélio-ortopiroxenito do corpo setentrional CC (Tabela 7.3) resultou em idade neoproterozóica de $600 \pm 17 \mathrm{Ma}$, interpretada como representativa da idade da deformação da SMUP.

Tabela 7.3 - Análises isotópicas e idades K-Ar da SMUP.

\begin{tabular}{|c|c|c|c|c|c|c|}
\hline No de Campo & Mineral & Rocha & $\begin{array}{c}K \\
(\%)\end{array}$ & ${ }_{B}^{A r^{40}} \operatorname{Rad} \operatorname{ccSTP} / g^{*} 10^{\circ}$ & $\begin{array}{c}\mathrm{Ar}^{40} \mathrm{Atm} \\
(\%)\end{array}$ & $\begin{array}{c}\text { Idade } \pm \text { Erro } \\
(\mathrm{Ma})\end{array}$ \\
\hline OM 149B-5†8B & Plagioclásio & $\begin{array}{l}\text { Pag-Esp- } \\
\text { Ortopiroxeniro }\end{array}$ & 1.4934 & 42.10 & 2.43 & $610 \pm 17$ \\
\hline
\end{tabular}

Em uma amostra de serpentinito, duas amostras de piroxenitos e uma amostra de gabro do corpo setentrional CC, Siga Jr. (1995) obteve uma idade isocrônica Sm-Nd em rocha total de $2248 \pm 46 \mathrm{Ma}$ e idades modelo ( $\mathrm{T}_{D M}$ ) entre 2.5 e $3.2 \mathrm{Ga}$ (Figura 7.8). Segundo este autor, a idade isocrônica Sm-Nd data o metamorfismo granulítico (?) paleoproterozóico sofrido pelas rochas da SMUP, similar e sincrônico ao das rochas do TGAG adjacente, enquanto as idades modelo ( $\left.\mathrm{T}_{\mathrm{DM}}\right)$ indicam a diferenciaçäo destas rochas a partir do manto. Ressaltamos que as idades isocrônicas Sm-Nd (rocha total) para as rochas do TGAG e da SGPM, quando possíveis de calcular, são da ordem de $1.8 \mathrm{Ga}$ e 2.2 a $2.0 \mathrm{Ga}$ respectivamente. Os valores de $\in \mathrm{Nd}^{(\mathrm{T})}$ nestas rochas, para idades neoproterozóicas $\mathrm{e}$ paleoproterozóicas, apresentam grande dispersão $\left(E x: \in N d^{(T)}\right.$ para $600 \mathrm{Ma}$ são $-6,-16,-22$ e $-24)$.

As análises Sm-Nd (rocha total) ainda não finalizadas estão sendo aplicadas em peridotitos (dunitos, harzburgitos serpentinizados e serpentinitos), piroxenitos (olivinapiroxenitos e piroxenitos e, gabros desta unidade.

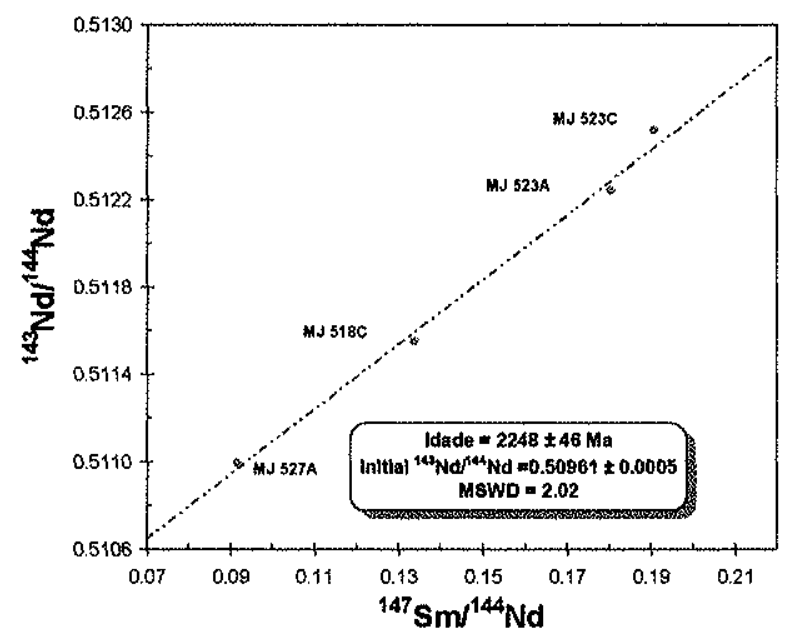

Figura 7.8 - Diagrama Isocrónico $\mathrm{Sm}^{147} / \mathrm{Nd}^{144} \times \mathrm{Nd}^{143} / \mathrm{Nd}^{144}$ do corpo $\mathrm{CC}$ da SMUP. (Fonte: Siga Jr. 1995). 


\section{0 - Terreno Gnáissico Anfibolítico Granulítico do Paraná e Santa Catarina (TGAG)}

\section{1- Introdução}

O Terreno Gnáissico Anfibolitico Granulitico do Paraná e Santa Catarina (TGAG) é constituído, nesta região, principalmente por ortognaisses granulíticos máficos a intermediário e félsicos e gnaisses biotíticos e anfibolíticos. Na área estudada, esta unidade ocorre como dois segmentos descontínuos, separados pelas rochas vulcanossedimentares da Bacia de Campo Alegre. Estes segmentos serão aqui denominados trechos NE e SW, respectivamente.

Os gnaisses granulíticos máficos a intermediários (ortopiroxênio \pm clinopiroxênio \pm anfibólio \pm biotita noritos e quartzo-noritos) predominam sobre os félsicos (ortopiroxênio \pm clinopiroxênio \pm anfibólio \pm biotita enderbitos). Ocorrem ainda charnoquitos máficos a intermediários e félsicos. Os gnaisses granulíticos apresentam bandamento fino a grosso, paralelo à foliação, ocorrendo ainda, porções "charnoquíticas" isótropas. Este bandamento é caracterizado pela alternância de níveis heterogêneos milimétricos a centimétricos félsicos (plagioclásio + quartzo \pm K-feldspato) e máficos (ortopiroxênio \pm clinopiroxênio \pm anfibólio \pm biotita). Os principais minerais acessórios são apatita, rutilo, zircão e magnetita. 0 zircão apresenta-se como cristais esféricos e/ou elipsoidais.

Os gnaisses granulíticos máficos e félsicos apresentam assembléias mineralógicas com plagioclásio (oligoclásio a labradorita), ortopiroxênio, clinopiroxênio, anfibólio e biotita, características do metamorfismo de alto grau (fácies granulito). Este metamorfismo ocorreu durante o Paleoproterozóico, entre 2,1 e 2,0 Ga, conforme indicam as idades U-Pb obtidas, tanto nos zircões esféricos, como nos elipsoidais. Exceções são os charnoquitos máficos ricos em biotita e anfibólio do trecho NE do TGAG, que apresentaram idades U-Pb da ordem de 2,2 Ga obtidas em zircões elipsoidais e aciculares. O resfriamento e a estabilização tectônica do TGAG ocorreram por volta de 1,8 Ga, conforme indicam as idades $\mathrm{K}$-Ar em anfibólio e, principalmente, biotita.

Os gnaisses biotíticos e anfibolíticos (dioritos/monzodioritos/quartzo dioritos/tonalitos, raros granodioritos e monzogranitos), rochas sem evidências de granulitização ou passagem por metamorfismo de alto grau, afloram expressivamente no trecho $N E$, subordinadamente, no SW intercalados nos gnaisses granulíticos máficos a intermediários e félsicos. Apresentam em geral assembléias mineralógicas contendo plagioclásio (oligoclásio a andesina), \pm K-feldspato (microclínio), quartzo, anfibólio, biotita e epídoto, com ausência total de ortopiroxênio e clinopiroxênio ou presença somente de pseudomorfos destes dois minerais. Os minerais acessórios mais freqüentes são zircão, apatita, titanita e 
allanita. O zircão apresenta morfologia elipsoidal semelhante a encontrada nos gnaisses granulíticos máficos a intermediários e félsicos.

São freqüentes lentes de anfibolitos e rochas ultramáficas (piroxenitos e peridotitos serpentinizados) e, mais raramente, lentes de quartzitos.

Não foram encontrados no TGAG desta região, litotipos granulíticos de origem pelítica tais como, gnaisses e xistos com assembléias mineralógicas contendo corderita, granada, cianita e sillimanita e com minerais acessórios como, a monazita.

Reativações tectônicas neoproterozóicas estão registradas principalmente nos litotipos gnáissicos da porção norte do trecho SW. Evidências são sugeridas pela deformação e o paralelismo das estruturas tectônicas das rochas do TGAG e as da SGPM e da SMUP, o retrometamorfismo de baixo a médio grau imposto às paragêneses minerais de alto grau, a forte orientação e recristalização da biotita dos gnaisses anfibolíticos e biotíticos e as idades K-Ar obtidas em biotita e anfibólio.

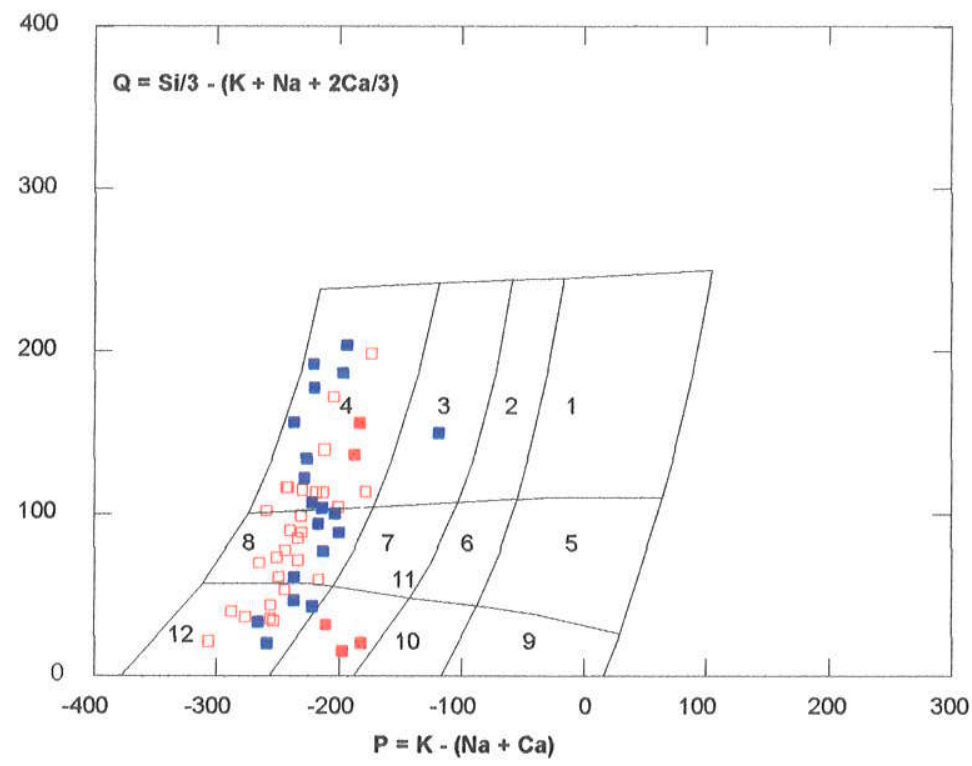

Figura 8.1 - Diagrama P-Q (Modificado de Debon \&. Lefort 1983) indicando a composição dos principais litotipos do TGAG.

1- Granitos, 2- Piroxênio-Monzogranitos (Charnoquitos), 3- Piroxênio-Granodioritos (Charno-enderbitos), 4Piroxênio Tonalitos-Thronjimitos (Enderbitos), 5- Quartzo-Sienitos, 6-Quartzo-Monzonitos, 7- Piroxênio-QuartzoMonzodioritos, 8- Quartzo-Dioritos/Piroxênio-Quartzo-Noritos, 9-Sienitos, 10- Monzonitos, 11Monzodioritos/Monzogabros, 12- Dioritos/Gabros/Noritos.

Quadrado azul cheio : gnaisses granulíticos do TGAG da região investigada. Quadrado vermelho cheio: Gnaisses não granulíticos do TGAG. Círculo meio cheio vermelho: gnaisses granulíticos e anfibolíticos ricos em porfiroblastos de granada. Quadrado vazio vermelho: litotipos granulíticos da porção meridional do TGAG (dados retirados de Fornari 1998). 


\section{2 - Petrográfica e metamorfismo}

A seguir serão apresentadas as principais caracteristicas macro e microscópicas dos litotipos do TGAG. Os litotipos granulíticos são gnaisses granulíticos máficos a intermediários e félsicos e gnaisses granulíticos máficos ricos em granada. Os litotipos não granulíticos são aqui designados de gnaisses biotíticos e anfibolíticos (dioritos/monzodioritos, quartzo dioritos e tonalitos) com anfibólio \pm biotita, biotita \pm anfibólio, biotita-anfibólio e anfibólio-biotita

\subsection{1- Gnaisses Granuliticos Félsicos (ortopiroxênio \pm clinopiroxênio \pm anfibólio \pm biotia- enderbitos, P.Q modificado de Debon \& Le Fort 1983)}

Estas rochas ocorrem principalmente nas porções norte dos dois trechos SW e NE, e como lentes inclusas nos gnaisses granulíticos máficos a intermediários. São rochas de coloração cinza-verde, granulação média a grossa, com bandamento fino a grosso paralelo à foliação. Mais, raramente, ocorrem tipos isótropos. Apresentam texturas geralmente granoblásticas e granoblásticas deformadas.

Os principais minerais constituintes desses gnaisses são plagioclásio (oligoclásio a andesina), quartzo, ortopiroxênio (hiperstênio), clinopiroxênio (diopsídio), anfibólio (hornblenda, cor verde oliva), biotita (cor castanho-vermelho), K-feldspato (microclínio) e granada. Esta última ocorre somente nos tipos com granada. Os principais minerais acessórios são rutilo, apatita e zircão, que ocorrem geralmente associados ou inclusos nos minerais máficos. Os cristais de zircão apresentam duas principais morfologias: esféricos e elipsoidais.

O ortopiroxênio ocorre geralmente como cristais euhédricos a subédricos e anédricos, associados ou não a clinopiroxênio e constituindo com o plagioclásio, a textura granoblástica ou granoblástica deformada caracterizadas pelo alinhamento principalmente destes dois minerais. Os cristais de ortopiroxênio ocorrem ainda em simplectitos com restos de anfibólio, biotita e clinopiroxênio, concentrados em bandas máficas cujas relações texturais são sugestivas da formação do ortopiroxênio \pm clinopiroxênio por substituição metamórfica de alto grau da biotita e do anfibólio.

Os cristais de quartzo (freqüentemente com extinção ondulante) e K-feldspato (microclínio), quando presentes, são anédricos e intersticiais a plagioclásio e ortopiroxênio. O quartzo pode ocorrer como inclusões em ortopiroxênio, associados a raros cristais de biotita e anfibólio, o que sugere que a formação do ortopiroxênio tenha se dado por consumo de biotita e, subordinadamente, de anfibólio. 
Geralmente associadas e inclusas nestas rochas ocorrem lentes que diferem de suas encaixantes pela presença expressiva de granada, bandadas, finamente foliadas e até isótropas. As relações texturais entre a granada e o ortopiroxênio sugerem a formação da granada por substituição metamórfica em alto grau de ortopiroxênio.

As texturas e as paragêneses minerais presentes indicam que estas rochas foram submetidas a forte deformação em condições metamórficas de alto grau.

As assembléias mineralógicas indicativas do metamorfismo do alto grau (fácies granulito) encontradas nestes gnaisses, com ou sem granada, são : plagioclásio + quartzo + ortopiroxênio (hiperstênio) \pm clinopiroxênio (diopsídio) \pm hornblenda \pm biotita \pm granada $\pm \mathrm{K}$ feldspato (microclínio) + rutilo + zircão (elipsoidal e esférico) + magnetita e plagioclásio + quartzo + granada \pm ortopiroxênio \pm hornblenda \pm biotita + rutilo + zircão

A presença do ortopiroxênio \pm anfibólio \pm biotita sugere protólitos tonalíticos contendo plagioclásio, biotita, hornblenda e quartzo com ou sem K-feldspato (mineralogia essencial e predominante das rochas dos terrenos TTG paleoproterozóicos e arqueanos em geral, Martin 1993, 1994 e 1998) submetidos ao metamorfismo de alto grau. As possiveis reações de consumo de biotita elou hornblenda para a formação de ortopiroxênio e clinopiroxênio durante o metamorfismo de alto grau em rochas ígneas máficas a intermediárias e félsicas seriam (Hariey 1989 e 1992): biotita + anfibólio + quartzo = ortopiroxênio (clinopiroxênio) + $\mathrm{K}$-feldspato + plagioclásio $+\mathrm{H}_{2} \mathrm{O}$; biotita + quartzo $=$ ortopiroxênio (clinopiroxênio) $+\mathrm{K}$ feldspato + plagioclásio $+\mathrm{H}_{2} \mathrm{O}$; anfibólio + quartzo $=$ clinopiroxênio + ortopiroxênio + plagioclásio $+\mathrm{H}_{2} \mathrm{O}$; ortopiroxênio + plagioclásio = granada + quartzo .

As duas primeiras reaçöes são as mais prováveis, em razão do pequeno volume de anfibólio, biotita e clinopiroxênio e predominância de ortopiroxênio. Outras hipóteses podem ser sugeridas como, a maior ou menor presença de biotita e anfibólio no protólito submetido à granulitização, consumo total da biotita em relação ao anfibólio (diferenças de temperaturas do consumo da biotita e da hornblenda durante as reações metamórficas de alto grau) ou somente a formação do ortopiroxênio por consumo de biotita e, subordinadamente, de anfibólio.

Lentes de serpentinitos, gnaisses anfiboliticos, gnaisses granuliticos máficos e rochas quartzo-feldspáticas ocorrem intercaladas nos gnaisses granulíticos félsicos do trecho SW do TGAG.

Próximo e ao longo da ZCPT, além de mudança na direção da estruturação para direção NE paralela a da SGPM e da SMUP, os gnaisses félsicos apresentam estruturas miloniticas caracterizadas pelo forte estiramento e orientação de quartzo, plagioclásio, epídoto e tremolita-actinolita-cumingtonia. Estes últimos são formados por substituição 
parcial a total do ortopiroxênio e clinopiroxênio, ao redor dos quais concentram-se, estando orientados segundo foliação. Epídoto metamórfico ocorre também preenchendo fraturas e microfraturas paralelas ou obliquas à foliação.

8.2.2 - Gnaisses granulíticos máficos a intermediários (noritos e quartzo-noritos Q.P modificado de Debon \& Lefort 1983) com lentes de gnaisses granulíticos máficos ricos em biotita e anfibolio

Estas rochas apresentam coloração cinza escuro-verde e bandamento gnáissico fino a grosso paralelo à foliação. Tipos isótropos ocorrem raramente, como os charnoquíticos máficos presentes nos dois trechos, SW e NE. O bandamento é caracterizado pela alternância de niveis félsicos constituidos por plagioclásio (andesina-labradorita) + quartzo \pm FK e níveis máficos constituidos por ortopiroxênio (hiperstênio) + clinopiroxênio (diopsídio), \pm anfibólio (hornblenda, cor verde oliva) \pm biotita (cor castanha-avermelhada). Dentro deste bandamento os minerais constituintes apresentam textura granoblástica ou granoblástica orientada caracterizada pelo alongamento e orientação de cristais subédricos a anédricos de ortopiroxênio, clinopiroxênio, hornblenda, biotita e plagioclásio. A textura granolepidoblástica é típica dos tipos ricos em biotita e anfibólio e caracteriza-se pela orientação de biotita e hornblenda e pelo alongamento e orientação de piroxênio, que forma simplectitos sugestivos de sua formação por substituição de biotita e anfibólio. O volume e a preservação do anfibólio e da biotita nestes rochas variam de acordo com a evolução, em função da temperatura, das reações metamórficas típicas da fácies granulito que originam o clinopiroxênio e ortopiroxênio e do volume destes minerais nos protólitos ígneos. Similarmente a seus correspondentes félsicos, as relações texturais sugerem reações de consumo parcial a total da biotita e de hornblenda para a formação de ortopiroxênio e clinopiroxênio.

Os principais minerais acessórios são rutilo, magnetita, apatita e zircão que ocorrem geralmente associados ou inclusos em ortopiroxênio, clinopiroxênio, anfibólio e biotita.

As paragêneses minerais indicativas do metamorfismo de alto grau observadas na maioria das rochas são plagioclásio + ortopiroxênio \pm clinopiroxênio \pm anfibólio \pm biotita \pm quartzo \pm rutilo \pm zircão \pm magnetita.

Próximo à ZCPT e em zonas de falhas internas, além de apresentarem mudanças na estruturação, os gnaisses granulíticos máficos tornam-se gnaisses máficos anfibolíticos miloníticos com plagioclásio, anfibólio (hornblenda), tremolita-actinolita-cumingtonita e epídoto com textura grano-nematoblástica. Esta textura é produzida pela substituição parcial a total do ortopiroxênio e clinopiroxênio por anfibólios aciculares (tremolita-actínolitacumingtonita) orientados segundo a foliação. 
A mineralogia $e$ as relações texturais entre os minerais sugerem reações retrometamónficas do tipo: ortopiroxênio + clinopiroxênio + plagioclásio $+\mathrm{H}_{2} \mathrm{O}=$ anfibólio + quartzo ou ortopiroxênio + clinopiroxênio $+\mathrm{H}_{2} \mathrm{O}=$ cumingtonita-actinolita-tremolita

Intercalados nos gnaisses granulíticos máficos a intermediários ocorrem lentes de gnaisses granuliticos piroxeníticos, gnaisses granulíticos félsicos, anfibolitos, piroxenitos, peridotitos serpentinizados e veios quartzo-feldspáticos.

\subsection{3 - Gnaisses granuliticos máficos e anfibolíticos ricos em megacristais de granada (Noritos, P-Q de Debon \& Lefort 1983)}

Estas rochas ocorrem como corpos lenticulares ao longo da ZCPT, ao norte dos dois corpos setentrional e meridional da SMUP e na porção norte do trecho NE do TGAG. Apresentam coloração cinza escura, granulação fina a média e grossa e são constituídas principalmente por plagioclásio (andesina a labradorita), granada, ortopiroxênio (hiperstênio), clinopiroxênio (diopsídio), hornblenda (cor marrom) e raramente biotita (cor castanha-avermelhada). Os principais minerais acessórios são a apatita, magnetita e zircão. As duas principais morfologias de zircão são elipsoidais e esféricos. $O$ bandamento é caracterizado pela alternância de niveis máficos ricos em anfibólio e piroxênio e níveis félsicos ricos em plagioclásio.

A textura é granoblástica, caracterizada pela orientação e contornos relativamente retos entre cristais subédricos a anédricos de hornblenda, piroxênio e plagioclásio. A granada ocorre como porfiroblastos anédricos (2 a $5 \mathrm{~cm}$ de diâmetro) ou como cristais menores concentrados preferencialmente em niveis que definem a foliação e/ou o bandamento. A granada concentrada nestas bandas máficas apresenta freqüentes inclusões de ortopiroxênio, clinopiroxênio, hornblenda e plagioclásio. As relações texturais entre estes minerais máficos, principalmente ortopiroxênio, clinopiroxênio e plagioclásio, com a granada sugerem a formação desta por substituição de piroxênios, em reações metamórficas em alta pressão do tipo: ortopiroxênio + plagioclásio = granada + quartzo ; ortopiroxênio + plagioclásio $=$ granada + diopsídio + quartzo .

Este tipo de relação textural entre granada e piroxênio em rochas de alto grau sugere, segundo Harley (1989 e 1992), Bohlen (1991) e outros, trajetórias metamórficas de alta temperatura e alta pressão que resultam na estabilidade e cristalização da granada. Isto é, ao contrário das reações da quebra da granada, em trajetórias metamórficas de descompressão em alto grau tipo ITD (descompressão isotermal) que resultam na formação de texturas coroníticas caracterizadas pela presença de granada no centro manteada por simplectitos de ortopiroxênio e plagioclásio nas margens. 
Ao longo da ZCPT ocorrem, associados a estas rochas, gnaisses anfibolíticos granatiferos de coloração cinza escura, granulação fina a média, constituidos por plagioclásio, hornblenda, ortopiroxênio, clinopiroxênio, granada, epidoto e tremolitaactínolita-cumingtonita. Apresentam texturas porfiro-nematoblásticas onde os anfibólios aciculares ou fibrosos são formados pela substituição parcial ou total de piroxênios e a granada, à partir de opacos. Estas transformações metamórficas são atribuidas à tectônica Neoproterozóica concentrada ao longo da ZCPT.

\subsection{4 - Gnaisses biotíticos e anfibolíticos (dioritos, monzodioritos, quartzo-dioritos e tonalitos, P-Q de Debon \& Lefort 1983)}

Estas rochas afloram principalmente ao longo da ZCPT, intercalados com os litotipos granulíticos e, em grande parte do trecho NE. São rochas de coloração verde-cinza, granulação média a grossa com foliação/bandamento fino a grosso caracterizado pela alternância de niveis félsicos de plagioclásio (oligoclásio a andesina), quartzo e K-feldspato e niveis máficos constituídos em geral de anfibólio (hornblenda) \pm biotita e biotita \pm anfibólio \pm epidoto. O piroxênio é ausente, mas em rochas próximas à ZCPT, foram identificados pseudomorfos de piroxênio (?), constituidos por tremolita-actinolita-cumingtonita. Os principais minerais acessórios são apatita, zircão, titanita e allanita. Os cristais de zircão são em geral elipsoidal, similar a uma das morfologias encontradas nos gnaisses granulíticos máficos e félsicos.

A biotita ocorre como cristais lamelares ou sigmoidais geralmente associados a anfibólio em simplectitos deformados, com ou sem epídoto, e encontram-se recristalizados e orientados segundo o bandamento/foliação. Os cristais de anfibólio são geralmente subédricos a anédricos ou sigmoidais, que ocorrem isolados ou associados em simplectitos e orientados segundo a foliação.

O quartzo apresenta forte estiramento e recristalização, aparecendo sob a forma de sigmóides orientados, principalmente nos niveis félsicos. Os cristais de plagioclásio são subédricos a anédricos e ocorrem preferencialmente nos níveis félsicos, apresentando forte estiramento e deformação

Ao longo e próximo à ZCPT, os dados U-Pb indicaram idades paleoproterozóicas em monzodioritos que afloram neste local. As análises $\mathrm{K}$-Ar em biotita e anfibólio, indicaram idades neoproterozóicas sugestivas da reativação tectono-metamórfica destas rochas neste trecho. 


\section{3 - Análise Estrutural}

A principal estrutura regional presente no TGAG é um bandamento e/ou foliação com direção regional predominante N60-70W/60NE (Figura 8.2) desenvolvidos, no caso dos litotipos granulíticos, durante a deformação e o metamorfismo granulítico durante o Paleoproterozóico. Este bandamento/foliação mostra, na porção sul do trecho SW, freqüentes inclinações para SW (Figura 8.2), sugerindo um dobramento com direção axial em torno de N50-60 W e eixo aproximadamente subhorizontal. Observa-se, localmente, mesodobras intrafoliais com eixos subhorizontais N50-60W e lineações minerais (biotita e anfibólio) orientadas $20^{\circ}-40^{\circ} / \mathrm{N} 40-60 \mathrm{~W}$, paralela ao eixo da dobra constituida e relacionadas a este dobramento.
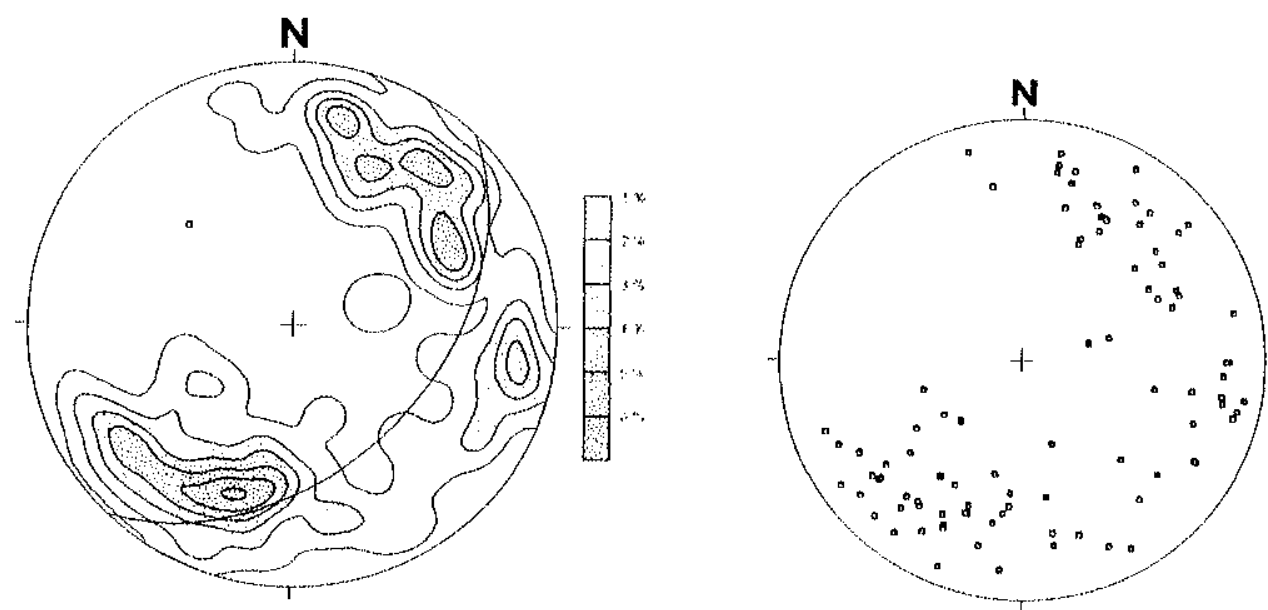

Figura 8.2 - Diagrama de frequiência dos pólos das foliaçōes Sn da porção sul do trecho SW do TGAG. No. das Foliações $=106$. Sn Máximo $=$ N70W/57NE.

Próximo e ao longo da ZCPT, principalmente na porção norte do trecho SW, ocorre uma mudança na direção da foliação gnáissica, acompanhada por substituição parcial a total dos piroxênios por anfibólios (tremolita-actinolita-cumingtonita), aparecimento de epídoto, forte estiramento de quartzo (nos gnaisses granulíticos máficos e félsicos) e forte recristalização e estiramento da biotita e anfibólio nos gnaisses biotíticos e anfibolíticos. $\mathrm{A}$ estruturação neste local, com foliações E-W/48N a N60-80E/50-70 para NW e SE (Figura 8.3) e lineações minerais $40^{\circ}-50 \%$ S $50-70 \mathrm{~W}$, é paralela a obliqua à estruturação da SMUP e da SGPM. Este paralelismo estrutural, somado ao retrometamorfismo de baixo a médio grau imposto ao TGAG e às idades K-Ar neoproterozóicas obtidas nos gnaisses biotíticos e anfibolíticos, sugerem o retrabalhamento tectono-metamórfico da porção norte do trecho SW. A posição das foliações e lineações neste trecho, a presença da "klippe" do corpo meridional da SMUP e o "decréscimo" das idades K-Ar neoproterozóicas obtidas sugerem 
um cavalgamento obliquo da SGPM sobre a SMUP e desta sobre o TGAG, associado com movimentação principal transpressional.

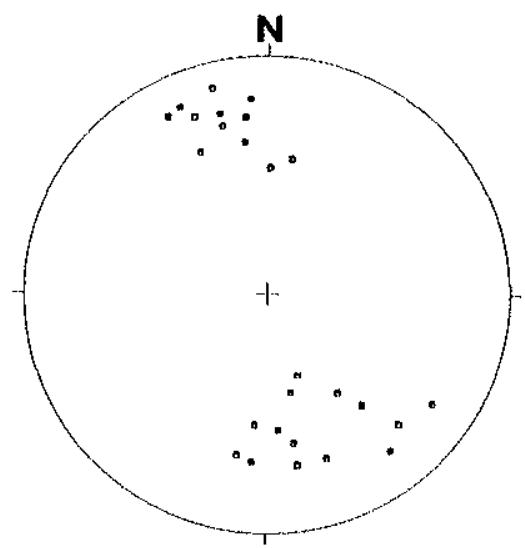

Figura 8.3 - Diagrama dos pólos das foliações Sn da porção norte do trecho SW do TGAG. No. das Foliaçōes $=26$. Sn Máximo. $=$ N71E/73SE e N80E $/ 62 \mathrm{NW}$.

\section{4 - Litogeoquímica}

Nesta seção, será apresentado um resumo das caracteristicas quimicas dos principais litotipos do TGAG nesta região.

As características litoquímicas dos gnaisses granulíticos máficos a intermediários e félsicos e dos gnaisses biotíticos e anfibolíticos serão resumidas a seguir. $O$ tratamento e a análise destes dados foram feitos com cuidado, observando o comportamento e o conteúdo dos elementos químicos dos litotipos granulíticos e não granulíticos. Além disso, devem ser levados em consideração o efeito do metamorfismo granulitico na alteração da assinatura química original e a possivel cogeneticidade anterior ao metamorfismo de alto grau.

$\mathrm{Em}$ diagramas $\mathrm{K}_{2} \mathrm{O}+\mathrm{Na}_{2} \mathrm{O}-\mathrm{FeO}-\mathrm{MgO}$ e $\mathrm{SiO}_{2} \times \mathrm{K}_{2} \mathrm{O}$ e $\mathrm{SiO}_{2} \times \mathrm{Na}_{2} \mathrm{O}$, os gnaisses granuliticos máficos, intermediários e félsicos $\left(\mathrm{SiO}_{2}=52\right.$ a $\left.74 \%\right)$ apresentam afinidades com a série cálcio-alcalina-throndjimitica de baixo $\mathrm{K}_{2} \mathrm{O}$ e alto $\mathrm{Na}_{2} \mathrm{O}$. Os gnaisses biotíticos e anfibolíticos $\left(\mathrm{SiO}_{2}=47\right.$ a $\left.70 \%\right)$ do TGAG apresentam afinidade com a série cálcio-alcalinathrondjimítica de baixo $\mathrm{K}_{2} \mathrm{O}$. A maioria dos gnaisses biotíticos e anfibolíticos, excetuando-se alguns gnaisses biotíticos e anfibolíticos (monzodioritos) que ocorrem ao longo da ZCPT, apresentam afinidades shoshoníticas. Nos gnaisses granulíticos, principalmente félsicos, correlação positiva do $\mathrm{Na}_{2} \mathrm{O} \operatorname{com} \mathrm{SiO}_{2}$ e negativa com $\mathrm{K}_{2} \mathrm{O}$, sugere o aumento do $\mathrm{Na}_{2} \mathrm{O}$ e não do $\mathrm{K}_{2} \mathrm{O}$, distinguindo assim, a série cálcio-alcalina-throndjimítica de baixo $\mathrm{K}$ da clássica série cálcio-alcalina. A correlação $\mathrm{SiO}_{2} \times \mathrm{K}_{2} \mathrm{O}$ indica que os litotipos granuliticos (gnaisses granuliticos máficos a intermediários e félsicos) e os litotipos não granulíticos (gnaisses 
biotíticos e anfibolíticos) são cálcio-alcalinos de baixo $K$, com exceção dos gnaisses biotíticos e anfibolíticos (monzodioritos), que apresentam afinidades shoshoniticas.

Tanto os tipos granulíticos como os não granulíticos são metaluminosos. Os gnaisses granulíticos máficos a intermediários e félsicos ANK entre 2,3 e 1,5 e ACNK entre 0,8 e 1,0, enquanto os gnaisses biotíticos e anfibolíticos exibem ANK entre 2,3 e 1,5 e ACNK entre 0,8 e 1,0. Do mesmo modo, os dois tipos apresentam correlação negativa com silica em diagramas $\mathrm{SiO}_{2} \mathrm{X}$ óxidos $\left(\mathrm{TiO}_{2}, \mathrm{Fe}_{2} \mathrm{O}_{3}, \mathrm{Al}_{2} \mathrm{O}_{3}, \mathrm{MnO}, \mathrm{MgO}, \mathrm{CaO}\right.$ e $\left.\mathrm{P}_{2} \mathrm{O}_{5}\right)$. A correlação positiva é observada somente em $\mathrm{SiO}_{2} \times \mathrm{Na}_{2} \mathrm{O}$, onde os gnaisses máficos a intermediários apresentam valores de $\mathrm{Na}_{2} \mathrm{O}$ entre 3 e $4 \%$ e os gnaisses félsicos entre 5 e 6 $\%$. Os gnaisses biotiticos e anfibolíticos apresentam valores de $\mathrm{Na}_{2} \mathrm{O}$ entre 3 e $4 \%$.

Os gnaisses granulíticos máficos a intermediários e félsicos em geral são empobrecidos em Rb (a maioria tem < 20 ppm, algumas rochas com biotita e K-feldspato entre 30 e $40 \mathrm{ppm}), \mathrm{K}_{2} \mathrm{O}(0,5$ a $1,5 \%$ para os gnaisses granulíticos máficos a intermediários $e<1,2 \%$ para os félsicos) e muito empobrecidos em $U$ e Th $(<0,1 \mathrm{ppm})$. Os tipos félsicos são os mais empobrecidos em $\mathrm{K}_{2} \mathrm{O}, \mathrm{Rb}, \mathrm{U}$ e Th. Os gnaisses biotíticos e anfibolíticos apresentam valores mais elevados em $\mathrm{Rb}$ (40 a $80 \mathrm{ppm}$ ), valores relativamente similares de $\mathrm{K}_{2} \mathrm{O}, \mathrm{U}$ e Th (exceto os gnaisses biotíticos e anfibolíticos shoshoníticos).

$\mathrm{O}$ empobrecimento em $\mathrm{Rb}, \mathrm{K}_{2} \mathrm{O}, \mathrm{U}$ e Th dos gnaisses granuliticos máficos e félsicos é típico também de muitos terrenos ortogranulíticos arqueanos e paleoproterozóicos. Este fato é atribuido a vários fatores como: a) remoção de líquidos graníticos que carregam estes elementos deixando um restito com mineralogia típica de granulitos e empobrecido em $\mathrm{Rb}$, $\mathrm{K}, \mathrm{U}$ e Th; b) fluidos liberados durante as reações de desidratação típicas de metamorfismo de alto grau, como consumo de biotita e anfibólio para a formação de ortopiroxênio e remoção do $\mathrm{Rb}$ presente nestes minerais; c) invasão de fluidos ricos em $\mathrm{CO}_{2}$ que podem causar remoção e empobrecimento dos granulitos nestes elementos. Outra hipótese sugere que o baixo conteúdo em $\mathrm{K}, \mathrm{Rb}, \mathrm{U}$ e Th, pode refletir a composição dos protólitos ígneos destes granulitos (Rudnick e Presper 1990, Hubbard 1989, Tarney \& Weaver 1987, entre outros). Fluidos ricos em $\mathrm{F}$ e $\mathrm{Cl}$, combinados ou não com fluidos ricos em $\mathrm{CO}_{2}$ resultantes da quebra da biotita e anfibólio durante as reações de fácies anfibolito/granulito e granulito podem ser também responsáveis pela remoção do U e Th (Keppler \& Wyllie 1990, Lamb et al 1986).

A razão $\mathrm{Rb} / \mathrm{Sr}$ nos gnaisses biotíticos e anfibolíticos está entre 0,05 e 0,1 e é maior do que a apresentada pelos gnaisses granulíticos máficos a intermediários e félsicos $(\mathrm{Rb} / \mathrm{Sr}$ $=0,01$ a 0,05 ) 
Em correlações negativas da $\mathrm{SiO}_{2} \times \mathrm{Ba}$ e $\mathrm{SiO}_{2} \times \mathrm{Sr}$, os gnaisses granulíticos máficos a intermediários apresentam valores mais elevados de $\mathrm{Ba}$ e $\mathrm{Sr}(\mathrm{Ba}=1000$ a 500 e $\mathrm{Sr}=800$ a $500 \mathrm{ppm}$ ), do que os gnaisses granuliticos félsicos ( $\mathrm{Ba}=500$ a $200 \mathrm{ppm}$ e Sr entre 500 e 100). Valores mais elevados de $\mathrm{Ba}$ e $\mathrm{Sr}$ são apresentados pelos gnaisses biotíticos e anfibolíticos shoshoníticos $(B a=3000$ a $3500 \mathrm{ppm}$ e $\mathrm{Sr}=1000$ a 1300) e por um charnoquito máfico (OM 906) rico em biotita $\left(\mathrm{SiO}_{2}=46 \%, \mathrm{Ba}=3400 \mathrm{ppm}\right.$ e $\left.\mathrm{Sr}=1500 \mathrm{ppm}\right)$. Nos demais gnaisses biotíticos e anfibolíticos, os valores de $\mathrm{Ba}$ e $\mathrm{Sr}$, para similares valores de sílica, estão dentro dos valores apresentados pelos gnaisses granulíticos máficos a intermediários e félsicos. A correlação $\mathrm{SiO}_{2} \times Y$ tende a ser negativa, tanto nos gnaisses granulíticos máficos a intermediários e félsicos como nos gnaisses biotíticos e anfibolíticos.

Uma grande dispersão no conteúdo dos elementos traços principalmente Ga (10 a $25 \mathrm{ppm}$ ), $\mathrm{Nb}$ (1 a $18 \mathrm{ppm}$ ) e Ta (0.1 a $2.5 \mathrm{ppm}$ ), sem correlação com $\mathrm{SiO}_{2}$ é observada tanto nos gnaisses granulíticos máficos a intermediários e félsicos quanto nos gnaisses biotíticos e anfibolíticos. O mesmo ocorre com os conteúdos em $\mathrm{Zr}$ ( 250 a 20 ppm) e Hf (7 a $<1 \mathrm{ppm}$ ), que apresentam tendências caóticas de aumento e decréscimo ao longo do todo o intervalo da sílica. Um charnoquito máfico rico em biotita e anfibólio do trecho NE apresenta valores bem mais elevados de $\mathrm{Zr}$ (550 ppm) e Hf (12 ppm).

Em diagramas de $\mathrm{SiO}_{2} \times$ ETRL e $\mathrm{SiO}_{2} \times$ ETRP nota-se uma progressiva diminuição dos ETRL e ETRP desde os gnaisses granuliticos máficos a intermediários até os félsicos. O mesmo ocorre nos gnaisses biotíticos e anfibolíticos.

Os perfis de ETR nos granulitos máficos a intermediários, normalizados ao condrito, mostram um progressivo empobrecimento em ETRP $\left(\mathrm{Yb}_{\mathrm{N}}=15\right.$ a 2$)$ e ETRL. $\left(\mathrm{La}_{\mathrm{N}}=200\right.$ a 100) correlacionável negativamente com aumento da sílica e sem mostrar qualquer tipo de anomalia de Eu. Nos gnaisses granulíticos félsicos, observa-se, em relação aos gnaisses granulíticos máficos maior e mais pronunciado empobrecimento em ETRP $\left(\mathrm{Yb}_{\mathrm{N}}=5 \mathrm{a} 0.3\right)$ e valores mais baixos em ETRL $\left(L_{N}=90\right.$ a 50$)$, correlacionáveis negativamente com a silica, com aparecimento ou não de uma fraca anomalia negativa de Eu. Estes perfis de ETR são similares aos apresentados pelos gnaisses granulíticos tipo Lewisian e pelos gnaisses TTG metamorfisados ou não (Tarney \& Weaver 1987, Martin 1993, 1994 e 1998 e outros). 


\section{5 - Geocronologia}

Nesta seção serão apresentados e discutidos os resultados geocronológicos e isotópicos nos principais litotipos granulíticos desta unidade.

A metodologia U-Pb foi aplicada em litotipos granuliticos representativos do TGAG desta região. Estas amostras são: um charnoquito máfico (norito-quartzo-norito), com ortopiroxênio \pm clinopiroxênio e rico em biotita e anfibólio do trecho NE (amostra OM 904), um gnaisse granulítico máfico com ortopiroxênio \pm clinopiroxênio e com traços ou restos de biotita e anfibólio do trecho SW (amostra OM 298) e, um gnaisse granulítico félsico com ortopiroxênio e traços de biotita e anfibólio do trecho SW (amostra OM 388).

A aplicação da metodologia U-Pb em zircões foi precedida de uma observação, em lupa, da morfologia dos zircões que ocorrem nestas rochas. Nos gnaisses granulíticos máficos e félsicos foram encontradas duas principais morfologias: esféricos e elipsoidais. Uma terceira morfologia (zircões aciculares com terminações arredondadas) foi encontrada somente no charnoquito máfico. Os resultados analíticos U-Pb são apresentados na Tabela 8.1 .

A metodologia K-Ar em biotita e anfibólio foi aplicada nos gnaisses granulíticos principalmente máficos a intermediários do trecho $S W$ e em gnaisses biotíticos e anfibolíticos que ocorrem ao longo da ZCPT.

A metodologia Sm-Nd em rocha total foi aplicada nos principais litotipos granulíticos e nos gnaisses biotiticos e anfibolíticos e em rocha total e minerais nos gnaisses granuliticos máficos ricos em granada.

Os resultados da geoquimica isotópica obtidos pelas metodologias $\mathrm{Sm}-\mathrm{Nd}$ em rocha total, a análise das razões $\mathrm{Sr}^{87} / \mathrm{Sr}^{86}$ e $\mathrm{O}^{18}$ (zircão) referentes aos principais litotipos da TGAG, são apresentados e discutidos no Capítulo 9.0, referente à Geologia Isotópica.

Os resultados $\mathrm{U}-\mathrm{Pb}$ em zircões elipsoidais e aciculares com terminações arredondadas do charnoquito máfico ricos em biotita e anfibólio são apresentados na Tabela 8.1. Duas morfologias de zircões, elipsoidais e aciculares com terminações arredondadas, foram analisados nesta rocha. Os zircões esféricos (típicos de metamorfismo de alto grau), presença constante nos gnaisses granulíticos máficos e félsicos do TGAG, não foram encontrados neste charnoquito. 
Tabela 8.1 - Análises isotópicas U-Pb em zircōes dos litotipos ortogranulíticos do TGAG

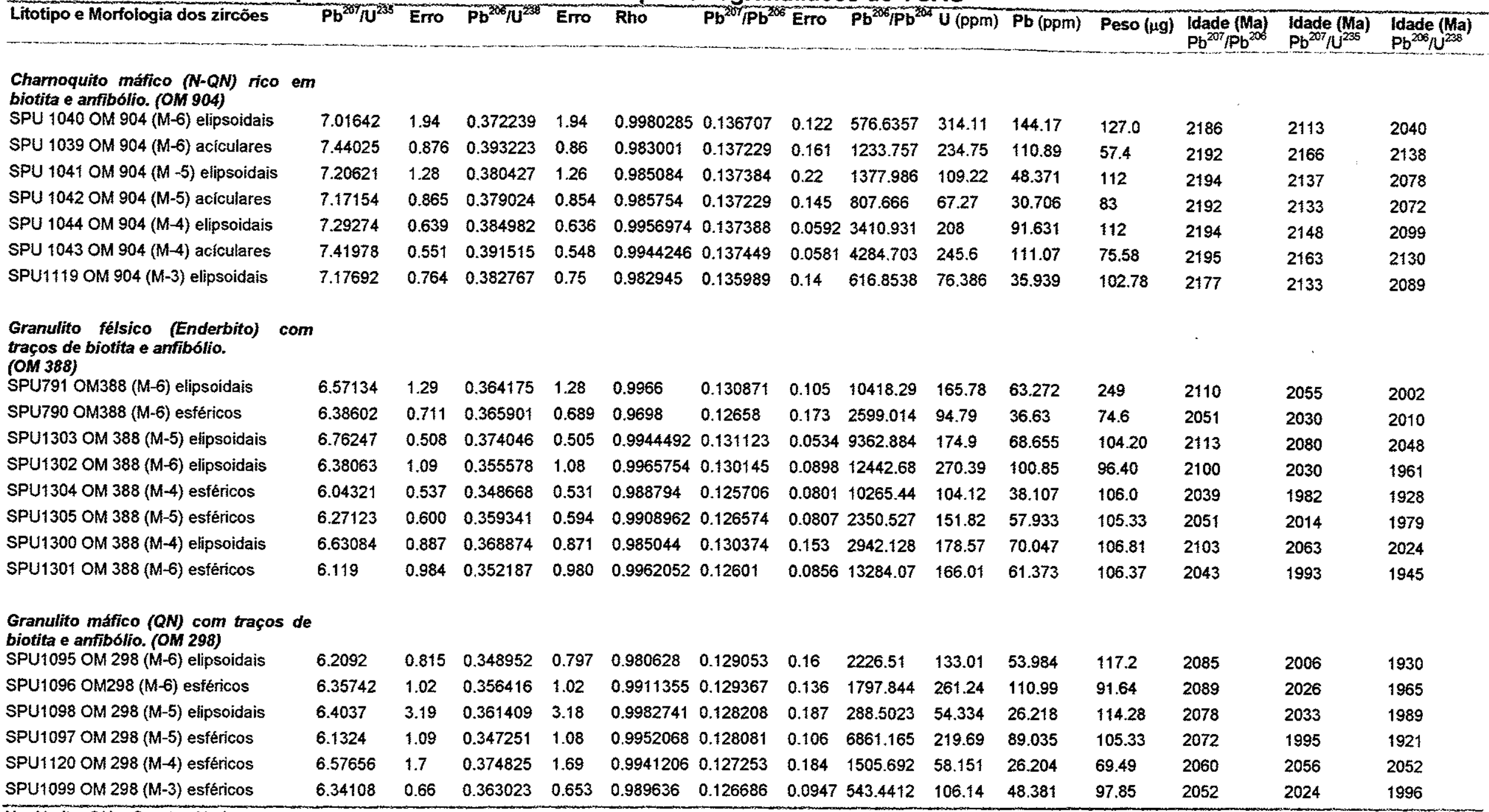

$\mathrm{N}=$ Norito $\mathrm{QN}=$ Quarto-Norito 
Os resultados $\mathrm{U}-\mathrm{Pb}$ em zircões elipsoidais desta rocha forneceram idade do intercepto superior de $2209 \pm 11 / \pm 13 \mathrm{Ma}$ (Figura 8.4). Os zircões aciculares da mesma rocha forneceram idade do intercepto superior de $2194.7 \pm 3.5 / \pm 7.1 \mathrm{Ma}$ (Figura 8.5). Nota-se que ambas as idades são praticamente similares, sendo a idade dos zircões aciculares cerca de 15 Ma menor do que a idade dos zircões elipsoidais. Quando o cálculo é feito utilizando-se os dois tipos de zircões, a idade do intercepto superior é de $2200.5 \pm 7.3 / \pm 9.9 \mathrm{Ma}$ (Figura 8.6), interpretada como a idade da recristalização metamórfica em alto grau (metamorfismo granulítico). Nota-se que os os zircões aciculares apresentam geralmente razões $\mathrm{Pb}^{207} / \mathrm{U}^{235}$ e $\mathrm{Pb}^{206} / \mathrm{U}^{238}$ mais altas do que os zircões elipsoidais (Figura 8.6).
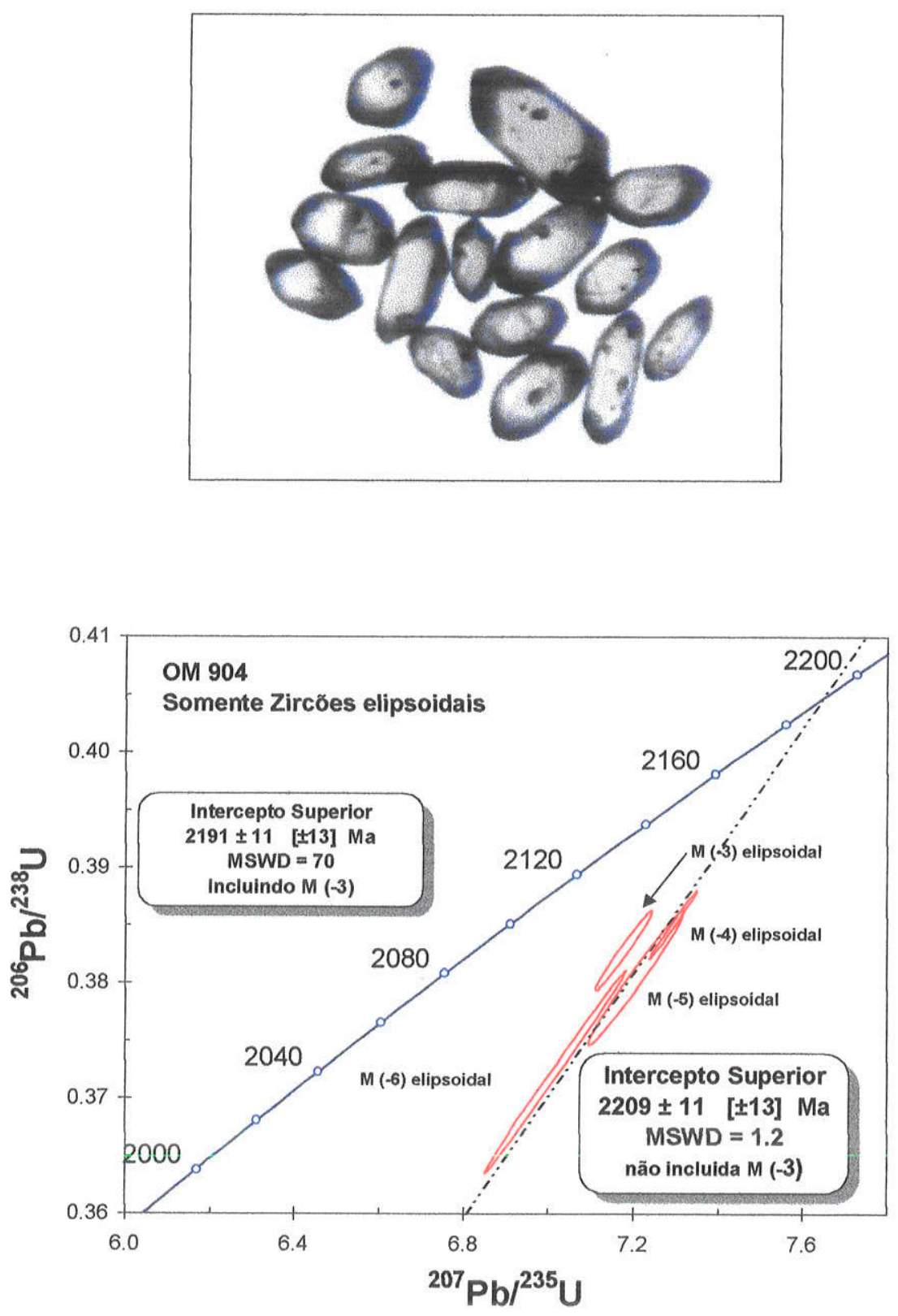

Figura 8.4 - Diagrama concórdia U-Pb para os zircões elipsoidais do charnoquito máfico rico em biotita e anfibólio. 

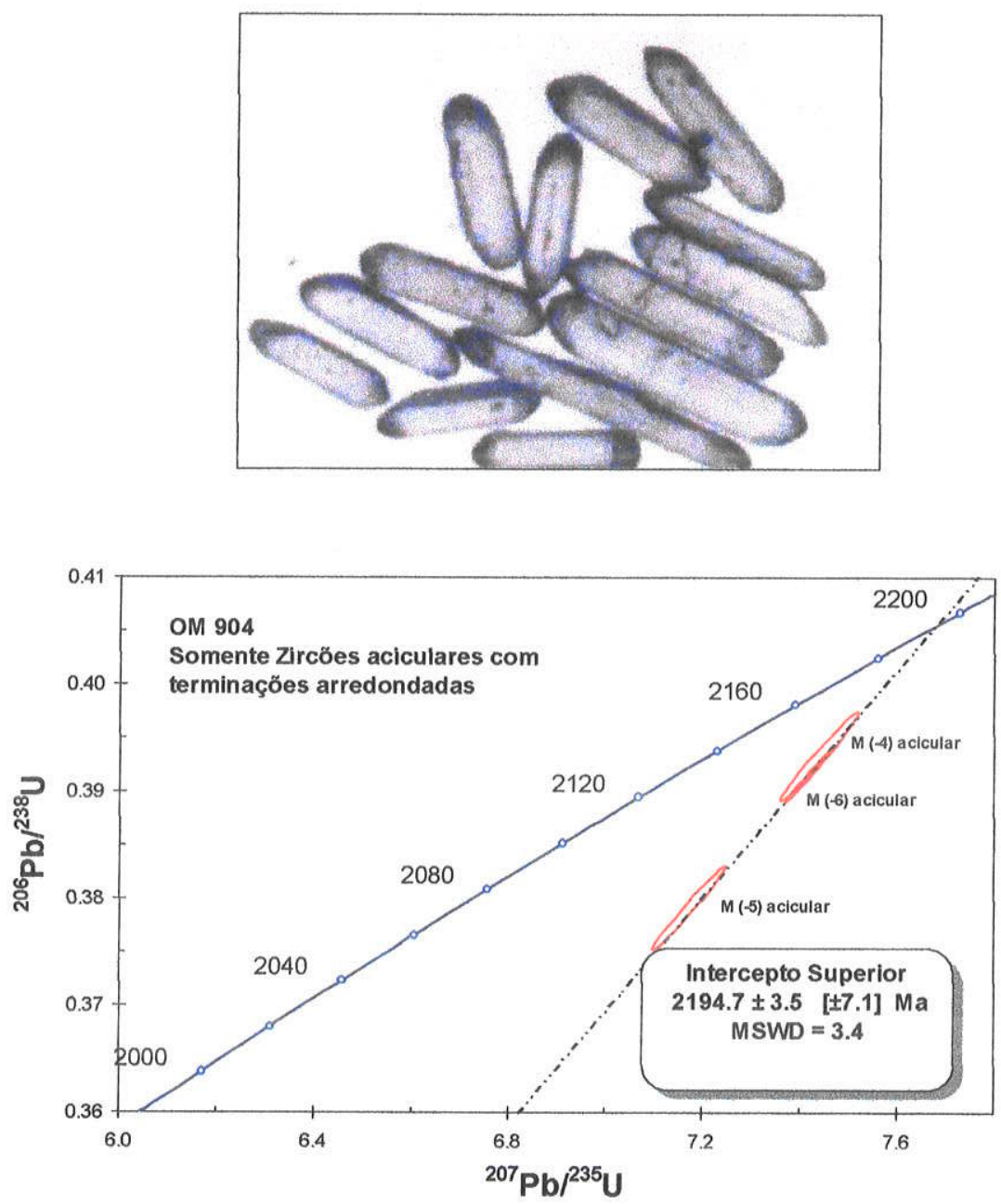

Figura 8.5 - Diagrama concórdia U-Pb para os zircões aciculares com terminações arredondadas do charnoquito máfico rico em biotita e anfibólio.

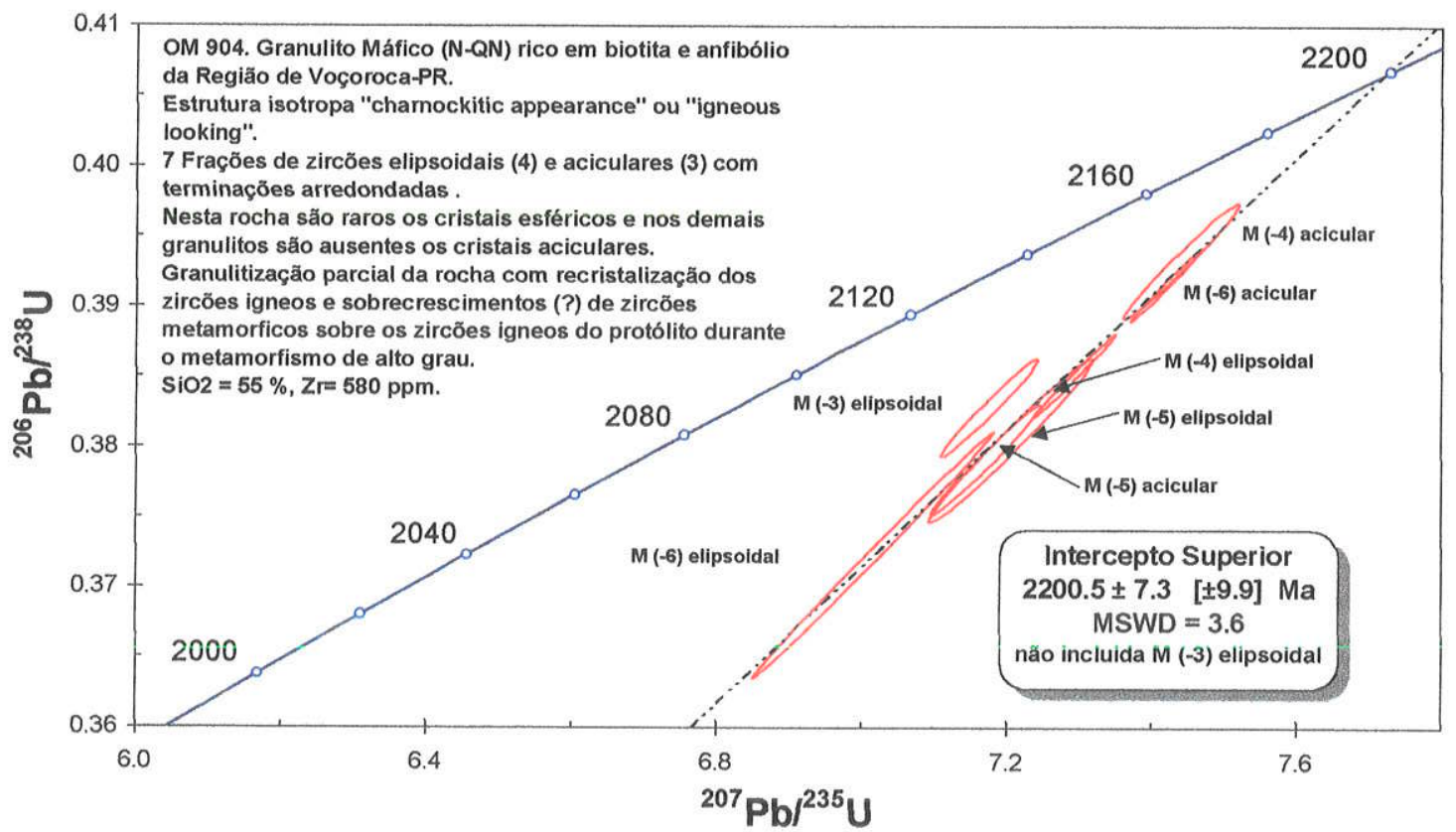

Figura 8.6 - Diagrama concórdia U-Pb para os zircões elipsoidais e aciculares com terminações arredondadas do charnoquito máfico rico em biotita e anfibólio. 
A presença, nesta rocha, de grande quantidade de biotita e anfibólio com substituição parcial por ortopiroxênio e clinopiroxênio, a falta de foliação e o alojamento preferencial dos dois tipos de zircões junto ou inclusos nos máficos (biotita, anfibólio e piroxênio) sugerem que a rocha não foi completamente metamorfisada em alto grau e não sofreu contemporânea deformação. A presença ou não de deformação e a temperatura alcançada durante o metamorfismo de alto grau, que resultam no consumo parcial ou total da biotita e do anfibólio para a formação do ortopiroxênio e clinopiroxênio, são importantes fatores que controlam e afetam o sistema U-Pb em zircões de rochas granulíticas, com a formação ou não de zircões esféricos e elipsoidais como resultado da recristalização metamórfica. Consequentemente, ocorre rejuvenescimento total ou parcial do sistema U-Pb ígneo, com a destruição parcial ou total de antigos registros de zircões magmáticos. $O$ resultado desta história metamórfica seria a obtenção de idades próximas às do pico térmico do metamorfismo de alto grau, como pode ser o caso deste charnoquito máfico, cuja idade de recristalização metamórfica (metamorfismo granulítico) é de 2200,5 $\pm 7,3 / \pm 9,9 \mathrm{Ma}$.

Como estes charnoquitos máficos ocorrem como núcleos no meio dos gnaisses biotíticos e anfiboliticos do trecho NE do TGAG, uma outra coerente explicação seria um outro evento metamórfico anterior de alto grau, ocorrido ao redor de $2.2 \mathrm{Ga}$. Estas rochas seriam preservadas do principal evento metamórfico, ao redor de $2.05 \mathrm{Ga}$, registrado na região.

Os resultados analíticos U-Pb em zircões elipsoidais e esféricos de um gnaisse granulítico máfico com restos de biotita e anfibólio são apresentados na Tabela 8.1. Não foram encontrados, nesta rocha, zircões aciculares com terminações arredondadas similares aos encontrados no charnoquito máfico.

O cálculo da idade U-Pb para os zircões elipsoidais forneceu idade do intercepto superior de $2068 \pm 15 / \pm 16$ Ma (Figura 8.7), enquanto para os zircões esféricos uma idade do intercepto superior de $2062 \pm 65$ Ma foi obtida (Figura 8.8). Uma das frações (M-4) destes zircões esféricos é concordante apresentando idade de $2059.9 \pm 6.6 \mathrm{Ma}$. 


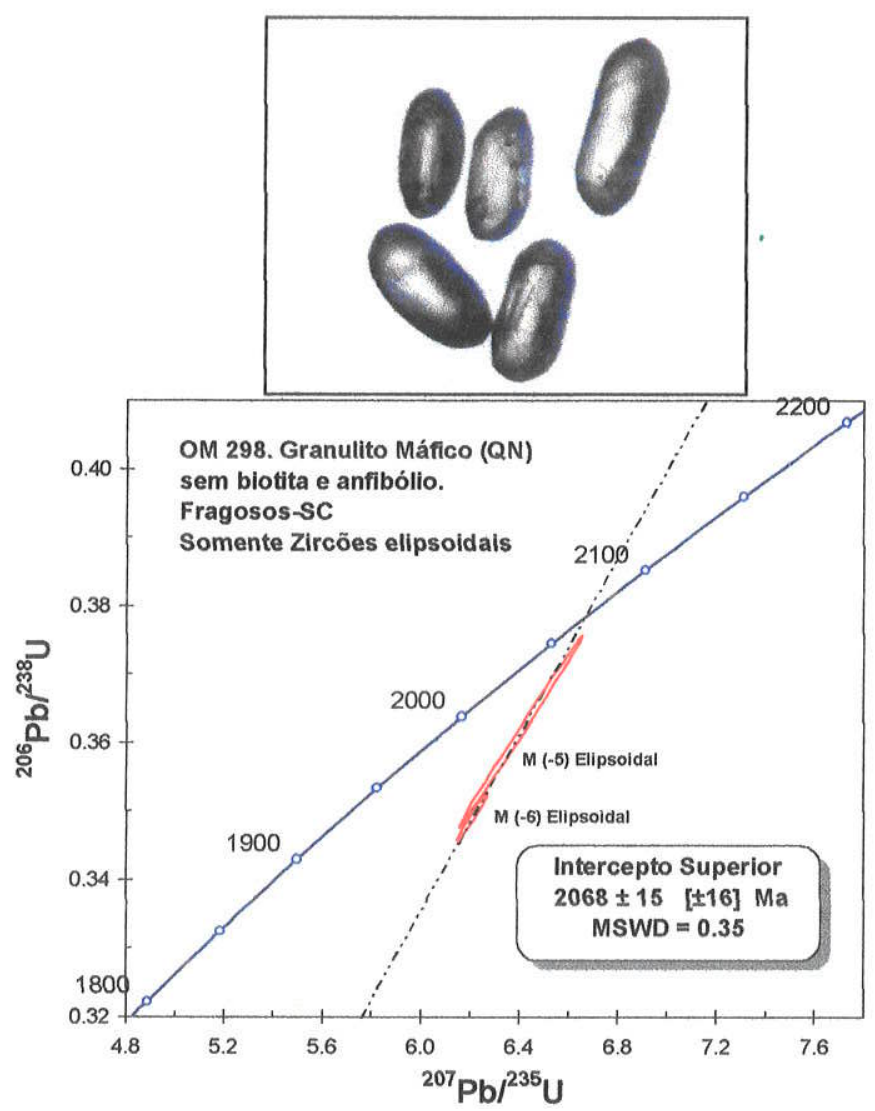

Figura 8.7 - Diagrama concórdia U-Pb para os zircões elipsoidais dos gnaisses granulíticos máficos.
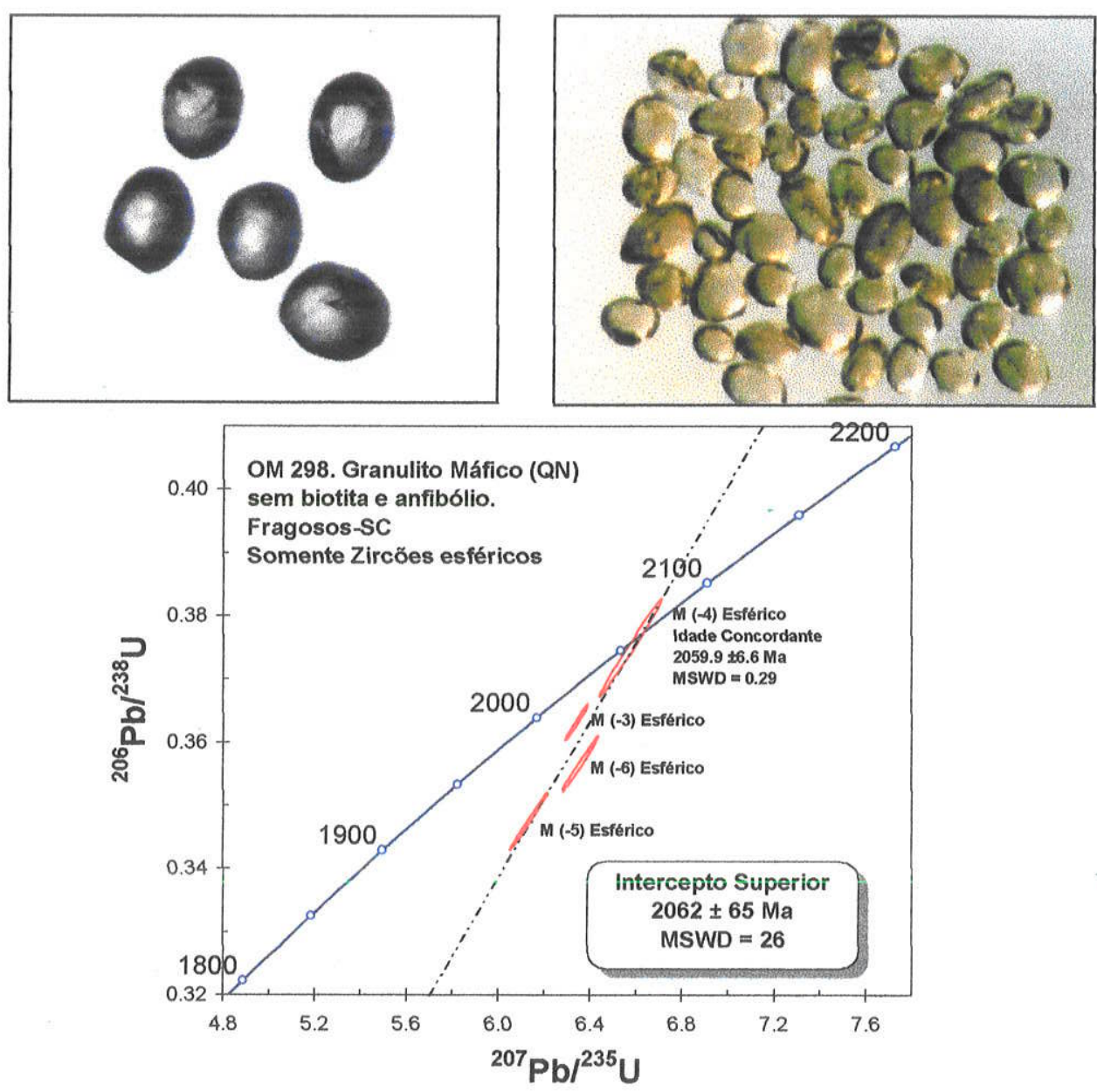

Figura 8.8 - Diagrama concórdia U-Pb para os zircões esféricos dos gnaisses granulíticos máficos do TGAG. 
Nota-se que as idades dos zircões esféricos e elipsoidais nesta rocha são similares. O cálculo da idade U-Pb para todos os zircões elipsoidais e esféricos desta rocha forneceu idade do intercepto superior de $2063 \pm 29 / \pm 30$ Ma (Figura 8.9) indicativa da recristalização metamórfica destes zircões em alto grau, ou seja, a idade do metamorfismo granulítico. A idade mais precisa deste metamorfismo é sugerida pela idade concordante de $2060 \pm 6.6$ Ma obtida em zircões esféricos, morfologia mais típica e representativa da recristalização metamórfica em alto grau.

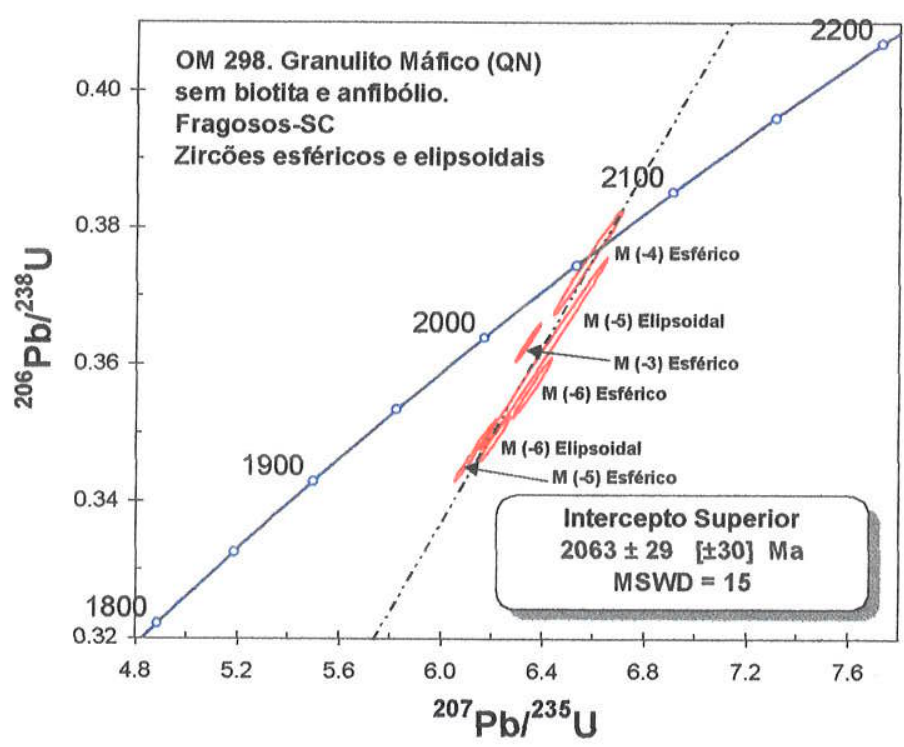

Figura 8.9 - Diagrama concórdia U-Pb para os zircões esféricos e elipsoidais dos gnaisses granulíticos máficos.

Os resultados U-Pb em zircões elipsoidais e esféricos de um gnaisse granulítico félsico com restos de biotita e anfibólio são apresentados na Tabela 8.1. Foram analisados, da mesma forma que para os gnaisses granulíticos máficos, zircões elipsoidais e esféricos. Não foram encontrados zircões aciculares.

O cálculo da idade U-Pb para os zircões elipsoidais desta rocha forneceu idade do intercepto superior de $2125 \pm 31$ Ma (Figura 8.10) e, para os zircões esféricos, uma idade do intercepto superior de $2060 \pm 19 / \pm 20$ Ma (Figura 8.11). A idade do metamorfismo de alto grau é sugerida pela idade dos zircões esféricos. Os zircões elipsoidais são mais antigos (da ordem de $60 \mathrm{Ma}$ ) do que os zircões esféricos, diferença que pode representar a duração do metamorfismo granulítico. Nota-se também que, enquanto a idade dos zircões elipsoidais neste gnaisse granulítico félsico difere da obtida nos zircões elipsoidais do gnaisse granulítico máfico, as idades dos zircões esféricos em ambas as rochas são idênticas e estão ao redor de $2060 \mathrm{Ma}$. Esta similaridade indica claramente a contemporaneidade do metamorfismo de alto grau sofrido por estas rochas. 


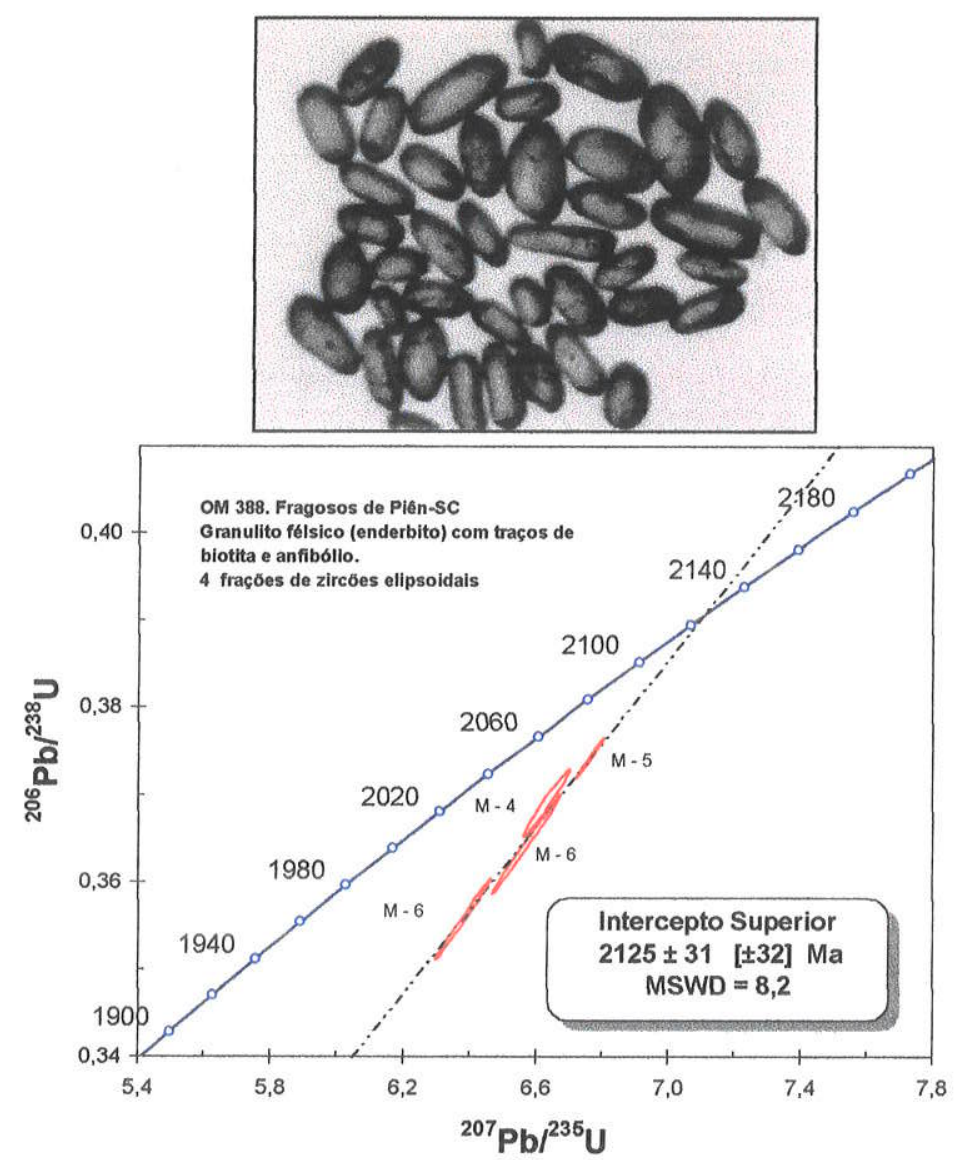

Figura 8.10 - Diagrama concórdia U-Pb para os zircões elipsoidais dos gnaisses granulíticos félsicos.

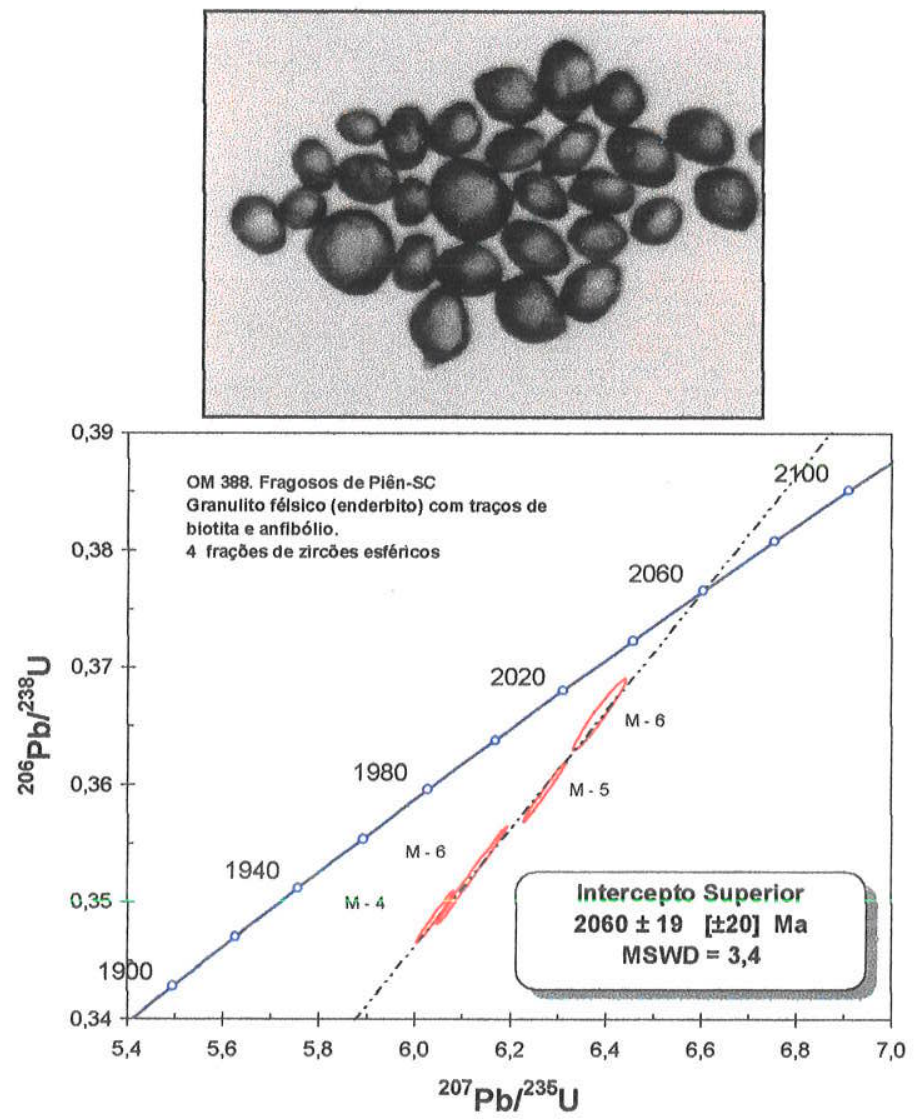

Figura 8.11 - Diagrama concórdia U-Pb para os zircões esféricos dos gnaisses granulíticos félsicos. 
A análise conjunta dos resultados $\mathrm{U}-\mathrm{Pb}$ em zircões elipsoidais e esféricos dos gnaisses granulíticos félsicos (Figura 8.12) aponta, para um intervalo de idades entre $2,1 \mathrm{e}$ $2,0 \mathrm{Ga}$, dentro do qual ocorreu o metamorfismo granulítico nestas rochas. A idade do pico do metamorfismo granulitico é sugerida pela idade dos zircões esféricos.

Idades ao redor de 2,2 Ga foram obtidas somente em zircōes aciculares e elipsoidais do charnoquito máfico. De acordo com as características mineralógicas e texturais anteriormente mencionadas, esta idade, é interpretada como representativa da idade do metamorfismo granulítico. Como estes charnoquitos ocorrem em núcleos em meio aos gnaisses biotíticos e anfibolíticos do trecho NE, há uma grande possibilidade destas rochas representarem antigos núcleos granulíticos metamorfisados em um evento metamórfico anterior e de alto grau, ao redor de 2,2 Ga. Entretanto, o fato destes charnoquitos máficos apresentarem idades modelo $\mathrm{Sm}-\mathrm{Nd}$ ao redor de $3,4 \mathrm{Ga}$, bem mais antigas do que as obtidas na maioria dos gnaisses granulíticos máficos e félsicos desta região, não corrobora esta possibilidade. Idades U-Pb ao redor de 2,2 $\mathrm{Ga}$ e 2,3 $\mathrm{Ga}$, obtidas em zircões esféricos, elipsoidais e prismáticos de ortogranulitos e em monazitas de granada-quartzito, são aparentemente freqüentes nas porções, central e meridional do TGAG, conforme apresentado por Siga Jr. (1995) e Basei (2000). Estes dados sugerem eventos metamórficos anteriores de alto grau, fora dos aqui encontrados entre 2,1 e 2,0 $\mathrm{Ga}$, que podem ser contemporâneas aos dos charnoquitos máficos desta região, com idades $\mathrm{U}-\mathrm{Pb}$ em zircões ao redor $2.2 \mathrm{Ga}$.

O diagrama concórdia U.Pb (Figura 8.13) para todas as rochas granulíticas aqui datadas, sugere um intercepto superior com idade ao redor de $2,5 \mathrm{Ga}$ e um intercepto inferior ao redor de 1,8 $\mathrm{Ga}$. A idade de 2,4 é interpretada como possivel idade do protólito igneo dos gnaisses granulíticos máficos e félsicos e é mais jovem do que as idades modelo Sm-Nd (2.7-2.5 Ga) na maioria dos gnaisses granulíticos e máficos. A idade do intercepto inferior, ao redor de $1.8 \mathrm{Ga}$, é similar às idades $\mathrm{K}$-Ar obtidas em principalmente biotita e anfibólio (Tabela 8.2) nos gnaisses granulíticos máficos e félsicos, e interpretada como a idade do resfriamento e estabilidade tectônica destas rochas e deste terreno. 


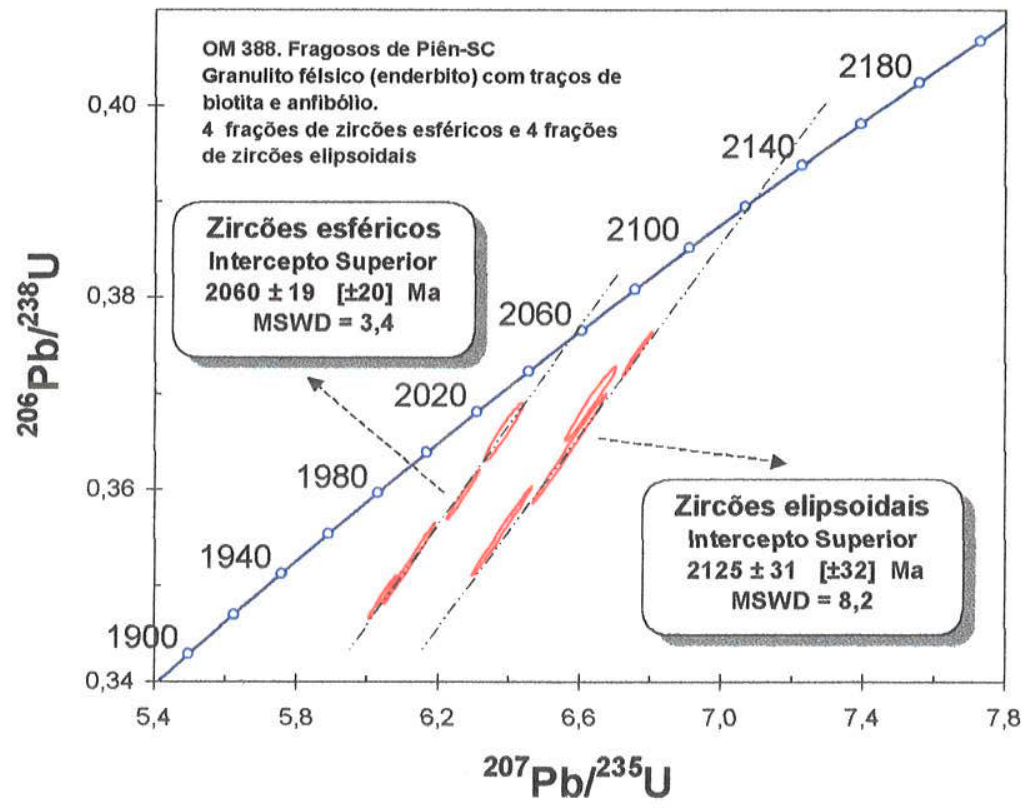

Figura 8.12 - Diagrama concórdia U-Pb para os zircões esféricos e elipsoidais dos gnaisses granulíticos félsicos.

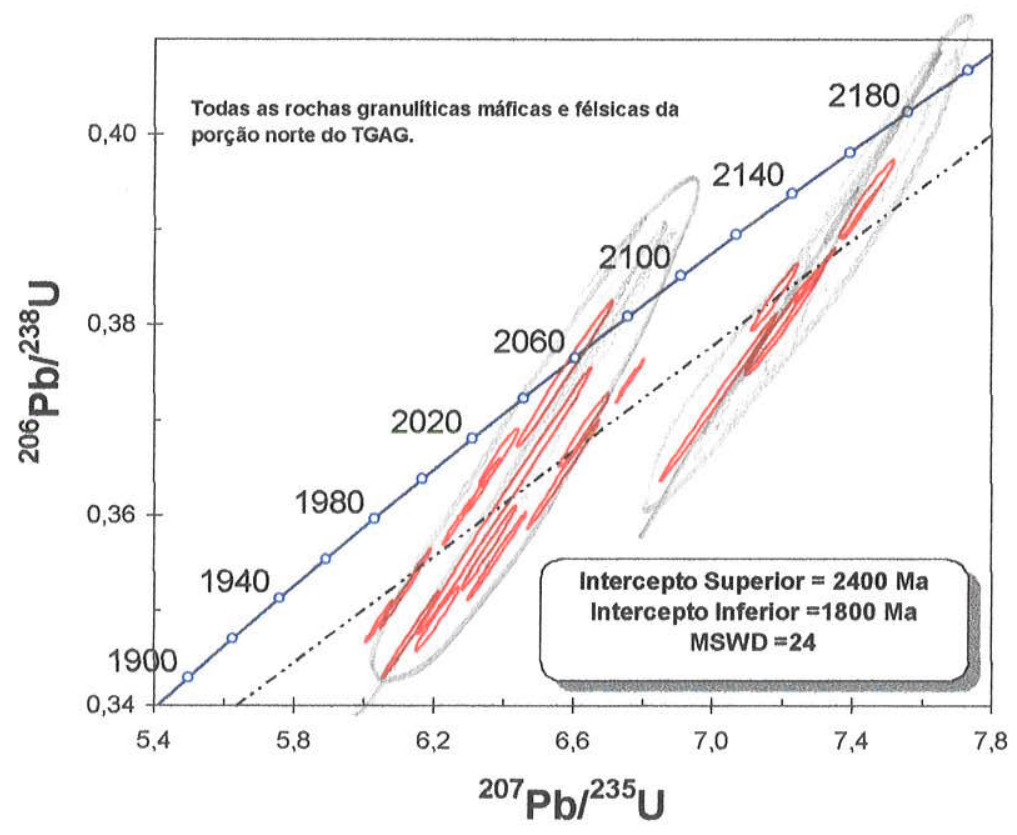

Figura 8.13 - Diagrama concórdia U-Pb para os zircões de todas as rochas granulíticas da região investigada. 
Tabela 8.2 - Análises isotópicas e idades K-Ar da porção norte do TGAG* (somente dados em biotita e anfibólio das Folhas Campo Alegre, Tijucas do Sul e São Miguei).

\begin{tabular}{|c|c|c|c|c|c|c|c|}
\hline$N^{\circ}$. amostra & Mineral & Rocha & $\mathbf{K}(\%)$ & $\begin{array}{l}\mathrm{Ar}^{46} \text { Rad.ccSTP/g } \\
10^{-6}\end{array}$ & $\begin{array}{l}\text { Ar Atm. } \\
(\%)\end{array}$ & $\begin{array}{l}\text { Idade } \pm \text { Erro } \\
\text { (M.a) }\end{array}$ & Fonte Bibliográfica \\
\hline OM 369 & Biotita & Gnaisses Biotiticos & 6.0131 & 172.86 & 6.32 & $620 \pm 13$ & Inédito \\
\hline OM 216 B & Biotita & Gnaisses Biotiticos & 7.2832 & 212.35 & 6.06 & $628 \pm 22$ & Inédito \\
\hline AM 27 & Biotita & Biotita- Piroxenito & 7.7334 & 237.36 & 2.10 & $655 \pm 14$ & Machiavelli (1991) \\
\hline OM 185 & Anfibólio & Gnaisses anfibollticos & 0.8360 & 26.03 & 14.76 & $663 \pm 13$ & Inédito \\
\hline OM 242 & Biotita & Granulito Máfico & 6.7749 & 779.23 & 0.71 & $1752 \pm 24$ & Inédito \\
\hline OM 70 & Biotita & Granulito Máfico & 6.8555 & 866.86 & 0.55 & $1861 \pm 38$ & Inédito \\
\hline AM 70 & Biotita & Granulito & 7.1138 & 937.61 & 0.71 & $1910 \pm 48$ & Machiavelli (1991) \\
\hline MJ 80 & Biotita & Granulito & 6.9082 & 725.53 & 0.93 & $1654 \pm 54$ & Siga Jr (1995) \\
\hline MJ 332B & Biotita & Granulito & 7.1833 & 756.48 & 1.06 & $1656 \pm 28$ & Siga Jr (1995) \\
\hline MJ 184A & Biotita & Granulito & 6.5438 & 830.85 & 3.67 & $1865 \pm 38$ & Siga Jr (1995) \\
\hline MJ 13 & Anfibolio & Granulito & 0.9256 & 115.88 & 3.12 & $1849 \pm 36$ & Siga Jr (1995) \\
\hline MJ 92 & Anfibólio & Granulito & 1.3077 & 166.73 & 45.46 & $1870 \pm 66$ & Siga Jr (1995) \\
\hline MJ 245 & Anfibollo & Granulito & 1.1435 & 132.37 & 1.86 & $1760 \pm 32$ & Slga Jr (1995) \\
\hline VG 24 & Anfibólio & Granulito & 1.193 & 153.450 & 32.10 & $1866 \pm 56$ & Girardi et al. (1974) \\
\hline Vo 263 & Anfibólio & Granulito & 1.000 & 1.191 & 3.30 & $1787 \pm 25$ & Girardi et al. (1974) \\
\hline
\end{tabular}

" = Análises inéditas e seleção das análises geocronológicas K-Ar em biotita e anfibólio disponiveis (Girardi 1974, Machiavelli 1991 e Siga Jr. 1995)

As idades K-Ar obtidas em anfibólio e biotita (Tabela 8.2) nas rochas granulíticas do TGAG estão entre 1,7 e 1,9 Ga, com concentração ao redor de 1,8 Ga. Estas idades registram o resfriamento e a estabilidade tectônica das rochas granulíticas não só desta região mas também de toda as porções meridional e central do TGAG, independe da idade e da quantidade de eventos metamórficos. O resfriamento e a estabilidade tectônica das rochas granuliticas nesta região ocorreram aproximadamente $200 \mathrm{Ma}$ após o metamorfismo granulítico entre 2,1 -2,0 Ga. Isto pode implicar na classificação do TGAG como um terreno granulítico com histórias de estabilização tectônica e resfriamento lento.

Após o metamorfismo granulítico, o TGAG permaneceu estável e frio desde aproximadamente 1,8 Ga (fim do Paleoproterozóico) até o Neoproterozóico, quando ocorreu uma reativação tectono-térmica registrada principalmente ao longo da ZCPT. Esta reativação é indicada pelas texturas presentes nos gnaisses granuliticos e gnaisses biotíticos e anfibolíticos, pelo paralelismo das foliações nestas rochas e as da SGPM e SMUP e, principalmente, pelas idades neoproterozóicas $\mathrm{K}$-Ar em biotita e anfibólio das rochas deste local (Tabela 8.2 e Figura 8.14). O perfil térmico-geocronológico K-Ar mostra que as idades das rochas do TGAG concentram-se ao redor de 1,8 $\mathrm{Ga}$ e, à medida em que 
se aproxima da ZCPT, as idades nas rochas do TGAG tornam-se Neoproterozóicas (entre 660 e $620 \mathrm{Ma}$ ), passando para idades $\mathrm{K}$-Ar em biotita na SGPM entre 607 e $595 \mathrm{Ma}$. Notase também o "decréscimo" das idades K-Ar em biotita, de sul para o norte, próximo a ZCPT (nas rochas do TGAG) e dentro da SGPM, que sugere a atuação da tectônica tangencial. As rochas do TGAG foram parcialmente (anfibólio dos gnaisses anfibolíticos) a totalmente (biotita dos gnaisses biotíticos) reaquecidas durante 0 Neoproterozóico por retrometamorfismo ou metamorfismo de baixo a médio grau, permitindo o rejuvenescimento das idades K-Ar e envolvendo neste processo a SGPM e a SMUP.

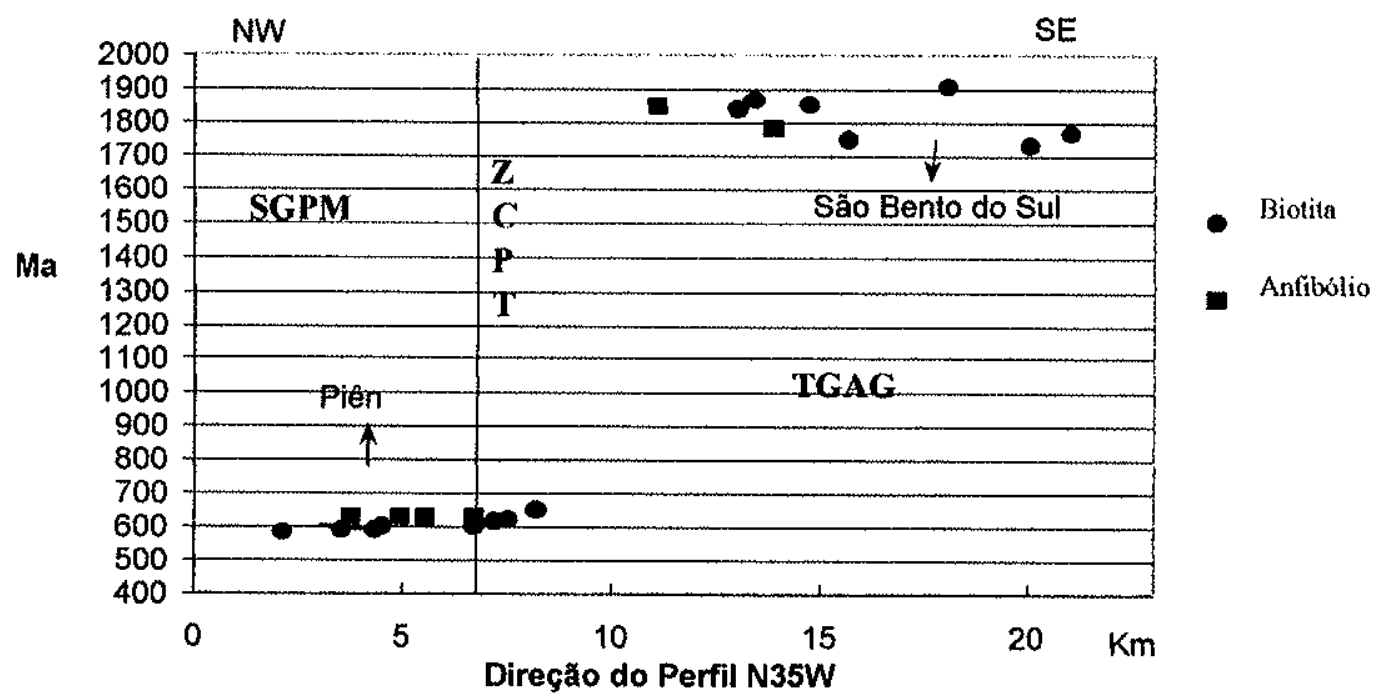

Figura 8.14 - Perfil térmico-geocronológico K-Ar (biotita e anfibólio) entre o TGAG e a SGPM.

As análises $\mathrm{Sm}-\mathrm{Nd}$ em rocha total e minerais (plagioclásio e granada) dos gnaisses granulíticos máficos com megacristais de granada (dados analíticos Tabela 8.3) indicaram uma isócrona com idade de $1831 \pm 17 \mathrm{Ma}$ (Figura 8.15) e uma errócrona com idade de 1704 $\pm 540 \mathrm{Ma}$ (Figura 8.16). Estas idades isocrônicas Sm-Nd (granada, plagioclásio e rocha total) são similares às idades K-Ar em biotita e anfibólio obtidas na maioria dos gnaisses granulíticos sem megacristais de granada.

Devido à diferença entre a temperatura média do metamorfismo granulítico (800 a $1000^{\circ} \mathrm{C}$, capaz de alterar completamente o sistema U-Pb dos zircőes dos protólitos dos gnaisses granulíticos), a temperatura de difusão do $\mathrm{Nd}$ em granada $\left(500-700^{\circ} \mathrm{C}\right.$ Hamphries \& Cliff $1982,600 \pm 30^{\circ} \mathrm{C}$, Mezger et al.1992) e a temperatura de difusão de Ar em biotita $\left(250^{\circ} \mathrm{C} \pm 50^{\circ} \mathrm{C}\right)$ e anfibólio $\left(450^{\circ} \mathrm{C} \pm 50^{\circ} \mathrm{C}\right)$, as idades $\mathrm{Sm}-\mathrm{Nd}$ obtidas não poderiam indicar a idade do resfriamento destas rochas. Mesmo assim, o significado geológico destas idades Sm-Nd são interpretados como representantes do período do resfriamento. 
Tabela 8.3 - Análises Sm-Nd dos gnaisses granulíticos e anfibolíticos ricos em megacristais de granada do TGAG

\begin{tabular}{|c|c|c|c|c|c|}
\hline Amostra & Mineral ou rocha Total & Sm (ppm) & Nd (ppm) & $S m^{147} / \mathrm{Nd}^{144}$ & $\mathrm{Nd}^{143} / \mathrm{Nd}^{144}$ \\
\hline OM 379 & Rocha Total & 4.35 & 14.95 & $0.177085 \pm 1$ & $0.512040 \pm 32$ \\
\hline OM 379 & Granada & 3.86 & 3.85 & $0.60981 \pm 30$ & $0.517034 \pm 24$ \\
\hline OM 379 & Plagioclásio & 0.90 & 7.50 & $0.07297 \pm 13$ & $0.511054 \pm 22$ \\
\hline OM 173 & Rocha Total & 6.14 & 27.28 & $0.13698 \pm 6$ & $0.511836 \pm 34$ \\
\hline OM 173 & Granada & 7.16 & 5.45 & $0.79988 \pm 38$ & $0.519829 \pm 31$ \\
\hline OM 173 & Plagioclásio & 0.88 & 6.75 & $0.079160 \pm 7$ & $0.511153 \pm 36$ \\
\hline
\end{tabular}

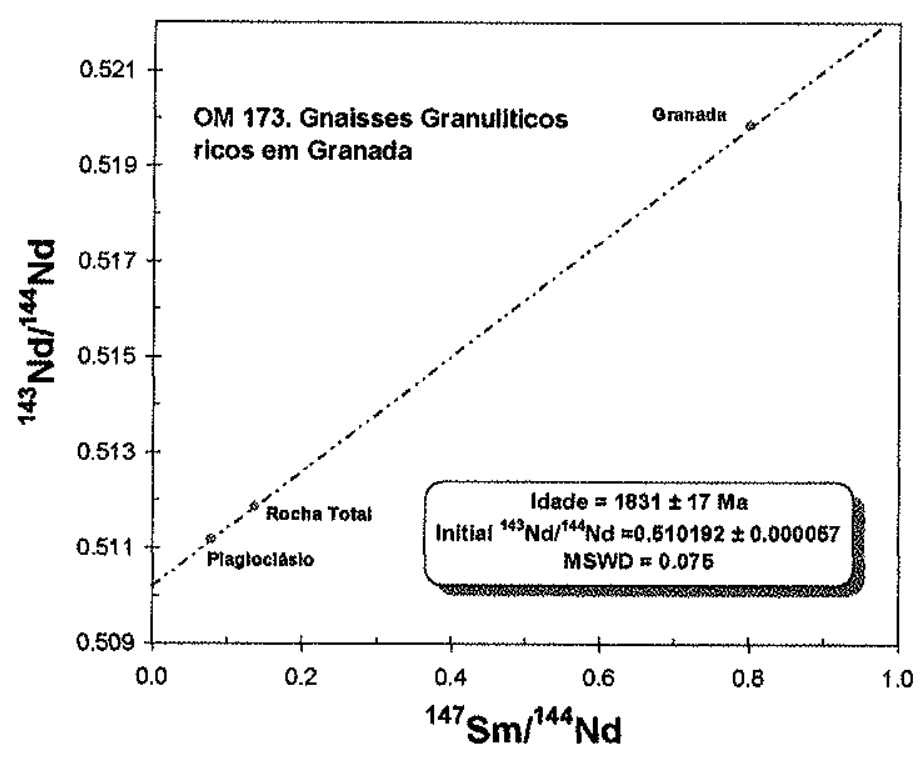

Figura 8.15 -. Diagrama isocrônico $\mathrm{Sm}^{147} / \mathrm{Nd}^{144}-\mathrm{Nd}^{143} / \mathrm{Nd}^{144}$ (rocha total, plagioclásio e granada) para os gnaisses granulíticos máficos com megacristais de granada.

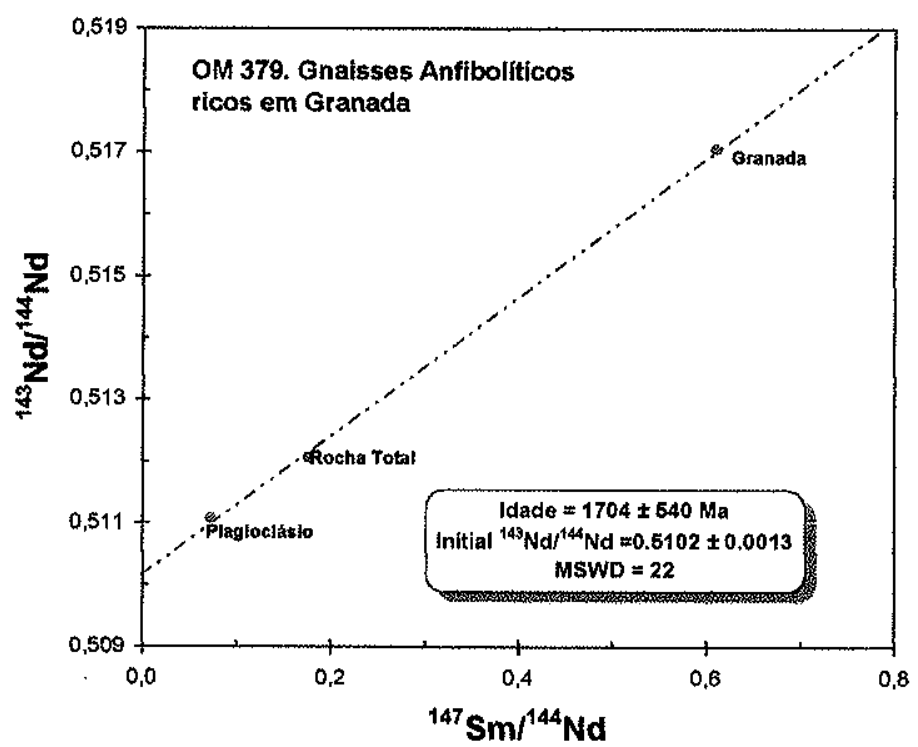

Figura 8.16 - Diagrama isocrônico $\mathrm{Sm}^{147} / \mathrm{Nd}^{144}-\mathrm{Nd}^{143} / \mathrm{Nd}^{144}$ (rocha total, plagioclásio e granada) para os gnaisses granulíticos máficos com megacristais de granada. 


\section{0 - Geologia Isotópica (Sm-Nd, Sr e $\delta^{18} \mathrm{O}$ em zircões)}

Os resultados $\mathrm{Sm}-\mathrm{Nd}, \mathrm{Sr}^{87} / \mathrm{Sr}^{86}$ e $\delta^{18} \mathrm{O}$ em zircões, obtidos nos principais litotipos do GP, GRN, GAS, GT, SGPM e o TGAG são apresentados em diagramas $\mathrm{SiO}_{2} \times \delta^{18} \mathrm{O}$, $\mathrm{Sr}^{87} / \mathrm{Sr}^{86(T c)} X \in \mathrm{Nd}^{(T c)}$ e tempo $X \in N d$ (Figuras $9.1,9.2$ e 9.3). Os valores de $\in N d^{(T c)}$ e $\mathrm{Sr}^{87} / \mathrm{Sr}^{86 \text { (Tc) }}$ são calculados para as idades de cristalização destas rochas, exceto nas rochas do TGAG, onde estas razões foram calculadas para a idade de $600 \mathrm{Ma}$. No diagrama $\mathrm{Sr}^{87} / \mathrm{Sr}^{86(\mathrm{Tc})} \mathrm{X} \in \mathrm{Nd}^{\left(\mathrm{Tc}^{(0)}\right.}$ são apresentadas as principais assinaturas isotópicas de $\mathrm{Sr}$ e $\mathrm{Nd}$ das principais rochas basálticas como o MORB, OIB, CFB e basaltos de zonas de subducção. As análises $\delta^{18} \mathrm{O}(\mathrm{Zrc})$ em zircões foram efetuadas nas principais rochas do TGAG, nas rochas graníticas com e sem epídoto magmático, em monzogabro do GRN e monzosienogranito do GP. Todas estas rochas foram datadas pela metodologia U-Pb em zircões. Os valores de $\delta^{18} \mathrm{O}$ em zircões são apresentados em unidades per mil \%o relativas ao Standard Mean Ocean Water (SMOW).

O zircão preserva os valores magmáticos de $\delta^{18} \mathrm{O}$ em magmas sem contaminação, contribuição ou assimilação crustal e apresentam valores uniformes, distintos dos magmas que assimilaram ou foram gerados diretamente de fontes infra ou supracrustais (Valley et al. 1994 e King et al 1998).

Os valores de $\delta^{18} \mathrm{O}$ do manto são estimados em $5.5 \%$ per mil e são baseados em peridotitos mantélicos (Mattey et al. 1994). Os basaltos MORB apresentam valores homogêneos de $\delta^{18} \mathrm{O}$ e estão ao redor de $5.7 \%$ (Harmon \& Hoefs 1995) e são similares a maioria dos basaltos OIB (Eiler et al 1997). Os basaltos gerados em zonas de subducção (arc-related basalts) apresentam valores entre 6.0 e $6.8 \%$ e os basaltos tipo CFB ou intraplaca apresentam valores de até $7.1 \%$ (basaltos toleíticos) e até $6.1 \%$ (alcalibasaltos) até $6.1 \%$ ). Segundo King et al. (1998), valores da ordem de $50 \%$ de assimilação crustal pode elevar o valor de $\delta^{18} \mathrm{O}(\mathrm{Zrc})$ de $5.5 \%$ para $6.5 \%$

Os isótopos de $\delta^{18} \mathrm{O}(\mathrm{Zrc}$ ) em zircão (Figura 9.1) sugerem da mesma forma que os isótopos de $\mathrm{Nd}$ e $\mathrm{Sr}$ (Figura 9.2), valores distintos para as rochas graníticas com e sem epídoto magmático da SGPM. Os quartzo monzodioritos e quartzo monzodioritos/granodioritos sem epídoto magmático apresentam valores de $\delta^{18} \mathrm{O}(\mathrm{Zrc})$ entre 6.0 e $6.3 \%$ que aumentam com aumento da sílica e com aumento da razão $\mathrm{Sr}^{87} / \mathrm{Sr}^{86(\mathrm{Tc})}$ e sugerem a contaminação, contribuição ou assimilação infracrustal durante o processo de cristalização destas rochas. Os quartzo monzodioritos e quartzo monzodioritos/granodioritos com epídoto magmático apresentam valores mais baixos e similares, entre 5.7 e $5.6 \%$. 
Estes valores de $\delta^{18} \mathrm{O}(\mathrm{Zrc})$ somados aos baixos valores das razões $\mathrm{Sr}^{87} / \mathrm{Sr}^{86(T c)}$, pouca ou nenhuma contaminação crustal durante o curso de cristalização destas rochas, em relação as rochas sem epídoto magmático

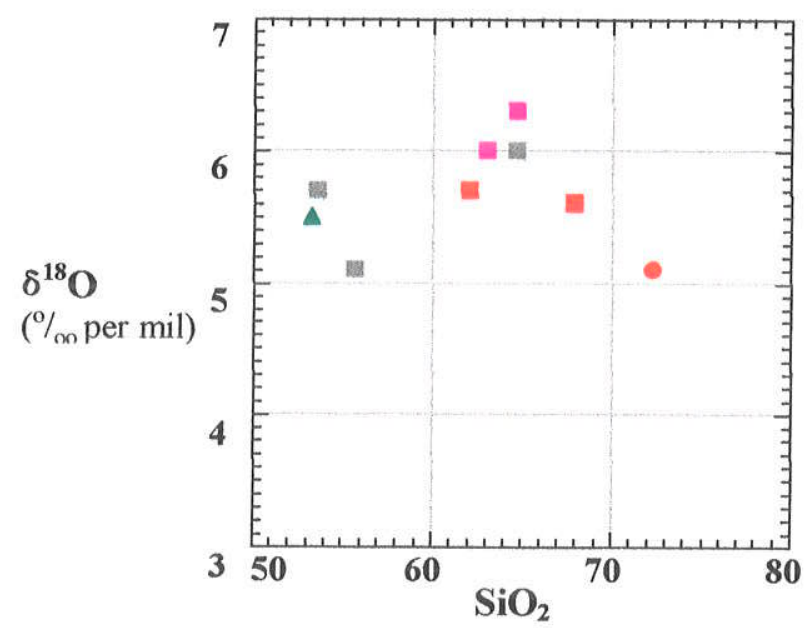

Figura 9.1 - Diagrama $\mathrm{SiO}_{2} \times \delta^{18} \mathrm{O}(\mathrm{Zrc}$ ) para as rochas graniticas sem (valores de 6.0 e $6.30 \%$ e $\mathrm{com}$ $(5.6$ e $5.7 \%$ epídoto magmático da SGPM, os monzo-sienogranitos do GP $(5.10 \%$ \% $)$, os monzogabros do GRN $(5.5 \%)$, os gnaisses máficos $(5.7 \%$ e félsicos $(6.1 \%$ ) do TGAG e os charnoquitos máficos ricos em biotita e anfibólio (5.10) do trecho NE do TGAG. Símbolos conforme os diagramas seguintes.

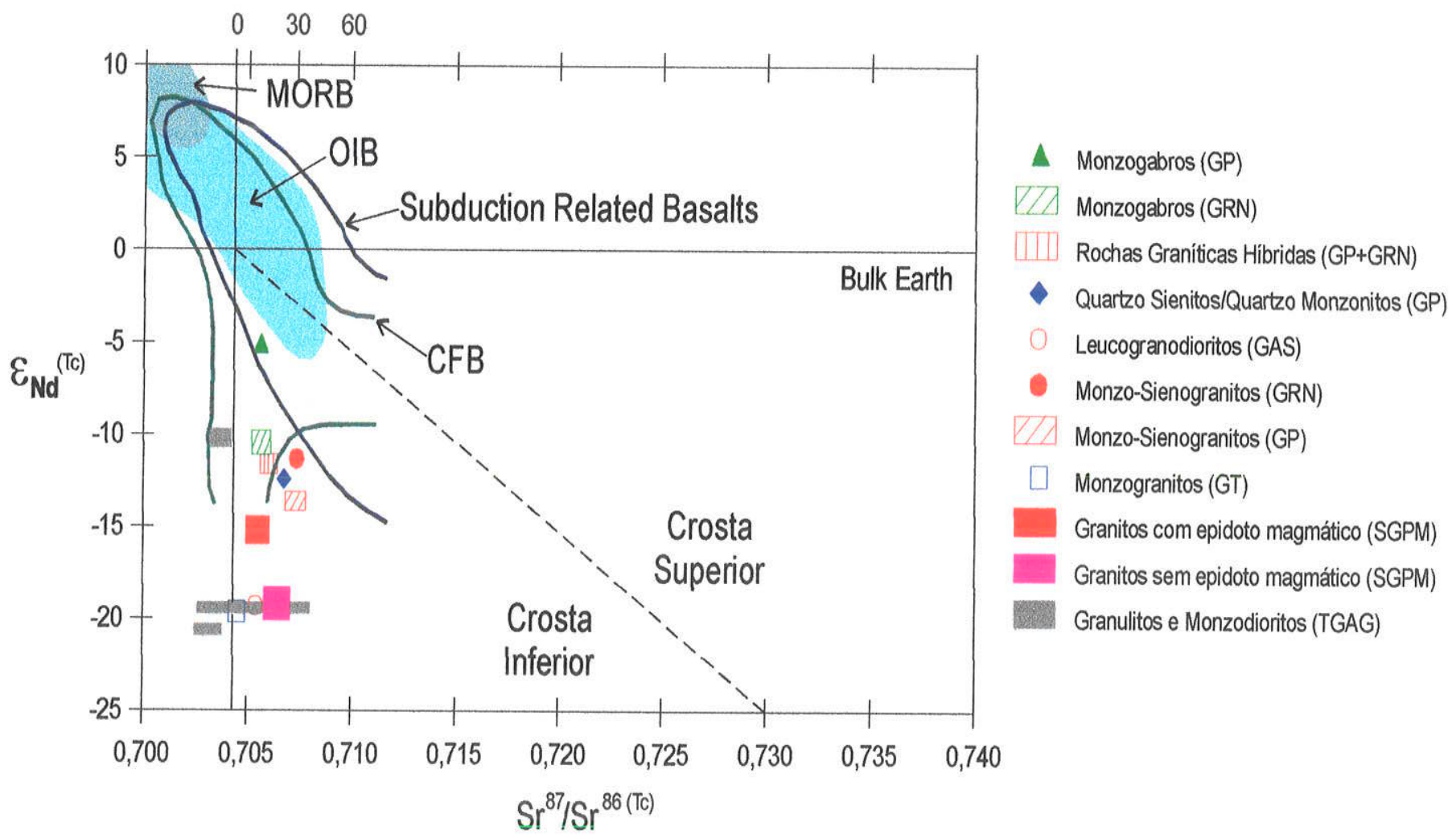

Figura $9.2-\in \mathrm{Nd}^{(\mathrm{Tc})} \times \mathrm{Sr}^{87} / \mathrm{Sr}^{86(\mathrm{Tc})}$ para as rochas do TGAG (Tc $\left.=600 \mathrm{Ma}\right)$, SGPM, GP, GAS, GRN e GT. (valores de $\in \mathrm{Nd}^{(\mathrm{Tc})} \times \mathrm{Sr}^{87} / \mathrm{Sr}^{86(\mathrm{Tc})}$ das rochas basálticas MORB, OIB, CFB e basaltos de arcos magmáticos, Wilson 1989, Saunders et al. 1992, Menzies et al. 1992 e Sun McDonough 1989). 
Os valores de $\delta^{18} \mathrm{O}(\mathrm{Zrc})$ apresentados pelos rochas graníticas com epídoto magmático são similares às rochas basáticas tipo MORB e os valores de $\delta^{18} \mathrm{O}(\mathrm{Zrc})$ das rochas graníticas sem epídoto magmático são mais altos em relação aos valores do MORB (MORB contaminado ?), e similares a rochas basálticas contaminadas tais como basaltos de zonas de subducção

As rochas graníticas sem epidoto magmático indicaram idades Modelo $\left(T_{D M}\right)$ entre 2.3 e $2.2 \mathrm{Ga}$, valores de $\in \mathrm{Nd}^{(T c)}$ negativos entre -18 e -19 e razões $\mathrm{Sr}^{87} / \mathrm{Sr}{ }^{86(T c)}$ entre 0.706 e 0.707 (Figuras 9.2 e 9.3 ). As rochas graníticas com epídoto magmático indicaram idades modelo $\left(\mathrm{T}_{\mathrm{DM}}\right)$ entre 2.2 e $2.1 \mathrm{Ga}$ sendo que os cogenéticos leucogranodioritos $\left(\mathrm{SiO}_{2}=73.72\right.$ \%) apresentam idades mais antigas ao redor de 2.35. Os valores de $\in \mathrm{Nd}^{(\mathrm{Tc})}$ das rochas graníticas com epídoto estão ao redor de -15 . As razões $\mathrm{Sr}^{87} / \mathrm{Sr}^{86(T 0)}$ nestas rochas são baixas e estão entre 0.705 e 0.706 . (Figura 9.2). O aumento nas idades modelo, da ordem de $150 \mathrm{Ma}$, no caso destes leucogranodioritos com epídoto magmático deve-se, principalmente, ao baixo conteúdo em $\mathrm{Sm}$ e $\mathrm{Nd}$ nestas rochas e ao aumento da razão $\mathrm{Sm} / \mathrm{Nd}$ e $\mathrm{Sm}^{147} / \mathrm{Nd}^{144}$.

As razões $\mathrm{Sr}^{87} / \mathrm{Sr}^{86(T c)}$ obtidas nas rochas graníticas sem epidoto magmático (0.706 a $0.707, \mathrm{SiO}_{2}=60-70 \%$ ) e com epidoto magmático $\left(0.705\right.$ a $\left.0.706, \mathrm{SiO}_{2}=60-75 \%\right)$ indicam pouca variação desta razão isotópica entre estes dois grupos e dentro de cada grupo durante o curso de cristalização destes rochas, sendo um pouco mais altas nas rochas sem epídoto magmático.

Nota-se que as rochas graníticas sem epídoto magmático em geral apresentam valores de $\in \mathrm{Nd}^{(T \mathrm{Tc})}$ mais negativos e $\mathrm{Sr}^{87} / \mathrm{Sr}^{86(\mathrm{Tc})}$ e $\delta^{180}(\mathrm{Zrc})$ mais altos do que as rochas graníticas com epídoto magmático (Figuras 9.1, 9.2 e 9.3). Isto somado às características químicas destas rochas, sugere, além da cogeneticidade dentro da cada grupo destas rochas, derivação de fontes máficas (basaltos e anfibolitos) variavelmente contaminadas. As assinaturas químicas sobrepostas das rochas com e sem epídoto magmático da SGPM, sugerem, independentemente da idade da formação/cristalização de cada suite, fontes máficas com semelhantes composições químicas, bem mais contaminadas (rochas sem epídoto) e menos contaminadas (rochas com epídoto) por rochas infracrustais paleoproterozóicas. Composições isotópicas de $\mathrm{Nd}$ e $\mathrm{Sr}$ em muitas rochas de arcos magmáticos são interpretados como reflexo da mistura ou interação de rochas derivadas do manto com rochas infra ou supra crustais (Hildreth and Moorbath 1988). Enquanto os valores de $\delta^{18} \mathrm{O}(\mathrm{Zrc})$ nas rochas sem epidoto magmático sugerem esta contaminação, o mesmo não é sugerido pelas rochas com epídoto magmático. Ao mesmo tempo, as 
diferenças desta contaminação ou contribuição crustal são sugeridas pelos isótopos de $\mathrm{Nd}$ e Sr e estão relacionadas ao grau de contaminação infracrustal destas rochas.

As idades modelo $\mathrm{Sm}-\mathrm{Nd}$ apresentadas pelas rochas graníticas sem epídoto magmático (2.3-2.2 Ga) e com epídoto magmático (2.2-2.1 Ga), são interpretadas como idade de mistura de $\mathrm{Nd}$ das rochas fontes máficas e $\mathrm{Nd}$ proveniente de rochas contaminantes infracrustais paleoproterozóicas (TGAG). As rochas sem epídoto magmático apresentam valores de $\in \mathrm{Nd}^{(T 0)}$ iguais as rochas do TGAG (Figura 9.2) corroborando as indicações dos isótopos de $\mathrm{Nd}, \mathrm{Sr}$ e $\delta^{18} \mathrm{O}(\mathrm{ZrC})$.

As rochas graníticas sem epídoto magmático poderiam ? resultar-se do retrabalhamento e refusão dos gnaisses granuliticos máficos tais com os do TGAG que apresentam valores semelhantes de $\in \mathrm{Nd}^{(\mathrm{Tc})}$ e $\mathrm{Sr}^{87} / \mathrm{Sr}^{86(\mathrm{Tc})}$ (para $\mathrm{T}=600 \mathrm{Ma}$ ) aos obtidos nestas rochas graníticas (Figuras 9.1 e 9.2). Este tipo de rochas granulíticas seriam rochas férteis para este magmatismo granítico inicial da SGPM ou são as principais contaminantes.

Os componentes do GP indicaram valores de $\in \mathrm{Nd}^{(\mathrm{Tc})}$ negativos (Figuras 9.2 e 9.3 ) para os monzo-sienogranitos (-13.53 a -14.53), quartzo monzonitos/quartzo sienitos (12.46), quartzo monzonitos híbridos $(-10.96)$ e monzogabros $(-5.43)$. Valores de $\in \mathrm{Nd}^{(T c)}$ negativos são apresentados pelos componentes do GRN, a saber: monzo-sienogranitos (11.72), quartzo monzodioritos e quartzo monzonitos/monzogranitos híbridos (-11.56 a 11.29) e os monzogabros (-11.57 e -11.42). Nota-se que os componentes do GRN apresentam valores de $\in \mathrm{Nd}^{(\mathrm{Tc})}$ e idades modelo praticamente similares nos monzogabros, as rochas hibridas e os monzo-sienogranitos.

Os quartzo monzonitos híbridos do GP apresentam valores de $\in \mathrm{Nd}^{(\mathrm{To})}$ e valores de idades modelo similares aos correspondentes híbridos do GRN. Os valores de $\in N d^{(T c)}$ dos monzo-sienogranitos do GP são mais negativos da ordem de 2 a 3 unidades $\epsilon$ do que os correspondentes monzo-sienogranitos do GRN.

Os monzogabros do GP apresentam valores de $\in \mathrm{Nd}^{(T 0)}$ bem menores (da ordem de 5 a 6 unidades $\epsilon$ ) do que os correspondentes monzogabros do GRN (Figura 9.2). Os monzogabros tanto no GP quanto no GRN estão dentro do campo da variação do $\mathrm{Sr}$ e $\mathrm{Nd}$ dos basaltos intraplaca porém os monzogabros do GP assemelham-se aos basaltos menos contaminados e os do GRN aos basaltos intraplaca com forte contaminaçáo crustal (Figura 9.2). Enquanto que as rochas híbridas do GRN apresentam valores de $\in \mathrm{Nd}^{(\mathrm{Tc})} \in \mathrm{Sr}^{87} / \mathrm{Sr}^{86(\mathrm{Tc})}$ próximos aos seus componentes de mistura, as rochas híbridas do GP apresentam valores próximos do componente félsico e distantes do componente máfico. 


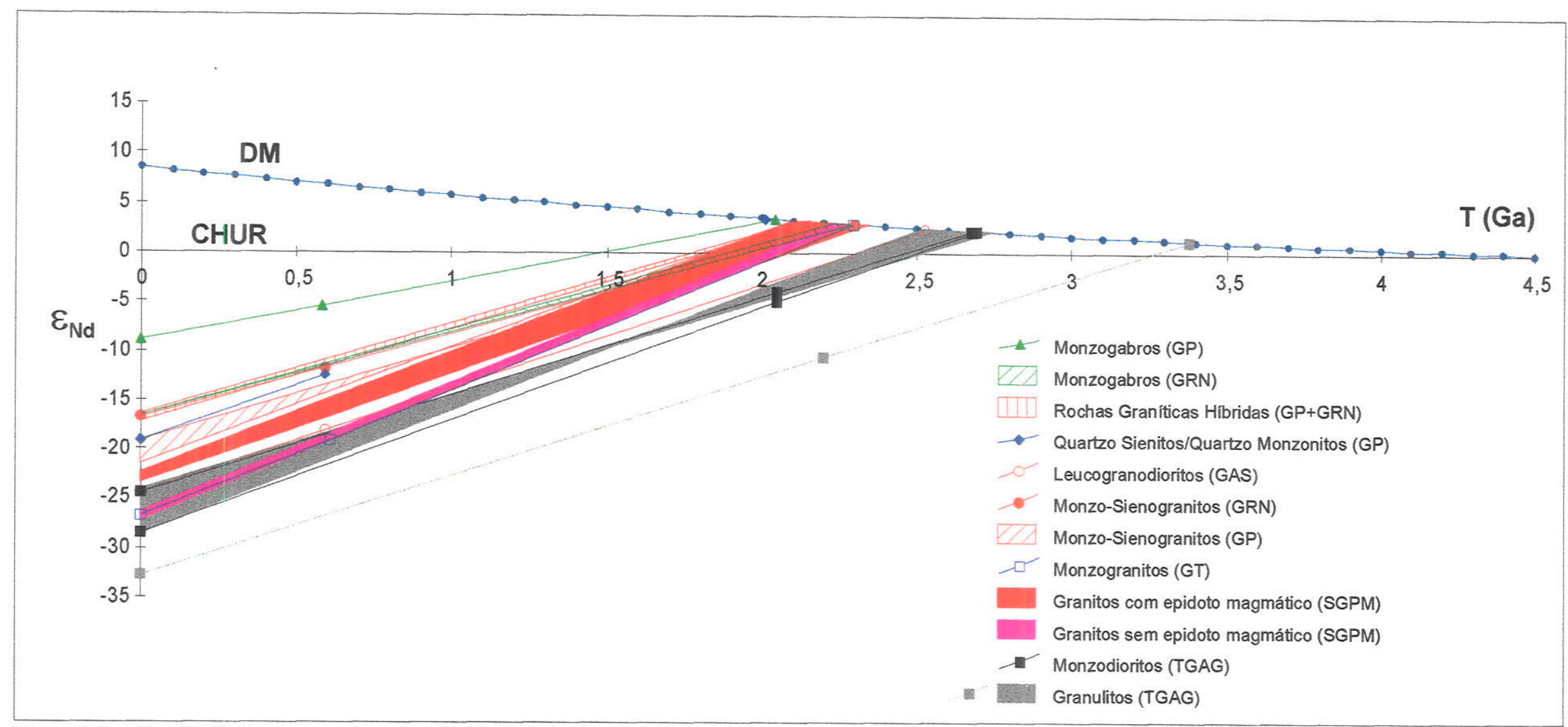

Figura $9.3-\in N d X T$ (Ga) para as rochas dos TGAG, SGPM, GP, GAS, GRN e GT. 
Segundo Menzies (1992) e Saunders et al. (1992) as caraterísticas de isótopos de Nd em vários basaltos continentais deve-se, principalmente, à interação de fusões do manto astenosférico com a crosta inferior ou superior; fusão de litosfera subcontinental enriquecida com contaminação crustal; e mistura de fontes mantélicas enriquecidas e empobrecidas e combinação destes processos.

As idades modelo $T_{D M}$ nas rochas do GP e GRN são paleoproterozóicas. Os monzo-sienogranitos do GP apresentam idades entre 2.35 e $2.1 \mathrm{Ga}$ e os do GRN idade modelo ao redor de $2.3 \mathrm{Ga}$. As idades modelo dos monzogabros do GRN estão ao redor de $2.3 \mathrm{Ga}$ e são similares aos monzo-sienogranitos do GRN e aos monzogabros do GP ( ao redor de $2.0 \mathrm{Ga}$ ). As rochas híbridas do GP e GRN apresentam idades modelo similares ao redor de 2.1 e os valores de $\in \mathrm{Nd}^{(\mathrm{Tc})}$ destas rochas são também similares (Figura 9.2). As idades Modelo $T_{D M}$ paleoproterozóicas em geral nestas rochas são interpretadas como idades de mistura do $\mathrm{Nd}$ da rocha fonte com o Nd do contaminante paleoproterozóico.

Os valores de $\delta^{18} \mathrm{O}(\mathrm{Zrc})$ dos monzo-sienogranitos do GP são da ordem de 5.1 $\%$ e dos monzogabros do GRN estão ao redor de $5.5 \%$ (Figura 9.1). Os valores $\delta^{18} \mathrm{O}$ ( $\mathrm{Zrc}$ ) dos monzogabros são semelhantes principalmente aos valores do manto, mais baixos do que os do MORB e, dentro dos valores mínimos sem contaminação das típicas rochas basalticas toleíticas e alcalinas intraplaca. Enquanto que os isótopos de Nd sugerem maior ou menor contaminação e contribuição infracrustal nos monzogabros do GRN e GP, os isótopos de $\delta^{18} \mathrm{O}(\mathrm{Zrc})$ descartam esta indicação e sugerem a origem mantélica.

Valor de $\in \mathrm{Nd}^{(T C)}$ mais alto ao redor de -18 e idade $\mathrm{T}_{\mathrm{DM}}$ de $2.5 \mathrm{Ga}$ mais antiga em relação aos monzo-sienogranitos do GP e do GRN são obtidos em leucogranodiorito do GAS. Estas rochas do GAS apresentam, além do alto valor da sílica, generalizado empobrecimento em ETRL e ETRP que justificam estes valores exóticos de $\in \mathrm{Nd}^{(T C)}$ e das idades $T_{D M}$, em relação aos monzo-sienogranitos do GP e GRN.

Valor de $\in \mathrm{Nd}^{(\mathrm{TC})}$ de -19.11 e idade $\mathrm{T}_{\mathrm{DM}}$ de $2.3 \mathrm{Ga}$ são obtidos nos monzogranitos do GT e são bem mais altos do que os adjacentes monzogabros, rochas graníticas híbridas e os monzo-sienogranitos.

A análise conjunta dos resultados dos isótopos de $\mathrm{Nd}$ e $\mathrm{Sr}$ das rochas do TGAG, SGPM, GP e GRN (Figura 9.2 e 9.3) sugerem a diminuição da influencia da componente infracrustal com a diminuição gradativa do valor de $\in \mathrm{Nd}^{(T c)}$ e a mudança do regime tectônico compressional (SGPM) para um regime extensional (GP e GRN). 
Esta mudança resulta na diminuição da influencia do contaminante infracrustal paleoproterozóico-arqueano durante o alojamento das rochas do GP e do GRN. Nesta situação, estas rochas apresentam valores proximos de $\in \mathrm{Nd}^{(T c)}$ incluindo os monzogabros e as híbridas. Os isótopos de $\mathrm{Nd}$ sugerem também a formaçăo dos monzo-sienogranitos por fusão de rochas infracrustais com incorporação de $\mathrm{Nd}$ proveniente das rochas máficas contaminadas ou, a partir de fusão de rochas máficos contaminados (monzogabros do GP e do GRN).

As análises Sm-Nd nas rochas do TGAG indicaram idades modelo $T_{D M}$ entre 2.75 e $2.6 \mathrm{Ga}$ para os gnaisses granulíticos máficos (ricos ou não em biotita e anfibólio) e para os gnaisses monzodioríticos shoshoníticos. Já para os gnaisses granuliticos félsicos com traços de biotita e anfibólio as idades modelo encontram-se ao redor de $2.5 \mathrm{Ga}$. Estes resultados são similares a maioria dos resultados obtidos por Siga Jr. (1995) na porção central e meridional do TGAG. Para os charnoquitos máficos ricos em biotita e anfibólio do trecho NE do TGAG as análises $\mathrm{Sm}-\mathrm{Nd}$ indicaram idades modelo mais antigas, ao redor de $3.4 \mathrm{Ga}$.

A comparação entre os resultados $\mathrm{Sm}-\mathrm{Nd}$ dos gnaisses granulíticos máficos sem biotita e anfibólio e dos gnaisses granulíticos máficos ricos em biotita e anfibólio sugerem a não mobilidade ou fracionamento do $\mathrm{Sm} e$ do $\mathrm{Nd}$ durante o mesmo metamorfismo de alto grau que afetou estas duas rochas permanecendo com similares assinaturas isotópicas de $\mathrm{Nd}$ e com similares idades modelo.

Baseando-se nos resultados $\mathrm{Sm}-\mathrm{Nd}$ dos gnaisses granulíticos máficos e félsicos e dos gnaisses biotíticos e anfibolíticos do TGAG, o período entre 2.7 a $2.5 \mathrm{Ga}$ (Arqueano-Paleoproterozóico) pode representar o principal tempo da adição e diferenciação do manto para crosta dos protólitos dos gnaisses granulíticos máficos e félsicos e dos gnaisses biotíticos e anfibolíticos. 


\section{0 - Considerações finais e conclusões}

New and recent geological investigations around Piên-Tijucas (suture) shear zone led to the identification of successive and different Neoproterozoic magmatic activities between 630 and $585 \mathrm{Ma}$. These magmatic activities are continuous responses to geotectonic scenery, which changes from subduction to collision and to late and post-collision extensional settings. The main geological units that were mapped and investigated by geochronological and petrological studies are: Gneiss-granulite Terrain, the Piên Maficultramafic Suite, the Piên-Mandirituba Granite Belt, and the Palermo, Agudos do Sul, Rio Negro and Tarumã Granites.

The Piên-Mandirituba calc-alkaline l-type Granite Belt is a magmatic arc-related to NW subduction zone. The suture zone results from oblique collision between the PiênMandirituba Granite Belt, to the north, and the reworked Neo-Archean-? Paleoproterozoic Gneiss-granulite Terrain, to the south. As a consequence the neoproterozoic supra subduction zone (SSZ) Piên Mafic-ultramafic Suite is tectonically emplaced between these units. The Palermo, Agudos do Sul and Rio Negro Granites are late to post-collision A-PA type granites with mafic rocks and magma mixing processes.

The Piên-Mandirituba Granite Belt, approximately $30-\mathrm{Km}$ width, is formed by three main granite suites. The older, pre-collisional granite suite is constituted by magmatic epidote-free, amphibole- and biotite-bearing deformed quartz monzodiorites to granodiorites and by deformed cumulate amphibolite (diorite/quartz diorite) to a less extent. The younger, sin-collisional granite suite is constituted by amphibole-, biotite- and magmatic epidotebearing deformed quartz monzodiorites, granodiorites and leuco-granodiorites. The third sin to late collisional granite suite is constituted by deformed biotite \pm amphibole monzogranites. Despite the same granite compositions, the older, epidote-free suite, is less expanded $\left(\mathrm{SiO}_{2}=\right.$ $60-70 \%$ ) and with biotite, amphibole and accessories minerals (titanite, zircon and allanite) contents that are higher than those from the younger, epidotembearing suite $\left(\mathrm{SiO}_{2}=60-75 \%\right)$. The protomylonitic to mylonitic foliation present in all granite suites is N50E/69NW-trending and characterised by high deformation and orientation of feldspars, quartz, biotite, amphibole and magmatic epidote (when present).

The epidote-free quartz monzodiorites to granodiorites and epidote-bearing quartz monzodiorites to leuco-granodiorites of this granite belt are high $\mathrm{K}$ calc-alkaline, mainly metaaluminous to rarely slightly peraluminous, with similar high $\mathrm{Ba}(1000-2000 \mathrm{ppm}), \mathrm{Sr}(1000-$ $2000 \mathrm{ppm})$ and low Rb (50-100 ppm) contents. The epidote-free granite suite is less expanded and have generally slightly higher $\mathrm{K}_{2} \mathrm{O}\left(\mathrm{Na}_{2} \mathrm{O} / \mathrm{K}_{2} \mathrm{O}=1-1.5\right), \mathrm{TiO}_{2}, \mathrm{MgO}, \mathrm{Zr}, \mathrm{Hf}, \mathrm{Th}$, 
$\mathrm{Y}, \mathrm{Cr}, \mathrm{Ni}, \mathrm{Sc}, \mathrm{V}, \mathrm{LREE}$, and HREE contents than the epidote-bearing, more expanded granite suite, which have higher $\mathrm{Na}_{2} \mathrm{O}\left(\mathrm{Na}_{2} \mathrm{O} / \mathrm{K}_{2} \mathrm{O}=1.5-2\right)$ and $\mathrm{Al}_{2} \mathrm{O}_{3}$ contents. Trace element contents such as $\mathrm{Rb}, \mathrm{Y}$, and $\mathrm{Nb}$, are compatible with continental arc-related granites both for the epidote-free and epidote-bearing granite suites.

$\mathrm{U}-\mathrm{Pb}$ zircon and titanite dating of epidote-free granite suite yielded ages between 620-615 Ma for the crystallization of the initial quartz monzodiorites and between 615-610 Ma for the crystallization of the co-genetic quartz monzodiorites to granodiorites.

U-Pb zircon dating of epidote-bearing granite suite, suggests inherited, older $\mathrm{Pb}$ components in the zircons history, with lower intercept ages between 605 and $597 \mathrm{Ma}$ and rare concordant ages around $605 \pm 5 \mathrm{Ma}$ which were interpreted as the crystallization age of the initial quartz monzodiorites. U-Pb zircon and titanite dating of the co-genetic quartz monzodiorites /granodiorites and leuco-granodiorites yielded a concordant age of $596 \pm 6.7$ $\mathrm{Ma}$ (titanite) and upper intercept discordant ages between $604 \pm 16 \mathrm{Ma}$ and $602 \pm 14 \mathrm{Ma}$ (zircons). $\mathrm{Rb}-\mathrm{Sr}$ whole rock dating of the main epidote-free granite suite yielded an isochronic age of $605 \pm 24 \mathrm{Ma}$. The K-Ar biotite ages between 607 and $595 \mathrm{Ma}$ obtained for the epidote-bearing granite suite are superimposed to the main U-Pb zircon and titanite ages in the same rocks. This age superposition suggests synchronic crystallisation and fast emplacement and cooling of the epidote-bearing granite suite and may be responsible for the preservation of the magmatic epidote in this suite. The K-Ar biotite ages between 607-595 $\mathrm{Ma}$ also indicate the deformation and the tectonic stability of all granite suites of PiênMandirituba Granite Belt and represent the principal collision age.

$\mathrm{Nd}, \mathrm{Sr}$ and $\delta^{18} \mathrm{O}(\mathrm{Zrc})$ isotope investigations show clear differences between both suites. The epidote-free granite suite $(-18,0.706-0.707,6.0-6.5 \%)$ presents more negative $\in \mathrm{Nd}^{(T c)}$, and higher $\mathrm{Sr}^{87} / \mathrm{Sr}^{86(\mathrm{Tc})}$ and $\delta^{18} \mathrm{O}(\mathrm{Zrc})$ values than the epidote-bearing granite suite ($15,0.705-0.706,5.6-5.6 \%$. These isotopic and also the mentioned chemical data suggest mantle-derived mafic sources (amphibolitic, basaltic), more (epidote-free) or less contaminated (epidote-bearing) by infracrustal paleoproterozoic component (Gneiss-granulite Terrain) during the independent fractional crystallization course of these granite suites.

The Piên Mafic-Ultramafic Suite, $11-\mathrm{Km}$ long and N40-50E-trending, is composed by two ultramafic bodies tectonically emplaced along the Piên-Tijucas (Suture) shear zone. The northern body is emplaced between the southern border of the Piên-Mandirituba Granite Belt (north) and the reworked northern border of the Gneiss-granulite Terrain (south). The southern ultramafic body is tectonically emplaced as klippe on the reworked border of the latter. This suite is constituted by serpentinized peridotites (harzburgites and olivine- 
pyroxenites), pyroxenites and rare tholeitic gabbros. Compared with the Penrose definition, the Piên Mafic-ultramafic Suite is an incomplete ophiolite sequence with expositions of the mantle section and absence of the crustal section (volcanic and associated sediments). The supra subduction zone (SSZ-type) residual mantle characteristics are indicated by the lithochemical signature such as $\mathrm{TiO}_{2}, \mathrm{Cr}, \mathrm{Co}, \mathrm{Y}$, and $\mathrm{Yb}$ contents of the peridotites.

New U-Pb geochronological data (SHRIMP) on the main prismatic zircons of the tholeitic gabbros yielded ages of $631-632 \pm 17 / 18 \mathrm{Ma}$, interpreted as the crystallisation age of these rocks. In the same rock, Paleoproterozoic ages (2.2-2.1 Ga) were obtained from core and rim of rare rounded zircons (typical of the adjacent Gneiss-granulite Terrain) incorporated during emplacement of these gabbros at 631-632 Ma.

The Palermo, Agudos do Sul, and Rio Negro Granites are components of the expressive Neoproterozoic volcanic and plutonic alkaline-peralkaline Serra do Mar Suite (Kaul 1997), which was emplaced along the central and northern border of the Paleoproterozoic Gneiss-granulite Terrain, in extensional, late to post-collisional and anorogenic settings. Magma mixing evidences are rare or absent in the other components of the Serra do Mar volcanic and plutonic suite.

The Palermo Granite, N-S- trending, is emplaced along the tectonic contact between the Pien-Mandirituba Granite Belt and the Paleoproterozic Gneiss-granulite Terrain. It is constituted mainly by medium- to coarse-grained, non-deformed A-type amphibole-biotite and biotite \pm amphibole monzo-syenogranites. Slightly peralkaline (PA-type), sodic amphibole- and pyroxene-bearing quartz monzonites/quartz syenites and small intrusions of monzogabbros associated with mafic and felsic hybrid granites occur secondarily.

The Rio Negro Granite is emplaced as an elliptical body approximately N45Etrending along the tectonic contact (Piên-Tijucas Shear zone) between the Piên-Mandirituba Granite Belt and the reworked Paleoproterozoic Gneiss-granulite Terrain. This unit exhibits a concentric zonation characterised by the presence, in the internal portion, of a high quantity small intrusions of monzogabbros and associated mafic and felsic hybrid granite rocks. In the external portion occur non-deformed, A-type biotitetamphibole monzo-syenogranites. The mafic and felsic hybrid granite rocks and associated monzogabbros occur more extensively in this granite than in the Palermo Granite. The slightly peralkaline quartz monzonites/quartz syenites are absent. 
The fine-grained isotrope monzogranites of the Tarumã Granite occur only in the central portion of the Rio Negro Granite and are not involved in the mixing between the adjacent A-type monzo-syenogranites and monzogabbros. These biotitetamphibole monzogranites are characterised by the presence of elliptical and rounded microgranular enclaves with biotite, amphibole and plagioclase concentrations.

The Agudos do Sul Granite, N-S-trending, is emplaced between the Palermo (north) and Rio Negro (south) granites, within the epidote-bearing granite suite, component of the Piên-Mandirituba Granite Suite. The Agudos do Sul Granite is essentially constituted by Atype leucogranodiorites with low contents of biotite and muscovite and miarolitic cavities with fluorite. The main accessories minerals are zircon, titanite, and apatite.

The monzogabbros, mainly emplaced within Rio Negro Granite and subordinately Palermo Granite form, by mixing with the adjacent A-type monzo-syenogranites, a great variety of mafic (monzodiorites/ monzogabbros, quartz-monzodiorites to quartz-monzonitos) and felsic (quartz-monzodiorites, quartz-monzonitos to monzogranitos) hybrid rocks. The mafic and felsic hybrid rocks of Palermo and Rio Negro granites are mainly characterised by the presence of typical mixing textures, such as rounded and elliptical quartz-ocelli, with or without interstitial perthite, mantled by amphibole with pyroxene and biotite; chaotic acicular apatite, rounded and elliptical mafic concentrations (biotite, amphibole, pyroxene) and rapakivi and anti-rapakivi textures. These mixing textures are absent in the monzogabros and monzo-syenogranites.

The A-type monzo-syenogranites of the Palermo and Rio Negro granites are constituted by perthitic K-feldspar, sodic plagioclase, quartz, biotite, and amphibole. Miarolitic cavities with fluorite and granophiric intergrowths between quartz and feldspar are common features in these rocks and suggest synchronic crystallization of quartz and feldspar and low pressure crystallization. The main mafic mineral phases are biotite and biotite \pm amphibole and the main accessory minerals are zircon, allanite, titanite, fluorite, and apatite. The late crystallized biotite and accessory minerals are interstitial to the initial crystallized quartz and feldspars. The same textural features are present in the slightly peralkaline quartz monzonites/quartz syenites, in which biotite, sodic amphibole and pyroxene (aegirine-augite, aegirine and riebeckite-arfvedsonite) are interstitial to quartz and feldspars, a feature indicative of late crystallisation.

The A-type monzo-syenogranites of Palermo and Rio Negro are high silica $\left(\mathrm{SiO}_{2} 70-\right.$ $80 \%$ ), aluminous (meta-aluminous to slightly peraluminous) with low $\mathrm{Al}_{2} \mathrm{O}_{3}, \mathrm{CaO}, \mathrm{MgO}, \mathrm{Sr}$, and $\mathrm{Ba}$ contents and high $\mathrm{K}_{2} \mathrm{O}, \mathrm{Rb}, \mathrm{Ga}, \mathrm{Ta}, \mathrm{Nb}, \mathrm{Zr}, \mathrm{Hf}, \mathrm{U}, \mathrm{Th}$, LREE, and HREE contents, with high Eu negative anomalies. The slightly peralkaline quartz-monzonites/quartz-syenites 
$\left(\mathrm{SiO}_{2}=60-65 \%\right)$ of Palermo Granite present similar lithochemical characteristics to the monzo-syenogranites, but with higher $\mathrm{K}_{2} \mathrm{O}$ and $\mathrm{Na}_{2} \mathrm{O}, \mathrm{Zr}, \mathrm{Hf}, \mathrm{Y}$ contents, as well as LREE and HREE enrichment, also with high Eu negative anomalies. These whole lithochemical characteristics, with clearly late- to post-collisional and anorogenic intraplate granite signature are similar to all Serra do Mar volcanic and plutonic suite and to many world-wide A-PA type granites.

The monzogranites of the Tarumã Granite are slightly peraluminous, high $\mathrm{K}$ calcalkaline with trace elements such as $\mathrm{Rb}, \mathrm{Ba}, \mathrm{Sr}, \mathrm{Zr}, \mathrm{Y}, \mathrm{Nb}$, and $\mathrm{Yb}$ contents indicative of intermediate characteristics between the l-type epidote-free and epidote-bearing granite suites of the Piên-Mandirituba Granite Belt and the A-type monzo-syenogranites of Palermo and Rio Negro granites. The Tarumä Granite represents the continuous magmatic activity between these contrasting granite typology.

The monzogabbros intraplated in the Palermo and Rio Negro granites are alkaline $\left(\mathrm{Na}_{2} \mathrm{O}=3-4 \%, \mathrm{~K}_{2} \mathrm{O}=1-2.2 \%, \mathrm{Na}_{2} \mathrm{O} / \mathrm{K}_{2} \mathrm{O}=1.8-3.6\right)$ and chemically characterised by high $\mathrm{Rb}$ (30-60 ppm), Ba, Sr, Ga, $\mathrm{Zr}, \mathrm{Hf}, \mathrm{Nb}$, and $\mathrm{Y}$, and by LREE and HREE enrichment with low $\mathrm{Al}_{2} \mathrm{O}_{3}$. The $\mathrm{Zr}$ and $\mathrm{Y}$ contents and the main other trace elements such as $\mathrm{Nb}, \mathrm{Ta}, \mathrm{Th}$, and $\mathrm{Yb}$ clearly indicate within plate signatures for both monzogabbros of Palermo and Rio Negro granites.

The mafic and felsic hybrid granite rocks present intermediate chemical characteristics between the mafic (monzogabbros) and felsic (monzo-syenogranites), their progenitors that imprint in these rocks lithochemical intraplate characteristics such as high contents of $\mathrm{Rb}, \mathrm{Ga}, \mathrm{Nb}, \mathrm{Hf}, \mathrm{Zr}$, and $\mathrm{Y}$ with high LREE and HREE with Eu low negative anomalies.

$\mathrm{U}-\mathrm{Pb}$ zircons dating yielded an upper intercept age of $593 \pm 12 \mathrm{Ma}$ for the monzo-

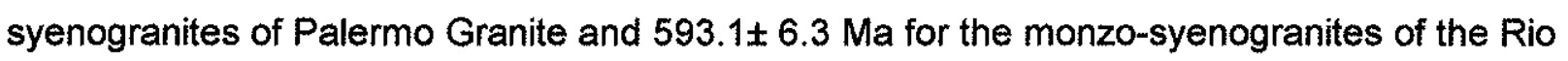
Negro Granite, interpreted as the crystallization age of these rocks. For the monzogabbros of the Rio Negro Granite, U-Pb zircons isotopic data yielded an upper intercept age of $584 \pm 7$ Ma. This age is interpreted as the crystallization and cooling of the monzogabbros. The cooling ages for the monzo-syenogranites of the Rio Negro Granite and Tarumã Granite, as indicated by K-Ar biotite results, are around 574-572 Ma, whereas for the monzosyenogranites of Palermo Granite these ages are around $581 \mathrm{Ma}$. The differences between $\mathrm{U}-\mathrm{Pb}$ zircon and $\mathrm{K}-\mathrm{Ar}$ biotite ages of the monzogabbros and monzo-syenogranites of Palermo and Rio Negro granites suggest that the monzogabbros are late crystallized and fast cooling and represent the final magmatic activity in the investigated area. 
Sm-Nd isotopic data indicated similar negative $\in N^{(T)}(-11 /-12)$ values and Paleoproterozoic depleted mantle ages $\left(T_{D M}\right)$ for monzo-syenogranites, mafic and felsic hybrid granite rocks and monzogabbros of the Rio Negro Granite. In the Palermo Granite, The $\in N d^{(T)}$ values for the monzo-syenogranites are slightly more negative $(-13 /-14)$, hybrid quartz-monzonite are $(-11)$ and slightly peralkaline quartz monzonite are -12 . The $\in \mathrm{Nd}^{(\mathrm{T})}$ values for the monzogabbros of Palermo Granite are -5 , lower than by 5 to $6 \in$ units the $\in \mathrm{Nd}^{(\mathrm{T})}$ value of the monzogbbros of Rio Negro Granite. This difference between Palermo and Rio Negro Monzogabbros indicate low infracrustal contamination in the former. The $\in \mathrm{Nd}^{(\mathrm{T})}$ and $\mathrm{Sr}^{87} / \mathrm{Sr}^{86(\mathrm{~T})}$ of Palermo and Rio Negro monzogabbros are compatible with the contaminated intraplate and rift zone basalts. The same $\in \mathrm{Nd}^{(T)}$ for the monzo-syenogranites, hybrid rocks and monzogabbros of the Rio Negro Granite suggest mixing, homogenisation and infracrustal contamination or probably generation of A-type monzo-syenogranites by melting of the contaminated monzogabbros. The $\delta^{18} \mathrm{O}$ values of the bulk mantle are $5.5 \%$ based on mantle peridotites (Mattey et al. 1994). Mid-ocean ridge basalts (MORB) have homogeneous $\delta^{18} \mathrm{O}$ values of $5.7 \%$ (Harmon \& Hoefs 1995), similar to most ocean island basalts "OIB" (Eiler et al. 1997). These ${ }^{18} \delta 0 \%$ values are lower than those of the subduction-related basalts $(6.0-6.8 \%$ ) and continental intraplate basalts (maximum 6.1 for alcali-basalts and maximum 7.1 for tholeitic basalts). Where the high negative $\in \mathrm{Nd}^{(T c)}$ values range from -5 to -11 indicate, for the monzogabbros of Palermo and Rio Negro Granites, mantle-derived mafic melts with variable infracrustal interaction, the average $\delta^{18} \mathrm{O}$ of $5.5 \%$ ( $\mathrm{Zrc})$ are similar to the mantle values and do not indicate crustal contamination or contribution. The monzo-syenogranites of the Palermo and Rio Negro Granites present an average $\delta \mathrm{O}^{18}(\mathrm{Zrc})$ around $5.1 \%$, which are lower than the monzogabbros $\delta^{18} \mathrm{O} \%$ values. This value may be also suggests the possible generation of A-type monzo-syenogranites by melting of the adjacent intraplated monzogabbros.

The Gneiss-granulite Terrain occurs in the southern portion of the mapped area, being constituted mainly by LILE (Rb, Th, $K, U$ )-depleted mafic and felsic orthogranulites (norites, quartz norites, and enderbites), and pyroxene-free biotitic and amphibolitic gneiss (diorites/monzodiorites, quartz diorites, and tonalites). Biotite and amphibole-rich mafic orthogranulite also occur. Garnet-rich mafic orthogranulites occur mainly along the PiênTijucas shear zone. The principal mineral assemblages in the mafic and felsic orthogranulites are orthopyroxene, clinopyroxene, quartz, plagioclase (oligoclase/andesine to labradorite) and minor amphibole biotite, and $\mathrm{K}$-feldspar.. The accessories minerals are apatite, rounded and elliptical zircon, and rutile. The principal mineral assemblages in the biotitic and 
amphibolitic gneiss are plagioclase, quartz, biotite, amphibole, epidote and orthopyroxene relicts. The accessories minerals are apatite, elliptical zircon, allanite and titanite.

New U-Pb geochronological investigations on rounded and elliptical (Potato-type) zircon populations extracted from mafic and felsic orthogranulites yielded ages between 2.1 and $2.0 \mathrm{Ga}$, interpreted as representative of high grade metamorphism period in the Gneissgranulite Terrain. In the mafic granulite, elliptical and rounded zircons yielded an upper intercept age of $2062 \pm 65 \mathrm{Ma}$ with a zircon concordant age of $2059 \pm 6.6 \mathrm{Ma}$, when in the felsic granulites, rounded zircons yielded upper intercept age of $2.060 \pm 19 \mathrm{Ma}$ and the elliptical zircons yielded an upper intercept age of $2115 \pm 31 \mathrm{Ma}$. The age around $2060 \mathrm{Ma}$ of rounded metamorphic zircons in both mafic and felsic orthogranulites (or concordant rounded zircon age of $2059 \pm 6.6 \mathrm{Ma}$ ) is interpreted as the age of high grade metamorphism peak. In the north-eastern portion of this terrain, biotite and amphibole- rich charnockites nuclei within biotitic and amphibolitic gneiss were dated. Elliptical and acicular zircons extracted from this rock indicated similar ages that yielded an upper intercept age of $2200 \pm 7.3 / 9.9$. This age probably represents and indicates a previous high grade metamorphism.

The time gap between $\mathrm{K}-\mathrm{Ar}$ amphibole and biotite ages and $\mathrm{Sm}-\mathrm{Nd}$ isochronic ages (whole rock, plagioclase and garnet) around $1.8 \mathrm{Ga}$, and the U-Pb rounded metamorphic zircon ages (2060 Ma) obtained on mafic and felsic orthogranulites suggests a slow cooling path after the high grade metamorphism peak, in the Gneiss -granulite Terrain.

$\mathrm{Sm}-\mathrm{Nd}$ isotopic data indicate Neoarchean-paleoproterozoic depleted mantle Ages between 2.7 and $2.5 \mathrm{Ga}$ and suggesting the principal period of the mantle differentiation of the gneiss and granulite protholites.

This terrain remained tectonically stable and cold until Neoproterozoic period, between 630 and $585 \mathrm{Ma}$, when its northern portion was heated and involved by Neoproterozoic subduction, collision and post-collision tectonic-magmatic activities. The central and northern border of the whole Gneiss-granulite Terrain are characterised by Neoproterozoic (600-585 Ma) vertical accretion of late- to post-collision and anorogenic volcanic and plutonic Serra do Mar Suite. The Palermo, Rio Negro and Agudos do Sul granites, and the Campo Alegre volcanic rocks, which outcrop in the investigated area, are components of this suite.

These reworked Neoproterozoic thermal and tectonic events in the Gneiss-granulite Terrain are suggested by low to medium retrometamorphic mineral assemblages with pyroxene replacement by amphiboles and formation of metamorphic epidote in the mafic and felsic orthogranulites, biotite recrystallization in the biotitic and amphibolitic gneiss. Also, the tectonic foliations in these rocks are parallel and oblique to those present in the Piên Mafic- 
ultramafic Suite and Piên-Mandirituba Granite Belt. K-Ar biotite and amphibole ages between 650 (amphibole) to $620 \mathrm{Ma}$ (biotite) also suggest thermal reworking of the granulite and gneiss types, near Piên-Tijucas shear zone.

Neoproterozoic Late to post-collisional extensional settings with underplating and intraplating of mantle derived mafic melts caused heating of the lower crust (central and northern settings of the Gneiss-granulite Terrain) and production of many high temperaturelow pressure felsic A-PA melts. These felsic melts are mixed or not with the intraplated and contaminated mafic meits. The appropriate setting for this tectonic-thermal scenery in the plutonic and vulcanic Serra do Mar Suite could be around this pre-sutured and probable delaminated region. 


\section{1 - Referências Bibliográficas}

Anderson, J.L \& Bender, E.E. (1989) Nature and origin of Proterozoic A-type granitic magmatism in the south-western United States of America. Lithos, 23:19-52.

Anderson, J.L (1983) Proterozoic anorogenic granite Plutonism of North America. Geological Society of America Mem., 161:133-154.

Barbarin, B. (1999) A review of the relationships between granitoid types, their origins and their geodynamic environments. Lithos, 46:605-626.

Basei, .M.A.S., Citroni, S.B. Siga Jr. O. (1998a) Stratigraphy and age of Fini-Proterozoic basins of Paraná and Santa Catarina States, Southern Brazil. Boletim. IG-USP, Série Científica, No. 29.

Basei, .M.A.S., Siga Jr. O., Masquelin, H., Harara, O.M., Reis Neto, J.M., Preciozzi, F. (2000) The Dom Feliciano Belt of Brazil and Uruguay and its Foreland domain, the Rio de La Plata Craton: Framework, tectonic evolution and correlation with similar provinces of southwestern Africa. In : Cordani, U.G., Milani, E.J., Campos, D.A. (Eds.) Tectonic Evolution of South America. Pag.311-334. Rio de Janeiro.

Basei, M.A.S. \& Teixeira, W. (1987) Geocronologia dos terrenos Pré-cambrianos a Eopaleozóicos de Santa Catarina. In: Silva, L.A. \& Bertoluzzi, C.A. (eds.). Texto explicativo para o mapa geológico do estado de Santa Catarina - 1:500.000. Florianópolis, DNPM/CPRM.

Basei, M.A.S. (1985) O Cinturão Dom Feliciano em Santa Catarina. São Paulo, 190p. (Tese de Doutorado apresentada ao Instituto de Geociéncias da Universidade de São Paulo)

Basei, M.A.S. (2000) Geologia e modelagem geotectônica dos terrenos pré-cambrianos das regiões Sul-Oriental Brasileira e Uruguaia: possiveis correlações com províncias similares do sudoeste africano. Tese de Livre-Docencia apresentada ao instituto de Geociências da Universidade de São Paulo.124 Páginas.

Basei, M.A.S.; Macreath, I. \& Siga JR., O. (1998 b) The Santa Catarina granulite Complex of southern Brazil: a review. Gondwana Research, 1(3/4): 383-391.

Basei, M.A.S.; Siga Jr., O. \& Reis Neto, J.M. (1990) O Batolito Paranaguá. Proposição, idade, considerações petrogenéticas e implicações tectônicas. In: CONGRESSO BRASILEIRO DE GEOLOGIA, 36, Natal. Anais. Natal, SBG, v.4, p.1684-1699.

Basei, M.A.S.; Siga Jr., O.; Machiavelli, A. \& Mancini, F. (1992) Evolução tectônica dos terrenos entre os Cinturões Ribeira e Dom Feliciano (PR - SC). Revista Brasileira de Geociências, 22(2):216-221.

Basei, M.A.S.; Siga Jr., O.; Reis Neto, J.M., Harara, O. M., Passarelli. R.C \& Machiavelli, A. (1997) Geochronological Map of the Pre-Camprian Terrains of Parana and Santa Catarina States, Southern Brazil. In: South American Symposium on Isotope Geology, Campos do Jordão. Extended Abstracts, Pag. 44-46

Basei, M.A.S.; Siga Jr., O.; Sato. K., Sproesser, W.M. (1995) A Metodologia Urânio-Chumbo na Universidade de São Paulo. Princípios metodológicos, aplicações e resultados obtidos. Anais. Acad. Bras. Ciên., 67 (2):221-237.

Basei.A.S.; Siga Jr., O.; Reis Neto, J.M.,Passarelli, C.R, Prazeres, H.J., Kaulfuss, G., Sato, K. \& Lima, P.S. De. (1999) Paleoproterozoic granulitic Belts of the Brazilian Soutern Region (PR-SC). In: II South American Symposium on Isotope Geology, Actas, p..291294., Cordoba, Argentine. 
Beard, J.S. \& Lofgren, G.E. (1991) Dehydration melting and water -saturated melting of basaltic and andesitic greenstones and amphibolites at 1,3 and $6.9 \mathrm{~Kb}$. Journal of Petrology, 32:365-401.

Bell,T.H. (1979) The deformation and recrystallization of biotite in the Woodroffe Thrust mylonite zone. Tectonophysics, 58:139-158.

Biondi, J.C.; Cava, L.T.; Soares, P.C. (1989) Mapa Geológico do Estado do Paraná (Escala 1:650.000). Curitiba, DNPM/MINEROPAR.

Bodinier, J.L, Vasseur, G., Verniers, J., Dupuy,C. \&Fabries, J. (1990) Mechanism of mantle metasomatism: Geochemical evidence from Lherz orogenic peridotite. Journal of Petrology, 31:597-628.

Bodinier, J.L. (1988a) Geochemistry and petrogenesis of the Lanzo peridotite body, Western Alpes. Tectonophysics, 149:67-88.

Bodinier, J.L., Dupuy,C., Dostal, J. \& Merlet (1988b) Behaviour of trace elements during upper mantle metasomatism: evidence from Lherz Massif. Chem. Geol.70:152.

Bodinier, J.L.; Dupuy, C., Dostal, J. (1988c) Geochemistry and petrogenesis of eastern Pyrenean peridotites. Geochimica and Cosmochimica. Acta, 52: 2893-2907.

Bohlen, S.R. \& Mezeger, K. (1989) Origin of granulite terranes and the formation of the lowermost continental crust. Science, 244:326-329.

Bohlen, S.R. (1991) On the origin of granulites. J. Metamorphic Geology, 9:223-229.

Brandon, A.D, Creaser, R.A., Thomas, C. (1996) Constraints on rates of granitic magma transport from epidote dissolution kinetics. Science, 271:1845-1848.

Brito Neves, B.B. \& Cordani, U.G. (1991) Tectonic evolution of South America during the Late Proterozoic. Precambrian Research, 53(1/2):23-40.

Campos Neto, M.C. \& Figueiredo, M.C.H. (1995). The Rio Doce Orogeny, southeastern Brazil. Joumal of South American Earth Sciences, 8(2): 143-162.

Caruso, L.J \& Chernosky, J.V.Jr. (1979) The stability of lizardite. Can. Mineral.:757-769.

Castro, N.A.; P. Jr., V. \& Reis Neto, J.M. (1994) Formação Guaratubinha: a importância das rochas vulcanoclásticas. In: CONGRESSO BRASILEIRO DE GEOLOGIA, 38, Camboriú. Boletim de Resumos Expandidos. Camboriú, SBG, v.3, p.72-73.

Chappel, B.W. \& White, A.J.R. (1974) Two contrasting granite types. Pacific Geology, 8, Pag.173-174.

Chappel, B.W. \& White, A.J.R. (1982) I and Stype granites in the Lachlan Fold Belt, southeastern Australia. Philosophical transactions of the Royal Society of London. V.A310, p.693-707.

Chappel, B.W. \& White, A.J.R. (1992) I and S-type granites in the Lachlan Fold Belt. Transaction. Roy. Soc. Edinburgh, Earth Science, .83:1-26.

Cherniak, D.J., (1993) Lead diffusion in titanite and preliminary results on the effects of radiation damage on $\mathrm{Pb}$ transport. Chemical Geology, 110:17194.

Citroni, S.B. (1998). Bacia de Campo Alegre -SC. Aspectos petrológicos, estratigráficos e caracterização geotectônica. Tese de Doutoramento, IGC-USP, São Paulo. (Inédito) $185 p$.

Citroni, S.B., Basei, M.A.S.,Kei. S. \& Siga Jr. O. (1999) Petrogenesis of the Campo Alegre Basin magmatism, based on geochemical and isotopic data. In: II SOUTH AMERICAN SYMPOSIUM ON ISOTOPE GEOLOGY, Actas, Pag.., Córdoba, Argentine. 
Clemens, J.D; Holloway, J.R, \& White, A. (1986). origin of an A-type granite: Experimental Constraints. American Mineralogist, 71:317-324.

Coleman, R.G. \& Irwin, W.P. (1974) Ophiolites and ancient continental margins. In: BURK, C.A. \& DRAKE, C.L. The Geology of continental margins, Springer-Verlag, New York, p. 921-931.

Coleman, R.G. (1977a) Ophiolites, Oceanic litosphere. Berlin, Springer-Verlag., 229p.

Coleman, R.G. (1977b) Plate tectonic emplacement of upper mantle peridotite along continental edges. Journal Geophysical Resarch, 76 (5): 1212-1222.

Collins, W.Y; Beams, S.D; White, A. \& Chappel, B.W. (1982) Nature and origin of A-type granites with particular reference to southeastern Australia. Contribution to Mineralogy and Petrology, 80:189-200.

Cordani, U. \& Brito Neves, B.B. (1982) The geological evolution of South America during the Archean and Early Proterozoic. Rev.Bras. Geoc. 12(1/3):78-88.

Cordani, U.G. (1974) Comentários sobre as determinações geocronológicas disponiveis nas Folhas Assunción e Curitiba. In: Monaco, O.A.; Zir Filho, J.A.; Valentine, N. (Eds.). Carta Geologica do Brasil ao Milionésimo, Folha Assunción- SG.21 e Cunitiba- SG.22. Brasília, DNPM, p.58-67.

Cordani, U.G., Kaul, P.A.T. \& Siga Jr., O. (2000) Geochronology of the Neoproterozoic granitoid Complexes of the Serra do Mar, Southern Brazil. In : INTERNATIONAL GEOLOGICAL CONGRESS, 31, Rio de Janeiro, . CD ROM volume.

Creaser, R, A.; Price, R.C \& Wornalad, R.J. (1991). A type granites revisited: assessment of a residual-source model. Geology, 19:163-166.

Dall"Agnol R., Ramo, O.T., Magalhães, M.S., Macambira, M.J.B. (1990) Petrology of the anorogenic, oxidised Jamon and Musa Granites. Amazonian Craton: implications for the genesis of Proterozoic A-type Granites. Lithos, 46:431-162.

Dall"Agnol R.,Lafon, J.M., Macambira, M.J.B. (1994) Proterozoic anorogenic magmatism in the Central Amazon Province, Amazonian Craton: Geochronological, petrological and geochemical aspects. Mineralogy and Petrology, 50:113-138.

Debon, A. \& Le Fort, P. (1983) A chemical-mineralogical classification of common plutonic rocks and associations. Transaction of the Royal Society of Edinburgh Earth Sciences, 73: 135-149.

Debon, A. \& Le Fort, P., Sheppard, S.M.F \& Sonet, J. (1986) The Four plutonic belts of the TransHimalaya-Himalaya: a chemical, mineralogical, isotopic and chronological synthesis along a Tibet-Nepal section, Journal of Petrology, 27:219-250.

Dewey, J.F. \& Bird, J.M. (1971) Origin and emplacement of the ophiolite suite: Appalachian ophiolites in Newfoundland. Joumal of Geophysical Research, 76 (14): 3179-3206.

Dewey, J.F. (1974) Continental Margins and Ophiolite Obduction: Appalachian Caledonian System. In: BURK, C.A. E DRAKE, C.L. The geology of continental margins, New York, Springer-Verlag, p. 933-950.

Dewey, J.F. (1988) Extensional collapse of orogens. Tectonics., 7:1123-1139.

Dick, H.J.B. (1989) Abyssal peridotites, very slow spreading ridges and ocean ridge magmatism. In: A.D. Saunders \& M.J. Norry (Editors), Magmatism in the Ocean Basins. Geol. Soc. Spec.Publ., 42: 71-105.

Didier, J. \& Barbarin, B. (1991) The different types of enclaves in granites. Nomenclature. Enclaves and granite petrology. In: Didier, J. \& Barbarin, B. (eds.), Development in Petrology. Vol. 3, Elsevier, Amsterdam, Pag.19-23. 
Eby, G.N (1990) The A-type granitoids: a review of their occurrence and chemical characteristics and speculations on their petrogenesis. Lithos, 26:115-134.

Eby, G.N (1992) Chemical subdivision of the A-type granitoids: Petrogenetic and tectonic implications. Geology, 20:641-644.

Eiler, J.M., Farley, K.A.,Valley , J.W., Hauri, E., Craig,H., Hart, S.R. \& Stolper, E.M. (1997) Oxygen isotope variations in ocean island basalt phenocrysts. Geochim. Cosmochim. Acta, 61:22.81-2293.

Ellis, D.J. (1987) Origin and evolution of granulites in normal and thickened crust. Geology, 15:167-170.

Elthon, D. (1991) Geochemical evidence for formation of the Bay of Island Ophiolite above a subduction zone, Nature 354:140-143.

Etheridge, M.A \& Hobbs, B.E (1974) Chemical and deformation controls on recrystallization of mica. Contr. Miner. Petrol., 43: 11-124.

Etheridge, M.A; Hobbs, B.E \& Patterson, M.S. (1973). Experimental deformation of single crystals of biotite. Contr. Miner. Petrol., 38: 21-36.

Evans, B.W. (1977) Metamorphism of alpine peridotite and serpentinite. Annual Review of Earth and Planetary Sciences, 5: 397-447.

Figueiredo, M.C.H.; Basei, M.A.S.; Mantovani, M.S.M. \& Fryer, B.J. (1991) O Complexo Granulítico de Santa Catarina: um arco insular arqueano? Boletim IG-USP, Publicação Especial, 9:35-40.

Fornari, A. (1998). Geologia e Metalogênese da porção meridional do Cráton Luis Alves-SC. Campinas, $136 \mathrm{p}$. (Tese de Doutoramento apresentada ao Instituto de Geociências da Universidade de Campinas).

Fragoso Cesar, A.R.S. (1980) O Cráton do Rio de La Plata e o Cinturão Dom Feliciano no Escudo Uruguaio-Sul Riograndense. In: CONGRESSO BRASILEIRO DE GEOLOGIA, 31, Camboriú. Anais. Camboriú, SBG, v. 5, p.2879-2892.

Frey, F. A (1984) Rare earth element abundances in upper mantle rocks. In : Henderson, P. (ed.). Rare Earth Element Geochemistry. Amsterdam, p. 153-196.

Frey, F.A., Suen, C.J \& Stockman, H.W (1985). The Ronda high temperature peridotite: Geochemistry and Petrogenesis. Geochim. Cosmochim. Acta, 49; 2469-2491.

Fuck, R.A. (1967) Geologia da Folha de São José dos Pinhais. Curitiba, Comissão da Carta Geológica do Paraná, 46p. (Relatório inédito).

Fuck, R.A. (1991) Aprovada nova escala de tempo para o Pré-Cambriano. Revista Brasileira de Geociências, 21(2):182-183.

Fuck. R.A.; Marini, O.J. \& Trein, E (1967) A Formação Guaratubinha. Boletim Paranaense de Geociências, 23/25:237-256.

Furnes, H; Pedersen, R.B.; Hertogen, J.; \& Albrektsen, B.A. (1992) Magma development of the Leka ophiolite complex, central Norwegian Caledonides. Lithos, 27:259-277.

Girardi, V.A.V. \& Ulbrich, H.H.G.J. (1980) Origin and evolution of the Piên Mafic-Ultramafic Complex, southern Brazil. Journal of Geology, 88(3):251-269.

Girardi, V.A.V. (1974) Petrologia do Complexo Básico-Ultrabásico de Piên - PR. São Paulo, 146p. (Tese de Livre Docência apresentada ao Instituto पe Geociências da Universidade de São Paulo).

Girardi, V.A.V. (1976) Geologia e petrologia do Complexo Básico-Ultrabásico de Piên, Paraná. Revista Brasileira de Geociências, 6(2):109-124. 
Girardi, V.A.V.; Cordani, U.G.; Candida, A; Melfi, A.J. \& Kawashita, K. (1974) Geocronologia do Complexo Básico-Ultrabásico pré-Brasiliano de Piên, PR. In: CONGRESSO BRASILEIRO DE GEOLOGIA, 28, Porto Alegre. Resumo das Comunicaçōes. Porto Alegre, SBG, p.532-533.

Gois, J.R. (1995) Contribuição a petrografia e geoquímica da parte setentrional do Complexo vulcânico-plutônico Morro Redondo, divisa dos estados do Paraná com Santa Catarina. São Paulo, $86 \mathrm{p}$ (Dissertação de Mestrado apresentada ao Instituto de Geociencias da Universidade de São Paulo)

Haapala, I. \& Ramo. O.T. (1992) Tectonic setting and the origin of the Proterozoic rapakivi granites of southeastern Fennoscandia. Transactions. Royal.Soc. Edinburgh: earth Sciences, 83:165-171.

Haapala, I. \& Ramo. O.T. (1999) Rapakivi granites and related rocks: an introduction. Precambrian Research, 95:1-7

Hamphries, F.J. \& Cliff, R. A.(1982) Sm-Nd dating and cooling history of Scourian granulites. Sutherland, NW Scotland. Nature, 295:515-517.

Harara, M.O (1996) Análise estrutural, petrológica e geocronológica dos litotipos da região de Piên (PR) e adjacencias. São Paulo, 196p (Dissertação de Mestrado apresentada ao Instituto de Geociências da Universidade de São Paulo).

Harara, M.O.; Basei, M.A.S. \& Siga Jr., O. (1994) Contribuição ao estudo geológico da região de Piên - PR. In: CONGRESSO BRASILEIRO DE GEOLOGIA, 38, Camboriú. Boletim de Resumos Expandidos. Camboriú (SC), SBG, v.1, p.64-65.

Harara, M.O.; Basei, M.A.S. \& Siga Jr., O. (1995) Perfil Geológico-Geocronológico entre Piên (PR) e São Bento do Sul (SC): Indicação de reativação termo-tectônica Neoproterozóica do Complexo Granulitico de Santa Catarina. In: SIMPÓSIO NACIONAL DE ESTUDOS TECTÓNICOS, 5, Gramado. Boletim de Resumos Expandidos.Gramado, SBG, p. 382-383.

Harara, M.O.; Basei, M.A.S. \& Siga Jr., O. (1997 a) Geochemistry, Geochronology and Tectonic Setting of the Granitic Magmatism occurring at Piên region, South Brazil. In: SECOND INTERNATIONAL SYMPOSIUM ON GRANITES AND ASSOCIATED MINERALIZATIONS (ISGAM), Salvador-Brazil Extended Abstracts. Pag. 204-205

Harara, M.O.; Basei, M.A.S. \& Siga Jr., O. (1997 b) Geochonological and Geochemical Data on the Transition Zone between Luis Alves and Atuba Complexes, South Brazil. In: I SOUTH AMERICAN SYMPOSIUM ON ISOTOPE GEOLOGY, Campos do Jordão. Extended Abstracts, Pag. 134-136.

Harley, S.L. (1989) The origins of granulites: a metamorphic perspective. Geological Magazine, 126:215-247.

Harley, S.L. (1992) Proterozoic granulite terrains. In: Condei, K.C. ed. Proterozoic crustal evolution. Amsterdam. Elsevier. p. 301-359.

Harmon, R.S., Hoefs, J. (1995) Oxygen isotope heterogeneity of the mantle deduced from global ${ }^{18} \mathrm{O}$ systematics of basalts from different geotectonic settings. Contrib. Mineral. Petrol., 120:95-114.

Harris, N.B.W., Ronghua, Xu., Lewis, C.L., Chengwei, Jin. (1988a) Isotope geochemistry of the 1985 Tibet Geotraverse, Lhasa to Golmud. Philosofical Transactions of the Royal Society of London. A 327:263-285.

Harris, N.B.W., Ronghua, Xu., Lewis, C.L., Chengwei, Jin. (1988b). Plutonic rocks of the 1985 Tibet geotraverse, Lhasa to Golmud. Philosofical Transactions of the Royal Society of London. A 327:145-168. 
Harris, N.B.W.; Pearce, J.A. \& Tindle, A.G. (1986) Geochemical characteristics of collisionzone magmatism. In: Coward, M.P. \& Ries, A.C. (Eds). Collision Tectonics. London, Geological Society Special Publication, 18:67-81.

Harrison, T.M. (1981) Diffusion of $\mathrm{Ar}^{40}$ in hornblende Contrib. Mineral. Petrol. 78:324-331.

Harrison , T.M. Duncan, I., Mcdougall I (1985) Diffusion of $\mathrm{Ar}^{40}$ in biotite: temperature, pressure and compositional effects. Geochim. Cosmochim. Acta. 49: 2461-2468.

Harrison T.M. \& Fitz Gerald. J.D. (1986) exsolution in hornblende and its consequence for $\mathrm{Ar}^{40} / \mathrm{Ar}^{39}$ age spectra and closure temperature. Geochim. Cosmochim. Acta. 50:247-253.

Hartmann, L.A. (1988) Geoquímica de terras raras e geotermobarometria de granulitos de Dom Pedrito e Luis Alves no extremo sul do Brazil. Geochimica Brasiliensis, 2(1): 1-14.

Hartmann, L.A., Basei. M.A.S.\& Simas. M.W. (1998) Geochemistry of the Lower Proterozoic Granulite-Faceis Grant Syenite Gneiss, Barra Velha, Santa Catarina State, Southern Brazil. Pesquisas, 25 (2), p.3-9. Instituto de Geociencias, UFRGS.

Hartmann, L.A.; Silva, L.C. \& Orlandi Filho, V. (1979) O Complexo Granulítico de Santa Catarina. Descrição e implicações genéticas. Acta Geológica Leopoldensia, 3(6):93-112.

Hasui, Y.; Carneiro, C.D.R. \& Coimbra, A.M. (1975) The Ribeira Folded Belt. Revista Brasileira de Geociéncias, 5(4):257-266.

Helmstaedt, H.H. \& Scott, D.J. (1992) The Proterozoic ophiolite problem. Proterozoic crustal evolution. Condie K.C.(Eds). p. 55-92.

Hibbard, M.J. (1981) The magma mixing origin of mantled feldspars. Contrib. Mineral. Petrol., 76:158-170.

Hibbard, M.J. (1991) textural anatomy of twelve magma-mixed granitoid systems. Enclaves and granite petrology. In: DIDIER, J. \& BARBARIN, B. (eds.), development in petrology.
Vol. 3, Elsevier, Amsterdam, p.431-444.

Hildreth, W. \& Moorbath, S. (1988) Crustal contributions to arc magmatism in the Andes of central Chile. Contributions to Mineralogy and Petrology , 98: 455 489. Hogan, J.P., Gilbert, M.C. \& Weaver, B.L. (1992) A-type granites and rhyolites: is A for
ambiguous?. Eos, 73, p. 508 Hubbard, F.H. (1989) The geochemistry of Proterozoic lower crustal depletion in southwest
Sweden. Lithos., 23:101-113.

Inger, S. \& Harris, N.B.W. (1993) Geochemical constraints on leucogranite magmatism in the Langtang Valley, Nepal Himalaya. Journal of Petrologyogy. 34:345-368.

Inger, S. (1994) Magmagenesis associated with extension in orogenic belts. examples from the Himalaya and Tibet. Tectonophysics, 238:183-197.

Irvine, T.N. \& Baragar, W.R.A. (1971) A guide to the chemical classification of the common volcanic rocks. Canadin J. Earth Sciences, 8: 523-548.

lyer, S.S.,Choudhuri, A . Cordani, U. (1987) Granulite facies rocks of Brazil: a review of their geologic setting, geochonological evolution. Petrographic and geochemical characteristics. Journal Geological Society of India. 29:309-326. Jacobsen, S.B. \& Wasserburg, G.J. (1980) Sm-Nd isotopic evolution of chondrites.
Earth.Planet.Sci. Lett. 50:139-155. Jacobsen, S.B. \& Wasserburg, G.J. (1984) Sm-Nd isotope evolution of chondrites and
achondrites, II. Earth.Planet.Sci.Lett. $67: 137-150$. 
Johnson, K.J.T.M \& Dick, H.J.B (1992) Open sustem melting and temporal and spatial variations of peridotites and basalts at the Atlantis II fracture zone. J. Geophys. Res.; 97 : 9219-9241.

Jost, H. \& Hartmann, L. A. (1984). Província Mantiqueira, Setor Meridional. In: O PréCambriano do Brasil. F.F.M. de Almeida \& Y. Hasui Coord. Editora Edgard Blücher Ltda., São Paulo, 378p.

Jung, S., Mezger, K. \& Hoernes, S. (1998) Petrology and geochemistry of syn- to postcollisional metaluminous A-type granites - a major and trace element and $\mathrm{Nd}-\mathrm{Sr}-\mathrm{Pb}-\mathrm{O}$ isotope study from the Proterozoic Damara Belt, Namibia. Lithos, 45:147-175.

Kaul, P.F.T. \& Cordani, U.G. (1994) Aspectos petrográficos, geoquímicos e geocronológicos dos maciços graníticos da Serra do Mar no leste do Paraná e vizinhanças. In: CONGRESSO BRASILEIRO DE GEOLOGIA, 38, Camboriú. Boletim de Resumos Expandidos. Camboriú, SBG, v.2, p.371-372.

Kaul, P.F.T. \& Teixeira, W. (1982) Archean and early Proterozoic complexes of Santa Catarina, Paraná and São Paulo States, south-southeastern, Brazil: an outline of their geological evolution. Revista Brasileira de Geociências, 12(1/3): 172-182.

Kaul, P.F.T. (1980) O Cráton de Luiz Alves. In: Congresso Brasileiro de Geologia, 31, Camboriú. Anais. Camboriú, SBG, v.5, p.2677-2683.

Kaul, P.F.T. (1984) Significado dos granitos anorogênicos da Suite Intrusiva Serra do Mar na evolução da crosta do sul-sudeste do Brasil, no âmbito das Folhas SG-22 - Curitiba e SG-23 - Iguape. In: Congresso Brasileiro de Geologia, 33, Rio de Janeiro. Anais. Rio de Janeiro, SBG, v.6, p.2815-2825.

Kaul, P.F.T. (1987) The granites and granitoids of the alkaline sllica-oversatured magmatic province of Southern Brazil. In: INTERNATIONAL SIMPOSIUM GRANITE AND ASSOCIATED MINERALIZATIONS, Salvador. Extended abstracts, Salvador, p. 81-88.

Kaul, P.F.T. (1997) O Magmatiso na Serra do Mar e adjacências (Sul do Brasil) no final do Neoproterozóico e seus condicionantes Tectônicos. São Paulo, 293 p. (Tese de Doutoramento apresentada ao Instituto de Geociéncias-USP).

Kawashita, K.; Sato, K.; Dias, M. \& Tassinari, C.C.G. (1991) Metodologia Sm/Nd no IG-USP: testes e resultados preliminares. In: CONGRESSO BRASILEIRO DE GEOQUIMCA, 3, São Paulo. Boletim de Resumos. São Paulo, SBGq/Sociedade Geológica de Portugal, v.2, p.442-446.

Keppler, H. \& Wyllie, P.J. (1990) Role of fluids in transport and fractionation of uranium and thorium in magmatic processes. Nature, 348:531-533.

King, E.M., Valley, J.W., Davis, D.W., Edwards, G.R. (1998) Oxygen isotope rations of Archean plutonic zircons from granite-greenstone belts of the Superior Province: indicator of magmatic source. Precambrian Research, 92:365-387.

King, P.L; White, A.J.R, Chappel, B.W \& Allen, C.M. (1995) Characterisation and origin of aluminous A-type granites from Lachlan Fold Belt, Southeastern Australia. Journal of Petrologyogy, 38:371-391.

Lamb, R.C., Smalley, P.C. \& Field, D. (1986) P-T conditions for the Arendal granulites, southern Norway: implications for the roles of $P, T$ and $\mathrm{CO}_{2}$ in deep crustal LILEdepletion. J. Metamorph. Geol., 4:143-160.

Le Fort, P, (1988) Granites in the tectonic evolution of the Himalaya, Karakoram and southern Tibet. Philosofical Transactions of the Royal Society of London, A326:281-299.

Le Maitre, R.W. (1989) A classification of igneous rocks and glossary of terms. Oxford. Blackwell, $193 \mathrm{p}$. 
Lee, K.W.J., Williams, I.S. \& Ellis, D.J. (1997) Pb, $U$ and Th diffusion in natural zircon. Nature, 390:159-161.

Lendenberger, B. \& Collins, W.J. (1996) derivation of A-type granites from a dehydrated charnockitic lower crust: evidence from Chaelundi Complex, eastern Australia. Journal of Petrology, 37:145-170.

Loiselle, M.C \& Wones, D.R. (1979) Characteristics and origin of anorogenic granites. Geological Society of America, Abstracts with programs, 92:468.

Lopes, O.F. (1987a) Zoneamento metamórfico da Formação Rio das Cobras do préCambriano do Estado do Paraná. In: SIMPÓSIO SUL-BRASILEIRO DE GEOLOGIA, 3, Curitiba. Atas. Curitiba, SBG, v.1, p.303-312.

Lopes, O.F. (1987b) O granito sin-tectônico Cubatãozinho: petrogênese e evolução geológica. In: SIMPOSIO SUL-BRASILEIRO DE GEOLOGIA, 3, Curitiba. Atas. Curitiba, SBG, v.2, p.481-490.

Loubet, M., Shimizou, N., \& Allégre, C. (1975) Rare earth elements in alpine peridotites. Contrib. Mineral. Petrol., 53:1-12.

Ludwig, K.R. (1994) ISOPLOT. a plotting and regression program for radiogenic isotope data. Ver.2.71. Ver. U.S. Geol. Sur. Open-File Report.82-820.

Machiavelli, A. (1991) Os granitóides deformados da Região de Pien (PR): Um provável Arco Magmático do Proterozóico Superior. São Paulo, 89p. (Dissertação de Mestrado apresentada ao Instituto de Geociências da Universidade de São Paulo).

Machiavelli, A.; Basei, M.A.S. \& Siga Jr., O. (1993) Suíte Granítica Rio Pien: um arco magmático do Proterozóico Superior na Microplaca Curitiba. Geochimica Brasiliensis, $7(2): 113-129$.

Malpas, J. \& Stevens, R.K. (1977) The origin and emplacement of the Ophiolite suite with examples from Western Newfounland. Geotectonics, 11(6):.453-466

Maniar, P.D. \& Piccoli, P.M. (1989) Tectonic discrimination of granitoids. Geological Society of America Bulletin, 101: 635-643.

Mantovani, M.S.M.; Shukowsky, W.; Basei, M.A.S. \& Vasconcelos, A.C.B.C. (1989) Modelo gravimétrico das principais descontinuidades crustais nos terrenos pré-Cambrianos dos Estados do Paraná e Santa Catarina. Revista Brasileira de Geociências, 19(3):367-374.

Marini, O.J.; Trein. E.; Fuck, R.A. (1970) Folha geológica de Mandirituba (escala 1:70.000). Curitiba, Comissão da Carta Geológica do Paraná.

Martin, H (1993) The mechanisms of petrogenesis of the Archean continental crust.Comparison with modern processes. Lithos, 30:373-388.

Martin, $H(1994)$ The Archean grey gneisses and the genesis of continental crust. In: Condie, K.C. (Ed.) Archean crustal evolution: Development in Precambrian Geology. Elssvier Science, Amsterdam, p.205-259.

Martin, $H$ (1998) The adakitic magmas: modern analogues of Archean granitoids. Lithos, 46 : 411-429.

Mattey, D., Lowry, D., Macpherson, C. (1994) Oxygen isotope composition of mantle peridotites. Earth.Palnet.Sci, Lett., 128:231-241.

Mcdonough,W.F \& Frey, F (1989) Rare earth elements in upper mantle rocks. In: Lipin, B.R \& McKay,G.A (eds)Geochemistry and mineralogy of rare earth elements (Reviws in mineralogy 21) Mieral.Soc. Am. p.99-145.

Mcdonough,W.F (1990) constraints on the composition of the continental lithospheric mantle. Earth. Sci. Planett. Lett., 101:1-18. 
Menzies, M.A .(1992) The lower lithosphere as a major source for continental flood basalts: a re-appraisal. Geological Society Special Publication. No. 68:31-39.

Menzies, M.A., Long, A., Ingram, G., Tatnell, M. \& Janecky, D. (1993) MORB peridotite sea water interaction: experimental constraints on the behaviour of trace elements, $\mathrm{Sr}^{87} / \mathrm{Sr}^{86}$, $\mathrm{Nd}^{143} / \mathrm{Nd}^{144}$ rations. In: Prichard, H.M., Alabaster, T. Harris, N.B.W. \& Neary, C.R.(eds). Magmatic Processes and Plate Tectonics. Geol. Soc. London, Special Publication,76: 309-322.

Mercier, J.J.C. \& Nicolas, A. (1975) Textures and fabrics of upper mantle peridotites as illustrated by xenoliths from basalts. Journal of Petrology, 16: 454-487.

Mezger, K. (1990) Geochronology in granulites. In: D. Vielzeuf and Ph. Vidal (Editors) Granulites and crustal evolution, Kluwer, Dordrecht. p. 451-470.

Mezger, K., Essence, E.J. \& Halliday, A .N. (1992) Closure temperatures of the Sm-Nd system in metamorphic garnets. Earth. Sci. Planet. Letters.

Mezger, K., Rawnsley, C.M., Bohlen, S.R. \& Hanson, G.N. (1991) U-Pb garnet, sphene, monazite and rutile ages: implications for the duration of high-grade metamorphism and cooling histories, Adirondack Mountains, New York. Journal of Geology.99: 415-428.

Minioli, B. (1972) Aspectos Geológicos da região litorânea de Piçarras, Barra Velha, SC. São Paulo, 104p. (Tese de Doutorado apresentada ao Instituto de Geociências da Universidade de São Paulo).

Moench, R.H. (1986) Comment on "implications of magmatic epidote-bearing plutons on crustal evolution in the accreted terranes of North America" and "Magmatic epidote and its petrological significance". Geology, 14:.187-188.

Moody, J.B. (1976) Serpentinization: a review. Lithos, 9:125-138.

Moores (1986) The Proterozoic ophiolite problem, continental emergence, and the Venus connection. Science, 234: 65-68.

Nakamura, N. (1974) Determination of REE, Ba, Fe, Mg, Na and $\mathrm{K}$ in carbonaceus and ordinary chondrites. Geochim. Cosmochim. Acta, 38: 757-775.

Naney, M.T. (1983) Phase equilibria of rock-forming ferromagnesian silicates in granitic systems. American Journal of Science, 283:993-1033.

Nédélec, A, Stephens, W.E., Fallick, E. (1995) The Panafrican stratoid granites of Madaascar: Alkaline magmatism in a post-collisional extensional setting. Journal of Petrology 36:1367-1391.

Orberger, B; Lorand, J.P; Girardeau, J ; Mercier, J.C.C \& Pitragool, S. (1995) Petrogenesis pf ultramafic rocks and associated chromitites in the Nan Uttaradit ophiolite, Northern Thailand. Lithos, 35:153-182.

Parkinson, I.J \& Pearce, J.A. (1998) Peridotites from the Izu-Bonin-Mariana Forearc (ODP Leg 125): Evidence for mantle melting and melt-Mantle interaction in a supra-subduction zone setting. Journal of Petrology, 39:1577-1618.

Patiño Douce, A.E. (1997) Generation of meta-aluminous A-type granites by low-pressure melting of calc-alkaline granitoids. Geology, 25:743-746.

Peacock, M.A. (1931) Classification of igneous rocks series. Journal of Geology, 39: 54-67.

Peacock, S.M., Rushmer, T., Thompson, A.B. (1994) Partial melting of subducting oceanic crust. Earth. Sci. Planett. Lett., 121:227-244.

Pearce, J.A \& Norry M.J (1979) Petrogenesis implications of $\mathrm{Ti}, \mathrm{Zr}, \mathrm{Y}$ and $\mathrm{Nb}$ variations in volcanic rocks. Contrib. Mineral. Petrol. , 69: 33-47. 
Pearce, J.A. \& Parkison, I.J. (1993) Trace element models for mantle melting: application to volcanic arc petrogenesis. In: Prichard, H.M. Alabaster, T., Harris, N.B.W. \& Neary, C.R. (Eds) Magmatic processes and plate tectonics. Geological Society of London, Special Publication, 76:373-403.

Pearce, J.A. (1991) Ocean floor comes ashore. Nature, 354:110-111.

Pearce, J.A.; Harris, N.B.W. \& Tindle, A.G. (1984) Trace element discrimination diagrams for the tectonic interpretation of granitic rocks. Joumal of Petrology, 25(4):956-983.

Pearce, J.A; Lippard, S.J. \& Robertis, S. (1984) Characteristics and Tectonic Significance of Supra Subduction Zone Ophiolites. In: B.P. Kokelaar \& M.F. Howells (editors), Marginal Basin Geology. Geol.Soc.London.Spec.Publ., 16: 77-94.

Peltonen, P., Kontinen, A., Huhma, H. (1998) Petrogenesis of the mantle sequence of the Jormua Ophiolite (Finland): Melt migration in the Upper Mantle during Paleoproterozoic Continental break-up. Journal of Petrology., 39:297-329.

Penrose (1972) Penrose field conference on Ophiolites. Geotimes, 17:24-25.

Picanço, J. Tassinari, C.C.G., Cordani, U.G. \& Nutman, A.P. (1998) Idades U-Pb (SHRIMP), $\mathrm{Sm}-\mathrm{Nd}$ e Rb-Sr em rochas do Maciço de Itatins (SP): Evidências de evolução policiclica. Acad. Bras. Ciências., 70 (1):139-150.

Prichard, H.M. (1979) A Petrographic study of the process of serpentinization in ophiolites and ocean crust. Contrib. Mineral.Petrol. ,68:231-241.

Prinzhofer, A \& Allégre, A. (1985) Residual peridotitos and mechanisms of partial melting. Earth.Planet.Sci.Lett., 74:251-265.

Pupin, J.P. 1980. Zircon and granite petrology. Contrib. Mineral. Petrol. 73, 207-220.

Ramo. O.T. \& Haapala, I. (1995) One hundred years of rapakivi granite. Contributions to Mineralogy and Petrology 52:129-183.

Rampone, E., Hofmann, A.W.; Piccardo, G.B., Vannucci, R., Bottazzi, P.\& Ottolini, L. (1996) Trace element and isotope geochemistry of depleted peridotites from an N-MORB type ophiolite (Internal Liguride, N.Italy). Contrib. Mineral. Petrol., 123:61-76.

Rapp, R.P., Watson, E.B. (1995) Dehydration melting of metabasalt at 8-32 Kbar. Implications for continental growth and crust-mantle recycling. Journal of Petrology 36 : 891-931.

Rapp, R.P., Watson, E.B., Miller, C.F. (1991) Partial melting of amphibolite/eclogite and the origin of Archean trondjemites and tonalites. Precambrian Research, 51:1-25.

Ribas, S.M. (1993) O complexo máfico-ultramáfico de Tijucas do Sul, correlação com o Complexo de Piên, PR e considerações metalogenéticas. Campinas, 130p. (Dissertação de Mestrado apresentada ao Instituto de Geociências da Universidade de Campinas).

Rickwood, P.C. (1989) Boundary lines within petrologic diagrams which use oxides of major and menor elements . Lithos, 22:247-263.

Rogers, J.J.W. \& Greenberg, J.K. (1990) Late-orogenic, Post-orogenic and anorogenic granites: distinction by major-element and trace-element chemistry and possible origins. Journal of Geology, 98:291-309.

Rudnick, R.L., Presper, I. (1990) Geochemistry of intermediate to high pressure granulites. In. D. Vielzeuf and Ph. Vidal (Editors) Granulites and crustal evolution, Kluwer, Dordrecht. p. 523-550.

Rushmer, T. (1991) partial melting of two amphibolites: Contrasting experimental results under fluid-absent conditions. Contributions to Mineralogy and Petrology, 107:41-59. 
Sato, K; Tassinari, C.C.G.; Kawashita, K.; Petronilho, L. (1995). O método geocronológico $\mathrm{Sm}-\mathrm{Nd}$ no IGc/USP e suas aplicações. Acad. Bras. Cienc. 67(3):315-336.

Saunders, A.D., Storey, M.; Kent, R.W. \& Norry, M.J. (1992) Consequences of plume lithosphere interactions. Geological Society Special Publication. No. 68:41-60.

Schmidt, M.W. \& Thompson, A.B.(1996) Epidote in calc-alkaline magmas: An experimental study of stability, phase relationships, and the role of epidote in magmatic evolution. American Mineralogist, 81:462-474.

Sial, A. N., Toselli, A. J, Saavedra, J., Parada, M. A \& Ferreira V.P.' (1999) Emplacement, petrological and magnetic susceptility characteristics of diverse magamtic epidotebearing granitoid rocks in Brazil, Argentina and Chile. Lithos, 46:367-392.

Sibson, R.H. (1977) Fault rocks and fault mechanisms. J. Geol. Soc. London, 133 (1): 191213.

Siga Jr. (1995) Dominios tectônicos do sudeste do Paraná e nordeste de Santa Catarina: Geocronologia e evolução Crustal. São Paulo, 212 p. (Tese de Doutorado apresentada ao Instituto de Geociências-USP).

Siga Jr., O.; Basei, M.A.S. \& Kawashita, K. (1990) Perfil Térmico K-Ar através do Maciço de Joinville (PR e SC) e do Cinturão Dom Feliciano (SC). Implicações tectônicas. In: CONGRESSO BRASILEIRO DE GEOLOGIA, 36, Natal. Anais. Natal, SBG, v.6, p.27732785.

Siga Jr., O.; Basei, M.A.S. \& Machiavelli, A. (1991) Compartimentação geológicogeotectônica do Maciço de Joinville, PR e SC. Boletim IG-USP, Publicação Especial, 9:67-73.

Siga Jr., O.; Basei, M.A.S., Kei S., Citroni, S.B., Reis Neto, J.M. dos., Weber, W., De Lima, P.S., Sproesser, W.M. (1999) Post-orogenic magmatism and sedimentation in Neoproterozoic extensional regimes in the Brazilian Southern region. II South American Symposium on Isotope Geology, Actas, Pag.., Cordoba, Argentina.

Siga Jr., O.; Basei, M.A.S., Sato, K., Cordani, U.G., \& Citroni. (2000) U-Pb and Sm-Nd isotopic studies of Campo Alegre and Guaratubinha volcanosedimentary Basins, Southern Region. In: international geological congress, 31, Rio de Janeiro, RJ. CD ROM volume.

Siga Jr., O.; Basei, M.A.S.; Reis Neto, J.M. \& Buba, R.M. (1994) Maciços graníticos da porção sudeste do Paraná e nordeste de Santa Catarina: geocronologia e implicaçóes tectônicas. In: CONGRESSO BRASILEIRO DE GEOLOGIA, 38, Camboriú. Boletim de Resumos Expandidos. Camboriú, SBG, v.2, p.400-401.

Siga Jr., O.; Basei, M.A.S.; Reis Neto, J.M. Dos., Machiavelli, A. \& Harara, O.M. (1995) O Complexo Atuba: Um cinturão Paleoproterozóico intensamente retrabalhado no Neoproterozóico. Boletim IG-USP, Série Científica, 26:69-98.

Siga Jr., O.; Basei, M.A.S.; Reis Neto, J.M.Dos., Harara, O. M., Passarelli. R.C, Prazeres, H, Weber, W. \& Machiavelli, A. (1997) Ages and Tectonic setting of Alkaline-Peralkaline granitoids of Paraná and Santa Catarina States, Southern Brazil. In: South American Symposium on Isotope Geology, Campos do Jordão. Extended Abstracts, Pag.301-303.

Silva, L.C. (1984) Os terrenos metamórficos de médio a alto grau do Pré-Cambriano de Santa Catarina. In: CONGRESSO BRASILEIRO DE GEOLOGIA, 33, Rio de Janeiro. Anais. Rio de Janeiro, SBG, v.3, p.3069-3080.

Silva, L.C. (1987) Geologia do pré-Cambriano - Eopaleozóico de Santa Catarina. In: Silva, L.C. \& Bortoluzzi, C.A. Texto explicativo para o mapa geologico do Estado de SC. Florianópolis, DNPM/CPRM, p.12-90. 
Simpson, C. (1985). Deformation of granitic rocks across the brittle-ductile transition. Journal of. Structural. Geology.,7(5): 503-511.

Streckeisen, A. (1976) To each plutonic rock its proper name. Earth Science Reviews, 12:133.

Sun, S.S \& Mcdonough, W.F. (1989) Chemical and isotopic systematics of oceanic basalts: Implications for mantle composition and process. In: A.D. Saunders and M.J.Norry (editors), Magmatism in the Ocean Basins, Geol. Spec. Publ, 42. Black-Well, Oxford, p.313-345.

Sylvester, P.J. (1989) Post collisional alkaline granites. Journal of Geology, 97:261-280.

Sylvester, P.J. (1999) Post collisional strongly peraluminous granites. Lithos, 45:29-44.

Tarney, J. \& Jones, C.E. (1994) Trace element geochemistry of orogenic igneous rocks and crustal growth models.J. Geol. Soc. London, 151:855-868.

Tarney, J. \& Weaver, B.L, \& (1987) Geochemistry of the Scourian Complex: petrogenesis and tectonic models. In: Park, R.G. \& Tarney, J. (eds). Evolution of the Lewisian and Comparable Precambrian high grade Terrains. Geol. Soc. Spec. Publ. 27, p. 45-56.

Teixeira, W. (1982) Folhas Assunción, Curitiba e lguape. Considerações sobre os dados radiométricos e evolução geocronológica. Projeto RADAMBRASIL, DNPM/MME, 38p. (Relatório interno).

Trein, E.; Fuck, R.A. \& Muratori, A. (1969a) Folha geológica de Tijucas do Sul (escala 1:70.000). Curitiba, Comissão da Carta Geológica do Paraná.

Trein, E.; Muratori, A.; Basumallick, S.; Fuck, R.A.; Marini, O.J.; Dairiki, J. \& Dairiki, M. (1969b) Folha geológica de Piên (escala 1:70.000). Curitiba, Comissão da Carta Geológica do Paraná.

Tucker, R.D., Rahiem, A., Krogh, T.E and Corfu, F. (1987) Uranium-lead zircon and titanite ages from the northern portion of the Western Gneiss Region, south-Central Norway. Earth. Planet. Sci. Lett. 81:203-211.

Tullis, J.A. (1983) Deformation of Feldspar. In: RIBBE, P.H. (ed.). Feldspar Mineralogy. Miner. Soc. Am., 2: 297-323.

Tulloch, A.J. (1986) Comment on "implications of magmatic epidote-bearing plutons on crustal evolution in the accreted terranes of North America" and "Magmatic epidote and its petrological significance". Geology, 14:187-188

Turner, S.P., Fodes, J.D \& Morrison, R.S. (1992) Derivation of some A-type magmas by fractionation of basaltic magma: An exemple from the Padthway Ridge, South Australia. Lithos, 28:151-179.

Turner, S.P., Sandiford, M. \& Foden, J. (1992) Some geodynamic and composicional constraints on "postorogenic" magamtism. Geology, 20: 931-934.

Ulmer, P. \& Trommsdorff, V. (1995) Serpentine stability to mantle depths and subduction related magmatism. Science, 268:858-861.

Valley, J.W., Chiarenzelli, J.R., Mclelland, J.M. (1994) Oxygen isotope geochemistry of zircon. Earth Planet.Sci.Lett. 126:187-206.

Wernick, E. \& Oliveira, M.A.F. (1982) Composition of Archean Granulites from southern Brazil and its implication for the nature of the early crust. Rev.Bras.Geoc. 12(2): 403-409.

Wernick, E. \& Penalva, F. (1978) Contribuição ao conhecimento das rochas granitóides do sul do Brasil. Rev. Bras.Geoc., 8(2): 113-133.

Wernick, E. (1979) Arqueano no Brasil: Tentativa de uma sintese. An. Acad. Bras. de Ciências, 51 (2): 287-310. 
Wernick, E. (1982) Contribuição à caracterização das linhagens de granitóides brasilianos do sul do Brasil. In: CONGRESSO BRASILEIRO DE GEOLOGIA, 32, Salvador. Anais. Salvador, SBG, v.2, p.490-499.

Whalen, J.B; Currie, K.L \& Chappel, B.W. (1987) A-type granites: geochemical Characteristics discriminations and petrogenesis. Contribution to Mineralogy and Petrology, 95:407-419.

Whalen, J.B;Jenner, G.A, Longstaffe, F.J Robert, F., Gariépy, C. (1996) Geochemical and isotopic $(\mathrm{O}, \mathrm{Nd}, \mathrm{Pb}$ and $\mathrm{Sr})$ constraints on A-type granite petrogenesis based on the Topsails igneous suite, Newfoundland Appalachians. Journal of Petrologyogy, 37:14631489.

White, A.J.R. \& Chappel, B.W. (1983) Granitoids types and their distribution in the Lachlan Fold Belt, southeastern Australia. Geological Society of American Mineralogist., 159: 2134.

White, A.J.R. \& Chappel, B.W. (1988) Some supracrustal (S types) granites of the Lachlan Fold Belt. Trans. R. Soc. Edinburgh ,Earth Science, V.79: 169-181.

White, S.H. (1975) Tectonic deformation and recrystallization of plagioclase. Contr.Miner.Petrol., 50: 287-304.

Wicks, F.J \& Whittaker, E.J.W (1977) Serpentine textures and serpentinisation. Can. Mineral., 15:459-488.

Wilson, C.J.L. \& Bell, I.A. (1979) Deformation of biotite and muscovite: optical microstructure. Tectonophysics, 58: 179-200.

Wilson, M. (1989) Igneous Petrogenesis. Unwin Hyman, London, 466 pag.

Windley, B.F. (1993) Proterozoic anorogenic magmatism and its orogenic connections. J. Geol. Soc. London., 150:39-50.

Wolf, M.B. \& Wyllie, P.J (1993) Garnet growth during amphibolite anatexis: Implications of a garnetiferous restite. Journal of Geology, 101: 357-373.

Wolf, M.B. \& Wyllie, P.J (1994) Dehydration melting of amphibolite at 10 Kbar: the effects of temperature and time. Contrib. Mineral. Petrol., 115: 369-383.

Wunder, B. \& Schreyer, W. (1997) Antigorite: High pressure stability in the system MgO$\mathrm{Si} 2 \mathrm{O}-\mathrm{H} 2 \mathrm{O}(\mathrm{MSH})$. Lithos, 41: 213-227.

Zen ,E-An \& Hammarston, J.M. (1984). Magmatic epidote and its petrological significance, Geology, 12: 515-518.

Zen ,E-An (1986) Reply on the comments on "implications of magmatic epidote-bearing plutons on crustal evolution in the accreted terranes of North America" and "Magmatic epidote and its petrological significance". By A.J. Tulloch and by R.H. Moench. Geology, 14:187-188.

Zhang, L-S. \& Scharer, U. (1996) Inherited $\mathrm{Pb}$ components in magmatic titanite and their consequence for the interpretations of U-Pb ages. Earth. Palnet. Sci. Lett. 138:57-65. 
Anexo 3.0 
Granito Palermo (GP) 


\begin{tabular}{|c|c|c|c|c|c|}
\hline Amostra & OM 683 & OM 1008-B & OM 94 & OM 118 & OM 1057 \\
\hline $\mathrm{SiO} 2$ & 50,88 & 51,09 & 55,61 & 62,36 & 66,44 \\
\hline TiO2 & 1,68 & 2,01 & 1,59 & 1,06 & 0,57 \\
\hline $\mathrm{Al} 2 \mathrm{O} 3$ & 16,92 & 16,78 & 15,65 & 15,14 & 15,31 \\
\hline FezO3T & 9,70 & 10,33 & 8,39 & 6,72 & 4,59 \\
\hline Mno & 0,15 & 0,16 & 0,13 & 0,14 & 0,13 \\
\hline $\mathrm{MgO}$ & 6,22 & 4,70 & 3,51 & 1,23 & 0,38 \\
\hline $\mathrm{CaO}$ & 8,73 & 7,87 & 5,48 & 2,95 & 1,68 \\
\hline $\mathrm{Na2O}$ & 3,42 & 3,57 & 3,91 & 4,74 & 4,96 \\
\hline $\mathrm{K} 20$ & 1,34 & 2,03 & 3,33 & 4,41 & 5,67 \\
\hline P2O5 & 0,38 & 0,59 & 0,42 & 0,46 & 0,10 \\
\hline LOI & 0,98 & 1,09 & 0,79 & 0,47 & 0,34 \\
\hline TOTAL & 100,40 & 100,23 & 98,82 & 99,64 & 100,17 \\
\hline $\mathbf{B a}$ & 573 & 1090 & 974 & 1430 & 1310 \\
\hline $\mathbf{R b}$ & 39 & 52 & 89 & 143 & 111 \\
\hline Sr & 439 & 535 & 405 & 254 & 68 \\
\hline Cs & 0,70 & 1,70 & 1,20 & 3,10 & 2,10 \\
\hline $\mathbf{G a}$ & 16 & 21 & 22 & 24 & 21 \\
\hline $\mathbf{T a}$ & 0,50 & 0,70 & 1,20 & 9,50 & 1,40 \\
\hline $\mathrm{Nb}$ & 7 & 10 & 21 & 22 & 21 \\
\hline Hf & 3,90 & 5,00 & 6,30 & 9,60 & 10,80 \\
\hline $\mathbf{Z r}$ & 140 & 204 & 236 & 372 & 438 \\
\hline$Y$ & 56 & 29 & 43 & 48 & 39 \\
\hline Th & 1,40 & 1,00 & 2,40 & 7,80 & 6,10 \\
\hline $\mathbf{U}$ & 0,30 & 0,30 & 0,50 & 1,70 & 1,30 \\
\hline $\mathrm{Cr}$ & 134 & 86 & 38 & -20 & -20 \\
\hline $\mathrm{Ni}$ & 35 & 34 & -15 & -15 & -15 \\
\hline Sc & 29 & 26 & 19 & 14 & 13 \\
\hline$v$ & 177 & 195 & 156 & 31 & .5 \\
\hline La & 15,00 & 20,20 & 30,70 & 46,00 & 45,40 \\
\hline $\mathrm{Ce}$ & 34,30 & 45,20 & 66,70 & 100,00 & 92,10 \\
\hline Pr & 4,87 & 6,32 & 8,68 & 12,70 & 11,10 \\
\hline Nd & 21,10 & 27,00 & 33,90 & 48,30 & 42,00 \\
\hline $\mathrm{Sm}$ & 4,90 & 6,00 & 7,40 & 9,70 & 8,30 \\
\hline $\mathrm{Eu}$ & 1,71 & 2,20 & 1,67 & 2,54 & 2,14 \\
\hline Gd & 5,60 & 6,10 & 7,50 & 9,10 & 7,80 \\
\hline Tb & 1,00 & 0,90 & 1,20 & 1,50 & 1,20 \\
\hline Dy & 6,10 & 5,30 & 7,10 & 8,30 & 7,30 \\
\hline Ho & 1,40 & 1,10 & 1,40 & 1,70 & 1,50 \\
\hline Er & 3,90 & 3,10 & 4,20 & 5,10 & 4,40 \\
\hline $\mathrm{Tm}$ & 0,52 & 0,40 & 0,57 & 0.73 & 0,64 \\
\hline $\mathrm{Yb}$ & 3,10 & 2,60 & 3,70 & 4,70 & 4,30 \\
\hline Lu & 0,45 & 0,38 & 0,52 & 0,69 & 0,63 \\
\hline
\end{tabular}




\begin{tabular}{|c|c|c|c|c|c|c|c|}
\hline Amostra & OM 638 & OM 677 & OM 674-B & OM 656 & OM 641 & OM 655 & OM 690 \\
\hline SiO2 & 65,47 & 66,26 & 67,14 & 67,34 & 68,01 & 69,41 & 70,05 \\
\hline TiO2 & 0,39 & 0,39 & 0,37 & 0,41 & 0,28 & 0,27 & 0,26 \\
\hline $\mathrm{Al} 2 \mathrm{O3}$ & 15,89 & 15,63 & 14,87 & 15,11 & 14,76 & 14,56 & 14,72 \\
\hline Fe2O3r & 4,39 & 3,93 & 5,18 & 4,01 & 3,37 & 3,38 & 2,90 \\
\hline Mno & 0,12 & 0,12 & 0,14 & 0,14 & 0,08 & 0,08 & 0,07 \\
\hline Mgo & 0,16 & 0,16 & 0,02 & 0,05 & 0,04 & 0,04 & 0,04 \\
\hline $\mathrm{CaO}$ & 1,46 & 1,46 & 1,47 & 1,58 & 0,97 & 0,85 & 0,98 \\
\hline $\mathrm{Na} 2 \mathrm{O}$ & 5,03 & 5,17 & 5,20 & 5,23 & 5,15 & 5,11 & 5,06 \\
\hline $\mathrm{K} 20$ & 6,09 & 5,92 & 5,50 & 5,85 & 5,56 & 5,39 & 5,53 \\
\hline P2O5 & 0,07 & 0,06 & 0,03 & 0,03 & 0,03 & 0,03 & 0,03 \\
\hline LOI & 0,45 & 0,54 & 0,35 & 0,38 & 0,62 & 1,11 & 0,78 \\
\hline TOTAL. & 99,53 & 99,63 & 100,26 & 100,14 & 98,87 & 100,23 & 100,41 \\
\hline $\mathbf{B a}$ & 484 & 474 & 21 & 100 & 90 & 125 & 170 \\
\hline $\mathbf{R b}$ & 152 & 167 & 152 & 138 & 175 & 161 & 175 \\
\hline $\mathbf{s r}$ & 42 & 45 & 5 & 9 & 17 & 21 & 23 \\
\hline Cs & 1,60 & 2,20 & 1,70 & 1,20 & 2,20 & 1,10 & 2,10 \\
\hline $\mathbf{G a}$ & 19 & 22 & 12 & 19 & 26 & 18 & 29 \\
\hline $\mathrm{Ta}$ & 1,30 & 1,40 & 1,70 & 1,40 & 1,80 & 1,50 & 2,20 \\
\hline Nb & 16 & 17 & 19 & 23 & 34 & 26 & 36 \\
\hline Hf & 9,60 & 9,70 & 17,50 & 18,20 & 19,80 & 21,60 & 19,10 \\
\hline $\mathbf{Z r}$ & 427 & 451 & 815 & 923 & 865 & 965 & 794 \\
\hline $\mathbf{Y}$ & 43 & 49 & 64 & 127 & 209 & 126 & 255 \\
\hline Th & 6,00 & 7,40 & 7,50 & 6,90 & 10,30 & 9,80 & 12,80 \\
\hline $\mathbf{U}$ & 1,20 & 1,20 & 1,10 & 1,00 & 1,40 & 1,30 & 2,10 \\
\hline $\mathrm{Cr}$ & -20 & -20 & -20 & -20 & -20 & 29 & -20 \\
\hline $\mathbf{N i}$ & -15 & -15 & -15 & -15 & -15 & -15 & -15 \\
\hline Sc & 10 & 8 & 2 & 6 & 4 & 3 & 3 \\
\hline v & -5 & -5 & -5 & -5 & -5 & -5 & -5 \\
\hline La & 47,10 & 70,00 & 79,40 & 187,00 & 361,00 & 191,00 & 473,00 \\
\hline $\mathrm{Ce}$ & 87,20 & 121,00 & 161,00 & 278,00 & 452,00 & 321,00 & 404,00 \\
\hline Pr & 11,30 & 15,00 & 19,40 & 35,10 & 72,70 & 40,70 & 95,30 \\
\hline Nd & 42,90 & 54,80 & 72,60 & 132,00 & 248,00 & 146,00 & 342,00 \\
\hline Sm & 8,40 & 9,70 & 13,40 & 22,40 & 43,30 & 24,60 & 57,40 \\
\hline Eu & 1,74 & 1,92 & 0,54 & 0,99 & 1,31 & 0,68 & 2,20 \\
\hline Gd & 7,90 & 9,40 & 12,00 & 24,80 & 39,10 & 23,30 & 58,80 \\
\hline Tb & 1,30 & 1,40 & 1,90 & 3,60 & 5,40 & 3,50 & 8,20 \\
\hline Dy & 7,40 & 8,30 & 11,40 & 21,50 & 29,40 & 20,30 & 45,70 \\
\hline Ho & 1,50 & 1,70 & 2,40 & 4,60 & 5,60 & 4,20 & 9,00 \\
\hline $\mathrm{Er}$ & 4,80 & 5,10 & 7,20 & 13,30 & 15,10 & $\$ 1,90$ & 24,10 \\
\hline $\mathrm{Tm}$ & 0,72 & 0,75 & 1,06 & 1,84 & 2,06 & 1,73 & 3,27 \\
\hline$Y_{b}$ & 4,90 & 4,90 & 7,40 & 11,90 & 12,70 & 10,30 & 19,80 \\
\hline Lu & 0,71 & 0,74 & 1,12 & 1,92 & 1,82 & 1,51 & 2,73 \\
\hline
\end{tabular}




\begin{tabular}{|c|c|c|c|c|c|c|c|}
\hline Amostra & OM 888 & OM 691 & OM 679 & OM 672 & OM 740 & OM 1058 & OM 748 \\
\hline $\mathrm{SiO}_{2}$ & 71,62 & 72,27 & 74,72 & 74,94 & 75,87 & 76,12 & 76,28 \\
\hline TiO2 & 0,32 & 0,33 & 0,12 & 0,22 & 0,13 & 0,10 & 0,14 \\
\hline Al2O3 & 13,93 & 13,32 & 13,46 & 13,11 & 12,85 & 12,84 & 12,49 \\
\hline Fe2O3T & 2,86 & 2,59 & 1,30 & 2,18 & 1,23 & 1,53 & 1,42 \\
\hline Mno & 0,06 & 0,06 & 0,03 & 0,05 & 0,03 & 0,04 & 0,03 \\
\hline Mgo & 0,19 & 0,31 & 0,21 & 0,15 & 0,12 & 0,06 & 0,11 \\
\hline CaO & 1,02 & 1,14 & 0,88 & 0,77 & 0,51 & 0,62 & 0,60 \\
\hline $\mathrm{Na2O}$ & 4,38 & 3,80 & 4,80 & 4,15 & 3,60 & 3,97 & 3,75 \\
\hline $\mathrm{K2O}$ & 5,10 & 5,26 & 4,09 & 4,98 & 5,32 & 4,64 & 4,82 \\
\hline P2O5 & 0,09 & 0,08 & 0,04 & 0,04 & 0,03 & 0,03 & 0,03 \\
\hline LOI & 0,66 & 0,52 & 0,43 & 0,28 & 0,60 & 0,48 & 0,71 \\
\hline TOTAL. & 100,23 & 99,69 & 100,08 & 100,87 & 100,29 & 100,42 & 100,38 \\
\hline $\mathbf{B a}$ & 742 & 716 & 550 & 506 & 311 & 125 & 258 \\
\hline $\mathbf{R b}$ & 214 & 203 & 210 & 251 & 228 & 364 & 221 \\
\hline $\mathrm{Sr}$ & 81 & 93 & 110 & 57 & 62 & 21 & 51 \\
\hline Cs & 3,50 & 4,00 & 2,10 & 8,20 & 1,50 & 5,10 & 2,70 \\
\hline Ga & 24 & 21 & 24 & 27 & 22 & 25 & 22 \\
\hline $\mathrm{Ta}$ & 1,60 & 2,70 & 0,60 & 2,83 & 2,60 & 3,10 & 2,10 \\
\hline $\mathrm{Nb}$ & 24 & 29 & 10 & 30 & 26 & 41 & 27 \\
\hline Hf & 11,10 & 9,10 & 4,40 & 7,80 & 5,70 & 8,30 & 6,80 \\
\hline $\mathrm{Zr}$ & 439 & 298 & 168 & 245 & 160 & 178 & 172 \\
\hline $\mathbf{Y}$ & 68 & 51 & 45 & 46 & 58 & 81 & 48 \\
\hline Th & 11,50 & 10,70 & 9,90 & 23,50 & 18,70 & 27,00 & 20,40 \\
\hline $\mathbf{U}$ & 2,20 & 2,60 & 2,60 & 4,98 & 2,80 & 6,60 & 3,40 \\
\hline $\mathrm{Cr}$ & -20 & 18 & -20 & -10 & -20 & -20 & -20 \\
\hline $\mathbf{N i}$ & -15 & 10 & -15 & -10 & -15 & -15 & -15 \\
\hline Sc & 6 & 7 & 2 & 4 & 3 & 2 & 3 \\
\hline$v$ & -5 & 8 & 8 & -5 & -5 & -5 & -5 \\
\hline La & 76,30 & 57,70 & 44,60 & 45,20 & 72,20 & 31,30 & 59,70 \\
\hline $\mathrm{Ce}$ & 134,00 & 111,00 & 84,60 & 90,70 & 128,00 & 66,60 & 115,00 \\
\hline $\mathrm{Pr}$ & 15,70 & 12,50 & 9,07 & 9,03 & 14,10 & 7,92 & 12,40 \\
\hline Nd & 54,70 & 42,50 & 28,60 & 33,70 & 45,10 & 28,00 & 40,20 \\
\hline $\mathrm{Sm}$ & 9,70 & 8,60 & 4,50 & 6,31 & 7,70 & 7,00 & 7,50 \\
\hline Eu & 1,14 & 1,05 & 0,22 & 0,64 & 0,46 & 0,27 & 0,40 \\
\hline Gd & 9,70 & 7,70 & 3,40 & 6,02 & 7,70 & 7,70 & 7,10 \\
\hline Tb & 1,60 & 1,40 & 0,88 & 1,13 & 1,40 & 1,50 & 1,20 \\
\hline Dy & 9,80 & 8,20 & 2,40 & 6,33 & 8,30 & 10,50 & 7,60 \\
\hline Ho & 2,00 & 1,80 & 0,50 & 1,35 & 1,80 & 2,40 & 1,60 \\
\hline Er & 6,20 & 5,40 & 1,40 & 4,66 & 5,40 & 8,10 & 5,10 \\
\hline $\mathrm{Tm}$ & 0,93 & 0,80 & 0,21 & 0,87 & 0,78 & 1,35 & 0,80 \\
\hline $\mathbf{Y b}$ & 5,90 & 5,20 & 5,30 & 5,17 & 4,80 & 9,30 & 5,10 \\
\hline Lu & 0,85 & 0,76 & 0,19 & 0,78 & 0,69 & 1,31 & 0,72 \\
\hline
\end{tabular}




\begin{tabular}{|c|c|c|}
\hline Amostra & OM 649 & OM 610 \\
\hline $\mathrm{SiO} 2$ & 76,89 & 78,72 \\
\hline TiO2 & 0,09 & 0,05 \\
\hline $\mathrm{Al} 2 \mathrm{O} 3$ & 12,35 & 11,60 \\
\hline Fe2O3T & 1,39 & 1,37 \\
\hline Mno & 0,02 & 0,02 \\
\hline $\mathrm{MgO}$ & 0,05 & 0,02 \\
\hline $\mathrm{CaO}$ & 0,50 & 0,42 \\
\hline $\mathrm{Na2O}$ & 3,62 & 3,99 \\
\hline K2O & 4,87 & 4,39 \\
\hline P2O5 & 0,03 & 0,01 \\
\hline LOI & 0,62 & 0,38 \\
\hline TOTAL & 100,43 & 100,97 \\
\hline $\mathbf{B a}$ & 102 & 11 \\
\hline $\mathbf{R b}$ & 283 & 250 \\
\hline $\mathbf{S r}$ & 18 & 12 \\
\hline Cs & 3,20 & 5,70 \\
\hline $\mathbf{G a}$ & 23 & 33 \\
\hline $\mathrm{Ta}$ & 3,20 & 3,38 \\
\hline Nb & 32 & 45 \\
\hline Hf & 6,00 & 7,50 \\
\hline $\mathrm{Zr}$ & 142 & 182 \\
\hline$Y$ & 41 & 72 \\
\hline Th & 23,90 & 20,90 \\
\hline $\mathbf{u}$ & 4,50 & 3,57 \\
\hline $\mathrm{Cr}$ & -20 & -10 \\
\hline $\mathrm{Ni}$ & -15 & -10 \\
\hline Sc & -1 & 2 \\
\hline$v$ & -5 & -5 \\
\hline La & 28,20 & 36,80 \\
\hline $\mathrm{Ce}$ & 59,70 & 85,10 \\
\hline $\mathbf{P r}$ & 6,67 & 9,29 \\
\hline Nd & 21,80 & 40,10 \\
\hline $\mathrm{Sm}$ & 4,60 & 10,50 \\
\hline Eu & 0,21 & 0,04 \\
\hline Gd & 4,50 & 8,33 \\
\hline Tb & 0,80 & 1,91 \\
\hline Dy & 5,50 & 11,10 \\
\hline Ho & 1,30 & 2,12 \\
\hline $\mathrm{Er}$ & 4,20 & 6,57 \\
\hline $\mathrm{Tm}$ & 0,72 & 1,32 \\
\hline Yb & 4,80 & 8,11 \\
\hline Lu & 0,71 & 1,07 \\
\hline
\end{tabular}


Granito Rio Negro (GRN) 


\begin{tabular}{|c|c|c|c|c|c|c|c|}
\hline Amostra & OM 500 & OM 200 & OM 428-A & OM 450 & OM 473 & OM 507 & OM 547-E \\
\hline $\mathrm{SiO}_{2}$ & 48,08 & 49,96 & 51,37 & 52,65 & 53,22 & 53,22 & 54,25 \\
\hline TiO2 & 1,21 & 2,63 & 2,33 & 2,22 & 2,20 & 2,22 & 2,12 \\
\hline Al2O3 & 15,66 & 15,45 & 15,27 & 15,03 & 14,76 & 15,15 & 14,58 \\
\hline $\mathrm{Fe} 2 \mathrm{O} 3 \mathrm{~T}$ & 10,99 & 12,46 & 11,74 & 11,15 & 11,55 & 11,13 & 10,47 \\
\hline Mno & 0,17 & 0,19 & 0,17 & 0,17 & 0,17 & 0,18 & 0,15 \\
\hline $\mathrm{MgO}$ & 10,22 & 5,19 & 4,82 & 4,22 & 4,20 & 4,05 & 3,74 \\
\hline $\mathrm{CaO}$ & 7,09 & 8,41 & 7,43 & 7,20 & 7,16 & 6,72 & 6,47 \\
\hline $\mathrm{Na2O}$ & 3,08 & 3,85 & 3,89 & 3,92 & 4,04 & 4,03 & 4,03 \\
\hline K2O & 1,21 & 1,06 & 1,82 & 1,78 & 2,14 & 2,10 & 2,27 \\
\hline P2O5 & 0,40 & 0,91 & 0,75 & 0,69 & 0,65 & 0,75 & 0,65 \\
\hline LOI & 0,65 & 0,26 & 0,82 & 0,45 & 0,39 & 0,61 & 0,51 \\
\hline TOTAL & 98,74 & 100,37 & 100,41 & 99,48 & 100,48 & 100,17 & 99,26 \\
\hline $\mathbf{B a}$ & 599 & 992 & 919 & 892 & 966 & 1140 & 794 \\
\hline $\mathbf{R b}$ & 18 & 14 & 39 & 34 & 38 & 50 & 48 \\
\hline $\mathbf{s r}$ & 581 & 675 & 508 & 464 & 493 & 572 & 412 \\
\hline $\mathrm{Cs}$ & 1,10 & 0,80 & 0,50 & $-0,50$ & 0,50 & 0,60 & $-0,50$ \\
\hline $\mathbf{G a}$ & 10 & 21 & 21 & 16 & 21 & 21 & 8 \\
\hline $\mathrm{Ta}$ & 0,40 & 0,80 & 0,90 & 0,90 & 0,82 & 0,90 & 1,00 \\
\hline $\mathrm{Nb}$ & 6 & 15 & 16 & 13 & 17 & 16 & 8 \\
\hline Hf & 2,70 & 4,40 & 6,70 & 6,90 & 6,90 & 7,40 & 8,60 \\
\hline $\mathrm{Zr}$ & 129 & 184 & 292 & 326 & 287 & 315 & 353 \\
\hline $\mathbf{Y}$ & 18 & 40 & 44 & 43 & 44 & 43 & 57 \\
\hline Th & 0,60 & 0,70 & 1,90 & 1,80 & 1,83 & 1,90 & 3,10 \\
\hline $\mathbf{u}$ & 0,20 & 0,20 & 0,40 & 0,40 & 0,32 & 0,60 & 0,70 \\
\hline $\mathrm{Cr}$ & 413 & 88 & 69 & 74 & 61 & 51 & 44 \\
\hline $\mathbf{N i}$ & 86 & 16 & 31 & -15 & 68 & -15 & -15 \\
\hline Sc & 15 & 30 & 25 & 26 & 27 & 24 & 24 \\
\hline v & 98 & 237 & 211 & 181 & 206 & 188 & 118 \\
\hline La & 19,40 & 37,30 & 40,80 & 38,90 & 42,90 & 46,60 & 45,30 \\
\hline $\mathrm{Ce}$ & 40,70 & 80,70 & 86,20 & 82,90 & 87,10 & 97,70 & 96,10 \\
\hline $\mathbf{P r}$ & 5,17 & 10,70 & 11,20 & 10,70 & 9,52 & 12,50 & 12,30 \\
\hline Nd & 20,80 & 45,00 & 45,40 & 42,10 & 43,00 & 50,20 & 48,30 \\
\hline $8 m$ & 4,20 & 9,10 & 9,30 & 8,60 & 9,84 & 9,60 & 9,90 \\
\hline Eu & 1,58 & 3,08 & 2,85 & 2,64 & 2,80 & 3,02 & 2,70 \\
\hline Gd & 4,10 & 8,90 & 9,30 & 8,50 & 7,83 & 9,60 & 10,10 \\
\hline Tb & 0,60 & 1,30 & 1,40 & 1,30 & 1,40 & 1,40 & 1,60 \\
\hline Dy & 3,40 & 7,50 & 7,80 & 7,40 & 7,68 & 7,80 & 9,30 \\
\hline Ho & 0,70 & 1,50 & 1,50 & 1,50 & 1,49 & 1,50 & 1,90 \\
\hline Er & 1,90 & 4,10 & 4,40 & 4,30 & 4,05 & 4,40 & 5,70 \\
\hline $\mathrm{Tm}$ & 0,26 & 0,54 & 0,60 & 0,58 & 0,63 & 0,61 & 0,79 \\
\hline $\mathbf{Y b}$ & 1,70 & 3,40 & 3,90 & 3,70 & 4,11 & 3,80 & 4,90 \\
\hline Lu & 0,25 & 0,48 & 0,56 & 0,55 & 0,56 & 0,55 & 0,71 \\
\hline
\end{tabular}




\begin{tabular}{|c|c|c|c|c|c|c|}
\hline Amostra & OM 602 & OM 545 & OM 428 & OM 430 & OM 469 & OM 519 \\
\hline $\mathrm{SiO} 2$ & 57,03 & 61,96 & 62,26 & 63,85 & 63,48 & 63,55 \\
\hline TiO2 & 2,05 & 1,43 & 1,31 & 1,28 & 1,21 & 1,08 \\
\hline $\mathrm{Al} 2 \mathrm{O} 3$ & 14,31 & 14,24 & 13,96 & 13,35 & 14,61 & 15,52 \\
\hline Fe2O3T & 9,19 & 7,29 & 7,41 & 6,51 & 6,24 & 6,38 \\
\hline Mno & 0,19 & 0,13 & 0,11 & 0,10 & 0,09 & 0,11 \\
\hline Mgo & 2,85 & 2,55 & 2,38 & 1,66 & 1,57 & 1,02 \\
\hline $\mathrm{CaO}$ & 5,04 & 4,24 & 4,22 & 3,20 & 2,98 & 2,61 \\
\hline $\mathrm{Na2O}$ & 3,89 & 4,69 & 4,18 & 3,98 & 5,21 & 4,61 \\
\hline $\mathrm{K} 2 \mathrm{O}$ & 3,31 & 3,16 & 3,53 & 4,07 & 3,79 & 4,71 \\
\hline P2O5 & 0,60 & 0,41 & 0,39 & 0,38 & 0,39 & 0,30 \\
\hline LOI & 0,77 & 0,37 & 0,58 & 0,23 & 0,38 & 0,26 \\
\hline TOTAL & 99,22 & 100,47 & 100,33 & 98,61 & 99,97 & 100,15 \\
\hline $\mathbf{B a}$ & 898 & 726 & 706 & 711 & 964 & 2130 \\
\hline $\mathbf{R b}$ & 86 & 53 & 81 & 66 & 57 & 87 \\
\hline $\mathbf{s r}$ & 368 & 317 & 322 & 235 & 336 & 258 \\
\hline Cs & 1,00 & $-0,50$ & $-0,50$ & $-0,50$ & $-0,50$ & 1,00 \\
\hline $\mathbf{G a}$ & 19 & 26 & 26 & 27 & 26 & 17 \\
\hline $\mathbf{T a}$ & 1,30 & 1,80 & 1,60 & 1,80 & 1,50 & 1,40 \\
\hline $\mathrm{Nb}$ & 18 & 34 & 28 & 32 & 29 & 20 \\
\hline Hf & 8,80 & 15,00 & 15,60 & 18,80 & 14,50 & 13,50 \\
\hline$z r$ & 394 & 611 & 652 & 828 & 616 & 595 \\
\hline $\mathbf{Y}$ & 56 & 82 & 71 & 84 & 76 & 58 \\
\hline Th & 4,60 & 3,00 & 4,50 & 3,20 & 3,20 & 3,70 \\
\hline $\mathbf{u}$ & 1,00 & 1,00 & 1,20 & 0,90 & 0,80 & 1,10 \\
\hline $\mathrm{Cr}$ & -20 & 42 & 34 & -20 & 22 & -20 \\
\hline $\mathrm{Ni}$ & -15 & 32 & -15 & -15 & 38 & -15 \\
\hline $\mathrm{Sc}$ & 22 & 15 & 16 & 13 & 11 & 14 \\
\hline$v$ & 155 & 119 & 124 & 101 & 86 & 23 \\
\hline La & 60,90 & 69,50 & 64,00 & 78,90 & 64,20 & 57,80 \\
\hline $\mathrm{Ce}$ & 125,00 & 148,00 & 135,00 & 166,00 & 133,00 & 120,00 \\
\hline $\mathrm{Pr}$ & 15,20 & 18,40 & 16,90 & 20,60 & 16,90 & 15,10 \\
\hline Nd & 58,10 & 70,50 & 63,90 & 78,00 & 64,40 & 58,80 \\
\hline Sm & 11,20 & 14,60 & 12,50 & 15,30 & 13,40 & 11,40 \\
\hline Eu & 2,58 & 2,07 & 1,90 & 1,92 & 2,14 & 3,38 \\
\hline Gd & 10,90 & 14,00 & 12,70 & 14,80 & 13,20 & 10,80 \\
\hline $\mathrm{rb}$ & 1,70 & 2,40 & 2,10 & 2,40 & 2,10 & 1,70 \\
\hline Dy & 9,70 & 14,10 & 12,00 & 14,30 & 12,60 & 10,20 \\
\hline Ho & 2,00 & 2,90 & 2,50 & 3,00 & 2,70 & 2,10 \\
\hline Er & 5,80 & 8,60 & 7,40 & 8,80 & 7,80 & 6,10 \\
\hline $\mathrm{Tm}$ & 0,82 & 1,25 & 1,06 & 1,25 & 1,09 & 0,88 \\
\hline $\mathbf{Y b}$ & 5,30 & 7,80 & 6,80 & 8,10 & 6,70 & 5,70 \\
\hline Lu & 0,76 & 1,09 & 0,95 & 1,15 & 0,98 & 0,84 \\
\hline
\end{tabular}




\begin{tabular}{|c|c|c|c|c|}
\hline Amostra & OM 499 & OM 425 & OM 67 & OM 589 \\
\hline $\mathrm{SiO} 2$ & 65,25 & 65,28 & 68,94 & 76,30 \\
\hline TiO2 & 1,32 & 1,13 & 0,93 & 0,17 \\
\hline Al2O3 & 13,50 & 13,31 & 13,78 & 11,62 \\
\hline Fe203T & 6,58 & 6,72 & 4,73 & 1,95 \\
\hline Mno & 0,10 & 0,09 & 0,08 & 0,04 \\
\hline $\mathrm{MgO}$ & 1,59 & 1,84 & 1,03 & 0,12 \\
\hline $\mathrm{CaO}$ & 3,36 & 3,05 & 2,24 & 0,42 \\
\hline $\mathrm{Na2O}$ & 4,02 & 3,69 & 3,97 & 3,92 \\
\hline K2O & 3,84 & 4,50 & 4,22 & 4,64 \\
\hline P2O5 & 0,44 & 0,37 & 0,24 & 0,03 \\
\hline L.OI & 0,80 & 0,53 & 0,62 & 0,44 \\
\hline TOTAL & 100,80 & 100,49 & 100,78 & 99,65 \\
\hline $\mathbf{B a}$ & 607 & 678 & 532 & 197 \\
\hline $\mathbf{R b}$ & 161 & 71 & 196 & 226 \\
\hline $\mathbf{S r}$ & 289 & 228 & 200 & 37 \\
\hline Cs & 1,30 & $-0,50$ & 2,50 & 2,90 \\
\hline $\mathbf{G a}$ & 29 & 16 & 25 & 29 \\
\hline $\mathrm{Ta}$ & 2,02 & 1,10 & 3,60 & 2,96 \\
\hline $\mathrm{Nb}$ & 37 & 16 & 29 & 45 \\
\hline Hf & 5,20 & 21,30 & 11,40 & 10,00 \\
\hline $\mathbf{Z r}$ & 189 & 985 & 363 & 324 \\
\hline$Y$ & 98 & 101 & 71 & 73 \\
\hline$T h$ & 8,71 & 3,40 & 16,50 & 18,30 \\
\hline $\mathbf{u}$ & 2,49 & 1,10 & 2,60 & 3,81 \\
\hline $\mathrm{Cr}$ & 13 & 21 & 12 & 13 \\
\hline $\mathrm{Ni}$ & 33 & -15 & 3 & 13 \\
\hline Sc & 12 & 12 & 8 & 1 \\
\hline$v$ & 104 & 67 & 49 & -5 \\
\hline La & 66,30 & 73,70 & 92,50 & 65,60 \\
\hline $\mathrm{Ce}$ & 109,00 & 169,00 & 201,00 & 109,00 \\
\hline $\mathbf{P r}_{\mathbf{r}}$ & 14,49 & 22,20 & 0,00 & 12,67 \\
\hline Nd & 65,30 & 85,70 & 78,00 & 46,80 \\
\hline $\mathrm{Sm}$ & 13,80 & 18,10 & 11,70 & 10,10 \\
\hline Eu & 1,95 & $\{, 73$ & 1,74 & 0,46 \\
\hline $\mathbf{G d}$ & 12,80 & 18,00 & 0,00 & 9,10 \\
\hline Tb & 2,60 & 3,00 & 1,80 & 1,76 \\
\hline Dy & 14,50 & 18,00 & 0,00 & 10,70 \\
\hline Ho & 2,92 & 3,60 & 0,00 & 2,27 \\
\hline $\mathbf{E r}$ & 8,94 & 10,40 & 0,00 & 6,94 \\
\hline $\mathrm{Tm}$ & 1,49 & 1,47 & 0,00 & 1,25 \\
\hline $\mathbf{Y b}$ & 8,05 & 9,00 & 7,63 & 7,39 \\
\hline Lu & 1,08 & 1,22 & 0,96 & 1,05 \\
\hline
\end{tabular}


Granito Agudos do Sul (GAS) 


\begin{tabular}{|c|c|c|c|c|c|c|}
\hline Amostra & OM 661 & OM $661 A 2$ & OM 661B3 & OM 661C1 & OM 661E & OM 700 \\
\hline $\mathrm{SiO} 2$ & 75,96 & 75,16 & 74,74 & 75,12 & 75,52 & 75,68 \\
\hline TiO2 & 0,03 & 0,02 & 0,04 & 0,02 & $-0,01$ & 0,02 \\
\hline $\mathrm{A} 1203$ & 13,08 & 13,30 & 13,03 & 13,18 & 12,52 & 13,48 \\
\hline Fe203T & 0,63 & 0,67 & 0,71 & 0,61 & 1,05 & 0,84 \\
\hline Mno & 0,04 & 0,05 & 0,03 & 0,04 & 0,03 & 0,02 \\
\hline $\mathrm{MgO}$ & 0,07 & 0,03 & 0,04 & 0,05 & 0,01 & 0,04 \\
\hline $\mathrm{CaO}$ & 0,82 & 0,85 & 0,88 & 0,81 & 0,35 & 0,73 \\
\hline $\mathrm{Na2O}$ & 4,80 & 5,06 & 5,11 & 4,96 & 4,85 & 5,03 \\
\hline $\mathrm{K} 2 \mathrm{O}$ & 3,84 & 3,68 & 3,44 & 3,85 & 3,87 & 4,02 \\
\hline P2O5 & 0,02 & 0,02 & 0,03 & 0,02 & 0,03 & 0,08 \\
\hline Lol & 0,34 & 0,29 & 0,59 & 0,56 & 0,35 & 0,47 \\
\hline TOTAL & 99,63 & 99,13 & 98,64 & 99,22 & 98,57 & 100,41 \\
\hline $\mathbf{B a}$ & 503 & 407 & 353 & 406 & 27 & 162 \\
\hline $\mathbf{R b}$ & 196 & 176 & 162 & 183 & 341 & 199 \\
\hline Sr & 265 & 231 & 225 & 244 & 14 & 168 \\
\hline Cs & 3,00 & 3,80 & 2,80 & 3,20 & 1,70 & 5,30 \\
\hline Ga & 41 & 39 & 43 & 40 & 47 & 43 \\
\hline $\mathrm{Ta}$ & 0,68 & 2,38 & 1,83 & 0,84 & 9,33 & 3,20 \\
\hline $\mathrm{Nb}$ & 15 & 59 & 54 & 17 & 88 & 55 \\
\hline Hf & 3,90 & 5,90 & 8,10 & 4,30 & 8,70 & 3,20 \\
\hline $\mathbf{Z r}$ & 68 & 66 & 89 & 62 & 119 & 48 \\
\hline$Y$ & 4 & 4 & 6 & 3 & 137 & 3 \\
\hline Th & 4,84 & 12,30 & 16,50 & 5,15 & 24,50 & 5,14 \\
\hline $\mathbf{U}$ & 4,91 & 50,00 & 40,00 & 27,50 & 15,50 & 57,50 \\
\hline $\mathrm{Cr}$ & -10 & 11 & -10 & -10 & 17 & 12 \\
\hline $\mathrm{Ni}$ & -10 & -10 & -10 & -10 & -10 & -10 \\
\hline Sc & -1 & -1 & -1 & -1 & -1 & -1 \\
\hline$v$ & -5 & -5 & -5 & -5 & -5 & -5 \\
\hline La & 3,71 & 5,07 & 2,19 & 3,10 & 7,02 & 2,35 \\
\hline $\mathrm{Ce}$ & 6,65 & 11,20 & 4,46 & 6,30 & 24,70 & 4,61 \\
\hline Pr & 0,66 & 0,98 & 0,50 & 0,62 & 3,43 & 0,50 \\
\hline Nd & 2,59 & 3,81 & 2,21 & 2,31 & 16,80 & 2,20 \\
\hline $\mathrm{Sm}$ & 0,42 & 0,78 & 0,73 & 0,46 & 8,93 & 0,49 \\
\hline Eu & 0,16 & 0,19 & 0,22 & 0,17 & 0,05 & 0,13 \\
\hline Gd & 0,39 & 0,60 & 0,62 & 0,40 & 9,03 & 0,38 \\
\hline $\mathbf{T b}$ & 0,05 & 0,08 & 0,12 & 0,05 & 2,71 & 0,06 \\
\hline Dy & 0,26 & 0,40 & 0,59 & 0,23 & 18,30 & 0,28 \\
\hline Ho & 0,05 & 0,08 & 0,12 & 0,05 & 3,92 & 0,05 \\
\hline Er & 0,20 & 0,26 & 0,40 & 0,20 & 12,00 & 0,18 \\
\hline $\mathrm{Tm}$ & 0,04 & 0,05 & 0,08 & 0,03 & 2,39 & 0,03 \\
\hline $\mathrm{Yb}$ & 0,32 & 0,43 & 0,59 & 0,30 & 15,00 & 0,24 \\
\hline Lu & 0,05 & 0,08 & 0,10 & 0,06 & 2,05 & 0,04 \\
\hline
\end{tabular}


Granito Tarumã (GT) 


\begin{tabular}{|c|c|c|c|}
\hline Amostra & OM 504 & OM 66 & OM 80 \\
\hline $\mathrm{SiO} 2$ & 72,14 & 72,35 & 73,80 \\
\hline TiO2 & 0,26 & 0,27 & 0,24 \\
\hline $\mathrm{Al} 2 \mathrm{O} 3$ & 13,28 & 14,39 & 14,08 \\
\hline $\mathrm{Fe} 2 \mathrm{O} 3 \mathrm{~T}$ & 2,19 & 2,21 & 1,93 \\
\hline Mno & 0,05 & 0,05 & 0,04 \\
\hline MgO & 0,48 & 0,66 & 0,40 \\
\hline $\mathrm{CaO}$ & 1,55 & 1,88 & 1,23 \\
\hline $\mathrm{Na2O}$ & 3,58 & 3,70 & 3,47 \\
\hline $\mathrm{K} 20$ & 4,31 & 4,41 & 5,31 \\
\hline P2O5 & 0,08 & 0,09 & 0,04 \\
\hline LOI & 0,71 & 0,80 & 0,01 \\
\hline TOTAL & 98,63 & 100,81 & 100,55 \\
\hline $\mathbf{B a}$ & 1230 & 1580 & 1010 \\
\hline $\mathbf{R b}$ & 187 & 160 & 194 \\
\hline $\mathbf{S r}$ & 285 & 407 & 215 \\
\hline Cs & 3,00 & 3,20 & 2,40 \\
\hline Ga & 22 & 19 & 19 \\
\hline $\mathrm{Ta}$ & 1,32 & 2,90 & 3,10 \\
\hline $\mathbf{N b}$ & 22 & 16 & 20 \\
\hline Hf & 5,00 & 5,70 & 7,40 \\
\hline $\mathbf{Z r}$ & 197 & 173 & 207 \\
\hline $\mathbf{Y}$ & 19 & 16 & 24 \\
\hline Th & 14,50 & 13,60 & 20,10 \\
\hline $\mathbf{u}$ & 2,32 & 2,00 & 3,00 \\
\hline $\mathrm{Cr}$ & 30 & 24 & 43 \\
\hline $\mathrm{Ni}$ & -10 & 3 & 2 \\
\hline Sc & 3 & 4 & 3 \\
\hline v & 18 & 17 & 10 \\
\hline La & 67,40 & 58,10 & 93,50 \\
\hline $\mathrm{Ce}$ & 96,20 & 115,00 & 172,00 \\
\hline $\mathrm{Pr}$ & 11,05 & & \\
\hline Nd & 41,40 & 44,00 & 58,00 \\
\hline $\mathrm{Sm}$ & 6,39 & 5,67 & 6,91 \\
\hline Eu & 0,83 & 1,17 & 0,91 \\
\hline Gd & 5,42 & 0,00 & 0,00 \\
\hline $\mathbf{T b}$ & 0,70 & 0,50 & 0,50 \\
\hline Dy & 3,28 & 0,00 & 0,00 \\
\hline Ho & 0,59 & 0,00 & 0,00 \\
\hline Er & 1,90 & 0,00 & 0,00 \\
\hline $\mathrm{Tm}$ & 0,31 & & \\
\hline $\mathbf{Y b}$ & 1,73 & 1,54 & 2,60 \\
\hline Lu & 0,25 & 0,21 & 0,34 \\
\hline
\end{tabular}


Suite Granítica Piên-Mandirituba (SGPM)

(Quartzo Monzodioritos a Granodioritos sem epidoto magmático) 


\begin{tabular}{|c|c|c|c|c|c|c|c|}
\hline Amostra & OM 369 & OM SA & OM 165 & OM 206 & OM 414 & OM 1106 & OM 409 \\
\hline $\mathrm{SiO} 2$ & 49,69 & 52,43 & 52,54 & 60,97 & 61,42 & 63,07 & 64,63 \\
\hline TiO2 & 0,71 & 0,32 & 0,56 & 0,40 & 0,66 & 0,56 & 0,49 \\
\hline $\mathrm{A} 12 \mathrm{O} 3$ & 19,05 & 5,30 & 18,76 & 17,47 & 15,60 & 15,80 & 15,07 \\
\hline Fe2O3T & 8,83 & 8,83 & 7,38 & 4,80 & 5,68 & 4,92 & 4,38 \\
\hline Mno & 0,15 & 0,21 & 0,14 & 0,10 & 0,09 & 0,09 & 0,10 \\
\hline $\mathrm{MgO}$ & 3,45 & 16,25 & 2,78 & 1,60 & 2,87 & 2,51 & 2,07 \\
\hline $\mathrm{CaO}$ & 6,98 & 11,31 & 6,13 & 4,21 & 4,88 & 4,23 & 3,50 \\
\hline $\mathrm{Na} 2 \mathrm{O}$ & 3,98 & 1,10 & 4,18 & 4,77 & 4,32 & 4,05 & 4,13 \\
\hline $\mathrm{K} 2 \mathrm{O}$ & 2,97 & 1,04 & 3,47 & 3,36 & 2,82 & 3,11 & 3,53 \\
\hline P2O5 & 0,43 & 0,02 & 0,34 & 0,27 & 0,40 & 0,37 & 0,29 \\
\hline L.OI & 1,30 & 1,53 & 1,59 & 0,59 & 0,81 & 0,97 & 0,84 \\
\hline TOTAL. & 97,54 & 98,34 & 97,87 & 98,54 & 99,55 & 99,67 & 99,03 \\
\hline $\mathbf{B a}$ & 3254 & 562 & 3610 & 1864 & 1630 & 1780 & 1886 \\
\hline $\mathbf{R b}$ & 36 & 26 & 48 & 72 & 66 & 75 & 78 \\
\hline Sr & 1032 & 221 & 1329 & 1727 & 1240 & 1230 & 1067 \\
\hline Cs & 0,60 & $-0,50$ & 0,50 & 0,50 & 1,30 & 1,40 & 0,90 \\
\hline $\mathbf{G a}$ & 18 & 11 & 18 & 20 & 21 & 21 & 21 \\
\hline Ta & 0,60 & 0,40 & 1,00 & 2,80 & 0,50 & 0,80 & 3,10 \\
\hline Nb & 6 & 6 & 6 & 14 & 12 & 11 & 15 \\
\hline Hf & 1,90 & 1,80 & 2,20 & 4,70 & 5,50 & 5,40 & 4,20 \\
\hline$Z_{r}$ & 119 & 58 & 98 & 140 & 233 & 230 & 184 \\
\hline $\mathbf{Y}$ & 25 & 11 & 17 & 13 & 14 & 16 & 15 \\
\hline Th & 0,20 & 2,20 & 0,40 & 8,10 & 11,30 & 10,60 & 11,10 \\
\hline $\mathbf{U}$ & 0,20 & 0,40 & 0,20 & 0,20 & 0,54 & 1,30 & 1,50 \\
\hline $\mathrm{Cr}$ & 19 & $\uparrow 490$ & 18 & 24 & 80 & 69 & 49 \\
\hline $\mathrm{Ni}$ & 8 & 267 & 9 & 7 & 31 & 21 & 16 \\
\hline Co & 0 & 56 & 0 & 0 & 36 & 50 & 0 \\
\hline Sc & 22 & 40 & 17 & 6 & 12 & 10 & 8 \\
\hline V & 113 & 100 & 93 & 56 & 93 & 82 & 57 \\
\hline $\mathrm{Cu}$ & 7 & 11 & 56 & 7 & 14 & -10 & 9 \\
\hline $\mathbf{P b}$ & 20 & 5 & 25 & 14 & 19 & 44 & 26 \\
\hline $\mathrm{Zn}$ & 88 & 98 & 77 & 48 & 66 & 86 & 58 \\
\hline La & 36,90 & 12,00 & 40,20 & 52,80 & 72,70 & 66,30 & 63,20 \\
\hline $\mathrm{Ce}$ & 75,00 & 31,90 & 77,00 & 102,00 & 106,00 & 105,00 & 95,00 \\
\hline Pr & & 4,25 & & & 11,98 & 11,80 & \\
\hline Nd & 40,00 & 18,80 & 34,00 & 38,00 & 43,00 & 39,80 & 35,00 \\
\hline $\mathrm{Sm}$ & 6,99 & 3,90 & 5,50 & 5,85 & 6,78 & 6,00 & 5,08 \\
\hline Eu & 2,10 & 1,07 & 1,94 & 1,73 & 1,87 & 1,61 & 1,15 \\
\hline Gd & 0,00 & 3,40 & 0,00 & 0,00 & 5,91 & 4,60 & 0,00 \\
\hline Tb & 0,90 & 0,40 & 0,80 & 0,50 & 0,61 & 0,50 & 0,60 \\
\hline Dy & 0,00 & 2,10 & 0,00 & 0,00 & 2,65 & 2,60 & 0,00 \\
\hline Ho & 0,00 & 0,40 & 0,00 & 0,00 & 0,49 & 0,50 & 0,00 \\
\hline Er & 0,00 & 1,10 & 0,00 & 0,00 & 1,44 & 1,30 & 0,00 \\
\hline $\mathrm{Tm}$ & & 0,14 & & & 0,16 & 0,16 & \\
\hline $\mathrm{Yb}$ & 1,87 & 0,90 & 1,25 & 1,25 & 0,94 & 1,10 & 0,96 \\
\hline Lu & 0,27 & 0,11 & 0,17 & 0,17 & 0,14 & 0,16 & 0,13 \\
\hline
\end{tabular}




\begin{tabular}{|c|c|c|c|}
\hline Amostra & OM 406 & OM 1120 & OM 1108 \\
\hline $\mathrm{SiO} 2$ & 67,24 & 69,49 & 70,37 \\
\hline TiO2 & 0,37 & 0,28 & 0,27 \\
\hline Al2O3 & 14,77 & 15,81 & 15,73 \\
\hline $\mathrm{Fe} 2 \mathrm{O} 3 \mathrm{~T}$ & 3,30 & 2,26 & 2,15 \\
\hline MnO & 0,06 & 0,04 & 0,04 \\
\hline $\mathrm{MgO}$ & 1,49 & 0,78 & 1,02 \\
\hline $\mathrm{CaO}$ & 3,00 & 2,26 & 2,87 \\
\hline $\mathrm{Na} 2 \mathrm{O}$ & 4,26 & 4,83 & 4,08 \\
\hline $\mathrm{K} 20$ & 3,32 & 3,60 & 3,14 \\
\hline P2O5 & 0,22 & 0,14 & 0,14 \\
\hline LOI & 0,75 & 0,56 & 0,49 \\
\hline TOTAL. & 98,78 & 100,05 & 100,30 \\
\hline $\mathbf{B a}$ & 1340 & 1910 & 1820 \\
\hline $\mathbf{R} \mathbf{b}$ & 90 & 84 & 62 \\
\hline $\mathrm{Sr}$ & 901 & 1270 & 1010 \\
\hline Cs & 1,70 & 1,00 & 1,40 \\
\hline $\mathbf{G a}$ & 20 & 19 & 17 \\
\hline $\mathrm{Ta}$ & 1,40 & 1,00 & 0,80 \\
\hline $\mathbf{N b}$ & 14 & 10 & 9 \\
\hline Hf & 5,00 & 4,10 & 3,70 \\
\hline $\mathbf{Z r}$ & 168 & 136 & 136 \\
\hline $\mathbf{Y}$ & 11 & 11 & 8 \\
\hline Th & 14,40 & 3,80 & 6,10 \\
\hline $\mathbf{u}$ & 2,60 & 0,60 & 1,20 \\
\hline $\mathrm{Cr}$ & 44 & 24 & -20 \\
\hline $\mathrm{Ni}$ & -20 & 31 & -15 \\
\hline Co & 62 & 51 & 37 \\
\hline Sc & 7 & 4 & 4 \\
\hline$v$ & 50 & 26 & 26 \\
\hline $\mathrm{Cu}$ & 15 & -10 & -10 \\
\hline $\mathbf{P b}$ & 35 & 19 & 15 \\
\hline$Z n$ & 53 & 37 & -30 \\
\hline La & 52,20 & 26,30 & 35,10 \\
\hline $\mathrm{Ce}$ & 88,80 & 45,20 & 60,10 \\
\hline Pr & 8,88 & 5,24 & 6,42 \\
\hline Nd & 30,80 & 21,20 & 21,20 \\
\hline Sm & 4,90 & 4,00 & 3,20 \\
\hline Eu & 1,38 & 1,24 & 0,71 \\
\hline Gd & 4,30 & 4,50 & 2,40 \\
\hline Tb & 0,40 & 0,60 & 0,30 \\
\hline Dy & 2,10 & 3,90 & 1,40 \\
\hline Ho & 0,40 & 1,00 & 0,30 \\
\hline Er & 1,10 & 3,40 & 0,80 \\
\hline Tm & 0,16 & 0,51 & 0,10 \\
\hline $\mathrm{Yb}$ & 1,00 & 3,00 & 0,60 \\
\hline Lu & 0,12 & 0,46 & 0,10 \\
\hline
\end{tabular}




\section{Suite Granítica Piên-Mandirituba (SGPM)}

(Quartzo Monzodioritos, Granodioritos e Leucogranodioritos com epídoto magmático) 


\begin{tabular}{|c|c|c|c|c|c|c|c|c|}
\hline Amostra & OM 183-105 & OM 180 & OM 182 & OM 04 & OM 981 & OM 629 & OM 432 & OM 705 \\
\hline $\mathrm{SiO} 2$ & 60,16 & 62,01 & 63,82 & 64,08 & 67,74 & 67,85 & 68,58 & 69,84 \\
\hline TiO2 & 0,52 & 0,52 & 0,47 & 0,42 & 0,34 & 0,25 & 0,27 & 0,26 \\
\hline $\mathrm{Al} 203$ & 17,35 & 17,17 & 16,56 & 15,75 & 15,54 & 15,72 & 15,97 & 14,48 \\
\hline Fe2O3T & 5,45 & 5,59 & 4,72 & 4,31 & 3,43 & 2,51 & 2,97 & 2,18 \\
\hline Mno & 0,12 & 0,13 & 0,12 & 0,09 & 0,07 & 0,06 & 0,07 & 0,04 \\
\hline MgO & 1,89 & 1,64 & 1,48 & 1,60 & 1,00 & 0,71 & 0,76 & 0,86 \\
\hline $\mathrm{CaO}$ & 5,01 & 4,67 & 4,11 & 3,21 & 2,90 & 2,57 & 2,82 & 1,89 \\
\hline $\mathrm{Na2O}$ & 4,74 & 4,62 & 4,78 & 4,12 & 4,61 & 5,49 & 5,17 & 5,02 \\
\hline K2O & 2,50 & 2,83 & 2,69 & 3,58 & 3,74 & 3,00 & 3,40 & 3,52 \\
\hline P2O5 & 0,34 & 0,33 & 0,30 & 0,23 & 0,20 & 0,14 & 0,15 & 0,15 \\
\hline LOI & 0,82 & 0,82 & 0,84 & 0,94 & 0,71 & 0,39 & 0,37 & 2,22 \\
\hline TOTAL & 98,90 & 100,33 & 99,89 & 98,33 & 100,28 & 98,68 & 100,53 & 100,46 \\
\hline $\mathbf{B a}$ & 1690 & 1457 & 1451 & 1533 & 1390 & 1680 & 1220 & 1230 \\
\hline $\mathbf{R b}$ & 69 & 77 & 76 & 85 & 82 & 78 & 90 & 85 \\
\hline $\mathrm{Sr}$ & 1410 & 1416 & 1254 & 964 & 1060 & 1100 & 1170 & 918 \\
\hline Cs & 1,00 & 0,50 & 0,50 & 2,20 & 1,10 & 1,10 & 2,60 & 2,50 \\
\hline $\mathbf{G a}$ & 23 & 21 & 21 & 18 & 21 & 21 & 23 & 22 \\
\hline $\mathrm{Ta}$ & 0,90 & 1,90 & 2,10 & 3,20 & 1,10 & 1,10 & 0,91 & 0,40 \\
\hline $\mathrm{Nb}$ & 11 & 12 & 12 & 13 & 11 & 11 & 12 & 7 \\
\hline Hf & 5,00 & 5,50 & 4,20 & 4,90 & 4,40 & 3,90 & 3,20 & 3,40 \\
\hline $\mathrm{Zr}$ & 188 & 167 & 151 & 198 & 180 & 137 & 123 & 104 \\
\hline$Y$ & 20 & 16 & 18 & 15 & 13 & 8 & 10 & 5 \\
\hline Th & 6,30 & 4,40 & 5,40 & 8,90 & 7,90 & 4,50 & 4,19 & 5,70 \\
\hline $\mathbf{u}$ & 0,50 & 2,00 & 0,20 & 4,30 & 1,10 & 1,40 & 2,69 & 1,30 \\
\hline $\mathrm{Cr}$ & -20 & 15 & 16 & 25 & -20 & -20 & 13 & -20 \\
\hline $\mathrm{Ni}$ & -20 & 2 & 4 & 3 & -15 & -15 & -10 & -15 \\
\hline Sc & 9 & 7 & 7 & 6 & 4 & 4 & 3 & 3 \\
\hline$v$ & 76 & 53 & 44 & 47 & 49 & 30 & 32 & 30 \\
\hline La & 69,00 & 50,20 & 48,20 & 53,90 & 54,50 & 25,80 & 28,80 & 17,10 \\
\hline $\mathrm{Ce}$ & 124,00 & 109,00 & 89,00 & 99,00 & 71,30 & 47,10 & 49,90 & 31,90 \\
\hline $\mathrm{Pr}$ & 12,80 & & & & 10,60 & 5,15 & 5,25 & 3,64 \\
\hline $\mathrm{Nd}$ & 46,90 & 47,00 & 35,00 & 48,00 & 39,70 & 18,30 & 21,70 & 13,90 \\
\hline $\mathrm{Sm}$ & 7,20 & 7,11 & 5,75 & 8,34 & 7,50 & 2,90 & 3,86 & 2,40 \\
\hline Eu & 2,12 & 2,06 & 1,51 & 2,22 & 1,38 & 0,72 & 1,09 & 0,63 \\
\hline Gd & 6,30 & 0,00 & 0,00 & 0,00 & 9,10 & 2,20 & 2,83 & 1,90 \\
\hline Tb & 0,70 & 0,55 & 0,45 & 0,48 & 0,42 & 0,30 & 0,35 & 0,20 \\
\hline Dy & 3,30 & 0,00 & 0,00 & 0,00 & 7,70 & 1,40 & $\uparrow, 68$ & 1,00 \\
\hline Ho & 0,60 & 0,00 & 0,00 & 0,00 & 1,70 & 0,30 & 0,29 & 0,20 \\
\hline $\mathrm{Er}$ & 1,80 & 0,00 & 0,00 & 0,00 & 5,20 & 0,80 & 0,87 & 0,40 \\
\hline $\mathrm{Tm}$ & 0,25 & & & & 0,78 & 0,11 & 0,12 & 0,06 \\
\hline $\mathrm{Yb}$ & 1,60 & 1,64 & 1,55 & 1,20 & 0,88 & 0,70 & 0,83 & 0,40 \\
\hline Lut & 0,22 & 0,25 & 0,17 & 0,23 & 0,18 & 0,12 & 0,13 & 0,06 \\
\hline
\end{tabular}




\begin{tabular}{|c|c|c|c|c|c|c|}
\hline Amostra & OM 136 & ОМ 35 & OM 959 & OM 942 & OM 933 & OM 26 \\
\hline $\mathrm{SiO} 2$ & 69,96 & 71,62 & 72,76 & 72,97 & 73,72 & 74,41 \\
\hline TiO2 & 0,16 & 0,17 & 0,16 & 0,13 & 0,15 & 0,13 \\
\hline $\mathrm{Al} 2 \mathrm{O} 3$ & 15,60 & 15,02 & 14,67 & 14,60 & 14,52 & 14,40 \\
\hline Fe2O3T & 1,53 & 1,84 & 1,43 & 1,18 & 0,79 & 1,18 \\
\hline Mno & 0,05 & 0,06 & 0,03 & 0,02 & 0,02 & 0,02 \\
\hline $\mathrm{MgO}$ & 0,43 & 0,47 & 0,43 & 0,33 & 0,32 & 0,29 \\
\hline $\mathrm{CaO}$ & 1,83 & 2,06 & 1,49 & 1,23 & 1,33 & 1,10 \\
\hline $\mathrm{Na2O}$ & 5,16 & 4,77 & 5,43 & 5,47 & 5,17 & 5,45 \\
\hline $\mathrm{K} 2 \mathrm{O}$ & 3,07 & 3,21 & 3,34 & 3,59 & 3,76 & 3,47 \\
\hline P2O5 & 0,07 & 0,08 & 0,09 & 0,08 & 0,04 & 0,08 \\
\hline LOI & 0,66 & 0,49 & 0,37 & 0,68 & 0,61 & 0,39 \\
\hline TOTAL & 98,52 & 99,79 & 100,19 & 100,29 & 100,43 & 100,92 \\
\hline $\mathrm{Ba}$ & 1945 & 1161 & 1760 & 1910 & 1300 & 1560 \\
\hline $\mathbf{R b}$ & 72 & 52 & 67 & 63 & 77 & 84 \\
\hline $\mathbf{S r}$ & 1256 & 1043 & 1190 & 1240 & 929 & 1130 \\
\hline Cs & 0,80 & 1,40 & 0,70 & 1,10 & $-0,50$ & 0,90 \\
\hline $\mathbf{G a}$ & 21 & 18 & 21 & 20 & 21 & 19 \\
\hline Ta & 0,50 & 0,50 & 0,30 & 0,30 & 1,00 & 0,91 \\
\hline Nb & 7 & 6 & 5 & 5 & 5 & 5 \\
\hline Hf & 3,30 & 3,50 & 2,70 & 3,00 & 2,70 & 2,90 \\
\hline $\mathrm{Zr}$ & 125 & 87 & 87 & 89 & 84 & 99 \\
\hline$Y$ & 8 & 5 & 4 & 3 & 3 & 6 \\
\hline Th & 2,70 & 1,70 & 1,80 & 1,80 & 2,80 & 4,20 \\
\hline $\mathbf{U}$ & 0,20 & 0,20 & 0,60 & 0,60 & 0,70 & 1,12 \\
\hline $\mathrm{Cr}$ & 12 & 19 & -20 & -20 & -20 & -10 \\
\hline $\mathrm{Ni}$ & 3 & 2 & -15 & -15 & -15 & -10 \\
\hline Sc & 2 & 2 & 3 & -1 & 2 & 1 \\
\hline$v$ & 11 & 14 & 16 & 10 & 9 & 10 \\
\hline La & 14,70 & & $\nmid 2,00$ & 13,50 & 14,60 & 22,10 \\
\hline $\mathrm{Ce}$ & 31,00 & & 22,10 & 24,50 & 26,50 & 28,30 \\
\hline $\mathbf{P r}$ & & & 2,60 & 2,86 & 3,01 & 3,38 \\
\hline$N d$ & 12,00 & & 9,50 & 10,30 & 10,70 & 14,70 \\
\hline Sm & 2,06 & & 1,70 & 2,00 & 1,90 & 2,98 \\
\hline Eu & 0,81 & & 0,37 & 0,40 & 0,47 & 0,55 \\
\hline Gd & 0,00 & & 1,30 & 1,50 & 1,50 & 1,60 \\
\hline $\mathrm{Tb}$ & 0,28 & & 0,20 & 0,20 & 0,20 & 0,25 \\
\hline Dy & 0,00 & & 0,70 & 0,70 & 0,70 & 1,83 \\
\hline Ho & 0,00 & & 0,10 & 0,10 & 0,10 & 0,34 \\
\hline Er & 0,00 & & 0,30 & 0,30 & 0,30 & 0,96 \\
\hline $\mathrm{Tm}$ & & & $-0,05$ & $-0,05$ & $-0,05$ & 0,16 \\
\hline $\mathrm{Yb}$ & 0,66 & & 0,30 & 0,20 & 0,30 & 0,25 \\
\hline Lu & 0,76 & & 0,05 & $-0,04$ & 0,04 & 0,12 \\
\hline
\end{tabular}




\section{Suite Granítica Piên-Mandirituba (SGPM)}

(Monzogranitos) 

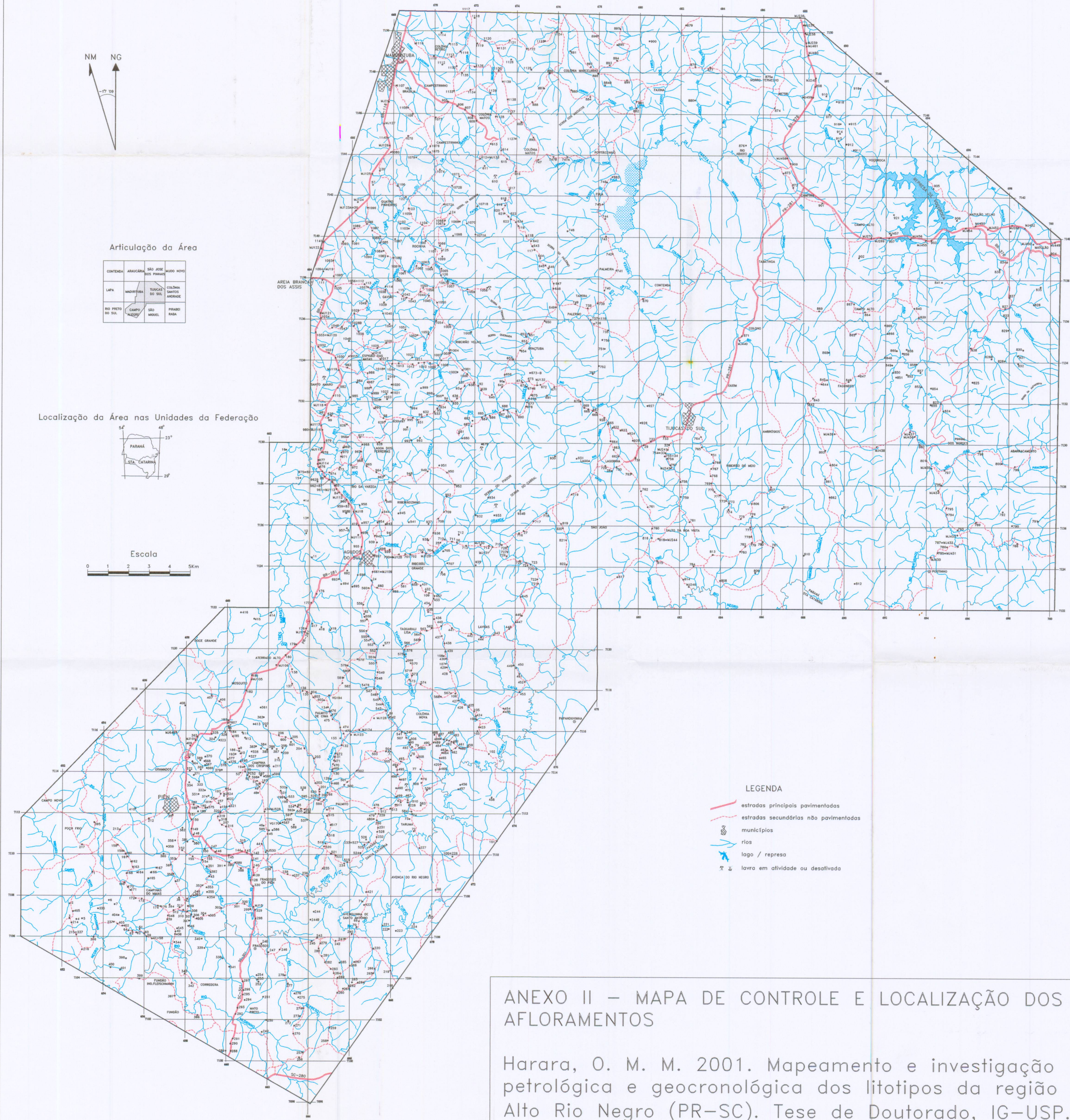

ANEXO $\|$ - MAPA DE CONTROLE E LOCALIZAÇÃO DOS AFLORAMENTOS

Harara, O. M. M. 2001. Mapeamento e investigação petrológica e geocronológica dos litotipos da região do Alto Rio Negro (PR-SC). Tese de Doutorado, IG-USP. 


\section{Mapa Geológico da região do alto Rio Negro (PR-SC)}

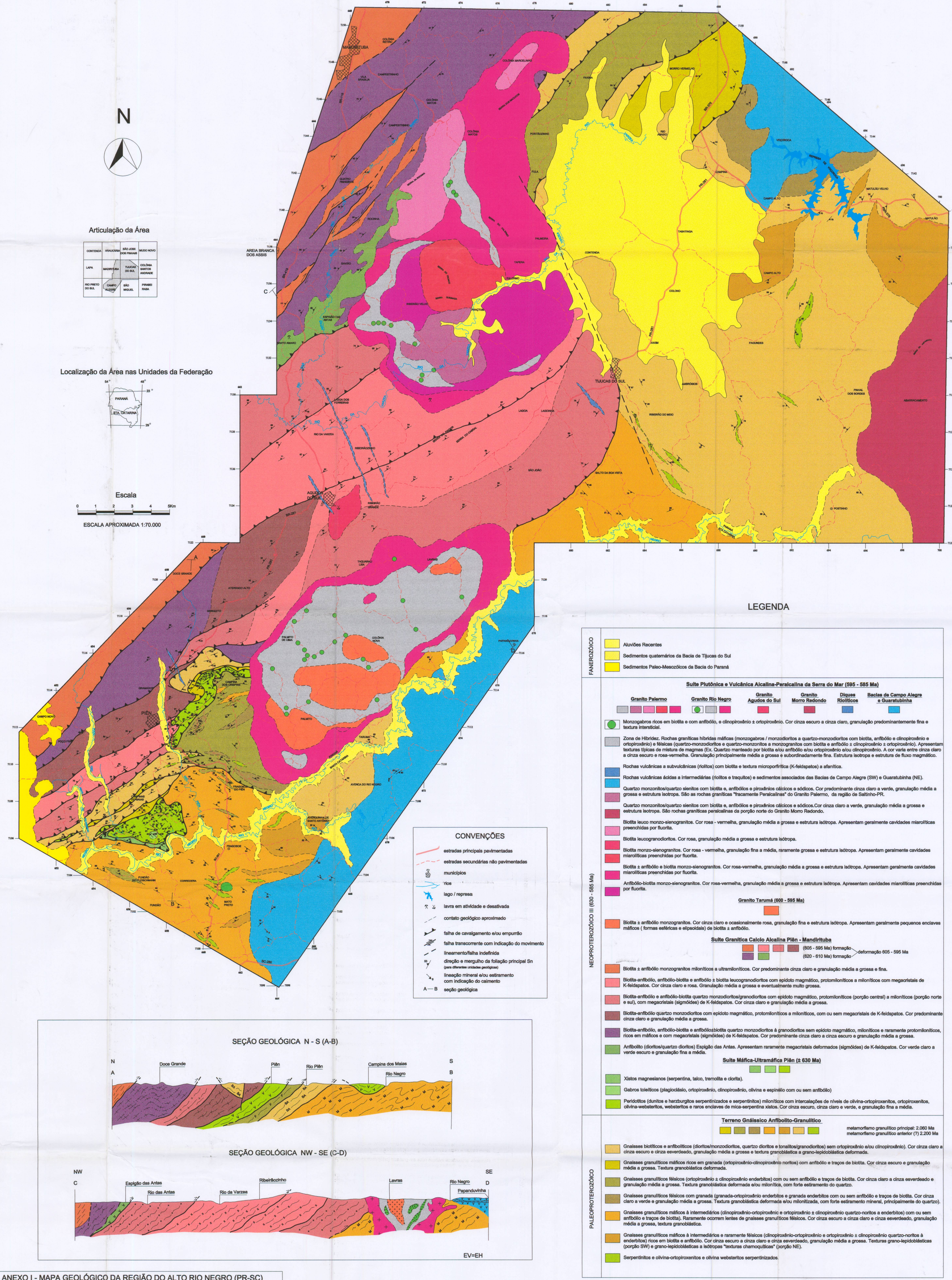

